\title{
Idaho National Engineering Laboratory Code Assessment of the Rocky Flats Transuranic Waste
}

WASTREN, Inc.

Published July 1995

WASTREN, Inc.

Westminster, Colorado 80234
Prepared for Lockheed Martin Idaho Technologies Waste Operations Department Under Subcontract No. C94-170739 and for the

U.S. Department of Energy Assistant Secretary for Environmental Management Under DOE Idaho Operations Office Contract DE-AC07-94ID13223 


\section{ABSTRACT}

This report is an assessment of the content codes associated with transuranic waste shipped from the Rocky Flats Plant in Golden, Colorado, to INEL. The primary objective of this document is to characterize and describe the transuranic wastes shipped to INEL from Rocky Flats by item description code (IDC). This information will aid INEL in determining if the waste meets the waste acceptance criteria (WAC) of the Waste Isolation Pilot Plant (WIPP). The waste covered by this content code assessment was shipped from Rocky Flats between 1985 and 1989. These years coincide with the dates for information available in the Rocky Flats Solid Waste Information Management System (SWIMS). The majority of waste shipped during this time was certified to the existing WIPP WAC. This waste is referred to as precertified waste. Reassessment of these precertified waste containers is necessary because of changes in the WIPP WAC. To accomplish this assessment, the analytical and process knowledge available on the various IDCs used at Rocky Flats were evaluated. Rocky Flats sources for this information include employee interviews, SWIMS, Transuranic Waste Certification Program, Transuranic Waste Inspection Procedure, Backlog Waste Baseline Books, WIPP Experimental Waste Characterization Program (headspace analysis), and other related documents, procedures, and programs. Summaries are provided of (a) certification information, (b) waste description, (c) generation source, (d) recovery method, (e) waste packaging and handling information, (f) container preparation information, $(\mathrm{g})$ assay information, (h) inspection information, (i) analytical data, and (j) RCRA characterization.

\section{DISCLAIMER}

This report was prepared as an account of work sponsored by an agency of the United States employees, makes any warranty, express or implied, nor any agency thereof, nor any of their bility for the accuracy, completeness, or usefulnes, or assumes any legal liability or responsiprocess disclosed, or represents that its use woulness of any information, apparatus, product, or ence herein to any specific commercial use would not infringe privately owned rights. Refermanufacturer, or otherwise does not necessarily constitute or service by trade name, trademark, mendation, or favoring by the United States Gonstitute or imply its endorsement, recomand opinions of authors expressed herein Government or any agency thereof. The views United States Government or any agency thereof. 


\section{DISCLAIMER}

Portions of this document may be illegible electronic image products. Images are produced from the best available original document. 


\section{EXECUTIVE SUMMARY}

To support the Idaho National Engineering Laboratory (INEL) in its examination and certification of waste stored at the Stored Waste Examination Pilot Plant (SWEPP), WASTREN, Inc., has prepared an assessment of the content codes associated with transuranic waste shipped from the Rocky Flats Plant in Golden, Colorado, to INEL. That assessment is presented in this document.

The primary objective of this document is to characterize and describe the transuranic wastes shipped to INEL from Rocky Flats from September 1985 to August 1989, by item description code (IDC). This information will aid INEL in determining if the waste meets the waste acceptance criteria (WAC) of the Waste Isolation Pilot Plant (WIPP).

The waste covered by this content code assessment was shipped from Rocky Flats between 1985 and 1989. These years coincide with the dates for information available in the Rocky Flats Solid Waste Information Management System (SWIMS). The majority of waste shipped during this time was certified to the existing WIPP WAC. This waste is referred to as precertified waste. Reassessment of these precertified waste containers is necessary because of changes in the WIPP WAC. To accomplish this assessment, WASTREN evaluated the analytical and process knowledge available on the various IDCs used at Rocky Flats. Rocky Flats sources for this information include

- Employee interviews

- $\quad$ Solid Waste Information Management System (SWIMS)

- Transuranic Waste Certification Program

- Transuranic Waste Inspection Procedure

1 Backlog Waste Baseline Books

- WIPP Experimental Waste Characterization Program (headspace analysis)

- Other related documents, procedures, and programs.

INEL also provided information to aid in WASTREN's assessment of the IDCs.

The WASTREN team evaluated the information in the above references and provided summaries of

- Certification information

- Waste description

- Generation source

- $\quad$ Recovery method 
- Waste packaging and handling information

- Container preparation information

- Assay information

- Inspection information

- Analytical data

- RCRA characterization.

Certification information is the first subsection presented in each IDC subsection, offering WASTREN's recommendations on what additional, IDC-specific concerns should be addressed before the waste can be shipped to WIPP. The rest of the sections provide INEL with information on the characterization of each IDC for evaluation against the WIPP WAC.

Included in the appendices to this document are

- Selected references used in compiling this information

- A list of the people contacted at Rocky Flats in the compilation of this information

- Waste container drawings, showing cross-sections of how wastes were packaged

- A list of source documents used in the compilation of this information

- Acronyms and abbreviations used in this document.

WASTREN is committed to providing INEL with the best information available for its certification effort, in a format that is as logical and easy-to-use as possible. 


\section{CONTENTS}

ABSTRACT $\ldots \ldots \ldots \ldots \ldots \ldots \ldots \ldots \ldots \ldots \ldots \ldots \ldots \ldots \ldots \ldots \ldots \ldots$ iii

EXECUTIVE SUMMARY $\ldots \ldots \ldots \ldots \ldots \ldots \ldots \ldots \ldots \ldots \ldots \ldots \ldots \ldots$

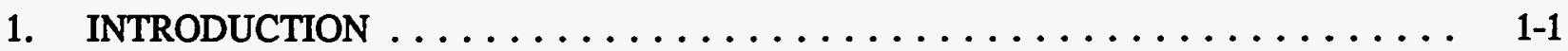

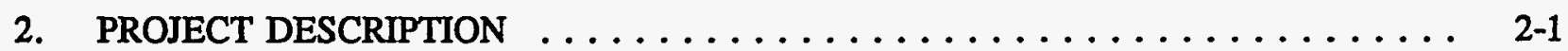

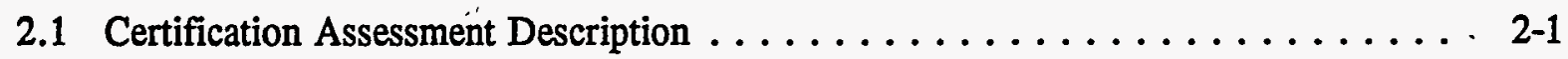

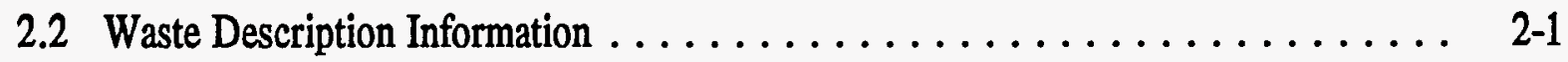

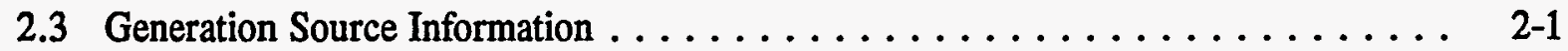

2.4 Recovery Method Information $\ldots \ldots \ldots \ldots \ldots \ldots \ldots \ldots \ldots \ldots \ldots \ldots \ldots \ldots .2-2$

2.5 Waste Packaging and Handling Information $\ldots \ldots \ldots \ldots \ldots \ldots \ldots . \ldots \ldots$

2.6 Container Preparation Information $\ldots \ldots \ldots \ldots \ldots \ldots \ldots \ldots \ldots .2-2$

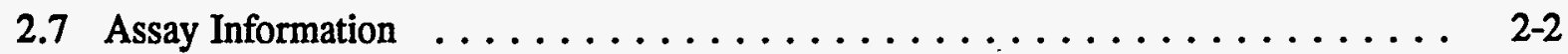

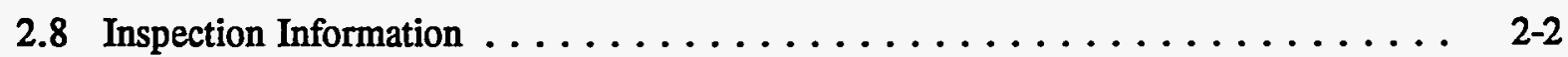

2.9 Waste Form Evaluation Information $\ldots \ldots \ldots \ldots \ldots \ldots \ldots \ldots \ldots .2-2$

2.10 Combustible and Organic Content Information $\ldots \ldots \ldots \ldots \ldots \ldots \ldots$ 2-3

2.11 Analytical Information Section $\ldots \ldots \ldots \ldots \ldots \ldots \ldots \ldots \ldots \ldots \ldots \ldots .2-3$

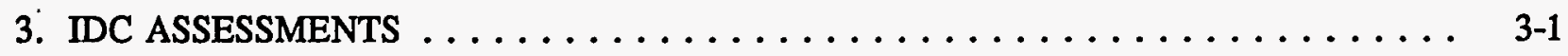

3.1 Waste Form Number (no waste form number), Content Code RF 111A

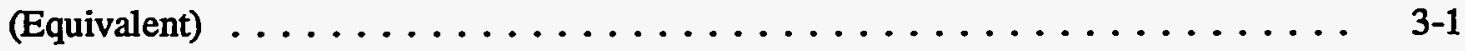

3.1.1 Item Description Code 001-First Stage Sludge, B774 $\ldots \ldots \ldots \ldots$ 3-1

3.1 Waste Form Number (no waste form number), Content Code RF 112A (Equivalent) 3-15

3.1.2 Item Description Code 003-Grease, B774 . . . . . . . . . 3-15

3.1 Waste Form Number (no waste form number), Content Code RF 114A (Equivalent) 3-24

3.1.3 Item Description Code $292-$ Incinerator Sludge $\ldots \ldots \ldots \ldots \ldots$. . . . . . 
3.1 Waste Form Number (no waste form number), Content Code RF 122A (Equivalent) 3-32 3.1.4 Item Description Code 393-Sand, Slag, and Crucible Heels . . . . . . 3-32

3.1 Waste Form Number (no waste form number), Content Code RF 124A (Equivalent) 3-38 3.1.5 Item Description Code 409-Molten Salt 30\% Unpulverized . . . . . . . 3-38

3.1 Waste Form Number (no waste form number), Content Code RF 124A (Equivalent) 3-45 3.1.6 Item Description Code $414-$ DOR Salt $\ldots \ldots \ldots \ldots \ldots \ldots \ldots$. . . . . . . .

3.1 Waste Form Number (no waste form number), Content Code RF 122A (Equivalent) 3-52 3.1.7 Item Description Code $422-$ Soot $\ldots \ldots \ldots \ldots \ldots \ldots \ldots$ 3-52

3.1 Waste Form Number (no waste form number), Content Code RF 126A (Equivalent) 3-58 3.1.8 Item Description Code 432-Resin, Cemented . . . . . . . . . . . 3-58

3.2 Waste Form Number 111-Solidified Aqueous Sludge, Content Code RF 111A . . . . . . . . . . . . . . . . . 3-66

3.2.1 Item Description Code 007-Cemented Sludge, B374 . . . . . . . . 3-66

3.2 Waste Form Number 111-Solidified Aqueous Sludge, Content Code RF 111A . . . . . . . . . . . . . . . . . . 3-77

3.2.2 Item Description Code 800-Solidified Sludge, B774 $\ldots \ldots \ldots \ldots \ldots$ 3-77

3.2 Waste Form Number 111-Solidified Aqueous Sludge, Content Code RF 111A . . . . . . . . . . . . . . . . . . . . . . 3-92

3.2.3 Item Description Code $803-$ Solidified DCP Sludge $\ldots \ldots \ldots \ldots$. . . . 3-92

3.2 Waste Form Number 111-Solidified Aqueous Sludge, Content Code RF 111A . . . . . . . . . . . . . . . . . . . 3-102

3.2.4 Item Description Code 807-Solidified Bypass Solids . . . . . . . . . 3-102

3.3 Waste Form Number 112-Solidified Organics, Content Code RF 112A . . . . 3-112

3.3.1 Item Description Code 700-Organic and Sludge Immobilization System Waste . . . . . . . . . . . . . 3-112

3.3 Waste Form Number 112-Solidified Organics, Content Code RF 112A . . . . 3 3-118 
3.3.2 Item Description Code 801-Solidified Organics $\ldots \ldots \ldots \ldots \ldots$. . . . . .

3.4 Waste Form Number 113-Solidified Lab Waste, Content Code RF 113A . . . . 3-130

3.4.1 Item Description Code 802-Solidified Lab Waste . . . . . . . . . 3-130

3.5 Waste Form Number 114-Solidified Process Solids,

Content Code RF 114A . . . . . . . . . . . . . . . 3-136

3.5.1 Item Description Code 806-Solidified Process Solids . . . . . . . . . 3-136

3.5 Waste Form Number 114-Solidified Process Solids,

Content Code RF 114A . . . . . . . . . . . . . . . . 3-142

3.5.2 . Item Description Code 817-Cemented SS\&C Heels . . . . . . . . 3-142

3.5 Waste Form Number 114-Solidified Process Solids,

Content Code RF 114A . . . . . . . . . . . . . . . . 3-148

3.5.3 Item Description Code 818-Cemented Ash . . . . . . . . . . 3-148

3.5 Waste Form Number 114-Solidified Process Solids, Content Code RF 114A . . . . . . . . . . . . . . . . 3-154

3.5.4 Item Description Code 820-Cemented Soot . . . . . . . . . . 3-154

3.5 Waste Form Number 114-Solidified Process Solids, Content Code RF 114A ..................... 3-160

3.5.5 Item Description Code 823-Cemented Miscellaneous Sludge . . . . . . 3-160

3.6 Waste Form Number 115-TRU Graphite Waste, Content Code RF 115A . . . . 3-166

3.6.1 Item Description Code 300-Graphite Molds $\ldots \ldots \ldots \ldots \ldots \ldots$ 3-166

3.6 Waste Form Number 115-TRU Graphite Waste, Content Code RF 115A . . . . 3-174

3.6.2 Item Description Code 303-Scarfed Graphite Chunks $\ldots \ldots \ldots . .3-174$

3.7 Waste Form Number 116-TRU Combustible Waste,

Content Code RF 116A . . . . . . . . . . . . . . . 3-180

3.7.1 Item Description Code 330-Combustibles, Dry $\ldots \ldots \ldots \ldots \ldots$ 3-180 
3.7 Waste Form Number 116-TRU Combustible Waste, Content Code RF 116A . . . . . . . . . . . . . . . . . . . . . . . . . 3-189

3.7.2 Item Description Code 336-Combustibles, Wet . . . . . . . . . . . 3-189

3.7 Waste Form Number 116-TRU Combustible Waste,

Content Code RF 116A . . . . . . . . . . . . . . . . . . . . . . . 3-198

3.7.3 Item Description Code 337-Plastic and Nonlead Rubber . . . . . . . . 3-198

3.7 Waste Form Number 116-TRU Combustible Waste,

Content Code RF 116A

3-206

3.7.4 Item Description Code 491-Plenum Prefilters . . . . . . . . . . 3-206

3.7 Waste Form Number 116-TRU Combustible Waste,

Content Code RF 116A . . . . . . . . . . . . . . . . . . . 3-212

3.7.5 Item Description Code 831-Dry Combustibles TRU Mixed . . . . . . . . . 3-212

3.7 Waste Form Number 116-TRU Combustible Waste,

Content Code RF 116A . . . . . . . . . . . . . . . . . . . . 3-224

3.7.6 Item Description Code 832-Wet Combustibles TRU Mixed . . . . . . . 3-224

3.7 Waste Form Number 116-TRU Combustible Waste,

Content Code RF 116A . . . . . . . . . . . . . . . . . . 3-233

3.7.7 Item Description Code 833-Plastics TRU Mixed . . . . . . . . . . 3-233

3.8 Waste Form Number 117-TRU Metal Waste, Content Code RF 117A . . . . . . 3-242

3.8.1 Item Description Code 320-Heavy Non-SS Metal . . . . . . . . . . . 3-242

3.8 Waste Form Number 117-TRU Metal Waste, Content Code RF 117A . . . . . . 3-250

3.8.2 Item Description Code $321-$ Lead $\ldots \ldots \ldots \ldots \ldots \ldots \ldots$. . . . . . . . . . . . . .

3.8 Waste Form Number 117-TRU Metal Waste, Content Code RF 117A . . . . . . 3-256

3.8.3 Item Description Code 480-Light Metal . . . . . . . . . . . 3-256

3.8 Waste Form Number 117-TRU Metal Waste, Content Code RF 117A . . . . . . 3-270

3.8.4 Item Description Code 481-Leached Non-SS Metals . . . . . . . . 3-270

3.8 Waste Form Number 117-TRU Metal Waste, Content Code RF 117A . . . . . . 3-277 
3.8.5 Item Description Code 488-Glovebox Parts with Lead . . . . . . . 3-277

3.9 Waste Form Number 118-TRU Glass Waste, Content Code RF 118A . . . . . 3-282

3.9.1 Item Description Code 368-Magnesium Oxide Crucibles $\ldots \ldots \ldots$ 3-282

3.9 Waste Form Number 118-TRU Glass Waste, Content Code RF 118A . . . . . 3-288

3.9.2 Item Description Code $440-$ Glass $\ldots \ldots \ldots \ldots \ldots \ldots \ldots \ldots$ 3-288

3.9 Waste Form Number 118-TRU Glass Waste, Content Code RF 118A . . . . . . 3-296

3.9.3 Item Description Code 441-Unleached Raschig Rings . . . . . . . . 3-296

3.9 Waste Form Number 118-TRU Glass Waste, Content Code RF 118A . . . . . 3-303

3.9.4 Item Description Code 442-Leached Raschig Rings . . . . . . . 3-303

3.10 Waste Form Number 119-TRU Filter Waste, Content Code RF 119A . . . . 3 3-312

3.10.1 Item Description Code 335-Absolute Drybox Filters $\ldots \ldots \ldots \ldots$ 3-312

3.10 Waste Form Number 119-TRU Filter Waste, Content Code RF 119A . . . . . 3 3-319

3.10.2 Item Description Code 376-Processed Filter Media . . . . . . 3-319

3.10 Waste Form Number 119-TRU Filter Waste, Content Code RF 119A . . . . . 3-326

3.10.3 Item Description Code 490-HEPA Filters . . . . . . . . 3-326

3.11 Waste Form Number 121-TRU Organic Solid Waste,

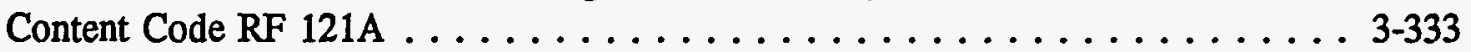

3.11.1 Item Description Code 302-Benelex \& Plexiglas . . . . . . . . . 3-333

3.12 Waste Form Number 122-TRU Inorganic Solid Waste,

Content Code RF 122A . . . . . . . . . . . . . . . . . 3-341

3.12.1 Item Description Code 371-Firebrick . . . . . . . . . . 3-341

3.12 Waste Form Number 122-TRU Inorganic Solid Waste,

Content Code RF 122A . . . . . . . . . . . . . . . . . . . .

3.12.2 Item Description Code 374-Blacktop/Concrete/Dirt . . . . . . . 3-348

3.12 Waste Form Number 122-TRU Inorganic Solid Waste, Content Code RF 122A . . . . . . . . . . . . . . . . . . . . 
3.12.3 Item Description Code 377-Firebrick, Coarse $\ldots \ldots \ldots \ldots \ldots$ 3-354

3.13 Waste Form Number 123-TRU Leaded Rubber, Content Code RF 123A . . . . 3-361

3.13.1 Item Description Code 339-Leaded Gloves $\ldots \ldots \ldots \ldots \ldots \ldots$. . . . . . .

3.14 Waste Form Number 124-TRU Pyrochemical Salt Waste, Content Code RF 124A . . . . . . . . . . . . . . . . . 3-371

3.14.1 Item Description Code 411-Electrorefining Salt $\ldots \ldots \ldots \ldots \ldots$ 3-371

3.15 Waste Form Number 126-Solidified Process Solids,

Content Code RF 126A . . . . . . . . . . . . . . . . . . . 3-377

3.15.1 Item Description Code 822 -Cemented Resin . . . . . . . . . . 3-377

Appendix A-Selected References $\ldots \ldots \ldots \ldots \ldots \ldots \ldots \ldots \ldots \ldots \ldots \ldots \ldots \ldots \ldots \ldots \ldots$

Appendix B-List of EG\&G Rocky Flats Contacts $\ldots \ldots \ldots \ldots \ldots \ldots \ldots \ldots$ B-1

Appendix C-Waste Container Drawings $\ldots \ldots \ldots \ldots \ldots \ldots \ldots \ldots \ldots \ldots \ldots \ldots \ldots \ldots \ldots$

Appendix D-Source Documentation $\ldots \ldots \ldots \ldots \ldots \ldots \ldots \ldots \ldots \ldots \ldots \ldots \ldots \ldots \ldots$

Appendix E-Acronyms and Abbreviations $\ldots \ldots \ldots \ldots \ldots \ldots \ldots \ldots \ldots \ldots$ E-1

\section{TABLES}

3.1.1-1. Item Description Code 001 Container Information $\ldots \ldots \ldots \ldots \ldots \ldots . . \ldots \ldots$

3.1.1-2. Item Description Code 001 Dose Information $\ldots \ldots \ldots \ldots \ldots \ldots \ldots$

3.1.1-3. Item Description Code 001 Assay Information $\ldots \ldots \ldots \ldots \ldots \ldots \ldots$ 3-3

3.1.1-4. Waste Form Evaluation $\ldots \ldots \ldots \ldots \ldots \ldots \ldots \ldots \ldots \ldots \ldots \ldots \ldots \ldots$

3.1.1-5. TRUPACT Evaluation $\ldots \ldots \ldots \ldots \ldots \ldots \ldots \ldots \ldots \ldots \ldots \ldots \ldots$

3.1.1-6. Item Description Code 001 Data Summary for Combustible and

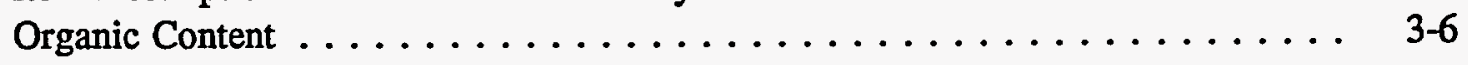

3.1.1-7. Gas Mass Spectrometry Results (vol\%) $\ldots \ldots \ldots \ldots \ldots \ldots \ldots \ldots$ 3-8

3.1.1-8. Volatile Organic Compound Gas Chromatography/Mass Spectrometry Results . . . 3-9

3.1.1-9. Volatile Organic Compound Gas Chromatography/Mass Spectrometry Results . . 3-10 
3.1.1-10. Volatile Organic Compound Gas Chromatography/Mass Spectrometry Results (parts per million by volume) . . . . . . . . . . 3-12

3.1.1-11. Gas Sampling Results-Compositional Analysis (vol\%) $\ldots \ldots \ldots \ldots \ldots$ 3-14

3.1.2-1. Item Description Code 003 Container Information $\ldots \ldots \ldots \ldots \ldots \ldots$ 3-16

3.1.2-2. Item Description Code 003 Dose Information $\ldots \ldots \ldots \ldots \ldots \ldots \ldots \ldots$

3.1.2-3. Item Description Code 003 Assay Information $\ldots \ldots \ldots \ldots \ldots \ldots \ldots$ 3-17

3.1.2-4. Waste Form Evaluation $\ldots \ldots \ldots \ldots \ldots \ldots \ldots \ldots \ldots \ldots \ldots \ldots \ldots \ldots$

3.1.2-5. TRUPACT Evaluation $\ldots \ldots \ldots \ldots \ldots \ldots \ldots \ldots \ldots \ldots \ldots \ldots \ldots \ldots$

3.1.2-6. Item Description Code 003 Data Summary for Combustible

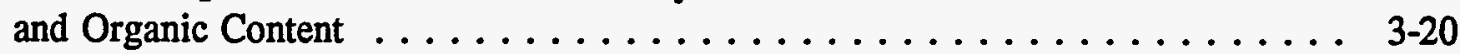

3.1.2-7. Analytical Results for Solidified Organics $\ldots \ldots \ldots \ldots \ldots \ldots \ldots \ldots$. $\ldots \ldots$. . . .

3.1.2-8 Gas Sampling Results-Compositional Analysis (vol\%) $\ldots \ldots \ldots \ldots \ldots$ 3-22

3.1.3-1. Item Description Code 292 Container Information $\ldots \ldots \ldots \ldots \ldots \ldots$ 3-25

3.1.3-2. Item Description Code 292 Dose Information . . . . . . . . . . . . . 3-25

3.1.3-3. Item Description Code 292 Assay Information $\ldots \ldots \ldots \ldots \ldots \ldots \ldots . . \ldots \ldots$

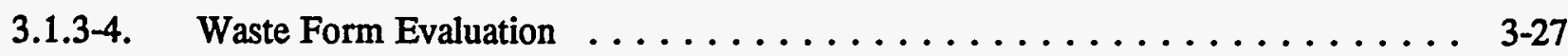

3.1.3-5. TRUPACT Evaluation $\ldots \ldots \ldots \ldots \ldots \ldots \ldots \ldots \ldots \ldots \ldots \ldots \ldots \ldots \ldots \ldots \ldots .28$

3.1.3-6. Item Description Code 292 Data Summary for Combustible and Organic Content ........................ 3-29

3.1.3-7. Gas Mass Spectrometry Results (vol\%) $\ldots \ldots \ldots \ldots \ldots \ldots \ldots$ 3-30

3.1.3-8. Gas Sampling Results-Compositional Analysis (vol\%) $\ldots \ldots \ldots \ldots \ldots$ 3-31

3.1.4-1. Item Description Code 393 Container Information $\ldots \ldots \ldots \ldots \ldots \ldots$ 3-33

3.1.4-2. Item Description Code 393 Dose Information $\ldots \ldots \ldots \ldots \ldots \ldots \ldots \ldots$

3.1.4-3. Item Description Code 393 Assay Information $\ldots \ldots \ldots \ldots \ldots \ldots \ldots \ldots$ 3-34

3.1.4-4. Waste Form Evaluation $\ldots \ldots \ldots \ldots \ldots \ldots \ldots \ldots \ldots \ldots \ldots \ldots \ldots \ldots$ 
3.1.4-5. TRUPACT Evaluation $\ldots \ldots \ldots \ldots \ldots \ldots \ldots \ldots \ldots \ldots \ldots \ldots \ldots \ldots$

3.1.5-1. Item Description Code 409 Container Information . . . . . . . . . 3-39

3.1.5-2. Item Description Code 409 Dose Information . . . . . . . . . . . 39

3.1.5-3. Item Description Code 409 Assay Information $\ldots \ldots \ldots \ldots \ldots \ldots . .40$

3.1.5-4. Waste Form Evaluation $\ldots \ldots \ldots \ldots \ldots \ldots \ldots \ldots \ldots \ldots \ldots \ldots \ldots .4 .41$

3.1.5-5. TRUPACT Evaluation $\ldots \ldots \ldots \ldots \ldots \ldots \ldots \ldots \ldots \ldots \ldots \ldots \ldots \ldots \ldots .42$

3.1.5-6. Item Description Code 409 Data Summary for Combustible and Organic Content $\ldots \ldots \ldots \ldots \ldots \ldots \ldots \ldots \ldots \ldots \ldots \ldots \ldots \ldots \ldots \ldots \ldots$

3.1.5-7. Gas Sampling Results-Compositional Analysis (vol\%) $\ldots \ldots \ldots \ldots \ldots$ 3-44

3.1.6-1. Item Description Code 414 Container Information $\ldots \ldots \ldots \ldots \ldots \ldots$ 3-46

3.1.6-2. Item Description Code 414 Dose Information $\ldots \ldots \ldots \ldots \ldots \ldots \ldots \ldots$

3.1.6-3. Item Description Code 414 Assay Information $\ldots \ldots \ldots \ldots \ldots \ldots \ldots$ 3-47

3.1.6-4. Waste Form Evaluation $\ldots \ldots \ldots \ldots \ldots \ldots \ldots \ldots \ldots \ldots \ldots \ldots \ldots$

3.1.6-5. TRUPACT Evaluation $\ldots \ldots \ldots \ldots \ldots \ldots \ldots \ldots \ldots \ldots \ldots \ldots \ldots \ldots \ldots$

3.1.6-6. Item Description Code 414 Data Summary for Combustible and Organic Content ........................... 3-50

3.1.6-7. Gas Sampling Results-Compositional Analysis (vol\%) $\ldots \ldots \ldots \ldots \ldots$ 3-51

3.1.7-1. Item Description Code 422 Container Information $\ldots \ldots \ldots \ldots \ldots \ldots \ldots$

3.1.7-2. Item Description Code 422 Dose Information $\ldots \ldots \ldots \ldots \ldots \ldots \ldots \ldots$ 3-53

3.1.7-3. Item Description Code 422 Assay Information $\ldots \ldots \ldots \ldots \ldots \ldots \ldots . \ldots \ldots$

3.1.7-4. Waste Form Evaluation $\ldots \ldots \ldots \ldots \ldots \ldots \ldots \ldots \ldots \ldots \ldots \ldots \ldots$

3.1.7-5. TRUPACT Evaluation $\ldots \ldots \ldots \ldots \ldots \ldots \ldots \ldots \ldots \ldots \ldots \ldots \ldots \ldots \ldots \ldots$

3.1.8-1. Item Description Code 432 Container Information $\ldots \ldots \ldots \ldots \ldots \ldots$ 3-59

3.1.8-2. Item Description Code 432 Dose Information $\ldots \ldots \ldots \ldots \ldots \ldots \ldots$ 3-59

3.1.8-3. Item Description Code 432 Assay Information $\ldots \ldots \ldots \ldots \ldots \ldots \ldots$ 
3.1.8-4. Waste Form Evaluation $\ldots \ldots \ldots \ldots \ldots \ldots \ldots \ldots \ldots \ldots \ldots \ldots$ 3-61

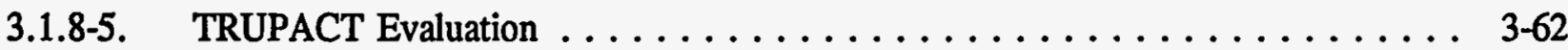

3.1.8-6. Item Description Code 432 Data Summary for Combustible and Organic

Content ........................... 3-63

3.1.8-7. Gas Sampling Results-Compositional Analysis (vol\%) $\ldots \ldots \ldots \ldots \ldots$ 3-65

3.2.1-1. Item Description Code 007 Container Information $\ldots \ldots \ldots \ldots \ldots \ldots$ 3-67

3.2.1-2. Item Description Code 007 Dose Information $\ldots \ldots \ldots \ldots \ldots \ldots \ldots$

3.2.1-3. Item Description Code 007 Assay Information $\ldots \ldots \ldots \ldots \ldots \ldots \ldots$ 3-68

3.2.1-4. Waste Form Evaluation $\ldots \ldots \ldots \ldots \ldots \ldots \ldots \ldots \ldots \ldots$ 3-69

3.2.1-5. TRUPACT Evaluation $\ldots \ldots \ldots \ldots \ldots \ldots \ldots \ldots \ldots \ldots \ldots \ldots \ldots \ldots \ldots$

3.2.1-6. Item Description Code 007 Data Summary for Combustible

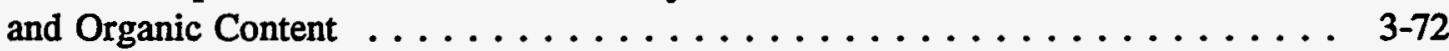

3.2.1-7. Analytical Data Summary $\ldots \ldots \ldots \ldots \ldots \ldots \ldots \ldots \ldots \ldots \ldots \ldots$

3.2.1-8. Gas Mass Spectrometry Results (vol\%) $\ldots \ldots \ldots \ldots \ldots \ldots \ldots \ldots \ldots$ 3-74

3.2.1-9. Volatile Organic Compound Gas Chromatography/Mass

Spectrometry Results (parts per million by volume) . . . . . . . . . 3-75

3.2.1-10. Volatile Organic Compound Gas Chromatography/Mass

Spectrometry Results (parts per million by volume) $\ldots \ldots \ldots \ldots \ldots \ldots \ldots$ 3-75

3.2.1-11. Gas Sampling Results-Compositional Analysis (vol\%) $\ldots \ldots \ldots \ldots \ldots$ 3-76

3.2.2-1. Item Description Code 800 Container Information $\ldots \ldots \ldots \ldots \ldots \ldots$ 3-78

3.2.2-2. Item Description Code 800 Dose Information . . . . . . . . . . . 3-79

3.2.2-3. Item Description Code 800 Assay Information $\ldots \ldots \ldots \ldots \ldots \ldots \ldots$ 3-79

3.2.2-4. Waste Form Evaluation $\ldots \ldots \ldots \ldots \ldots \ldots \ldots \ldots \ldots \ldots \ldots \ldots$ 3-80

3.2.2-5. TRUPACT Evaluation $\ldots \ldots \ldots \ldots \ldots \ldots \ldots \ldots \ldots \ldots \ldots \ldots \ldots$

3.2.2-6. Analytical Results for Sample of Building 774
Aqueous Sludge Sample $\ldots \ldots \ldots \ldots \ldots \ldots \ldots \ldots \ldots \ldots \ldots \ldots \ldots$ 
3.2.2-7. Analytical and Calculated Results Summary from Drum

Headspace Analyses . . . . . . . . . . . . . . . . . . . . . 3-83

3.2.2-8. Gas Mass Spectrometry Results (vol\%) $\ldots \ldots \ldots \ldots \ldots \ldots \ldots \ldots \ldots$ 3-84

3.2.2-9. Volatile Organic Compound Gas Chromatography/Mass

Spectrometry Results (parts per million by volume) . . . . . . . . . . 3-87

3.2.2-10. Volatile Organic Compound Gas Chromatography/Mass

Spectrometry Results (parts per million by volume) . . . . . . . . . 3-88

3.2.2-11. Volatile Organic Compound Gas Chromatography/Mass

Spectrometry Results (parts per million by volume) . . . . . . . . . . 3-89

3.2.3-1. Item Description Code 803 Container Information $\ldots \ldots \ldots \ldots \ldots \ldots . . \ldots 3$

3.2.3-2. Item Description Code 803 Dose Information . . . . . . . . . . . . . . 3-93

3.2.3-3. Item Description Code 803 Assay Information . . . . . . . . . . . . . . . 3-94

3.2.3-4. Waste Form Evaluation $\ldots \ldots \ldots \ldots \ldots \ldots \ldots \ldots \ldots \ldots \ldots$ 3-95

3.2.3-5. TRUPACT Evaluation $\ldots \ldots \ldots \ldots \ldots \ldots \ldots \ldots \ldots \ldots \ldots \ldots \ldots \ldots$ 3-96

3.2.3-6. Analytical Data Summary $\ldots \ldots \ldots \ldots \ldots \ldots \ldots \ldots \ldots \ldots \ldots . \ldots \ldots$

3.2.3-7. Gas Mass Spectrometry Results (vol\%) $\ldots \ldots \ldots \ldots \ldots \ldots \ldots \ldots \ldots$. . . . . . . .

3.2.3-8. Volatile Organic Compound Gas Chromatography/Mass

Spectrometry Results (parts per million by volume) . . . . . . . . . . . 3-100

3.2.3-9. Volatile Organic Compound Gas Chromatography/Mass

Spectrometry Results (parts per million by volume) . . . . . . . . . . 3-101

3.2.4-1. Item Description Code 807 Container Information . . . . . . . . . . . . . 3-103

3.2.4-2. Item Description Code 807 Dose Information . . . . . . . . . . . . 3-104

3.2.4-3. Item Description Code 807 Assay Information . . . . . . . . . . . . . . 3-104

3.2.4-4. Waste Form Evaluation $\ldots \ldots \ldots \ldots \ldots \ldots \ldots \ldots \ldots$. . . . . . . . . . . . . . . .

3.2.4-5. TRUPACT Evaluation $\ldots \ldots \ldots \ldots \ldots \ldots \ldots \ldots \ldots \ldots \ldots \ldots . \ldots \ldots$ 3-106

3.2.4-6. Item Description Code 007 Data Summary for Combustible

and Organic Content . . . . . . . . . . . . . . . . . . 3-107 
3.2.4-7. Analytical Data Summary $\ldots \ldots \ldots \ldots \ldots \ldots \ldots \ldots \ldots \ldots \ldots \ldots \ldots \ldots$

3.2.4-8. Analytical Data Summary $\ldots \ldots \ldots \ldots \ldots \ldots \ldots \ldots \ldots \ldots . \ldots \ldots$. $\ldots \ldots$

3.2.4-9. Volatiles Report (nanograms per gram) $\ldots \ldots \ldots \ldots \ldots \ldots \ldots \ldots \ldots$ 3-110

3.2.4-10. Gas Mass Spectrometry Results (vol\%) $\ldots \ldots \ldots \ldots \ldots \ldots \ldots \ldots \ldots$ 3-111

3.3.1-1. Item Description Code 700 Container Information $\ldots \ldots \ldots \ldots \ldots \ldots$ 3-113

3.3.1-2. Item Description Code 700 Dose Information $\ldots \ldots \ldots \ldots \ldots \ldots \ldots$ 3-114

3.3.1-3. Item Description Code 700 Assay Information $\ldots \ldots \ldots \ldots \ldots \ldots \ldots$ 3-114

3.3.1-4. Waste Form Evaluation $\ldots \ldots \ldots \ldots \ldots \ldots \ldots \ldots \ldots \ldots \ldots \ldots \ldots \ldots \ldots \ldots \ldots .115$

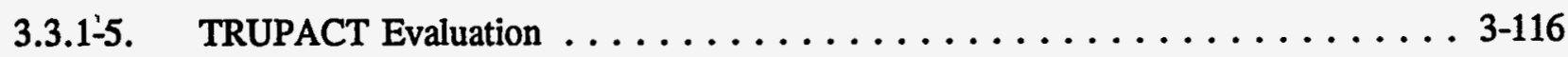

3.3.2-1. Item Description Code 801 Container Information . . . . . . . . . . 3-119

3.3.2-2. Item Description Code 801 Dose Information $\ldots \ldots \ldots \ldots \ldots \ldots \ldots \ldots$ 3-120

3.3.2-3. Item Description Code 801 Assay Information . . . . . . . . . . . . 3-120

3.3.2-4. Waste Form Evaluation $\ldots \ldots \ldots \ldots \ldots \ldots \ldots \ldots \ldots \ldots \ldots \ldots \ldots \ldots \ldots \ldots \ldots .121$

3.3.2-5. TRUPACT Evaluation $\ldots \ldots \ldots \ldots \ldots \ldots \ldots \ldots \ldots \ldots \ldots \ldots \ldots \ldots \ldots \ldots \ldots \ldots .122$

3.3.2-6. Analytical Results for Solidified Organics $\ldots \ldots \ldots \ldots \ldots \ldots \ldots \ldots \ldots$ 3-123

3.3.2-7. Gas Mass Spectrometry Results (vol\%) $\ldots \ldots \ldots \ldots \ldots \ldots \ldots \ldots$ 3-124

3.3.2-8. Volatile Organic Compound Gas Chromatography/Mass

Spectrometry Results (parts per million by volume) $\ldots \ldots \ldots \ldots \ldots \ldots \ldots$ 3-126

3.3.2-9. Volatile Organic Compound Gas Chromatography/Mass Spectrometry Results

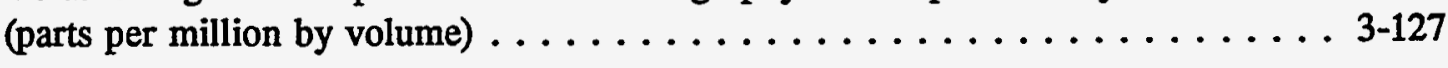

3.3.2-10. Volatile Organic Compound Gas Chromatography/Mass Spectrometry Results (parts per million by volume) $\ldots \ldots \ldots \ldots \ldots \ldots \ldots \ldots \ldots \ldots \ldots$ 3-129

3.4.1-1. Item Description Code 802 Container Information $\ldots \ldots \ldots \ldots \ldots \ldots \ldots$ 3-131

3.4.1-2. Item Description Code 802 Dose Information $\ldots \ldots \ldots \ldots \ldots \ldots \ldots \ldots$ 3-132

3.4.1-3. Item Description Code 802 Assay Information. . . . . . . . . . 3-132 
3.4.1-4. Waste Form Evaluation $\ldots \ldots \ldots \ldots \ldots \ldots \ldots \ldots \ldots \ldots \ldots \ldots \ldots \ldots \ldots .133$

3.4.1-5. TRUPACT Evaluation $\ldots \ldots \ldots \ldots \ldots \ldots \ldots \ldots \ldots \ldots \ldots \ldots \ldots \ldots \ldots \ldots \ldots .134$

3.5.1-1. Item Description Code 806 Container Information . . . . . . . . . . 3-137

3.5.1-2. Item Description Code 806 Dose Information . . . . . . . . . . 3-137

3.5.1-3. Item Description Code 806 Assay Information $\ldots \ldots \ldots \ldots \ldots \ldots \ldots$ 3-138

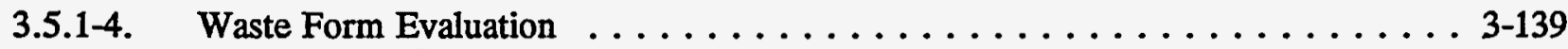

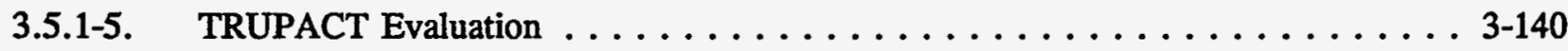

3.5.2-1. Item Description Code 817 Container Information $\ldots \ldots \ldots \ldots \ldots \ldots$ 3-143

3.5.2-2. Item Description Code 817 Dose Information $\ldots \ldots \ldots \ldots \ldots \ldots \ldots \ldots$ 3-143

3.5.2-3. Item Description Code 817 Assay Information $\ldots \ldots \ldots \ldots \ldots \ldots \ldots$. $3-144$

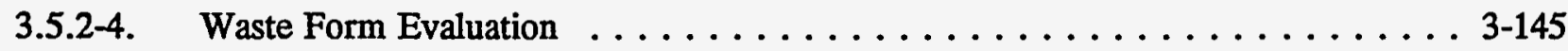

3.5.2-5. TRUPACT Evaluation $\ldots \ldots \ldots \ldots \ldots \ldots \ldots \ldots \ldots \ldots \ldots \ldots \ldots \ldots \ldots \ldots$ 3-146

3.5.3-1. Item Description Code 818 Container Information $\ldots \ldots \ldots \ldots \ldots \ldots$ 3-149

3.5.3-2. Item Description Code 818 Dose Information $\ldots \ldots \ldots \ldots \ldots \ldots \ldots$ 3-149

3.5.3-3. Item Description Code 818 Assay Information $\ldots \ldots \ldots \ldots \ldots \ldots \ldots \ldots$ 3-150

3.5.3-4. Waste Form Evaluation $\ldots \ldots \ldots \ldots \ldots \ldots \ldots \ldots \ldots \ldots \ldots \ldots \ldots \ldots \ldots \ldots .151$

3.5.3-5. TRUPACT Evaluation $\ldots \ldots \ldots \ldots \ldots \ldots \ldots \ldots \ldots \ldots \ldots \ldots \ldots \ldots \ldots$ 3-152

3.5.4-1. Item Description Code 820 Container Information $\ldots \ldots \ldots \ldots \ldots \ldots$ 3-155

3.5.4-2. Item Description Code 820 Dose Information $\ldots \ldots \ldots \ldots \ldots \ldots \ldots \ldots$ 3-155

3.5.4-3. Item Description Code 820 Assay Information $\ldots \ldots \ldots \ldots \ldots \ldots \ldots$ 3-156

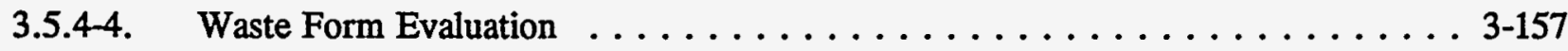

3.5.4-5. TRUPACT Evaluation $\ldots \ldots \ldots \ldots \ldots \ldots \ldots \ldots \ldots \ldots \ldots \ldots \ldots \ldots \ldots$

3.5.5-1. Item Description Code 823 Container Information . . . . . . . . . . 3-161

3.5.5-2. Item Description Code 823 Dose Information . . . . . . . . . . . 3-161 
3.5.5-3. Item Description Code 823 Assay Information $\ldots \ldots \ldots \ldots \ldots \ldots \ldots$ 3-162

3.5.5-4. Waste Form Evaluation $\ldots \ldots \ldots \ldots \ldots \ldots \ldots \ldots \ldots \ldots \ldots \ldots \ldots \ldots$

3.5.5-5. TRUPACT Evaluation $\ldots \ldots \ldots \ldots \ldots \ldots \ldots \ldots \ldots \ldots \ldots \ldots \ldots . \ldots \ldots$. . . . . . . . . . . .

3.6.1-1. Item Description Code 300 Container Information $\ldots \ldots \ldots \ldots \ldots \ldots$ 3-167

3.6.1-2. Item Description Code 300 Dose Information . . . . . . . . . . . 3-167

3.6.1-3. Item Description Code 300 Assay Information $\ldots \ldots \ldots \ldots \ldots \ldots$ 3-168

3.6.1-4. Waste Form Evaluation $\ldots \ldots \ldots \ldots \ldots \ldots \ldots \ldots \ldots \ldots \ldots . .6 \ldots \ldots$

3.6.1-5. TRUPACT Evaluation $\ldots \ldots \ldots \ldots \ldots \ldots \ldots \ldots \ldots \ldots \ldots \ldots \ldots \ldots \ldots \ldots \ldots \ldots .170$

3.6.1-6. Item Description Code 300 Data Summary for Combustible

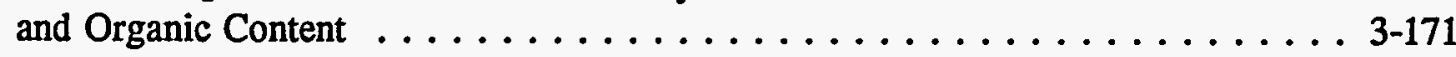

3.6.1-7. Gas Sampling Results-Compositional Analysis (vol\%). . . . . . . . . . 3-173

3.6.2-1. Item Description Code 303 Container Information . . . . . . . . 3-175

3.6.2-2. Item Description Code 303 Dose Information $\ldots \ldots \ldots \ldots \ldots \ldots \ldots$ 3-175

3.6.2-3. Item Description Code 303 Assay Information $\ldots \ldots \ldots \ldots \ldots \ldots \ldots$ 3-176

3.6.2-4. Waste Form Evaluation $\ldots \ldots \ldots \ldots \ldots \ldots \ldots \ldots \ldots \ldots \ldots \ldots \ldots \ldots \ldots .177$

3.6.2-5. TRUPACT Evaluation $\ldots \ldots \ldots \ldots \ldots \ldots \ldots \ldots \ldots \ldots \ldots \ldots \ldots \ldots \ldots \ldots .178$

3.7.1-1. Item Description Code 330 Container Information $\ldots \ldots \ldots \ldots \ldots \ldots$ 3-181

3.7.1-2. Item Description Code 330 Dose Information $\ldots \ldots \ldots \ldots \ldots \ldots \ldots \ldots$ 3-182

3.7.1-3. Item Description Code 330 Assay Information $\ldots \ldots \ldots \ldots \ldots \ldots$ 3-183

3.7.1-4. Waste Form Evaluation $\ldots \ldots \ldots \ldots \ldots \ldots \ldots \ldots \ldots \ldots \ldots \ldots \ldots \ldots \ldots \ldots .184$

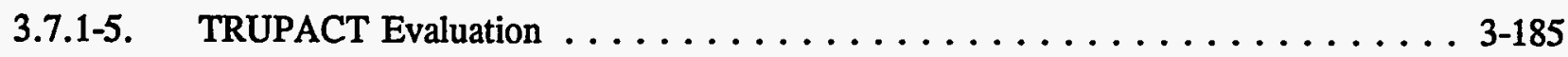

3.7.1-6. Item Description Code 330 Data Summary for Combustible

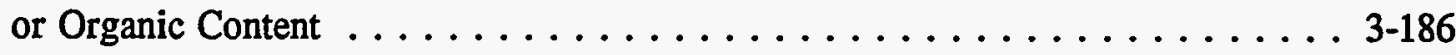

3.7.1-7. Gas Sampling Results-Compositional Analysis (vol\%) $\ldots \ldots \ldots \ldots \ldots$ 3-188

3.7.2-1. Item Description Code 336 Container Information $\ldots \ldots \ldots \ldots \ldots \ldots$ 3-190 
3.7.2-2. Item Description Code 336 Dose Information . . . . . . . . . . . . . 3-191

3.7.2-3. Item Description Code 336 Assay Information . . . . . . . . . . . . 3-192

3.7.2-4. Waste Form Evaluation $\ldots \ldots \ldots \ldots \ldots \ldots \ldots \ldots \ldots \ldots \ldots \ldots \ldots \ldots \ldots$

3.7.2-5. TRUPACT Evaluation $\ldots \ldots \ldots \ldots \ldots \ldots \ldots \ldots \ldots \ldots \ldots \ldots \ldots \ldots \ldots \ldots .194$

3.7.2-6. Item Description Code 336 Data Summary for Combustible

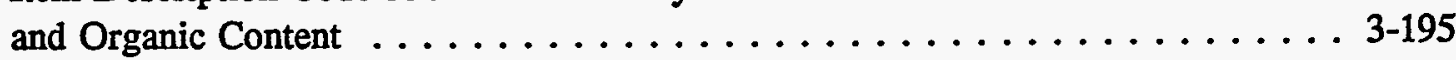

3.7.2-7. Gas Mass Spectrometry Results (vol\%). . . . . . . . . . . . 3-196

3.7.2-8. Gas Sampling Results-Compositional Analysis (vol\%). . . . . . . . . . 3-197

3.7.3-1. Item Description Code 337 Container Information . . . . . . . . . . . 3-199

3.7.3-2. Item Description Code 337 Dose Information . . . . . . . . . . . . 3-200

3.7.3-3. Item Description Code 337 Assay Information $\ldots \ldots \ldots \ldots \ldots \ldots \ldots \ldots$

3.7.3-4. Waste Form Evaluation $\ldots \ldots \ldots \ldots \ldots \ldots \ldots \ldots \ldots \ldots$. . . . . . . . . . . .

3.7.3-5. TRUPACT Evaluation $\ldots \ldots \ldots \ldots \ldots \ldots \ldots \ldots \ldots \ldots \ldots \ldots \ldots \ldots \ldots \ldots \ldots \ldots .202$

3.7.3-6. Item Description Code 337 Data Summary for Combustible

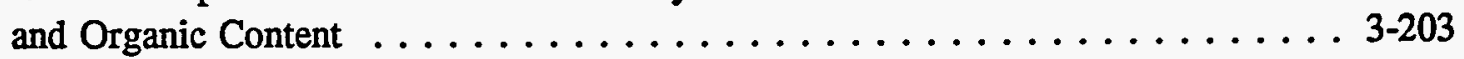

3.7.3-7. Gas Sampling Results-Compositional Analysis (Vol\%) . . . . . . . . . 3-205

3.7.4-1. Item Description Code 491 Container Information $\ldots \ldots \ldots \ldots \ldots \ldots \ldots$ 3-207

3.7.4-2. Item Description Code 491 Dose Information $\ldots \ldots \ldots \ldots \ldots \ldots \ldots \ldots$ 3-208

3.7.4-3. Item Description Code 491 Assay Information $\ldots \ldots \ldots \ldots \ldots \ldots \ldots \ldots$ 3-208

3.7.4-4. Waste Form Evaluation. . . . . . . . . . . . . . . . . . 3-209

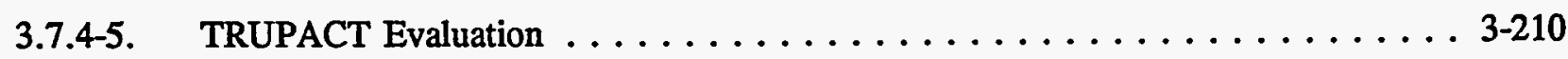

3.7.5-1. Item Description Code 831 Container Information $\ldots \ldots \ldots \ldots \ldots \ldots \ldots$ 3-213

3.7.5-2. Item Description Code 831 Dose Information $\ldots \ldots \ldots \ldots \ldots \ldots \ldots \ldots \ldots$ 3-214

3.7.5-3. Item Description Code 831 Assay Information $\ldots \ldots \ldots \ldots \ldots \ldots \ldots \ldots .214$

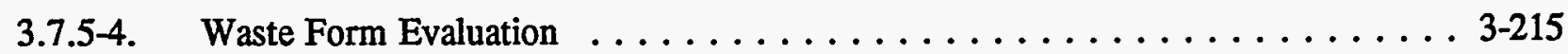


3.7.5-5. TRUPACT Evaluation $\ldots \ldots \ldots \ldots \ldots \ldots \ldots \ldots \ldots \ldots \ldots \ldots \ldots \ldots \ldots \ldots \ldots \ldots$

3.7.5-6. Gas Mass Spectrometry Results (vol\%) $\ldots \ldots \ldots \ldots \ldots \ldots \ldots \ldots \ldots$ 3-218

3.7.5-7. Volatile Organic Compound Gas Chromatography/Mass

Spectrometry Results (parts per million by volume) . . . . . . . . 3-220

3.7.5-8. Volatile Organic Compound Gas Chromatography/Mass

Spectrometry Results (parts per million by volume) . . . . . . . . 3-221

3.7.5-9. Volatile Organic Compound Gas Chromatography/Mass

Spectrometry Results (parts per million by volume) . . . . . . . . 3-223

3.7.6-1. Item Description Code 832 Container Information . . . . . . . . . . . 3-225

3.7.6-2. Item Description Code 832 Dose Information $\ldots \ldots \ldots \ldots \ldots \ldots \ldots \ldots$

3.7.6-3. Item Description Code 832 Assay Information $\ldots \ldots \ldots \ldots \ldots \ldots \ldots \ldots .3-226$

3.7.6-4. Waste Form Evaluation $\ldots \ldots \ldots \ldots \ldots \ldots \ldots \ldots \ldots \ldots \ldots \ldots \ldots \ldots \ldots \ldots \ldots .227$

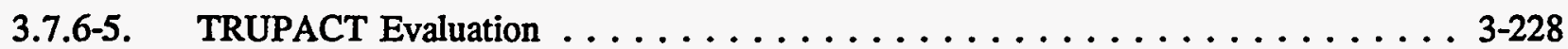

3.7.6-6. Gas Mass Spectrometry Results (vol\%) $\ldots \ldots \ldots \ldots \ldots \ldots \ldots \ldots \ldots$ 3-230

3.7.6-7. VOC Gas Chromatography/Mass Spectrometry Results

(parts per million by volume) $\ldots \ldots \ldots \ldots \ldots \ldots \ldots \ldots \ldots \ldots \ldots \ldots \ldots \ldots \ldots, 231$

3.7.6-8. VOC Gas Chromatography/Mass Spectrometry Results $\ldots \ldots \ldots \ldots \ldots$ 3-231

3.7.6-9. VOC Gas Chromatography/Mass Spectrometry Results (ppmv) $\ldots \ldots \ldots \ldots$ 3-232

3.7.7-1. Item Description Code 833 Container Information $\ldots \ldots \ldots \ldots \ldots \ldots . . \ldots$ 3-234

3.7.7-2. Item Description Code 833 Dose Information $\ldots \ldots \ldots \ldots \ldots \ldots \ldots \ldots$ 3-235

3.7.7-3. Item Description Code 833 Assay Information $\ldots \ldots \ldots \ldots \ldots \ldots \ldots \ldots$

3.7.7-4. Waste Form Evaluation $\ldots \ldots \ldots \ldots \ldots \ldots \ldots \ldots \ldots \ldots \ldots \ldots \ldots \ldots \ldots \ldots \ldots$

3.7.7-5. TRUPACT Evaluation $\ldots \ldots \ldots \ldots \ldots \ldots \ldots \ldots \ldots \ldots \ldots \ldots \ldots \ldots \ldots \ldots .237$

3.7.7-6. Gas Mass Spectrometry Results (vol\%) . . . . . . . . . . . . 3-239

3.7.7-7. Volatile Organic Compound Gas Chromatography/Mass Spectrometry

Results (parts per million by volume) $\ldots \ldots \ldots \ldots \ldots \ldots \ldots \ldots \ldots \ldots .3-240$ 
3.7.7-8. Volatile Organic Compound Gas Chromatography/Mass Spectrometry

Results (parts per million by volume) . . . . . . . . . . . . . . . 3-241

3.8.1-1. Item Description Code 320 Container Information . . . . . . . . . . . . 3-243

3.8.1-2. Item Description Code 320 Dose Information . . . . . . . . . . . . . . 3-244

3.8.1-3. Item Description Code 320 Assay Information . . . . . . . . . . . . . . . 3-244

3.8.1-4. Waste Form Evaluation $\ldots \ldots \ldots \ldots \ldots \ldots \ldots \ldots \ldots \ldots \ldots \ldots$

3.8.1-5. TRUPACT Evaluation . . . . . . . . . . . . . . . . 3-246

3.8.1-6. IDC 320 Data Summary for Combustible and Organic Content . . . . . . . . . 3-247

3.8.1-7. Gas Sampling Results-Compositional Analysis (vol\%) $\ldots \ldots \ldots$. . . . . . 3-249

3.8.2-1. Item Description Code 321 Container Information . . . . . . . . . . . 3-251

3.8.2-2. Item Description Code 321 Dose Information . . . . . . . . . . . . . 3-252

3.8.2-3. Item Description Code 321 Assay Information . . . . . . . . . . . . . . 3-252

3.8.2-4. Waste Form Evaluation $\ldots \ldots \ldots \ldots \ldots \ldots \ldots \ldots \ldots \ldots$

3.8.2-5. TRUPACT Evaluation . . . . . . . . . . . . . . . . . 3-254

3.8.2-6. Item Description Code 321 Analytical Data Summary . . . . . . . . . . 3-255

3.8.2-7. Gas Mass Spectrometry Results (vol\%) $\ldots \ldots \ldots \ldots \ldots \ldots \ldots \ldots$

3.8.3-1. Item Description Code 480 Container Information . . . . . . . . . . . . 3-257

3.8.3-2. Item Description Code 480 Dose Information $\ldots \ldots \ldots \ldots \ldots \ldots$. . . . . . . . . . .

3.8.3-3. Item Description Code 480 Assay Information $\ldots \ldots \ldots \ldots \ldots$. . . . . . . . . . .

3.8.3-4. Waste Form Evaluation $\ldots \ldots \ldots \ldots \ldots \ldots \ldots$. . . . . . . . . . 3-260

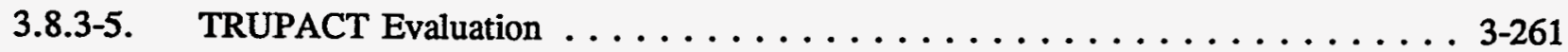

3.8.3-6. Item Description Code 480 Data Summary for Combustible and Organic Content ............................ 3-262

3.8.3-7. Gas Mass Spectrometry Results (vol\%) . . . . . . . . . . . . . 3-265

3.8.3-8. Volatile Organic Compound Gas Chromatography/Mass Spectrometry 
Results (parts per million by volume) $\ldots \ldots \ldots \ldots \ldots \ldots \ldots \ldots \ldots$ 3-266

3.8.3-9. Volatile Organic Compound Gas Chromatography/Mass Spectrometry

Results (parts per million by volume) . . . . . . . . . . . . . 3-267

3.8.3-10. Volatile Organic Compound Gas Chromatography/Mass Spectrometry

Results (parts per million by volume) $\ldots \ldots \ldots \ldots \ldots \ldots \ldots \ldots \ldots \ldots \ldots \ldots$

3.8.3-11. Gas Sampling Results-Compositional Analysis (vol\%) . . . . . . . . . . 3-269

3.8.4-1. Item Description Code 481 Container Information $\ldots \ldots \ldots \ldots \ldots \ldots$ 3-271

3.8.4-2. Item Description Code 481 Dose Information $\ldots \ldots \ldots \ldots \ldots \ldots \ldots$ 3-272

3.8.4-3. Item Description Code 481 Assay Information $\ldots \ldots \ldots \ldots \ldots \ldots \ldots \ldots .272$

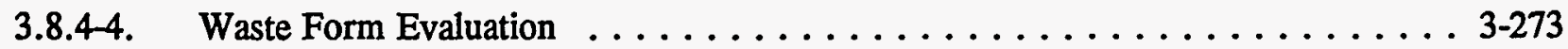

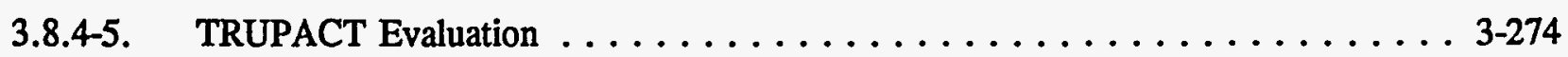

3.8.4-6. Item Description Code 481 Data Summary for Combustible and Organic

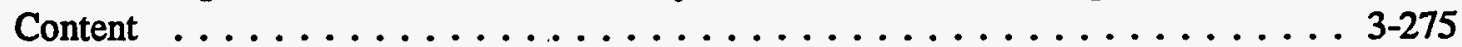

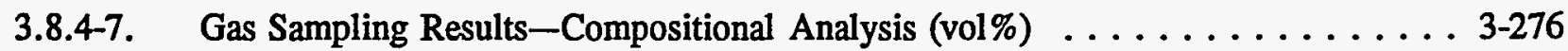

3.8.5-1. Item Description Code 488 Container Information $\ldots \ldots \ldots \ldots \ldots \ldots$ 3-278

3.8.5-2. Item Description Code 488 Dose Information . . . . . . . . . . . 3-279

3.8.5-3. Item Description Code 488 Assay Information . . . . . . . . . . . . 3-279

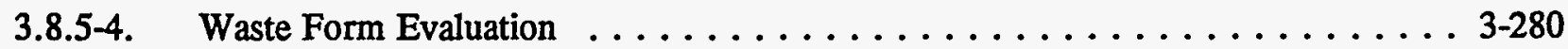

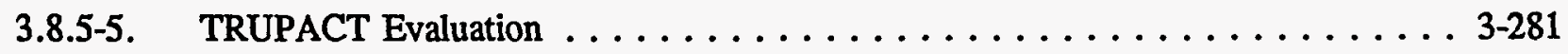

3.9.1-1. Item Description Code 368 Container Information $\ldots \ldots \ldots \ldots \ldots \ldots \ldots$ 3-283

3.9.1-2. Item Description Code 368 Dose Information $\ldots \ldots \ldots \ldots \ldots \ldots \ldots \ldots .283$

3.9.1-3. Item Description Code 368 Assay Information $\ldots \ldots \ldots \ldots \ldots \ldots \ldots \ldots$ 3-284

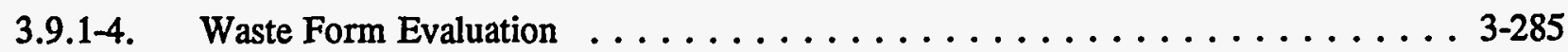

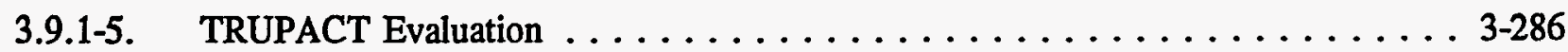

3.9.2-1. Item Description Code 440 Container Information $\ldots \ldots \ldots \ldots \ldots \ldots$ 3-289 
3.9.2-2. Item Description Code 440 Dose Information . . . . . . . . . . . 3-290

3.9.2-3. Item Description Code 440 Assay Information $\ldots \ldots \ldots \ldots \ldots \ldots$. . . . . . . . . .

3.9.2-4. Waste Form Evaluation $\ldots \ldots \ldots \ldots \ldots \ldots \ldots \ldots \ldots \ldots \ldots \ldots \ldots \ldots \ldots \ldots \ldots .291$

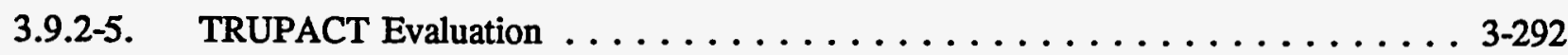

3.9.2-6. Item Description Code 440 Data Summary for Combustible and Organic

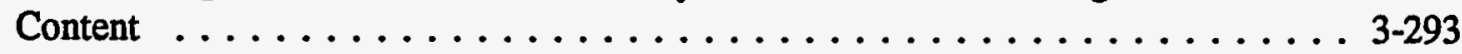

3.9.2-7. Gas Mass Spectrometry Results (vol\%) $\ldots \ldots \ldots \ldots \ldots \ldots \ldots \ldots$ 3-294

3.9.2-8. Gas Sampling Results-Compositional Analysis (vol\%) . . . . . . . . . 3-295

3.9.3-1. Item Description Code 441 Container Information . . . . . . . . . . . 3-297

3.9.3-2. Item Description Code 441 Dose Information . . . . . . . . . . . 3-298

3.9.3-3. Item Description Code 441 Assay Information $\ldots \ldots \ldots \ldots \ldots \ldots \ldots$ 3-298

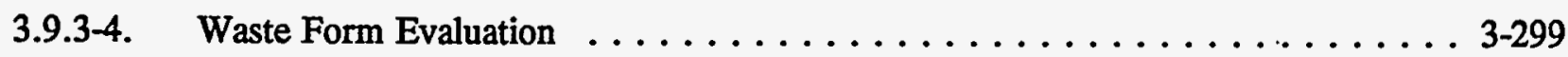

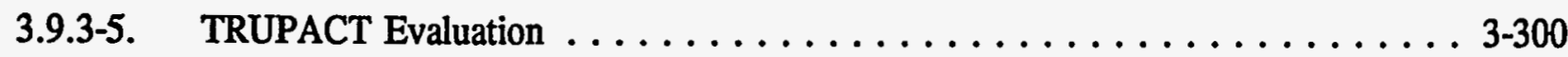

3.9.3-6. Item Description Code 441 Data Summary for Combustible and Organic

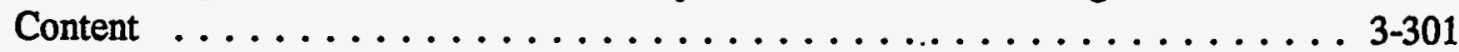

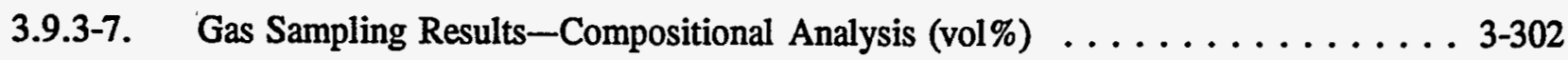

3.9.4-1. Item Description Code 442 Container Information $\ldots \ldots \ldots \ldots \ldots \ldots$ 3-304

3.9.4-2. Item Description Code 442 Dose Information $\ldots \ldots \ldots \ldots \ldots \ldots$ 3-305

3.9.4-3. Item Description Code 442 Assay Information $\ldots \ldots \ldots \ldots \ldots$ 3-305

3.9.4-4. Waste Form Evaluation $\ldots \ldots \ldots \ldots \ldots \ldots \ldots \ldots \ldots \ldots \ldots . . \ldots \ldots$ 3-307

3.9.4-5. TRUPACT Evaluation $\ldots \ldots \ldots \ldots \ldots \ldots \ldots \ldots \ldots \ldots \ldots \ldots \ldots \ldots \ldots .3-308$

3.9.4-6. Item Description Code 442 Data Summary for Combustible and Organic

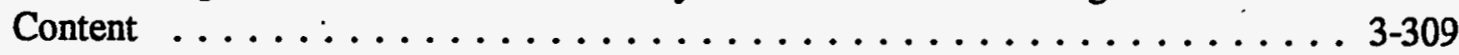

3.9.4-7. Gas Sampling Results-Compositional Analysis (vol\%) $\ldots \ldots \ldots \ldots$. . . . . . .

3.10.1-1. Item Description Code 335 Container Information $\ldots \ldots \ldots \ldots \ldots$ 3-313 
3.10.1-2. Item Description Code 335 Dose Information . . . . . . . . . . . . . 3-314

3.10.1-3. Item Description Code 335 Assay Information $\ldots \ldots \ldots \ldots \ldots \ldots \ldots$ 3-314

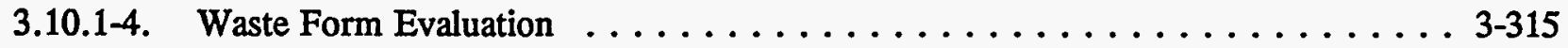

3.10.1-5. TRUPACT Evaluation $\ldots \ldots \ldots \ldots \ldots \ldots \ldots \ldots \ldots \ldots \ldots \ldots \ldots \ldots \ldots \ldots \ldots$

3.10.1-6. Gas Sampling Results-Compositional Analysis (vol\%) $\ldots \ldots \ldots \ldots \ldots \ldots$ 3-318

3.10.2-1. Item Description Code 376 Container Information $\ldots \ldots \ldots \ldots$. . . . . . . . .

3.10.2-2. Item Description Code 376 Dose Information $\ldots \ldots \ldots \ldots \ldots \ldots \ldots \ldots$ 3-320

3.10.2-3. Item Description Code 376 Assay Information $\ldots \ldots \ldots \ldots \ldots \ldots \ldots \ldots$ 3-321

3.10.2-4. Waste Form Evaluation $\ldots \ldots \ldots \ldots \ldots \ldots \ldots \ldots \ldots \ldots \ldots \ldots \ldots \ldots \ldots \ldots \ldots .322$

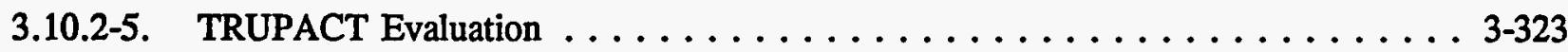

3.10.2-6. Gas Sampling Results-Compositional Analysis (vol\%) $\ldots \ldots \ldots \ldots \ldots$ 3-325

3.10.3-1. Item Description Code 490 Container Information . . . . . . . . . . 3-327

3.10.3-2. Item Description Code 490 Dose Information $\ldots \ldots \ldots \ldots \ldots \ldots \ldots$ 3-328

3.10.3-3. Item Description Code 490 Assay Information $\ldots \ldots \ldots \ldots \ldots \ldots \ldots$ 3-329

3.10.3-4 Waste Form Evaluation $\ldots \ldots \ldots \ldots \ldots \ldots \ldots \ldots \ldots \ldots \ldots \ldots \ldots \ldots \ldots .330 \ldots \ldots$

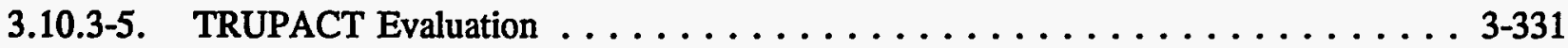

3.11.1-1. Item Description Code 302 Container Information $\ldots \ldots \ldots \ldots \ldots \ldots$ 3-334

3.11.1-2. Item Description Code 302 Dose Information . . . . . . . . . . 3-334

3.11.1-3. Item Description Code 302 Assay Information $\ldots \ldots \ldots \ldots \ldots \ldots \ldots$

3.11.1-4. Waste Form Evaluation $\ldots \ldots \ldots \ldots \ldots \ldots \ldots \ldots \ldots \ldots \ldots \ldots \ldots \ldots . .336$

3.11.1-5. TRUPACT Evaluation $\ldots \ldots \ldots \ldots \ldots \ldots \ldots \ldots \ldots \ldots \ldots \ldots \ldots \ldots \ldots \ldots \ldots \ldots .337$

3.11.1-6. Item Description Code 302 Data Summary for Combustible and Organic Content .............................338

3.11.1-7. Gas Sampling Results-Compositional Analysis (vol\%) $\ldots \ldots \ldots \ldots \ldots \ldots$ 3-340 
3.12.1-1. Item Description Code 371 Container Information $\ldots \ldots \ldots \ldots \ldots \ldots$. . . . . . 341

3.12.1-2. Item Description Code 371 Dose Information . . . . . . . . . . . . . . 3-342

3.12.1-3. Item Description Code 371 Assay Information $\ldots \ldots \ldots \ldots \ldots$. . . . . . . . 3-342

3.12.1-4. Waste Form Evaluation $\ldots \ldots \ldots \ldots \ldots \ldots \ldots \ldots \ldots \ldots \ldots$

3.12.1-5. TRUPACT Evaluation . . . . . . . . . . . . . . . . . . . . 3-344

3.12.1-6. Item Description Code 371 Data Summary for Combustible and Organic

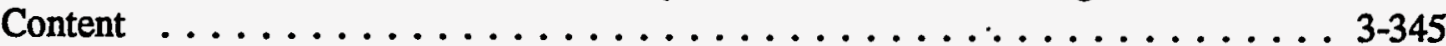

3.12.1-7. Gas Sampling Results-Compositional Analysis (vol\%) $\ldots \ldots \ldots \ldots$. . . . . 3-347

3.12.2-1. Item Description Code 374 Container Information $\ldots \ldots \ldots \ldots \ldots$. . . . . . 348

3.12.2-2. Item Description Code 374 Dose Information . . . . . . . . . . . . . . . . . . 3-349

3.12.2-3. Item Description Code 374 Assay Information . . . . . . . . . . . . 3-349

3.12.2-4. Waste Form Evaluation $\ldots \ldots \ldots \ldots \ldots \ldots \ldots \ldots \ldots \ldots \ldots \ldots$

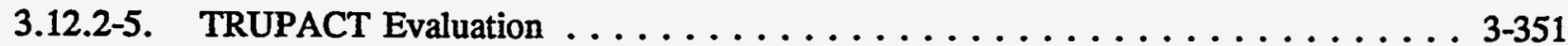

3.12.2-6. Gas Sampling Results-Compositional Analysis (vol\%) . . . . . . . . . . 3-353

3.12.3-1. Item Description Code 377 Container Information $\ldots \ldots \ldots \ldots \ldots \ldots \ldots$

3.12.3-2. Item Description Code 377 Dose Information . . . . . . . . . . . . . . . 3-355

3.12.3-3. Item Description Code 377 Assay Information . . . . . . . . . . . . . 3-355

3.12.3-4. Waste Form Evaluation $\ldots \ldots \ldots \ldots \ldots \ldots \ldots \ldots \ldots \ldots \ldots$

3.12.3-5. TRUPACT Evaluation $\ldots \ldots \ldots \ldots \ldots \ldots \ldots \ldots \ldots \ldots \ldots \ldots$

3.12.3-6. Item Description Code 377 Data Summary for Combustible and Organic

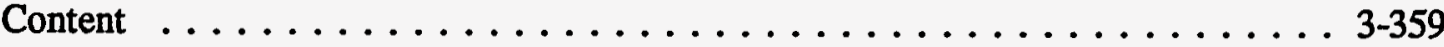

3.12.3-7. Gas Mass Spectrometry Results (vol\%) . . . . . . . . . . . . . . . . . . . 3-360

3.13.1-1. Item Description Code 339 Container Information . . . . . . . . . . . . 3-362

3.13.1-2. Item Description Code 339 Dose Information . . . . . . . . . . . . . . . . . 3-362

3.13.1-3. Item Description Code 339 Assay Information $\ldots \ldots \ldots \ldots \ldots \ldots$. . . . . . . . . 


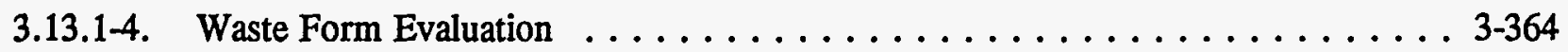

3.13.1-5. TRUPACT Evaluation $\ldots \ldots \ldots \ldots \ldots \ldots \ldots \ldots \ldots \ldots \ldots \ldots \ldots \ldots \ldots \ldots \ldots \ldots$

3.13.1-6. Item Description Code 339 Data Summary for Combustible and Organic

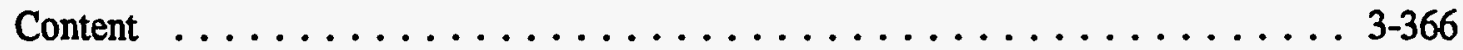

3.13.1-7. Analytical Data Summary $\ldots \ldots \ldots \ldots \ldots \ldots \ldots \ldots \ldots \ldots \ldots$ 3-367

3.13.1-8. Gas Mass Spectrometry Results (vol\%) $\ldots \ldots \ldots \ldots \ldots \ldots \ldots \ldots$ 3-368

3.13.1-9. Volatile Organic Compound Gas Chromatography/Mass Spectrometry Results (parts per million by volume) $\ldots \ldots \ldots \ldots \ldots \ldots \ldots \ldots \ldots$ 3-369

3.13.1-10. Volatile Organic Compound Gas Chromatography/Mass Spectrometry Results (parts per million by volume) . . . . . . . . . . . . . . . .

3.13.1-11. Gas Sampling Results-Compositional Analysis (vol\%) $\ldots \ldots \ldots \ldots \ldots$ 3-370

3.14.1-1. Item Description Code 411 Container Information $\ldots \ldots \ldots \ldots \ldots \ldots .372$

3.14.1-2. Item Description Code 411 Dose Information $\ldots \ldots \ldots \ldots \ldots \ldots \ldots \ldots$ 3-372

3.14.1-3. Item Description Code 411 Assay Information $\ldots \ldots \ldots \ldots \ldots \ldots \ldots$ 3-373

3.14.1-4. Waste Form Evaluation $\ldots \ldots \ldots \ldots \ldots \ldots \ldots \ldots \ldots \ldots \ldots \ldots \ldots \ldots \ldots .374$

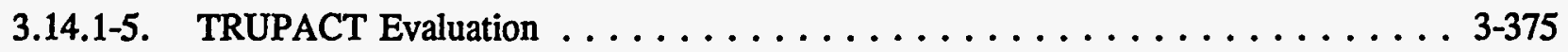

3.15.1-1. Item Description Code 822 Container Information $\ldots \ldots \ldots \ldots \ldots \ldots$ 3-378

3.15.1-2. Item Description Code 822 Dose Information $\ldots \ldots \ldots \ldots \ldots \ldots \ldots \ldots$ 3-378

3.15.1-3. Item Description Code 822 Assay Information $\ldots \ldots \ldots \ldots \ldots \ldots \ldots$ 3-379

3.15.1-4. Waste Form Evaluation $\ldots \ldots \ldots \ldots \ldots \ldots \ldots \ldots \ldots \ldots \ldots \ldots \ldots \ldots \ldots \ldots$

3.15.1-5. TRUPACT Evaluation $\ldots \ldots \ldots \ldots \ldots \ldots \ldots \ldots \ldots \ldots \ldots \ldots \ldots \ldots \ldots \ldots \ldots \ldots .381$ 


\section{Idaho National Engineering Laboratory Code Assessment of the Rocky Flats Transuranic Waste}

\section{INTRODUCTION}

The object of this assessment is to facilitate certification of transuranic wastes shipped from EG\&G Rocky Flats in Golden, Colorado, to the Idaho National Engineering Laboratory (INEL) for shipment to the Waste Isolation Pilot Plant (WIPP). The waste covered by this assessment includes those transuranic wastes shipped from 1985 to 1989 . These dates were chosen because they aligned with the dates covered by the main source of characterization and certification information on this waste, the Rocky Flats Solid Waste Information Management System (SWIMS). This assessment presents a summary of the characterization information applicable to the waste mentioned above, and gives recommendations on what WIPP waste acceptance criteria (WAC) must be addressed by INEL before the waste can be shipped to WIPP.

The key assumptions that underlie this plan are:

- The SWIMS has a complete and accurate record of the waste shipped to INEL from September 1985 through August 1989.

- The analytical data obtained to date are representative of the constituents within the waste.

- The waste form evaluation and Resource Conservation and Recovery Act (RCRA) characterization assume the container contains $100 \%$ of the indicated Item Description Code (IDC), and does not account for the possibility of mixed IDCs.

This document helps provide INEL with the tools it needs to certify the specific wastes mentioned above for shipment to WIPP, and identifies those waste acceptance criteria that are unaddressed at this time regarding these wastes.

Section 2 describes the work that was involved in producing this document. Section 3 describes the waste form information, and is broken down by Waste Form Number sections and by IDC subsections. Appendix A lists the selected references used in compiling the waste form information in this report. Appendix B lists the personnel contacted for additional information and process knowledge regarding these waste forms. Appendix $\mathrm{C}$ shows waste container cross-sections, illustrating the manner in which the various wastes were packaged at Rocky Flats Plant (RFP). Appendix D provides additional source documentation (for example, telephone conversation record sheets) used in the compilation of the information contained in this document. Acronyms and abbreviations used in this document are presented in Appendix E. 


\section{PROJECT DESCRIPTION}

This section describes the information gathered and presented in this document. This information was obtained from several sources, including

- $\quad$ SWIMS

- Rocky Flats personnel interviews

- Rocky Flats Transuranic Waste Certification Program

- Rocky Flats Transuranic Waste Inspection Procedure

- Rocky Flats Backlog Baseline Books

- $\quad$ Rocky Flats Waste Packaging Procedures

- Content Code Assessment for INEL Contact-Handled Stored Transuranic Wastes (Clements 1982)

- Other information pertaining to Rocky Flats transuranic waste generation, packaging, characterization, and similar topics.

The following sections describe the subsections in Section 3 and how the above information was used in this document.

\subsection{Certification Assessment Description}

The information sources were used in determining which of the WIPP WAC are not, or may not, be met by the wastes covered in this document. The main intent of this section is to determine if the waste will require treatment to meet the WIPP WAC. This subsection identifies areas of concern that must be addressed before the waste can be shipped to WIPP. An example of these concerns is the need for replacement of the flow-in ventable drum filters with carbon filters as required by the WIPP WAC.

\subsection{Waste Description Information}

In most cases, this information was taken from Backlog Baseline Books and from the TRU (Transuranic) Waste Compliance Program for WIPP WAC (Rockwell International 1989b). The waste descriptions reflected the years 1985 through 1989 as accurately as possible.

\subsection{Generation Source Information}

In most cases, this information was taken from Backlog Baseline Books and from the TRU Waste Compliance Program for WIPP WAC (Rockwell International 1989b). The waste descriptions reflected the years 1985 through 1989 as accurately as possible. 


\subsection{Recovery Method Information}

This subsection describes the recovery methods for wastes at Rocky Flats for IDCs that were shipped to INEL. Where applicable, this information was taken from Backlog Baseline Books, the Content Code Assessment for INEL Contact-Handled Stored Transuranic Wastes, and Rocky Flats employee interviews.

\subsection{Waste Packaging and Handling Information}

This subsection explains the "flow" of the waste-where it came from and where it is going. This information was taken from those documents and interviews that could provide the best description of the waste packaging and handling. It describes the collection, treatment (if any), and packaging of the waste.

\subsection{Container Preparation Information}

This subsection describes the packaging containers used to contain the waste prior to shipment. This information was taken from those documents and interviews that could provide the best representation of the containers, the requirements regarding those containers, and it provides a table that lists data pertinent to the packaging of that waste form. Where applicable, separate sub-subsections describe the different container preparations that were used in the packaging of this waste. These sub-subsections are "Drum Preparation" and "Box Preparation."

\subsection{Assay Information}

This subsection describes the types and results of any assays that Rocky Flats performed on the waste form. This includes the number of drums evaluated for americium and uranium (this number does not include all of the drums in the inventory for the IDC). Also included are tables showing the relevant assay information in an efficient, easy-to-read format. This information came from interviews of waste generators and assay personnel.

\subsection{Inspection Information}

"Inspection" describes the process that the waste underwent after packaging to ensure that it met the WIPP WAC at that time. Such inspections included visual examination of the waste packages, review of the process documentation, and real-time radiography (RTR). This information was obtained from waste inspection procedures and interviews with waste certification personnel.

\subsection{Waste Form Evaluation Information}

This subsection includes two tables, which describe the evaluation of the waste form and packaging to the current WIPP WAC. Included are evaluations for free liquids, pyrophoric materials, criticality, and gas generation. The information in these tables came from those documents and interviews capable of portraying an accurate representation of the evaluations performed by Rocky Flats personnel. 


\subsection{Combustible and Organic Content Information}

This information was obtained from appropriate documents, process knowledge interviews, and SWIMS data to show the approximate content believed to be in the waste containers.

\subsection{Analytical Information Section}

Where applicable, this section presents the analytical data available on the waste form. The general information is presented in text, listing the types of analyses performed and, in some cases, the results of the analyses. More specific analytical results are presented in the tables that follow the text, if any. The RCRA characterization determined by EG\&G Rocky Flats is also provided. 


\section{IDC ASSESSMENTS}

\subsection{Waste Form Number (no waste form number), Content Code RF 111A (Equivalent)}

\subsubsection{Item Description Code 001-First Stage Sludge, B774}

3.1.1.1 Certification Assessment. This IDC may not be certifiable without further waste treatment due to particulates. The sludge was not mixed with cement and may contain significant amounts of particulates. Assay and thermal power calculations, including error, need to be updated to meet the current WIPP WAC. Several gas generation criteria need to be addressed. Carbon filters may need to be installed, drums will require inspection to identify unvented or unpunctured rigid liners, and headspace gas analysis and visual waste characterization will need to be performed.

3.1.1.2 Waste Description. This waste consists of immobilized materials from aqueous waste treatment operations. A two-stage basic waste treatment, precipitation, and filtration process generates IDC 001 aqueous sludge. Acidic wastes were neutralized with sodium hydroxide in stage one. Ferric sulfate and Purifloc flocculent were added to the neutralized waste (containing metal ions) to precipitate the sludge prior to filtration. In stage two, ferric sulfate, magnesium sulfate, calcium chloride, and Purifloc flocculent were added to basic wastes during the two-stage treatment to precipitate sludge. The sludge slurry from the acidic and basic waste treatment was drawn through diatomite filter media on a rotating drum filter to trap the solids. The filter media and sludge were continuously scraped off the drum filter and fed into a 55-gal drum. Portland cement was added to the bottom of the IDC 001 drum prior to placing the sludge in the drum. In some cases, additional Portland cement was added on top of the sludge (EG\&G RFP 1994c).

3.1.1.3 Generation Source. IDC 001 waste was generated by the high-level aqueous waste treatment system in Building 774. After August 1984 and the start-up of the Building 374 Precipitation Process, only waste piped from Building 771 (steam condensate, scrubber waste, ion column effluent, and process waste sinks), containerized waste from various buildings, and wastes generated within Building 774 (silver recovery effluent, seal liquid, floor washdown) were accepted. IDC 001 was replaced by IDC 800 in 1986 . Building 774 sludge has not been generated since March 1991 (EG\&G RFP 1994c).

3.1.1.4 Recovery Method. This IDC was never generated as a residue and therefore has no recovery method.

3.1.1.5 Waste Packaging and Handling. The drums used were U.S. Department of Transportation (DOT)-17C, white, 55-gal drums. IDC 001 sludge was packaged as shown in Figure C-3. Portland cement was added, as shown, to ensure absorption of any free liquids that may dewater from the sludge. The total quantity of cement added ranged up to 40 or $50 \mathrm{lb}$ (Clements 1982). When the drum was full, the liners were twisted and taped closed, the lid was secured with a bolted ring, the Drum Count label was completed and taped to the drum lid by the generator, and a Tamper Indicating Device (TID) was attached to the drum (Rockwell International 1989b). 
3.1.1.6 Container Preparation. Only approved containers could be used to package TRU waste for shipment offsite. The containers approved for shipment to INEL during this time were DOT-17C, white, 55-gal drums (Rockwell specification SX-200). These containers met the requirements for certification as DOT-7A Type A packaging (Rockwell International 1989e).

Table 3.1.1-1 shows the current inventory of IDC 001 waste containers from the Rocky Flats Plant that have been shipped to INEL since 1985.

Table 3.1.1-1. Item Description Code 001 Container Information.

\begin{tabular}{lrcc}
\multicolumn{1}{c}{ Information } & & Drums & Boxes \\
\hline Total Containers & & 902 & 0 \\
Net Container Weight $(\mathrm{lb})$ & Maximum & 543 & N/A \\
& Minimum & 37 & N/A \\
& Average & 382 & N/A \\
\hline
\end{tabular}

3.1.1.6.1 Drum Preparation-Approved liners for drums of TRU waste packaged for offsite shipment as of 1989 were the round-bottom liner (Rockwell specification SX-203), inside a rigid polyethylene liner (Rockwell specification SX-202), or an O-ring bag and a polyethylene bag placed inside the rigid liner if the drum is attached to a glovebox. All bags were closed using the twist-and-tape method (Rockwell International 1989e).

The IDC 001 sludge mixture was placed in 55-gal drums that were lined with a Type III highdensity polyethylene rigid liner, 14-mil PVC O-ring bag, and a 5-mil polyethylene bag. The polyethylene bag was not required from a waste packaging standpoint, but it aided in contamination control (DOE/WIPP 1992).

Flow-in ventable gaskets were installed in the drums beginning in December 1982. They were used until October 1988, when tubular gaskets with carbon filters were required. Drums shipped to the INEL between 1985 and 1988 may not meet the current WIPP WAC, owing to their lack of carbon filters (Bearly 1989a).

3.1. 1.6.2 Box Preparation-No boxes of IDC 001 waste were shipped to INEL between 1985 and 1989.

3.1.1.7 Assay. The assay was based on the amount of plutonium and americium received in the aqueous waste treatment system for a period of operations, usually one month. The total amount received was divided evenly between the drums of sludge produced over that period of operation. Uranium was not included on the majority of the assays. In some cases, a sample of the sludge from each drum was taken to determine the amount and identity of the radionuclides (plutonium, americium, and uranium) in the sludge. The sludge sample was analyzed using a radiochemical assay. The results of the analysis were expressed in terms of grams of each radionuclide present for each gram of sludge. Containers of waste that have not been Passive-Active Drum Counter (PADC) assayed and had Segmented Gamma Scan (SGS) assay values of 1 gram or less should be PADC assayed to verify that they are transuranic waste. Table 3.1.1-2 summarizes the dose rates measured 
on containers of this IDC. Table 3.1.1-3 provides a summary of the assay information. Americium content was noted in 901 drums. Uranium content was not evaluated.

Table 3.1.1-2. Item Description Code 001 Dose Information.

\begin{tabular}{|c|c|c|c|}
\hline \multicolumn{2}{|l|}{ Information } & \multirow{2}{*}{$\begin{array}{c}\text { Drums } \\
191 \\
711\end{array}$} & \multirow{2}{*}{$\begin{array}{c}\text { Boxes } \\
\text { N/A } \\
\text { N/A }\end{array}$} \\
\hline One Meter Dose Rate (mrem/h) & $\begin{array}{r}0-0.5 \\
0.5-10\end{array}$ & & \\
\hline Surface Dose Rate (mrem/h) & $\begin{array}{r}<10 \\
10-200\end{array}$ & $\begin{array}{l}397 \\
505\end{array}$ & $\begin{array}{l}\text { N/A } \\
\text { N/A }\end{array}$ \\
\hline
\end{tabular}

Table 3.1.1-3. Item Description Code 001 Assay Information.

\begin{tabular}{|c|c|c|c|}
\hline \multicolumn{2}{|c|}{ Radionuclide Inventory } & $\frac{\text { Drums }}{19}$ & $\frac{\text { Boxes }}{\text { N/A }}$ \\
\hline Plutonium (g) & $\begin{array}{r}\text { Maximum } \\
\text { Minimum } \\
\text { Average }\end{array}$ & $\begin{array}{l}19 \\
0 \\
4.2\end{array}$ & $\begin{array}{l}\text { N/A } \\
\text { N/A } \\
\text { N/A }\end{array}$ \\
\hline Americium (g) & $\begin{array}{r}\text { Maximum } \\
\text { Minimum } \\
\text { Average }\end{array}$ & $\begin{array}{l}2.7 \\
0 \\
0.7\end{array}$ & $\begin{array}{l}\text { N/A } \\
\text { N/A } \\
\text { N/A }\end{array}$ \\
\hline Uranium-235 (g) & $\begin{array}{r}\text { Maximum } \\
\text { Minimum } \\
\text { Average }\end{array}$ & $\begin{array}{l}0 \\
0 \\
0\end{array}$ & $\begin{array}{l}\text { N/A } \\
\text { N/A } \\
\text { N/A }\end{array}$ \\
\hline
\end{tabular}

3.1.1.8 Inspection. Waste Certification periodically reviews the process documentation to ensure that the solidification process is being operated according to procedure. This inspection is performed to ensure that free liquids and particulates will not be found in this waste form. In addition to review of process documentation, Waste Certification personnel performed periodic inspections of the generating and packaging process to verify compliance with waste acceptance criteria. Each drum was viewed using RTR to

- Ensure the drum does not contain nonconforming items

- Ensure the drum is properly packaged

- Verify the waste form description

- Evaluate the presence of free liquids.

3.1.1.9 Waste Form Evaluation. Table 3.1.1-4 evaluates the waste form against the WIPP WAC for such items as free liquids, pyrophoric materials, and compressed gases. Table 3.1.1-5 evaluates the waste against Transuranic Package Transporter (TRUPACT) criteria. 
Table 3.1.1-4. Waste Form Evaluation.

Criterion or requirement

Limiting parameters ${ }^{2}$

Immobilization

The amount of particulate material in this waste form will need to be determined. The sludge was not mixed with cement and may contain significant amounts of particulate material.

Liquids

The sludge should meet the free liquid criteria by procedural control and RTR inspection before shipment from Rocky Flats. However, the sludge should be checked for the possibility that the sludge may have dewatered.

Pyrophoric Mate- Pyrophoric materials were prohibited by procedural control. The absence of rials the pyrophoric materials was verified by the generating supervisor and periodic inspection by the Waste Certification Organization.

Explosives and Compressed Gases

Explosives and compressed gases were prohibited by procedural control. The absence of the explosives and compressed gases was verified by the generating supervisor and periodic inspection by the Waste Certification Organization. In addition, unvented, closed containers and pressurized containers were excluded by procedural controls and RTR examination.

TRU-Mixed Wastes The RCRA constituents exist as co-contaminants with the transuranic radionuclides. Compliance with the WIPP RCRA permits and No Migration Determination (NMD) will be required before shipment of the stored waste to WIPP.

Specific Activity of A portion of the waste stored at INEL may contain $<100$ nanocuries per gram Waste transuranic radionuclides.

$\mathrm{Pu}^{239}$ Equivalent None of the IDC 001 waste containers recorded as shipped to INEL in the Activity SWIMS exceed $1,000 \mathrm{Ci}$ of plutonium-equivalent activity.

a. Many of the limiting parameters were taken from TRU Waste Compliance Program (Rockwell International 1983a, 1987e, and 1989b). 
Table 3.1.1-5. TRUPACT Evaluation.

\begin{tabular}{ll}
\hline Criterion or requirement & \multicolumn{1}{c}{ Limiting parameters } \\
\hline Waste Package Weight & $\begin{array}{l}\text { Rocky Flats limited the gross weight of drums to } 800 \mathrm{lb} \text {. The TRUPACT and } \\
\text { vehicle weight limits must be verified at the time of payload assembly at INEL. }\end{array}$ \\
Waste Containers & The solidified sludge was packaged in 55-gal DOT-7A, Type A containers. \\
Nuclear Criticality & $\begin{array}{l}\text { Rocky Flats limited the fissile content of the drums to } 200 \text { grams. However, the } \\
\text { error-times-two requirement was not in place at the time the drums were shipped to } \\
\text { INEL; therefore, it is not reported as part of the assay of the drum. The } \\
\text { TRUPACT limit must be verified at the time of payload assembly at INEL. Based } \\
\text { on the typical assays of the IDC } 001 \text { drums, the criticality criteria will be met but } \\
\text { must be recalculated or assayed to meet the error-times-two requirement. }\end{array}$
\end{tabular}

Surface Dose Rate The surface dose rate criteria used by Rocky Flats was $200 \mathrm{mrem} / \mathrm{hr}$ at the drum surface and $10 \mathrm{mrem} / \mathrm{hr}$ at 1 meter. Lead tape wrapped around the rigid liner may have been used as shielding for two IDC 001 drums. The TRUPACT limit must be verified at the time of payload assembly at INEL. Based on the typical dose rates from the IDC 001 drums, the dose rate criteria will be met.

Removable Surface The Rocky Flats limit for removable contamination (for TRU assumed to be all alpha) was 20 disintegrations per minute $100 \mathrm{~cm}^{2}$. The Rocky Flats limit is equivalent to 9 picocuries per $100 \mathrm{~cm}^{2}$, which is well within the WIPP criteria.

Thermal Power

The thermal power calculation reported in the SWIMS data package is based on the reported assay value without an error/uncertainty correction. The thermal power must be recalculated based on the assay error determination.

Gas Generation

Based on the procedural requirements for packaging IDC 001 waste and the waste description, the only areas of noncompliance are carbon filters, unpunctured rigid liners, headspace gas analysis, and visual characterization.

Benzene and trichloroethylene were detected by headspace analysis in IDC 001 , but are not listed in the TRUPACT Chemical list for RF 111A. 1,1,1-Trichloroethane, methylene chloride, carbon tetrachloride, toluene, ethyl benzene, $m, p-x y l e n e$, and 0 xylene were detected by headspace analysis and are on the TRUPACT Chemical List. These chemicals appear to be in total concentrations $<1 \%$. $1,1,2$-Trichloro1,2,2-trifluoroethane is on the TRUPACT Chemical List for halogenated organics and aromatic hydrocarbons, but was not detected. Alcohols on the TRUPACT Chemical List were not detected.

Personnel performing RTR examination at Rocky Flats would accept up to $10 \%$ of another IDC. The other IDCs could be combustibles, concrete, metal, and plastics.

a. Many of the limiting parameters were taken from TRU Waste Compliance Program (Rockwell International 1983a, 1987e, and 1989b). 
3.1.1.10 Combustible and Organic Content. Table 3.1.1-6 outlines available data from the TRU Waste Sampling Program for IDC 001. SWIMS data indicate that this waste form does not contain $>20 \%$ combustibles or $>20 \%$ organics.

Table 3.1.1-6. Item Description Code 001 Data Summary for Combustible and Organic Content.

\begin{tabular}{|c|c|c|c|c|c|c|}
\hline Container & $\begin{array}{c}\text { Wt. } \\
\text { combustibles } \\
\text { (b) }\end{array}$ & $\begin{array}{l}\text { Wt. } \\
\text { organics } \\
\text { (lb) }\end{array}$ & $\begin{array}{l}\text { Net wt. of } \\
\text { container } \\
\text { (lb) }\end{array}$ & $\begin{array}{c}\text { Wt\% } \\
\text { combustibles }^{d}\end{array}$ & $\begin{array}{c}\text { Vol\% } \\
\text { combustibles }\end{array}$ & $\begin{array}{l}\text { Wt\% } \\
\text { organics }^{\mathrm{f}}\end{array}$ \\
\hline $7412-03121$ & 4.5 & 4.5 & 288.2 & 2 & 2 & 2 \\
\hline $7412-03125$ & 4.5 & 4.5 & 361.1 & 1 & 5 & 1 \\
\hline $7412-03127$ & 4.5 & 4.5 & 279.0 & 2 & 5 & 2 \\
\hline $7412-03128$ & 4.5 & 4.5 & 344.6 & 1 & 5 & 1 \\
\hline $7412-00483$ & 4.5 & 4.5 & 469.5 & 1 & 5 & 1 \\
\hline $7412-00636$ & 5.5 & 5.5 & 400.0 & 1 & 5 & 1 \\
\hline $7412-00766$ & 4.5 & 4.5 & 434.0 & 1 & 5 & 1 \\
\hline $7412-00797$ & 4.5 & 4.5 & 346.75 & 1 & 5 & 1 \\
\hline $741-12404$ & 4.0 & 4.0 & 453.5 & 1 & 5 & 1 \\
\hline $741-12411$ & 4.0 & 4.0 & 311.0 & 1 & 5 & 1 \\
\hline $741-12794$ & 4.0 & 4.0 & 389.0 & 1 & 5 & 1 \\
\hline $741-12847$ & 4.0 & 4.0 & 423.0 & 1 & 5 & 1 \\
\hline $741-12858$ & 4.0 & 4.0 & 433.5 & 1 & 5 & 1 \\
\hline \multicolumn{7}{|c|}{ a. Sum of weights of all combustible material and leaded rubber from Table 25 (Clements and Kudera 1985). } \\
\hline \multicolumn{7}{|c|}{ b. Sum of weights of all combustible material, leaded rubber, and organic material from Table 25 (Clements and Kudera 1985). } \\
\hline \multicolumn{7}{|c|}{ c. Net weight of container from Table 25 (Clements and Kudera 1985). } \\
\hline \multicolumn{7}{|c|}{ d. Weight of combustible material/net weight of container $\times 100$. } \\
\hline \multicolumn{7}{|c|}{ e. Volume percent of combustible material from visual examination, obtained from Appendix B (Clements and Kudera 1985). } \\
\hline \multicolumn{7}{|c|}{ f. Weight of organic material/net weight of container $\times 100$. } \\
\hline
\end{tabular}

3.1.1.10.1 Combustible Content-SWIMS data show that IDC 001 waste is noncombustible (Rockwell International 1985a). In support of the TRU Waste Sampling Program, 13 drums of IDC 001 waste were opened. They were found to contain an average wt\% combustible content of $1.2 \%$. Visual inspection showed an average vol\% combustible content of $10.3 \%$. (Clements and Kudera 1985).

3.1.1.10.2 Organic Content-SWIMS data show that IDC 001 waste may contain 5\% organics (Rockwell International 1985a). In support of the TRU Waste Sampling Program, 13 drums 
of IDC 001 waste were opened. They were found to contain an average wt\% organic content of 1.2\% (Clements and Kudera 1985).

3.1.1.11 Analytical Information. Analytical data from the WIPP Experimental Waste Characterization Program for IDC 001-First Stage Sludge, B774, indicate that 11 drums were subject to headspace gas analysis for Gas Mass Spectrometry and 12 drums for volatile organic compounds (VOC) Gas Chromatography/Mass Spectrometry (EG\&G RFP 1994t).

IDC 001 Gas Mass Spectrometry analytical results are presented in Table 3.1.1-7. Drums were subject to four possible headspace sampling programs: detailed bag, detailed lid, operational lid, and operational bag. Hydrogen, nitrogen, oxygen, argon, and carbon monoxide analytes were detected.

IDC 001 VOC Gas Chromatography/Mass Spectrometry analytical results are presented in Tables 3.1.1-8 through 3.1.1-10. Drums were subject to the four possible headspace sampling programs described above. Unreported analyte values indicate analytes were undetected, or detected at or above the Method Detection Limit (MDL) but at a level below the Program Required Quantitation Limit (PRQL) in these drums.

Analytical results for nine analytes are presented in Table 3.1.1-8. Analytes were detected in 2 of the 12 drums tested. One analyte (methylene chloride) was detected in the drums.

Analytical results for nine analytes are presented in Table 3.1.1-9. Analytes were detected in 10 of the 12 drums tested. Four analytes (1,1,1-trichloroethane, carbon tetrachloride, benzene, and trichloroethene) were detected in the drums.

Analytical results for ten analytes are presented in Table 3.1.1-10. Analytes were detected in 8 of the 12 drums tested. Four analytes (toluene, ethyl-benzene, m,p-xylene, and o-xylene) were detected in the drums.

Analytical data from the TRU Waste Sampling Waste Characterization Program for IDC 001First Stage Sludge, B774, indicate that 13 drums were subject to headspace gas analysis (Clements and Kudera 1985). Gas composition analytical results are presented in Table 3.1.1-11. Waste boxes were not sampled. Hydrogen, oxygen, nitrogen, argon, carbon dioxide, nitrogen oxide(s), saturated hydrocarbons, 1,1,1-trichloroethane, dichloromethane, carbon tetrachloride, and trichloroethylene were detected in the drums.

Information contained in the WSRIC Building 771 Book (EG\&G RFP 1993g) and WSRIC Building 774 Book (EG\&G 1993h) indicate that wastes sent to Building 774 after August 1984 were intermittently contaminated with cadmium (D006), chromium (D007), and silver (D011). It will be assumed that IDC 001 solidified sludge generated after August 1985 exhibits the characteristic of toxicity for these metals until Toxicity Characteristic Leaching Procedure (TCLP) analysis of the waste under EPA SW-846 proves the waste does not exceed toxicity characteristic criteria (EPA 1990). IDC 001 waste generated after August 1985 was not mixed with listed wastes and does not carry listed EPA codes (EG\&G RFP 1994c). 
Table 3.1.1-7. Gas Mass Spectrometry Results (vol\%).

\begin{tabular}{|c|c|c|c|c|c|c|c|c|c|c|c|c|}
\hline \multirow{2}{*}{$\begin{array}{l}\text { Drum } \\
\text { no. }\end{array}$} & \multirow{2}{*}{$\begin{array}{c}\text { Headspace } \\
\text { sample } \\
\text { program }\end{array}$} & \multirow[b]{2}{*}{ Vented } & \multicolumn{10}{|c|}{ Anslytes } \\
\hline & & & $\mathrm{H}_{2}$ & $\mathrm{~N}_{2}$ & $\mathrm{O}_{2}$ & $\mathrm{Ar}$ & $\mathrm{CO}_{2}$ & $\mathrm{co}$ & $\mathrm{CH}_{4}$ & $\mathrm{C}_{2} \mathrm{H}_{6}$ & $\mathrm{C}_{3} \mathrm{H}_{3}$ & No $_{x}$ \\
\hline D70675 & $3 \mathrm{~A}$ & - & - & 77.7 & 21.3 & 25 & - & - & - & - & - & - \\
\hline D71504 & $3 \mathrm{~A}$ & - & - & 77.3 & 21.8 & 0.860 & - & - & - & - & - & - \\
\hline D72127 & $4 A$ & - & - & 76.2 & 22.8 & 0.899 & - & - & - & - & - & - \\
\hline D72127 & $3 \mathrm{~A}$ & - & - & 76.9 & 22.1 & 0.912 & - & - & - & - & - & - \\
\hline D72132 & $3 A$ & - & 0.100 & 79.3 & 19.6 & 0.908 & - & - & - & - & - & - \\
\hline D72136 & $1 \mathrm{~A}$ & $\mathbf{Y}$ & - & 78.2 & 20.8 & 0.924 & - & - & - & - & - & - \\
\hline D72136 & $2 A$ & $\mathbf{Y}$ & - & 78.2 & 20.8 & 0.932 & - & - & - & - & - & - \\
\hline D72136 & $3 \mathrm{~A}$ & - & - & 79.9 & 19.1 & 0.960 & - & 0.030 & - & - & - & - \\
\hline D72619 & $4 A$ & - & - & 77.0 & 22.0 & 0.908 & - & - & - & - & - & - \\
\hline D72619 & $3 A$ & - & - & 77.5 & 21.5 & 0.872 & - & - & - & - & - & - \\
\hline D72631 & $4 \mathrm{~A}$ & - & - & 77.2 & 21.8 & 0.918 & - & - & - & - & - & - \\
\hline D72631 & $3 \mathrm{~A}$ & - & - & 77.2 & 21.8 & 0.918 & - & - & - & - & - & - \\
\hline D72632 & $4 \mathrm{~A}$ & - & - & 77.4 & 21.6 & 0.926 & - & - & - & - & - & - \\
\hline D72632 & $3 \mathrm{~A}$ & - & - & 77.3 & 21.8 & 0.915 & - & - & - & - & - & - \\
\hline D76142 & $1 \mathrm{~A}$ & $\mathbf{Y}$ & - & 80.9 & 18.0 & 0.944 & - & 0.050 & - & - & - & - \\
\hline D76142 & $2 \mathrm{~A}$ & $\mathbf{Y}$ & - & 78.1 & 20.9 & 0.942 & - & - & - & - & - & - \\
\hline D76142 & $3 \mathrm{~A}$ & - & - & 78.0 & 20.9 & 0.964 & - & 0.011 & - & - & - & - \\
\hline D76144 & $1 \mathrm{~A}$ & $\mathbf{Y}$ & - & 75.8 & 23.2 & 0.856 & - & - & - & - & - & - \\
\hline D76144 & $2 \mathrm{~A}$ & $\mathbf{Y}$ & - & 77.0 & 22.0 & 0.851 & - & - & - & - & - & - \\
\hline D76144 & $3 \mathrm{~A}$ & - & - & 77.5 & 21.5 & 0.904 & - & - & - & - & - & - \\
\hline D76183 & $3 \mathrm{~A}$ & - & - & 77.3 & 21.7 & 0.928 & - & - & - & - & - & - \\
\hline
\end{tabular}

Notes:

Headspace Sample Program

1A Detailed Bag, Gas Mass Spectrometry Results (vol\%)

2A Detailed Lid, Gas Mass Spectrometry Results (vol\%)

3A Operational Lid, Gas Mass Spectrometry Results (vol\%)

4A Operational Bag, Gas Mass Spectrometry Results (vol\%)

Y Yes

Unreported analyte values indicate that analyte was undetected, or was detected at or above the MDL but at a level below the PRQL. 
Table 3.1.1-8. Volatile Organic Compound Gas Chromatography/Mass Spectrometry Results. (parts per million by volume)

\begin{tabular}{|c|c|c|c|c|c|c|c|c|c|c|c|c|}
\hline \multirow[b]{2}{*}{$\begin{array}{l}\text { Drum } \\
\text { no. }\end{array}$} & \multirow{2}{*}{\multicolumn{2}{|c|}{$\begin{array}{c}\text { Headspace } \\
\text { sample } \\
\text { program }\end{array}$}} & \multirow[b]{2}{*}{ Vented } & \multicolumn{9}{|c|}{ Analytes } \\
\hline & & & & Methanol & $\begin{array}{l}\text { Ethyl } \\
\text { Ether }\end{array}$ & $\begin{array}{l}\text { Trichloro- } \\
\text { trifluoro- } \\
\text { ethane }\end{array}$ & $\begin{array}{c}1,1- \\
\text { Dichloro- } \\
\text { ethene }\end{array}$ & Acetone & $\begin{array}{c}\text { Methylene } \\
\text { Chloride }\end{array}$ & $\begin{array}{c}1,1- \\
\text { Dichloro- } \\
\text { ethane }\end{array}$ & $\begin{array}{l}\text { cis-1,2- } \\
\text { Dichloro- } \\
\text { ethene }\end{array}$ & $\begin{array}{c}2- \\
\text { Butanone }\end{array}$ \\
\hline D72132 & & $3 B$ & - & - & - & - & - & - & 8081.0 & - & - & - \\
\hline D72136 & & $1 \mathrm{~B}$ & $\mathbf{Y}$ & - & - & - & - & - & 570.5 & - & - & - \\
\hline D72136 & & $2 B$ & $\mathbf{Y}$ & - & - & - & - & - & 475.2 & - & - & - \\
\hline D72136 & & $3 B$ & - & - & - & - & 一 & - & 665.7 & - & - & - \\
\hline \multicolumn{13}{|l|}{ Notes: } \\
\hline & $\begin{array}{l}1 B \\
2 B \\
3 B \\
Y \\
U n\end{array}$ & $\begin{array}{l}\text { Detaile } \\
\text { Detaile } \\
\text { Operat } \\
\text { Yes } \\
\text { reported ar }\end{array}$ & $\begin{array}{l}\text { Bag, VOC } \\
\text { id, VOC } \\
\text { al Lid, VC } \\
\text { yte values }\end{array}$ & $\begin{array}{l}\text { ias Chromato } \\
\text { as Chromatog } \\
\text { Gas Chrome } \\
\text { dicate that an }\end{array}$ & $\begin{array}{l}\text { aphy/M: } \\
\text { aphy/Ma } \\
\text { ography/ } \\
\text { lyte was }\end{array}$ & $\begin{array}{l}\text { Spectrometry } \\
\text { Spectrometry } \\
\text { ass Spectrome } \\
\text { detected, or }\end{array}$ & $\begin{array}{l}\text { Results (ppmv } \\
\text { esults (ppmv } \\
\text { y Results (pp } \\
\text { s detected at }\end{array}$ & above the & L but at a ls & elow the 1 & & \\
\hline
\end{tabular}


Table 3.1.1-9. Volatile Organic Compound Gas Chromatography/Mass Spectrometry Results. (parts per million by volume)

\begin{tabular}{|c|c|c|c|c|c|c|c|c|c|c|c|}
\hline \multirow[b]{2}{*}{$\begin{array}{c}\text { Drum } \\
\text { no. }\end{array}$} & \multirow[b]{2}{*}{$\begin{array}{c}\text { Headspace } \\
\text { sample } \\
\text { program }\end{array}$} & \multirow[b]{2}{*}{ Vented } & \multicolumn{9}{|c|}{ Analytes } \\
\hline & & & $\begin{array}{l}\text { Chloro- } \\
\text { form }\end{array}$ & $\begin{array}{c}1,1,1- \\
\text { Trichloro- } \\
\text { ethane }\end{array}$ & $\begin{array}{l}\text { Cyclo- } \\
\text { hexane }\end{array}$ & $\begin{array}{l}\text { Carbon } \\
\text { Tetra- } \\
\text { chloride }\end{array}$ & Benzene & $\begin{array}{c}1,2- \\
\text { Dichloro- } \\
\text { ethane }\end{array}$ & $\stackrel{1-}{\text { Butanol }}$ & $\begin{array}{l}\text { Trichloro- } \\
\text { ethene }\end{array}$ & $\begin{array}{c}\text { 4-Methyl-2- } \\
\text { pentanone }\end{array}$ \\
\hline D70675 & $3 B$ & - & - & 6.3 & - & 1.3 & - & - & - & 8.5 & - \\
\hline D71494 & $3 B$ & - & - & 1.7 & - & - & - & - & - & 10.2 & - \\
\hline D71504 & 3B & - & - & 一 & - & - & - & - & - & 11.4 & - \\
\hline D72127 & 4B & - & - & - & - & - & - & - & - & 28.3 & - \\
\hline D72127 & 3B & - & - & - & 一 & - & - & - & - & 24.6 & - \\
\hline D72619 & 4B & - & - & 3.1 & - & - & - & - & - & 4.0 & - \\
\hline D72619 & 3B & - & - & - & - & - & - & - & - & 1.8 & - \\
\hline D72631 & $4 B$ & - & - & 2.0 & - & - & - & - & - & 11.1 & - \\
\hline D72631 & 3B & - & - & 1.8 & - & - & - & - & - & 10.2 & - \\
\hline D72632 & 4B & - & - & 2.4 & - & - & - & - & - & 8.3 & - \\
\hline D72632 & 3B & - & - & 1.5 & - & - & - & - & - & 6.9 & - \\
\hline D76142 & 1B & $\mathbf{Y}$ & - & 24.6 & - & - & 5.0 & - & - & - & - \\
\hline D76142 & $2 \mathrm{~B}$ & $\mathbf{Y}$ & - & 18.9 & - & - & 4.2 & - & - & - & - \\
\hline D76142 & 3B & - & - & 7.6 & - & - & - & - & - & - & - \\
\hline D76144 & 1B & $\mathbf{Y}$ & - & 155.8 & - & 18.5 & - & - & - & - & - \\
\hline D76144 & $2 B$ & $\mathbf{Y}$ & - & 120.5 & - & - & - & - & - & - & - \\
\hline
\end{tabular}


Table 3.1.1-9. (continued).

\begin{tabular}{|c|c|c|c|c|c|c|c|c|c|c|c|}
\hline \multirow[b]{2}{*}{$\begin{array}{c}\text { Drum } \\
\text { no. }\end{array}$} & \multirow[b]{2}{*}{$\begin{array}{c}\text { Headspace } \\
\text { sample } \\
\text { program }\end{array}$} & \multirow[b]{2}{*}{ Vented } & \multicolumn{9}{|c|}{ Analytes } \\
\hline & & & $\begin{array}{l}\text { Chloro- } \\
\text { form }\end{array}$ & $\begin{array}{l}\text { 1,1,1- } \\
\text { Trichloro- } \\
\text { ethane }\end{array}$ & $\begin{array}{l}\text { Cyclo- } \\
\text { hexane }\end{array}$ & $\begin{array}{c}\text { Carbon } \\
\text { Tetra- } \\
\text { chloride }\end{array}$ & Benzene & $\begin{array}{c}1,2- \\
\text { Dichloro- } \\
\text { ethane }\end{array}$ & $\begin{array}{c}1- \\
\text { Butanol }\end{array}$ & $\begin{array}{c}\text { Trichloro- } \\
\text { ethene }\end{array}$ & $\begin{array}{l}\text { 4-Methyl-2- } \\
\text { pentanone }\end{array}$ \\
\hline D76144 & 3B & - & - & 48.1 & - & - & - & - & - & 一 & - \\
\hline D76183 & 3B & - & - & 4.3 & - & - & - & - & - & 28.3 & - \\
\hline \multicolumn{12}{|l|}{ Notes: } \\
\hline \multicolumn{12}{|c|}{ Headspace Sample Program } \\
\hline 1B & \multirow{2}{*}{\multicolumn{11}{|c|}{ Detailed Bag, VOC Gas Chromatography/Mass Spectrometry Results (ppmv) }} \\
\hline 2B & & & & & & \multicolumn{6}{|c|}{ Detailed Lid, VOC Gas Chromatography/Mass Spectrometry Results (ppmv) } \\
\hline 3B & \multicolumn{11}{|c|}{ Operational Lid, VOC Gas Chromatography/Mass Spectrometry Results (ppmv) } \\
\hline 4B & \multicolumn{11}{|c|}{ Operational Bag, VOC Gas Chromatography/Mass Spectrometry Results (ppmv) } \\
\hline $\mathbf{Y}$ & \multicolumn{11}{|l|}{ Yes } \\
\hline
\end{tabular}


Table 3.1.1-10. Volatile Organic Compound Gas Chromatography/Mass Spectrometry Results. (parts per million by volume)

\begin{tabular}{|c|c|c|c|c|c|c|c|c|c|c|c|c|}
\hline \multirow[b]{2}{*}{$\begin{array}{l}\text { Drum } \\
\text { No. }\end{array}$} & \multirow[b]{2}{*}{$\begin{array}{c}\text { Headspace } \\
\text { sample } \\
\text { program } \\
\end{array}$} & \multirow[b]{2}{*}{ Vented } & \multicolumn{10}{|c|}{ Analytes } \\
\hline & & & Toluene & $\begin{array}{l}\text { Tetra- } \\
\text { chloro- } \\
\text { ethene }\end{array}$ & $\begin{array}{l}\text { Chloro- } \\
\text { benzene }\end{array}$ & $\begin{array}{c}\text { Ethyl- } \\
\text { benzene }\end{array}$ & $\begin{array}{c}\text { m,p- } \\
\text { Xylene }\end{array}$ & $\begin{array}{c}0- \\
\text { Xylene }\end{array}$ & $\begin{array}{c}\text { Bromo- } \\
\text { form }\end{array}$ & $\begin{array}{c}1,1,2,2- \\
\text { Tetrachloro- } \\
\text { ethane }\end{array}$ & $\begin{array}{c}\text { 1,3,6-Tri- } \\
\text { methyl- } \\
\text { benzene }\end{array}$ & $\begin{array}{c}1,2,4-\text { Tri- } \\
\text { methyl- } \\
\text { benzene }\end{array}$ \\
\hline D70675 & 3B & - & 1.9 & - & - & - & - & - & - & - & - & - \\
\hline D71504 & $3 B$ & - & 2.6 & - & - & - & - & - & - & - & - & - \\
\hline D72136 & $1 \mathrm{~B}$ & $\mathbf{Y}$ & $1,739.6$ & - & - & - & - & - & - & - & - & - \\
\hline $\mathrm{D} 72136$ & $2 \mathrm{~B}$ & $\mathbf{Y}$ & $1,341.6$ & - & - & - & - & - & - & - & - & - \\
\hline D72136 & $3 \mathrm{~B}$ & - & $1,395.5$ & - & - & - & - & - & - & - & - & - \\
\hline D72619 & $4 \mathrm{~B}$ & - & 7.8 & - & - & - & - & - & - & - & - & - \\
\hline D72619 & 3B & - & 3.6 & - & - & - & - & - & - & - & - & - \\
\hline D72631 & $4 B$ & - & 2.0 & - & - & - & - & - & - & - & - & - \\
\hline D72631 & 3B & - & 1.9 & - & - & - & - & - & - & - & - & - \\
\hline D72632 & $4 B$ & - & 4.5 & - & - & - & - & - & - & - & - & - \\
\hline D72632 & $3 B$ & - & 4.0 & - & - & - & - & - & - & - & - & - \\
\hline D76142 & $1 B$ & $\mathbf{Y}$ & 5.1 & - & - & 5.9 & 25.4 & 5.0 & - & - & - & - \\
\hline D76142 & $2 B$ & $\mathbf{Y}$ & 4.3 & - & - & 5.4 & 18.5 & 4.2 & - & - & - & - \\
\hline D76142 & 3B & $\mathbf{Y}$ & 4.3 & - & - & 5.4 & 18.5 & 4.2 & - & - & - & - \\
\hline
\end{tabular}


Table 3.1.1-10. (continued).

\begin{tabular}{|c|c|c|c|c|c|c|c|c|c|c|c|c|c|}
\hline \multirow[b]{2}{*}{$\begin{array}{c}\text { Drum } \\
\text { No. }\end{array}$} & \multirow{2}{*}{\multicolumn{2}{|c|}{$\begin{array}{c}\text { Headspace } \\
\text { sample } \\
\text { program }\end{array}$}} & \multirow[b]{2}{*}{ Vented } & \multicolumn{10}{|c|}{ Analytes } \\
\hline & & & & Toluene & $\begin{array}{l}\text { Tetra- } \\
\text { chloro- } \\
\text { ethene }\end{array}$ & $\begin{array}{l}\text { Chloro- } \\
\text { benzene }\end{array}$ & $\begin{array}{c}\text { Ethyl- } \\
\text { benzene }\end{array}$ & $\begin{array}{c}\text { m,p- } \\
\text { Xylene }\end{array}$ & $\begin{array}{c}0- \\
\text { Xylene }\end{array}$ & $\begin{array}{l}\text { Bromo- } \\
\text { form }\end{array}$ & $\begin{array}{l}1,1,2,2- \\
\text { Tetrachloro- } \\
\text { ethane }\end{array}$ & $\begin{array}{c}\text { 1,3,6-Tri- } \\
\text { methyl- } \\
\text { benzene }\end{array}$ & $\begin{array}{c}\text { 1,2,4-Tri- } \\
\text { methyl- } \\
\text { benzene }\end{array}$ \\
\hline D76142 & 3 & B & - & 2.6 & - & - & 4.4 & 18.1 & 3.5 & - & - & - & - \\
\hline D76183 & 3 & B & - & 4.0 & - & - & - & - & - & - & - & - & - \\
\hline \multicolumn{14}{|l|}{ Notes: } \\
\hline \multicolumn{14}{|c|}{ Headspace Sample Program } \\
\hline & $1 \mathrm{~B}$ & \multicolumn{12}{|c|}{ Detailed Bag, VOC Gas Chromatography/Mass Spectrometry Results (ppmv) } \\
\hline & $2 B$ & \multirow{2}{*}{\multicolumn{12}{|c|}{ Detailed Lid, VOC Gas Chromatography/Mass Spectrometry Results (ppmv) }} \\
\hline & 3B & \multirow{2}{*}{\multicolumn{12}{|c|}{ Operational Lid, VOC Gas Chromatography/Mass Spectrometry Results (ppmv) }} \\
\hline & $4 \mathrm{~B}$ & \multicolumn{3}{|c|}{ Operational Bag, VOC Gas Chromatography/Mass Spectrometry Results (ppmv) } & & & & & & & & & \\
\hline & & \multicolumn{12}{|c|}{ Yes } \\
\hline & Un & ported & yte vo & cate $t$ & lyte & idetect & ias d & at 0 & the & & & & \\
\hline
\end{tabular}


Table 3.1.1-11. Gas Sampling Results-Compositional Analysis (vol\%).

\begin{tabular}{|c|c|c|c|c|c|c|c|c|c|c|c|}
\hline \multirow[b]{2}{*}{$\begin{array}{c}\text { Container } \\
\text { ID. }\end{array}$} & \multirow[b]{2}{*}{$\begin{array}{c}\text { Storage } \\
\text { time } \\
\text { (days) }\end{array}$} & \multicolumn{10}{|c|}{ Analytes } \\
\hline & & $\mathrm{H}_{2}$ & $\mathrm{O}_{2}$ & $\mathrm{~N}_{2}$ & Ar & $\mathrm{CO}_{2}$ & $\mathrm{CO}$ & $\mathrm{NO}_{\mathrm{x}}$ & $\begin{array}{l}\text { Hydrocarbons } \\
\text { (saturated) }^{1}\end{array}$ & $\begin{array}{c}1,1,1- \\
\text { trichloro- } \\
\text { ethane }\end{array}$ & $\begin{array}{c}\text { Other } \\
\text { Hydrocarbons }^{2}\end{array}$ \\
\hline $7412-03121$ & 144 & 0.03 & 21.1 & 77.5 & 0.94 & 0.02 & - & - & 0.07 & 0.29 & $0.04^{a}$ \\
\hline $7412-03125$ & 144 & 0.24 & 18.2 & 80.2 & 0.96 & 0.01 & - & - & 0.06 & 0.30 & $0.04^{a}$ \\
\hline $7412-03127$ & 144 & 0.18 & 18.1 & 79.9 & 0.95 & 0.02 & - & - & 0.13 & 0.58 & $0.12^{n}$ \\
\hline \multirow[t]{2}{*}{$7412-03128$} & 144 & 0.11 & 20.1 & 77.5 & 0.94 & 0.02 & - & - & 0.11 & 0.94 & $0.22^{2}$ \\
\hline & & & & & & & & & & & $0.01^{b}$ \\
\hline $7412-00483$ & 1,089 & 1.2 & 21.1 & 76.4 & 0.90 & 0.09 & - & - & 0.35 & - & - \\
\hline $7412-00636$ & 975 & 5.30 & 15.6 & 77.4 & 0.96 & 0.11 & - & - & 0.24 & 0.38 & - \\
\hline $7412-00766$ & 904 & 2.02 & 21.0 & 75.5 & 0.95 & 0.11 & - & - & 0.16 & 0.24 & - \\
\hline $7412-00797$ & 902 & 0.78 & 3.87 & 94.0 & 1.2 & - & - & - & 0.11 & - & - \\
\hline $741-12404$ & 4,326 & 5.19 & 65.9 & 27.7 & 0.32 & 0.09 & - & 0.66 & - & - & - \\
\hline $741-12794$ & 4,205 & 4.12 & 46.8 & 48.0 & 0.58 & 0.14 & - & 0.27 & - & 0.05 & $0.04^{\circ}$ \\
\hline $741-12858$ & 4,213 & 11.7 & 35.7 & 51.3 & 0.61 & 0.14 & - & 0.46 & - & 0.04 & $0.01^{\circ}$ \\
\hline $741-12387$ & 4,304 & 1.85 & 30.9 & 66.2 & 0.79 & 0.09 & - & 0.15 & - & 0.03 & $0.01^{\circ}$ \\
\hline \multirow[t]{2}{*}{$741-12795$} & 4,203 & 11.0 & 73.4 & 14.5 & 0.17 & 0.13 & - & 0.63 & - & 0.94 & $0.02^{c}$ \\
\hline & & & & & & & & & & & $0.01^{b}$ \\
\hline \multicolumn{12}{|c|}{ 1. Saturated hydrocarbons -methane through propane. } \\
\hline \multicolumn{12}{|c|}{ 2. Other hydrocarbons-as specified. } \\
\hline \multicolumn{12}{|c|}{ a. Dichloromethane } \\
\hline \multicolumn{12}{|c|}{ b. Carbon tetrachloride } \\
\hline c. Tric & ethylene & & & & & & & & & & \\
\hline
\end{tabular}




\subsection{Waste Form Number (no waste form number), Content Code RF 112A (Equivalent)}

\subsubsection{Item Description Code 003-Grease, B774}

3.1.2.1 Certification Assessment. This IDC is certifiable without further waste treatment, provided drums containing free liquids are treated. Assay and thermal power calculations, including error, need to be updated to meet the current WIPP WAC. Several gas generation criteria need to be addressed. Carbon filters may need to be installed, drums will require inspection to identify unvented or unpunctured rigid liners, and headspace gas analysis and visual waste characterization will need to be performed.

3.1.2.2 Waste Description. Solidified organics are solidified waste oils and solvents that were generated as a result of machining and tool degreasing. Waste oil was transferred primarily from Buildings 707 and 777. Cementation was performed in Waste Management Unit (WMU) 56, Room 210, Building 774. IDC 003 solidified organics waste was generated by the Grease Plant Process (EG\&G 1994n).

3.1.2.3 Generation Source. The waste oils were generated primarily by processes in Buildings 707 and 777 . Solvent-contaminated waste oils were generated by plutonium machining and tool degreasing. IDC 003 solidified organics waste was generated by the Grease Plant Process in Building 774. This treatment process operated until November 1985 (EG\&G 1994n).

3.1.2.4 Recovery Method. This IDC was never generated as a residue and therefore has no recovery method.

3.1.2.5 Waste Packaging and Handling. In the Grease Plant Process, waste oil and Microcel E (calcium silicate) were fed separately into a continuous mixer. Small amounts of Oil Dri were sometimes added to the mixture as well. The amounts of materials added to the mixture were not metered. However, the operator (EG\&G 1994n) would adjust the composition if the outgoing mixture did not have a paste-like consistency. The mixture would then drop into an O-ring bag contained in a 55-gal drum (EG\&G 1994n). The drum packaging for this IDC was very similar to that of IDC 001 as pictured in Figure C-3. In IDC 003, the Portland cement was replaced by $4 \mathrm{lb}$ of Oil Dri in the bottom of each drum liner and 3 to $8 \mathrm{lb}$ of Oil Dri in the top of the liner bags. Vermiculite was used to fill the space between the outer sealed polyethylene drum bag and the rigid liner (Clements 1982).

3.1.2.6 Container Preparation. Only approved containers could be used to package TRU waste for shipment offsite. These containers approved for shipment to INEL during this time were DOT-17C, white, 55-gal drums (Rockwell specification SX-200). These containers met the requirements for certification as DOT-7A Type A packaging (Rockwell International 1989e).

Table 3.1.2-1 shows the current inventory of IDC 003 waste containers from the Rocky Flats Plant that have been shipped to INEL since 1985. 
Table 3.1.2-1. Item Description Code 003 Container Information.

\begin{tabular}{|c|c|c|c|}
\hline Information & & Drums & Boxes \\
\hline \multicolumn{2}{|l|}{ Total Containers } & 253 & 0 \\
\hline \multirow[t]{3}{*}{ Net Container Weight (lb) } & Maximum & 665 & $\mathrm{~N} / \mathrm{A}$ \\
\hline & Minimum & 260 & N/A \\
\hline & Average & 462 & N/A \\
\hline
\end{tabular}

Flow-in ventable gaskets were installed in the drums beginning in December 1982. They were used until October 1988, when tubular gaskets with carbon filters were required. Drums shipped to the INEL between 1985 and 1988 may not meet the current WIPP WAC, owing to their lack of carbon filters.

3.1.2.6.1 Drum Preparation-Approved liners for drums of TRU waste packaged for offsite shipment as of 1989 were the round-bottom liner (Rockwell specification SX-203), inside a rigid polyethylene liner (Rockwell specification SX-202), or an O-ring bag and a polyethylene bag placed inside the rigid liner if the drum was attached to a glovebox. All bags were closed using the twist-and-tape method (Rockwell International 1989e).

The IDC 003 sludge mixture was placed in 55-gal drums that were lined with a high-density polyethylene rigid liner, a 14-mil PVC O-ring bag, and a 5-mil polyethylene bag. The polyethylene bag was not required from a waste packaging standpoint, but it aided in contamination control (DOE/WIPP 1992).

3.1.2.6.2 Box Preparation-No boxes of IDC 003 waste were shipped to INEL between 1985 and 1989.

3.1.2.7 Assay. Assay was performed radiochemically. The drum assay value was based on a batch process. The plutonium and americium value for the liquid in the batch tank was divided evenly between the drums produced in the batch. Uranium assay was not routinely performed. Table 3.1.2-2 summarizes the dose rates measured on containers of this IDC. Table 3.1.2-3 provides a summary of the assay information.

Table 3.1.2-2. Item Description Code 003 Dose Information.

\begin{tabular}{lrrr}
\hline Information & & Drums & Boxes \\
\cline { 2 - 4 } One Meter Dose Rate & $0-0.5$ & 252 & N/A \\
(mrem/h) & $0.5-10$ & 1 & N/A \\
Surface Dose Rate & $<10$ & 253 & N/A \\
(mrem/h) & $10-200$ & 0 & N/A \\
\hline
\end{tabular}


Table 3.1.2-3. Item Description Code 003 Assay Information.

\begin{tabular}{|c|c|c|c|}
\hline \multicolumn{2}{|c|}{ Radionuclide Inventory } & \multirow{2}{*}{$\begin{array}{c}\text { Drums } \\
7.6\end{array}$} & \multirow{2}{*}{$\frac{\text { Boxes }}{\text { N/A }}$} \\
\hline Plutonium (g) & Maximum & & \\
\hline & Minimum & 0 & N/A \\
\hline & Average & 2.2 & N/A \\
\hline \multirow[t]{3}{*}{ Americium (g) } & Maximum & 0 & N/A \\
\hline & Minimum & 0 & N/A \\
\hline & Average & 0 & N/A \\
\hline \multirow{3}{*}{ Uranium-235 (g) } & Maximum & 0 & N/A \\
\hline & Minimum & 0 & N/A \\
\hline & Average & 0 & N/A \\
\hline
\end{tabular}

3.1.2.8 Inspection. Waste Certification periodically reviews the process documentation to ensure that the solidification process is being operated according to procedure. This inspection is performed to ensure that free liquids and particulates will not be found in this waste form. In addition to review of process documentation, Waste Certification personnel performed periodic inspections of the generating and packaging process to verify compliance with waste acceptance criteria. Each drum is viewed using RTR to

- Ensure the drum does not contain nonconforming items

- Ensure the drum is properly packaged

- Verify the waste form description

- Evaluate the presence of free liquids.

3.1.2.9 Waste Form Evaluation. Table 3.1.2-4 evaluates the waste form against the WIPP WAC for such items as free liquids, pyrophoric materials, and compressed gases. Table 3.1.2-5 evaluates the waste against TRUPACT criteria. 
Table 3.1.2-4. Waste Form Evaluation.

Criterion or

requirement

Limiting parameters ${ }^{2}$

Immobilization Particulates were prohibited by procedural control. Based on the description of the waste, fine particulates are not expected in this IDC.

Liquids

The solidified organics should meet the free liquid criteria by procedural control and RTR inspection prior to shipment from Rocky Flats. However, the solidified organics should be checked for the possibility that it may have dewatered. Drums identified as containing free liquids will not be certifiable.

Pyrophoric

Materials

Pyrophoric materials were prohibited by procedural control. The absence of the pyrophoric materials was verified by the generating supervisor and periodic inspection by the Waste Certification Organization.

Explosives and Explosives and compressed gases were prohibited by procedural control. The Compressed Gases absence of the explosives and compressed gases was verified by the generating supervisor and periodic inspection by the Waste Certification Organization. In addition, unvented, closed containers and pressurized containers were excluded by procedural controls and RTR examination.

TRU-Mixed

The RCRA constituents exist as co-contaminants with the transuranic

Wastes radionuclides. Compliance with the WIPP RCRA permits and NMD will be required prior to shipment of the stored waste to WIPP.

Specific Activity of Waste

A portion of the waste stored at INEL may contain $<100$ nanocuries per gram transuranic radionuclides.

$\mathrm{Pu}^{239}$ Equivalent None of the IDC 003 waste containers recorded as shipped to INEL in the Activity SWIMS exceed 1,000 Ci of plutonium-equivalent activity.

a. Many of the limiting parameters were taken from TRU Waste Compliance Program (Rockwell International 1983a, 1987e, and 1989b). 
Table 3.1.2-5. TRUPACT Evaluation.

Criterion or

requirement

Limiting parameters

Waste Package

Weight

Waste Containers

Nuclear Criticality

Surface Dose Rate

Removable Surface

Contamination

Thermal Power

Gas Generation

Rocky Flats limited the gross weight of drums to $800 \mathrm{lb}$. The TRUPACT and vehicle weight limits must be verified at the time of payload assembly at INEL. Based on the typical weights of the IDC 003 drums, load management will be required to ensure 42 drums will meet the gross vehicle weight (average gross weight of $462 \mathrm{lb}$ ).

The solidified organics waste was packaged in 55-gal DOT-7A, Type A containers.

Rocky Flats limited the fissile content of the drums to 200 grams. However, the errortimes-two requirement was not in place at the time the drums were shipped to INEL; therefore, it is not reported as part of the assay of the drum. The TRUPACT limit must be verified at the time of payload assembly at INEL. Based on the typical assays of the IDC 003 drums, the criticality criteria will be met but must be recalculated or assayed to meet the error-times-two requirement.

The surface dose rate criteria used by Rocky Flats was $200 \mathrm{mrem} / \mathrm{hr}$ at the drum surface and $10 \mathrm{mrem} / \mathrm{hr}$ at 1 meter. Shielding was not necessary for IDC 003 drums. The TRUPACT limit must be verified at the time of payload assembly at INEL. Based on the typical dose rates from the IDC 003 drums, the dose rate criteria will be met.

The Rocky Flats limit for removable contamination (for TRU assumed to be all alpha) was 20 disintegrations per minute $/ 100 \mathrm{~cm}^{2}$. The Rocky Flats limit is equivalent to 9 picocuries per $100 \mathrm{~cm}^{2}$, which is well within the WIPP criteria.

The thermal power calculation reported in the SWIMS data package is based on the reported assay value without an error/uncertainty correction. The thermal power must be recalculated based on the assay error determination.

Based on the procedural requirements for packaging IDC 003 waste and the waste description, the only areas of noncompliance are carbon filters, unpunctured rigid liners, headspace gas analysis, and visual characterization.

Dichloromethane, 1,1,1-trichloroethane, 1,1,2-trichloro-1,2,2-trifluoroethane, trichloroethylene, and carbon tetrachloride were detected by headspace gas analysis in IDC 003, but are not listed in the TRUPACT Chemical List for RF 113A. Tetrachloroethylene and carbon tetrachloride were detected using Toxicity Characteristic Leaching Procedure (TCLP). Xylene is on the TRUPACT Chemical List for aromatic hydrocarbons, but was not detected. Alcohols on the TRUPACT Chemical List were not detected.

Personnel performing RTR examination at Rocky Flats would accept up to $10 \%$ of another IDC. The other IDCs could be combustibles, concrete, metal, and plastics.

a. Many of the limiting parameters were taken from TRU Waste Compliance Program (Rockwell International 1983a, 1987e, and 1989b). 
3.1.2.10 Combustible and Organic Content. Table 3.1.2-6 outlines available data from the TRU Waste Sampling Program for IDC 003. SWIMS data indicate that this waste form does not contain $>20 \%$ combustibles, but contains $>20 \%$ organics.

Table 3.1.2-6. Item Description Code 003 Data Summary for Combustible and Organic Content.

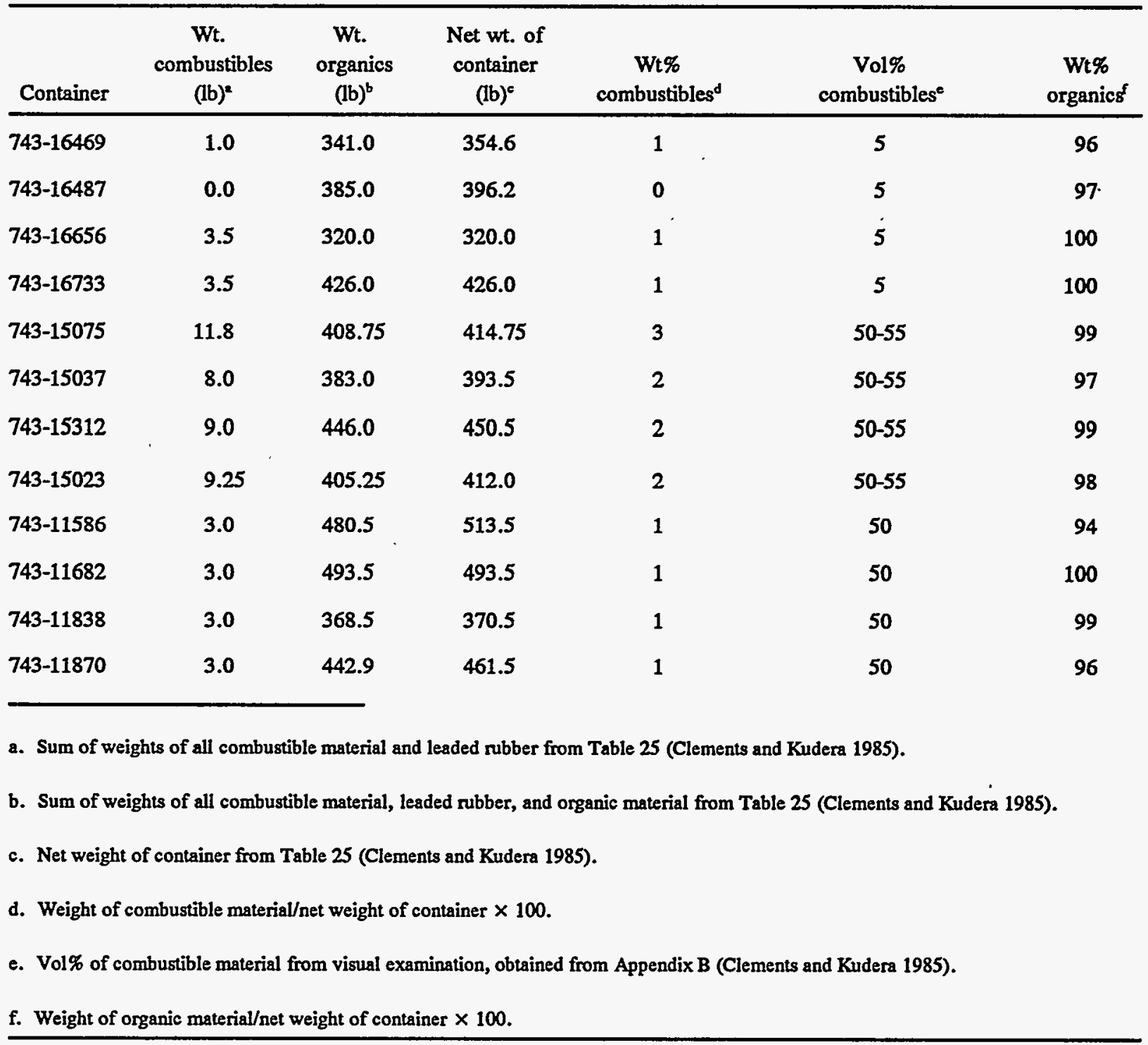

3.1.2.10.1 Combustible Content-SWIMS data show that IDC 003 waste is noncombustible (Rockwell International 1985a). In support of the TRU Waste Sampling Program, 12 drums of IDC 003 waste were opened. They were found to contain an average wt\% combustible content of $1.3 \%$. Visual inspection showed an average vol\% combustible content of $35.8 \%$. (Clements and Kudera 1985).

3.1.2.10.2 Organic Content-SWIMS data show that IDC 003 waste may contain $55 \%$ organics (Rockwell International 1985a). In support of the TRU Waste Sampling Program, 12 drums of IDC 003 waste were opened. They were found to contain an average wt\% organic content of 97.9\% (Clements and Kudera 1985). 
3.1.2.11 Analytical Information. Analytical data from the Waste Drum Gas Generation Sampling Program at Rocky Flats indicate that three drums were subject to sludge analysis for VOC's (Roggenthen and others 1989). The analytical results and toxicity characteristic limits are presented in Table 3.1.2-7. Sampling and analysis of three solidified organics samples in 1988 and 1989 indicated the waste exceeded toxicity characteristic criteria for carbon tetrachloride (EPA Code D019). The concentration of tetrachloroethylene exceeded the toxicity characteristic criteria level in one sample. However, the concentrations in the other samples were undetected or below characteristic levels (EG\&G 1994n). In addition, EPA Codes F001 and F002 were assigned to all solidified organics because these wastes were contaminated with regulated spent solvents in the past.

Table 3.1.2-7. Analytical Results for Solidified Organics.

\begin{tabular}{|c|c|c|c|c|}
\hline \multirow[b]{2}{*}{ Constituent } & \multirow[b]{2}{*}{$\begin{array}{c}\text { TCLP } \\
\text { limit } \\
(\mathrm{mg} / \mathrm{L})\end{array}$} & \multicolumn{3}{|c|}{ Sample results (ppm) } \\
\hline & & $\begin{array}{l}\text { Drum } \\
7431- \\
6930^{2}\end{array}$ & $\begin{array}{l}\text { Drum } \\
0250- \\
0484^{b}\end{array}$ & $\begin{array}{l}\text { Request } \\
63537^{\circ}\end{array}$ \\
\hline Carbon tetrachloride & 0.5 & 2.2 & 0.7 & 78.3 \\
\hline Chlorobenzene & 100.0 & $\mathrm{U}^{\dagger}$ & $\mathrm{U}^{\dagger}$ & $U^{\dagger}$ \\
\hline o-Dichlorobenzene & - & $\mathbf{N M} *$ & NM* & NM* \\
\hline Methylene chloride & - & $\mathrm{U}^{\dagger}$ & $\mathrm{U}^{\dagger}$ & $U^{t}$ \\
\hline Nitrobenzene & 2.0 & $\mathrm{NM}^{*}$ & $\mathrm{NM}^{*}$ & NM* \\
\hline Tetrachloroethylene & 0.7 & 1.2 & 0.04 & Ut \\
\hline 1,1,1-Trichloroethane & - & $U^{t}$ & $U^{t}$ & 35.1 \\
\hline Trichloroethylene & 0.5 & $\mathrm{U}^{\dagger}$ & $\mathrm{U}^{\dagger}$ & $\mathrm{U}^{+}$ \\
\hline 1,1,2-Trichloro-1,2,2-trifluoroethane & - & 4.0 & $\mathrm{U}^{\dagger}$ & $\mathrm{U}^{\dagger}$ \\
\hline Trichlorofluoro-methane & - & NM* & $\mathrm{NM}^{*}$ & $\mathrm{NM}^{*}$ \\
\hline \multicolumn{5}{|c|}{ a. Sample of IDC 003 solidified organics generated in 1984 (Roggenthen \& others 1989). } \\
\hline \multicolumn{5}{|c|}{ b. Sample of IDC 003 solidified organics generated in 1985 . } \\
\hline \multicolumn{5}{|c|}{ c. Sample origin not listed in analytical report. } \\
\hline \multicolumn{5}{|l|}{$\dagger$ Undetected. } \\
\hline * Not Measured. & & & & \\
\hline
\end{tabular}

Analytical data from the TRU Waste Sampling Waste Characterization Program for IDC 003Grease, B774, indicate that 12 drums were subject to headspace gas analysis (Clements and Kudera 1985). Gas composition analytical results are presented in Table 3.1.2-8. Waste boxes were not sampled. Hydrogen, oxygen, nitrogen, argon, carbon dioxide, nitrogen oxide(s), saturated hydrocarbons, 1,1,1-trichloroethane, dichloromethane, carbon tetrachloride, 1,1,2-trichloro1,2,2-trifluoroethane, and trichloroethylene were detected in the drums. 
Table 3.1.2-8 Gas Sampling Results-Compositional Analysis (vol\%).

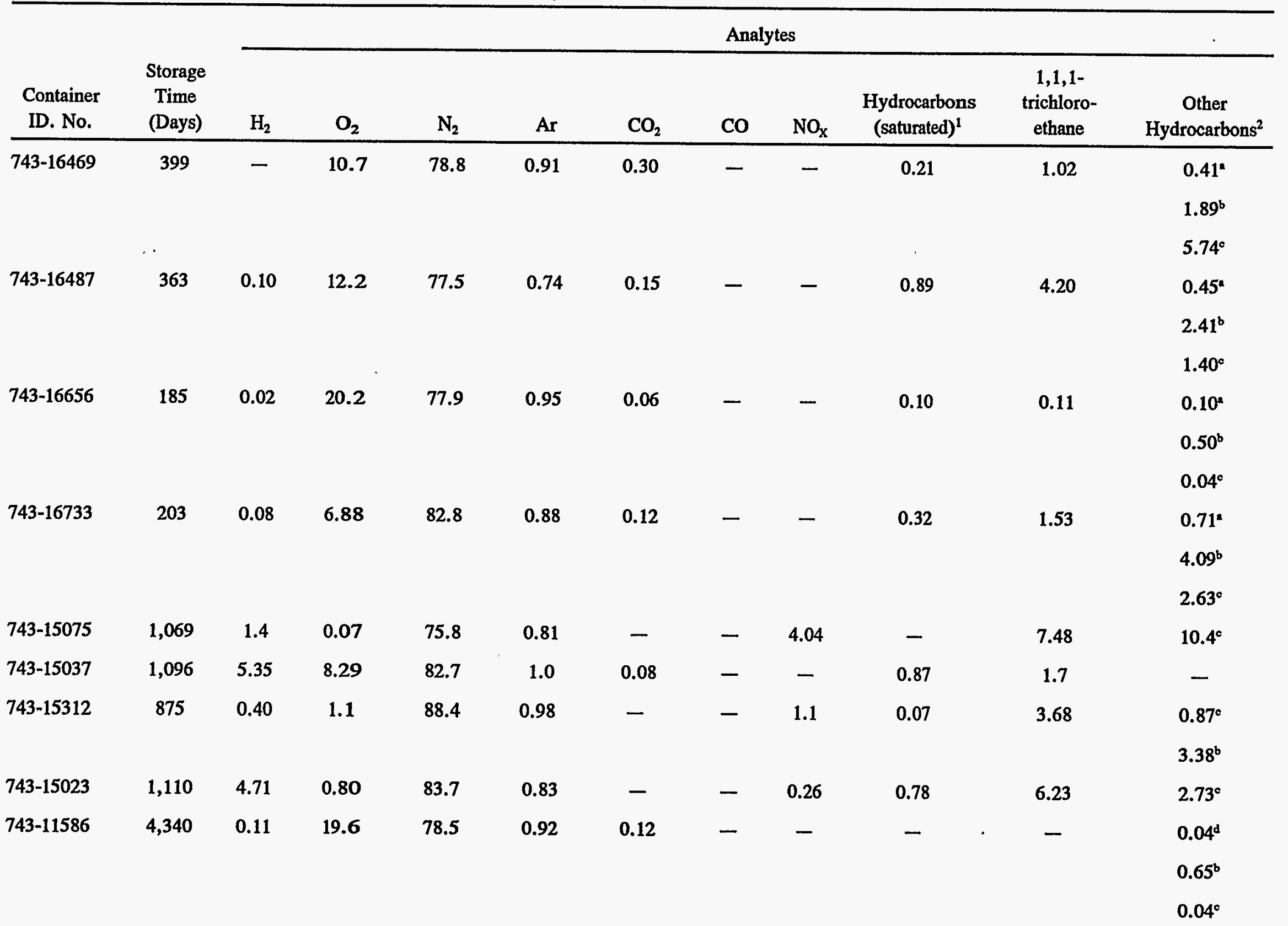




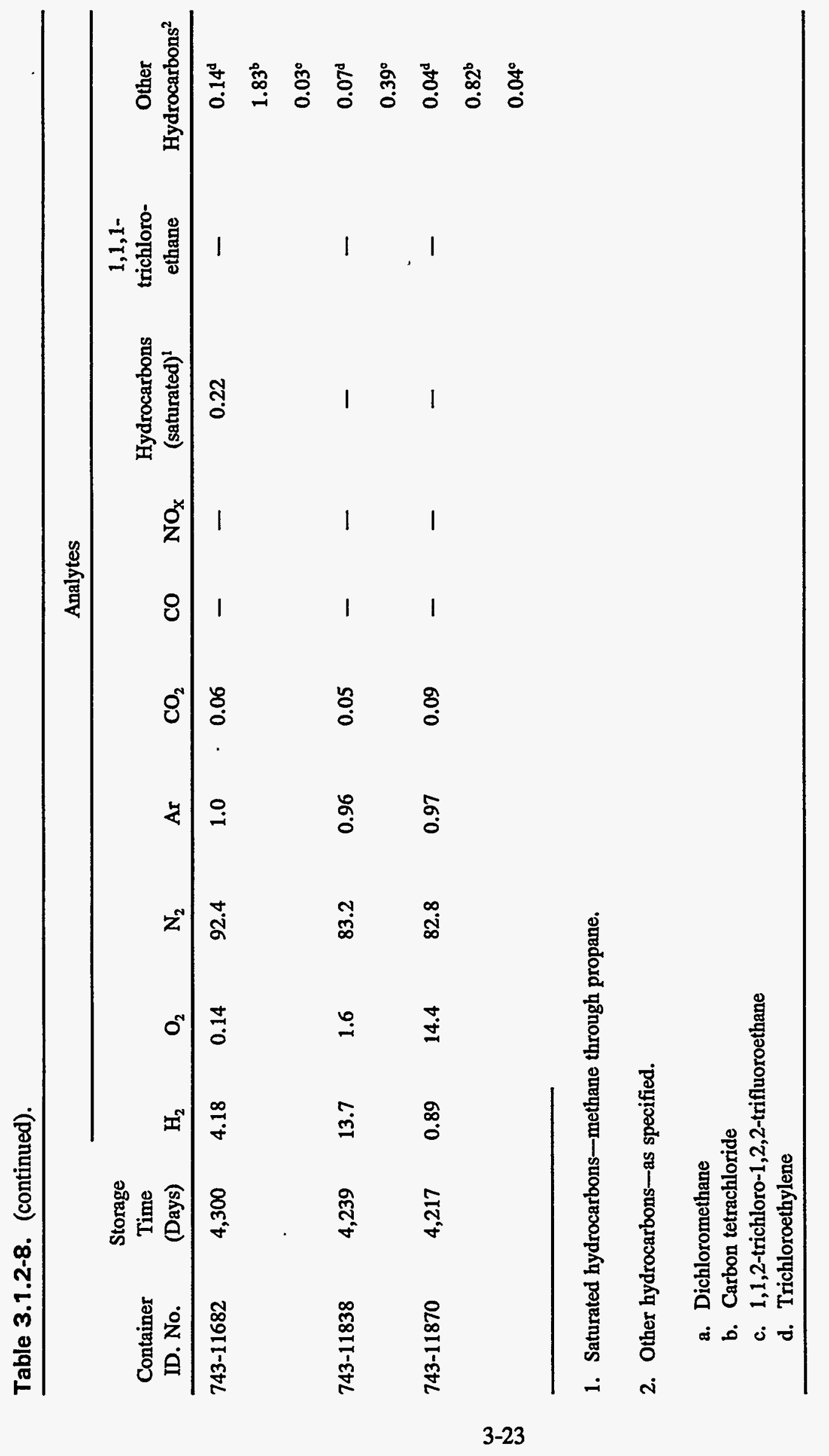




\subsection{Waste Form Number (no waste form number), Content Code RF 114A (Equivalent)}

\subsubsection{Item Description Code 292-Incinerator Sludge}

3.1.3.1 Certification Assessment. This IDC may not be certifiable because of particulate material. Assay and thermal power calculations, including error, need to be updated to meet the current WIPP WAC. Several gas generation criteria need to be addressed. Carbon filters may need to be installed, drums will require inspection to identify unvented or unpunctured rigid liners, and headspace gas analysis and visual waste characterization will need to be performed.

3.1.3.2 Waste Description. During normal process operations, IDC 292-Incinerator Sludge was generated as a by-product of the incineration process in Building 771 . The sludge was generated during the filtration of the potassium hydroxide (KOH) scrubber liquid. The caustic $\mathrm{KOH}$ solution from the scrubber was processed through a drum filter generating a damp sludge consisting primarily of the diatomite filter bed (A). IDC 292 replaced IDC 290 in 1974 (EG\&G RFP 1992c).

3. 1.3.3 Generation Source. IDC 292 incinerator sludge was generated as a by-product of the Incineration Process in Building 771 (A).

3.1.3.4 Recovery Method. Plutonium was recovered from incinerator sludge that was above the discard limit by dissolving the sludge in acid. The filter solution was then run through anionic exchange, and the plutonium was precipitated out of solution. This waste form was generally low in plutonium content and was seldom processed.

3.1.3.5 Waste Packaging and Handling. IDC 292 waste was placed in 2- or 4-liter Nalgene bottles. Before the startup of the cementation process for solids and sludges in Building 371, Portland cement was added to the bottle as a moisture absorbent. Each bottle was placed in a PVC bag-out bag, and the bagged bottle placed inside two plastic bags before final placement in a DOT17C, white, 55-gal drum. Up to fourteen bottles were placed in each 55-gal drum (X). When the drum was full, the polyethylene liners were twisted and taped closed, the lid was secured with a bolted ring, the Drum Count label was completed and taped to the drum lid by the generator, and a TID was attached to the drum (Rockwell International 1989b).

3.1.3.6 Container Preparation. Only approved containers could be used to package TRU waste for shipment offsite. The containers approved for shipment to INEL during this time were DOT-17C, white, 55-gal drums (Rockwell specification SX-200). These containers met the requirements for certification as DOT-7A Type A packaging (Rockwell International 1989e).

Table 3.1.3-1 shows the current inventory of IDC 292 waste containers from the Rocky Flats Plant that have been shipped to INEL since 1985. 
Table 3.1.3-1. Item Description Code 292 Container Information.

\begin{tabular}{|c|c|c|c|}
\hline \multicolumn{2}{|c|}{ Information } & \multirow{2}{*}{$\frac{\text { Drums }}{164}$} & \multirow{2}{*}{$\frac{\text { Boxes }}{0}$} \\
\hline Total Containers & & & \\
\hline \multirow[t]{3}{*}{ Net Container Weight (lb) } & Maximum & 415 & N/A \\
\hline & Minimum & 36 & N/A \\
\hline & Average & 271 & N/A \\
\hline
\end{tabular}

3.1.3.6.1 Drum Preparation-Approved liners for drums of TRU waste packaged for offsite shipment as of 1989 were the round-bottom liner (Rockwell specification SX-203), inside a rigid polyethylene liner (Rockwell specification SX-202), or an O-ring bag and a polyethylene bag placed inside the rigid liner if the drum was attached to a glovebox. All bags were closed using the twist-and-tape method (Rockwell International 1989e).

The IDC 292 sludge mixture was placed in 55-gal drums that were lined with a high-density polyethylene rigid liner, a fiberboard liner, and two polyethylene bags (Rockwell International 1988c). Figure C-1 shows the packaging appropriate for this waste form.

Flow-in ventable gaskets were installed in the drums beginning in December 1982. They were used until October 1988, when tubular gaskets with carbon filters were required. Drums shipped to the INEL between 1985 and 1988 may not meet the current WIPP WAC owing to their lack of carbon filters (Bearly 1989a).

3.1.3.6.2 Box Preparation-No boxes of IDC 292 waste were shipped to INEL between 1985 and 1989.

3.1.3.7 Assay. Individual 4-liter containers were assayed. The assay values for the individual containers placed into a drum were totaled to provide an assay value for the drum. The drums may have been assayed on a SGS counter or a PADC to verify the assigned assay value. Table 3.1.3-2 summarizes the dose rates measured on containers of this IDC. Table 3.1.3-3 is a summary of assay information.

Table 3.1.3-2. Item Description Code 292 Dose Information.

\begin{tabular}{|c|c|c|c|}
\hline Information & & Drums & Boxes \\
\hline One Meter Dose Rate (mrem/h) & $\begin{array}{r}0-0.5 \\
0.5-10\end{array}$ & $\begin{array}{r}146 \\
18\end{array}$ & $\begin{array}{l}\text { N/A } \\
\text { N/A }\end{array}$ \\
\hline Surface Dose Rate $(\mathrm{mrem} / \mathrm{h})$ & $\begin{array}{r}<10 \\
10-200\end{array}$ & $\begin{array}{r}164 \\
0\end{array}$ & $\begin{array}{l}\text { N/A } \\
\text { N/A }\end{array}$ \\
\hline
\end{tabular}


Table 3.1.3-3. Item Description Code 292 Assay Information.

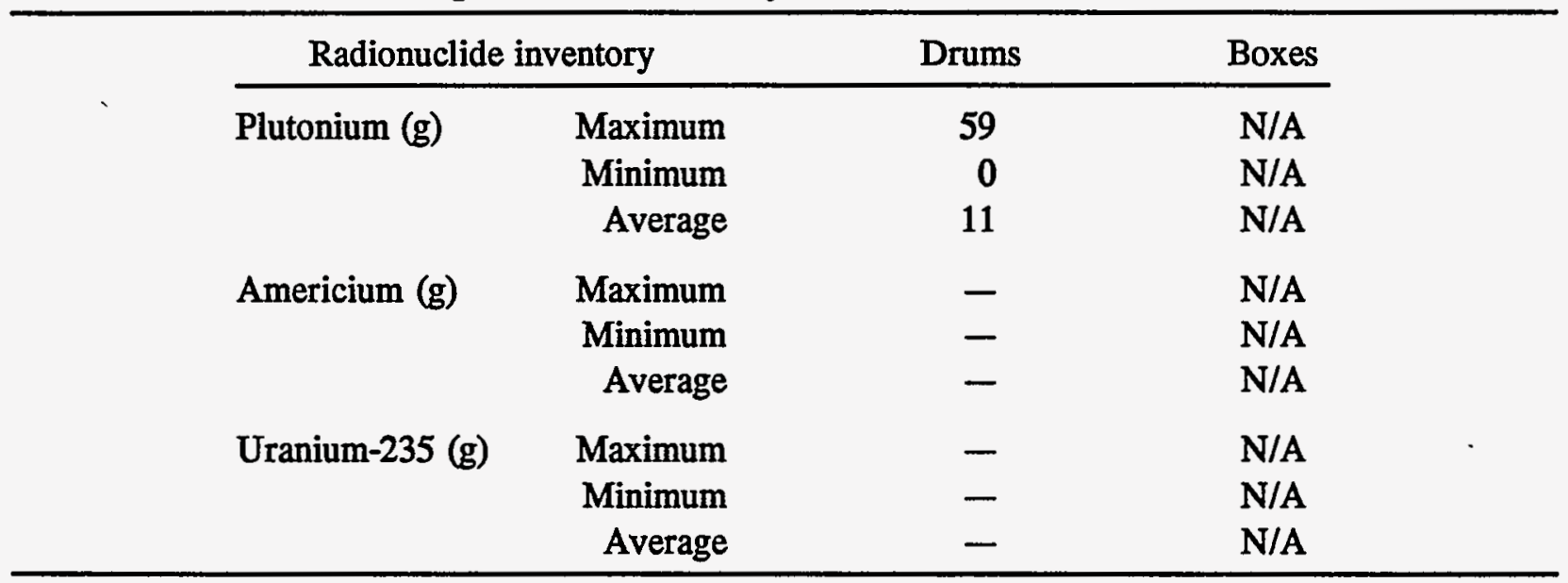

3. 1.3.8 Inspection. Waste Certification periodically reviews the process documentation to ensure that the solidification process is being operated according to procedure. This inspection is performed to ensure that free liquids and particulates will not be found in this waste form. In addition to review of process documentation, Waste Certification personnel performed periodic inspections of the generating and packaging process to verify compliance with waste acceptance criteria. Each drum is viewed using RTR to

- Ensure the drum does not contain nonconforming items

- Ensure the drum is properly packaged

- Verify the waste form description

- Evaluate the presence of free liquids.

3.1.3.9 Waste Form Evaluation. Table 3.1.3-4 evaluates the waste form against the WIPP WAC for such items as free liquids, pyrophoric materials, and compressed gases. Table 3.1.3-5 evaluates the waste against TRUPACT criteria. 
Table 3.1.3-4. Waste Form Evaluation.

Criterion or

requirement

Limiting parameters ${ }^{2}$

Immobilization

Particulates were prohibited by procedural control. Based on the description of the waste, incinerator sludge is not expected to meet the WIPP WAC for particulates.

Liquids The solidified sludge should meet the free liquid criteria by procedural control and RTR inspection prior to shipment from Rocky Flats. However, the sludge should be checked for the possibility that the sludge may have dewatered.

Pyrophoric Pyrophoric materials were prohibited by procedural control. The absence of Materials the pyrophoric materials was verified by the generating supervisor and periodic inspection by the Waste Certification Organization.

Explosives and Compressed Gases

Explosives and compressed gases were prohibited by procedural control. The absence of the explosives and compressed gases was verified by the generating supervisor and periodic inspection by the Waste Certification Organization. In addition, unvented, closed containers and pressurized containers were excluded by procedural controls and RTR examination.

TRU-Mixed Wastes The RCRA constituents exist as co-contaminants with the transuranic radionuclides. Compliance with the WIPP RCRA permits and NMD will be required prior to shipment of the stored waste to WIPP.

Specific Activity of Waste

A portion of the waste stored at INEL may contain $<100$ nanocuries per gram transuranic radionuclides.

$\mathrm{Pu}^{239}$ Equivalent

Activity

None of the IDC 292 waste containers recorded as shipped to INEL in the SWIMS exceed 1,000 $\mathrm{Ci}$ of plutonium-equivalent activity.

a. Many of the limiting parameters were taken from TRU Waste Compliance Program (Rockwell International 1983a, 1987e, and 1989b). 
Table 3.1.3-5. TRUPACT Evaluation.

Criterion or

requirement

Limiting parameters ${ }^{\mathrm{a}}$

Waste Package

Weight

Waste

Containers

Nuclear

Criticality

Rocky Flats limited the fissile content of the drums to 200 grams. However, the error-times-two requirement was not in place at the time the drums were shipped to INEL; therefore, it is not reported as part of the assay of the drum. The TRUPACT limit must be verified at the time of payload assembly at INEL. Based on the typical assays of the IDC 292 drums, the criticality criteria will be met, but must be recalculated or assayed to meet the errortimes-two requirement.

Surface Dose Rate

The surface dose rate criteria used by Rocky Flats was $200 \mathrm{mrem} / \mathrm{hr}$ at the drum surface and $10 \mathrm{mrem} / \mathrm{hr}$ at 1 meter. Shielding was not necessary for IDC 292 drums. The TRUPACT limit must be verified at the time of payload assembly at INEL. Based on the typical dose rates from the IDC 292 drums, the dose rate criteria will be met.

Removable

Surface

The Rocky Flats limit for removable contamination (for TRU assumed to be all

Contamination alpha) was 20 disintegrations per minute $/ 100 \mathrm{~cm}^{2}$. The Rocky Flats limit is equivalent to 9 picocuries per $100 \mathrm{~cm}^{2}$, which is well within the WIPP criteria.

Thermal Power

The thermal power calculation reported in the SWIMS data package is based on the reported assay value without an error/uncertainty correction. The thermal power must be recalculated based on the assay error determination.

Gas Generation Based on the procedural requirements for packaging IDC 292 waste and the waste description, the only areas of noncompliance are carbon filters, unpunctured rigid liners, and headspace gas analysis, and visual characterization.

Toluene was detected by headspace analysis in IDC 292, but is not listed in the TRUPACT Chemical list for RF 114A. 1,1,1-Trichloroethane was detected by headspace analysis and is on the TRUPACT Chemical List. These chemicals appear to be in concentrations of $<1 \%$. Xylene, 1,1,2-trichloro-1,2,2trifluoroethane, carbon tetrachloride and methylene chloride are on the TRUPACT Chemical List for halogenated organics and aromatic hydrocarbons, but were not detected. Alcohols on the TRUPACT Chemical List were not detected.

Personnel performing RTR examination at Rocky Flats would accept up to $10 \%$ of another IDC. The other IDCs could be combustibles, concrete, metal, and plastics.

a. Many of the limiting parameters were taken from TRU Waste Compliance Program (Rockwell International 1983a, 1987e, and 1989b). 
3.1.3.10 Combustible and Organic Content. Table 3.1.3-6 outlines available data from the TRU Waste Sampling Program for IDC 292. SWIMS data indicate that this waste form does not contain $>20 \%$ combustibles or $>20 \%$ organics.

Table 3.1.3-6. Item Description Code 292 Data Summary for Combustible and Organic Content.

\begin{tabular}{ccccccc}
\hline Container & $\begin{array}{c}\text { Wt. } \\
\text { combustibles } \\
(\mathrm{lb})^{\mathrm{a}}\end{array}$ & $\begin{array}{c}\text { Wt. } \\
\text { organics } \\
(\mathrm{lb})^{\mathrm{b}}\end{array}$ & $\begin{array}{c}\text { Net wt. of } \\
\text { container }_{(\mathrm{b})^{\mathrm{c}}}\end{array}$ & $\begin{array}{c}\text { Wt\% } \\
\text { combustibles }^{\mathrm{d}}\end{array}$ & $\begin{array}{c}\text { Vol\% } \\
\text { combustibles }^{\mathrm{e}}\end{array}$ & $\begin{array}{c}\text { Wt\% } \\
\text { organics }^{\mathrm{f}}\end{array}$ \\
\hline $02-40342$ & 31.3 & 31.3 & 177.75 & 18 & 20 & 18 \\
$02-39229$ & 30.3 & 30.3 & 152.75 & 20 & 20 & 20 \\
$02-39213$ & 26.8 & 26.8 & 113.5 & 24 & 15 & 24 \\
$02-39435$ & 20.8 & 20.8 & 151.75 & 14 & 25 & 14 \\
$40-00063$ & 37.8 & 37.8 & 195.5 & 19 & 20 & 19 \\
$76-01642$ & 5.0 & 5.0 & 228.0 & 2 & 5 & 2 \\
$76-01643$ & 5.5 & 5.5 & 83.3 & 7 & 30 & 7 \\
$76-01644$ & 5.0 & 5.0 & 159.5 & 3 & 5 & 3 \\
\hline
\end{tabular}

a. Sum of weights of all combustible material and leaded rubber from Table 25 (Clements and Kudera 1985).

b. Sum of weights of all combustible material, leaded rubber, and organic material from Table 25 (Clements and Kudera 1985).

c. Net weight of container from Table 25 (Clements and Kudera 1985).

d. Weight of combustible material/net weight of container $\times 100$.

e. Vol\% of combustible material from visual examination, obtained from Appendix B (Clements and Kudera 1985).

f. Weight of organic material/net weight of container $\times 100$.

3.1.3.10.1 Combustible Content-SWIMS data show that IDC 292 waste is noncombustible (Rockwell International 1985a). In support of the TRU Waste Sampling Program, eight drums of IDC 292 waste were opened. They were found to contain an average wt\% combustible content of $13.4 \%$. Visual inspection showed an average vol\% combustible content of $17.5 \%$ (Clements and Kudera 1985).

3.1.3.10.2 Organic Content-SWIMS data show that IDC 292 waste may contain $10 \%$ organics (Rockwell International 1985a). In support of the TRU Waste Sampling Program, eight drums of IDC 292 waste were opened. They were found to contain an average wt\% organic content of $13.4 \%$ (Clements and Kudera 1985). 
3.1.3.11 Analytical Information. Analytical data from the WIPP Experimental Waste Characterization Program for IDC 292-Incinerator Sludge, indicate that two drums were subject to headspace gas analysis (EG\&G RFP 1994t).

IDC 292 Gas Mass Spectrometry analytical results are presented in Table 3.1.3-7. The drums were subject to the operational lid headspace sampling program. Nitrogen, oxygen, and argon analytes were detected in the drum.

IDC 292 VOC Gas Chromatography/Mass Spectrometry analytical results indicate 6.2 and 3.3 parts per million by volume (ppmv) toluene in drums D49662 and D76146, respectively.

Analytical data from the TRU Waste Sampling Waste Characterization Program for IDC 292, Incinerator Sludge, indicate that eight drums were subject to headspace gas analysis (Clements and Kudera 1985). Gas composition analytical results are presented in Table 3.1.3-8. Waste boxes were not sampled. Hydrogen, oxygen, nitrogen, argon, carbon dioxide, saturated hydrocarbons, and 1,1,1-trichloroethane were detected in the drums.

IDC 292 will contain most of the same constituents as the ash from which it was derived. Because the specific sources of the incinerator feed cannot be determined at this time, it has been assumed that the process could have accepted any of the combustible, plastic, or filter waste that was generated during the time the incinerator was operational. Alcohols, glycols, halogenated solvents, and metals may have been introduced into the incinerator. The EPA Codes assigned to this waste include D004-D011, F001, F002, F003, and F005 (A).

Table 3.1.3-7. Gas Mass Spectrometry Results (vol\%).

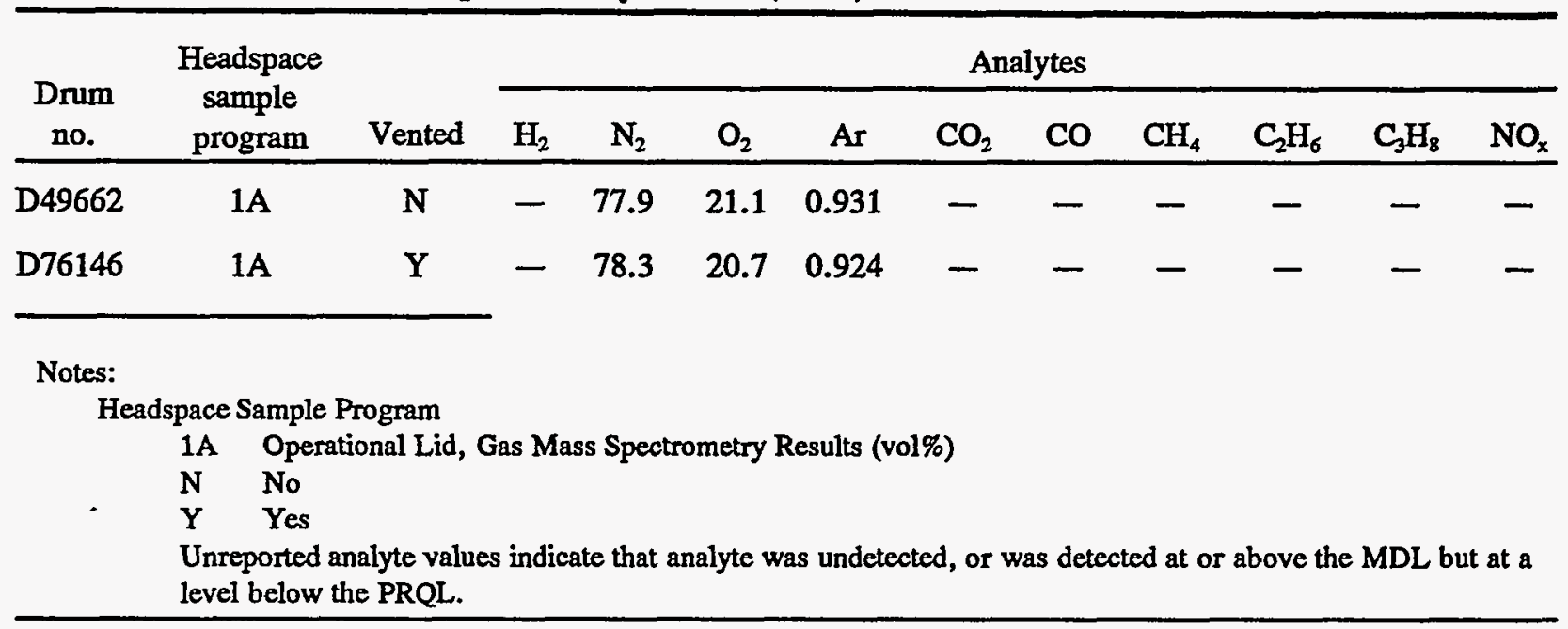


Table 3.1.3-8. Gas Sampling Results-Compositional Analysis (vol\%).

\begin{tabular}{|c|c|c|c|c|c|c|c|c|c|c|c|}
\hline \multirow[b]{2}{*}{$\begin{array}{c}\text { Container } \\
\text { ID. no. }\end{array}$} & \multirow{2}{*}{$\begin{array}{c}\text { Storage } \\
\text { time } \\
\text { (days) }\end{array}$} & \multicolumn{10}{|c|}{ Analytes } \\
\hline & & $\mathrm{H}_{2}$ & $\mathbf{O}_{2}$ & $\mathrm{~N}_{2}$ & $\mathrm{Ar}$ & $\mathrm{CO}_{2}$ & $\mathrm{CO}$ & $\mathrm{NO}_{\mathrm{x}}$ & $\begin{array}{l}\text { Hydrocarbons } \\
\text { (saturated) }^{2}\end{array}$ & $\begin{array}{c}1,1,1- \\
\text { trichloroethane }\end{array}$ & $\begin{array}{c}\text { Other } \\
\text { hydrocarbons }\end{array}$ \\
\hline $02-40342$ & 160 & 4.75 & 0.25 & 93.4 & 1.1 & - & - & - & 0.14 & 0.31 & - \\
\hline $02-39229$ & 327 & 9.08 & 0.09 & 89.1 & 1.1 & - & - & - & 0.15 & 0.49 & - \\
\hline $02-39213$ & 321 & 2.35 & 18.7 & 77.6 & 0.93 & - & - & - & 0.16 & 0.25 & - \\
\hline $02-39435$ & 260 & 1.8 & 9.92 & 86.7 & 1.0 & - & - & - & 0.29 & 0.25 & - \\
\hline $40-00063$ & 1081 & 23.2 & - & 75.6 & 0.89 & - & - & - & - & 0.31 & - \\
\hline $76-01642$ & 880 & 7.50 & 5.62 & 85.2 & 1.0 & - & - & - & 0.64 & - & - \\
\hline $76-01643$ & 887 & 0.55 & 17.9 & 80.4 & 0.97 & 0.07 & - & - & 0.12 & - & - \\
\hline $76-01644$ & 880 & 4.66 & 6.92 & 86.9 & 1.0 & - & - & - & 0.51 & - & - \\
\hline
\end{tabular}




\subsection{Waste Form Number (no waste form number), Content Code RF 122A (Equivalent)}

\subsubsection{Item Description Code 393-Sand, Slag, and Crucible Heels}

3.1.4.1 Certification Assessment. This IDC is not certifiable without further waste treatment for particulates. Assay and thermal power calculations, including error, need to be updated to meet the current WIPP WAC. Several gas generation criteria need to be addressed. Carbon filters may need to be installed, drums will require inspection to identify unvented or unpunctured rigid liners, and headspace gas analysis and visual waste characterization will need to be performed.

3.1.4.2 Waste Description. IDC 393 consists of undissolved solids (sand, calcium fluoride slag, and crucible heels) produced in the Dissolution Process in Gloveboxes (Lines) 23 and 25 in Building 771. Pulverized sand, slag, and crucible from the Crushing Process was placed in a dissolution pot with heated nitric acid and aluminum nitrate. The solution (plutonium nitrate) was pulled by vacuum through an R-6 filter to remove undissolved solids. The undissolved solids were dried on a hot plate and placed in 4-liter, wide-mouth, polyethylene bottles for removal from the glovebox. After the containers were bagged out, they were assayed individually. The residue sand, slag, and crucible heels were stored awaiting plutonium recovery by dissolution (EG\&G RFP 1994d).

3.1.4.3 Generation Source. IDC 393 was produced in the Dissolution Process in Gloveboxes (Lines) 23 and 25 in Building 771 (EG\&G RFP 1994d).

3.1.4.4 Recovery Method. Above-discard contaminated sand, slag, and crucibles (material that is above the discard limit), generated from metal-reduction operations, were pulverized and leached with nitric acid. The remaining insoluble residue or heel from the leaching process was collected, vacuum-dried, washed with water, and then dried on a hot plate (Clements 1982). Belowdiscard heels were packaged as waste while above-discard heels were staged for acid dissolution.

3.1.4.5 Waste Packaging and Handling. TRU inorganic solid waste was segregated from all noncomplying materials and was bagged out of the glovebox. The waste was then placed in a DOT-17C, 55-gal drum. When the drum was full, the drum liners were sealed and the drum was closed. The drum label, completed with all necessary information, was then taped to the drum lid and a TID was attached to the drum.

3.1.4.6 Container Preparation. Only approved containers could be used to package TRU waste for shipment offsite. The containers approved for shipment to INEL during this time were DOT-17C. These containers met the requirements for certification as DOT-7A Type A packaging (Rockwell International 1989e).

Table 3.1.4-1 shows the current inventory of IDC 393 waste containers from the Rocky Flats Plant that have been shipped to INEL since 1985. 
Table 3.1.4-1. Item Description Code 393 Container Information.

\begin{tabular}{lccc}
\multicolumn{1}{c}{ Information } & & Drums & Boxes \\
\cline { 2 - 4 } Total Containers & & 5 & 0 \\
Net Container Weight $(\mathrm{lb})$ & Maximum & 158 & N/A \\
& Minimum & 141 & N/A \\
& Average & 152 & N/A \\
\hline
\end{tabular}

3. 1.4.6.1 Drum Preparation-Approved liners for drums of TRU waste packaged for offsite shipment were the round-bottom liner (Rockwell specification SX-203) inside a 90-mil rigid polyethylene liner (Rockwell specification SX-202), or an O-ring bag and a polyethylene bag placed inside the rigid liner if the drum was attached to a glovebox (Rockwell International 1989e). Type III rigid liners have been used since September 1983 (Bearly 1989a). The IDC 393 waste packaged for offsite shipment required a fiberboard liner and two polyethylene bags inside the rigid liner (Rockwell International 1988c) Figure C-1 shows the appropriate drum liners for this IDC. All bags were closed using the twist-and-tape method (Rockwell International 1989e).

Flow-in, ventable gaskets were installed in the drums beginning in December 1982. They were used until October 1988, when tubular gaskets with carbon filters were required. Drums shipped to INEL between 1985 and 1988 may not meet the current WIPP WAC, owing to their lack of carbon filters (Bearly 1989a).

3.1.4.6.2 Box Preparation-No boxes of IDC 393 waste were shipped to INEL between 1985 and 1989.

3.1.4.7 Assay. Individual 4-liter containers were assayed. The assay values for the individual containers placed into a drum were totaled to provide an assay value for the drum. The drums may have been assayed on a SGS counter or a PADC to verify the assigned assay value. Table 3.1.4-2 summarizes the dose rates measured on containers of this IDC. Table 3.1.4-3 provides a summary of the assay information.

Table 3.1.4-2. Item Description Code 393 Dose Information.

\begin{tabular}{|c|c|c|c|}
\hline Information & & Drums & Boxes \\
\hline One Meter Dose Rate (mrem/h) & $\begin{array}{r}0-0.5 \\
0.5-10\end{array}$ & $\begin{array}{l}0 \\
5\end{array}$ & $\begin{array}{l}\text { N/A } \\
\text { N/A }\end{array}$ \\
\hline Surface Dose Rate (mrem/h) & $\begin{array}{r}<10 \\
10-200\end{array}$ & $\begin{array}{l}4 \\
1\end{array}$ & $\begin{array}{l}\text { N/A } \\
\text { N/A }\end{array}$ \\
\hline
\end{tabular}


Table 3.1.4-3. Item Description Code 393 Assay Information.

\begin{tabular}{lcccc}
\hline \multicolumn{2}{c}{ Radionuclide inventory } & Drums & Boxes \\
\cline { 2 - 5 } Plutonium (g) & Maximum & 174 & N/A \\
& Minimum & 168 & N/A \\
& Average & 171 & N/A \\
& Americium (g) & Maximum & - & N/A \\
& Minimum & - & N/A \\
& Average & - & N/A \\
& Uranium-235 (g) & Maximum & - & N/A \\
& Minimum & - & N/A \\
\hline
\end{tabular}

3.1.4.8 Inspection. Waste Certification personnel performed periodic inspections of the generating and packaging process to verify compliance with packaging procedures. This material would not have been certifiable for disposal until it was processed into IDC 806.

3.1.4.9 Waste Form Evaluation. Table 3.1.4-4 evaluates the waste form against the WIPP WAC for such items as free liquids, pyrophoric materials, and compressed gases. Table 3.1.4-5 evaluates the waste against TRUPACT criteria. 
Table 3.1.4-4. Waste Form Evaluation.

Criterion or requirement

Immobilization

Liquids

Pyrophoric Materials

Explosives and Compressed Gases

TRU-Mixed Wastes

Specific Activity of Waste

$\mathrm{Pu}^{239}$ Equivalent Activity
Limiting parameters ${ }^{2}$

This IDC consists of pulverized materials. The WIPP WAC for particulates will not be met without further treatment.

There are normally no liquids associated with this IDC. Personnel performing RTR examination at Rocky Flats would accept up to 2 cups of free liquid, if liquids were present.

Pyrophoric materials were prohibited by procedural control. The absence of the pyrophoric materials was verified by the generating supervisor and periodic inspection by the Waste Certification Organization.

Explosives and compressed gases were prohibited by procedural control. The absence of the explosives and compressed gases was verified by the generating supervisor and periodic inspection by the Waste Certification Organization. In addition, unvented, closed containers and pressurized containers were excluded by procedural controls and RTR examination.

The RCRA constituents exist as co-contaminants with the transuranic radionuclides. Compliance with the WIPP RCRA permits and NM) will be required before shipment of the stored waste to WIPP.

This waste contains at least 100 nanocuries per gram transuranic radionuclides.

None of the IDC 393 waste containers recorded as shipped to INEL in the SWIMS exceed $1,000 \mathrm{Ci}$ of plutonium-equivalent activity.

a. Many of the limiting parameters were taken from TRU Waste Compliance Program (Rockwell International 1983a, 1987e, and 1989b). 
Table 3.1.4-5. TRUPACT Evaluation.

Criterion or

requirement

Limiting parameters ${ }^{a}$

Waste Package

Weight

Rocky Flats limited the gross weight of drums to $800 \mathrm{lb}$. The TRUPACT

and vehicle weight limits must be verified at the time of payload assembly

at INEL.

Waste Containers

Waste was shipped in 55-gal DOT-7A, Type A drums.

Nuclear Criticality

Rocky Flats limited the fissile content of the drums to 200 grams.

However, the error-times-two requirement was not in place at the time the drums were shipped to INEL; therefore, it is not reported as part of the assay of the drum. The TRUPACT limit must be verified at the time of payload assembly at INEL. Based on the typical assays of the IDC 393 drums, the criticality criteria must be recalculated or assayed to meet the error-times-two requirement.

Surface Dose Rate The surface dose rate criteria used by Rocky Flats was $200 \mathrm{mrem} / \mathrm{hr}$ at the drum surface and $10 \mathrm{mrem} / \mathrm{hr}$ at 1 meter. Shielding was not necessary for IDC 393 drums. The TRUPACT limit must be verified at the time of payload assembly at INEL. Based on the typical dose rates from the IDC 393 drums, the dose rate criteria will be met.

Removable Surface Contamination

The Rocky Flats limit for removable contamination (for TRU assumed to be all alpha) was 20 disintegrations per minute $/ 100 \mathrm{~cm}^{2}$. The Rocky Flats limit is equivalent to 9 picocuries per $100 \mathrm{~cm}^{2}$, which is well within the WIPP criteria.

Thermal Power

The thermal power calculation reported in the SWIMS data package is based on the reported assay value without an error/uncertainty correction. The thermal power must be recalculated based on the assay error determination.

Gas Generation

Based on the procedural requirements for packaging IDC 393 waste and the waste description, the only areas of noncompliance are carbon filters, unpunctured rigid liners, and headspace gas analysis, and visual characterization.

Personnel performing RTR examination at Rocky Flats would accept up to $10 \%$ of another IDC. The other IDCs could be combustibles, glass, concrete, metal, leaded gloves, and plastics.

a. Many of the limiting parameters were taken from TRU Waste Compliance Program (Rockwell International 1983a, 1987e, and 1989b).

3.1.4.10 Combustible and Organic Content. SWIMS data indicate that this waste form does not contain $>20 \%$ combustibles or $>20 \%$ organics.

3.1.4.10.1 Combustible Content-SWIMS data show that IDC 393 waste is noncombustible (Rockwell International 1985a). 
3.1.4.10.2 Organic Content-SWIMS data show that IDC 393 waste contains $10 \%$ organics (Rockwell International 1985a).

3.1.4.11 Analytical Information. No analytical information is available for IDC 393 .

IDC 393 is assigned the EPA Code D007 (EG\&G RFP 1992a, EG\&G RFP 1993g, EG\&G RFP 1992b). Chromium can be added to the heel from the corrosion of the stainless steel in the dissolution process area (EG\&G RFP 1994d). 


\subsection{Waste Form Number (no waste form number), Content Code RF 124A (Equivalent)}

\subsubsection{Item Description Code 409-Molten Salt 30\% Unpulverized}

3.1.5.1 Certification Assessment. This IDC is certifiable without further waste treatment. Assay and thermal power calculations, including error, need to be updated to meet the current WIPP WAC. Several gas generation criteria need to be addressed. Carbon filters may need to be installed, drums will require inspection to identify unvented or unpunctured rigid liners, and headspace gas analysis and visual waste characterization will need to be performed.

3.1.5.2 Waste Description. This waste was produced during the molten salt extraction (MSE) of plutonium metal containing unacceptable levels of americium. Plutonium metal containing unacceptable levels of americium was combined with an equimolar mixture of sodium chloride and potassium chloride with magnesium chloride. The metal and salts were placed in a tantalum crucible and then in a furnace and heated until molten. The molten material was then stirred. While the mixture was molten, the magnesium chloride oxidized most of the americium and some of the plutonium, and the oxidized actinides went to the salt phase. After stirring, the salt and metal phases would separate. IDC 409 waste was formed when a 30-mole-percent ratio of magnesium chloride was used in the fresh salt. IDC 409 waste is composed primarily of sodium chloride, potassium chloride, residual magnesium chloride, entrained magnesium metal, and various plutonium and americium compounds (EG\&G RFP 19941).

3.1.5.3 Generation Source. The primary buildings of generation of IDC 409 were Buildings 371, 771, 776, and 779 (EG\&G RFP 19941).

3.1.5.4 Recovery Method. Salt Scrub was a process used to recover plutonium from MSE salts. In this process, MSE salts were combined with a reducing agent and an alloying agent; the combinations of magnesium and aluminum, calcium, and gallium, and calcium and cerium have been used. The crucible and contents were placed in a furnace and heated until the contents were molten and the mixture was stirred. While molten, the plutonium and americium were reduced by the calcium or magnesium and the actinides went into the metal alloy phase. After cooling, the crucible was broken and the salt and scrub alloy were separated. (EG\&G RFP 19941).

3.1.5.5 Waste Packaging and Handling. Waste molten salts were packaged in produce cans. They were then assayed and packaged in prepared 55-gal drums (Rockwell International $1989 \mathrm{~b})$. When the drum was full, the drum liners were sealed and the drum was closed. The drum label, completed with all necessary information, was then taped to the drum lid and a TID was attached to the drum.

3.1.5.6 Container Preparation. Only approved containers could be used to package TRU waste for shipment offsite. The containers approved for shipment to INEL during this time were DOT-17C, white, 55-gal drums (Rockwell specification SX-200). These containers met the requirements for certification as DOT-7A Type A packaging (Rockwell International 1989e).

Table 3.1.5-1 shows the current inventory of IDC 409 waste containers from the Rocky Flats Plant that have been shipped to INEL since 1985. 
Table 3.1.5-1. Item Description Code 409 Container Information.

\begin{tabular}{lrcc}
\hline \multicolumn{1}{c}{ Information } & & Drums & Boxes \\
\hline Total Containers & & 7 & 0 \\
Net Container Weight (lb) & Maximum & 213 & N/A \\
& Minimum & 10 & N/A \\
& Average & 169 & N/A \\
\hline
\end{tabular}

3.1.5.6.1 Drum Preparation-Approved liners for drums of TRU waste packaged for offsite shipment were the round-bottom liner (Rockwell specification SX-203) inside a 90-mil rigid polyethylene liner (Rockwell specification SX-202), or an O-ring bag and a polyethylene bag placed inside the rigid liner if the drum was attached to a glovebox (Rockwell International 1989e). Type III rigid liners have been used since September 1983. The IDC 409 waste packaged for offsite shipment required a fiberboard liner and a round bottom liner inside the rigid liner (Rockwell International 1989e). Data from the TRU Waste Sampling Program indicate that some of this waste was put in drums with lead liners and some was not (Clements and Kudera 1985). Figure C-1 shows the appropriate drum liners for this IDC. All bags were closed using the twist-and-tape method (Rockwell International 1989e).

Flow-in, ventable gaskets were installed in the drums beginning in December 1982. They were used until October 1988, when tubular gaskets with carbon filters were required. Drums shipped to INEL between 1985 and 1988 may not meet the current WIPP WAC, owing to their lack of carbon filters (Bearly 1989a).

3.1.5.6.2 Box Preparation. - No boxes of IDC 409 waste were shipped to INEL between 1985 and 1989 .

3.1.5.7 Assay. Small containers of spent salt were assayed in the "in-line can counter." These cans were then checked using SGS assay equipment. This safeguard check was not used to document assay values. Table 3.1.5-2 summarizes the dose rates measured on containers of this IDC. Table 3.1.5-3 provides a summary of the assay information. Five drums were evaluated for americium content, no drums were evaluated for uranium content.

Table 3.1.5-2. Item Description Code 409 Dose Information.

\begin{tabular}{crcc}
\hline Information & & Drums & Boxes \\
\hline One Meter Dose Rate (mrem/h) & $0-0.5$ & 2 & N/A \\
& $0.5-10$ & 5 & N/A \\
Surface Dose Rate (mrem/h) & $<10$ & 7 & N/A \\
& $10-200$ & 0 & N/A \\
\hline
\end{tabular}


Table 3.1.5-3. Item Description Code 409 Assay Information.

\begin{tabular}{|c|c|c|c|}
\hline \multicolumn{2}{|c|}{ Radionuclide inventory } & Drums & Boxes \\
\hline Plutonium (g) & $\begin{array}{r}\text { Maximum } \\
\text { Minimum } \\
\text { Average }\end{array}$ & $\begin{array}{r}167 \\
57 \\
104\end{array}$ & $\begin{array}{l}\text { N/A } \\
\text { N/A } \\
\text { N/A }\end{array}$ \\
\hline Americium (g) & $\begin{array}{r}\text { Maximum } \\
\text { Minimum } \\
\text { Average }\end{array}$ & $\begin{array}{l}7 \\
2 \\
4\end{array}$ & $\begin{array}{l}\text { N/A } \\
\text { N/A } \\
\text { N/A }\end{array}$ \\
\hline Uranium-235 (g) & $\begin{array}{r}\text { Maximum } \\
\text { Minimum } \\
\text { Average }\end{array}$ & $\begin{array}{l}- \\
-\end{array}$ & $\begin{array}{l}\text { N/A } \\
\text { N/A } \\
\text { N/A }\end{array}$ \\
\hline
\end{tabular}

3.1.5.8 Inspection. Waste Certification personnel performed periodic inspections of the generating and packaging process to verify compliance with waste acceptance criteria. In addition, drums that are not lead-lined were viewed using RTR to

- Ensure the drum does not contain nonconforming items

- Ensure the drum is properly packaged

- Verify the waste form description

- Evaluate the presence of free liquids.

3.1.5.9 Waste Form Evaluation. Table 3.1.5-4 evaluates the waste form against the WIPP WAC for such items as free liquids, pyrophoric materials, and compressed gases. Table 3.1.5-5 evaluates the waste against TRUPACT criteria. 
Table 3.1.5-4. Waste Form Evaluation.

Criterion or

requirement

Limiting parameters ${ }^{2}$

Immobilization

This waste consists of fused salts. Based on the description of the waste, fine particulates are not expected in this IDC.

Liquids

There are normally no liquids associated with this IDC. Personnel performing RTR examination at Rocky Flats would accept up to 2 cups of free liquid, if liquids were present.

Pyrophoric

Materials

Pyrophoric materials were prohibited by procedural control. The absence of the pyrophoric materials was verified by the generating supervisor and periodic inspection by the Waste Certification Organization.

Explosives and Compressed Gases

Explosives and compressed gases were prohibited by procedural control. The absence of the explosives and compressed gases was verified by the generating supervisor and periodic inspection by the Waste Certification Organization. In addition, unvented, closed containers and pressurized containers were excluded by procedural controls and RTR examination.

TRU-Mixed Wastes This is a nonhazardous waste form. Compliance with the WIPP RCRA permits and NMD will be required before shipment of the stored waste to WIPP.

Specific Activity of This waste contains at least 100 nanocuries per gram transuranic Waste radionuclides.

$\mathrm{Pu}^{239}$ Equivalent Activity

None of the IDC 409 waste containers recorded as shipped to INEL in the SWIMS exceed 1,000 Ci of plutonium-equivalent activity.

a. Many of the limiting parameters were taken from TRU Waste Compliance Program (Rockwell International 1983a, 1987e, and 1989b). 
Table 3.1.5-5. TRUPACT Evaluation.

Criterion or requirement

Limiting parameters ${ }^{2}$

Waste Package

Weight

Rocky Flats limited the gross weight of drums to $800 \mathrm{lb}$. The TRUPACT and vehicle weight limits must be verified at the time of payload assembly at INEL. Based on the typical weights of the IDC 409 drums, the maximum payload weight will not be reached.

Waste Containers

Waste was shipped in 55-gal, DOT-7A, Type A drums.

Nuclear Criticality

Rocky Flats limited the fissile content of the drums to 200 grams. However, the error-times-two requirement was not in place at the time the drums were shipped to INEL; therefore, it is not reported as part of the assay of the drum. The TRUPACT limit must be verified at the time of payload assembly at INEL. Based on the typical assays of the IDC 409 drums, the criticality criteria will require re-assayed to meet the error-times-two requirement.

Surface Dose Rate The surface dose rate criteria used by Rocky Flats was $200 \mathrm{mrem} / \mathrm{hr}$ at the drum surface and $10 \mathrm{mrem} / \mathrm{hr}$ at 1 meter. Shielding was not necessary for IDC 409. The TRUPACT limit must be verified at the time of payload assembly at INEL. Based on the typical dose rates from the IDC 409 drums, the dose rate criteria will be met.

Removable Surface

The Rocky Flats limit for removable contamination (for TRU assumed to be all Contamination alpha) was 20 disintegrations per minute $/ 100 \mathrm{~cm}^{2}$. The Rocky Flats limit is equivalent to 9 picocuries per $100 \mathrm{~cm}^{2}$, which is well within the WIPP criteria.

Thermal Power

The thermal power calculation reported in the SWIMS data package is based on the reported assay value without an error/uncertainty correction. The thermal power must be recalculated based on the assay error determination.

Gas Generation Based on the procedural requirements for packaging IDC 409 waste and the waste description, the only areas of noncompliance are carbon filters, unpunctured rigid liners, and headspace gas analysis, and visual characterization.

1,1,1-Trichloroethane and 1,2-dichloroethane were detected during headspace gas analysis; however no organics are listed on the TRUPACT Chemical List for Content Code RF 124A.

Personnel performing RTR examination at Rocky Flats would accept up to $10 \%$ of another IDC. The other IDCs could be combustibles, glass, concrete, metal, leaded gloves, and plastics.

a. Many of the limiting parameters were taken from TRU Waste Compliance Program (Rockwell International 1983a, 1987e, and 1989b).

3.1.5.10 Combustible and Organic Content. Table 3.1.5-6 outlines available data from the TRU Waste Sampling Program for IDC 409. SWIMS data indicate that this waste form does not contain $>20 \%$ combustibles or $>20 \%$ organics. 
Table 3.1.5-6. Item Description Code 409 Data Summary for Combustible and Organic Content.

\begin{tabular}{lcccccc}
\hline & $\begin{array}{c}\text { Wt. } \\
\text { combustibles } \\
\text { Container }\end{array}$ & $\begin{array}{c}\text { Wt. } \\
\text { organics } \\
(\mathrm{lb})^{\mathrm{a}}\end{array}$ & $\begin{array}{c}\text { Net wt. of } \\
\text { container } \\
(\mathrm{lb})^{\mathrm{b}}\end{array}$ & $\begin{array}{c}\text { Wt\% } \\
\text { combustibles }^{\mathrm{d}}\end{array}$ & $\begin{array}{c}\text { Vol\% } \\
\text { combustibles }^{\mathrm{e}}\end{array}$ & $\begin{array}{c}\text { Wt\% } \\
\text { organics }^{\mathrm{f}}\end{array}$ \\
\hline $01-05779$ & 3.0 & 3.0 & 32.25 & 9 & 5 & 9 \\
$03-02724$ & 18.2 & 18.2 & 165.2 & 11 & 10 & 11 \\
\hline
\end{tabular}

a. Sum of weights of all combustible material and leaded rubber from Table 28 (Clements and Kudera 1985).

b. Sum of weights of all combustible material, leaded rubber, and organic material from Table 28 (Clements and Kudera 1985).

c. Net weight of container from Table 28 (Clements and Kudera 1985).

d. Weight of combustible material/net weight of container $\times 100$.

e. Vol \% of combustible material from visual examination, obtained from Appendix B (Clements and Kudera 1985).

f. Weight of organic material/net weight of container $\times 100$.

3.1.5.10.1 Combustible Content-SWIMS data show that IDC 409 waste is noncombustible (Rockwell International 1985a). In support of the TRU Waste Sampling Program, two drums of IDC 409 waste were opened. They were found to contain an average wt\% combustible content of $10 \%$. Visual inspection showed an average vol\% combustible content of $7.5 \%$ (Clements and Kudera 1985).

3.1.5.10.2 Organic Content-SWIMS data show that IDC 409 waste may contain zero percent organics (Rockwell International 1985a). In support of the TRU Waste Sampling Program, two drums of IDC 409 waste were opened. They were found to contain an average wt\% organic content of $10 \%$ (Clements and Kudera 1985).

3.1.5.11 Analytical Information. Analytical data from the TRU Waste Sampling Waste Characterization Program (Clements and Kudera 1985) for IDC 409-Molten Salt 30\% Unpulverized, indicate that two drums were subject to headspace gas analysis. Gas composition analytical results are presented in Table 3.1.5-7. Waste boxes were not sampled. Hydrogen, oxygen, nitrogen, argon, carbon dioxide, saturated hydrocarbons, 1,1,1-trichloroethane, and 1,2-dichloroethane were detected in the drums.

IDC 409 is not a RCRA-hazardous waste and has been assigned no EPA codes (EG\&G RFP 19941). 
Table 3.1.5-7. Gas Sampling Results-Compositional Analysis (vol\%).

\begin{tabular}{|c|c|c|c|c|c|c|c|c|c|c|c|}
\hline \multirow[b]{2}{*}{$\begin{array}{c}\text { Container } \\
\text { ID. no. }\end{array}$} & \multirow{2}{*}{$\begin{array}{c}\text { Storage } \\
\text { time } \\
\text { (days) }\end{array}$} & \multicolumn{10}{|c|}{ Analytes } \\
\hline & & $\mathrm{H}_{2}$ & $\mathrm{O}_{2}$ & $\mathbf{N}_{2}$ & $\mathrm{Ar}$ & $\mathrm{CO}_{2}$ & $\mathrm{CO}$ & $\mathrm{NO}_{\mathrm{x}}$ & $\begin{array}{l}\text { Hydrocarbons } \\
\text { (saturated) }^{1}\end{array}$ & $\begin{array}{c}1,1,1- \\
\text { trichloroethane }\end{array}$ & $\begin{array}{c}\text { Other } \\
\text { hydrocarbons }{ }^{2}\end{array}$ \\
\hline $01-05779$ & 230 & 0.09 & 21.08 & 76.61 & 0.92 & 0.09 & - & - & 0.05 & 0.92 & $0.23^{a}$ \\
\hline $03-02724^{3}$ & 104 & 0.02 & 21.2 & 77.7 & 0.96 & 0.08 & - & - & 0.01 & - & -1 \\
\hline
\end{tabular}

1. Saturated hydrocarbons-methane through propane.

2. Other hydrocarbons-as specified.

a. 1,2-dichloroethane

3. Drum sealed with semi-permeable gasket. 


\subsection{Waste Form Number (no waste form number), Content Code RF 124A (Equivalent)}

\subsubsection{Item Description Code 414-DOR Salt}

3.1.6.1 Certification Assessment. This IDC may not be certifiable without further waste treatment to remove reactive metals (pyrophoric). Assay and thermal power calculations, including error, need to be updated to meet the current WIPP WAC. Several gas generation criteria need to be addressed. Carbon filters may need to be installed, drums will require inspection to identify unvented or unpunctured rigid liners, and headspace gas analysis and visual waste characterization will need to be performed.

3.1.6.2 Waste Description. This waste was produced during the direct oxide reduction (DOR) of calcined plutonium oxide. Calcined plutonium oxide was placed in a magnesium oxide crucible with calcium chloride and calcium metal. The crucible and contents were placed in a furnace and heated until the contents were molten. The molten material was stirred to initiate and promote the reduction of the plutonium oxide. After the reaction, the melt was allowed to separate into plutonium metal and salt phases. After cooling, the crucible was broken and separated from the salt, calcium, and plutonium metal. IDC 414 is composed primarily of calcium chloride, calcium oxide, calcium metal entrained in the salt, and various plutonium compounds. A "button" of excess calcium is also present in most containers of these salts (EG\&G RFP 19941).

3.1.6.3 Generation Source. The primary buildings of generation for IDC 414 were Buildings 371, 771, 776, and 779 (EG\&G RFP 19941).

3. 1.6.4 Recovery Method. This IDC has no recovery method.

3.1.6.5 Waste Packaging and Handling. Pyrochemical salt wastes were packaged in prepared 55-gal drums. When the drum was full, the drum liners were sealed and the drum was closed. The drum label, completed with all necessary information, was then taped to the drum lid and a TID was attached to the drum (Rockwell International 1989b).

3.1.6.6 Container Preparation. Only approved containers could be used to package TRU waste for shipment offsite. The containers approved for shipment to INEL during this time were DOT-17C, white, 55-gal drums (Rockwell specification SX-200). These containers met the requirements for certification as DOT-7A Type A packaging (Rockwell International 1989e).

Table 3.1.6-1 shows the current inventory of IDC 414 waste containers from the Rocky Flats Plant that have been shipped to INEL since 1985. 
Table 3.1.6-1. Item Description Code 414 Container Information.

\begin{tabular}{lccc}
\hline \multicolumn{1}{c}{ Information } & & Drums & Boxes \\
\hline Total Containers & & 1 & 0 \\
Net Container Weight (lb) & Maximum & 257 & N/A \\
& Minimum & 257 & N/A \\
& Average & 257 & N/A \\
\hline
\end{tabular}

3.1.6.6.1 Drum Preparation-Approved liners for drums of TRU waste packaged for offsite shipment were the round-bottom liner (Rockwell specification SX-203) inside a 90-mil rigid polyethylene liner (Rockwell specification SX-202), or an O-ring bag and a polyethylene bag placed inside the rigid liner if the drum was attached to a glovebox (Rockwell International 1989e) Type III rigid liners have been used since September 1983. The IDC 414 waste packaged for offsite shipment required a fiberboard liner and two polyethylene bags inside the rigid liner (Rockwell International 1988c). Figure C-1 shows the appropriate drum liners for this IDC. All bags were closed using the twist-and-tape method (Rockwell International 1989e).

Flow-in, ventable gaskets were installed in the drums beginning in December 1982. They were used until October 1988, when tubular gaskets with carbon filters were required. Drums shipped to INEL between 1985 and 1988 may not meet the current WIPP WAC, owing to their lack of carbon filters (Bearly 1989a).

3 1.6.6.2 Box Preparation-No boxes of IDC 414 waste were shipped to INEL between 1985 and 1989.

3.1.6.7 Assay. Small containers of spent salt may have been assayed in the "in-line can counter." These cans would then have been checked using SGS assay equipment. The SGS check was not used to document assay values. Table 3.1.6-2 summarizes the dose rates measured on containers of this IDC. Table 3.1.6-3 provides a summary of the assay information.

Table 3.1.6-2. Item Description Code 414 Dose Information.

\begin{tabular}{lrcc}
\multicolumn{1}{c}{ Information } & & Drums & Boxes \\
\hline One Meter Dose Rate (mrem/h) & $0-0.5$ & 1 & N/A \\
& $0.5-10$ & 0 & N/A \\
Surface Dose Rate (mrem/h) & $<10$ & 1 & N/A \\
& $10-200$ & 0 & N/A \\
\hline
\end{tabular}


Table 3.1.6-3. Item Description Code 414 Assay Information.

\begin{tabular}{lrcc}
\hline \multicolumn{2}{c}{ Radionuclide inventory } & Drums & Boxes \\
\cline { 2 - 5 } Plutonium (g) & Maximum & 194 & N/A \\
& Minimum & 194 & N/A \\
& Average & 194 & N/A \\
Americium (g) & Maximum & 0 & N/A \\
& Minimum & 0 & N/A \\
& Average & 0 & N/A \\
Uranium-235 (g) & Maximum & - & N/A \\
& Minimum & - & N/A \\
& Average & - & N/A \\
\hline
\end{tabular}

3.1.6.8 Inspection. Waste Certification personnel performed periodic inspections of the generating and packaging process to verify compliance with waste acceptance criteria. In addition, drums were viewed using RTR to

- Ensure the drum does not contain nonconforming items

- Ensure the drum is properly packaged

- Verify the waste form description

- Evaluate the presence of free liquids.

3.1.6.9 Waste Form Evaluation. Table 3.1.6-4 evaluates the waste form against the WIPP WAC for such items as free liquids, pyrophoric materials, and compressed gases. Table 3.1.6-5 evaluates the waste against TRUPACT criteria. 
Table 3.1.6-4. Waste Form Evaluation.

Criterion or

requirement

Limiting parameters ${ }^{2}$

Immobilization This waste consists of fused salts. Based on the description of the waste, fine particulates are not expected in this IDC.

Liquids There are normally no liquids associated with this IDC. Personnel performing RTR examination at Rocky Flats would accept up to 2 cups of free liquid, if liquids were present.

Pyrophoric This IDC contains calcium metal and may be pyrophoric.

Materials

Explosives and Explosives and compressed gases were prohibited by procedural control. The

Compressed Gases absence of the explosives and compressed gases was verified by the generating supervisor and periodic inspection by the Waste Certification Organization. In addition, unvented, closed containers and pressurized containers were excluded by procedural controls and RTR examination.

TRU-Mixed The RCRA constituents exist as co-contaminants with the transuranic

Wastes radionuclides. Compliance with the WIPP RCRA permits and NMD will be required before shipment of the stored waste to WIPP.

- Specific Activity This waste contains at least 100 nanocuries per gram transuranic radionuclides. of Waste

$\mathrm{Pu}^{239}$ Equivalent None of the IDC 414 waste containers recorded as shipped to INEL in the Activity SWIMS exceed $1,000 \mathrm{Ci}$ of plutonium-equivalent activity.

a. Many of the limiting parameters were taken from TRU Waste Compliance Program (Rockwell International 1983a, 1987e, and 1989b). 
Table 3.1.6-5. TRUPACT Evaluation.

Criterion or

requirement

Limiting parameters ${ }^{2}$

Waste Package Rocky Flats limited the gross weight of drums to $800 \mathrm{lb}$. The TRUPACT and

Weight

vehicle weight limits must be verified at the time of payload assembly at INEL.

Based on the typical weights of the IDC 414 drums, the maximum payload weight will not be reached.

Waste Containers Waste was shipped in 55-gal DOT-7A, Type A drums.

Nuclear Criticality Rocky Flats limited the fissile content of the drums to 200 grams. However, the error-times-two requirement was not in place at the time the drums were shipped to INEL; therefore, it is not reported as part of the assay of the drum. The TRUPACT limit must be verified at the time of payload assembly at INEL. Based on the typical assays of the IDC 414 drums, the criticality criteria will require re-assayed to meet the error-times-two requirement.

Surface Dose Rate The surface dose rate criteria used by Rocky Flats was $200 \mathrm{mrem} / \mathrm{hr}$ at the drum surface and $10 \mathrm{mrem} / \mathrm{hr}$ at 1 meter. Shielding was not necessary for IDC 414 drums. The TRUPACT limit must be verified at the time of payload assembly at INEL. Based on the typical dose rates from the IDC 414 drums, the dose rate criteria will be met.

Removable Surface Contamination

Thermal Power

Gas Generation
The Rocky Flats limit for removable contamination (for TRU assumed to be all alpha) was 20 disintegrations per minute $/ 100 \mathrm{~cm}^{2}$. The Rocky Flats limit is equivalent to 9 picocuries per $100 \mathrm{~cm}^{2}$, which is well within the WIPP criteria.

The thermal power calculation reported in the SWIMS data package is based on the reported assay value without an error/uncertainty correction. The thermal power must be recalculated based on the assay error determination.

Based on the procedural requirements for packaging IDC 414 waste and the waste description, the only areas of noncompliance are carbon filters, unpunctured rigid liners, and headspace gas analysis, and visual characterization.

1,1,1-Trichloroethane was detected in the headspace gas; however, no organics are listed on the TRUPACT Chemical List for RF 124A. This chemical appears to have a total concentration of $<1 \%$.

Personnel performing RTR examination at Rocky Flats would accept up to $10 \%$ of another IDC. The other IDCs could be combustibles, glass, concrete, metal, leaded gloves, and plastics.

a. Many of the limiting parameters were taken from TRU Waste Compliance Program (Rockwell International 1983a, 1987e, and 1989b). 
3.1.6.10 Combustible and Organic Content. Table 3.1.6-6 outlines available data from the TRU Waste Sampling Program for IDC 414. SWIMS data indicate that this waste form does not contain $>20 \%$ combustibles or $>20 \%$ organics.

Table 3.1.6-6. Item Description Code 414 Data Summary for Combustible and Organic Content.

\begin{tabular}{ccccccc}
\hline Container & $\begin{array}{c}\text { Wt. } \\
\text { combustibles } \\
(\mathrm{lb})^{\mathrm{a}}\end{array}$ & $\begin{array}{c}\text { Wt. } \\
\text { organics } \\
(\mathrm{lb})^{\mathrm{b}}\end{array}$ & $\begin{array}{c}\text { Net wt. of } \\
\text { container } \\
(\mathrm{lb})^{\mathrm{c}}\end{array}$ & $\begin{array}{c}\text { Wt\% } \\
\text { combustibles }^{\mathrm{d}}\end{array}$ & $\begin{array}{c}\text { Vol\% } \\
\text { combustibles }^{\mathrm{e}}\end{array}$ & $\begin{array}{c}\text { Wt\% } \\
\text { organics }^{\mathrm{f}}\end{array}$ \\
\hline $01-05486$ & 16.0 & 16.0 & 104.5 & 15 & 10 & 15
\end{tabular}

a. Sum of weights of all combustible material and leaded rubber from Table 28 (Clements and Kudera 1985).

b. Sum of weights of all combustible material, leaded rubber, and organic material from Table 28 (Clements and Kudera 1985).

c. Net weight of container from Table 28 (Clements and Kudera 1985).

d. Weight of combustible material/net weight of container $\times 100$.

e. Vol\% of combustible material from visual examination, obtained from Appendix B (Clements and Kudera 1985).

f. Weight of organic material/net weight of container $\times 100$.

3.1.6.10.1 Combustible Content-SWIMS data show that IDC 414 waste is noncombustible (Rockwell International 1985a). In support of the TRU Waste Sampling Program, one drum of IDC 414 waste was opened. It was found to contain a wt\% combustible content of $10 \%$. Visual inspection showed an average vol\% combustible content of 10\%. (Clements and Kudera 1985).

3.1.6.10.2 Organic Content-SWIMS data shown that IDC 414 waste may contain $10 \%$ organics (Rockwell International 1985a). In support of the TRU Waste Sampling Program, one drum of IDC 414 waste was opened. It was found to contain an average wt\% organic content of 4.5\% (Clements and Kudera 1985).

3.1.6.11 Analytical Information. Analytical data from the TRU Waste Sampling Waste Characterization Program (Clements and Kudera 1985) for IDC 414, DOR Salt, indicate that one drum was subject to headspace gas analysis. Gas composition analytical results are presented in Table 3.1.6-7. Waste boxes were not sampled. Hydrogen, oxygen, nitrogen, argon, carbon dioxide, saturated hydrocarbons, and 1,1,1-trichloroethane were detected in the drum.

IDC 414 waste exhibits the characteristic of reactivity (D003) (EG\&G RFP 19941) as defined by 6 CCR 1007-3, Part 261.23, because it could form a potentially explosive mixture of hydrogen and oxygen when mixed with water, or could rapidly build up pressure within a container if exposed to water (EG\&G RFP 1994r). 
Table 3.1.6-7. Gas Sampling Results-Compositional Analysis (vol\%).

\begin{tabular}{|c|c|c|c|c|c|c|c|c|c|c|c|}
\hline \multirow[b]{2}{*}{$\begin{array}{c}\text { Container } \\
\text { ID. no. }\end{array}$} & \multirow{2}{*}{$\begin{array}{c}\text { Storage } \\
\text { time } \\
\text { (days) }\end{array}$} & \multicolumn{10}{|c|}{ Analytes } \\
\hline & & $\mathrm{H}_{2}$ & $\mathrm{O}_{2}$ & $\mathrm{~N}_{2}$ & Ar & $\mathrm{CO}_{2}$ & $\mathrm{CO}$ & $\mathrm{NO}_{\mathrm{x}}$ & $\begin{array}{l}\text { Hydrocarbons } \\
\text { (saturated) }\end{array}$ & $\begin{array}{c}1,1,1- \\
\text { trichloroethane }\end{array}$ & $\begin{array}{c}\text { Other } \\
\text { hydrocarbons }\end{array}$ \\
\hline $01-05486$ & 260 & 0.30 & 18.5 & 79.0 & 0.91 & 0.24 & - & 一 & 0.26 & 0.75 & - \\
\hline
\end{tabular}




\subsection{Waste Form Number (no waste form number), Content Code RF 122A (Equivalent)}

\subsubsection{Item Description Code 422-Soot}

3.1.7.1 Certification Assessment. This IDC is not certifiable without further waste treatment for particulates. This IDC would not have been certifiable for disposal until it had been processed into IDC 806. Assay and thermal power calculations, including error, need to be updated to meet the current WIPP WAC. Several gas generation criteria need to be addressed. Carbon filters may need to be installed, drums will require inspection to identify unvented or unpunctured rigid liners, and headspace gas analysis and visual waste characterization will need to be performed.

3.1.7.2 Waste Description. IDC 422-Soot consists of a fine and very fine particulate fly ash that was removed from the incinerator off-gas treatment system. The soot generally contained a higher concentration of carbon and fine particulate oxidation of some feed materials (A).

3.1.7.3 Generation Source. IDC 422 was generated by the Residue Recovery Incinerator system in Building 771. The function of the Residue Recovery Incinerator was to reduce volume and destroy volatile constituents prior to plutonium recovery operations for combustible wastes from production processes (primarily IDCs $330,331,336$, and 337 ) (A).

3.1.7.4 Recovery Method. Plutonium was recovered from above-discard soot by dissolving it in acid. The filter solution was then run through an anion exchange process, and the plutonium was precipitated out of solution.

3.1.7.5 Waste Packaging and Handling. IDC 422 waste was placed in 2- or 4-liter Nalgene bottles. Each bottle was placed in a PVC bag-out bag, and the bagged bottle placed inside two plastic bags before final placement in a DOT-17C, white, 55-gal drum. Up to fourteen bottles were placed in each 55-gal drum $(X)$. When the drum was full, the drum liners were sealed and the drum was closed. The drum label, completed with all necessary information, was then taped to the drum lid and a TID was attached to the drum.

3.7.7.6 Container Preparation. Only approved containers could be used to package TRU waste for shipment offsite. The containers approved for shipment to INEL during this time were DOT-17C, white, 55-gal drums (Rockwell specification SX-200). These containers met the requirements for certification as DOT-7A Type A packaging (Rockwell International 1989e).

Table 3.1.7-1 shows the current inventory of IDC 422 waste containers from the Rocky Flats Plant that have been shipped to INEL since 1985. 
Table 3.1.7-1. Item Description Code 422 Container Information.

\begin{tabular}{lccc}
\hline \multicolumn{1}{c}{ Information } & & Drums & Boxes \\
\hline Total Containers & & 4 & 0 \\
Net Container Weight (lb) & Maximum & 380 & N/A \\
& Minimum & 41 & N/A \\
& Average & 250 & N/A \\
\hline
\end{tabular}

3.1.7.6.1 Drum Preparation-Approved liners for drums of TRU waste packaged for offsite shipment were the round-bottom liner (Rockwell specification SX-203) inside a 90-mil rigid polyethylene liner (Rockwell specification SX-202), or an O-ring bag and a polyethylene bag placed inside the rigid liner if the drum was attached to a glovebox (Rockwell International 1989e). Type III rigid liners have been used since September 1983 (Bearly 1989a). The IDC 422 waste packaged for offsite shipment required a fiberboard liner and two polyethylene bags inside the rigid liner (Rockwell International 1988c) Figure C-1 shows the appropriate drum liners for this IDC. All bags were closed using the twist-and-tape method (Rockwell International 1989e).

Flow-in, ventable gaskets were installed in the drums beginning in December 1982. They were used until October 1988, when tubular gaskets with carbon filters were required. Drums shipped to INEL between 1985 and 1988 may not meet the current WIPP WAC, owing to their lack of carbon filters (Bearly 1989a).

3.1.7.6.2 Box Preparation-No boxes of IDC 422 waste were shipped to INEL between 1985 and 1989.

3.1.7.7 Assay. Individual 4-liter containers were assayed. The assay values for the individual containers placed into a drum were totaled to provide an assay value for the drum. The drums may have been assayed on a SGS counter or a PADC to verify the assigned assay value. Table 3.1.7-2 summarizes the dose rates measured on containers of this IDC. Table 3.1.7-3 provides a summary of the assay information.

Table 3.1.7-2. Item Description Code 422 Dose Information.

\begin{tabular}{crcc} 
Information & & Drums & Boxes \\
\hline One Meter Dose Rate (mrem/h) & $0-0.5$ & 4 & N/A \\
& $0.5-10$ & 0 & N/A \\
Surface Dose Rate (mrem/h) & $<10$ & 4 & N/A \\
& $10-200$ & 0 & N/A \\
\hline
\end{tabular}


Table 3.1.7-3. Item Description Code 422 Assay Information.

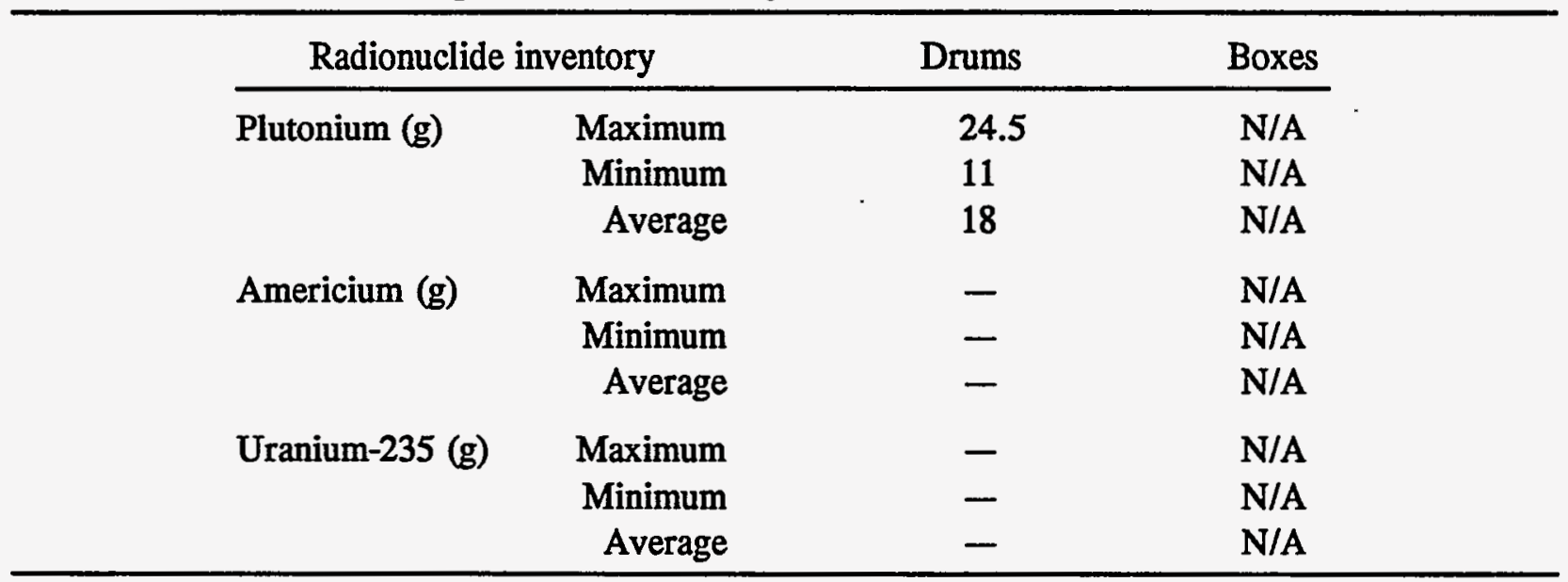

3. 1.7.8 Inspection. Waste Certification personnel performed periodic inspections of the generating and packaging process to verify compliance with waste acceptance criteria. In addition, each drum was viewed using RTR to

- Ensure the drum does not contain nonconforming items

- Ensure the drum is properly packaged

- Verify the waste form description

- Evaluate the presence of free liquids.

3.1.7.9 Waste Form Evaluation. Table 3.1.7-4 evaluates the waste form against the WIPP WAC for such items as free liquids, pyrophoric materials, and compressed gases. Table 3.1.7-5 evaluates the waste against TRUPACT criteria. 
Table 3.1.7-4. Waste Form Evaluation.

Criterion or

requirement

Limiting parameters ${ }^{\mathrm{a}}$

Immobilization Soot and fly-ash are not expected to meet the WIPP WAC for particulates.

Liquids There are normally no liquids associated with this IDC. Personnel performing RTR examination at Rocky Flats would accept up to 2 cups of free liquid, if liquids were present.

Pyrophoric Pyrophoric materials were prohibited by procedural control. The absence of the

Materials pyrophoric materials was verified by the generating supervisor and periodic inspection by the Waste Certification Organization.

Explosives and Compressed

Gases

Explosives and compressed gases were prohibited by procedural control. The absence of the explosives and compressed gases was verified by the generating supervisor and periodic inspection by the Waste Certification Organization. In addition, unvented, closed containers and pressurized containers were excluded by procedural controls and RTR examination.

TRU-Mixed The RCRA constituents exist as co-contaminants with the transuranic

Wastes radionuclides. Compliance with the WIPP RCRA permits and NMD will be required prior to shipment of the stored waste to WIPP.

Specific Activity This waste contains at least 100 nanocuries per gram transuranic radionuclides. of Waste

$\mathrm{Pu}^{239}$ Equivalent None of the IDC 422 waste containers recorded as shipped to INEL in the Activity SWIMS exceed $1,000 \mathrm{Ci}$ of plutonium-equivalent activity.

a. Many of the limiting parameters were taken from TRU Waste Compliance Program (Rockwell International 1983a, 1987e, and 1989b). 
Table 3.1.7-5. TRUPACT Evaluation.

Criterion or

requirement

Limiting parameters ${ }^{2}$

Waste Package

Weight

Rocky Flats limited the gross weight of drums to $800 \mathrm{lb}$. The TRUPACT and vehicle weight limits must be verified at the time of payload assembly at INEL. Based on the typical weights of the IDC 422 drums, the maximum payload weight will not be reached.

Waste Containers Waste was shipped in 55-gal DOT-7A, Type A drums.

Nuclear Criticality Rocky Flats limited the fissile content of the drums to 200 grams. However, the error-times-two requirement was not in place at the time the drums were shipped to INEL; therefore, it is not reported as part of the assay of the drum. The TRUPACT limit must be verified at the time of payload assembly at INEL. Based on the typical assays of the IDC 422 drums, the criticality criteria will be met but must be recalculated or assayed to meet the error-timestwo requirement.

Surface Dose Rate The surface dose rate criteria used by Rocky Flats was $200 \mathrm{mrem} / \mathrm{hr}$ at the drum surface and $10 \mathrm{mrem} / \mathrm{hr}$ at 1 meter. Shielding was not necessary for IDC 422 drums. The TRUPACT limit must be verified at the time of payload assembly at INEL. Based on the typical dose rates from the IDC 422 drums, the dose rate criteria will be met.

Removable Surface

Contamination

The Rocky.Flats limit for removable contamination (for TRU assumed to be all alpha) was 20 disintegrations per minute $/ 100 \mathrm{~cm}^{2}$. The Rocky Flats limit is equivalent to 9 picocuries per $100 \mathrm{~cm}^{2}$, which is well within the WIPP criteria.

Thermal Power

The thermal power calculation reported in the SWIMS data package is based on the reported assay value without an error/uncertainty correction. The thermal power must be recalculated based on the assay error determination.

Gas Generation Based on the procedural requirements for packaging IDC 422 waste and the waste description, the only areas of noncompliance are carbon filters, unpunctured rigid liners, and headspace gas analysis, and visual characterization.

Personnel performing RTR examination at Rocky Flats would accept up to $10 \%$ of another IDC. The other IDCs could be combustibles, glass, concrete, metal, leaded gloves, and plastics.

a. Many of the limiting parameters were taken from TRU Waste Compliance Program (Rockwell International 1983a, 1987e, and 1989b). 
3.1.7.10 Combustible and Organic Content. SWIMS data indicate that this waste form does not contain $>20 \%$ combustibles or $>20 \%$ organics.

3.1.7.10.1 Combustible Content-SWIMS data show that IDC 422 waste is noncombustible (Rockwell International 1985a).

3.1.7.10.2 Organic Content-SWIMS data show that IDC 422 waste contains zero percent organics (Rockwell International 1985a).

3.1.7.11 Analytical Information. No analytical information is available for IDC 422 .

IDC 422 will contain most of the same constituents as the ash from which it was derived. Because the specific sources of the incinerator feed cannot be determined at this time, it has been assumed that the process could have accepted any of the combustible, plastic, or filter waste that was generated during the time the incinerator was operational. Alcohols, glycols, halogenated solvents, and metals may have been introduced into the incinerator. The EPA Codes assigned to this waste include D004-D011, F001, F002, F003, and F005 (A). 


\subsection{Waste Form Number (no waste form number), Content Code RF 126A (Equivalent)}

\subsubsection{Item Description Code 432-Resin, Cemented}

3.1.8.1 Certification Assessment. This IDC is certifiable without further waste treatment. Assay and thermal power calculations, including error, need to be updated to meet the current WIPP WAC. Several gas generation criteria need to be addressed. Carbon filters may need to be installed, drums will require inspection to identify unvented or unpunctured rigid liners, and headspace gas analysis and visual waste characterization will need to be performed.

3.1.8.2 Waste Description. IDC 432, cemented resin, consists of anion and cation exchange resins used in the purification and recovery of plutonium. The resins were leached prior to cementation. IDC 432 differs from IDC 822 in the method of cementation used-dry Portland cement was added to IDC 432 as an absorbent, whereas IDC 822 was subject to a solidification process using Portland cement (Rockwell International 1987e). IDC 432 is included in IDC 806 (Rockwell International 1987e, Rockwell International 1989b).

3.1.8.3 Generation Source. The majority of the waste was generated by Plutonium Recovery Operations (Building 771) (Rockwell International 1987e).

3.1.8.4 Recovery Method. This IDC was never generated as a residue and therefore has no recovery method.

3.1.8.5 Waste Packaging and Handling. The drums used were DOT-17C, white, 55-gal drums. When the drum was full, the polyethylene liners were twisted and taped closed, the lid was secured with a bolted ring, the Drum Count label was completed and taped to the drum lid by the generator, and a TID was attached to the drum (Rockwell International 1989b).

3.1.8.6 Container Preparation. Only approved containers could be used to package TRU waste for shipment offsite. The containers approved for shipment to INEL during this time were DOT-17C, white, 55-gal drums (Rockwell specification SX-200). These containers met the requirements for certification as DOT-7A Type A packaging (Rockwell International 1989b).

Table 3.1.8-1 shows the current inventory of IDC 432 waste containers from the Rocky Flats Plant that have been shipped to INEL since 1985. 
Table 3.1.8-1. Item Description Code 432 Container Information.

\begin{tabular}{|c|c|c|c|}
\hline \multicolumn{2}{|l|}{ Information } & \multirow{2}{*}{$\frac{\text { Drums }}{18}$} & \multirow{2}{*}{$\frac{\text { Boxes }}{0}$} \\
\hline Total Containers & & & \\
\hline \multirow[t]{3}{*}{ Net Container Weight (lb) } & Maximum & 329 & N/A \\
\hline & Minimum & 4 & N/A \\
\hline & Average & 203 & N/A \\
\hline
\end{tabular}

3.1.8.6.1 Drum Preparation-Approved liners for drums of TRU waste packaged for offsite shipment as of 1989 were the round-bottom liner (Rockwell specification SX-203), inside a rigid polyethylene liner (Rockwell specification SX-202), or an O-ring bag and a polyethylene bag placed inside the rigid liner if the drum is attached to a glovebox. All bags were closed using the twist-and-tape method (Rockwell International 1989b).

IDC 432 waste is assumed to have been packaged like IDC 807 sludge. The IDC 807 sludge mixture was placed in 55-gal drums that were lined with a high-density polyethylene rigid liner, 14mil PVC O-ring bag, and a 5-mil polyethylene bag DOE/WIPP 1992). Figure C-2 shows the packaging appropriate for this waste form.

Flow-in ventable gaskets were installed in the drums beginning in December 1982 . They were used until October 1988, when tubular gaskets with carbon filters were required. Drums shipped to the INEL between 1985 and 1988 may not meet the current WIPP WAC, owing to their lack of carbon filters.

3. 1.8.6.2 Box Preparation-No boxes of IDC 432 waste were shipped to INEL between 1985 and 1989.

3.1.8.7 Assay. The drums may have been assayed on an SGS counter or a PADC. Containers of waste that have not been PADC assayed and had SGS assay values of 1 gram or less should be PADC assayed to verify that they are transuranic waste. Table 3.1.8-2 summarizes the dose rates measured on containers of this IDC. Table 3.1.8-3 provides a summary of the assay information.

Table 3.1.8-2. Item Description Code 432 Dose Information.

\begin{tabular}{crrr}
\hline \multicolumn{1}{c}{ Information } & & Drums & Boxes \\
\cline { 2 - 4 } One Meter Dose Rate (mrem/h) & $0-0.5$ & 18 & N/A \\
& $0.5-10$ & 0 & N/A \\
Surface Dose Rate (mrem/h) & $<10$ & 18 & N/A \\
& $10-200$ & 0 & N/A \\
\hline
\end{tabular}


Table 3.1.8-3. Item Description Code 432 Assay Information.

\begin{tabular}{|c|c|c|c|}
\hline \multicolumn{2}{|c|}{ Radionuclide inventory } & \multirow{2}{*}{$\frac{\text { Drums }}{55}$} & \multirow{2}{*}{$\frac{\text { Boxes }}{\text { N/A }}$} \\
\hline Plutonium (g) & Maximum & & \\
\hline & Minimum & 0 & N/A \\
\hline & Average & 6 & N/A \\
\hline Americium (g) & Maximum & 0 & N/A \\
\hline & Minimum & 0 & N/A \\
\hline & Average & 0 & N/A \\
\hline Uranium-235 (g) & Maximum & - & N/A \\
\hline & Minimum & 一 & N/A \\
\hline & Average & - & N/A \\
\hline
\end{tabular}

3.1.8.8 Inspection. Waste Certification personnel performed periodic inspections of the generating and packaging process to verify compliance with waste acceptance criteria. In addition, each drum was viewed using RTR to

- Ensure the drum does not contain nonconforming items

- Ensure the drum is properly packaged

- Verify the waste form description

- Evaluate the presence of free liquids.

3.1.8.9 Waste Form Evaluation. Table 3.1.8-4 evaluates the waste form against the WIPP WAC for such items as free liquids, pyrophoric materials, and compressed gases. Table 3.1.8-5 evaluates the waste against TRUPACT criteria. 
Table 3.1.8-4. Waste Form Evaluation.

Criterion or

requirement

Limiting parameters ${ }^{\mathbf{a}}$

Immobilization

This is a cemented waste form. Based on the description of the waste, fine particulates are not expected in this IDC.

Liquids

There are normally no liquids associated with this IDC. Personnel performing RTR examination at Rocky Flats would accept up to 2 cups of free liquid, if liquids were present.

Pyrophoric

Pyrophoric materials were prohibited by procedural control. The absence of

Materials the pyrophoric materials was verified by the generating supervisor and periodic inspection by the Waste Certification Organization.

Explosives and Compressed Gases

Explosives and compressed gases were prohibited by procedural control. The absence of the explosives and compressed gases was verified by the generating supervisor and periodic inspection by the Waste Certification Organization. In addition, unvented, closed containers and pressurized containers were excluded by procedural controls and RTR examination.

TRU-Mixed Wastes The RCRA constituents exist as co-contaminants with the transuranic radionuclides. Compliance with the WIPP RCRA permits and NMD will be required prior to shipment of the stored waste to WIPP.

Specific Activity of Waste A portion of the waste stored at INEL may contain < 100 nanocuries per gram transuranic radionuclides.

$\mathrm{Pu}^{239}$ Equivalent None of the IDC 432 waste containers recorded as shipped to INEL in the Activity SWIMS exceed $1,000 \mathrm{Ci}$ of plutonium-equivalent activity.

a. Many of the limiting parameters were taken from TRU Waste Compliance Program (Rockwell International 1983a, 1987e, and 1989b). 
Table 3.1.8-5. TRUPACT Evaluation.

Criterion or

requirement

Limiting parameters ${ }^{2}$

Waste Package

Weight

Rocky Flats limited the gross weight of drums to $800 \mathrm{lb}$. The TRUPACT and vehicle weight limits must be verified at the time of payload assembly at INEL. Based on the typical weights of the IDC 432 drums, the maximum payload weight will not be reached.

Waste Containers

Waste was shipped in 55-gal DOT-7A, Type A drums.

Nuclear Criticality

Rocky Flats limited the fissile content of the drums to 200 grams. However, the error-times-two requirement was not in place at the time the drums were shipped to INEL; therefore, it is not reported as part of the assay of the drum. The TRUPACT limit must be verified at the time of payload assembly at INEL. Based on the typical assays of the IDC 432 drums, the criticality criteria will be met but must be recalculated or assayed to meet the error-timestwo requirement.

Surface Dose Rate The surface dose rate criteria used by Rocky Flats was $200 \mathrm{mrem} / \mathrm{hr}$ at the drum surface and $10 \mathrm{mrem} / \mathrm{hr}$ at 1 meter. Shielding was not necessary for IDC 432 drums. The TRUPACT limit must be verified at the time of payload assembly at INEL. Based on the typical dose rates from the IDC 432 drums, the dose rate criteria will be met.

Removable Surface

Contamination

The Rocky Flats limit for removable contamination (for TRU assumed to be all alpha) was 20 disintegrations per minute $/ 100 \mathrm{~cm}^{2}$. The Rocky Flats limit is equivalent to 9 picocuries per $100 \mathrm{~cm}^{2}$, which is well within the WIPP criteria.

Thermal Power

The thermal power calculation reported in the SWIMS data package is based on the reported assay value without an error/uncertainty correction. The thermal power must be recalculated based on the assay error determination.

Gas Generation

Based on the procedural requirements for packaging IDC 432 waste and the waste description, the only areas of noncompliance are carbon filters, unpunctured rigid liners, and headspace gas analysis, and visual characterization.

Trichloroethylene and isopropanol were detected by headspace gas analysis in IDC 432, but are not listed in the TRUPACT Chemical list for RF 114A. Dichloromethane, 1,1,1-trichloroethane, and carbon tetrachloride were detected by headspace analysis and are on the TRUPACT Chemical List. All of the chemicals appear to be in total concentrations of $<1 \%$. Xylene, $1,1,2-$ trichloro-1,2,2-trifluoroethane, butanol and methanol are on the TRUPACT Chemical List for halogenated organics, aromatic hydrocarbons, and alcohols, but were not detected.

Personnel performing RTR examination at Rocky Flats would accept up to $10 \%$ of another IDC. The other IDCs could be combustibles, glass, concrete, metal, leaded gloves, and plastics.

a. Many of the limiting parameters were taken from TRU Waste Compliance Program (Rockwell International 1983a, 1987e, and 1989b). 
3.1.8.10 Combustible and Organic Content. Table 3.1.8-6 outlines available data from the TRU Waste Sampling Program for IDC 432. SWIMS data indicate that this waste form does not contain $>20 \%$ combustibles or $>20 \%$ organics.

Table 3.1.8-6. Item Description Code 432 Data Summary for Combustible and Organic Content.

\begin{tabular}{ccccccc}
\hline Container & $\begin{array}{c}\text { Wt. } \\
\text { combustibles } \\
(\mathrm{lb})^{\mathrm{a}}\end{array}$ & $\begin{array}{c}\text { Wt. } \\
\text { organics } \\
(\mathrm{lb})^{\mathrm{b}}\end{array}$ & $\begin{array}{c}\text { Net wt. of } \\
\text { container }^{(\mathrm{lb})^{\mathrm{c}}}\end{array}$ & $\begin{array}{c}\text { Wt\% } \\
\text { combustibles }^{\mathrm{d}}\end{array}$ & $\begin{array}{c}\text { Vol\% } \\
\text { combustibles }^{\mathrm{e}}\end{array}$ & $\begin{array}{c}\text { Wt\% } \\
\text { organics }^{\mathrm{f}}\end{array}$ \\
\hline $02-39189$ & 31.5 & 31.5 & 220.25 & 14 & 12 & 14 \\
$02-39215$ & 35.0 & 35.0 & 271.5 & 13 & 15 & 13 \\
$02-39296$ & 30.0 & 30.0 & 217.25 & 14 & 20 & 14 \\
$02-44427$ & 6.9 & 6.9 & 13.9 & 50 & 15 & 50 \\
$02-34829$ & 31.5 & 31.5 & 214.5 & 15 & 30 & 15 \\
$02-34844$ & 13.0 & 13.0 & 87.25 & 15 & 30 & 15 \\
$02-34830$ & 29.8 & 29.8 & 241.0 & 12 & 30 & 12 \\
$01-08811$ & 21.7 & 21.7 & 234.6 & 9 & 10 & 9 \\
$01-08956$ & 22.7 & 22.7 & 233.2 & 10 & 10 & 10 \\
$02-10070$ & 19.9 & 19.9 & 237.6 & 8 & 10 & 8 \\
$02-10195$ & 24.2 & 24.2 & 224.7 & 11 & 20 & 11 \\
$02-10286$ & 22.2 & 22.2 & 227.4 & 10 & 10 & 10 \\
$02-10288$ & 21.7 & 21.7 & 187.8 & 12 & 20 & 12 \\
\hline
\end{tabular}

a. Sum of weights of all combustible material and leaded rubber from Table 31 (Clements and Kudera 1985).

b. Sum of weights of all combustible material, leaded rubber, and organic material from Table 31 (Clements and Kudera 1985).

c. Net weight of container from Table 31 (Clements and Kudera 1985).

d. Weight of combustible material/net weight of container $\times 100$.

e. Vol\% of combustible material from visual examination, obtained from Appendix B (Clements and Kudera 1985).

f. Weight of organic material/net weight of container $\times 100$. 
3.1.8.10.1 Combustible Content-SWIMS data show that IDC 432 waste is noncombustible (Rockwell International 1985a). In support of the TRU Waste Sampling Program, 13 drums of IDC 432 waste were opened. They were found to contain an average wt\% combustible content of $14.8 \%$. Visual inspection showed an average vol\% combustible content of $17.8 \%$.

(Clements and Kudera 1985).

3.1.8.10.2 Organic Content-SWIMS data show that IDC waste may contain 20\% organics (Rockwell International 1985a). In support of the TRU Waste Sampling Program, 13 drums of IDC 432 waste were opened. They were found to contain an average wt\% organic content of 14.8\% (Clements and Kudera 1985).

3.1.8.11 Analytical Information. Analytical data from the TRU Waste Sampling Waste Characterization Program (Clements and Kudera 1985) for IDC 432- Resin, Cemented, indicate that 13 drums were subject to headspace gas analysis. Gas composition analytical results are presented in Table 3.1.8-7. Waste boxes were not sampled. Hydrogen, oxygen, nitrogen, argon, carbon dioxide, nitrogen oxide(s), saturated hydrocarbons, 1,1,1-trichloroethane, dichloromethane, carbon tetrachloride, trichloroethylene, and isopropanol were detected in the drums.

IDC 432 is not a RCRA-hazardous waste and has been assigned no EPA codes. 
Table 3.1.8-7. Gas Sampling Results-Compositional Analysis (vol\%).

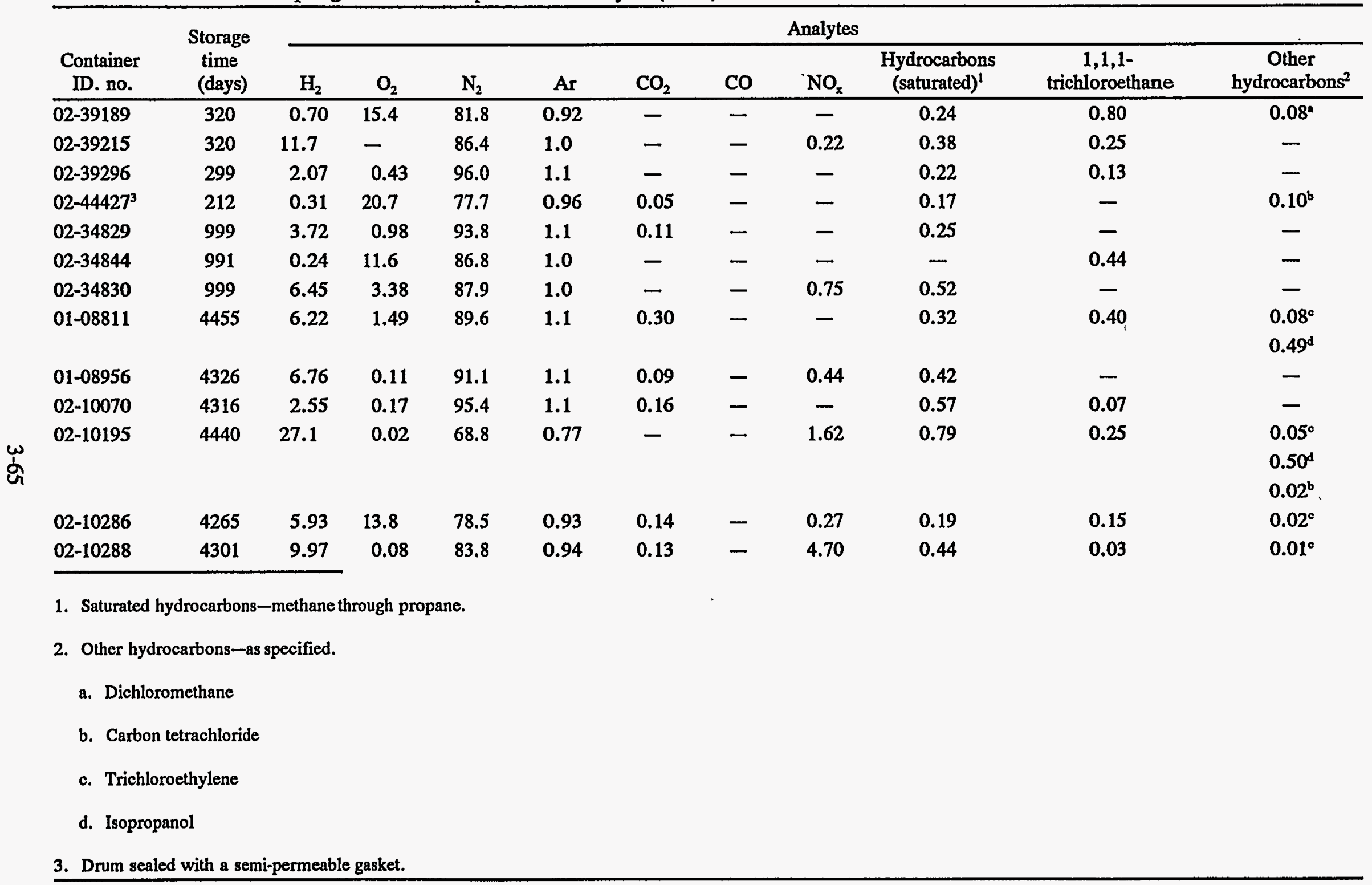




\subsection{Waste Form Number 111-Solidified Aqueous Sludge, Content Code RF 111A}

\subsubsection{Item Description Code 007-Cemented Sludge, B374}

3.2.1.1 Certification Assessment. This IDC is certifiable without further waste treatment. Assay and thermal power calculations, including error, need to be updated to meet the current WIPP WAC. Several gas generation criteria need to be addressed. Carbon filters may need to be installed, drums will require inspection to identify unvented or unpunctured rigid liners, and headspace gas analysis and visual waste characterization will need to be performed.

3.2. 1.2 Waste Description. This waste consists of immobilized materials from the Decontamination-Precipitation and Neutralization Process in the Liquid Waste Treatment Facility. This waste consisted of clarifier slurry from the Radioactive Decontamination Process, Acid Neutralization Process wastes, and acid descaling solution from the Evaporation Process. The slurry was drawn through a filter drum where a sludge of precipitated solids was skimmed from the surface of the filter media. It was then transferred directly into a 55-gal drum where it was mixed with Portland cement and diatomite. The IDC for Solidified Bypass Sludge (IDC 807) was created in 1987 to replace Cemented Sludge (IDC 007) (EG\&G RFP 1994b).

3.2.1.3 Generation Source. The Cemented Sludge was generated by the Liquid Waste Treatment Facility (Building 374). Generation dates indicate IDC 007 Cemented Sludge was produced from December 1986 to July 1987 (EG\&G RFP 1994b).

3.2.1.4 Recovery Method. This IDC was never generated as a residue and therefore had no recovery method.

3.2.1.5 Waste Packaging and Handling. The drums used were DOT-17C, white, 55-gal drums. For IDC 007, a 90-mil rigid polyethylene liner was required (Rockwell International 1989e). Before 1986, sludge was transferred from the filter drum directly into 55-gal drums and mixed with metered amounts of cement. The resulting mixture of sludge and cement was tamped down during the metering process (EG\&G RFP 1994b). Since April 1986, diatomite and cement, in a 1-to-1 ratio, have been mixed into the sludge. This mixture has been determined to be a better absorbent, and no free liquids or condensation have been found in the drums generated after that time (Watson 1987 and Roggenthen and others 1989). When the drum was full, the polyethylene liners were twisted and taped closed, the lid was secured with a bolted ring, the Drum Count label was completed and taped to the drum lid by the generator, and a TID was attached to the drum (Rockwell International 1989e).

Four IDC 007 drums (RF 74702579, RF 74703541, RF 74704299, and RF 74705458) were opened in 1987 in support of the SWEPP Sampling Program. The drum contents and packaging were inspected. Following their inspection, the drums were assigned IDC 807. The four drums were each found to contain a rigid liner, a round-bottom outer drum bag, and an inner PVC O-ring bag-out bag which contained the sludge. One of the drums (RF 74704299) was determined to contain 11,875 ml of free liquid at the bottom of the inner PVC O-ring bag, and consequently did not meet the WIPP criteria for uncemented wastes. The waste contained in this drum was generated in 1985, before the 
use of the 1-to-1 diatomite and cement absorbent mixture. Three of the drums were found to be in good condition inside; however, a small amount of rust was found inside of drum RF 74705453. The drums were all 80-95\% full (Watson 1987).

3.2.1.6 Container Preparation. Only approved containers could be used to package TRU waste for shipment offsite. The containers approved for shipment to INEL were the DOT-17C, white, 55-gal drums (Rockwell specification SX-200). These containers met the requirements for certification as DOT-7A Type A packaging (Rockwell International 1989e). Table 3.2.1-1 shows the current inventory of IDC 007 waste containers from the Rocky Flats Plant that had been shipped to INEL since 1985.

Table 3.2.1-1. Item Description Code 007 Container Information.

\begin{tabular}{lccc}
\hline \multicolumn{1}{c}{ Information } & Drums & Boxes \\
\hline Total Containers & & 1,383 & 0 \\
Net Container Weight (lb) & Maximum & 650 & N/A \\
& Minimum & 117 & N/A \\
& Average & 410 & N/A \\
\hline
\end{tabular}

3.2.1.6.1 Drum Preparation-Approved liners for drums of TRU waste packaged for offsite shipment as of 1989 were the round-bottom liner (Rockwell specification SX-203), inside a rigid polyethylene liner (Rockwell specification SX-202), or an O-ring bag and a polyethylene bag placed inside the rigid liner if the drum was attached to a glovebox. All bags were closed using the twist-and-tape method (Rockwell International 1989e).

The IDC 007 sludge mixture was placed in 55-gal drums that were lined with a high-density polyethylene rigid liner, 14-mil PVC O-ring bag, and a 5-mil polyethylene bag. Figure C-2 shows the packaging appropriate for this waste form. The polyethylene bag was not required from a waste packaging standpoint, but it aided in contamination control (DOE/WIPP 1992). 1989).

3.2.1.6.2 Box Preparation-No boxes of IDC 007 waste were shipped to INEL (DOT

3.2.1.7 Assay. A sample of the sludge from each drum was taken to determine the amount and identity of the radionuclides (plutonium, americium, and uranium) in the sludge. The sludge sample was analyzed using a radiochemical assay. The results of the analysis were expressed in terms of grams of each radionuclide present for each gram of sludge. Containers of waste that have not been PADC assayed and had SGS assay values of 1 gram or less should be PADC assayed to verify that they are transuranic waste. Table 3.2.1-2 summarizes the dose rates measured on containers of this IDC. Table 3.2.1-3 provides a summary of the assay information. Americium was evaluated in 1,346 drums, no drums were evaluated for uranium. 
Table 3.2.1-2. Item Description Code 007 Dose Information.

\begin{tabular}{crrc} 
Information & & Drums & Boxes \\
\hline One Meter Dose Rate (mrem/h) & $0-0.5$ & 1,379 & N/A \\
& $0.5-10$ & 4 & N/A \\
Surface Dose Rate (mrem/h) & $<10$ & 1,382 & N/A \\
& $10-200$ & 1 & N/A
\end{tabular}

Table 3.2.1-3. Item Description Code 007 Assay Information.

\begin{tabular}{|c|c|c|c|}
\hline \multicolumn{2}{|c|}{ Radionuclide inventory } & \multirow{2}{*}{$\begin{array}{c}\text { Drums } \\
29 \\
0 \\
0\end{array}$} & \multirow{2}{*}{$\begin{array}{c}\text { Boxes } \\
\text { N/A } \\
\text { N/A } \\
\text { N/A }\end{array}$} \\
\hline Plutonium (g) & $\begin{array}{r}\text { Maximum } \\
\text { Minimum } \\
\text { Average }\end{array}$ & & \\
\hline Americium (g) & $\begin{array}{r}\text { Maximum } \\
\text { Minimum } \\
\text { Average }\end{array}$ & $\begin{array}{l}0.06 \\
0 \\
0\end{array}$ & $\begin{array}{l}\text { N/A } \\
\text { N/A } \\
\text { N/A }\end{array}$ \\
\hline Uranium-235 (g) & $\begin{array}{r}\text { Maximum } \\
\text { Minimum } \\
\text { Average }\end{array}$ & $\begin{array}{l}- \\
-\end{array}$ & $\begin{array}{l}\text { N/A } \\
\text { N/A } \\
\text { N/A }\end{array}$ \\
\hline
\end{tabular}

3.2.1.8 Inspection. Waste Certification periodically reviewed the process documentation to ensure that the solidification process was being operated according to procedure. This inspection was performed to ensure that free liquids and particulates would not be found in this waste form. In addition to review of process documentation, Waste Certification personnel performed periodic inspections of the generating and packaging process to verify compliance with waste acceptance criteria. Each drum is viewed using RTR to

- Ensure the drum did not contain nonconforming items

- $\quad$ Ensure the drum was properly packaged

- Verify the waste form description

- Evaluate the presence of free liquids.

3.2.1.9 Waste Form Evaluation. Table 3.2.1-4 evaluates the waste form against the WIPP WAC for such items as free liquids, pyrophoric materials, and compressed gases. Table 3.2.1-5 evaluates the waste against TRUPACT criteria. 
Table 3.2.1-4. Waste Form Evaluation.

\begin{tabular}{|c|c|}
\hline $\begin{array}{l}\text { Criterion or } \\
\text { requirement }\end{array}$ & Limiting parameters ${ }^{2}$ \\
\hline Immobilization & $\begin{array}{l}\text { Particulates were prohibited by procedural control. Based on the description of } \\
\text { the waste, fine particulates are not expected in this IDC. }\end{array}$ \\
\hline Liquids & $\begin{array}{l}\text { The solidified sludge should meet the free liquid criteria by procedural control } \\
\text { and RTR inspection before shipment from Rocky Flats. However, the sludge } \\
\text { should be checked for the possibility that the sludge may have dewatered. }\end{array}$ \\
\hline $\begin{array}{l}\text { Pyrophoric } \\
\text { Materials }\end{array}$ & $\begin{array}{l}\text { Pyrophoric materials were prohibited by procedural control. The absence of the } \\
\text { pyrophoric materials was verified by the generating supervisor and periodic } \\
\text { inspection by the Waste Certification Organization. }\end{array}$ \\
\hline $\begin{array}{l}\text { Explosives and } \\
\text { Compressed Gases }\end{array}$ & $\begin{array}{l}\text { Explosives and compressed gases were prohibited by procedural control. The } \\
\text { absence of the explosives and compressed gases was verified by the generating } \\
\text { supervisor and periodic inspection by the Waste Certification Organization. In } \\
\text { addition, unvented, closed containers and pressurized containers were excluded } \\
\text { by procedural controls and RTR examination. }\end{array}$ \\
\hline $\begin{array}{l}\text { TRU-Mixed } \\
\text { Wastes }\end{array}$ & $\begin{array}{l}\text { The RCRA constituents exist as co-contaminants with the transuranic } \\
\text { radionuclides. Compliance with the WIPP RCRA permits and NMD will be } \\
\text { required before shipment of the stored waste to WIPP. }\end{array}$ \\
\hline $\begin{array}{l}\text { Specific Activity } \\
\text { of Waste }\end{array}$ & $\begin{array}{l}\text { A portion of the waste stored at INEL may contain }<100 \text { nanocuries per gram } \\
\text { transuranic radionuclides. }\end{array}$ \\
\hline $\begin{array}{l}\mathrm{Pu}^{239} \text { Equivalent } \\
\text { Activity }\end{array}$ & $\begin{array}{l}\text { None of the IDC } 007 \text { waste containers recorded as shipped to INEL in the } \\
\text { SWIMS exceed } 1,000 \mathrm{Ci} \text { of plutonium-equivalent activity. }\end{array}$ \\
\hline
\end{tabular}


Table 3.2.1-5. TRUPACT Evaluation.

Criterion or

requirement

Waste Package

Weight

Waste Containers

Nuclear Criticality

Surface Dose Rate

Removable Surface Contamination

Thermal Power

Gas Generation
Limiting parameters ${ }^{a}$

Rocky Flats limited the gross weight of drums to $800 \mathrm{lb}$. The TRUPACT and vehicle weight limits must be verified at the time of payload assembly at INEL.

The solidified sludge was packaged in 55-gal DOT-7A, Type A containers.

Rocky Flats limited the fissile content of the drums to 200 grams. However, the error-times-two requirement was not in place at the time the drums were shipped to INEL; therefore, it is not reported as part of the assay of the drum. The TRUPACT limit must be verified at the time of payload assembly at INEL. Based on the typical assays of the IDC 007 drums, the criticality criteria will be met but must be recalculated or assayed to meet the error-timestwo requirement.

The surface dose rate criteria used by Rocky Flats was $200 \mathrm{mrem} / \mathrm{hr}$ at the drum surface and $10 \mathrm{mrem} / \mathrm{hr}$ at 1 meter. Shielding was not necessary for IDC 007 drums. The TRUPACT limit must be verified at the time of payload assembly at INEL. Based on the typical dose rates from the IDC 007 drums, the dose rate criteria will be met.

The Rocky Flats limit for removable contamination (for TRU assumed to be all alpha) was 20 disintegrations per minute $/ 100 \mathrm{~cm}^{2}$. The Rocky Flats limit is equivalent to 9 picocuries per $100 \mathrm{~cm}^{2}$, which is well within the WIPP criteria.

The thermal power calculation reported in the SWIMS data package is based on the reported assay value without an error/uncertainty correction. The thermal power must be recalculated based on the assay error determination.

Based on the procedural requirements for packaging IDC 007 waste and the waste description, the only areas of noncompliance are carbon filters, unpunctured rigid liners, and headspace gas analysis, and visual characterization.

1,1,1-Trichloroethane, 1,1,2-trichloro-1,2,2-trifluoroethane, methylene chloride, and carbon tetrachloride were detected by headspace analysis in IDC 007 and are listed in the TRUPACT Chemical List for RF 111A. These chemicals appear to be in total concentrations $<1 \%$. Ethyl benzene, toluene, and xylene are on the TRUPACT Chemical List for aromatic hydrocarbons and halogenated organics, but were not detected. Alcohols on the TRUPACT Chemical List were not detected. Toxicity Characteristic Leaching Procedure (TCLP) indicates that this waste is toxic for chromium and selenium.

Personnel performing RTR examination at Rocky Flats would accept up to $10 \%$ of another IDC. The other IDCs could be combustibles, concrete, metal, and plastics.

a. Many of the limiting parameters were taken from TRU Waste Compliance Program (Rockwell International 1983a, 1987e, and 1989b). 
3.2.1.10 Combustible and Organic Content. Table 3.2.1-6 outlines available data from the TRU Waste Sampling Program for IDC 007. SWIMS data indicate that this waste form does not contain $>20 \%$ combustibles or $>20 \%$ organics.

3.2.1.10.1 Combustible Content-SWIMS data show that IDC 007 waste is noncombustible (Rockwell International 1985a). In support of the TRU Waste Sampling Program, four drums of IDC 007 waste were opened. They were found to contain an average wt\% combustible content of $1.5 \%$. Visual inspection showed an average vol\% combustible content of 5\%. (Clements and Kudera 1985).

3.2.1.10.2 Organic Content-SWIMS data show that IDC 007 waste may contain 5\% organics (Rockwell International 1985a). In support of the TRU Waste Sampling Program, four drums of IDC 007 waste were opened. They were found to contain an average wt\% organic content of $1.5 \%$. (Clements and Kudera 1985). 
Table 3.2.1-6. Item Description Code 007 Data Summary for Combustible and Organic Content.

\begin{tabular}{ccccccc}
\hline Container & $\begin{array}{c}\text { Wt. } \\
\text { combustibles } \\
(\mathrm{lb})^{\mathrm{a}}\end{array}$ & $\begin{array}{c}\text { Wt. } \\
\text { organics } \\
(\mathrm{lb})^{\mathrm{b}}\end{array}$ & $\begin{array}{c}\text { Net wt. of } \\
\text { container } \\
(\mathrm{lb})^{\mathrm{c}}\end{array}$ & $\begin{array}{c}\text { Wt\% } \\
\text { combustibles }^{\mathrm{d}}\end{array}$ & $\begin{array}{c}\text { Vol\% } \\
\text { combustibles }^{\mathrm{e}}\end{array}$ & $\begin{array}{c}\text { Wt\% } \\
\text { organics }^{\mathrm{f}}\end{array}$ \\
\hline $747-00944$ & 4.5 & 4.5 & 395.2 & 1 & 5 & 1 \\
$747-01488$ & 4.5 & 4.5 & 339.6 & 1 & 5 & 1 \\
$747-01492$ & 4.5 & 4.5 & 280.7 & 2 & 5 & 2 \\
$747-01531$ & 4.5 & 4.5 & 262.9 & 2 & 5 & 2 \\
\hline
\end{tabular}

a. Sum of weights of all combustible material and leaded rubber from Table 25 (Clements and Kudera 1985).

b. Sum of weights of all combustible material, leaded rubber, and organic material from Table 25 (Clements and Kudera 1985).

c. Net weight of container from Table 25 (Clements and Kudera 1985).

d. Weight of combustible material/net weight of container $\times 100$.

e. Vol\% of combustible material from visual examination, obtained from Appendix B (Clements and Kudera 1985).

f. Weight of organic material/net weight of container $\times 100$.

3.2.1.11 Analytical Information. Analytical data obtained through the Waste Stream and Residue Identification and Characterization Sampling and Analysis Database for IDC 007, Cemented Sludge, found the waste exceeded toxicity characteristic criteria for chromium (EPA Code D007) and selenium (EPA Code D010) (EG\&G RFP 1994s). The sampled drums were actually IDC 807, however, the results are applied to all of the Building 374 solidified bypass sludge. These data should be reviewed for their validity under EPA SW-846 (EPA 1990). Additional EPA Codes assigned to IDC 007 are F001, F002, F003, F005, F006, F007, F009, and F039, and EPA Code D002 is assigned to IDC 007 should any containers be rejected by RTR for free liquids (EG\&G RFP 1994b, 1990b). Toxicity Characteristic Leaching Procedure (TCLP) limits and analytical results from sampling between 1989 and 1990 are presented in Table 3.2.1-7 (EG\&G RFP 1994b and EG\&G RFP 1993b).

Analysis of analytical results for TCLP limits were performed (EG\&G RFP 1990c). These results are compared to the TCLP limits for the constituents. If the upper $90-\%$ confidence limit is greater than the TCLP limit, the entire waste population is regulated by the Resource Conservation and Recovery Act (RCRA) as a hazardous waste. Owing to this determination, the waste is RCRAhazardous for chromium (D007) and selenium (D010). 
Table 3.2.1-7. Analytical Data Summary.

\begin{tabular}{|c|c|c|c|c|}
\hline Constituent & $\begin{array}{c}\text { TCLP } \\
\text { limit }^{2} \\
(\mathrm{mg} / \mathrm{L})\end{array}$ & $\begin{array}{c}\text { Sample } \\
\text { size }\end{array}$ & $\begin{array}{c}\text { Mean } \\
(\mathrm{mg} / \mathrm{L})\end{array}$ & $\begin{array}{c}\text { Upper } 90-\% \\
\text { confidence limit }\end{array}$ \\
\hline Arsenic & 5.0 & 7 & 0.6876 & 0.9085 \\
\hline Barium & 100.0 & 7 & 0.924 & 0.1118 \\
\hline Cadmium & 1.0 & 14 & 0.0448 & 0.0608 \\
\hline \multirow[t]{2}{*}{ Chromium $^{b}$} & 5.0 & 7 & 2.3743 & $4.1724^{c}$ \\
\hline & & 7 & 12.260 & $15.2886^{d}$ \\
\hline Lead & 5.0 & 14 & 0.7304 & 1.1503 \\
\hline Mercury & 0.2 & 6 & 0.0022 & 0.0042 \\
\hline Nickel & N/A & 7 & 0.7414 & -0 \\
\hline Selenium & 1.0 & 7 & 0.9391 & 1.3900 \\
\hline Silver & 5.0 & 14 & 0.7282 & 0.7414 \\
\hline \multicolumn{5}{|c|}{$\begin{array}{l}\text { a. Concentration of constituent at which a solid waste exhibits the characteristic of toxicity. A concentration } \\
\text { greater than or equal to this level characterizes a solid waste as a RCRA-hazardous waste. }\end{array}$} \\
\hline \multicolumn{5}{|c|}{ b. Chromium analyses in 1989 and 1990 used different analytical methods. } \\
\hline \multicolumn{5}{|c|}{ c. May 1990 data. } \\
\hline \multicolumn{5}{|c|}{ d. November 1989 data. } \\
\hline \multicolumn{5}{|c|}{ e. Not calculated in letter (EG\&G RFP 1990c). } \\
\hline
\end{tabular}

Analytical data from the WIPP Experimental Waste Characterization Program for IDC 007, Cemented Sludge, B374, indicates that two drums were subject to headspace gas analysis (EG\&G RFP 1994t).

IDC 007 Gas Mass Spectrometry analytical results are presented in Table 3.2.1-8. Drums were subject to the operational lid headspace sampling program. Hydrogen, nitrogen, oxygen, argon, and carbon monoxide analytes were detected.

IDC 007 VOC Gas Chromatography/Mass Spectrometry analytical results are presented in Tables 3.2.1-9 and 3.2.1-10. Drums were subject to the operational lid headspace sampling program. Unreported analyte values indicate analytes were undetected, or detected at or above the MDL, but at a level below the PRQL in these drums. 
Analytical results for nine analytes are presented in Table 3.2.1-9. Analytes were detected in one of the two drums tested. Two analytes (trichloro-trifluoroethane and methylene chloride) were detected in the drum.

Analytical results for nine analytes are presented in Table 3.2.1-10. One analyte (1,1,1-trichloroethane) was detected in both drums.

Analytical data from the TRU Waste Sampling Waste Characterization Program (Clements and Kudera 1985) for IDC 007-Cemented Sludge, B374, indicate that four drums were subject to headspace gas analysis. Gas composition analytical results are presented in Table 3.2.1-11. Waste boxes were not sampled. Hydrogen, oxygen, nitrogen, argon, carbon dioxide, saturated hydrocarbons, 1,1,1-trichloroethane, dichloromethane, and carbon tetrachloride were detected in the drums.

Table 3.2.1-8. Gas Mass Spectrometry Results (vol\%).

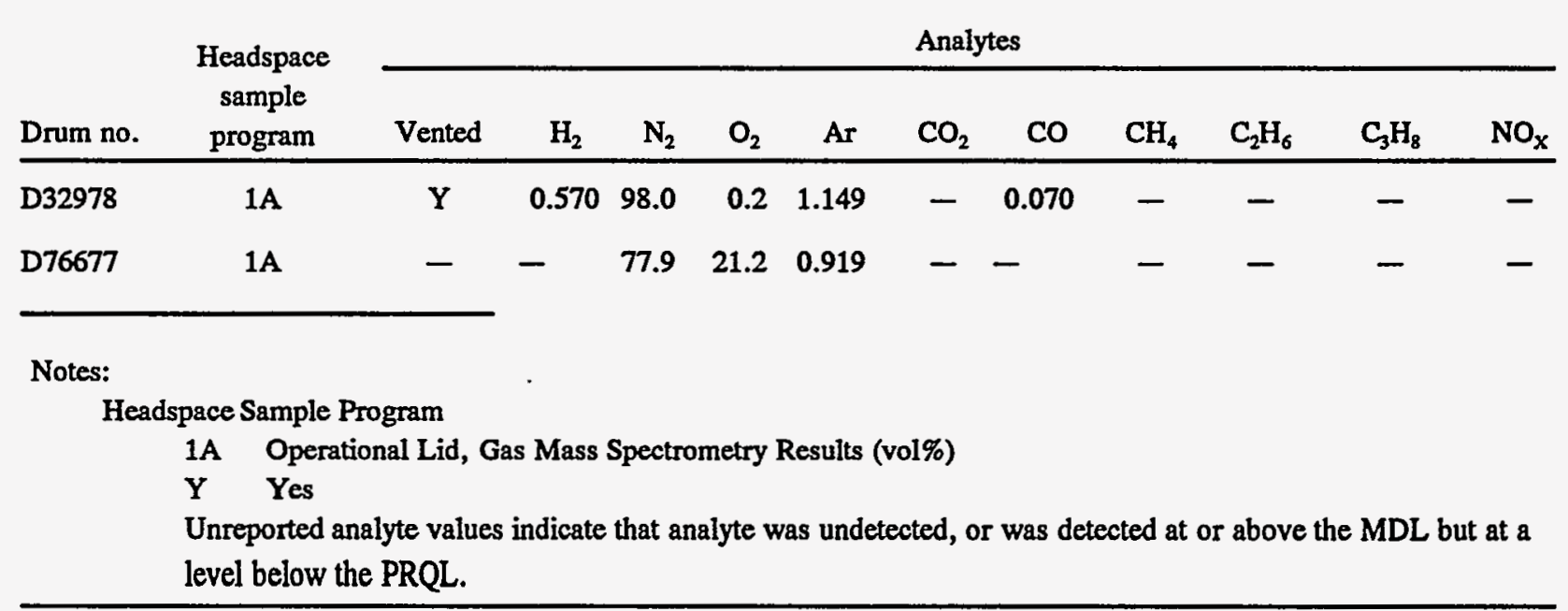


Table 3.2.1-9. Volatile Organic Compound Gas Chromatography/Mass Spectrometry Results (parts per million by volume).

\begin{tabular}{|c|c|c|c|c|c|c|c|c|c|c|c|}
\hline $\begin{array}{l}\text { Drum } \\
\text { no. }\end{array}$ & $\begin{array}{l}\text { Headspace } \\
\text { sample } \\
\text { program }\end{array}$ & Vented & Methanol & $\begin{array}{l}\text { Ethyl } \\
\text { Ether }\end{array}$ & $\begin{array}{l}\text { Trichloro- } \\
\text { trifluoro- } \\
\text { ethane }\end{array}$ & $\begin{array}{c}1,1- \\
\text { Dichloro- } \\
\text { ethene }\end{array}$ & Acetone & $\begin{array}{l}\text { Methylene } \\
\text { Chloride }\end{array}$ & $\begin{array}{c}1,1- \\
\text { Dichloro- } \\
\text { ethane }\end{array}$ & $\begin{array}{l}\text { cis-1,2- } \\
\text { Dichloro- } \\
\text { ethene }\end{array}$ & $\begin{array}{c}2- \\
\text { Butanone }\end{array}$ \\
\hline 32978 & $1 B$ & $\mathbf{Y}$ & - & - & 73.3 & - & - & 161.8 & - & - & - \\
\hline
\end{tabular}

Notes:

Headspace Sample Program

1B Operational Lid, VOC Gas Chromatography/Mass Spectrometry Results (ppmv)

Y Yes

Unreported analyte values indicate that analyte was undetected, or was detected at or above the MDL but at a level below the PRQL.

$\omega$ Table 3.2.1-10. Volatile Organic Compound Gas Chromatography/Mass Spectrometry Results (parts per million by volume).

\begin{tabular}{|c|c|c|c|c|c|c|c|c|c|c|c|}
\hline \multirow[b]{2}{*}{$\begin{array}{c}\text { Drum } \\
\text { no. }\end{array}$} & \multirow[b]{2}{*}{$\begin{array}{c}\text { Headspace } \\
\text { sample } \\
\text { program }\end{array}$} & \multirow[b]{2}{*}{ Vented } & \multicolumn{9}{|c|}{ Analytes } \\
\hline & & & $\begin{array}{l}\text { Chloro- } \\
\text { form }\end{array}$ & $\begin{array}{c}1,1,1- \\
\text { Trichloro- } \\
\text { ethane }\end{array}$ & $\begin{array}{l}\text { Cyclo- } \\
\text { hexane }\end{array}$ & $\begin{array}{l}\text { Carbon } \\
\text { Tetra- } \\
\text { chloride }\end{array}$ & Benzene & $\begin{array}{c}1,2- \\
\text { Dichloro } \\
\text {-ethane }\end{array}$ & $\begin{array}{c}1- \\
\text { Butanol }\end{array}$ & $\begin{array}{l}\text { Trichloro } \\
\text {-ethene }\end{array}$ & $\begin{array}{l}\text { 4-Methyl-2- } \\
\text { pentanone }\end{array}$ \\
\hline D32978 & 1B & $\mathbf{Y}$ & - & 429.2 & - & - & - & - & - & - & - \\
\hline D76677 & $1 B$ & - & - & 199.5 & - & - & - & - & - & - & - \\
\hline
\end{tabular}

Notes:

Headspace Sample Program

1B Operational Lid, VOC Gas Chromatography/Mass Spectrometry Results (ppmv)

Y Yes

Unreported analyte values indicate that analyte was undetected, or was detected at or above the MDL but at a level below the PRQL. 
Table 3.2.1-11. Gas Sampling Results-Compositional Analysis (vol\%).

\begin{tabular}{|c|c|c|c|c|c|c|c|c|c|c|c|}
\hline \multirow[b]{2}{*}{$\begin{array}{c}\text { Container } \\
\text { ID. no. }\end{array}$} & \multirow{2}{*}{$\begin{array}{c}\text { Storage } \\
\text { time } \\
\text { (days) }\end{array}$} & \multicolumn{10}{|c|}{ Analytes } \\
\hline & & $\mathrm{H}_{2}$ & $\mathrm{O}_{2}$ & $\mathrm{~N}_{2}$ & $\mathrm{Ar}$ & $\mathrm{CO}_{2}$ & $\mathrm{CO}$ & $\mathrm{NO}_{\mathrm{x}}$ & $\begin{array}{l}\text { Hydrocarbons } \\
\text { (saturated) }^{1}\end{array}$ & $\begin{array}{l}1,1,1- \\
\text { trichloroethane }\end{array}$ & $\begin{array}{c}\text { Other } \\
\text { hydrocarbons }\end{array}$ \\
\hline 747-00944 & 264 & - & 20.3 & 78.4 & 0.95 & 0.04 & - & - & 0.11 & 0.12 & $0.07^{a}$ \\
\hline $747-01488$ & 175 & 0.15 & 12.0 & 86.7 & 1.06 & 0.01 & - & - & 0.10 & - & - \\
\hline $747-01492$ & 176 & 0.03 & 21.1 & 77.7 & 0.96 & 0.05 & - & - & 0.06 & 0.06 & $0.02^{b}$ \\
\hline $747-01531$ & 177 & 0.10 & 19.1 & 79.6 & 0.96 & 0.04 & - & - & 0.12 & 0.03 & $0.04^{b}$ \\
\hline \multicolumn{12}{|c|}{ a. Saturated hydrocarbons-methane through propane. } \\
\hline \multicolumn{12}{|c|}{ b. Other hydrocarbons-as specified. } \\
\hline \multicolumn{11}{|c|}{ "Dichloromethane } & \\
\hline
\end{tabular}




\subsection{Waste Form Number 111-Solidified Aqueous Sludge, Content Code RF 111A}

\subsubsection{Item Description Code 800-Solidified Sludge, B774}

3.2.2.1 Certification Assessment. This IDC is certifiable without further waste treatment. Assay and thermal power calculations, including error, need to be updated to meet the current WIPP WAC. Several gas generation criteria need to be addressed. Carbon filters may need to be installed, drums will require inspection to identify unvented or unpunctured rigid liners, and headspace gas analysis and visual waste characterization will need to be performed.

3.2.2.2 Waste Description. This waste consists of immobilized materials from aqueous waste treatment operations. A two-stage basic waste treatment, precipitation, and filtration process generated IDC 800 aqueous sludge. Acidic wastes were neutralized with sodium hydroxide in stage one. Ferric sulfate and Purifloc flocculent was added to the neutralized waste (containing metal ions) to precipitate the sludge prior to filtration. In stage two, ferric sulfate, magnesium sulfate, calcium chloride, and Purifloc flocculent was added to basic wastes during the two-stage treatment to precipitate sludge. The sludge slurry from the acidic and basic waste treatment was drawn through a diatomite filter media on a rotating drum filter to trap the solids. The filter media and sludge were continuously scraped off the drum filter and co-fed into a 55-gal drum with additional diatomite and Portland cement making up the solidification process. No mechanical mixing of the sludge and cement was performed (EG\&G RFP 1994c).

3.2.2.3 Generation Source. DC 800 was generated by the high-level aqueous waste treatment system in Building 774. After August 1984 and the startup of the Building 374 Precipitation Process, only waste piped from Building 771 (steam condensate, scrubber waste, ion column effluent, and process waste sinks), containerized waste from various buildings, and wastes generated within Building 774 (silver recovery effluent, seal liquid, floor washdown) were accepted. IDC 800 replaced IDC 001 in 1986, and was produced by Building 774 until March 1991 (EG\&G RFP 1994c).

3.2.2.4 Recovery Method. This IDC was never generated as a residue and therefore has no recovery method.

3.2.2.5 Waste Packaging and Handling. The drums used were DOT-17C, white, 55-gal drums. The sludge was co-fed into the 55-gal drum with additional diatomite and Portland cement making up the solidification process. No mechanical mixing of the sludge and cement was performed (EG\&G RFP 1994c). When the drum was full, the liners were twisted and taped closed, the lid was secured with a bolted ring, the Drum Count label was completed and taped to the drum lid by the generator, and a TID was attached to the drum (Rockwell International 1989b).

3.2.2.6 Container Preparation. Only approved containers could be used to package TRU waste for shipment offsite. The containers approved for shipment to INEL during this time were DOT-17C, white, 55-gal drums (Rockwell specification SX-200). These containers met the requirements for certification as DOT-7A Type A packaging (Rockwell International 1989e). 
Table 3.2.2-1 shows the current inventory of IDC 800 waste containers from the Rocky Flats Plant that have been shipped to INEL since 1985.

Table 3.2.2-1. Item Description Code 800 Container Information.

\begin{tabular}{|c|c|c|c|}
\hline \multicolumn{2}{|l|}{ Information } & \multirow{2}{*}{$\frac{\text { Drums }}{1,586}$} & \multirow{2}{*}{$\frac{\text { Boxes }}{0}$} \\
\hline Total Containers & & & \\
\hline \multirow[t]{3}{*}{ Net Container Weight (lb) } & Maximum & 614 & N/A \\
\hline & Minimum & 157 & N/A \\
\hline & Average & 369 & N/A \\
\hline
\end{tabular}

3.2.2.6.1 Drum Preparation-Approved liners for drums of TRU waste packaged for offsite shipment as of 1989 are the round-bottom liner (Rockwell specification SX-203), inside a rigid polyethylene liner (Rockwell specification SX-202), or an O-ring bag and a polyethylene bag placed inside the rigid liner if the drum is attached to a glovebox. All bags were closed using the twist-andtape method (Rockwell International 1989e).

IDC 800 sludge is assumed to have been packaged like IDC 007 sludge. The IDC 007 sludge mixture was placed in 55-gal drums that were lined with a high-density polyethylene rigid liner, 14mil PVC O-ring bag, and a 5-mil polyethylene bag. The polyethylene bag was not required from a waste packaging standpoint, but it aided in contamination control (DOE/WIPP 1992).

Flow-in ventable gaskets were installed in the drums beginning in December 1982 . They were used until October 1988, when tubular gaskets with carbon filters were required. Drums shipped to the INEL between 1985 and 1988 may not meet the current WIPP WAC, owing to their lack of carbon filters (Bearly 1989a).

3.2.2.6.2 Box Preparation-No boxes of IDC 800 waste were shipped to INEL between 1985 and 1989.

3.2.2.7 Assay. Assay was performed radiochemically. The drum assay value was based on the amount of plutonium and americium received in the aqueous waste treatment system for a period of operations, usually one month. The total amount received was divided evenly between the drums of sludge produced over that period of operation. Uranium was not included on the majority of the assays. In some cases, a sample of the sludge from each drum was taken to determine the amount and identity of the radionuclides (plutonium, americium, and uranium) in the sludge. The sludge sample was analyzed using a radiochemical assay. The results of the analysis were expressed in terms of grams of each radionuclide present for each gram of sludge. Containers of waste that have not been PADC assayed and had SGS assay values of 1 gram or less should be PADC assayed to verify that they are transuranic waste. Table 3.2.2-2 summarizes the dose rates measured on containers of this IDC. Table 3.2.2-3 provides a summary of the assay information. Americium content was evaluated in 1,546 drums. Uranium content was evaluated in 22 drums. 
Table 3.2.2-2. Item Description Code 800 Dose Information.

\begin{tabular}{|c|c|c|c|}
\hline Information & & Drums & Boxes \\
\hline One Meter Dose Rate $(\mathrm{mrem} / \mathrm{h})$ & $\begin{array}{r}0-0.5 \\
0.5-10\end{array}$ & $\begin{array}{r}325 \\
1,261\end{array}$ & $\begin{array}{l}\text { N/A } \\
\text { N/A }\end{array}$ \\
\hline Surface Dose Rate (mrem $/ \mathrm{h})$ & $\begin{array}{r}<10 \\
10-200\end{array}$ & $\begin{array}{l}660 \\
926\end{array}$ & $\begin{array}{l}\text { N/A } \\
\text { N/A }\end{array}$ \\
\hline
\end{tabular}

Table 3.2.2-3. Item Description Code 800 Assay Information.

\begin{tabular}{|c|c|c|c|}
\hline \multicolumn{2}{|c|}{ Radionuclide inventory } & \multirow{2}{*}{$\frac{\text { Drums }}{32}$} & \multirow{2}{*}{$\frac{\text { Boxes }}{N / A}$} \\
\hline Plutonium (g) & Maximum & & \\
\hline & Minimum & 0 & N/A \\
\hline & Average & 4 & N/A \\
\hline Americium (g) & Maximum & 3.9 & N/A \\
\hline & Minimum & 0 & N/A \\
\hline & Average & 0.9 & N/A \\
\hline Uranium-235 (g) & Maximum & 1.7 & N/A \\
\hline & Minimum & 0.3 & N/A \\
\hline & Average & 0.7 & N/A \\
\hline
\end{tabular}

3.2.2.8 Inspection. Waste Certification periodically reviews the process documentation to ensure that the solidification process is being operated according to procedure. This inspection is performed to ensure that free liquids and particulates will not be found in this waste form. In addition to review of process documentation, Waste Certification personnel performed periodic inspections of the generating and packaging process to verify compliance with waste acceptance criteria. Each drum is viewed using RTR to

- Ensure the drum does not contain nonconforming items

- Ensure the drum is properly packaged

- Verify the waste form description

- Evaluate the presence of free liquids.

3.2.2.9 Waste Form Evaluation. Table 3.2.2-4 evaluates the waste form against the WIPP WAC for such items as free liquids, pyrophoric materials, and compressed gases. Table 3.2.2-5 evaluates the waste against TRUPACT criteria. 
Table 3.2.2-4. Waste Form Evaluation.

Criterion or requirement

Limiting parameters ${ }^{\mathrm{a}}$

Immobilization

Particulates were prohibited by procedural control. Based on the description of the waste, fine particulates are not expected in this IDC.

Liquids

The solidified sludge should meet the free liquid criteria by procedural control and RTR inspection prior to shipment from Rocky Flats. However, the sludge should be checked for the possibility that the sludge has dewatered.

Pyrophoric . Pyrophoric materials were prohibited by procedural control. The absence of Materials the pyrophoric materials was verified by the generating supervisor and periodic inspection by the Waste Certification Organization.

Explosives and Compressed Gases

Explosives and compressed gases were prohibited by procedural control. The absence of the explosives and compressed gases was verified by the generating supervisor and periodic inspection by the Waste Certification Organization. In addition, unvented, closed containers and pressurized containers were excluded by procedural controls and RTR examination.

TRU-Mixed Wastes The RCRA constituents exist as co-contaminants with the transuranic radionuclides. Compliance with the WIPP RCRA permits and NMD will be required prior to shipment of the stored waste to WIPP.

Specific Activity of Waste A portion of the waste stored at INEL may contain $<100$ nanocuries per gram transuranic radionuclides.

$\mathrm{Pu}^{239}$ Equivalent None of the IDC 800 waste containers recorded as shipped to INEL in the Activity SWIMS exceed $1,000 \mathrm{Ci}$ of plutonium-equivalent activity.

a. Many of the limiting parameters were taken from TRU Waste Compliance Program (Rockwell International 1983a, 1987e, and 1989b). 
Table 3.2.2-5. TRUPACT Evaluation.

Criterion or

requirement

Limiting parameters ${ }^{2}$

Waste Package

Rocky Flats limited the gross weight of drums to $800 \mathrm{lb}$. The TRUPACT and

Weight vehicle weight limits must be verified at the time of payload assembly at INEL.

Waste Containers The solidified sludge was packaged in 55-gal DOT-7A, Type A containers.

Nuclear Criticality Rocky Flats limited the fissile content of the drums to 200 grams. However, the error-times-two requirement was not in place at the time the drums were shipped to INEL; therefore, it is not reported as part of the assay of the drum. The TRUPACT limit must be verified at the time of payload assembly at INEL. Based on the typical assays of the IDC 800 drums, the criticality criteria will be met but must be recalculated or assayed to meet the error-times-two requirement.

Surface Dose Rate The surface dose rate criteria used by Rocky Flats was $200 \mathrm{mrem} / \mathrm{hr}$ at the drum surface and $10 \mathrm{mrem} / \mathrm{hr}$ at 1 meter. Shielding was not necessary for IDC 800 drums. The TRUPACT limit must be verified at the time of payload assembly at INEL. Based on the typical dose rates from the IDC 800 drums, the dose rate criteria will be met.

Removable

Surface

The Rocky Flats limit for removable contamination (for TRU assumed to be all

Contamination alpha) was 20 disintegrations per minute $/ 100 \mathrm{~cm}^{2}$. The Rocky Flats limit is equivalent to 9 picocuries per $100 \mathrm{~cm}^{2}$, which is well within the WIPP criteria.

Thermal Power

The thermal power calculation reported in the SWIMS data package is based on the reported assay value without an error/uncertainty correction. The thermal power must be recalculated based on the assay error determination.

Gas Generation Based on the procedural requirements for packaging IDC 800 waste and the waste description, the only areas of noncompliance are carbon filters, unpunctured rigid liners, and headspace gas analysis, and visual characterization.

Benzene and 1,1-dichloroethene were detected by headspace analysis in IDC 800 , but are not listed in the TRUPACT Chemical List for RF 111A. 1,1,1Trichloroethane, methylene chloride, toluene, $\mathrm{m}, \mathrm{p}$-xylene, o-xylene, ethyl benzene, and carbon tetrachloride were detected by headspace analysis and are on the TRUPACT Chemical List. These chemicals appear to be in total concentrations $<1 \%$. 1,1,2-Trichloro-1,2,2-trifluoroethane is on the TRUPACT Chemical List for halogenated organics, but was not detected. Alcohols on the TRUPACT Chemical List were not detected.

Personnel performing RTR examination at Rocky Flats would accept up to $10 \%$ of another IDC. The other IDCs could be combustibles, concrete, metal, and plastics.

a. Many of the limiting parameters were taken from TRU Waste Compliance Program (Rockwell International 1983a, 1987e, and 1989b). 
3.2.2.10 Combustible and Organic Content. SWIMS data indicate that this waste form does not contain $>20 \%$ combustibles or $>20 \%$ organics.

3.2.2.10.1 Combustible Content-SWIMS data show that IDC 800 waste is noncombustible (Rockwell International 1985a).

3.2.2.10.2 Organic Content-SWIMS data show that IDC 800 waste contains $5 \%$ organics (Rockwell International 1985a).

3.2.2.11 Analytical Information. Information contained in the WSRIC Building 771 Book (EG\&G RFP 1993g) and WSRIC Building 774 Book (EG\&G RFP 1993h) indicate that wastes sent to Building 774 after August 1984 were intermittently contaminated with cadmium (D006), chromium (D007), and silver (D011). It will be assumed that IDC 800 solidified sludge generated after August 1985 exhibits the characteristic of toxicity for these metals until TCLP analysis of the waste under EPA SW-846 (EPA 1990) proves the waste does not exceed toxicity characteristic criteria. IDC 800 waste generated after August 1985 was not mixed with listed wastes and does not carry listed EPA codes (EG\&G 1994c).

One sample of IDC 800 solidified sludge was analyzed for volatile organic constituents in 1988. Analytical results are presented in Table 3.2.2-6. Additionally, the highest organic levels of detected toxicity characteristic constituents from headspace analysis of drums of solidified sludge are presented in Table 3.2.2-7. A partitioning coefficient model, designed for environmental media, was used to calculate the waste contaminant levels in the sludge from the headspace analytical results. The analytical results from a solidified sludge sample in 1988 and calculated constituent levels from headspace analytical results both indicate that the waste is below toxicity characteristic criteria for RCRA organics (EG\&G RFP 1994c).

Table 3.2.2-6. Analytical Results for Sample of Building 774 Aqueous Sludge Sample.

\begin{tabular}{lcc}
\hline \multicolumn{1}{c}{ Constituent } & $\begin{array}{c}\text { TCLP } \\
\text { limit } \\
(\mathrm{mg} / \mathrm{L})\end{array}$ & $\begin{array}{c}\text { Sample } \\
\text { results } \\
(\mathrm{ppm})\end{array}$ \\
\hline Carbon tetrachloride & 0.5 & 0.082 \\
Chloroform & 6.0 & 0.187 \\
Ethylbenzene & - & 0.005 \\
Toluene & - & 0.015 \\
Methylene Chloride & - & 1.0 \\
1,1,1-Trichloroethane & - & 0.020 \\
Trichloroethylene & 0.5 & 0.030 \\
Xylene & - & 0.008 \\
\hline
\end{tabular}


Table 3.2.2-7. Analytical and Calculated Results Summary from Drum Headspace Analyses.

\begin{tabular}{lccc}
\hline \multicolumn{1}{c}{ Constituent } & $\begin{array}{c}\text { TCLP } \\
\text { limit } \\
(\mathrm{mg} / \mathrm{L})\end{array}$ & $\begin{array}{c}\text { Headspace } \\
\text { analytical results } \\
(\mathrm{mg} / \mathrm{kg})\end{array}$ & $\begin{array}{c}\text { Calculated } \\
\text { levels in } \\
\text { waste } \\
(\mathrm{mg} / \mathrm{L})\end{array}$ \\
\hline Benzene & 0.5 & 5.0 & 0.0590 \\
Carbon Tetrachloride & 0.5 & 0.9 & 0.0108 \\
1,1-Dichloroethene & 0.7 & 1.0 & 0.0016 \\
\hline
\end{tabular}

Analytical data from the WIPP Experimental Waste Characterization Program for IDC 800Solidified Sludge, B774, indicate that 22 drums were subject to headspace gas analysis for Gas Mass Spectrometry and 23 drums for VOC Gas Chromatography/Mass Spectrometry (EG\&G RFP 1994t).

IDC 800 Gas Mass Spectrometry analytical results are presented in Table 3.2.2-8. Drums were subject to three possible headspace sampling programs: detailed bag, detailed lid, and operational lid. An individual drum could be sampled by more than one program. All analytes, with the exception of methane, ethane, and propane were detected. Nitrogen, oxygen, and argon were detected in every drum.

IDC 800 VOC Gas Chromatography/Mass Spectrometry analytical results are presented in Tables 3.2.2-9 though 3.2.2-11. Drums were subject to the three possible headspace sampling programs as described above. Unreported analyte values indicate that analytes were undetected, or detected at or above the MDL, but at a level below the PRQL in these drums.

Analytical results for nine analytes are presented in Table 3.2.2-9. Analytes were detected in 2 of the 23 drums tested. One analyte (methylene chloride) was detected in the drums.

Analytical results for nine analytes are presented in Table 3.2.2-10. Analytes were detected in 3 of 23 drums tested. Two analytes (1,1,1-trichloroethane and carbon tetrachloride) were detected in the drums.

Analytical results for 10 analytes are presented in Table 3.2.2-11. Analytes were detected in 18 of the 23 drums tested. Four analytes (toluene, ethyl-benzene, m,p-xylene and o-xylene), were detected in the drums. 
Table 3.2.2-8. Gas Mass Spectrometry Results (vol\%).

\begin{tabular}{|c|c|c|c|c|c|c|c|c|c|c|c|c|}
\hline \multirow{2}{*}{$\begin{array}{c}\text { Drum } \\
\text { no. }\end{array}$} & \multirow{2}{*}{$\begin{array}{l}\text { Headspace } \\
\text { sample } \\
\text { program }\end{array}$} & \multicolumn{11}{|c|}{ Analytes } \\
\hline & & Vented & $\mathrm{H}_{2}$ & $\mathrm{~N}_{2}$ & $\mathrm{O}_{2}$ & $\mathrm{Ar}$ & $\mathrm{CO}_{2}$ & $\mathrm{CO}$ & $\mathrm{CH}_{4}$ & $\mathrm{C}_{2} \mathrm{H}_{6}$ & $\mathrm{C}_{3} \mathrm{H}_{8}$ & $\mathrm{NO}_{\mathrm{x}}$ \\
\hline D66525 & $1 \mathrm{~A}$ & $\mathbf{Y}$ & 0.048 & 76.9 & 22.1 & 0.908 & - & - & - & - & - & - \\
\hline D66525 & $2 A$ & $\mathbf{Y}$ & - & 77.1 & 21.9 & 0.944 & - & - & - & - & - & - \\
\hline D66525 & $3 A$ & $\mathbf{N}$ & 3.408 & 81.8 & 13.7 & 0.958 & 0.126 & - & - & - & - & 0.045 \\
\hline D67434 & $1 \mathrm{~A}$ & $\mathbf{Y}$ & - & 78.5 & 20.5 & 0.944 & - & - & - & - & - & - \\
\hline D67434 & $2 A$ & $\mathbf{Y}$ & - & 78.1 & 20.9 & 0.937 & - & - & - & - & - & - \\
\hline D67434 & $3 A$ & $\mathbf{N}$ & 1.891 & 96.0 & 0.8 & 1.165 & 0.159 & - & - & - & - & 0.062 \\
\hline D67436 & $1 \mathrm{~A}$ & $\mathbf{Y}$ & - & 86.1 & 12.8 & 1.030 & - & - & - & - & - & - \\
\hline D67436 & $2 \mathrm{~A}$ & $\mathbf{Y}$ & - & 78.7 & 20.3 & 0.947 & - & - & - & - & - & - \\
\hline D67436 & $3 A$ & $\mathbf{N}$ & 3.101 & 95.3 & 0.4 & 1.162 & - & - & - & - & - & 0.017 \\
\hline D67441 & $1 \mathrm{~A}$ & $\mathbf{Y}$ & - & 83.3 & 15.7 & 1.013 & - & - & - & - & - & - \\
\hline D67441 & $2 \mathrm{~A}$ & $Y^{\prime}$ & - & 78.8 & 20.2 & 0.965 & - & - & - & - & - & - \\
\hline D67441 & $3 A$ & $\mathbf{N}$ & 1.419 & 97.0 & 0.3 & 1.126 & 0.045 & - & - & - & - & - \\
\hline D67654 & $1 \mathrm{~A}$ & $\mathbf{Y}$ & - & 78.6 & 20.4 & 0.917 & - & - & - & - & - & - \\
\hline D67654 & $2 \mathrm{~A}$ & $\mathbf{Y}$ & - & 77.9 & 21.2 & 0.909 & - & - & - & - & - & - \\
\hline D67654 & $3 A$ & $\mathbf{N}$ & 2.485 & 94.7 & 1.6 & 1.155 & - & 0.017 & - & - & - & - \\
\hline D67657 & $1 \mathrm{~A}$ & $\mathbf{Y}$ & - & 82.3 & 16.7 & 0.948 & - & - & - & - & - & - \\
\hline D67657 & $2 A$ & $\mathbf{Y}$ & - & 77.8 & 21.2 & 0.954 & - & - & - & - & - & - \\
\hline D67657 & $3 A$ & $\mathbf{N}$ & 1.761 & 96.6 & 0.4 & 1.166 & - & - & - & - & - & - \\
\hline D67698 & $3 A$ & $\mathrm{Y}$ & - & 76.8 & 11.5 & 0.930 & 10.818 & 0.037 & - & - & - & - \\
\hline D68247 & $1 \mathrm{~A}$ & $\mathbf{Y}$ & - & 84.5 & 14.5 & 0.972 & - & - & - & - & - & - \\
\hline D68247 & $2 \mathrm{~A}$ & $\mathbf{Y}$ & - & 79.1 & 20.0 & 0.928 & - & - & - & - & - & - \\
\hline D68247 & $3 \mathrm{~A}$ & $\mathbf{N}$ & - & 81.4 & 17.6 & 0.991 & - & - & - & - & - & - \\
\hline D68254 & $1 \mathrm{~A}$ & $\mathbf{Y}$ & - & 84.0 & 15.0 & 0.964 & - & - & - & - & - & - \\
\hline D68254 & $2 A$ & $\mathbf{Y}$ & - & 78.8 & 20.3 & 0.921 & - & - & - & - & - & - \\
\hline D68254 & $3 A$ & $\mathbf{N}$ & - & 92.0 & 17.0 & 0.992 & - & - & - & - & - & - \\
\hline D68256 & $1 \mathrm{~A}$ & $\mathbf{Y}$ & - & 81.0 & 18.0 & 0.938 & - & - & - & - & - & - \\
\hline D68256 & $2 \mathrm{~A}$ & $\mathbf{Y}$ & - & 78.2 & 20.7 & 0.916 & - & - & - & - & - & - \\
\hline D68256 & $3 A$ & $\mathbf{N}$ & - & 95.7 & 2.5 & 1.121 & - & - & - & - & - & - \\
\hline D68480 & $1 \mathrm{~A}$ & $\mathbf{Y}$ & 0.178 & 74.5 & 24.4 & 0.900 & - & - & - & - & - & - \\
\hline
\end{tabular}


Table 3.2.2-8. (continued).

\begin{tabular}{|c|c|c|c|c|c|c|c|c|c|c|c|c|}
\hline \multirow{2}{*}{$\begin{array}{c}\text { Drum } \\
\text { no. }\end{array}$} & \multirow{2}{*}{$\begin{array}{c}\text { Headspace } \\
\text { sample } \\
\text { program }\end{array}$} & \multicolumn{11}{|c|}{ Analytes } \\
\hline & & Vented & $\mathrm{H}_{2}$ & $\mathrm{~N}_{2}$ & $\mathrm{O}_{2}$ & Ar & $\mathrm{CO}_{2}$ & $\mathrm{CO}$ & $\mathrm{CH}_{4}$ & $\mathrm{C}_{2} \mathrm{H}_{6}$ & $\mathrm{C}_{3} \mathrm{H}_{8}$ & $\mathrm{NO}_{\mathrm{x}}$ \\
\hline D68480 & $2 A$ & $\mathbf{Y}$ & - & 76.6 & 22.4 & 0.926 & - & - & - & - & - & - \\
\hline D68480 & $3 A$ & $\mathbf{N}$ & 0.151 & 76.2 & 22.6 & 0.929 & - & - & - & 一 & - & - \\
\hline D69312 & $1 \mathrm{~A}$ & $\mathbf{Y}$ & - & 78.1 & 20.9 & 0.937 & - & - & - & - & - & - \\
\hline D69312 & $2 \mathrm{~A}$ & $\mathbf{Y}$ & - & 78.1 & 20.9 & 0.937 & - & - & - & - & - & - \\
\hline D69312 & $3 A$ & $\mathbf{N}$ & 10.037 & 87.8 & 0.4 & 1.063 & 0.447 & - & - & - & - & 0.239 \\
\hline D72267 & $1 \mathrm{~A}$ & $\mathbf{Y}$ & - & 78.4 & 20.6 & 0.932 & - & - & - & - & - & - \\
\hline D72267 & $2 \mathrm{~A}$ & $\mathbf{Y}$ & - & 77.8 & 21.2 & 0.910 & - & - & - & - & - & - \\
\hline D72267 & $3 A$ & $\mathbf{Y}$ & - & 78.3 & 20.7 & 0.956 & - & - & - & - & - & - \\
\hline D72545 & $1 \mathrm{~A}$ & $\mathbf{Y}$ & - & 78.9 & 20.1 & 0.929 & - & - & - & - & - & - \\
\hline D72545 & $2 A$ & $\mathbf{Y}$ & - & 77.8 & 21.2 & 0.916 & - & - & - & - & - & - \\
\hline D72545 & $3 \mathrm{~A}$ & $\mathbf{Y}$ & - & 78.1 & 20.9 & 0.943 & - & - & - & - & - & - \\
\hline D76138 & $1 \mathrm{~A}$ & $\mathbf{Y}$ & - & 76.3 & 22.7 & 0.925 & - & - & - & - & - & - \\
\hline D76138 & $2 A$ & $\mathbf{Y}$ & - & 77.1 & 21.9 & 0.930 & - & - & - & - & - & - \\
\hline D76138 & $3 A$ & - & - & 77.6 & 21.4 & 0.930 & - & - & - & - & - & - \\
\hline D76185 & $1 A$ & $\mathbf{Y}$ & - & 77.2 & 21.9 & 0.902 & - & - & - & - & - & - \\
\hline D76185 & $2 A$ & $\mathbf{Y}$ & - & 77.3 & 21.7 & 0.912 & - & - & - & - & - & - \\
\hline D76185 & $3 A$ & - & - & 77.1 & 21.9 & 0.951 & - & - & - & - & - & - \\
\hline D76194 & $3 A$ & - & - & 77.0 & 22.0 & 0.938 & - & - & - & - & - & - \\
\hline D76205 & $1 \mathrm{~A}$ & $\mathbf{Y}$ & - & 75.7 & 23.2 & 0.896 & - & 0.018 & - & - & - & 0.025 \\
\hline D76205 & $2 A$ & $\mathbf{Y}$ & - & 77.2 & 21.8 & 0.909 & - & - & - & - & - & 0.026 \\
\hline D76205 & $3 A$ & - & - & 76.8 & 22.2 & 0.947 & - & - & - & - & - & - \\
\hline D76282 & $1 \mathrm{~A}$ & $\mathbf{Y}$ & - & 78.9 & 20.0 & 0.934 & - & 0.036 & - & - & - & - \\
\hline D76282 & $2 \mathrm{~A}$ & $\mathbf{Y}$ & - & 77.8 & 21.0 & 0.922 & - & 0.011 & - & - & - & - \\
\hline D76282 & $3 A$ & - & - & 78.1 & 20.9 & 0.941 & - & - & - & - & - & - \\
\hline D76287 & $1 \mathrm{~A}$ & $\mathbf{Y}$ & - & 78.2 & 20.7 & 0.949 & - & - & - & - & - & - \\
\hline D76287 & $2 A$ & $\mathbf{Y}$ & - & 78.0 & 20.9 & 0.970 & - & - & - & - & - & - \\
\hline D76287 & $3 \mathrm{~A}$ & - & - & 77.6 & 21.4 & 0.928 & - & - & - & - & - & 0.013 \\
\hline D76302 & $1 \mathrm{~A}$ & $\mathbf{Y}$ & - & 78.1 & 20.9 & 0.929 & - & - & - & - & - & - \\
\hline D76302 & $2 A$ & $\mathbf{Y}$ & - & 77.0 & 22.0 & 0.927 & - & - & - & - & - & - \\
\hline
\end{tabular}


Table 3.2.2-8. (continued).

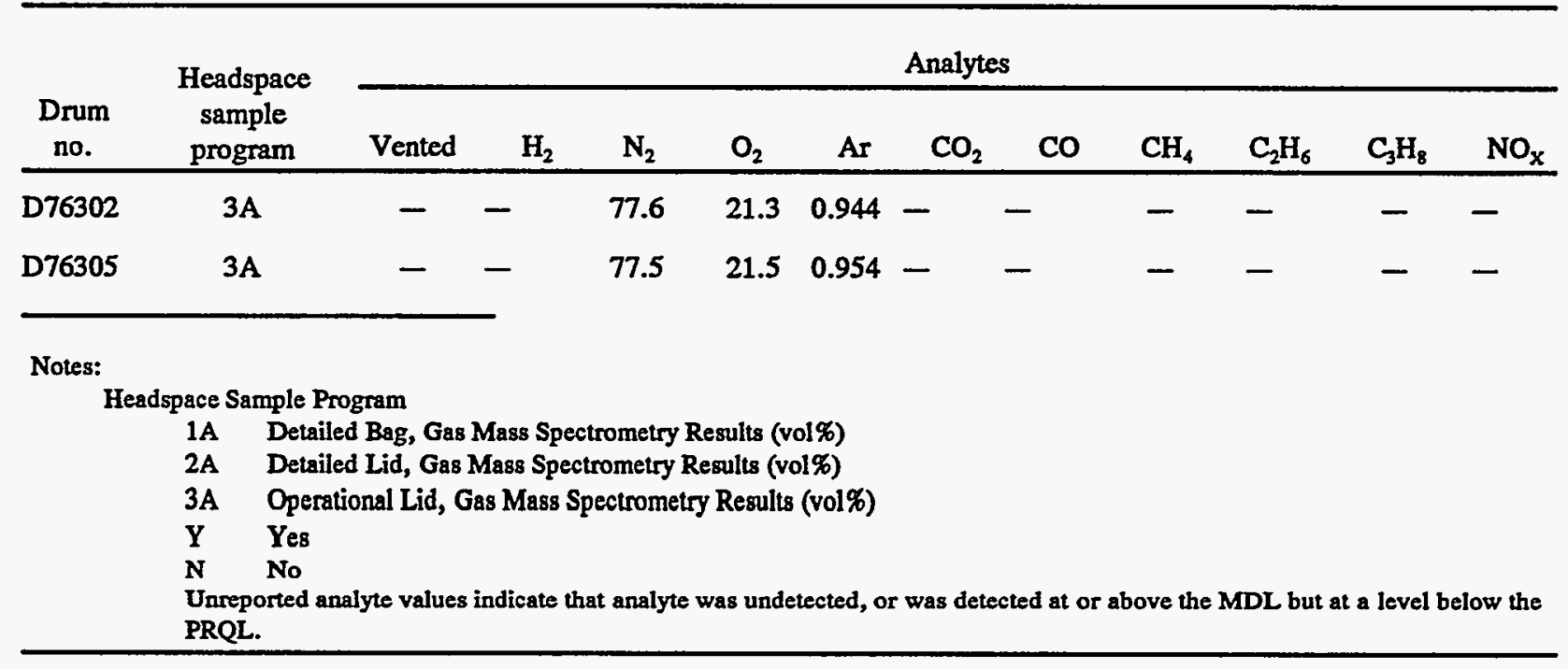


Table 3.2.2-9. Volatile Organic Compound Gas Chromatography/Mass Spectrometry Results (parts per million by volume). ${ }^{4}$

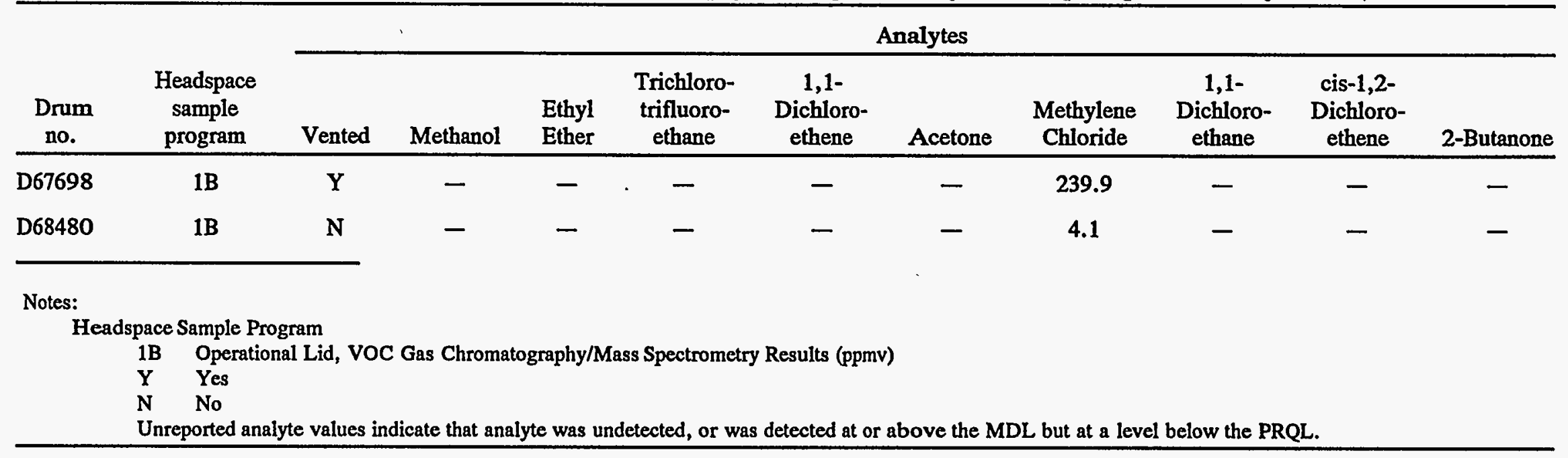


Table 3.2.2-10. Volatile Organic Compound Gas Chromatography/Mass Spectrometry Results (parts per million by volume).

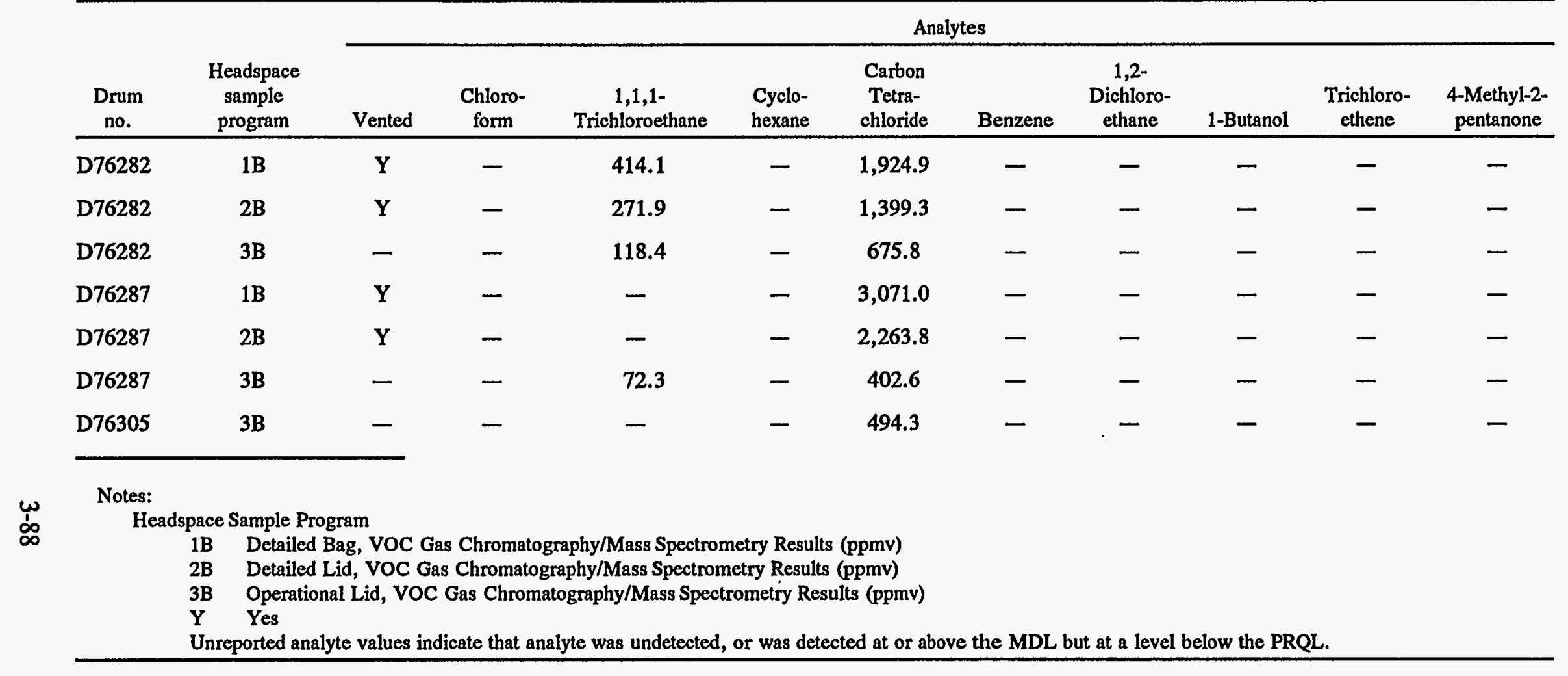


Table 3.2.2-11. Volatile Organic Compound Gas Chromatography/Mass Spectrometry Results (parts per million by volume).

\begin{tabular}{|c|c|c|c|c|c|c|c|c|c|c|c|c|}
\hline \multirow[b]{2}{*}{$\begin{array}{c}\text { Drum } \\
\text { no. }\end{array}$} & \multirow[b]{2}{*}{$\begin{array}{l}\text { Headspace } \\
\text { sample } \\
\text { program }\end{array}$} & \multicolumn{11}{|c|}{ Analytes } \\
\hline & & Vented & Toluene & $\begin{array}{l}\text { Tetra- } \\
\text { chloro- } \\
\text { ethene }\end{array}$ & $\begin{array}{l}\text { Chloro- } \\
\text { benzene }\end{array}$ & $\begin{array}{l}\text { Ethyl- } \\
\text { benzene }\end{array}$ & $\begin{array}{c}\text { m,p- } \\
\text { Xylene }\end{array}$ & $\begin{array}{c}0- \\
\text { Xylene } \\
\end{array}$ & $\begin{array}{c}\text { Bromo- } \\
\text { form }\end{array}$ & $\begin{array}{c}1,1,2,2- \\
\begin{array}{c}\text { Tetrachloro- } \\
\text { ethane }\end{array} \\
\end{array}$ & $\begin{array}{c}\begin{array}{c}1,3,6- \\
\text { Tri- } \\
\text { methyl- } \\
\text { benzene }\end{array} \\
\end{array}$ & $\begin{array}{c}\text { 1,2,4-Tri- } \\
\text { methyl- } \\
\text { benzene }\end{array}$ \\
\hline D66525 & $1 \mathrm{~B}$ & $\mathbf{Y}$ & 12.3 & - & - & - & - & - & - & - & - & - \\
\hline D66525 & $2 B$ & $\mathbf{Y}$ & 10.3 & - & - & - & - & - & - & - & - & - \\
\hline D66525 & 3B & $\mathbf{N}$ & 15.6 & - & - & - & - & - & - & - & - & - \\
\hline D67434 & 1B & $\mathbf{Y}$ & 11.8 & - & - & - & - & - & - & - & - & - \\
\hline D67434 & $2 \mathrm{~B}$ & $\mathbf{Y}$ & 9.7 & - & - & - & - & - & - & - & - & - \\
\hline D67434 & 3B & $\mathbf{N}$ & 14.9 & - & - & - & - & - & - & - & - & - \\
\hline D67436 & 1B & $\mathbf{Y}$ & 7.9 & - & - & - & - & - & - & - & - & - \\
\hline D67436 & 2B & $\mathbf{Y}$ & 6.6 & - & - & - & - & - & - & - & - & - \\
\hline D67436 & $3 B$ & $\mathbf{N}$ & 10.4 & - & - & - & - & - & - & - & - & - \\
\hline D67441 & $1 B$ & $\mathbf{Y}$ & 6.1 & - & - & - & - & - & - & - & - & - \\
\hline D67441 & $2 B$ & $\mathbf{Y}$ & 5.1 & - & - & - & - & - & - & - & - & - \\
\hline D67441 & $3 B$ & $\mathbf{N}$ & 7.7 & - & - & - & - & - & - & - & - & - \\
\hline D67654 & $1 \mathrm{~B}$ & $\mathbf{Y}$ & 10.3 & - & - & - & - & - & - & - & - & - \\
\hline D67654 & $2 B$ & $\mathbf{Y}$ & 8.8 & - & - & - & - & - & - & - & - & - \\
\hline D67654 & $3 B$ & $\mathbf{N}$ & 14.9 & - & - & - & - & - & - & - & - & - \\
\hline D67657 & 1B & $\mathbf{Y}$ & 16.1 & - & - & - & - & - & - & - & - & - \\
\hline D67657 & $2 \mathrm{~B}$ & $\mathbf{Y}$ & 10.9 & - & - & - & - & - & - & - & - & - \\
\hline D67657 & 3B & $\mathrm{N}$ & 20.0 & - & - & - & - & - & - & - & - & - \\
\hline D67698 & 3B & $\mathbf{Y}$ & 138.8 & - & - & - & - & - & - & - & - & - \\
\hline D68247 & $1 B$ & $\mathbf{Y}$ & 7.7 & - & - & - & - & - & - & - & - & - \\
\hline D68247 & $2 B$ & $\mathbf{Y}$ & 6.6 & - & - & - & - & - & - & - & - & - \\
\hline D68247 & 3B & $\mathrm{N}$ & 7.9 & - & - & - & - & - & - & - & - & - \\
\hline D68254 & 1B & $\mathbf{Y}$ & 5.9 & - & - & - & - & - & - & - & - & - \\
\hline
\end{tabular}


Table 3.2.2-11. (continued).

\begin{tabular}{|c|c|c|c|c|c|c|c|c|c|c|c|c|}
\hline \multirow[b]{2}{*}{$\begin{array}{c}\text { Drum } \\
\text { no. }\end{array}$} & \multirow[b]{2}{*}{$\begin{array}{c}\text { Headspace } \\
\text { sample } \\
\text { program } \\
\end{array}$} & \multicolumn{11}{|c|}{ Analytes } \\
\hline & & Vented & Toluene & $\begin{array}{l}\text { Tetra- } \\
\text { chloro- } \\
\text { ethene }\end{array}$ & $\begin{array}{l}\text { Chloro- } \\
\text { benzene }\end{array}$ & $\begin{array}{c}\text { Ethyl- } \\
\text { benzene }\end{array}$ & $\begin{array}{c}\text { m,p- } \\
\text { Xylene }\end{array}$ & $\begin{array}{c}0- \\
\text { Xylene }\end{array}$ & $\begin{array}{c}\text { Bromo- } \\
\text { form }\end{array}$ & $\begin{array}{c}1,1,2,2- \\
\text { Tetrachloro- } \\
\text { ethane }\end{array}$ & $\begin{array}{c}\text { 1,3,6- } \\
\text { Tri- } \\
\text { methyl- } \\
\text { benzene }\end{array}$ & $\begin{array}{c}\text { 1,2,4-Tri- } \\
\text { methyl- } \\
\text { benzene }\end{array}$ \\
\hline D68254 & $2 B$ & $Y$ & 5.6 & - & - & - & - & - & - & - & - & - \\
\hline D68254 & 3B & $\mathbf{N}$ & 8.3 & - & - & - & - & - & - & - & - & - \\
\hline D68256 & 1B & $\mathbf{Y}$ & 9.6 & - & - & - & - & - & - & - & - & - \\
\hline D68256 & $2 \mathrm{~B}$ & $\mathbf{Y}$ & 12.3 & - & - & - & - & - & - & - & - & - \\
\hline D68256 & 3B & $\mathrm{N}$ & $11.3^{\circ}$ & - & - & - & - & - & - & 一 & - & - \\
\hline D68480 & 1B & $\mathbf{Y}$ & 9.2 & - & - & - & - & - & - & - & - & - \\
\hline D68480 & $2 B$ & $\mathbf{Y}$ & 8.5 & - & - & - & - & - & - & - & - & - \\
\hline D68480 & $3 B$ & $\mathrm{~N}$ & 3.6 & - & - & - & - & - & - & - & - & - \\
\hline D69312 & 1B & $\mathbf{Y}$ & 9.1 & - & - & - & - & - & - & - & - & - \\
\hline D69312 & $2 B$ & $\mathbf{Y}$ & 9.7 & - & - & - & - & - & - & - & - & - \\
\hline D69312 & $3 B$ & $\mathbf{N}$ & 14.6 & - & - & - & - & - & - & - & - & - \\
\hline D72267 & $1 \mathrm{~B}$ & $\mathbf{Y}$ & 5.2 & - & - & - & 4.5 & - & - & - & - & - \\
\hline D72267 & $2 \mathrm{~B}$ & $\mathbf{Y}$ & 3.2 & - & - & - & 2.8 & - & - & - & - & - \\
\hline D72267 & $3 B$ & $\mathbf{Y}$ & 3.2 & - & - & - & 3.3 & - & - & - & - & - \\
\hline D72545 & $1 \mathrm{~B}$ & $\mathrm{Y}$ & 7.3 & - & - & - & - & - & - & - & - & - \\
\hline D72545 & 2B & $\mathrm{Y}$ & 5.6 & - & - & - & - & - & - & - & - & - \\
\hline D72545 & $3 B$ & $\mathbf{Y}$ & 5.3 & - & - & - & - & - & - & - & - & - \\
\hline D76138 & $1 B$ & - & 2.2 & - & - & - & - & - & - & - & - & - \\
\hline D76138 & $2 B$ & - & 1.9 & - & - & - & - & - & - & - & - & - \\
\hline D76138 & 3B & - & 1.2 & - & - & - & - & - & - & - & - & - \\
\hline D76199 & 3B & - & 1.3 & - & - & - & - & - & - & - & - & - \\
\hline D76205 & $1 \mathrm{~B}$ & $Y$ & 3.9 & - & - & - & - & - & - & - & - & - \\
\hline D76205 & 2B & $\mathbf{Y}$ & 2.9 & - & - & - & - & - & - & - & - & - \\
\hline
\end{tabular}


Table 3.2.2-11. (continued).

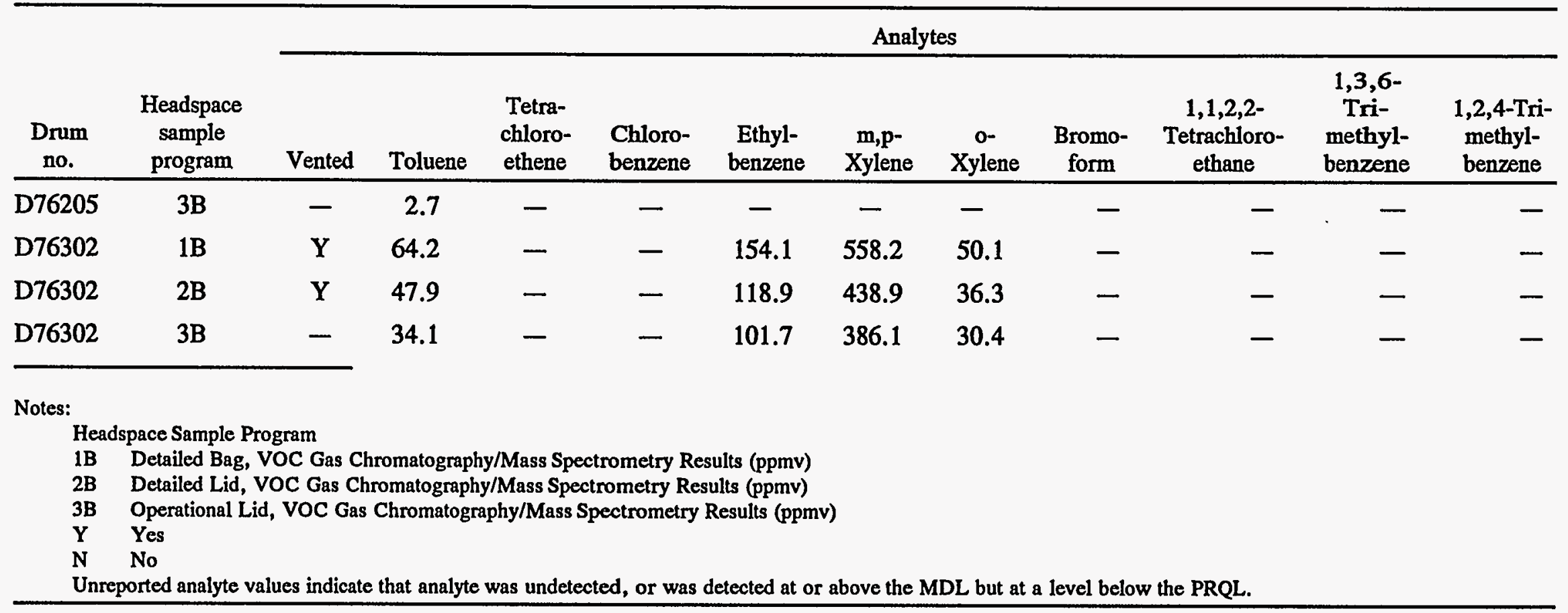




\subsection{Waste Form Number 111-Solidified Aqueous Sludge, Content Code RF 111A}

\subsubsection{Item Description Code 803-Solidified DCP Sludge}

3.2.3.1 Certification Assessment. This IDC is certifiable without further waste treatment. Assay and thermal power calculations, including error, need to be updated to meet the current WIPP WAC. Several gas generation criteria need to be addressed. Carbon filters may need to be installed, drums will require inspection to identify unvented or unpunctured rigid liners, and headspace gas analysis and visual waste characterization will need to be performed.

3.2.3.2 Waste Description. Waste consists of immobilized materials from the Decontamination-Precipitation and Neutralization Process in the Liquid Waste Treatment Facility. This waste consists of clarifier slurry from the Radioactive Decontamination Process, Acid Neutralization Process wastes, and acid descaling solution from the Evaporation Process. The slurry was drawn through a filter drum where a sludge of precipitated solids was skimmed from the surface of the filter media. The sludge from the rotary drum filter was dried in a two-flighted Porcupine dryer, then cemented in the Direct-Cementation Process (DCP) prior to packaging. The dried sludge overflowed directly into the conveying system of the DCP sludge hopper (EG\&G RFP 1994b).

3.2.3.3 Generation Source. The solidified bypass sludge was generated by the Liquid Waste Treatment Facility (Building 374). Generation dates indicate IDC 803 Solidified Bypass Sludge was produced in 1985 and continued for about nine months (EG\&G RFP 1994b).

3.2.3.4 Recovery Method. This IDC was never generated as a residue and therefore has no recovery method.

3.2.3.5 Waste Packaging and Handling. In DCP, dried sludge, Portland cement, and water were metered by a computer and mixed using a paddle mixer producing a cemented waste product. The sludge, cement, and water were then deposited in a DOT-17C, white, 55-gal drum and allowed to solidify. When the drum was full, the liners were twisted and taped closed, the lid was secured with a bolted ring, the Drum Count label was completed and taped to the drum lid by the generator, and a TID was attached to the drum (Rockwell International 1989e).

3.2.3.6 Container Preparation. Only approved containers can be used to package TRU waste for shipment offsite. Containers approved for shipment to INEL is DOT-17C, white, 55-gal drums (SX-200). These containers meet the requirements for certification as DOT-7A Type A packaging (Rockwell International 1989e).

Table 3.2.3-1 shows the current inventory of IDC 803 waste containers from the Rocky Flats Plant that have been shipped to INEL since 1985. 
Table 3.2.3-1. Item Description Code 803 Container Information.

\begin{tabular}{lccc}
\hline \multicolumn{1}{c}{ Information } & & Drums & Boxes \\
\cline { 2 - 4 } Total Containers & & 164 & 0 \\
Net Container Weight (lb) & Maximum & 672 & N/A \\
& Minimum & 157 & N/A \\
& Average & 530 & N/A \\
\hline
\end{tabular}

3.2.3.6.1 Drum Preparation-Approved liners for drums of TRU waste packaged for offsite shipment as of 1989 are the round-bottom liner (SX-203), inside a rigid polyethylene liner (SX-202), or an O-ring bag and a polyethylene bag placed inside the rigid liner if the drum is attached to a glovebox. All bags were closed using the twist-and-tape method (Rockwell International 1989e).

The IDC 803 sludge was packaged similarly to the 001 sludge. The IDC 803 sludge mixture was placed in 55-gal drums that were lined with a high-density polyethylene rigid liner, 14-mil PVC O-ring bag, and a 5-mil polyethylene bag. Figure C-3 shows the packaging appropriate for IDC 001. The polyethylene bag was not required from a waste packaging standpoint, but it aided in contamination control (DOE/WIPP 1992).

Flow-in ventable gaskets were installed in the drums beginning in December 1982. They were used until October 1988, when tubular gaskets with carbon filters were required. Drums shipped to the INEL between 1985 and 1988 may not meet the current WIPP WAC, owing to their lack of carbon filters (Bearly 1989a).

3.2.3.6.2 Box Preparation-No boxes of IDC 803 waste were shipped to INEL between 1985 and 1989.

3.2.3.7 Assay. A sample of the sludge from each drum was taken to determine the amount and identity of the radionuclides (plutonium, americium, and uranium) in the sludge. The sludge sample was analyzed using a radiochemical assay. The results of the analysis were expressed in terms of grams of each radionuclide present for each gram of sludge. Containers of waste that have not been PADC assayed and had SGS assay values of 1 gram or less should be PADC assayed to verify that they are transuranic waste. Table 3.2.3-2 summarizes the dose rates measured on containers of this IDC. Table 3.2.3-3 provides a summary of the assay information. Americium content was evaluated in 155 drums. Uranium content was not evaluated.

Table 3.2.3-2. Item Description Code 803 Dose Information.

\begin{tabular}{crrc}
\hline Information & & Drums & Boxes \\
\hline One Meter Dose Rate (mrem/h) & $0-0.5$ & 164 & N/A \\
& $0.5-10$ & 0 & N/A \\
Surface Dose Rate (mrem/h) & $<10$ & 164 & N/A \\
& $10-200$ & 0 & N/A \\
\hline
\end{tabular}


Table 3.2.3-3. Item Description Code 803 Assay Information.

\begin{tabular}{|c|c|c|c|}
\hline \multicolumn{2}{|c|}{ Radionuclide inventory } & \multirow{2}{*}{$\frac{\text { Drums }}{4.3}$} & \multirow{2}{*}{$\frac{\text { Boxes }}{\text { N/A }}$} \\
\hline Plutonium (g) & Maximum & & \\
\hline & Minimum & 0 & N/A \\
\hline & Average & 0.3 & N/A \\
\hline \multirow{3}{*}{ Americium (g) } & Maximum & 0.3 & N/A \\
\hline & Minimum & 0 & N/A \\
\hline & Average & 0.1 & N/A \\
\hline \multirow{3}{*}{ Uranium-235 (g) } & Maximum & - & N/A \\
\hline & Minimum & - & N/A \\
\hline & Average & - & N/A \\
\hline
\end{tabular}

3.2.3.8 Inspection. Waste Certification periodically reviews the process documentation to ensure that the solidification process is being operated according to procedure. This inspection is performed to ensure that free liquids and particulates will not be found in this waste form. In addition to review of process documentation, Waste Certification personnel performed periodic inspections of the generating and packaging process to verify compliance with waste acceptance criteria. Each drum is viewed using RTR to

- Ensure the drum does not contain nonconforming items

- Ensure the drum is properly packaged

- Verify the waste form description

- Evaluate the presence of free liquids.

3.2.3.9 Waste Form Evaluation. Table 3.2.3-4 evaluates the waste form against the WIPP WAC for such items as free liquids, pyrophoric materials, and compressed gases. Table 3.2.3-5 evaluates the waste against TRUPACT criteria. 
Table 3.2.3-4. Waste Form Evaluation.

Criterion or

requirement

Limiting parameters ${ }^{2}$

Immobilization

Particulates were prohibited by procedural control. Based on the description of the waste, fine particulates are not expected in this IDC.

Liquids

The solidified sludge meets the free liquid criteria by procedural control and RTR inspection prior to shipment from Rocky Flats.

Pyrophoric

Materials

Pyrophoric materials were prohibited by procedural control. The absence of the pyrophoric materials was verified by the generating supervisor and periodic inspection by the Waste Certification Organization.

Explosives and Compressed Gases

Explosives and compressed gases were prohibited by procedural control. The absence of the explosives and compressed gases was verified by the generating supervisor and periodic inspection by the Waste Certification Organization. In addition, unvented, closed containers and pressurized containers were excluded by procedural controls and RTR examination.

TRU-Mixed Wastes The RCRA constituents exist as co-contaminants with the transuranic radionuclides. Compliance with the WIPP RCRA permits and NMD will be required before shipment of the stored waste to WIPP.

Specific Activity of Waste

A portion of the waste stored at INEL may contain $<100$ nanocuries per gram transuranic radionuclides.

$\mathrm{Pu}^{239}$ Equivalent

Activity

None of the IDC 803 waste containers recorded as shipped to INEL in the SWIMS exceed $1,000 \mathrm{Ci}$ of plutonium-equivalent activity.

a. Many of the limiting parameters were taken from TRU Waste Compliance Program (Rockwell International 1983a, 1987e, and 1989b). 
Table 3.2.3-5. TRUPACT Evaluation.

Criterion or

requirement

Limiting parameters ${ }^{2}$

Waste Package

Weight

Rocky Flats limited the gross weight of drums to $800 \mathrm{lb}$. The TRUPACT and

Waste Containers

vehicle weight limits must be verified at the time of payload assembly at INEL.

Nuclear

Criticality

The solidified sludge was packaged in 55-gal DOT-7A, Type A containers.

Rocky Flats limited the fissile content of the drums to 200 grams. However, the error-times-two requirement was not in place at the time the drums were shipped to INEL; therefore, it is not reported as part of the assay of the drum. The TRUPACT limit must be verified at the time of payload assembly at INEL. Based on the typical assays of the IDC 803 drums, the criticality criteria will be met but must be recalculated or assayed to meet the error-times-two requirement.

Surface Dose The surface dose rate criteria used by Rocky Flats was $200 \mathrm{mrem} / \mathrm{hr}$ at the drum Rate surface and $10 \mathrm{mrem} / \mathrm{hr}$ at 1 meter. Shielding was not necessary for IDC 803 drums. The TRUPACT limit must be verified at the time of payload assembly at INEL. Based on the typical dose rates from the IDC 803 drums, the dose rate criteria will be met.

Removable The Rocky Flats limit for removable contamination (for TRU assumed to be all Surface alpha) was 20 disintegrations per minute $/ 100 \mathrm{~cm}^{2}$. The Rocky Flats limit is Contamination equivalent to 9 picocuries per $100 \mathrm{~cm}^{2}$, which is well within the WIPP criteria.

Thermal Power

The thermal power calculation reported in the SWIMS data package is based on the reported assay value without an error/uncertainty correction. The thermal power must be recalculated based on the assay error determination.

Gas Generation Based on the procedural requirements for packaging IDC 803 waste and the waste description, the only areas of noncompliance are carbon filters, unpunctured rigid liners, headspace gas analysis, and visual characterization.

$1,1,2,2$-Tetrachloroethane was detected by headspace analysis in IDC 803 but is not listed in the TRUPACT Chemical List for RF 111A. 1,1,1-Trichloroethane, methylene chloride, 1,1,2-trichloro-1,2,2-trifluoroethane, toluene, and carbon tetrachloride were detected by headspace analysis and are on the TRUPACT Chemical List. These chemicals appear to be in total concentrations $<1 \%$. Ethyl benzene and xylene are on the TRUPACT Chemical List for aromatic hydrocarbons and halogenated organics but were not detected. Alcohols on the TRUPACT Chemical List were not detected.

Personnel performing RTR examination at Rocky Flats would accept up to $10 \%$ of another IDC. The other IDCs could be combustibles, concrete, metal, and plastics.

a. Many of the limiting parameters were taken from TRU Waste Compliance Program (Rockwell International 1983a, 1987e, and 1989b).

3.2.3.10 Combustible and Organic Content. SWIMS data indicate that this waste form does not contain $>20 \%$ combustibles or $>20 \%$ organics. 
3.2.3.10.1 Combustible Content-SWIMS data show that IDC 803 waste is noncombustible (Rockwell International 1985a).

3.2.3.10.2 Organic Content-SWIMS data show that IDC 803 waste contains 5\% organics (Rockwell International 1985a).

3.2.3.11 Analytical Information. Analytical data obtained through the Waste Stream and Residue Identification and Characterization Sampling and Analysis Database for IDC 803, Solidified DCP Sludge, found the waste exceeded toxicity characteristic criteria for chromium (EPA Code D007) and selenium (EPA Code D010) (EG\&G RFP 1994s). The sampled drums were actually IDC 807; however, the results are applied to all of the Building 374 solidified bypass sludge. These data should be reviewed for their validity under EPA SW-846 (EPA 1990). Additional EPA Codes assigned to IDC 803 are F001, F002, F003, F005, F006, F007, F009, and F039, and EPA Code D002 is assigned to IDC 803 should any containers be rejected by RTR for free liquids (EG\&G RFP 1994b, 1990b). TCLP limits and analytical results from sampling between 1989 and 1990 are presented in Table 3.2.3-6 (EG\&G RFP 1993b, EG\&G RFP 1994b).

Analysis of analytical results for TCLP limits were performed (EG\&G 1990c). These results are compared to the TCLP limits for the constituents. If the upper 90-percent confidence limit is greater than the TCLP limit, the entire waste population is regulated by RCRA as a hazardous waste. Owing to this determination, the waste is RCRA-hazardous for chromium (D007) and selenium (D010).

Analytical data from the WIPP Experimental Waste Characterization Program (EG\&G RFP 1994t) for IDC 803, Solidified DCP Sludge,. indicate that 10 drums were subject to headspace gas analysis.

IDC 803 Gas Mass Spectrometry analytical results are presented in Table 3.2.3-7. Drums were subject to three possible headspace sampling programs: detailed bag, detailed lid, and operational lid. An individual drum could be sampled by more than one program. Unreported analyte values indicate that analytes were undetected, or detected at or above the MDL, but at a level below the PRQL in these drums. Nitrogen, oxygen, argon, and carbon monoxide analytes were detected in the drums tested. 
Table 3.2.3-6. Analytical Data Summary.

\begin{tabular}{|c|c|c|c|c|}
\hline Constituent & $\begin{array}{c}\text { TCLP } \\
\text { limit }^{2} \\
(\mathrm{mg} / \mathrm{L})\end{array}$ & $\begin{array}{l}\text { Sample } \\
\text { size }\end{array}$ & $\begin{array}{c}\text { Mean } \\
(\mathrm{mg} / \mathrm{L})\end{array}$ & $\begin{array}{l}\text { Upper } 90 \text {-percent } \\
\text { confidence limit }\end{array}$ \\
\hline Arsenic & 5.0 & 7 & 0.6876 & 0.9085 \\
\hline Barium & 100.0 & 7 & 0.924 & 0.1118 \\
\hline Cadmium & 1.0 & 14 & 0.0448 & 0.0608 \\
\hline \multirow[t]{2}{*}{ Chromium $^{b}$} & 5.0 & 7 & 2.3743 & $4.1724^{c}$ \\
\hline & & 7 & 12.260 & $15.2886^{\mathrm{d}}$ \\
\hline Lead & 5.0 & 14 & 0.7304 & 1.1503 \\
\hline Mercury & 0.2 & 6 & 0.0022 & 0.0042 \\
\hline Nickel & N/A & 7 & 0.7414 & $一^{\circ}$ \\
\hline Selenium & 1.0 & 7 & 0.9391 & 1.3900 \\
\hline Silver & 5.0 & 14 & 0.7282 & 0.7414 \\
\hline \multicolumn{5}{|c|}{$\begin{array}{l}\text { a. Concentration of constituent at which a solid waste exhibits the characteristic of toxicity. A concentration } \\
\text { greater than or equal to this level characterizes a solid waste as a RCRA-hazardous waste. }\end{array}$} \\
\hline \multicolumn{5}{|c|}{ b. Chromium analyses in 1989 and 1990 used different analytical methods. } \\
\hline \multicolumn{5}{|c|}{ c. May 1990 data. } \\
\hline \multicolumn{5}{|c|}{ d. November 1989 data. } \\
\hline Not calcu & (91 & $985)$. & & \\
\hline
\end{tabular}

IDC 803 VOC Gas Chromatography/Mass Spectrometry analytical results are presented in Tables 3.2.3-8 through 3.2.3-10. Drums were subject to the three possible headspace sampling programs as described above.

Analytical results for nine analytes are presented in Table 3.2.3-8. Analytes were detected in 5 of the 10 drums tested. Two analytes (trichloro-trifluoroethane and methylene chloride) were detected in the drums.

Analytical results for nine analytes are presented in Table 3.2.3-9. Analytes were detected in 8 of 10 drums tested. Two analytes (1,1,1-trichloroethane and carbon tetrachloride) were detected in the drums.

Analytical results for 10 analytes are presented in Table 3.2.3-10. Analytes were detected in 4 of the 10 drums tested. Two analytes (toluene and 1,1,2,2-tetrachloroethane) were detected in the drums. 
Table 3.2.3-7. Gas Mass Spectrometry Results (vol\%).

\begin{tabular}{|c|c|c|c|c|c|c|c|c|c|c|c|c|}
\hline \multirow[b]{2}{*}{$\begin{array}{c}\text { Drum } \\
\text { no. }\end{array}$} & \multirow{2}{*}{$\begin{array}{c}\text { Headspace } \\
\text { sample } \\
\text { program }\end{array}$} & \multirow[b]{2}{*}{ Vented } & \multicolumn{10}{|c|}{ Analytes } \\
\hline & & & $\mathbf{H}_{2}$ & $\mathrm{~N}_{2}$ & $\mathrm{O}_{2}$ & $\mathrm{Ar}$ & $\mathrm{CO}_{2}$ & $\mathrm{CO}$ & $\mathrm{CH}_{4}$ & $\mathrm{C}_{2} \mathrm{H}_{6}$ & $\mathrm{C}_{3} \mathrm{H}_{8}$ & $\mathrm{NO}_{\mathrm{x}}$ \\
\hline D38859 & $3 A$ & - & - & 77.5 & 21.5 & 0.921 & - & - & - & - & - & - \\
\hline D76136 & $1 \mathrm{~A}$ & $\mathbf{Y}$ & - & 77.9 & 21.2 & 0.861 & - & - & - & - & - & - \\
\hline D76136 & $2 \mathrm{~A}$ & $\mathbf{Y}$ & - & 78.0 & 21.2 & 0.859 & - & - & - & - & - & - \\
\hline D76136 & $3 \mathrm{~A}$ & - & - & 77.9 & 21.1 & 0.938 & - & - & - & - & - & - \\
\hline D76143 & $1 \mathrm{~A}$ & $\mathbf{Y}$ & - & 78.1 & 20.9 & 0.927 & - & - & - & - & - & - \\
\hline D76143 & $2 A$ & $\mathbf{Y}$ & - & 78.4 & 20.7 & 0.938 & - & - & - & - & - & - \\
\hline D76143 & $3 A$ & - & - & 77.5 & 21.5 & 0.948 & - & - & - & - & - & - \\
\hline D76147 & $3 A$ & - & - & 77.9 & 21.1 & 0.919 & - & - & - & - & - & - \\
\hline D76187 & $1 \mathrm{~A}$ & $\mathbf{Y}$ & - & 78.2 & 20.8 & 0.930 & - & - & - & - & - & - \\
\hline D76187 & $2 \mathrm{~A}$ & $\mathbf{Y}$ & - & 78.0 & 21.0 & 0.926 & - & - & - & - & - & - \\
\hline D76187 & $3 A$ & - & - & 77.8 & 21.2 & 0.942 & - & - & - & - & - & - \\
\hline D76189 & $1 \mathrm{~A}$ & $\mathbf{Y}$ & - & 77.6 & 21.4 & 0.936 & - & - & - & - & - & - \\
\hline D76189 & $2 \mathrm{~A}$ & $\mathbf{Y}$ & - & 77.9 & 21.1 & 0.924 & - & - & - & - & - & - \\
\hline D76189 & $3 A$ & $\mathbf{Y}$ & - & 78.4 & 20.6 & 0.922 & - & 0.011 & - & - & - & - \\
\hline D76192 & $2 A$ & $\mathbf{Y}$ & - & 77.3 & 21.7 & 0.926 & - & - & - & - & - & - \\
\hline D76192 & $3 A$ & - & - & 77.7 & 21.3 & 0.936 & - & - & - & - & - & - \\
\hline D76206 & $1 \mathrm{~A}$ & $\mathbf{Y}$ & - & 77.9 & 21.2 & 0.865 & - & - & - & - & - & - \\
\hline D76206 & $3 A$ & - & - & 77.4 & 21.6 & 0.924 & - & - & - & - & - & - \\
\hline D76303 & $1 \mathrm{~A}$ & $\mathbf{Y}$ & - & 79.2 & 19.8 & 0.959 & - & - & - & - & - & - \\
\hline D76303 & $2 \mathrm{~A}$ & $\mathbf{Y}$ & - & 78.0 & 21.0 & 0.944 & - & - & - & - & - & - \\
\hline D76303 & $3 A$ & - & - & 78.0 & 21.0 & 0.935 & - & - & - & - & - & - \\
\hline D76470 & $3 A$ & - & - & 77.6 & 21.4 & 0.927 & - & - & - & - & - & - \\
\hline
\end{tabular}

Notes:

Headspace Sample Program

1 Detailed Bag, Gas Mass Spectrometry Results (vol\%)

2A Detailed Lid, Gas Mass Spectrometry Results (vol\%)

3A Operational Lid, Gas Mass Spectrometry Results (vol\%)

Y Yes

Unreported analyte values indicate that analyte was undetected, or was detected at or above the MDL but at a level below the PRQL. 
Table 3.2.3-8. Volatile Organic Compound Gas Chromatography/Mass Spectrometry Results (parts per million by volume).

\begin{tabular}{|c|c|c|c|c|c|c|c|c|c|c|c|c|}
\hline \multirow[b]{2}{*}{$\begin{array}{c}\text { Drum } \\
\text { no. }\end{array}$} & \multirow{2}{*}{\multicolumn{2}{|c|}{$\begin{array}{c}\text { Headspace } \\
\text { sample } \\
\text { program }\end{array}$}} & \multicolumn{10}{|c|}{ Analytes } \\
\hline & & & Vented & Methanol & $\begin{array}{l}\text { Ethyl } \\
\text { Ether }\end{array}$ & $\begin{array}{l}\text { Trichloro- } \\
\text { trifluoro- } \\
\text { ethane }\end{array}$ & $\begin{array}{c}1,1- \\
\text { Dichloro- } \\
\text { ethene }\end{array}$ & Acetone & $\begin{array}{c}\text { Methylene } \\
\text { Chloride }\end{array}$ & $\begin{array}{c}1,1- \\
\text { Dichloro- } \\
\text { ethane }\end{array}$ & $\begin{array}{l}\text { cis-1,2- } \\
\text { Dichloro- } \\
\text { ethene }\end{array}$ & $\begin{array}{c}2- \\
\text { Butanone }\end{array}$ \\
\hline D76136 & & B & - & - & - & - & - & - & 5.0 & - & - & - \\
\hline D76143 & & B & - & - & - & - & - & - & 3.3 & - & - & - \\
\hline D76147 & & B & - & - & - & 1.7 & - & - & - & - & - & - \\
\hline D76187 & & B & - & - & - & - & - & - & 6.4 & - & - & - \\
\hline D76206 & & B & $\mathbf{Y}$ & - & - & - & - & - & 9.6 & - & - & - \\
\hline D76206 & & B & $\mathbf{Y}$ & - & - & - & - & - & 7.0 & - & - & - \\
\hline D76206 & & B & - & - & - & - & - & - & 4.2 & - & - & - \\
\hline \multicolumn{13}{|l|}{ Notes: } \\
\hline & $\begin{array}{l}1 B \\
2 B \\
3 B \\
Y \\
\text { Unr }\end{array}$ & $\begin{array}{l}\text { Detai } \\
\text { Detai } \\
\text { Oper } \\
\text { Yes } \\
\text { ported }\end{array}$ & $\begin{array}{l}\text { d Bag, VC } \\
\text { d Lid, vo } \\
\text { onal Lid, } \\
\text { alyte valu }\end{array}$ & $\begin{array}{l}\text { Gas Chroma } \\
\text { Gas Chroma } \\
\text { OC Gas Chro } \\
\text { indicate that }\end{array}$ & $\begin{array}{l}\text { graphy/A } \\
\text { graphy/N } \\
\text { latograph } \\
\text { nalyte wa }\end{array}$ & $\begin{array}{l}\text { S Spectrometr } \\
\text { S Spectrometr } \\
\text { Aass Spectrom } \\
\text { ndetected, or }\end{array}$ & $\begin{array}{l}\text { Results (ppm } \\
\text { Results (ppm } \\
\text { ry Results ( } \\
\text { as detected a }\end{array}$ & above the & out at a le & low the $P$ & & \\
\hline
\end{tabular}


Table 3.2.3-9. Volatile Organic Compound Gas Chromatography/Mass Spectrometry Results (parts per million by volume).

\begin{tabular}{|c|c|c|c|c|c|c|c|c|c|c|c|}
\hline \multirow[b]{2}{*}{$\begin{array}{c}\text { Drum } \\
\text { no. }\end{array}$} & \multirow[b]{2}{*}{$\begin{array}{c}\text { Headspace } \\
\text { sample } \\
\text { program } \\
\end{array}$} & \multicolumn{10}{|c|}{ Analytes } \\
\hline & & Vented & $\begin{array}{c}\text { Chloro- } \\
\text { form }\end{array}$ & $\begin{array}{c}1,1,1- \\
\begin{array}{c}\text { Trichloro- } \\
\text { ethane }\end{array} \\
\end{array}$ & $\begin{array}{l}\text { Cyclo- } \\
\text { hexane }\end{array}$ & $\begin{array}{c}\text { Carbon } \\
\text { Tetra- } \\
\text { chloride }\end{array}$ & Benzene & $\begin{array}{c}1,2- \\
\text { Dichloro- } \\
\text { ethane }\end{array}$ & 1-Butanol & $\begin{array}{c}\text { Trichloro- } \\
\text { ethene }\end{array}$ & $\begin{array}{l}\text { 4-Methyl-2- } \\
\text { pentanone }\end{array}$ \\
\hline D76136 & $1 \mathrm{~B}$ & $\mathbf{Y}$ & - & 56.6 & - & - & - & - & - & - & - \\
\hline D76136 & $2 B$ & $\mathrm{Y}$ & - & 57.1 & - & - & - & - & - & - & - \\
\hline D76136 & 3B & - & - & 41.0 & - & 10.0 & - & - & - & - & - \\
\hline D76143 & 1B & $\mathbf{Y}$ & - & 87.9 & - & - & - & - & - & - & - \\
\hline D76143 & $2 B$ & $\mathbf{Y}$ & - & 67.0 & - & - & - & - & - & - & - \\
\hline D76143 & 3B & - & - & 31.4 & - & 4.3 & - & - & - & - & - \\
\hline D76147 & $3 B$ & - & - & 2.4 & - & - & - & - & - & - & - \\
\hline D76187 & 1B & $\mathbf{Y}$ & - & 143.5 & - & - & - & - & - & - & - \\
\hline D76187 & $2 B$ & $\mathbf{Y}$ & - & 104.7 & - & - & - & - & - & - & - \\
\hline D76187 & $3 B$ & - & - & 49.0 & - & 11.7 & - & - & - & - & - \\
\hline D76189 & 1B & $\mathbf{Y}$ & - & 164.7 & - & - & - & - & - & - & - \\
\hline D76189 & $2 B$ & $\mathbf{Y}$ & - & 130.2 & - & - & - & - & - & - & - \\
\hline D76189 & 3B & $\mathbf{Y}$ & - & 165.7 & - & - & - & - & - & - & - \\
\hline D76192 & 1B & $\mathbf{Y}$ & - & 2.6 & - & - & - & - & - & - & - \\
\hline D76192 & $2 B$ & $\mathbf{Y}$ & - & 2.0 & - & - & - & - & - & - & - \\
\hline D76206 & 1B & $\mathbf{Y}$ & - & 86.7 & - & - & - & - & - & - & - \\
\hline D76206 & 2B & $\mathbf{Y}$ & - & 57.6 & - & - & - & - & - & - & - \\
\hline D76206 & $3 B$ & - & - & 28.7 & - & - & - & - & - & - & - \\
\hline D76303 & 1B & $\mathbf{Y}$ & - & 84.3 & - & - & - & - & - & - & - \\
\hline D76303 & 2B & $\mathbf{Y}$ & - & 65.2 & - & - & - & - & - & - & - \\
\hline D76303 & 3B & - & - & 21.6 & - & - & - & - & - & - & - \\
\hline $\begin{aligned} \text { Notes: } \\
\\
\text { He } \\
1 \mathrm{~B} \\
2 \mathrm{~B} \\
3 \mathrm{~B} \\
\mathrm{Y} \\
\mathrm{U}\end{aligned}$ & $\begin{array}{l}\text { pace Sample } \\
\text { Detailed Bag } \\
\text { Detailed Lid, } \\
\text { Operational I } \\
\text { Yes } \\
\text { ported analyte }\end{array}$ & $\begin{array}{l}\mathrm{ram} \\
\mathrm{C} \text { Gas } \\
\mathrm{C} \text { Gas } \\
\text { VoC G } \\
\text { es indic }\end{array}$ & $\begin{array}{l}\text { romatogra } \\
\text { romatogra } \\
\text { Chromato } \\
\text { that analy }\end{array}$ & $\begin{array}{l}\text { yy/Mass Spec } \\
\text { y/Mass Spect } \\
\text { aphy/Mass S } \\
\text { was undetec }\end{array}$ & $\begin{array}{l}\text { metry Res } \\
\text { netry Res } \\
\text { trometry } \\
\text {, or was }\end{array}$ & $\begin{array}{l}\text { (ppmv) } \\
\text { (ppmv) } \\
\text { ults (ppmv) } \\
\text { cted at or a }\end{array}$ & 0 & 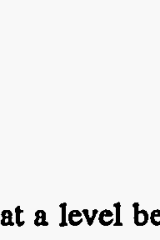 & 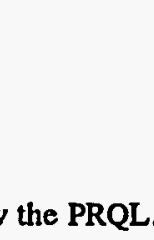 & & \\
\hline
\end{tabular}




\subsection{Waste Form Number 111-Solidified Aqueous Sludge, Content Code RF 111A}

\subsubsection{Item Description Code 807-Solidified Bypass Solids}

3.2.4.1 Certification Assessment. This IDC is certifiable without further waste treatment. Assay and thermal power calculations, including error, need to be updated to meet the current WIPP WAC. Several gas generation criteria need to be addressed. Carbon filters may need to be installed, drums will require inspection to identify unvented or unpunctured rigid liners, and headspace gas analysis and visual waste characterization will need to be performed.

3.2.4.2 Waste Description. This waste consists of immobilized materials from the Decontamination-Precipitation and Neutralization Process in the Liquid Waste Treatment Facility, clarifier slurry from the Radioactive Decontamination Process, Acid Neutralization Process wastes, and acid descaling solution from the Evaporation Process. The slurry was drawn through a filter drum where a sludge of precipitated solids was skimmed from the surface of the filter media. It was then transferred directly into a 55-gal drum where it was mixed with Portland cement and diatomite. The IDC for Solidified Bypass Sludge (IDC 807) was created in 1987 to replace Cemented Sludge (IDC 007) (EG\&G 1994b).

3.2.4.3 Generation Source. The solidified bypass sludge was generated by the Liquid Waste Treatment Facility (Building 374)(EG\&G RFP 1994b).

3.2.4.4 Recovery Method. This IDC was never generated as a residue and therefore had no recovery method.

3.2.4.5 Waste Packaging and Handling. All IDC 807 waste was line-generated. The drums used were DOT-17C, white, 55-gal drums. For IDC 807, a 90-mil rigid polyethylene liner was required (Rockwell International 1989b). Before 1986, sludge was transferred from the filter drum directly into 55-gal drums and mixed with cement. The resulting mixture of sludge and cement was tamped down during the metering process (EG\&G RFP 1994b). Since April 1986, diatomite and cement, in a 1-to-1 ratio, have been mixed into the sludge. This mixture had been determined to be a better absorbent, and no free liquids or condensation had been found in the drums generated after that time (Watson 1989; Roggenthen and others 1989). When the drum was full, the polyethylene liners were twisted and taped closed, the lid was secured with a bolted ring, the Drum Count label was completed and taped to the drum lid by the generator, and a TID was attached to the drum (Rockwell International 1989b).

Four IDC 007 drums (RF 74702579, RF 74703541, RF 74704299, and RF 74705458) were opened in 1987 in support of the SWEPP Sampling Program. The drum contents and packaging were inspected. Following their inspection, the drums were assigned IDC 807 . The four drums were each found to contain a rigid liner, a round-bottom outer drum bag, and an inner PVC O-ring bag-out bag which contained the sludge. One of the drums (RF 74704299) was determined to contain $11,875 \mathrm{~mL}$ of free liquid at the bottom of the inner PVC O-ring bag, and consequently did not meet the WIPP criteria for uncemented wastes. The waste contained in this drum was generated in 1985 , before the use of the 1-to-1 diatomite and cement absorbent mixture. Three of the drums were found to be in good condition inside; however, a small amount of rust was found inside of drum RF 74705453. The drums were all 80-95\% full (Watson 1987). 
3.2.4.6 Container Preparation. Only approved containers could be used to package TRU waste for shipment offsite. Containers approved for shipment to INEL during this time were DOT17C, white, 55-gal drums (Rockwell specification SX-200). These containers met the requirements for certification as DOT-7A Type A packaging (Rockwell International 1898e).

Table 3.2.4-1 shows the current inventory of IDC 807 waste containers from the Rocky Flats Plant that had been shipped to INEL since 1985 .

Table 3.2.4-1. Item Description Code 807 Container Information.

\begin{tabular}{lccc}
\hline \multicolumn{1}{c}{ Information } & & Drums & Boxes \\
\cline { 2 - 4 } Total Containers & & 1256 & 0 \\
Net Container Weight (lb) & Maximum & 509 & N/A \\
& Minimum & 10 & N/A \\
& Average & 353 & N/A \\
\hline
\end{tabular}

3.2.4.6.1 Drum Preparation-Approved liners for drums of TRU waste packaged for offsite shipment as of 1989 were the round-bottom liner (Rockwell specification SX-203), inside a rigid polyethylene liner (Rockwell specification SX-202), or an O-ring bag and a polyethylene bag placed inside the rigid liner if the drum was attached to a glovebox. All bags were closed using the twist-and-tape method (Rockwell International 1989e).

The IDC 807 sludge mixture was placed in 55-gal drums that were lined with a high-density polyethylene rigid liner, 14-mil PVC O-ring bag, and a 5-mil polyethylene bag. Figure C-2 shows the packaging appropriate for this waste form. The polyethylene bag was not required from a waste packaging standpoint, but it aided in contamination control (DOE/WIPP 1992).

3.2.4.6.2 Box Preparation-No boxes of IDC 807 waste were shipped to INEL between 1985 and 1989.

3.2.4.7 Assay. A grab sample of the sludge from each drum was taken to determine the amount and identity of the radionuclides (plutonium, americium, and uranium) in the sludge. The sludge sample was analyzed using a radiochemical assay. The results of the analysis were expressed in terms of grams of each radionuclide present for each gram of sludge.

IDC 807 drums were assayed using a PADC beginning in 1987. The PADC was used to "safeguards" check drums of sludge. This check was to ensure that special nuclear material (SNM) was not being diverted into the container. The results were not recorded for shipment. Containers of waste that have not been PADC assayed and had SGS assay values of 1 gram or less should be PADC assayed to verify that they are transuranic waste. Table 3.2.4-2 summarizes the dose rates measured on containers of this IDC. Table 3.2.4-3 provides a summary of the assay information. Americium content was evaluated for 474 drums; no drums were evaluated for uranium content. 
Table 3.2.4-2. Item Description Code 807 Dose Information.

\begin{tabular}{|c|c|c|c|}
\hline Information & & Drums & Boxes \\
\hline One Meter Dose Rate (mrem/h) & $\begin{array}{r}0-0.5 \\
0.5-10\end{array}$ & $\begin{array}{r}1,241 \\
15\end{array}$ & $\begin{array}{l}\text { N/A } \\
\text { N/A }\end{array}$ \\
\hline Surface Dose Rate (mrem/h) & $\begin{array}{r}<10 \\
10-200\end{array}$ & $\begin{array}{r}1,256 \\
0\end{array}$ & $\begin{array}{l}\text { N/A } \\
\text { N/A }\end{array}$ \\
\hline
\end{tabular}

Table 3.2.4-3. Item Description Code 807 Assay Information.

\begin{tabular}{|c|c|c|c|}
\hline \multicolumn{2}{|c|}{ Radionuclide inventory } & Drums & Boxes \\
\hline Plutonium (g) & $\begin{array}{r}\text { Maximum } \\
\text { Minimum } \\
\text { Average }\end{array}$ & $\begin{array}{r}161 \\
0 \\
2\end{array}$ & $\begin{array}{l}\text { N/A } \\
\text { N/A } \\
\text { N/A }\end{array}$ \\
\hline Americium (g) & $\begin{array}{r}\text { Maximum } \\
\text { Minimum } \\
\text { Average }\end{array}$ & $\begin{array}{l}0.155 \\
0 \\
0.01\end{array}$ & $\begin{array}{l}\text { N/A } \\
\text { N/A } \\
\text { N/A }\end{array}$ \\
\hline Uranium-235 (g) & $\begin{array}{r}\text { Maximum } \\
\text { Minimum } \\
\text { Average }\end{array}$ & $\begin{array}{l}- \\
- \\
-\end{array}$ & $\begin{array}{l}\text { N/A } \\
\text { N/A } \\
\text { N/A }\end{array}$ \\
\hline
\end{tabular}

3.2.4.8 Inspection. Waste Certification periodically reviewed the process documentation to ensure that the solidification process was being operated according to procedure. This inspection was performed to ensure that free liquids and particulates were not found in this waste form. Waste Certification personnel also performed periodic inspections to verify compliance with the waste acceptance criteria. In addition, each drum was viewed using RTR to

- Ensure the drum did not contain nonconforming items

- Ensure the drum was properly packaged

- Verify the waste form description

- Evaluate the presence of free liquids.

3.2.4.9 Waste Form Evaluation. Table 3.2.4-4 evaluates the waste form against the WIPP WAC for such items as free liquids, pyrophoric materials, and compressed gases. Table 3.2.4-5 evaluates the waste form against TRUPACT criteria. 
Table 3.2.4-4. Waste Form Evaluation.

Criterion or requirement

Limiting parameters ${ }^{2}$

Immobilization

The solidified sludge meets the immobilization criteria by procedural controls and Waste Certification audits of the cementation process.

Liquids

The solidified sludge meets the free liquid criteria by procedural control and RTR inspection prior to shipment from Rocky Flats. Personnel performing RTR Examination at Rocky Flats would accept up to 2 cups of liquid, if liquids were present.

Pyrophoric

Materials

Pyrophoric materials were prohibited by procedural control. The absence of the pyrophoric materials was verified by the generating supervisor and periodic inspection by the Waste Certification Organization.

Explosives and Compressed Gases

Explosives and compressed gases were prohibited by procedural control. The absence of the explosives and compressed gases was verified by the generating supervisor and periodic inspection by the Waste Certification Organization. In addition, unvented, closed containers and pressurized containers were excluded by procedural controls and RTR examination.

TRU-Mixed Wastes The RCRA constituents exist as co-contaminants with the transuranic radionuclides. Compliance with the WIPP RCRA permits and NMD will be required before shipment of the stored waste to WIPP.

Specific Activity of Waste Activity of $>100$ nanocuries per gram was verified by the radiochemistry results.

$\mathrm{Pu}^{239}$ Equivalent Activity

None of the IDC 807 waste containers recorded in SWIMS as shipped to INEL exceed 1,000 Curies of plutonium-equivalent activity.

a. Many of the limiting parameters were taken from TRU Waste Compliance Program (Rockwell International 1983a, 1987e, and 1989b). 
Table 3.2.4-5. TRUPACT Evaluation.

Criterion or

requirement

Limiting parameters ${ }^{2}$

Waste Package

Weight

Rocky Flats limited the gross weight of drums to $800 \mathrm{lb}$. The TRUPACT II and vehicle weight limits must be verified at the time of payload assembly at INEL.

Waste Containers The solidified sludge was packaged in 55-gal, DOT-7A, Type A containers.

Nuclear Criticality Rocky Flats limited the fissile content of the drums to 200 grams. However, the error-times-two requirement was not in place at the time the drums were shipped to INEL; therefore, it is not reported as part of the assay of the drum. The TRUPACT limit must be verified at the time of payload assembly at INEL. Based on the typical assays of the IDC 807 drums, the criticality criteria will be met but must be recalculated or assayed to meet the errortimes-two requirement.

Surface Dose Rate The surface dose rate criteria used by Rocky Flats was $200 \mathrm{mrem} / \mathrm{hr}$ at the drum surface and $10 \mathrm{mrem} / \mathrm{hr}$ at 1 meter. Shielding was not necessary for IDC 807 drums. The TRUPACT limit must be verified at the time of payload assembly at INEL. Based on the typical dose rates from the IDC 807 drums, the dose rate criteria will be met.

Removable Surface

The Rocky Flats limit for removable contamination (for TRU assumed to be Contamination all alpha) was 20 disintegrations per minute $100 \mathrm{~cm}^{2}$. The Rocky Flats limit is equivalent to 9 picocuries per $100 \mathrm{~cm}^{2}$, which is well within the WIPP criteria.

Thermal Power

The thermal power calculation reported in the SWIMS data package is based on the reported assay value without an error/uncertainty correction. The thermal power must be recalculated based on the assay error determination.

Gas Generation Based on the procedural requirements for packaging IDC 807 waste and the waste description, the only areas of noncompliance are carbon filters, unpunctured rigid liners, headspace gas analysis, and visual characterization.

Acetone, methyl ethyl ketone, 2-butanone, trichloroethene, benzene, trans-1,3dichloropropene, 1,1,2,2-tetrachloroethane, and styrene were detected in IDC 807 by TCLP but are not listed in the TRUPACT Chemical List for RF 111A. Methylene chloride, ethyl benzene, toluene and xylenes were detected by TCLP and are on the TRUPACT Chemical List. Toluene was also detected by headspace analysis. All of the chemicals appear to be in total concentrations $<1 \%$. 1,1,1 Trichloroethane, 1,1,2-Trichloro-1,2,2trifluoroethane and carbon tetrachloride are on the TRUPACT Chemical List for halogenated organics but were not detected. Alcohols on the TRUPACT Chemical List were not detected. Cyanide was detected in low ppm quantities.

a. Many of the limiting parameters were taken from TRU Waste Compliance Program (Rockwell International 1983a, 1987e, and 1989b).

3.2.4.10 Combustible and Organic Content. Table 3.2.4-6 outlines available data from the TRU Waste Sampling Program for IDC 007. IDC 007 data are presumed to be representative of 
IDC 807 waste. SWIMS data indicate that this waste form does not contain $>\mathbf{2 0 \%}$ combustibles or $>20 \%$ organics.

Table 3.2.4-6. Item Description Code 007 Data Summary for Combustible and Organic Content.

\begin{tabular}{ccccccc}
\hline Container & $\begin{array}{c}\text { Wt. } \\
\text { combustibles } \\
(\mathrm{lb})^{\mathrm{a}}\end{array}$ & $\begin{array}{c}\text { Wt. } \\
\text { organics } \\
(\mathrm{lb})^{\mathrm{b}}\end{array}$ & $\begin{array}{c}\text { Net wt. of } \\
\text { container }_{(\mathrm{lb})^{\mathrm{c}}}\end{array}$ & $\begin{array}{c}\text { Wt\% } \\
\text { combustibles }^{\mathrm{d}}\end{array}$ & $\begin{array}{c}\text { Vol\% } \\
\text { combustibles }^{\mathrm{c}}\end{array}$ & $\begin{array}{c}\text { Wt\% } \\
\text { organics }^{\mathrm{f}}\end{array}$ \\
\hline $747-00944$ & 4.5 & 4.5 & 395.2 & 1 & 5 & 1 \\
$747-01488$ & 4.5 & 4.5 & 339.6 & 1 & 5 & 1 \\
$747-01492$ & 4.5 & 4.5 & 280.7 & 2 & 5 & 2 \\
$747-01531$ & 4.5 & 4.5 & 262.9 & 2 & 5 & 2 \\
\hline
\end{tabular}

a. Sum of weights of all combustible material and leaded rubber from Table 25 (Clements and Kudera 1985).

b. Sum of weights of all combustible material, leaded rubber, and organic material from Table 25 (Clements and Kudera 1985).

c. Net weight of container from Table 25 (Clements and Kudera 1985).

d. Weight of combustible material/net weight of container $\times 100$.

e. Vol\% of combustible material from visual examination, obtained from Appendix B (Clements and Kudera 1985).

f. Weight of organic material/net weight of container $\times 100$.

3.2.4.10.1 Combustible Content-SWIMS data show that IDC 807 waste should be noncombustible (Rockwell International 1985a). In support of the TRU Waste Sampling Program, four drums of IDC 007 waste were opened. They were all found to contain $4.5 \mathrm{lb}$ of plastic. Since a drum liner weighs $1.8 \mathrm{~kg}$, it is presumed that the mass of the plastic contains two drum liners, and no other combustibles are present (Clements and Kudera 1985).

3.2.4.10.2 Organic Content-SWIMS data show that IDC 807 waste may contain about $10 \%$ organics (Rockwell International 1985a). In support of the TRU Waste Sampling Program, four drums of IDC 007 waste were opened. They were all found to contain $4.5 \mathrm{lb}$ of plastic. Since a drum liner weighs $1.8 \mathrm{~kg}$, it is presumed that the mass of the plastic contains two drum liners, and no other organics are present (Clements and Kudera 1985).

3.2.4.11 Analytical Information. Analytical data obtained through the Waste Stream and Residue Identification and Characterization Sampling and Analysis Database for IDC 807, Solidified Bypass Sludge, found the waste exceeded toxicity characteristic criteria for chromium (EPA Code D007) and selenium (EPA Code D010) (EG\&G 1994s). These results are applied to all of the Building 374 solidified bypass sludge. These data should be reviewed for their validity under EPA 
SW-846 (EPA 1990). TCLP limits and analytical results from sampling between 1989 and 1990 are presented in Table 3.2.4-7 (EG\&G RFP 1994b, 1993b).

Table 3.2.4-7. Analytical Data Summary.

\begin{tabular}{lcccc}
\hline Constituent & $\begin{array}{c}\text { TCLP } \\
\text { limit } \\
(\mathrm{mg} / \mathrm{L})\end{array}$ & $\begin{array}{c}\text { Sample } \\
\text { size }\end{array}$ & $\begin{array}{c}\text { Mean } \\
(\mathrm{mg} / \mathrm{L})\end{array}$ & $\begin{array}{c}\text { Upper 90-percent } \\
\text { confidence limit }\end{array}$ \\
\hline Arsenic & 5.0 & 7 & 0.6876 & 0.9085 \\
Barium & 100.0 & 7 & 0.924 & 0.1118 \\
Cadmium & 1.0 & 14 & 0.0448 & 0.0608 \\
Chromium $^{\mathrm{b}}$ & 5.0 & 7 & 2.3743 & $4.1724^{\mathrm{c}}$ \\
& & 7 & 12.260 & $15.2886^{\mathrm{d}}$ \\
Lead & 5.0 & 14 & 0.7304 & 1.1503 \\
Mercury & 0.2 & 6 & 0.0022 & 0.0042 \\
Nickel & N/A & 7 & 0.7414 & $-\mathrm{c}$ \\
Selenium & 1.0 & 7 & 0.9391 & 1.3900 \\
Silver & 5.0 & 14 & 0.7282 & 0.7414
\end{tabular}

a. Concentration of constituent at which a solid waste exhibits the characteristic of toxicity. A concentration greater than or equal to this level characterizes a solid waste as a RCRA-hazardous waste.

b. Chromium analyses in 1989 and 1990 used different analytical methods.

c. May 1990 data.

d. November 1989 data.

e. Not calculated in letter (EG\&G RFP 1993a).

Analysis of analytical results for TCLP limits were performed (EG\&G RFP 1990c). These results are compared to the TCLP limits for the constituents. If the upper $90 \%$ confidence limit is greater than the TCLP limit, the entire waste population is regulated by RCRA as a hazardous waste. Owing to this determination, the waste is RCRA-hazardous for chromium (D007) and selenium (D010). The EPA Codes assigned to IDC 807 are D007, D010, F001, F002, F003, F005, F006, F007, F009, and F039. In addition, EPA Code D002 is assigned to the IDC 807 containers rejected by RTR for free liquids (EG\&G RFP 1994b, 1990b).

TCLP analytical results for IDC 807 sampling between 1989 and 1990 (EG\&G 1990c) is provided in Table 3.2.4-8. The VOCs found in all of the 1990 sampling were not found in the 1989 sampling, except for acetone. Low levels of cyanide concentrations were found in both samplings. 
Analytical results of VOC analysis performed on one sample of IDC 807 material are presented in Table 3.2.4-9 (Rockwell International 1988a). The sample was analyzed for all EPA volatile organic target compounds. Analysis detected methylene chloride, trichloroethene, trans-1,3dichloropropene, 1,1,2,2-tetrachloroethane, toluene, ethylbenzene, styrene, and xylene analytes.

Analytical data from the WIPP Experimental Waste Characterization Program for IDC 807Solidified Bypass Sludge, indicate that one drum (D73136) was subject to headspace gas analysis (EG\&G 1994t).

IDC 807 Gas Mass Spectrometry analytical results are presented in Table 3.2.4-10. Three headspace sampling programs were used for Gas Mass analysis: detailed bag, detailed lid, and operational lid. All three sampling programs detected nitrogen, oxygen, and argon in the drum. Carbon monoxide was also detected in the drum when the operational lid sampling program was used.

IDC 807 VOC Gas Chromatography/Mass Spectrometry analytical results indicate 4.2, 3.5, and $3.4 \mathrm{ppmv}$ toluene for headspace sampling programs $3 \mathrm{~A}, 2 \mathrm{~A}$, and $1 \mathrm{~A}$, respectively. All other analytes were undetected, or detected at or above the MDL, but at a level below the PRQL. 
Table 3.2.4-8. Analytical Data Summary.

\begin{tabular}{|c|c|c|c|c|c|c|c|c|c|c|}
\hline \multirow{2}{*}{\multicolumn{2}{|c|}{ Sampling }} & \multicolumn{6}{|c|}{ Organics (mg/kg) } & \multicolumn{3}{|c|}{ Other $(\mathrm{mg} / \mathrm{kg})$} \\
\hline & & \multirow{2}{*}{$\begin{array}{r}\text { Acetone } \\
0.007\end{array}$} & \multirow{2}{*}{$\begin{array}{c}\text { Methylene } \\
\text { chloride }\end{array}$} & \multirow{2}{*}{$\frac{\begin{array}{c}2- \\
\text { butanone }\end{array}}{-}$} & \multirow{2}{*}{$\frac{\text { Benzene }}{-}$} & \multirow{2}{*}{$\frac{\text { Toluene }}{-}$} & \multirow{2}{*}{$\begin{array}{c}\text { Methyl } \\
\text { ethyl } \\
\text { ketone }\end{array}$} & \multirow{2}{*}{$\begin{array}{c}\begin{array}{c}\text { Total } \\
\text { cyanide }\end{array} \\
8.2\end{array}$} & \multirow{2}{*}{$\begin{array}{c}\begin{array}{c}\text { Cyanide } \\
\text { (amenable) }\end{array} \\
<3.9\end{array}$} & \multirow{2}{*}{$\frac{\text { Reactive }}{-}$} \\
\hline 1989 & High & & & & & & & & & \\
\hline & Low & 0.004 & - & - & - & 一 & - & $<3.1$ & $<2.7$ & - \\
\hline \multirow[t]{2}{*}{1990} & High & 1.6 & 4.0 & 2.9 & 0.14 & 1.1 & 2.9 & 5.36 & 0.3 & 5.36 \\
\hline & Low & 0.45 & 0.56 & 0.42 & 0.13 & 0.76 & 0.42 & $<0.1$ & $<0.1$ & $<0.1$ \\
\hline
\end{tabular}

Table 3.2.4-9. Volatiles Report (nanograms per gram).

\begin{tabular}{|c|c|c|c|c|c|c|c|c|c|}
\hline Sample ID & $\begin{array}{l}\text { Sample } \\
\text { type }\end{array}$ & $\begin{array}{l}\text { Methylene } \\
\text { chloride }\end{array}$ & $\begin{array}{c}\text { Trichloro- } \\
\text { ethene }\end{array}$ & $\begin{array}{c}\text { Trans-1,3- } \\
\text { dichloro- } \\
\text { propene }\end{array}$ & $\begin{array}{l}1,1,2,2- \\
\text { tetrachloro- } \\
\text { ethane }\end{array}$ & Toluene & $\begin{array}{l}\text { Ethyl- } \\
\text { benzene }\end{array}$ & Styrene & $\begin{array}{c}\text { Total } \\
\text { xylenes }\end{array}$ \\
\hline Bldg. 374 & $8-4286$ & 27 & 16 & 24 & 26 & 7 & 6 & 10 & 11 \\
\hline
\end{tabular}


Table 3.2.4-10. Gas Mass Spectrometry Results (vol\%).

\begin{tabular}{|c|c|c|c|c|c|c|c|c|c|c|c|c|}
\hline Drum & $\begin{array}{c}\text { Headspace } \\
\text { sample } \\
\text { program }\end{array}$ & Vented & $\mathrm{H}_{2}$ & $\mathrm{~N}_{2}$ & $\mathrm{O}_{2}$ & $\mathrm{Ar}$ & $\mathrm{CO}_{2}$ & $\mathrm{CO}$ & $\mathrm{CH}_{4}$ & $\mathrm{C}_{2} \mathrm{H}_{6}$ & $\mathrm{C}_{3} \mathrm{H}_{8}$ & $\mathrm{NO}_{\mathrm{x}}$ \\
\hline D73136 & $3 A$ & $\mathrm{Y}$ & - & 78.2 & 20.9 & 0.912 & - & - & - & - & - & - \\
\hline D73136 & $2 A$ & $\mathbf{Y}$ & - & 78.1 & 21.0 & 0.912 & - & - & - & - & - & - \\
\hline D73136 & $1 \mathrm{~A}$ & $\mathbf{Y}$ & - & 77.9 & 21.1 & 0.949 & - & 0.028 & - & - & - & - \\
\hline \multicolumn{13}{|l|}{ Notes: } \\
\hline \multicolumn{13}{|c|}{ Headspace Sample Program } \\
\hline $1 \mathrm{~A}$ & \multicolumn{12}{|c|}{ Operational Lid, Gas Mass Spectrometry Results (vol\%) } \\
\hline $2 A$ & \multicolumn{12}{|c|}{ Detailed Lid, Gas Mass Spectrometry Results (vol\%) } \\
\hline $3 A$ & \multicolumn{12}{|c|}{ Detailed Bag, Gas Mass Spectrometry Results (vol\%) } \\
\hline \multicolumn{13}{|c|}{$\begin{array}{l}\text { Unreported analyte values indicate that analyte was undetected, or was detected at or above the MDL but at a level } \\
\text { below the PRQL. }\end{array}$} \\
\hline
\end{tabular}




\subsection{Waste Form Number 112-Solidified Organics, Content Code RF 112A}

\subsubsection{Item Description Code 700-Organic and Sludge Immobilization System Waste}

3.3.1.1 Certification Assessment. This IDC is certifiable without further waste treatment. Assay and thermal power calculations, including error, need to be updated to meet the current WIPP WAC. Several gas generation criteria need to be addressed. Carbon filters may need to be installed, drums will require inspection to identify unvented or unpunctured rigid liners, and headspace gas analysis and visual waste characterization will need to be performed.

3.3.1.2 Waste Description. It is assumed that IDC 700 was the experimental prototype for IDC 801 and has the same waste description. IDC 801, Solidified organics, are cemented waste oils and solvents that were generated as a result of machining and tool degreasing. Waste oil was transferred primarily from Buildings 707 and 777. Cementation was performed in Waste Management Unit (WMU) 56, Room 210, Building 774. IDC 801 solidified organics waste was generated by the Organic and Sludge Immobilization System (OASIS) Process. OASIS was a batchtype process generating one drum per run. Waste oils were pumped into an O-ring bag contained in a 55-gal drum attached to the bottom of the OASIS glovebox. Envirostone emulsifier, gypsum cement, and accelerator were also metered into the bag. House water, which had not been used in any other processes, was added to the mixture as well. A lightning mixer was lowered into the drum after all of the materials were added. The amount of materials added to the mixture was computer controlled (EG\&G RFP 1994n).

3.3.1.3 Generation Source. It is assumed that IDC 700 was the experimental prototype for IDC 801 and has the same generation source. The waste oils were generated primarily by processes in Buildings 707 and 777 . Solvent-contaminated waste oils were generated by plutonium machining and tool degreasing. IDC 801 solidified organics waste was generated by the OASIS Process in Building 774. This cementation process operated from November 1985 to 1991 (EG\&G RFP 1994n).

3.3.1.4 Recovery Method. This IDC was never generated as a residue and therefore has no recovery method.

3.3.1.5 Waste Packaging and Handling. TRU-contaminated liquid organics were collected at or near the point of origin in appropriate tanks or containers as they were generated. The liquid organics were then sampled and analyzed for discardable concentrations of plutonium, americium, and other controlled components. If examination of the analysis showed that the waste was below the discard limit, it was transferred to the liquid waste treatment facility (Building 774) where it was collected in tanks or containers until enough waste was collected for a batch treatment run. The batch was homogenized, and the total plutonium content for the batch was controlled to $<200$ grams. The waste was transferred to 55-gal drums, each with a rigid liner, and attached to the mixing box by an O-ring bag. Each batch of liquid organic waste was then mixed with the appropriate binder. A highshear impeller was used to mix the batch until it began to stiffen. The mixer was then removed and the drum of waste was cut off from the mixing box at the O-ring bag and placed aside for set up to occur. Following set up, the liner and drum were closed, and a TID was attached to the drum. 
3.3.1.6 Container Preparation. Only approved containers could be used to package TRU waste for shipment offsite. The containers approved for shipment to INEL during this time were DOT-17C, white, 55-gal drums (Rockwell specification SX-200). These containers met the requirements for certification as DOT-7A Type A packaging (Rockwell International 1989e).

Table 3.3.1-1 shows the current inventory of IDC 700 waste containers from the Rocky Flats Plant that have been shipped to INEL since 1985.

Table 3.3.1-1. Item Description Code 700 Container Information.

\begin{tabular}{lccc}
\hline \multicolumn{1}{c}{ Information } & & Drums & Boxes \\
\hline Total Containers & & 60 & 0 \\
Net Container Weight (lb) & Maximum & 564 & N/A \\
& Minimum & 489 & N/A \\
& Average & 422 & N/A \\
\hline
\end{tabular}

3.3.1.6.1 Drum Preparation-Approved liners for drums of TRU waste packaged for offsite shipment were the round-bottom liner (Rockwell specification SX-203) inside a 90-mil rigid polyethylene liner (Rockwell specification SX-202), or an O-ring bag and a polyethylene bag placed inside the rigid liner if the drum was attached to a glovebox (Rockwell International 1989e). Type III rigid liners have been used since September 1983 (Bearly 1989a). The IDC 700 waste packaged for offsite shipment required two polyvinyl chloride (PVC) O-ring bags and a metal mesh retaining ring positioned inside the rigid liner (Peterson 1987). All bags were closed using the twist-and-tape method (Rockwell International 1989e).

Flow-in, ventable gaskets were installed in the drums beginning in December 1982. They were used until October 1988, when tubular gaskets with carbon filters were required. Drums shipped to INEL between 1985 and 1988 may not meet the current WIPP WAC, owing to their lack of carbon filters (Bearly 1989a).

3.3.1.6.2 Box Preparation-No boxes of IDC 700 waste were shipped to INEL between 1985 and 1989.

3.3.1.7 Assay. The assay was most likely performed using a batch process. Individual containers of liquid to be cemented were assayed. These individual assays were summed to provide a total amount of radioactive material. The plutonium and americium value for the liquid in the batch tank was divided evenly between the drums produced in the batch. Uranium assay was not routinely performed. Table 3.3.1-2 summarizes the dose rates measured on containers of this IDC. Table 3.3.1-3 provides a summary of the assay information. 
Table 3.3.1-2. Item Description Code 700 Dose Information.

\begin{tabular}{crcc} 
Information & & Drums & Boxes \\
\hline One Meter Dose Rate (mrem/h) & $0-0.5$ & 60 & N/A \\
& $0.5-10$ & 0 & N/A \\
Surface Dose Rate $(\mathrm{mrem} / \mathrm{h})$ & $<10$ & 60 & N/A \\
& $10-200$ & 0 & N/A \\
\hline
\end{tabular}

Table 3.3.1-3. Item Description Code 700 Assay Information.

\begin{tabular}{|c|c|c|c|}
\hline \multicolumn{2}{|c|}{ Radionuclide inventory } & \multirow{2}{*}{$\frac{\text { Drums }}{4.6}$} & \multirow{2}{*}{$\frac{\text { Boxes }}{\text { N/A }}$} \\
\hline Plutonium (g) & Maximum & & \\
\hline & Minimum & 1.1 & N/A \\
\hline & Average & 2.2 & N/A \\
\hline & & - & \\
\hline \multirow[t]{3}{*}{ Americium (g) } & Maximum & - & N/A \\
\hline & Minimum & - & N/A \\
\hline & Average & - & N/A \\
\hline \multirow[t]{3}{*}{ Uranium-235 (g) } & Maximum & - & N/A \\
\hline & Minimum & - & N/A \\
\hline & Average & - & N/A \\
\hline
\end{tabular}

3.3.1.8 Inspection. Waste Certification personnel reviewed process documentation to ensure the process was properly operated, producing a stable waste form. Waste Certification personnel also performed periodic inspections of the generating and packaging process to verify compliance with waste acceptance criteria. In addition, each drum was viewed using RTR to

- Ensure the drum does not contain nonconforming items

- Ensure the drum is properly packaged

- Verify the waste form description

- Evaluate the presence of free liquids.

3.3.1.9 Waste Form Evaluation. Table 3.3.1-4 evaluates the waste form against the WIPP WAC for such items as free liquids, pyrophoric materials, and compressed gases. Table 3.3.1-5 evaluates the waste against TRUPACT criteria. 
Table 3.3.1-4. Waste Form Evaluation.

Criterion or requirement

Limiting parameters ${ }^{2}$

Immobilization

This process was designed to produce a stable waste form. Particulate material is not expected to be found in this waste.

Liquids

The solidification process meets the free liquid criteria by procedural control and RTR inspection before shipment from Rocky Flats.

Pyrophoric Materials Pyrophoric materials were prohibited by procedural control. The absence of the pyrophoric materials was verified by the generating supervisor and periodic inspection by the Waste Certification Organization.

Explosives and Compressed Gases

Explosives and compressed gases were prohibited by procedural control. The absence of the explosives and compressed gases was verified by the generating supervisor and periodic inspection by the Waste Certification Organization. In addition, unvented, closed containers and pressurized containers were excluded by procedural controls and RTR examination.

TRU-Mixed Wastes The RCRA constituents exist as co-contaminants with the transuranic radionuclides. Compliance with the WIPP RCRA permits and NMD will be required before shipment of the stored waste to WIPP.

Specific Activity of A portion of the waste stored at INEL may contain $<100$ nanocuries per Waste gram transuranic radionuclides.

$\mathrm{Pu}^{239}$ Equivalent None of the IDC 700 waste containers recorded as shipped to INEL in the Activity SWIMS exceed $1,000 \mathrm{Ci}$ of plutonium-equivalent activity.

a. Many of the limiting parameters were taken from TRU Waste Compliance Program (Rockwell International 1983a, 1987e, and 1989b). 
Table 3.3.1-5. TRUPACT Evaluation.

Criterion or requirement

Limiting parameters ${ }^{2}$

Waste Package

Weight

Rocky Flats limited the gross weight of drums to $800 \mathrm{lb}$. The TRUPACT and

Waste Containers vehicle weight limits must be verified at the time of payload assembly at INEL.

The solidified organic waste was packaged in 55-gal DOT-7A, Type A containers.

Nuclear Criticality - Rocky Flats limited the fissile content of the drums to 200 grams. However, the error-times-two requirement was not in place at the time the drums were shipped to INEL; therefore, it is not reported as part of the assay of the drum. The TRUPACT limit must be verified at the time of payload assembly at INEL. Based on the typical assays of the IDC 700 drums, the criticality criteria will be met but must be recalculated or assayed to meet the error-timestwo requirement.

Surface Dose Rate The surface dose rate criteria used by Rocky Flats was $200 \mathrm{mrem} / \mathrm{hr}$ at the drum surface and $10 \mathrm{mrem} / \mathrm{hr}$ at 1 meter. Shielding was not necessary for IDC 700 drums. The TRUPACT limit must be verified at the time of payload assembly at INEL. Based on the typical dose rates from the IDC 700 drums, the dose rate criteria will be met.

Removable Surface The Rocky Flats limit for removable contamination (for TRU assumed to be all Contamination alpha) was 20 disintegrations per minute $/ 100 \mathrm{~cm}^{2}$. The Rocky Flats limit is equivalent to 9 picocuries per $100 \mathrm{~cm}^{2}$, which is well within the WIPP criteria.

Thermal Power The thermal power calculation reported in the SWIMS data package is based on the reported assay value without an error/uncertainty correction. The thermal power must be recalculated based on the assay error determination.

Gas Generation Based on the procedural requirements for packaging IDC 700 waste and the waste description, the only areas of noncompliance are carbon filters, unpunctured rigid liners, headspace gas analysis, and visual characterization.

Personnel performing RTR examination at Rocky Flats would accept up to $10 \%$ of another IDC. The other IDCs could be combustibles, glass, concrete, metal, leaded gloves, and plastics.

a. Many of the limiting parameters were taken from TRU Waste Compliance Program (Rockwell International 1983a, 1987e, and 1989b).

3.3.1.10 Combustible and Organic Content. SWIMS data indicate that this waste form does not contain $>20 \%$ combustibles, but does contain $>20 \%$ organics.

3.3.1.10.1 Combustible Content-SWIMS data show that IDC 700 waste is noncombustible (Rockwell International 1985a). 
3.3.1.10.2 Organic Content-SWIMS data show that IDC 700 waste contains 55\% organics (Rockwell International 1985a).

3.3.1.11 Analytical Information. No analytical information is available for IDC 700 .

It is presumed that IDC 801 EPA Codes also apply to IDC 700. Sampling and analysis of IDC 801 solidified organics samples indicate the waste exceeded toxicity characteristic criteria for carbon tetrachloride (EPA Code D019). In addition, EPA Codes F001 and F002 are assigned to all solidified organics because these wastes were contaminated with regulated spent solvents in the past (EG\&G RFP 1994n). 


\subsection{Waste Form Number 112-Solidified Organics, Content Code RF 112A}

\subsubsection{Item Description Code 801-Solidified Organics}

3.3.2.1 Certification Assessment. This IDC is certifiable without further waste treatment. Assay and thermal power calculations, including error, need to be updated to meet the current WIPP WAC. Several gas generation criteria need to be addressed. Carbon filters may need to be installed, drums will require inspection to identify unvented or unpunctured rigid liners, and headspace gas analysis and visual waste characterization will need to be performed.

3.3.2.2 Waste Description. Solidified organics are cemented waste oils and solvents that were generated as a result of machining and tool degreasing. Waste oil was transferred primarily from Buildings 707 and 777. Cementation was performed in Waste Management Unit (WMU) 56, Room 210, Building 774. IDC 801 solidified organics waste was generated by the OASIS Process. OASIS was a batch-type process generating one drum per run. Waste oils were pumped into an Oring bag contained in a 55-gal drum attached to the bottom of the OASIS glovebox. Envirostone emulsifier, gypsum cement, and accelerator were also metered into the bag. House water, which had not been used in any other processes, was added to the mixture as well. A lightning mixer was lowered into the drum after all of the materials were added. The amount of materials added to the mixture was computer controlled (EG\&G RFP 1994n).

3.3.2.3 Generation Source. The waste oils were generated primarily by processes in Buildings 707 and 777 . Solvent-contaminated waste oils were generated by plutonium machining and tool degreasing. IDC 801 solidified organics waste was generated by the OASIS Process in Building 774. This cementation process operated from November 1985 to 1991 (EG\&G RFP 1994n).

3.3.2.4 Recovery Method. This IDC was never generated as a residue and therefore had no recovery method.

3.3.2.5 Waste.Packaging and Handling. TRU-contaminated liquid organics were collected at or near the point of origin in appropriate tanks or containers as they were generated. The liquid organics were then sampled and analyzed for discardable concentrations of plutonium, americium, and other controlled components. If examination of the analysis shows that the waste is below the discard limit, it was transferred to the liquid waste treatment facility (Building 774) where it was collected in tanks or containers until enough waste was collected for a batch treatment run. The batch was homogenized, and the total plutonium content for the batch was controlled to $<200$ grams. The waste was transferred to 55-gal drums, each with a rigid liner and attached to the mixing box by an O-ring bag. Each batch of liquid organic waste was then mixed with the appropriate binder. A highshear impeller was used to mix the batch until it began to stiffen. The mixer was then removed and the drum of waste was cut off from the mixing box at the O-ring bag and placed aside for setup to occur. Following setup, the liner and drum were closed, and a TID was attached to the drum.

3.3.2.6 Container Preparation. Only approved containers could be used to package TRU waste for shipment offsite. Containers approved for shipment to the INEL during this time period 
were the DOT-17C, white, 55-gal drum (Rockwell specification SX-200). These containers met the requirements for certification as DOT-7A Type A packaging (Rockwell International 1989e).

Table 3.3.2-1 shows the current inventory of IDC 801 waste containers from the Rocky Flats Plant which had been shipped to INEL since 1985.

Table 3.3.2-1. Item Description Code 801 Container Information.

\begin{tabular}{|c|c|c|c|}
\hline \multicolumn{2}{|c|}{ Information } & \multirow{2}{*}{$\begin{array}{c}\text { Drums } \\
796\end{array}$} & \multirow{2}{*}{$\frac{\text { Boxes }}{0}$} \\
\hline Total Containers & & & \\
\hline \multirow[t]{3}{*}{ Net Container Weight (lb) } & Maximum & 598 & N/A \\
\hline & Minimum & 122 & N/A \\
\hline & Average & 453 & N/A \\
\hline
\end{tabular}

3.3.2.6.1 Drum Preparation-Approved liners for drums of TRU waste packaged for offsite shipment were the round-bottom liner (Rockwell specification SX-203) inside a 90-mil rigid polyethylene liner (Rockwell specification SX-202), or an O-ring bag and a polyethylene bag placed inside the rigid liner if the drum was attached to a glovebox (Rockwell International 1989e). Type III rigid liners had been used since September 1983 (Bearly 1989a). The IDC 801 waste packaged for offsite shipment required two polyvinyl chloride (PVC) O-ring bags and a metal mesh retaining ring positioned inside the rigid liner (Peterson 1987). All bags were closed using the twist-and-tape method (Rockwell International 1989e).

Flow-in ventable gaskets were installed in the drums beginning in December 1982. They were used until October 1988, when tubular gaskets with carbon filters were required. Drums shipped to the INEL between 1985 and 1988 may not meet the current WIPP WAC owing to their lack of carbon filters (Bearly 1989a).

3.3.2.6.2 Box Preparation-No boxes of IDC 801 waste were shipped to the INEL between 1985 and 1989.

3.3.2.7 Assay. Assay was performed radiochemically. The drum assay value was based on a batch process. The plutonium and americium value for the liquid in the batch tank was divided evenly between the drums produced in the batch. Uranium assay was not routinely performed. Table 3.3.2-2 summarizes the dose rates measured on containers of this IDC. Table 3.3.2-3 provides a summary of the assay information. Two drums were evaluated for americium, no drums were evaluated for uranium. 
Table 3.3.2-2. Item Description Code 801 Dose Information.

\begin{tabular}{crrr}
\hline Information & & Drums & Boxes \\
\cline { 2 - 4 } One Meter Dose Rate (mrem/h) & $0-0.5$ & 783 & N/A \\
& $0.5-10$ & 13 & N/A \\
Surface Dose Rate (mrem/h) & $<10$ & 792 & N/A \\
& $10-200$ & 4 & N/A \\
\hline
\end{tabular}

Table 3.3.2-3. Item Description Code 801 Assay Information.

\begin{tabular}{|c|c|c|c|}
\hline \multicolumn{2}{|c|}{ Radionuclide inventory } & $\frac{\text { Drums }}{70}$ & $\frac{\text { Boxes }}{\text { N/A }}$ \\
\hline Plutonium (g) & $\begin{array}{r}\text { Maximum } \\
\text { Minimum } \\
\text { Average }\end{array}$ & $\begin{array}{l}70 \\
0 \\
3.26\end{array}$ & $\begin{array}{l}\text { N/A } \\
\text { N/A } \\
\text { N/A }\end{array}$ \\
\hline Americium (g) & $\begin{array}{r}\text { Maximum } \\
\text { Minimum } \\
\text { Average }\end{array}$ & $\begin{array}{l}1 \\
1 \\
1\end{array}$ & $\begin{array}{l}\text { N/A } \\
\text { N/A } \\
\text { N/A }\end{array}$ \\
\hline Uranium-235 (g) & $\begin{array}{r}\text { Maximum } \\
\text { Minimum } \\
\text { Average }\end{array}$ & $\begin{array}{l}- \\
-\end{array}$ & $\begin{array}{l}\text { N/A } \\
\text { N/A } \\
\text { N/A }\end{array}$ \\
\hline
\end{tabular}

3.3.2.8 Inspection. Waste Certification personnel reviewed process documentation to ensure the process was properly operated, producing a stable waste form. Waste Certification personnel also performed periodic inspections of the generating and packaging process to verify compliance with waste acceptance criteria. In addition, each drum was viewed using RTR to

- $\quad$ Ensure the drum did not contain nonconforming items

- Ensure the drum was properly packaged

- Verify the waste form description, and

- Evaluate the presence of free liquids.

3.3.2.9 Waste Form Evaluation. Table 3.3.2-4 evaluates the waste form against the WIPP WAC for such items as free liquids, pyrophoric materials, and compressed gases. Table 3.3.2-5 evaluates the waste against TRUPACT criteria. 
Table 3.3.2-4. Waste Form Evaluation.

Criterion or

requirement

Limiting parameters ${ }^{2}$

Immobilization

This process was designed to produce a stable waste form. Particulate material is not expected to be found in this waste.

Liquids

The solidification process meets the free liquid criteria by procedural control and RTR inspection prior to shipment from Rocky Flats.

Pyrophoric

Materials

Pyrophoric materials were prohibited by procedural control. The absence of the pyrophoric materials was verified by the generating supervisor and periodic inspection by the Waste Certification Organization.

Explosives and Compressed Gases

Explosives and compressed gases were prohibited by procedural control. The absence of the explosives and compressed gases were verified by the generating supervisor and periodic inspection by the Waste Certification Organization. In addition, nonvented, closed containers and pressure containers were excluded by procedural controls and RTR examination.

TRU-Mixed Wastes The RCRA constituents exist as co-contaminants with the transuranic radionuclides. Compliance with the WIPP RCRA permits and NMD will be required before shipment of the stored waste to WIPP.

Specific Activity of A portion of the waste stored at INEL may contain $<100$ nanocuries per gram Waste transuranic radionuclides.

$\mathrm{Pu}^{239}$ Equivalent None of the IDC 801 waste containers recorded as shipped to INEL in the Activity SWIMS exceed $1,000 \mathrm{Ci}$ of plutonium-equivalent activity.

a. Many of the limiting parameters were taken from TRU Waste Compliance Program (Rockwell International 1983a, 1987e, and 1989b). 
Table 3.3.2-5. TRUPACT Evaluation.

Criterion or

requirement

Limiting parameters ${ }^{2}$

Waste Package

Weight

Rocky Flats limited the gross weight of drums to $800 \mathrm{lb}$. The TRUPACT and vehicle weight limits must be verified at the time of payload assembly at INEL. Based on the typical weights of the IDC 801 drums, load management will be required to ensure 42 drums will meet the gross vehicle weight (average gross weight of approximately 453 lb).

Waste Containers

The solidified organic waste was packaged in 55-gal DOT-7A, Type A containers.

Nuclear Criticality

Rocky Flats limited the fissile content of the drums to 200 grams. However, the errortimes-two requirement was not in place at the time the drums were shipped to INEL; therefore, it is not reported as part of the assay of the drum. The TRUPACT limit must be verified at the time of payload assembly at INEL. Based on the typical assays of the IDC 801 drums, the criticality criteria will be met but must be recalculated or assayed to meet the error-times-two requirement.

Surface Dose Rate The surface dose rate criteria used by Rocky Flats was $200 \mathrm{mrem} / \mathrm{hr}$ at the drum surface and $10 \mathrm{mrem} / \mathrm{hr}$ at 1 meter. Shielding was not necessary for IDC 801 drums. The TRUPACT limit must be verified at the time of payload assembly at INEL. Based on the typical dose rates from the IDC 801 drums, the dose rate criteria will be met.

Removable Surface Contamination

The Rocky Flats limit for removable contamination (for TRU assumed to be all alpha) was 20 disintegrations per minute $/ 100 \mathrm{~cm}^{2}$. The Rocky Flats limit is equivalent to 9 picocuries per $100 \mathrm{~cm}^{2}$, which is well within the WIPP criteria.

Thermal Power

The thermal power calculation reported in the SWIMS data package is based on the reported assay value without an error/uncertainty correction. The thermal power must be recalculated based on the assay error determination.

Gas Generation

Based on the procedural requirements for packaging IDC 801 waste and the waste description, the only areas of noncompliance are carbon filters, nonpunctured rigid liners, headspace gas analysis, and visual characterization.

Toluene, trichloroethene, and methylene chloride were detected in the headspace gas of IDC 801 but are not listed in the TRUPACT Chemical List for RF 112A. 1,1,1Trichloroethane, 1,1,2-trichloro-1,2,2-trifluoroethane, and carbon tetrachloride are on the TRUPACT Chemical List and were detected in the headspace gas. Tetrachloroethylene and carbon tetrachloride were detected using TCLP. Xylene and chloroform are on the TRUPACT Chemical List but were not detected. Alcohols on the TRUPACT Chemical List were not detected.

One drum (D40197-0743-18283) of IDC 801 waste was noted as containing 7.6 liters of solidified xylene (B).

Personnel performing RTR examination at Rocky Flats would accept up to $10 \%$ of another IDC. The other IDCs could be combustibles, glass, concrete, metal, leaded gloves, and plastics.

a. Many of the limiting parameters were taken from TRU Waste Compliance Program (Rockwell International 1983a, 1987e, and 1989b). 
3.3.2.10 Combustible and Organic Content. SWIMS data indicate that this waste form does not contain $>20 \%$ combustibles, but contains $>20 \%$ organics.

3.3.2.10.1 Combustible Content-SWIMS data show that IDC 801 waste is noncombustible (Rockwell International 1985a).

3.3.2.10.2 Organic Content-SWIMS data show that IDC 801 waste contains 55\% organics (Rockwell International 1985a).

3.3.2.11 Analytical Information. Analytical data from the Waste Drum Gas Generation Sampling Program at Rocky Flats (Roggenthen and others 1989) indicate that three drums were subject to sludge analysis for VOCs. The sampled drums contained IDC 003 waste; however, IDC 801 solidified organics are assigned the same EPA Codes as previously generated IDC 003 waste (EG\&G RFP 1994n). The analytical results and toxicity characteristic limits are presented in Table 3.3.2-6. Sampling and analysis of three solidified organics samples in 1988 and 1989 indicated the waste exceeded toxicity characteristic criteria for carbon tetrachloride (EPA Code D019). The concentration of tetrachloroethylene exceeded the toxicity characteristic criteria level in one sample. However, the concentrations in the other samples were undetected or below characteristic levels (EG\&G RFP 1994n). In addition, EPA Codes F001 and F002 are assigned to all solidified organics because these wastes were contaminated with regulated spent solvents in the past.

Table 3.3.2-6. Analytical Results for Solidified Organics.

\begin{tabular}{|c|c|c|c|c|}
\hline \multirow[b]{2}{*}{ Constituent } & \multirow[b]{2}{*}{$\begin{array}{c}\text { TCLP limit } \\
(\mathrm{mg} / \mathrm{L})\end{array}$} & \multicolumn{3}{|c|}{ Sample results (ppm) } \\
\hline & & $\begin{array}{c}\text { Drum } \\
7431-6930^{2} \\
\end{array}$ & $\begin{array}{c}\text { Drum } \\
0250-0484^{b}\end{array}$ & $\begin{array}{c}\text { Request } 6 \\
3537^{c}\end{array}$ \\
\hline Carbon tetrachloride & 0.5 & 2.2 & 0.7 & 78.3 \\
\hline Chlorobenzene & 100.0 & $\mathrm{U}^{\mathrm{d}}$ & $\mathrm{U}$ & $\mathbf{U}$ \\
\hline 0-Dichlorobenzene & - & N.M. ${ }^{\circ}$ & N.M. & N.M. \\
\hline Methylene chloride & - & $\mathbf{U}$ & $\mathbf{U}$ & $\mathbf{U}$ \\
\hline Nitrobenzene & 2.0 & N.M. & N.M. & N.M. \\
\hline Tetrachloroethylene & 0.7 & 1.2 & 0.04 & $\mathbf{U}$ \\
\hline 1,1,1-Trichloroethane & - & $\mathbf{U}$ & $\mathrm{U}$ & 35.1 \\
\hline Trichloroethylene & 0.5 & $\mathrm{U}$ & $\mathrm{U}$ & $\mathbf{U}$ \\
\hline $\begin{array}{l}\text { 1,1,2-Trichloro- } \\
\text { 1,2,2-trifluoroethane }\end{array}$ & - & 4.0 & $\mathrm{U}$ & $\mathbf{U}$ \\
\hline Trichlorofluoro-methane & - & N.M. & N.M. & N.M. \\
\hline $\begin{array}{l}\text { a. Sample of IDC } 003 \text { solic } \\
\text { b. Sample of IDC } 003 \text { solic } \\
\text { c. Sample origin not listed } \\
\text { d. Undetected. } \\
\text { e. Not measured. }\end{array}$ & $\begin{array}{l}\text { lics generated } \mathrm{i} \\
\text { lics generated } \\
1 \text { report. }\end{array}$ & $\begin{array}{l}4 \text { (Rockwell } 1 \\
5 .\end{array}$ & & \\
\hline
\end{tabular}


Analytical data from the WIPP Experimental Waste Characterization Program (EG\&G RFP 1994t) for IDC 801, Solidified Organics, indicate that 24 drums were subject to headspace gas analysis for Gas Mass Spectrometry and 27 drums for VOC Gas Chromatography/Mass Spectrometry.

IDC 801 Gas Mass Spectrometry analytical results are presented in Table 3.3.2-7. Drums were subject to four possible headspace sampling programs: operational lid, detailed lid, detailed bag, and operational bag. An individual drum could be sampled by more than one program. All analytes, with the exception of propane, were detected. Nitrogen, oxygen and argon were detected in every drum tested.

IDC 801 VOC Gas Chromatography/Mass Spectrometry analytical results are presented in Tables 3.3.2-8 through 3.3.2-10. Drums were subject to four possible headspace sampling programs: operational lid, operational bag, detailed bag, or detailed lid. An individual drum could be sampled by more than one program. Unreported analyte values indicate analytes were undetected, or detected at or above the MDL but at a level below the PRQL in these drums.

Analytical results for nine analytes are presented in Table 3.3.2-8. Analytes were detected in 5 of 27 drums tested. Two analytes (trichloro-trifluoroethane and methylene chloride) were detected in the drums.

Analytical results for nine analytes are presented in Table 3.3.2-9. Analytes were detected in 24 of 27 drums tested. Three analytes (1,1,1-trichloroethane, carbon tetrachloride and trichloroethene) were detected in the drums.

Analytical results for 10 analytes are presented in Table 3.3.2-10. Analytes were detected in 10 of the 27 drums tested. One analyte (toluene) was detected in the drums.

Table 3.3.2-7. Gas Mass Spectrometry Results (vol\%).

\begin{tabular}{|c|c|c|c|c|c|c|c|c|c|c|c|c|}
\hline \multirow[b]{2}{*}{ Drum no. } & \multirow{2}{*}{$\begin{array}{c}\text { Headspace } \\
\text { sample } \\
\text { program }\end{array}$} & \multirow[b]{2}{*}{ Vented } & \multicolumn{10}{|c|}{ Analytes } \\
\hline & & & $\mathrm{H}_{2}$ & $\mathrm{~N}_{2}$ & $\mathrm{O}_{2}$ & $\mathrm{Ar}$ & $\mathrm{CO}_{2}$ & $\mathrm{Co}$ & $\mathrm{CH}_{4}$ & $\mathrm{C}_{2} \mathrm{H}_{6}$ & $\mathrm{C}_{3} \mathrm{H}_{8}$ & No $_{x}$ \\
\hline D42280 & $1 \mathrm{~A}$ & $\mathbf{Y}$ & 11.499 & 78.5 & 1.1 & 0.937 & 0.164 & 1.502 & 0.203 & - & - & - \\
\hline D70543 & $4 \mathrm{~A}$ & - & - & 66.4 & 15.7 & 0.787 & - & 0.140 & - & 0.102 & - & - \\
\hline D70543 & $1 \mathrm{~A}$ & - & - & 69.6 & 16.6 & 0.818 & - & 0.099 & - & - & - & - \\
\hline D71020 & $1 \mathrm{~A}$ & - & - & 68.9 & 16.7 & 0.819 & - & 0.123 & - & - & - & - \\
\hline D71022 & $3 A$ & $\mathbf{Y}$ & - & 68.8 & 15.7 & 0.818 & - & 0.124 & - & - & - & - \\
\hline D71022 & $2 \mathrm{~A}$ & $\mathbf{Y}$ & - & 69.7 & 16.4 & 0.825 & - & 0.101 & - & - & - & - \\
\hline D71022 & $1 \mathrm{~A}$ & - & - & 70.5 & 19.1 & 0.876 & 0.085 & 0.030 & - & - & - & - \\
\hline D71932 & $1 \mathrm{~A}$ & - & - & 71.1 & 18.5 & 0.856 & - & 0.082 & - & 0.068 & - & - \\
\hline D71933 & $1 \mathrm{~A}$ & - & - & 77.3 & 21.7 & 0.939 & - & - & - & - & - & - \\
\hline D71934 & $4 \mathrm{~A}$ & $\mathbf{N}$ & - & 78.1 & 21.0 & 0.928 & - & - & - & - & - & - \\
\hline D71934 & $1 \mathrm{~A}$ & $\mathbf{N}$ & - & 78.3 & 20.7 & 0.939 & - & - & - & - & - & - \\
\hline D71941 & $1 \mathrm{~A}$ & - & - & 70.9 & 15.9 & 0.850 & - & 0.173 & - & - & - & - \\
\hline D72128 & $1 \mathrm{~A}$ & - & - & 78.1 & 20.8 & 0.930 & - & 0.031 & - & - & - & - \\
\hline D72139 & $1 \mathrm{~A}$ & - & - & 77.3 & 21.8 & 0.940 & - & - & - & - & - & - \\
\hline
\end{tabular}


Table 3.3.2-7. (continued).

\begin{tabular}{|c|c|c|c|c|c|c|c|c|c|c|c|c|}
\hline \multirow[b]{2}{*}{ Drum no. } & \multirow{2}{*}{$\begin{array}{l}\text { Headspace } \\
\text { sample } \\
\text { program }\end{array}$} & \multirow[b]{2}{*}{ Vented } & \multicolumn{10}{|c|}{ Analytes } \\
\hline & & & $\mathrm{H}_{2}$ & $\mathrm{~N}_{2}$ & $\mathrm{O}_{2}$ & Ar & $\mathrm{CO}_{2}$ & $\mathrm{CO}$ & $\mathrm{CH}_{4}$ & $\mathrm{C}_{2} \mathrm{H}_{6}$ & $\mathrm{C}_{3} \mathrm{H}_{8}$ & $\mathrm{NO}_{\mathrm{x}}$ \\
\hline D72566 & $1 \mathrm{~A}$ & - & - & 77.7 & 21.3 & 0.916 & - & - & - & - & - & - \\
\hline D73285 & $1 \mathrm{~A}$ & - & - & 77.5 & 21.6 & 0.862 & - & - & - & - & - & - \\
\hline D73293 & $1 \mathrm{~A}$ & - & - & 77.9 & 21.1 & 0.924 & - & - & - & - & - & - \\
\hline D73295 & $4 \mathrm{~A}$ & - & - & 75.9 & 23.1 & 0.897 & - & - & - & - & - & - \\
\hline D73295 & $1 \mathrm{~A}$ & - & - & 76.6 & 22.5 & 0.904 & - & - & - & - & - & - \\
\hline D73667 & $1 \mathrm{~A}$ & - & - & 77.9 & 21.2 & 0.890 & - & - & - & - & - & - \\
\hline D73672 & $4 \mathrm{~A}$ & - & - & 78.5 & 20.6 & 0.927 & - & - & - & - & - & - \\
\hline D73672 & $1 \mathrm{~A}$ & - & - & 77.4 & 21.6 & 0.922 & - & - & - & - & - & - \\
\hline D74147 & $1 \mathrm{~A}$ & - & - & 78.2 & 20.9 & 0.932 & - & - & - & - & - & - \\
\hline D74156 & $1 \mathrm{~A}$ & - & - & 78.1 & 21.0 & 0.922 & - & - & - & - & - & - \\
\hline D76135 & $3 A$ & $\mathbf{Y}$ & - & 77.5 & 20.9 & 0.923 & - & - & - & - & - & - \\
\hline D76135 & $2 A$ & $\mathbf{Y}$ & - & 77.7 & 20.9 & 0.916 & - & - & - & - & - & - \\
\hline D76135 & $1 \mathrm{~A}$ & $\mathbf{Y}$ & - & 78.1 & 20.6 & 0.952 & - & - & - & - & - & 0.017 \\
\hline D76195 & $4 \mathrm{~A}$ & - & - & 74.4 & 18.8 & 0.902 & - & 0.076 & - & 0.113 & - & - \\
\hline D76195 & $1 \mathrm{~A}$ & - & - & 76.9 & 20.5 & 0.896 & - & 0.034 & - & - & - & - \\
\hline D76196 & $3 A$ & $\mathbf{Y}$ & - & 76.2 & 18.9 & 0.870 & - & - & - & - & - & - \\
\hline D76196 & $2 A$ & $\mathbf{Y}$ & - & 76.9 & 18.2 & 0.912 & - & - & - & - & - & - \\
\hline D76196 & $1 \mathrm{~A}$ & - & - & 76.1 & 21.0 & 0.904 & 一 & - & - & - & - & 0.008 \\
\hline D76200 & $3 A$ & $\mathbf{Y}$ & - & 70.4 & 19.0 & 0.841 & - & 0.042 & - & - & - & - \\
\hline D76200 & $2 A$ & $\mathbf{Y}$ & - & 71.8 & 19.1 & 0.846 & - & - & - & - & - & - \\
\hline D76200 & $1 \mathrm{~A}$ & $\mathbf{Y}$ & - & 73.8 & 19.4 & 0.892 & - & 0.029 & - & - & - & - \\
\hline D76203 & $3 A$ & $\mathbf{Y}$ & - & 73.0 & 19.5 & 0.875 & - & 0.014 & - & - & - & - \\
\hline D76203 & $2 A$ & $\mathbf{Y}$ & - & 73.5 & 20.0 & 0.878 & - & - & - & - & - & - \\
\hline D76203 & $1 \mathrm{~A}$ & $\mathbf{Y}$ & - & 76.7 & 20.2 & 0.929 & - & 0.016 & - & - & - & - \\
\hline D76283 & $3 \mathrm{~A}$ & $\mathbf{Y}$ & - & 76.7 & 19.4 & 0.907 & - & - & - & - & - & - \\
\hline D76283 & $2 A$ & $\mathbf{Y}$ & - & 77.0 & 19.5 & 0.905 & - & - & - & - & - & 2 \\
\hline D76283 & $1 \mathrm{~A}$ & $\mathbf{Y}$ & - & 77.6 & 20.6 & $\begin{array}{l}0.941 \\
\text { - }\end{array}$ & - & - & - & - & $\rightarrow$ & - \\
\hline
\end{tabular}

Notes:

Headspace Sample Program

1A Operational Lid, Gas Mass Spectrometry Results (vol\%)

2A Detailed Lid, Gas Mass Spectrometry Results (vol\%)

3A Detailed Bag, Gas Mass Spectrometry Results (vol\%)

4A Operational Bag, Gas Mass Spectrometry Results (vol\%)

Y Yes

N No

Unreported analyte values indicate that analyte was undetected, or was detected at or above the MDL but at a level below the PRQL. 
Table 3.3.2-8. Volatile Organic Compound Gas Chromatography/Mass Spectrometry Results (parts per million by volume).

\begin{tabular}{|c|c|c|c|c|c|c|c|c|c|c|c|}
\hline \multirow[b]{2}{*}{ Drum no. } & \multirow[b]{2}{*}{$\begin{array}{l}\text { Headspace } \\
\text { sample } \\
\text { program }\end{array}$} & \multirow[b]{2}{*}{ Vented } & \multicolumn{9}{|c|}{ Analytes } \\
\hline & & & Methanol & Ethyl Ether & $\begin{array}{l}\text { Trichloro- } \\
\text { trifluoro- } \\
\text { ethane }\end{array}$ & $\begin{array}{l}\text { 1,1-Dichloro- } \\
\text { ethene }\end{array}$ & Acetone & $\begin{array}{l}\text { Methylene } \\
\text { Chloride }\end{array}$ & $\begin{array}{l}\text { 1,1-Dichloro- } \\
\text { ethane }\end{array}$ & $\begin{array}{l}\text { cis-1,2- } \\
\text { Dichloro- } \\
\text { ethene }\end{array}$ & 2-Butanone \\
\hline D70543 & 2B & - & - & - & $9,174.5$ & - & - & - & - & - & - \\
\hline D72128 & $1 B$ & - & - & - & - & - & - & $2,721.4$ & - & - & - \\
\hline D72139 & $1 B$ & - & - & - & - & - & - & 22.7 & - & - & - \\
\hline D76196 & $1 B$ & - & - & - & $2,042.3$ & - & - & - & - & - & - \\
\hline D76200 & 3B & $\mathbf{Y}$ & - & - & $15,236.0$ & - & - & - & - & - & - \\
\hline D76200 & $4 B$ & $\mathbf{Y}$ & - & - & $10,971.4$ & - & - & - & - & - & - \\
\hline \multirow{2}{*}{\multicolumn{12}{|c|}{$\begin{array}{l}\text { Notes: } \\
\quad \text { Headspace Sample Program }\end{array}$}} \\
\hline & & & & & & & & & & & \\
\hline & \multirow{2}{*}{\multicolumn{11}{|c|}{$\begin{array}{l}\text { Operational Lid, VOC Gas Chromatography/Mass Spectrometry Results (ppmv) } \\
\text { Operational Bag, VOC Gas Chromatography/Mass Spectrometry Results (ppmv) }\end{array}$}} \\
\hline & & & & & & & & & & & \\
\hline & \multicolumn{11}{|c|}{ Detailed Bag, VOC Gas Chromatography/Mass Spectrometry Results (ppmv) } \\
\hline & \multicolumn{11}{|c|}{ Detailed Lid, VOC Gas Chromatography/Mass Spectrometry Results (ppmv) } \\
\hline & \multicolumn{11}{|c|}{ Yes } \\
\hline \multicolumn{12}{|c|}{ Unreported analyte values indicate that analyte was undetected, or was detected at or above the MDL but at a level below the PRQL. } \\
\hline
\end{tabular}


Table 3.3.2-9. Volatile Organic Compound Gas Chromatography/Mass Spectrometry Results (parts per million by volume).

\begin{tabular}{|c|c|c|c|c|c|c|c|c|c|c|c|}
\hline \multirow[b]{2}{*}{ Drum no. } & \multirow[b]{2}{*}{$\begin{array}{c}\text { Headspace } \\
\text { sample } \\
\text { program } \\
\end{array}$} & \multirow[b]{2}{*}{ Vented } & \multicolumn{9}{|c|}{ Analytes } \\
\hline & & & $\begin{array}{c}\text { Chloro- } \\
\text { form }\end{array}$ & $\begin{array}{c}1,1,1- \\
\text { Trichloro-ethane }\end{array}$ & Cyclo-hexane & $\begin{array}{c}\text { Carbon } \\
\text { Tetra- } \\
\text { chloride }\end{array}$ & Benzene & $\begin{array}{c}\text { 1,2-Dichloro- } \\
\text { ethane }\end{array}$ & 1-Butanol & $\begin{array}{c}\text { Trichloro- } \\
\text { ethene }\end{array}$ & $\begin{array}{c}\text { 4-Methyl-2- } \\
\text { pentanone }\end{array}$ \\
\hline D42280 & 1B & $\mathbf{Y}$ & - & $24,947.1$ & - & $30,767.5$ & - & - & - & - & - \\
\hline D70543 & $2 B$ & - & - & $59,886.7$ & - & $67,162.4$ & - & - & - & - & - \\
\hline D70543 & 1B & - & - & $55,410.6$ & - & $62,380.7$ & - & - & - & - & - \\
\hline D71020 & $1 B$ & - & - & $44,413.8$ & - & $61,914.6$ & - & - & - & - & - \\
\hline D71022 & $3 B$ & $\mathbf{Y}$ & - & $58,550.0$ & - & $82,221.7$ & - & - & - & - & - \\
\hline D71022 & 4B & $\mathbf{Y}$ & - & $51,440.0$ & - & $69,895.0$ & - & - & - & - & - \\
\hline D71022 & 1B & - & - & $32,496.0$ & - & $66,727.2$ & - & - & - & - & - \\
\hline D71932 & $1 B$ & - & - & $85,795.5$ & - & $88,612.9$ & - & - & - & - & - \\
\hline D71933 & $1 \mathrm{~B}$ & - & - & 2.6 & - & - & - & - & - & 10.2 & - \\
\hline D71934 & 2B & $\mathbf{N}$ & - & 8.3 & - & 6.0 & - & - & - & 7.4 & - \\
\hline D71934 & 1B & $\mathbf{N}$ & - & 3.7 & - & 2.4 & - & - & - & 4.2 & - \\
\hline D71940 & 1B & - & - & $24,298.0$ & - & $67,542.0$ & - & - & - & - & - \\
\hline D71941 & 1B & - & - & $36,373.0$ & - & $88,979.0$ & - & - & - & - & - \\
\hline D72566 & 1B & - & - & 16.5 & - & - & - & - & - & 57.2 & - \\
\hline D73285 & IB & - & - & 1.5 & - & - & - & - & - & 10.6 & - \\
\hline D73293 & 1B & - & - & 3.2 & - & 2.4 & - & - & - & 3.3 & - \\
\hline D73295 & $2 \mathrm{~B}$ & - & - & 1.1 & - & - & - & - & - & 2.9 & - \\
\hline D73295 & 1B & - & - & 1.6 & - & - & - & - & - & 2.4 & - \\
\hline D73296 & 1B & - & - & 2.5 & - & - & - & - & - & - & - \\
\hline D73667 & 1B & - & - & 1.0 & - & - & - & - & - & 2.4 & - \\
\hline D73672 & $2 \mathrm{~B}$ & - & - & 2.5 & - & - & - & - & - & 2.9 & - \\
\hline D73672 & $1 B$ & - & - & 1.8 & - & - & - & - & - & 2.3 & - \\
\hline D74147 & 1B & - & - & 36.2 & - & - & - & - & - & - & - \\
\hline D74156 & $1 B$ & - & - & 36.8 & - & - & - & - & - & - & - \\
\hline D76135 & 3B & $\mathbf{Y}$ & - & 930.9 & - & $5,502.2$ & - & - & - & - & - \\
\hline
\end{tabular}


Table 3.3.2-9. (continued).

\begin{tabular}{|c|c|c|c|c|c|c|c|c|c|c|c|}
\hline \multirow[b]{2}{*}{ Drum no. } & \multirow[b]{2}{*}{$\begin{array}{l}\text { Headspace } \\
\text { sample } \\
\text { program }\end{array}$} & \multirow[b]{2}{*}{ Vented } & \multicolumn{9}{|c|}{ Analytes } \\
\hline & & & $\begin{array}{l}\text { Chloro- } \\
\text { form }\end{array}$ & $\begin{array}{c}1,1,1- \\
\text { Trichloro-ethane }\end{array}$ & Cyclo-hexane & $\begin{array}{c}\text { Carbon } \\
\text { Tetra- } \\
\text { chloride } \\
\end{array}$ & Benzene & $\begin{array}{l}\text { 1,2-Dichloro- } \\
\text { ethane }\end{array}$ & 1-Butanol & $\begin{array}{c}\text { Trichloro- } \\
\text { ethene }\end{array}$ & $\begin{array}{l}\text { 4-Methyl-2- } \\
\text { pentanone }\end{array}$ \\
\hline D76135 & 4B & $Y$ & - & 711.1 & - & $4,135.0$ & - & - & - & - & - \\
\hline D76135 & 1B & $\mathbf{Y}$ & - & - & - & $1,583.9$ & - & - & - & - & - \\
\hline D76195 & 2B & - & - & $56,578.3$ & - & $24,442.6$ & - & - & - & - & - \\
\hline D76195 & $1 \mathrm{~B}$ & - & - & $13,758.8$ & - & $6,208.6$ & - & - & - & - & - \\
\hline D76196 & 3B & $\mathbf{Y}$ & - & - & - & $29,752.4$ & - & - & - & - & - \\
\hline D76196 & 4B & $\mathbf{Y}$ & - & - & - & $25,409.1$ & - & - & - & - & - \\
\hline D76196 & 1B & - & - & - & - & $12,990.7$ & - & - & - & - & - \\
\hline D76200 & 3B & $\mathbf{Y}$ & - & - & - & $93,445.3$ & - & - & - & - & - \\
\hline D76200 & 4B & $\mathbf{Y}$ & - & - & - & $66,832.7$ & - & - & - & - & - \\
\hline D76200 & 1B & $\mathbf{Y}$ & - & - & - & $43,418.1$ & - & - & - & - & - \\
\hline D76203 & 3B & $Y$ & - & $17,865.6$ & - & $55,792.0$ & - & - & - & - & - \\
\hline D76203 & 4B & $\mathbf{Y}$ & - & $18,266.4$ & - & $60,295.2$ & - & - & - & - & - \\
\hline D76203 & 1B & $\mathbf{Y}$ & - & $3,535.4$ & - & $13,365.8$ & - & - & - & - & - \\
\hline D76283 & 3B & $\mathbf{Y}$ & - & $6,140.2$ & - & $24,561.9$ & - & - & - & - & - \\
\hline D76283 & 4B & $\mathbf{Y}$ & - & $5,038.7$ & - & $20,955.1$ & - & - & - & - & - \\
\hline D76283 & 1B & $\mathbf{Y}$ & - & $1,068.6$ & - & $5,328.2$ & - & - & - & - & - \\
\hline $\begin{array}{l}\text { Notes: } \\
\text { Hea }\end{array}$ & $\begin{array}{ll}\text { ppace } & \text { Sample } \\
\text { 1B } & \text { Operat } \\
\text { 2B } & \text { Operat } \\
\text { 3B } & \text { Detaile } \\
\text { 4B } & \text { Detaile } \\
\text { Y Yes } \\
\text { N No } \\
\text { Unreported a }\end{array}$ & $\begin{array}{l}\text { Program } \\
\text { onal Lid, } \\
\text { onal Bag, } \\
\text { d Bag, V } \\
\text { d Lid, VC } \\
\text { alyte val }\end{array}$ & $\begin{array}{l}\text { VOC Gas } \\
\text { VOC Gas } \\
\text { OC Gas C } \\
\mathrm{C} \text { Gas Cl } \\
\text { ues indica }\end{array}$ & $\begin{array}{l}\text { s Chromatograph } \\
\text { is Chromatograph } \\
\text { Thromatography/M } \\
\text { hromatography/M }\end{array}$ & $\begin{array}{l}\text { y/Mass Spectr } \\
\text { ly/Mass Specti } \\
\text { Mass Spectrom } \\
\text { Aass Spectrom } \\
\text { as undetected, }\end{array}$ & $\begin{array}{l}\text { metry Resul } \\
\text { metry Resu } \\
\text { try Results } \\
\text { try Results } \\
\text { or was detec }\end{array}$ & $\begin{array}{l}\text { (ppmv) } \\
\text { (ppmv) } \\
\text { pmv) } \\
\text { omv) } \\
d \text { at or ab }\end{array}$ & e the MDL b & 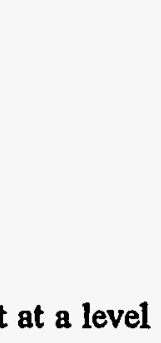 & 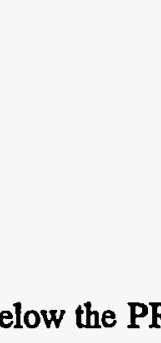 & \\
\hline
\end{tabular}




\subsection{Waste Form Number 113-Solidified Lab Waste, Content Code RF 113A}

\subsubsection{Item Description Code 802-Solidified Lab Waste}

3.4.1.1 Certification Assessment. This IDC is certifiable without further waste treatment. Assay and thermal power calculations, including error, need to be updated to meet the current WIPP WAC. Several gas generation criteria need to be addressed. Carbon filters may need to be installed, drums will require inspection to identify unvented or unpunctured rigid liners, and headspace gas analysis and visual waste characterization will need to be performed.

3.4.1.2 Waste Description. This waste stream is nonpipeline liquid lab waste containing hydrochloric acid that is immobilized with Portland cement and absorbent cement. The liquid waste consists of wastes from the analytical labs, research and development laboratories, and maintenance shops (EG\&G 1994a). Solidified laboratory waste specifically means the processing of those aqueous wastes which are intentionally excluded from the normal liquid waste treatment process and which are immobilized and rendered innocuous by a process that is tailored for each batch (Rockwell International 1989b). These streams were immobilized with the use of a Portland cement ( $42.3 \%$ by weight), Ramcote $(22.8 \%$ by weight) and the waste solution ( $35 \%$ by weight). This combination of cements allowed complete absorption and solidification to occur in the waste form (C).

3.4.1.3 Generation Source. Laboratory wastes were collected in containers at various labs through out the RFP complex. Upon batch accumulation, containers were identified and then transferred to Building 774. IDC 802, solidified lab waste, was generated in Building 774 (C).

3.4. 1.4 Recovery Method. This IDC was never generated as a residue and therefore has no recovery method.

3.4.1.5 Waste Packaging and Handling. TRU laboratory wastes were collected in 4-liter bottles at the point of origin. When enough waste had accumulated to make a transfer to Building 774, each bottle was identified by serial number and sampled. The sample was analyzed for plutonium and americium content. The total plutonium content for the batch was controlled to $<200$ grams. A batch could be as little as 1 liter or as much as several hundred liters of waste solution.

The batch, with each container identified, was then transferred to Waste Operations in Building 774. Packaged waste received in plastic bottles was entered via bag-in operations into the glovebox. The bottles containing acid waste were emptied by vacuum into receiver and neutralizer Tank T-7, adjacent to the glovebox. Sodium hydroxide reagent was added until the color indicator showed the contents of the tank to be basic. The neutralized waste was then drained by gravity back into the glovebox. There, a connecting hose directed the waste into the prepared drum. A maximum of 80 liters of basic waste solution could be added to the prepared drum. Solutions were verified basic by checking with $\mathrm{pH}$ paper. The combination of cements allowed complete absorption and solidification to occur in the waste form, thus creating the solidified lab waste, IDC 802 (C). 
When the drum was full, the drum liners were sealed and the drum was closed. The drum label, completed with all necessary information, was then taped to the drum lid and a TID was attached to the drum.

3.4.1.6 Container Preparation. Only approved containers could be used to package TRU waste for shipment offsite. The containers approved for shipment to INEL during this time were DOT-17C, white, 55-gal drums (Rockwell specification SX-200). These containers met the requirements for certification as DOT-7A Type A packaging (Rockwell International 1989e).

Table 3.4.1-1 shows the current inventory of IDC 802 waste containers from the Rocky Flats Plant that have been shipped to INEL since 1985.

Table 3.4.1-1. Item Description Code 802 Container Information.

\begin{tabular}{|c|c|c|c|}
\hline \multicolumn{2}{|l|}{ Information } & \multirow{2}{*}{$\frac{\text { Drums }}{78}$} & \multirow{2}{*}{$\frac{\text { Boxes }}{0}$} \\
\hline Total Containers & & & \\
\hline \multirow[t]{3}{*}{ Net Container Weight (lb) } & Maximum & 649 & N/A \\
\hline & Minimum & 239 & N/A \\
\hline & Average & 559 & N/A \\
\hline
\end{tabular}

3.4.1.6.1 Drum Preparation-Approved liners for drums of TRU waste packaged for offsite shipment were the round-bottom liner (Rockwell specification SX-203) inside a 90-mil rigid polyethylene liner (Rockwell specification SX-202), or an O-ring bag and a polyethylene bag placed inside the rigid liner if the drum was attached to a glovebox (Rockwell International 1989e). Type III rigid liners have been used since September 1983 (Bearly 1989a). The IDC 802 waste packaged for offsite shipment required an 0-ring bag and a polyethylene bag inside the rigid liner (Rockwell International 1988c). Figure C-2 shows the appropriate drum liners for this IDC. All bags were closed using the twist-and-tape method (Rockwell International 1989e).

Flow-in, ventable gaskets were installed in the drums beginning in December 1982. They were used until October 1988, when tubular gaskets with carbon filters were required. Drums shipped to INEL between 1985 and 1988 may not meet the current WIPP WAC, owing to their lack of carbon filters (Bearly 1989a).

3.4. 1.6.2 Box Preparation-No boxes of IDC 802 waste were shipped to INEL between 1985 and 1989.

3.4.1.7 Assay. Assay was performed radiochemically. The summation of the assays of individual bottles and tank waste placed in one drum was used for the drum assay. The batch was controlled to be $<200$ grams. Table 3.4.1-2 summarizes the dose rates measured on containers of this IDC. Table 3.4.1-3 provides a summary of the assay information. Two drums were evaluated for uranium, none were evaluated for americium. This IDC may contain plutonium-242. 
Table 3.4.1-2. Item Description Code 802 Dose Information.

\begin{tabular}{crrc}
\hline Information & & Drums & Boxes \\
\hline One Meter Dose Rate (mrem/h) & $0-0.5$ & 73 & N/A \\
& $0.5-10$ & 5 & N/A \\
Surface Dose Rate (mrem/h) & $<10$ & 78 & N/A \\
& $10-200$ & 0 & N/A \\
\hline
\end{tabular}

Table 3.4.1-3. Item Description Code 802 Assay Information.

\begin{tabular}{|c|c|c|c|}
\hline \multicolumn{2}{|c|}{ Radionuclide inventory } & $\frac{\text { Drums }}{21}$ & $\frac{\text { Boxes }}{\text { N/A }}$ \\
\hline Plutonium (g) & $\begin{array}{r}\text { Maximum } \\
\text { Minimum } \\
\text { Average }\end{array}$ & $\begin{array}{r}21 \\
0 \\
5\end{array}$ & $\begin{array}{l}\text { N/A } \\
\text { N/A } \\
\text { N/A }\end{array}$ \\
\hline Americium (g) & $\begin{array}{r}\text { Maximum } \\
\text { Minimum } \\
\text { Average }\end{array}$ & $\begin{array}{l}- \\
-\end{array}$ & $\begin{array}{l}\text { N/A } \\
\text { N/A } \\
\text { N/A }\end{array}$ \\
\hline Uranium-235 (g) & $\begin{array}{r}\text { Maximum } \\
\text { Minimum } \\
\text { Average }\end{array}$ & $\begin{array}{r}73 \\
1 \\
37\end{array}$ & $\begin{array}{l}\text { N/A } \\
\text { N/A } \\
\text { N/A }\end{array}$ \\
\hline
\end{tabular}

3.4.1.8 Inspection. Waste Certification personnel reviewed process documentation to ensure the process was operated properly. Waste Certification personnel also performed periodic inspections of the generating and packaging process to verify compliance with waste acceptance criteria. In addition, each drum was viewed using RTR to

- Ensure the drum does not contain nonconforming items

- Ensure the drum is properly packaged

- Verify the waste form description

- Evaluate the presence of free liquids.

3.4.1.9 Waste Form Evaluation. Table 3.4.1-4 evaluates the waste form against the WIPP WAC for such items as free liquids, pyrophoric materials, and compressed gases. Table 3.4.1-5 evaluates the waste against TRUPACT criteria. 
Table 3.4.1-4. Waste Form Evaluation.

Criterion or requirement

Limiting parameters ${ }^{\mathrm{a}}$

Immobilization

This IDC is from a process designed to produce a stable waste form. Based on the description of the waste, fine particulates are not expected in this IDC.

Liquids

There are normally no liquids associated with this IDC. Personnel performing RTR examination at Rocky Flats would accept up to 2 cups of free liquid, if liquids were present.

Pyrophoric

Materials

Pyrophoric materials were prohibited by procedural control. The absence of the pyrophoric materials was verified by the generating supervisor and periodic inspection by the Waste Certification Organization.

Explosives and

Compressed Gases

Explosives and compressed gases were prohibited by procedural control. The absence of the explosives and compressed gases was verified by the generating supervisor and periodic inspection by the Waste Certification Organization. In addition, unvented, closed containers and pressurized containers were excluded by procedural controls and RTR examination.

TRU-Mixed Wastes The RCRA constituents exist as co-contaminants with the transuranic radionuclides. Compliance with the WIPP RCRA permits and NMD will be required before shipment of the stored waste to WIPP.

Specific Activity of A portion of the waste stored at INEL may contain $<100$ nanocuries per gram Waste transuranic radionuclides. This IDC may contain plutonium-242.

$\mathrm{Pu}^{239}$ Equivalent Activity None of the IDC 802 waste containers recorded as shipped to INEL in the SWIMS exceed $1,000 \mathrm{Ci}$ of plutonium-equivalent activity.

a. Many of the limiting parameters were taken from TRU Waste Compliance Program (Rockwell International 1983a, 1987e, and 1989b). 
Table 3.4.1-5. TRUPACT Evaluation.

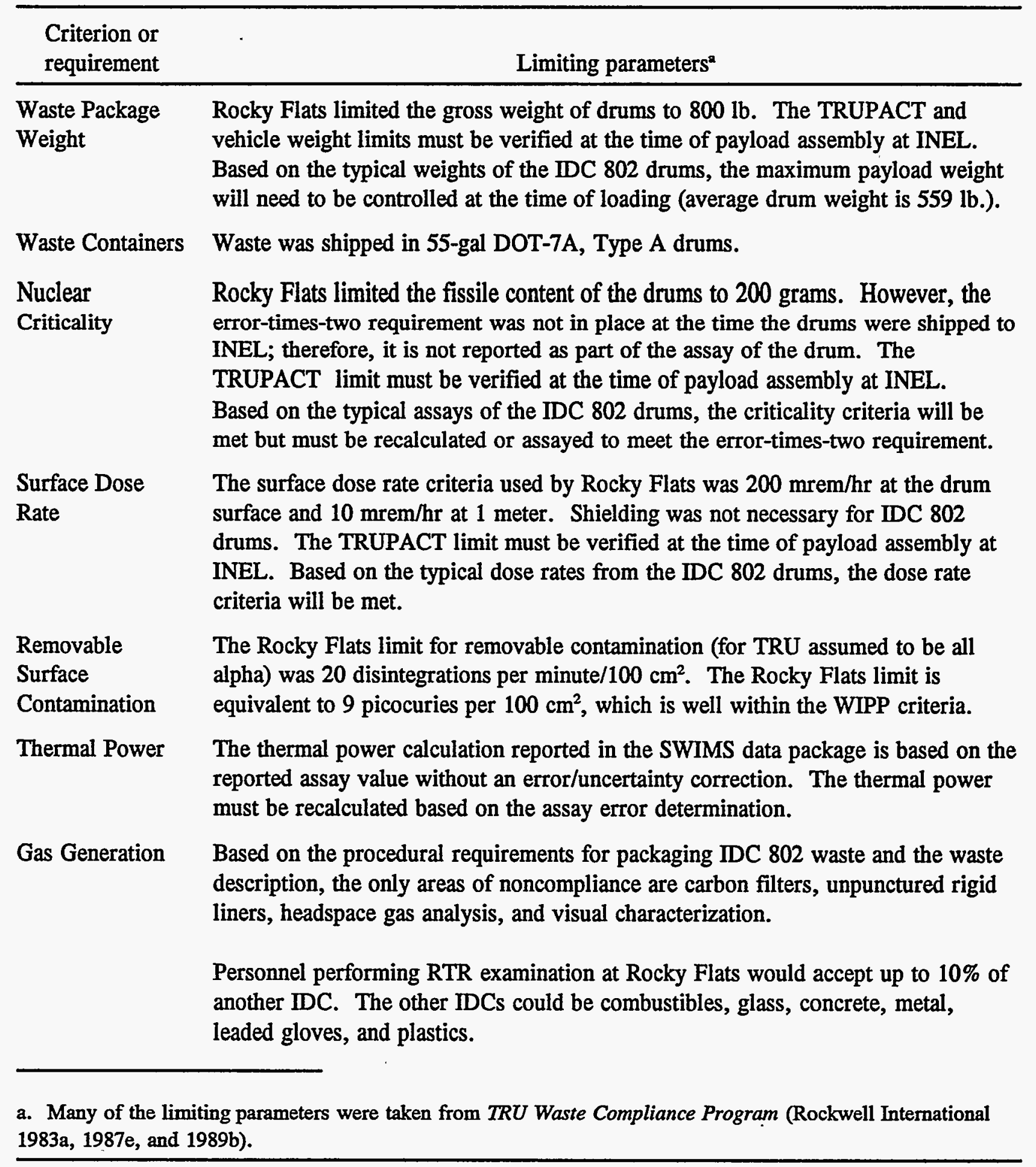


3.4.1.10 Combustible and Organic Content. SWIMS data indicate that this waste form does not contain $>20 \%$ combustibles, but contains $>20 \%$ organics.

3.4.1.10.1 Combustible Content-SWIMS data show that IDC 802 waste is noncombustible (Rockwell International 1985a).

3.4.1.10.2 Organic Content-SWIMS data show that IDC 802 waste contains 5\% organics (Rockwell International 1985a).

3.4.1.11 Analytical Information. No analytical information is available for IDC 802 .

A surrogate study, the TCLP Test Results of Cemented Surrogate Analytical Laboratory Solution Waste (Phillips and others, 1994), indicates that the cementation method used for laboratory waste solidification prevents leaching of cadmium, chromium, barium, lead, and nickel. The data collected for this study indicates further investigation is needed before a determination can be made for the treatability of silver. Therefore, EPA Code D011 is assigned to containers of IDC 802 waste that were generated from original waste materials containing silver $(C)$. 


\subsection{Waste Form Number 114-Solidified Process Solids, Content Code RF 114A}

\subsubsection{Item Description Code 806-Solidified Process Solids}

3.5.1.1 Certification Assessment. This IDC is certifiable without further waste treatment. Assay and thermal power calculations, including error, need to be updated to meet the current WIPP WAC. Several gas generation criteria need to be addressed. Carbon filters may need to be installed, drums will require inspection to identify unvented or unpunctured rigid liners, and headspace gas analysis and visual waste characterization will need to be performed.

3.5. 1.2 Waste Description. This waste includes all inorganic particulate and inorganic sludge that is immobilized into a solid with Portland cement. A formula for each waste type was used to precondition the waste (neutralize, thicken), and the amount of Portland cement, mixing method, and cure time was recorded. Cemented wastes were cast into 1-gal molds and allowed to cure. The cured "pucks" were removed from the molds in the form of a solid monolith (Rockwell International 1989b).

3.5.1.3 Generation Source. The major generator of this waste was Plutonium Recovery Operations in Building 771 (Rockwell International 1987e).

3.5. 1.4 Recovery Method. This IDC was never generated as a residue and therefore has no recovery method.

3.5.1.5 Waste Packaging and Handling. Process solids were the particulate and sludgetype wastes that had been processed to recover as much plutonium as was economically feasible. After processing, the wastes were removed from the glovebox in 4-liter (or smaller) polyethylene containers and assayed for plutonium. The waste packages were collected in a 55-gal drum for transfer to the solidification area (Rockwell International 1989b).

Each drum of process solids was processed as a batch. One drum of unsolidified waste produced three drums of solidified process solids. After solidification, the "pucks" were removed from the glovebox, double-bagged, and placed into a DOT-17C, 55-gal, steel drum with a 90-mil rigid liner.

3.5. 1.6 Container Preparation. Only approved containers could be used to package TRU waste for shipment offsite. The containers approved for shipment to INEL during this time were DOT-17C, white, 55-gal drums (Rockwell specification SX-200). These containers met the requirements for certification as DOT-7A Type A packaging (Rockwell International 1989e).

Table 3.5.1-1 shows the current inventory of IDC 806 waste containers from the Rocky Flats Plant that have been shipped to INEL since 1985. 
Table 3.5.1-1. Item Description Code 806 Container Information.

\begin{tabular}{|c|c|c|c|}
\hline \multicolumn{2}{|c|}{ Information } & \multirow{2}{*}{$\frac{\text { Drums }}{41}$} & \multirow{2}{*}{$\frac{\text { Boxes }}{0}$} \\
\hline Total Containers & & & \\
\hline \multirow[t]{3}{*}{ Net Container Weight (lb) } & Maximum & 370 & N/A \\
\hline & Minimum & 60 & N/A \\
\hline & Average & 236 & N/A \\
\hline
\end{tabular}

3.5.1.6.1 Drum Preparation-Approved liners for drums of TRU waste packaged for offsite shipment were the round-bottom liner (Rockwell specification SX-203) inside a 90-mil rigid polyethylene liner (Rockwell specification SX-202), or an O-rịng bag and a polyethylene bag placed inside the rigid liner if the drum was attached to a glovebox (Rockwell International 1989e). Type III rigid liners have been used since September 1983 (Bearly 1989a). No information regarding packaging requirements for this waste form could be located.

Flow-in, ventable gaskets were installed in the drums beginning in December 1982. They were used until October 1988, when tubular gaskets with carbon filters were required. Drums shipped to INEL between 1985 and 1988 may not meet the current WIPP WAC, owing to their lack of carbon filters (Bearly 1989a).

3.5. 1.6.2 Box Preparation-No boxes of IDC 806 waste were shipped to INEL between 1985 and 1989.

3.5.1.7 Assay. Individual containers of processed material are assayed in the "in-line can counter." The individual assay values for containers solidified in a batch and placed into a drum were totaled to provide an assigned assay value for the drum. The drums may have been checked on an SGS counter or PADC to verify the assay value. Containers of waste that have not been PADC assayed and had SGS or in-line can counter assay values of 1 gram or less should be PADC assayed to verify that they are transuranic waste. Table 3.5.1-2 summarizes the dose rates measured on containers of this IDC. Table 3.5.1-3 provides a summary of the assay information.

Table 3.5.1-2. Item Description Code 806 Dose Information.

\begin{tabular}{|c|c|c|c|}
\hline Information & & Drums & Boxes \\
\hline One Meter Dose Rate $(\mathrm{mrem} / \mathrm{h})$ & $\begin{array}{r}0-0.5 \\
0.5-10\end{array}$ & $\begin{array}{r}40 \\
1\end{array}$ & $\begin{array}{l}\text { N/A } \\
\text { N/A }\end{array}$ \\
\hline Surface Dose Rate (mrem/h) & $\begin{array}{r}<10 \\
10-200\end{array}$ & $\begin{array}{r}41 \\
0\end{array}$ & $\begin{array}{l}\text { N/A } \\
\text { N/A }\end{array}$ \\
\hline
\end{tabular}


Table 3.5.1-3. Item Description Code 806 Assay Information.

\begin{tabular}{|c|c|c|c|}
\hline \multicolumn{2}{|c|}{ Radionuclide inventory } & \multirow{2}{*}{$\begin{array}{c}\text { Drums } \\
180\end{array}$} & \multirow{2}{*}{$\frac{\text { Boxes }}{\text { N/A }}$} \\
\hline Plutonium (g) & Maximum & & \\
\hline & Minimum & 0 & N/A \\
\hline & Average & 14 & N/A \\
\hline Americium (g) & Maximum & $\mathbf{0}$ & N/A \\
\hline & Minimum & 0 & N/A \\
\hline & Average & 0 & N/A \\
\hline Uranium-235 (g) & Maximum & - & N/A \\
\hline & Minimum & - & N/A \\
\hline & Average & - & N/A \\
\hline
\end{tabular}

3.5.1.8 Inspection. Waste Certification periodically reviewed the process documentation to ensure that the process was operated properly. Waste Certification personnel also performed periodic inspections of the generating and packaging process to verify compliance with waste acceptance criteria. In addition, each drum was viewed using RTR to

- Ensure the drum does not contain nonconforming items

- Ensure the drum is properly packaged

- Verify the waste form description

- Evaluate the presence of free liquids.

3.5.1.9 Waste Form Evaluation. Table 3.5.1-4 evaluates the waste form against the WIPP WAC for such items as free liquids, pyrophoric materials, and compressed gases. Table 3.5.1-5 evaluates the waste against TRUPACT criteria. 
Table 3.5.1-4. Waste Form Evaluation.

Criterion or requirement

Limiting parameters

Immobilization

This waste form is the final product of a treatment system designed to immobilize particulates. Based on the description of the waste, fine particulates are not expected in this IDC.

Liquids There are normally no liquids associated with this IDC. Personnel performing RTR examination at Rocky Flats would accept up to 2 cups of free liquid, if liquids were present.

Pyrophoric Pyrophoric materials were prohibited by procedural control. The absence of the Materials pyrophoric materials was verified by the generating supervisor and periodic inspection by the Waste Certification Organization.

Explosives and Compressed Gases

Explosives and compressed gases were prohibited by procedural control. The absence of the explosives and compressed gases was verified by the generating supervisor and periodic inspection by the Waste Certification Organization. In addition, unvented, closed containers and pressurized containers were excluded by procedural controls and RTR examination.

TRU-Mixed Wastes The RCRA constituents exist as co-contaminants with the transuranic radionuclides. Compliance with the WIPP RCRA permits and NMD will be required before shipment of the stored waste to WIPP.

Specific Activity of A portion of the waste stored at INEL may contain $<100$ nanocuries per gram Waste transuranic radionuclides.

$\mathrm{Pu}^{239}$ Equivalent None of the IDC 806 waste containers recorded as shipped to INEL in the Activity SWIMS exceed 1,000 $\mathrm{Ci}$ of plutonium-equivalent activity.

a. Many of the limiting parameters were taken from TRU Waste Compliance Program (Rockwell International 1983a, 1987e, and 1989b). 
Table 3.5.1-5. TRUPACT Evaluation.

Criterion or requirement

Limiting parameters ${ }^{\mathbf{a}}$

Waste Package Rocky Flats limited the gross weight of drums to $800 \mathrm{lb}$. The TRUPACT and Weight vehicle weight limits must be verified at the time of payload assembly at INEL.

Waste Containers This waste was packaged in 55-gal DOT-7A, Type A containers.

Nuclear Criticality

Rocky Flats limited the fissile content of the drums to 200 grams. However, the error-times-two requirement was not in place at the time the drums were shipped to INEL; therefore, it is not reported as part of the assay of the drum. The TRUPACT limit must be verified at the time of payload assembly at INEL. Based on the typical assays of the IDC 806 drums, the criticality criteria will be met but must be recalculated or assayed to meet the error-times-two requirement.

Surface Dose The surface dose rate criteria used by Rocky Flats was $200 \mathrm{mrem} / \mathrm{hr}$ at the drum Rate surface and $10 \mathrm{mrem} / \mathrm{hr}$ at 1 meter. Shielding was not necessary for IDC 806 drums. The TRUPACT limit must be verified at the time of payload assembly at INEL. Based on the typical dose rates from the IDC 806 drums, the dose rate criteria will be met.

Removable The Rocky Flats limit for removable contamination (for TRU assumed to be all Surface alpha) was 20 disintegrations per minute $/ 100 \mathrm{~cm}^{2}$. The Rocky Flats limit is Contamination equivalent to 9 picocuries per $100 \mathrm{~cm}^{2}$, which is well within the WIPP criteria.

Thermal Power The thermal power calculation reported in the SWIMS data package is based on the reported assay value without an error/uncertainty correction. The thermal power must be recalculated based on the assay error determination.

Gas Generation Based on the procedural requirements for packaging IDC 806 waste and the waste description, the only areas of noncompliance are carbon filters, unpunctured rigid liners, headspace gas analysis, and visual characterization.

Personnel performing RTR examination at Rocky Flats would accept up to $10 \%$ of another IDC. The other IDCs could be combustibles, glass, concrete, metal, leaded gloves, and plastics.

a. Many of the limiting parameters were taken from TRU Waste Compliance Program (Rockwell International 1983a, 1987e, and 1989b). 
3.5.1.10 Combustible and Organic Content. SWIMS data indicate that this waste form does not contain $>20 \%$ combustibles or $>20 \%$ organics.

3.5.1.10.1 Combustible Content-SWIMS data show that IDC 806 waste is noncombustible (Rockwell International 1985a).

3.5.1.10.2 Organic Content-SWIMS data show that IDC 806 waste contains $20 \%$ organics (Rockwell International 1985a).

3.5.1.11 Analytical Information. No analytical information is available for IDC 806 .

The RCRA characterization for IDC 806 has not been established. 


\subsection{Waste Form Number 114-Solidified Process Solids, Content Code RF 114A}

\subsubsection{Item Description Code 817-Cemented SS\&C Heels}

3.5.2.1 Certification Assessment. This IDC is certifiable without further waste treatment. Assay and thermal power calculations, including error, need to be updated to meet the current WIPP WAC. Several gas generation criteria need to be addressed. Carbon filters may need to be installed, drums will require inspection to identify unvented or unpunctured rigid liners, and headspace gas analysis and visual waste characterization will need to be performed.

3.5.2.2 Waste Description. IDC 817, cemented sand, slag, and crucible heels, consists of the remaining insoluble residues generated following plutonium leaching with hot nitric acid. After leaching, the insoluble residue (heel) was collected on a filter and dried on a hotplate (Rockwell International 1987e). A formula was used to precondition the waste (that is, neutralize, thicken), and the amount of Portland cement, mixing method, and cure time were recorded. Cemented wastes were cast into 1-gal molds and allowed to cure. The cured "pucks" were removed from the molds in the form of a solid monolith. IDC 817 is included in IDC 806 (Rockwell International 1989b).

3.5.2.3 Generation Source. The major generator of this waste was Plutonium Recovery Operations in Building 771 (Rockwell International 1987e).

3.5.2.4 Recovery Method. This IDC was never generated as a residue and therefore has no recovery method.

3.5.2.5 Waste Packaging and Handling. Process solids were the particulate and sludgetype wastes that had been processed to recover as much plutonium as economically feasible. After processing, the wastes were removed from the glovebox in 4-liter (or smaller) polyethylene containers and assayed for plutonium. The waste packages were collected in a 55-gal drum for transfer to the solidification area (Rockwell International 1989b).

Each drum of process solids was processed as a batch. One drum of unsolidified waste produced three drums of solidified process solids. After solidification, the "pucks" were removed from the glovebox, double-bagged, and placed into a DOT-17C, 55-gal, steel drum with a 90-mil rigid liner.

3.5.2.6 Container Preparation. Only approved containers could be used to package TRU waste for shipment offsite. The containers approved for shipment to INEL during this time were DOT-17C, white, 55-gal drums (Rockwell specification SX-200). These containers met the requirements for certification as DOT-7A Type A packaging (Rockwell International 1989e).

Table 3.5.2-1 shows the current inventory of IDC 817 waste containers from the Rocky Flats Plant that have been shipped to INEL since 1985. 
Table 3.5.2-1. Item Description Code 817 Container Information.

\begin{tabular}{lrcc}
\hline \multicolumn{1}{c}{ Information } & & Drums & Boxes \\
\hline Total Containers & & 27 & 0 \\
Net Container Weight (lb) & Maximum & 435 & N/A \\
& Minimum & 114 & N/A \\
& Average & 333 & N/A \\
\hline
\end{tabular}

3.5.2.6.1 Drum Preparation-Approved liners for drums of TRU waste packaged for offsite shipment were the round-bottom liner (Rockwell specification SX-203) inside a 90-mil rigid polyethylene liner (Rockwell specification SX-202), or an O-ring bag and a polyethylene bag placed inside the rigid liner if the drum was attached to a glovebox (Rockwell International 1989e). Type III rigid liners have been used since September 1983 (Bearly 1989a). No information regarding packaging requirements for this waste form could be located.

Flow-in, ventable gaskets were installed in the drums beginning in December 1982. They were used until October 1988, when tubular gaskets with carbon filters were required. Drums shipped to INEL between 1985 and 1988 may not meet the current WIPP WAC, owing to their lack of carbon filters (Bearly 1989a).

3.5.2.6.2 Box Preparation-No boxes of IDC 817 waste were shipped to INEL between 1985 and 1989.

3.5.2.7 Assay. Individual containers of processed material are assayed in the "in-line can counter." The individual assay values for containers solidified in a batch and placed into a drum are totaled to provide an assigned assay value for the drum. The drums may have been assayed on an SGS counter or a PADC to verify this assay value. Table 3.5.2-2 summarizes the dose rates measured on containers of this IDC. Table $3.5 .2-3$ provides a summary of the assay information.

Table 3.5.2-2. Item Description Code 817 Dose Information.

\begin{tabular}{crrc}
\hline Information & & Drums & Boxes \\
\hline One Meter Dose Rate (mrem/h) & $0-0.5$ & 26 & N/A \\
& $0.5-10$ & 1 & N/A \\
Surface Dose Rate (mrem/h) & $<10$ & 27 & N/A \\
& $10-200$ & 0 & N/A \\
\hline
\end{tabular}


Table 3.5.2-3. Item Description Code 817 Assay Information.

\begin{tabular}{lcccc}
\hline \multicolumn{2}{c}{ Radionuclide inventory } & Drums & Boxes \\
\cline { 2 - 4 } Plutonium (g) & Maximum & 72.5 & N/A \\
& Minimum & 11.4 & N/A \\
& Average & 29.2 & N/A \\
& Maximum & - & N/A \\
& Americium (g) & Minimum & - & N/A \\
& Average & - & N/A \\
& Uranium-235 (g) & Maximum & - & N/A \\
& Minimum & - & N/A \\
\hline
\end{tabular}

3.5.2.8 Inspection. Waste Certification personnel periodically reviewed the process documentation to verify that the process was operated properly. Waste Certification personnel also performed periodic inspections of the generating and packaging process to verify compliance with waste acceptance criteria. In addition, each drum was viewed using RTR to

- Ensure the drum does not contain nonconforming items

- Ensure the drum is properly packaged

- Verify the waste form description

- Evaluate the presence of free liquids.

3.5.2.9 Waste Form Evaluation. Table 3.5.2-4 evaluates the waste form against the WIPP WAC for such items as free liquids, pyrophoric materials, and compressed gases. Table 3.5.2-5 evaluates the waste against TRUPACT criteria. 
Table 3.5.2-4. Waste Form Evaluation.

Criterion or requirement

Limiting parameters ${ }^{2}$

Immobilization

This waste form is the final product of a treatment system designed to immobilize particulates. Based on the description of the waste, fine particulates are not expected in this IDC.

Liquids There are normally no liquids associated with this IDC. Personnel performing RTR examination at Rocky Flats would accept up to 2 cups of free liquid, if liquids were present.

Pyrophoric

Pyrophoric materials were prohibited by procedural control. The absence of the Materials pyrophoric materials was verified by the generating supervisor and periodic inspection by the Waste Certification Organization.

Explosives and Compressed Gases

Explosives and compressed gases were prohibited by procedural control. The absence of the explosives and compressed gases was verified by the generating supervisor and periodic inspection by the Waste Certification Organization. In addition, unvented, closed containers and pressurized containers were excluded by procedural controls and RTR examination.

TRU-Mixed Wastes The RCRA constituents exist as co-contaminants with the transuranic radionuclides. Compliance with the WIPP RCRA permits and NMD will be required before shipment of the stored waste to WIPP.

Specific Activity of This waste contains at least 100 nanocuries per gram transuranic radionuclides. Waste

$\mathrm{Pu}^{299}$ Equivalent None of the IDC 817 waste containers recorded as shipped to INEL in the Activity SWIMS exceed $1,000 \mathrm{Ci}$ of plutonium-equivalent activity.

a. Many of the limiting parameters were taken from TRU Waste Compliance Program (Rockwell International 1983a, 1987e, and 1989b). 
Table 3.5.2-5. TRUPACT Evaluation.

\begin{tabular}{|c|c|}
\hline $\begin{array}{l}\text { Criterion or } \\
\text { requirement }\end{array}$ & Limiting parameters ${ }^{2}$ \\
\hline $\begin{array}{l}\text { Waste Package } \\
\text { Weight }\end{array}$ & $\begin{array}{l}\text { Rocky Flats limited the gross weight of drums to } 800 \mathrm{lb} \text {. The TRUPACT and } \\
\text { vehicle weight limits must be verified at the time of payload assembly at INEL. }\end{array}$ \\
\hline Waste Containers & This waste was packaged in 55-gal DOT-7A, Type A containers. \\
\hline $\begin{array}{l}\text { Nuclear } \\
\text { Criticality }\end{array}$ & $\begin{array}{l}\text { Rocky Flats limited the fissile content of the drums to } 200 \text { grams. However, the } \\
\text { error-times-two requirement was not in place at the time the drums were shipped to } \\
\text { INEL; therefore, it is not reported as part of the assay of the drum. The } \\
\text { TRUPACT limit must be verified at the time of payload assembly at INEL. Based } \\
\text { on the typical assays of the IDC } 817 \text { drums, the criticality criteria will be met but } \\
\text { must be recalculated or assayed to meet the error-times-two requirement. }\end{array}$ \\
\hline $\begin{array}{l}\text { Surface Dose } \\
\text { Rate }\end{array}$ & $\begin{array}{l}\text { The surface dose rate criteria used by Rocky Flats was } 200 \mathrm{mrem} / \mathrm{hr} \text { at the drum } \\
\text { surface and } 10 \mathrm{mrem} / \mathrm{hr} \text { at } 1 \text { meter. Shielding was not necessary for IDC } 817 \\
\text { drums. The TRUPACT limit must be verified at the time of payload assembly at } \\
\text { INEL. Based on the typical dose rates from the IDC } 817 \text { drums, the dose rate } \\
\text { criteria will be met. }\end{array}$ \\
\hline $\begin{array}{l}\text { Removable } \\
\text { Surface } \\
\text { Contamination }\end{array}$ & $\begin{array}{l}\text { The Rocky Flats limit for removable contamination (for TRU assumed to be all } \\
\text { alpha) was } 20 \text { disintegrations per minute } / 100 \mathrm{~cm}^{2} \text {. The Rocky Flats limit is } \\
\text { equivalent to } 9 \text { picocuries per } 100 \mathrm{~cm}^{2} \text {, which is well within the WIPP criteria. }\end{array}$ \\
\hline Thermal Power & $\begin{array}{l}\text { The thermal power calculation reported in the SWIMS data package is based on the } \\
\text { reported assay value without an error/uncertainty correction. The thermal power } \\
\text { must be recalculated based on the assay error determination. }\end{array}$ \\
\hline Gas Generation & $\begin{array}{l}\text { Based on the procedural requirements for packaging IDC } 817 \text { waste and the waste } \\
\text { description, the only areas of noncompliance are carbon filters, unpunctured rigid } \\
\text { liners, headspace gas analysis, and visual characterization. }\end{array}$ \\
\hline & $\begin{array}{l}\text { Personnel performing RTR examination at Rocky Flats would accept up to } 10 \% \text { of } \\
\text { another IDC. The other IDCs could be combustibles, glass, concrete, metal, } \\
\text { leaded gloves, and plastics. }\end{array}$ \\
\hline
\end{tabular}

a. Many of the limiting parameters were taken from TRU Waste Compliance Program (Rockwell International 1983a, 1987e, and 1989b).

3.5.2.9 Combustible and Organic Content. SWIMS data indicate that this waste form does not contain $>20 \%$ combustibles or $>20 \%$ organics.

3.5.2.9.1 Combustible Content-SWIMS data show that IDC 817 waste is noncombustible (Rockwell International 1985a).

3.5.2.9.2 Organic Content-SWIMS data show that IDC 817 waste contains $10 \%$ organics (Rockwell International 1985a). 
3.5.2.10 Analytical Information. No analytical information is available for IDC 817.

It is presumed that IDC 393 EPA codes also apply to IDC 817. IDC 393 is assigned the EPA Code D007 (EG\&G RFP 1992a, EG\&G RFP 1993g, EG\&G RFP 1992b). Chromium can be added to the heel from the corrosion of the stainless steel in the dissolution process area (EG\&G RFP 1994d). 


\subsection{Waste Form Number 114-Solidified Process Solids, Content Code RF 114A}

\subsubsection{Item Description Code 818-Cemented Ash}

3.5.3.1 Certification Assessment. This IDC is certifiable without further waste treatment. Assay and thermal power calculations, including error, need to be updated to meet the current WIPP WAC. Several gas generation criteria need to be addressed. Carbon filters may need to be installed, drums will require inspection to identify unvented or unpunctured rigid liners, and headspace gas analysis and visual waste characterization will need to be performed.

3.5.3.2 Waste Description. It is presumed that the waste description for IDC 420, Pulverized Incinerator Ash, also applies to IDC 818, Cemented Ash. IDC 420 consists of a mixture of coarse, granular, fine, and very fine particulates that have been ground by the ball mill. The ash contains miscellaneous tramp metal, bits of unburned feed material, and carbon from the incomplete oxidation of feed material (A).

IDC 818 was immobilized into a solid with Portland cement. A formula for each waste type was used to precondition the waste (that is, neutralize, thicken), and the amount of Portland cement, the mixing method, and cure time were recorded. Cemented wastes were cast into 1-gal molds and allowed to cure. The cured "pucks" were removed from the molds in the form of a solid monolith. IDC 818 is included in IDC 806.

3.5.3.3 Generation Source. It is presumed that IDC 818-Cemented Ash, was generated by the same source as IDC 420 as both are incinerator byproducts. IDC 420 -Pulverized Incinerator Ash, was generated by the Residue Recovery Incinerator system in Building 771. The function of the Residue Recovery Incinerator was to reduce volume and destroy volatile constituents prior to plutonium recovery operations for combustible wastes from production processes (primarily IDCs $330,331,336$, and 337) (A).

3.5.3.4 Recovery Method. This IDC was never generated as a residue and therefore has no recovery method.

3.5.3.5 Waste Packaging and Handling. Waste includes all incinerator ash that is immobilized into a solid with Portland cement. A formula for each waste type is used to precondition the waste (that is, neutralize, thicken), and the amount of Portland cement, the mixing method, and the cure time are recorded. Cemented wastes are cast into 1-gal molds and allowed to cure. The cured "pucks" are removed from the molds in the form of a solid monolith.

3.5.3.6 Container Preparation. Only approved containers could be used to package TRU waste for shipment offsite. The containers approved for shipment to INEL during this time were DOT-17C, white, 55-gal drums (Rockwell specification SX-200). These containers met the requirements for certification as DOT-7A Type A packaging (Rockwell International 1989e). 
Table 3.5.3-1 shows the current inventory of IDC 818 waste containers from the Rocky Flats Plant that have been shipped to INEL since 1985.

Table 3.5.3-1. Item Description Code 818 Container Information.

\begin{tabular}{|c|c|c|c|}
\hline \multicolumn{2}{|l|}{ Information } & \multirow{2}{*}{$\frac{\text { Drums }}{8}$} & \multirow{2}{*}{$\frac{\text { Boxes }}{0}$} \\
\hline Total Containers & & & \\
\hline \multirow[t]{3}{*}{ Net Container Weight (lb) } & Maximum & 334 & N/A \\
\hline & Minimum & 162 & N/A \\
\hline & Average & 261 & N/A \\
\hline
\end{tabular}

3.5.3.6.1 Drum Preparation-Approved liners for drums of TRU waste packaged for offsite shipment were the round-bottom liner (Rockwell specification SX-203) inside a 90-mil rigid polyethylene liner (Rockwell specification SX-202), or an O-ring bag and a polyethylene bag placed inside the rigid liner if the drum was attached to a glovebox (Rockwell International 1989e). Type III rigid liners have been used since September 1983 (Bearly 1989a). No information regarding packaging requirements for this waste form could be located.

Flow-in, ventable gaskets were installed in the drums beginning in December 1982. They were used until October 1988, when tubular gaskets with carbon filters were required. Drums shipped to INEL between 1985 and 1988 may not meet the current WIPP WAC, owing to their lack of carbon filters (Bearly 1989a).

3.5.3.6.2 Box Preparation-No boxes of IDC 818 waste were shipped to INEL between 1985 and 1989.

3.5.3.7 Assay. Individual containers of processed material are assayed in the "in-line can counter." The individual assay values for containers solidified in a batch and placed into a drum are totaled to provide an assigned assay value for the drum. The drums may have been assayed on an SGS counter or a PADC to verify the assigned assay value. Containers of waste that have not been PADC assayed and had SGS or in-line can counter assay values of 1 gram or less should be PADC assayed to verify that they are transuranic waste. Table 3.5.3-2 summarizes the dose rates measured on containers of this IDC. Table 3.5.3-3 provides a summary of the assay information.

Table 3.5.3-2. Item Description Code 818 Dose Information.

\begin{tabular}{|c|c|c|c|}
\hline Information & & Drums & Boxes \\
\hline One Meter Dose Rate (mrem/h) & $\begin{array}{r}0-0.5 \\
0.5-10\end{array}$ & $\begin{array}{l}8 \\
0\end{array}$ & $\begin{array}{l}\text { N/A } \\
\text { N/A }\end{array}$ \\
\hline Surface Dose Rate (mrem/h) & $\begin{array}{r}<10 \\
10-200\end{array}$ & $\begin{array}{l}8 \\
0\end{array}$ & $\begin{array}{l}\text { N/A } \\
\text { N/A }\end{array}$ \\
\hline
\end{tabular}


Table 3.5.3-3. Item Description Code 818 Assay Information.

\begin{tabular}{|c|c|c|c|}
\hline \multicolumn{2}{|c|}{ Radionuclide inventory } & \multirow{2}{*}{$\begin{array}{r}\text { Drums } \\
5.25\end{array}$} & \multirow{2}{*}{$\frac{\text { Boxes }}{\text { N/A }}$} \\
\hline Plutonium (g) & Maximum & & \\
\hline & Minimum & 0.66 & N/A \\
\hline & Average & 3.06 & N/A \\
\hline Americium (g) & Maximum & - & N/A \\
\hline & Minimum & - & N/A \\
\hline & Average & - & N/A \\
\hline Uranium-235 (g) & Maximum & - & N/A \\
\hline & Minimum & - & N/A \\
\hline & Average & - & N/A \\
\hline
\end{tabular}

3.5.3.8 Inspection. Waste Certification personnel periodically reviewed the process documentation to verify that the process was operated properly. Waste Certification personnel also performed periodic inspections of the generating and packaging process to verify compliance with waste acceptance criteria. In addition, each drum was viewed using RTR to

- Ensure the drum does not contain nonconforming items

- Ensure the drum is properly packaged

- Verify the waste form description

- Evaluate the presence of free liquids.

3.5.3.9 Waste Form Evaluation. Table 3.5.3-4 evaluates the waste form against the WIPP WAC for such items as free liquids, pyrophoric materials, and compressed gases. Table 3.5.3-5 evaluates the waste against TRUPACT criteria. 
Table 3.5.3-4. Waste Form Evaluation.

\section{Criterion or}

requirement

Immobilization

Liquids

Pyrophoric

Materials

Explosives and

Compressed Gases

TRU-Mixed Wastes

Specific Activity of Waste

$\mathrm{Pu}^{239}$ Equivalent

Activity
Limiting parameters ${ }^{2}$

This waste form is the final product of a treatment system designed to immobilize particulates. Based on the description of the waste, fine particulates are not expected in this IDC.

There are normally no liquids associated with this IDC. Personnel performing RTR examination at Rocky Flats would accept up to 2 cups of free liquid, if liquids were present.

Pyrophoric materials were prohibited by procedural control. The absence of the pyrophoric materials was verified by the generating supervisor and periodic inspection by the Waste Certification Organization.

Explosives and compressed gases were prohibited by procedural control. The absence of the explosives and compressed gases was verified by the generating supervisor and periodic inspection by the Waste Certification Organization. In addition, unvented, closed containers and pressurized containers were excluded by procedural controls and RTR examination.

The RCRA constituents exist as co-contaminants with the transuranic radionuclides. Compliance with the WIPP RCRA permits and NMD will be required before shipment of the stored waste to WIPP.

A portion of the waste stored at INEL may contain $<100$ nanocuries per gram transuranic radionuclides.

None of the IDC 818 waste containers recorded as shipped to INEL in the SWIMS exceed $1,000 \mathrm{Ci}$ of plutonium-equivalent activity.

a. Many of the limiting parameters were taken from TRU Waste Compliance Program (Rockwell International 1983a, 1987e, and 1989b). 
Table 3.5.3-5. TRUPACT Evaluation.

\begin{tabular}{|c|c|}
\hline $\begin{array}{l}\text { Criterion or } \\
\text { requirement }\end{array}$ & Limiting parameters ${ }^{2}$ \\
\hline $\begin{array}{l}\text { Waste Package } \\
\text { Weight }\end{array}$ & $\begin{array}{l}\text { Rocky Flats limited the gross weight of drums to } 800 \mathrm{lb} \text {. The TRUPACT and } \\
\text { vehicle weight limits must be verified at the time of payload assembly at INEL. }\end{array}$ \\
\hline Waste Containers & This waste was packaged in 55-gal DOT-7A, Type A containers. \\
\hline $\begin{array}{l}\text { Nuclear } \\
\text { Criticality }\end{array}$ & $\begin{array}{l}\text { Rocky Flats limited the fissile content of the drums to } 200 \text { grams. However, the } \\
\text { error-times-two requirement was not in place at the time the drums were shipped to } \\
\text { INEL; therefore, it is not reported as part of the assay of the drum. The } \\
\text { TRUPACT limit must be verified at the time of payload assembly at INEL. Based } \\
\text { on the typical assays of the IDC } 818 \text { drums, the criticality criteria will be met but } \\
\text { must be recalculated or assayed to meet the error-times-two requirement. }\end{array}$ \\
\hline $\begin{array}{l}\text { Surface Dose } \\
\text { Rate }\end{array}$ & $\begin{array}{l}\text { The surface dose rate criteria used by Rocky Flats was } 200 \mathrm{mrem} / \mathrm{hr} \text { at the drum } \\
\text { surface and } 10 \mathrm{mrem} / \mathrm{hr} \text { at } 1 \text { meter. Shielding was not necessary for IDC } 818 \\
\text { drums. The TRUPACT limit must be verified at the time of payload assembly at } \\
\text { INEL. Based on the typical dose rates from the IDC } 818 \text { drums, the dose rate } \\
\text { criteria will be met. }\end{array}$ \\
\hline $\begin{array}{l}\text { Removable } \\
\text { Surface } \\
\text { Contamination }\end{array}$ & $\begin{array}{l}\text { The Rocky Flats limit for removable contamination (for TRU assumed to be all } \\
\text { alpha) was } 20 \text { disintegrations per minute } / 100 \mathrm{~cm}^{2} \text {. The Rocky Flats limit is } \\
\text { equivalent to } 9 \text { picocuries per } 100 \mathrm{~cm}^{2} \text {, which is well within the WIPP criteria. }\end{array}$ \\
\hline Thermal Power & $\begin{array}{l}\text { The thermal power calculation reported in the SWIMS data package is based on the } \\
\text { reported assay value without an error/uncertainty correction. The thermal power } \\
\text { must be recalculated based on the assay error determination. }\end{array}$ \\
\hline Gas Generation & $\begin{array}{l}\text { Based on the procedural requirements for packaging IDC } 818 \text { waste and the waste } \\
\text { description, the only areas of noncompliance are carbon filters, unpunctured rigid } \\
\text { liners, headspace gas analysis, and visual characterization. } \\
\text { Personnel performing RTR examination at Rocky Flats would accept up to } 10 \% \text { of } \\
\text { another IDC. The other IDCs could be combustibles, glass, concrete, metal, } \\
\text { leaded gloves, and plastics. }\end{array}$ \\
\hline$N$ & parameters were taken from TRU Waste Compliance Program (Rockwell Int \\
\hline
\end{tabular}

3.5.3.10 Combustible and Organic Content. SWIMS data indicate that this waste form does not contain $>20 \%$ combustibles or $>20 \%$ organics.

3.5.3.10.1 Combustible Content-SWIMS data show that IDC 818 waste is noncombustible (Rockwell International 1985a).

3.5.3.10.2 Organic Content-SWIMS data show that IDC 818 waste contains zero\% organics (Rockwell International 1985a). 
3.5.3.11 Analytical Information. No analytical information is available for IDC 818.

It is presumed that IDC 818 is assigned the same EPA Codes as IDC 420 as both are incinerator byproducts. IDC 420 will contain most of the same constituents as the ash from which it was derived. Because the specific sources of the incinerator feed cannot be determined at this time, it has been assumed that the process could have accepted any of the combustible, plastic, or filter waste that was generated during the time the incinerator was operational. Alcohols, glycols, halogenated solvents, and metals may have been introduced into the incinerator. The EPA Codes assigned to this waste include D004-D011, F001, F002, F003, and F005 (A). 


\subsection{Waste Form Number 114-Solidified Process Solids, Content Code RF 114A}

\subsubsection{Item Description Code 820-Cemented Soot}

3.5.4.1 Certification Assessment. This IDC is certifiable without further waste treatment. Assay and thermal power calculations, including error, need to be updated to meet the current WIPP WAC. Several gas generation criteria need to be addressed. Carbon filters may need to be installed, drums will require inspection to identify unvented or unpunctured rigid liners, and headspace gas analysis and visual waste characterization will need to be performed.

3.5.4.2 Waste Description. It is presumed that the waste description for IDC 422-Soot, also applies to IDC 820-Cemented Soot. IDC 422 consists of a fine and very fine particulate fly ash that was removed from the incinerator off-gas treatment system. The soot generally contained a higher concentration of carbon and fine particulate oxidation of some feed materials (A).

IDC 820 waste was immobilized into a solid with Portland cement. A formula for each waste type was used to precondition the waste (that is, neutralize, thicken), and the amount of Portland cement, the mixing method, and the cure time were recorded. Cemented wastes were cast into 1-gal molds and allowed to cure. The cured "pucks" were removed from the molds in the form of a solid monolith (Rockwell International 1989b).

3.5.4.3 Generation Source. It is presumed that IDC 820-Cemented Soot, was generated by the same source as IDC 422 , as both are incinerator byproducts. IDC 422 was generated by the Residue Recovery Incinerator system in Building 771. The function of the Residue Recovery Incinerator was to reduce volume and destroy volatile constituents prior to plutonium recovery operations for combustible wastes from production processes (primarily IDCs $330,331,336$, and 337) (A).

3.5.4.4 Recovery Method. This IDC was never generated as a residue and therefore has no recovery method.

3.5.4.5 Waste Packaging and Handling. Process solids were the particulate and sludgetype wastes that had been processed to recover as much plutonium as economically feasible. After processing, the wastes were removed from the glovebox in 4-liter (or smaller) polyethylene containers and assayed for plutonium. The waste packages were collected in a 55-gal drum for transfer to the solidification area (Rockwell International 1989b).

Each drum of process solids is processed as a batch. One drum of unsolidified waste will produce three drums of solidified process solids. After solidification, the "pucks" are removed from the glovebox, double-bagged, and placed into a DOT-17C 55-gal steel drum with a 90-mil rigid liner.

3.5.4.6 Container Preparation. Only approved containers could be used to package TRU waste for shipment offsite. Containers approved for shipment to INEL during this time were DOT- 
17C, white, 55-gal drums (Rockwell specification SX-200). These containers met the requirements for certification as DOT-7A Type A packaging (Rockwell International 1989b).

Table 3.5.4-1 shows the current inventory of IDC 820 waste containers from the Rocky Flats Plant that have been shipped to INEL since 1985 .

Table 3.5.4-1. Item Description Code 820 Container Information.

\begin{tabular}{lccc}
\hline \multicolumn{1}{c}{ Information } & & Drums & Boxes \\
\hline Total Containers & & 28 & 0 \\
Net Container Weight (lb) & Maximum & 456 & N/A \\
& Minimum & 30 & N/A \\
& Average & 319 & N/A \\
\hline
\end{tabular}

3 5.4.6.1 Drum Preparation-Approved liners for drums of TRU waste packaged for offsite shipment were the round-bottom liner (Rockwell specification SX-203) inside a 90-mil rigid polyethylene liner (Rockwell specification SX-202), or an O-ring bag and a polyethylene bag placed inside the rigid liner if the drum was attached to a glovebox (Rockwell International 1989e). Type III rigid liners have been used since September 1983 (Bearly 1989a). No information regarding packaging requirements for this waste form could be located.

Flow-in, ventable gaskets were installed in the drums beginning in December 1982. They were used until October 1988, when tubular gaskets with carbon filters were required. Drums shipped to INEL between 1985 and 1988 may not meet the current WIPP WAC, owing to their lack of carbon filters (Bearly 1989a).

3.5.4.6.2 Box Preparation-No boxes of IDC 820 waste were shipped to INEL between 1985 and 1989.

3.5.4.7 Assay. Individual containers of processed material are assayed in the "in-line can counter." The individual assay values for containers solidified in a batch and placed into a drum are totaled to provide an assigned assay value for the drum. The drums may have been assayed on an SGS counter or a PADC to verify the assigned assay value. Table 3.5.4-2 summarizes the dose rates measured on containers of this IDC. Table $3.5 .4-3$ provides a summary of the assay information.

Table 3.5.4-2. Item Description Code 820 Dose Information.

\begin{tabular}{crrc} 
Information & & Drums & Boxes \\
\hline One Meter Dose Rate (mrem/h) & $0-0.5$ & 23 & N/A \\
& $0.5-10$ & 5 & N/A \\
Surface Dose Rate $(\mathrm{mrem} / \mathrm{h})$ & $<10$ & 28 & N/A \\
& $10-200$ & 0 & N/A \\
\hline
\end{tabular}


Table 3.5.4-3. Item Description Code 820 Assay Information.

\begin{tabular}{|c|c|c|c|}
\hline \multicolumn{2}{|c|}{ Radionuclide inventory } & \multirow{2}{*}{$\begin{array}{l}\text { Drums } \\
154.5 \\
41 \\
80.41\end{array}$} & \multirow{2}{*}{$\begin{array}{c}\text { Boxes } \\
\text { N/A } \\
\text { N/A } \\
\text { N/A }\end{array}$} \\
\hline Plutonium (g) & $\begin{array}{r}\text { Maximum } \\
\text { Minimum } \\
\text { Average }\end{array}$ & & \\
\hline Americium (g) & $\begin{array}{r}\text { Maximum } \\
\text { Minimum } \\
\text { Average }\end{array}$ & $\begin{array}{l}- \\
- \\
-\end{array}$ & $\begin{array}{l}\text { N/A } \\
\text { N/A } \\
\text { N/A }\end{array}$ \\
\hline Uranium-235 (g) & $\begin{array}{r}\text { Maximum } \\
\text { Minimum } \\
\text { Average }\end{array}$ & - & $\begin{array}{l}\text { N/A } \\
\text { N/A } \\
N / A\end{array}$ \\
\hline
\end{tabular}

3.5.4.8 Inspection. Waste Certification personnel periodically reviewed the process documentation to verify that the process was properly operated. Waste Certification personnel performed periodic inspections of the generating and packaging process to verify compliance with waste acceptance criteria. In addition, each drum was viewed using RTR to

- Ensure the drum does not contain nonconforming items

- Ensure the drum is properly packaged

- Verify the waste form description

- Evaluate the presence of free liquids.

3.5.4.9 Waste Form Evaluation. Table 3.5.4-4 evaluates the waste form against the WIPP WAC for such items as free liquids, pyrophoric materials, and compressed gases. Table 3.5.4-5 evaluates the waste against TRUPACT criteria. 
Table 3.5.4-4. Waste Form Evaluation.

Criterion or requirement

Limiting parameters ${ }^{2}$

Immobilization

This waste form is the final product of a treatment system designed to immobilize particulates. Based on the description of the waste, fine particulates are not expected in this IDC.

Liquids

There are normally no liquids associated with this IDC. Personnel performing RTR examination at Rocky Flats would accept up to 2 cups of free liquid, if liquids were present.

Pyrophoric

Materials

Pyrophoric materials were prohibited by procedural control. The absence of the pyrophoric materials was verified by the generating supervisor and periodic inspection by the Waste Certification Organization.

Explosives and Compressed Gases

Explosives and compressed gases were prohibited by procedural control. The absence of the explosives and compressed gases was verified by the generating supervisor and periodic inspection by the Waste Certification Organization. In addition, unvented, closed containers and pressurized containers were excluded by procedural controls and RTR examination.

TRU-Mixed Wastes The RCRA constituents exist as co-contaminants with the transuranic radionuclides. Compliance with the WIPP RCRA permits and NMD will be required before shipment of the stored waste to WIPP.

Specific Activity of This waste contains at least 100 nanocuries per gram transuranic radionuclides. Waste

$\mathrm{Pu}^{239}$ Equivalent None of the IDC 820 waste containers recorded as shipped to INEL in the Activity SWIMS exceed $1,000 \mathrm{Ci}$ of plutonium-equivalent activity.

a. Many of the limiting parameters were taken from TRU Waste Compliance Program (Rockwell International 1983a, 1987e, and 1989b). 
Table 3.5.4-5. TRUPACT Evaluation.

Criterion or

requirement

Limiting parameters ${ }^{2}$

Waste Package

Weight

Waste Containers

Rocky Flats limited the gross weight of drums to $800 \mathrm{lb}$. The TRUPACT and vehicle weight limits must be verified at the time of payload assembly at INEL.

Nuclear

Criticality

This waste was packaged in 55-gal DOT-7A, Type A containers.

Rocky Flats limited the fissile content of the drums to 200 grams. However, the error-times-two requirement was not in place at the time the drums were shipped to INEL; therefore, it is not reported as part of the assay of the drum. The TRUPACT limit must be verified at the time of payload assembly at INEL. Based on the typical assays of the IDC 820 drums, the criticality criteria will be met but must be recalculated or assayed to meet the error-times-two requirement.

Surface Dose

Rate

The surface dose rate criteria used by Rocky Flats was $200 \mathrm{mrem} / \mathrm{hr}$ at the drum surface and $10 \mathrm{mrem} / \mathrm{hr}$ at 1 meter. Shielding was not necessary for IDC 820 drums. The TRUPACT limit must be verified at the time of payload assembly at INEL. Based on the typical dose rates from the IDC 820 drums, the dose rate criteria will be met.

Removable

Surface

The Rocky Flats limit for removable contamination (for TRU assumed to be all

Contamination alpha) was 20 disintegrations per minute $/ 100 \mathrm{~cm}^{2}$. The Rocky Flats limit is equivalent to 9 picocuries per $100 \mathrm{~cm}^{2}$, which is well within the WIPP criteria.

Thermal Power

The thermal power calculation reported in the SWIMS data package is based on the reported assay value without an error/uncertainty correction. The thermal power must be recalculated based on the assay error determination.

Gas Generation

Based on the procedural requirements for packaging IDC 820 waste and the waste description, the only areas of noncompliance are carbon filters, unpunctured rigid liners, headspace gas analysis, and visual characterization.

Personnel performing RTR examination at Rocky Flats would accept up to $10 \%$ of another IDC. The other IDCs could be combustibles, glass, concrete, metal, leaded gloves, and plastics.

a. Many of the limiting parameters were taken from TRU Waste Compliance Program (Rockwell International 1983a, 1987e, and 1989b).

3.5.4.10 Combustible and Organic Content. SWIMS data indicate that this waste form does not contain $>20 \%$ combustibles or $>20 \%$ organics.

3.5.4.10.1 Combustible Content-SWIMS data show that IDC 820 waste is noncombustible (Rockwell International 1985a).

3.5.4.10.2 Organic Content-SWIMS data show that IDC 820 waste contains zero\% organics (Rockwell International 1985a). 
3.5.4.11 Analytical Information. No analytical information is available for IDC 820 .

It is presumed that IDC 820 is assigned the same EPA Codes as IDC 422 as both are incinerator byproducts. IDC 422 will contain most of the same constituents as the ash from which it was derived. Because the specific sources of the incinerator feed cannot be determined at this time, it has been assumed that the process could have accepted any of the combustible, plastic, or filter waste that was generated during the time the incinerator was operational. Alcohols, glycols, halogenated solvents, and metals may have been introduced into the incinerator. The EPA Codes assigned to this waste include D004-D011, F001, F002, F003, and F005 (A). 


\subsection{Waste Form Number 114-Solidified Process Solids, Content Code RF 114A}

\subsubsection{Item Description Code 823-Cemented Miscellaneous Sludge}

3.5.5.1 Certification Assessment. This IDC is certifiable without further waste treatment. Assay and thermal power calculations, including error, need to be updated to meet the current WIPP WAC. Several gas generation criteria need to be addressed. Carbon filters may need to be installed, drums will require inspection to identify unvented or unpunctured rigid liners, and headspace gas analysis and visual waste characterization will need to be performed.

3.5.5.2 Waste Description. It is presumed that the waste description for IDC 806 also applies to IDC 823. IDC 806 waste includes all inorganic sludge that was immobilized into a solid with Portland cement. A formula for each waste type is used to precondition the waste (that is, neutralize, thicken), and the amount of Portland cement, the mixing method, and the cure time are recorded. Cemented wastes were cast into 1-gal molds and allowed to cure. The cured "pucks" are removed from the molds in the form of a solid monolith (Rockwell International 1989b). IDC 823 is included in IDC 806.

3.5.5.3 Generation Source. It is presumed that the generation source for IDC 806 also applies to IDC 823. The major generator of IDC 806 waste was Plutonium Recovery Operations in Building 771 (Rockwell International 1987e).

3.5.5.4 Recovery Method. This IDC was never generated as a residue and therefore has no recovery method.

3.5.5.5 Waste Packaging and Handling. Process solids are the particulate and sludge-type wastes that had been processed to recover as much plutonium as economically feasible. After processing, the wastes were removed from the glovebox in 4-liter (or smaller) polyethylene containers and assayed for plutonium. The waste packages were collected in a 55-gal drum for transfer to the solidification area (Rockwell International 1989b).

Each drum of process solids was processed as a batch. One drum of unsolidified waste produced three drums of solidified process solids. After solidification, the "pucks" were removed from the glovebox, double-bagged, and placed into a DOT-17C, 55-gal steel drum with a 90-mil rigid liner.

3.5.5.6 Container Preparation. Only approved containers could be used to package TRU waste for shipment offsite. The containers approved for shipment to INEL during this time were DOT-17C, white, 55-gal drums (Rockwell specification SX-200). These containers met the requirements for certification as DOT-7A Type A packaging (Rockwell International 1989e).

Table 3.5.5-1 shows the current inventory of IDC 823 waste containers from the Rocky Flats Plant that have been shipped to INEL since 1985. 
Table 3.5.5-1. Item Description Code 823 Container Information.

\begin{tabular}{lrcc}
\hline \multicolumn{1}{c}{ Information } & & Drums & Boxes \\
\hline Total Containers & & 18 & 0 \\
Net Container Weight (lb) & Maximum & 437 & N/A \\
& Minimum & 50 & N/A \\
& Average & 263 & N/A \\
\hline
\end{tabular}

3.5.5.6.1 Drum Preparation-Approved liners for drums of TRU waste packaged for offsite shipment were the round-bottom liner (Rockwell specification SX-203) inside a 90-mil rigid polyethylene liner (Rockwell specification SX-202), or an O-ring bag and a polyethylene bag placed inside the rigid liner if the drum was attached to a glovebox (Rockwell International 1989e). Type III rigid liners have been used since September 1983 (Bearly 1989a). No information regarding packaging requirements for this waste form could be located.

Flow-in, ventable gaskets were installed in the drums beginning in December 1982. They were used until October 1988, when tubular gaskets with carbon filters were required. Drums shipped to INEL between 1985 and 1988 may not meet the current WIPP WAC, owing to their lack of carbon filters (Bearly 1989a).

3.5.5.6.2 Box Preparation-No boxes of IDC 823 waste were shipped to INEL between 1985 and 1989.

3.5.5.7 Assay. Individual containers of processed material were assayed in the "in-line can counter." The individual assay values for containers solidified in a batch and placed into a drum were totaled to provide an assigned assay value for the drum. The drums may have been assayed on an SGS counter or a PADC to verify the assigned assay value. Containers of waste that have not been PADC assayed and had SGS or in-line can counter assay values of 1 gram or less should be PADC assayed to verify that they are transuranic waste. Table 3.5.5-2 summarizes the dose rates measured on containers of this IDC. Table 3.5.5-3 provides a summary of the assay information.

Table 3.5.5-2. Item Description Code 823 Dose Information.

\begin{tabular}{crrr}
\hline Information & & Drums & Boxes \\
\hline One Meter Dose Rate (mrem/h) & $0-0.5$ & 18 & N/A \\
& $0.5-10$ & 0 & N/A \\
Surface Dose Rate (mrem/h) & $<10$ & 18 & N/A \\
& $10-200$ & 0 & N/A \\
\hline
\end{tabular}


Table 3.5.5-3. Item Description Code 823 Assay Information.

\begin{tabular}{lrccc}
\hline \multicolumn{2}{c}{ Radionuclide inventory } & Drums & Boxes \\
\cline { 2 - 5 } Plutonium (g) & Maximum & 18 & N/A \\
& Minimum & 0 & N/A \\
& Average & 2 & N/A \\
Americium (g) & Maximum & - & N/A \\
& Minimum & - & N/A \\
& Average & - & N/A \\
& Uranium-235 (g) & Maximum & - & N/A \\
& Minimum & - & N/A \\
& Average & - & N/A \\
\hline
\end{tabular}

3.5.5.8 Inspection. Waste Certification personnel periodically reviewed the process documentation to verify that the process was properly operated. Waste Certification personnel performed periodic inspections of the generating and packaging process to verify compliance with waste acceptance criteria. In addition, each drum was viewed using RTR to

- Ensure the drum does not contain nonconforming items

- Ensure the drum is properly packaged

- Verify the waste form description

- Evaluate the presence of free liquids.

3.5.5.9 Waste Form Evaluation. Table 3.5.5-4 evaluates the waste form against the WIPP WAC for such items as free liquids, pyrophoric materials, and compressed gases. Table 3.5.5-5 evaluates the waste against TRUPACT criteria. 
Table 3.5.5-4. Waste Form Evaluation.

Criterion or requirement

Limiting parameters ${ }^{2}$

Immobilization

This waste form is the final product of a treatment system designed to immobilize particulates. Based on the description of the waste, fine particulates are not expected in this IDC.

Liquids

There are normally no liquids associated with this IDC. Personnel performing RTR examination at Rocky Flats would accept up to 2 cups of free liquid, if liquids were present.

Pyrophoric

Materials

Pyrophoric materials were prohibited by procedural control. The absence of the pyrophoric materials was verified by the generating supervisor and periodic inspection by the Waste Certification Organization.

Explosives and Compressed Gases Explosives and compressed gases were prohibited by procedural control. The absence of the explosives and compressed gases was verified by the generating supervisor and periodic inspection by the Waste Certification Organization. In addition, unvented, closed containers and pressurized containers were excluded by procedural controls and RTR examination.

TRU-Mixed Wastes The RCRA constituents exist as co-contaminants with the transuranic radionuclides. Compliance with the WIPP RCRA permits and NMD will be required before shipment of the stored waste to WIPP.

Specific Activity of A portion of the waste stored at INEL may contain $<100$ nanocuries per gram Waste transuranic radionuclides.

$\mathrm{Pu}^{239}$ Equivalent None of the IDC 823 waste containers recorded as shipped to INEL in the Activity SWIMS exceed $1,000 \mathrm{Ci}$ of plutonium-equivalent activity.

a. Many of the limiting parameters were taken from TRU Waste Compliance Program (Rockwell International 1983a, 1987e, and 1989b). 
Table 3.5.5-5. TRUPACT Evaluation.

Criterion or

requirement

Waste Package

Weight

Waste Containers

Nuclear

Criticality

Surface Dose

Rate

Removable

Surface

Contamination

Thermal Power

Gas Generation
Limiting parameters ${ }^{2}$

Rocky Flats limited the gross weight of drums to $800 \mathrm{lb}$. The TRUPACT and vehicle weight limits must be verified at the time of payload assembly at INEL.

This waste was packaged in 55-gallon DOT-7A, Type A containers.

Rocky Flats limited the fissile content of the drums to 200 grams. However, the error-times-two requirement was not in place at the time the drums were shipped to INEL; therefore, it is not reported as part of the assay of the drum. The TRUPACT limit must be verified at the time of payload assembly at INEL. Based on the typical assays of the IDC 823 drums, the criticality criteria will be met but must be recalculated or assayed to meet the error-times-two requirement.

The surface dose rate criteria used by Rocky Flats was $200 \mathrm{mrem} / \mathrm{hr}$ at the drum surface and $10 \mathrm{mrem} / \mathrm{hr}$ at 1 meter. Shielding was not necessary for IDC 823 drums. The TRUPACT limit must be verified at the time of payload assembly at INEL. Based on the typical dose rates from the IDC 823 drums, the dose rate criteria will be met.

The Rocky Flats limit for removable contamination (for TRU assumed to be all alpha) was 20 disintegrations per minute $/ 100 \mathrm{~cm}^{2}$. The Rocky Flats limit is equivalent to 9 picocuries per $100 \mathrm{~cm}^{2}$, which is well within the WIPP criteria.

The thermal power calculation reported in the SWIMS data package is based on the reported assay value without an error/uncertainty correction. The thermal power must be recalculated based on the assay error determination.

Based on the procedural requirements for packaging IDC 823 waste and the waste description, the only areas of noncompliance are carbon filters, unpunctured rigid liners, headspace gas analysis, and visual characterization.

Personnel performing RTR examination at Rocky Flats would accept up to $10 \%$ of another IDC. The other IDCs could be combustibles, glass, concrete, metal, leaded gloves, and plastics.

a. Many of the limiting parameters were taken from TRU Waste Compliance Program (Rockwell International $1983 \mathrm{a}, 1987 \mathrm{e}$, and 1989b).

3.5.5.10 Combustible and Organic Content. SWIMS data indicate that this waste form does not contain $>20 \%$ combustibles or $>20 \%$ organics.

3.5.5.10.1 Combustible Content-SWIMS data show that IDC 823 waste is noncombustible (Rockwell International 1985a).

3.5.5.10.2 Organic Content-SWIMS data show that IDC 823 waste contains $20 \%$ organics (Rockwell International 1985a). 
3.5.5.11 Analytical Information. No analytical information is available for IDC 823.

It is presumed that the RCRA characterization for IDC 806 also applies to IDC 823. The RCRA characterization for IDC 806 has not been established. 


\subsection{Waste Form Number 115-TRU Graphite Waste, Content Code RF 115A}

\subsubsection{Item Description Code 300-Graphite Molds}

3.6.1.1 Certification Assessment. This IDC is certifiable without further waste treatment. Assay and thermal power calculations, including error, need to be updated to meet the current WIPP WAC. Several gas generation criteria need to be addressed. Carbon filters may need to be installed, drums will require inspection to identify unvented or unpunctured rigid liners, and headspace gas analysis and visual waste characterization will need to be performed.

3.6. 1.2 Waste Description. This waste consists of graphite molds used in plutonium casting. Graphite molds were cut from solid blocks, logs, or slabs which had high mechanical strength. The mechanical strength of mold graphite was sufficient to prevent the formation of fines and particulates during normal handling (Rockwell International 1989b). The working surfaces of the molds were coated with calcium fluoride prior to using the mold. After the plutonium casting was removed from the mold, the molds were collected in a drum. Drums that contained recoverable amounts of plutonium were stored for subsequent scarfing (D).

3.6.1.3 Generation Source. IDC 300-Graphite Molds, were generated by the plutonium casting operations in Building 707 (D).

3.6.1.4 Recovery Method. Graphite waste contaminated with above-discard amounts of plutonium was processed by Plutonium Recovery Operations. The graphite was "scarfed" or scraped to remove adhering plutonium. The scarfings were further processed by nitric acid leaching. Pieces of graphite remaining after the scarfing process were then repackaged for disposal (Clements 1982).

3.6.1.5 Waste Packaging and Handling. TRU graphite waste molds were cleaned and inspected in the glovebox to ensure that recoverable plutonium had been removed from the molds. The waste molds were segregated from all noncomplying materials, prepackaged, and bagged out of the glovebox and placed into a 55-gal waste drum or placed into a 55-gal waste drum that was connected to the glovebox by an 11-mil, PVC, O-ring bag. When the drum was full, the drum liners were sealed and the drum was closed. The drum label, completed with all necessary information, was then taped to the drum lid and a TID was attached to the drum.

If the drum contained classified graphite shapes, it was sent to Size Reduction in Building 776 to declassify the waste, and then repackaged into the drum.

3.6.1.6 Container Preparation. Only approved containers could be used to package TRU waste for shipment offsite. The containers approved for shipment to INEL during this time were DOT-17C, white, 55-gal drums (Rockwell specification SX-200). Each of these containers met the requirements for certification as DOT-7A Type A packaging (Rockwell International 1989e).

Table 3.6.1-1 shows the current inventory of IDC 300 waste containers from the Rocky Flats Plant that have been shipped to INEL since 1985. 
Table 3.6.1-1. Item Description Code 300 Container Information.

\begin{tabular}{lccc}
\hline \multicolumn{1}{c}{ Information } & & Drums & Boxes \\
\cline { 2 - 4 } Total Containers & & 325 & 0 \\
Net Container Weight $(\mathrm{lb})$ & Maximum & 400 & N/A \\
& Minimum & 17 & N/A \\
& Average & 157 & N/A \\
\hline
\end{tabular}

3.6. 1.6.1 Drum Preparation-Approved liners for drums of TRU waste packaged for offsite shipment were the round-bottom liner (Rockwell specification SX-203) inside a 90-mil rigid polyethylene liner (Rockwell specification SX-202), or an O-ring bag and a polyethylene bag placed inside the rigid liner if the drum was attached to a glovebox (Rockwell International 1989e). Type III rigid liners have been used since September 1983 (Bearly 1989a). The IDC 300 waste packaged for offsite shipment required a fiberboard liner and a round bottom liner inside the rigid liner (Rockwell International 1988c). Figure C-1 shows the appropriate drum liners for this IDC (Rockwell International 1989b). All bags were closed using the twist-and-tape method (Rockwell International 1989e).

Flow-in, ventable gaskets were installed in the drums beginning in December 1982. They were used until October 1988, when tubular gaskets with carbon filters were required. Drums shipped to INEL between 1985 and 1988 may not meet the current WIPP WAC, owing to their lack of carbon filters (Bearly 1989a).

3.6.1.6.2 Box Preparation-No boxes of IDC 300 waste were shipped to INEL between 1985 and 1989.

3.6.1.7 Assay. The drums may have been assayed on an SGS counter or a PADC. Containers of waste that have not been PADC assayed and had SGS assay values of 1 gram or less should be PADC assayed to verify that they are transuranic waste. Table 3.6.1-2 summarizes the dose rates measured on containers of this IDC. Table 3.6.1-3 provides a summary of the assay information. Two drums were evaluated for uranium content, no drums were evaluated for americium content.

Table 3.6.1-2.' Item Description Code 300 Dose Information.

\begin{tabular}{crrc}
\hline Information & & Drums & Boxes \\
\hline One Meter Dose Rate (mrem/h) & $0-0.5$ & 267 & N/A \\
& $0.5-10$ & 58 & N/A \\
Surface Dose Rate (mrem/h) & $<10$ & 318 & N/A \\
& $10-200$ & 7 & N/A \\
\hline
\end{tabular}


Table 3.6.1-3. Item Description Code 300 Assay Information.

\begin{tabular}{lrrr}
\multicolumn{2}{c}{ Radionuclide inventory } & Drums & Boxes \\
\hline Plutonium (g) & Maximum & 116 & N/A \\
& Minimum & 0 & N/A \\
& Average & 27 & N/A \\
Americium (g) & Maximum & 0 & N/A \\
& Minimum & 0 & N/A \\
& Average & 0 & N/A \\
Uranium-235 (g) & Maximum & 5 & N/A \\
& Minimum & 1 & N/A \\
& Average & 3 & N/A
\end{tabular}

3.6.1.8 Inspection. Waste Certification personnel performed periodic inspections of the generating and packaging process to verify compliance with waste acceptance criteria. In addition, each drum was viewed using RTR to

- Ensure the drum does not contain nonconforming items

- Ensure the drum is properly packaged

- Verify the waste form description

- Evaluate the presence of free liquids.

3.6. 1.9 Waste Form Evaluation. Table 3.6.1-4 evaluates the waste form against the WIPP WAC for such items as free liquids, pyrophoric materials, and compressed gases. Table 3.6.1-5 evaluates the waste against TRUPACT criteria. 
Table 3.6.1-4. Waste Form Evaluation.

Criterion or

requirement

Limiting parameters ${ }^{2}$

Immobilization

This waste form is the final product of a treatment system designed to immobilize particulates. Based on the description of the waste, fine particulates are not expected in this IDC.

Liquids

This waste form meets the free liquid criteria by procedural control and RTR inspection prior to shipment from Rocky Flats.

Pyrophoric

Materials

Pyrophoric materials were prohibited by procedural control. The absence of the pyrophoric materials was verified by the generating supervisor and periodic inspection by the Waste Certification Organization.

Explosives and Compressed Gases

Explosives and compressed gases were prohibited by procedural control. The absence of the explosives and compressed gases was verified by the generating supervisor and periodic inspection by the Waste Certification Organization. In addition, unvented, closed containers and pressurized containers were excluded by procedural controls and RTR examination.

TRU-Mixed Wastes The RCRA constituents exist as co-contaminants with the transuranic radionuclides. Compliance with the WIPP RCRA permits and NMD will be required before shipment of the stored waste to WIPP.

Specific Activity of A portion of the waste stored at INEL may contain < 100 nanocuries per gram Waste transuranic radionuclides.

$\mathrm{Pu}^{239}$ Equivalent None of the IDC 300 waste containers recorded as shipped to INEL in the Activity SWIMS exceed $1,000 \mathrm{Ci}$ of plutonium-equivalent activity.

a. Many of the limiting parameters were taken from TRU Waste Compliance Program (Rockwell International 1983a, 1987e, and 1989b). 
Table 3.6.1-5. TRUPACT Evaluation.

Criterion or

requirement

Limiting parameters ${ }^{2}$

Waste Package

Weight

Rocky Flats limited the gross weight of drums containing graphite to $285 \mathrm{lb}$. The TRUPACT and vehicle weight limits must be verified at the time of payload assembly at INEL.

Waste Containers This waste was packaged in 55-gal DOT-7A, Type A containers.

Nuclear

Criticality

Rocky Flats limited the fissile content of the drums to 200 grams. However, the error-times-two requirement was not in place at the time the drums were shipped to INEL; therefore, it is not reported as part of the assay of the drum. The TRUPACT limit must be verified at the time of payload assembly at INEL. Based on the typical assays of the IDC 300 drums, the criticality criteria will be met but must be recalculated or assayed to meet the error-times-two requirement.

Surface Dose The surface dose rate criteria used by Rocky Flats was $200 \mathrm{mrem} / \mathrm{hr}$ at the drum Rate surface and $10 \mathrm{mrem} / \mathrm{hr}$ at 1 meter. Shielding was not necessary for IDC 300 drums. The TRUPACT limit must be verified at the time of payload assembly at INEL. Based on the typical dose rates from the IDC 300 drums, the dose rate criteria will be met.

Removable The Rocky Flats limit for removable contamination (for TRU assumed to be all Surface Contamination alpha) was 20 disintegrations per minute $/ 100 \mathrm{~cm}^{2}$. The Rocky Flats limit is equivalent to 9 picocuries per $100 \mathrm{~cm}^{2}$, which is well within the WIPP criteria.

Thermal Power

The thermal power calculation reported in the SWIMS data package is based on the reported assay value without an error/uncertainty correction. The thermal power must be recalculated based on the assay error determination.

Gas Generation Based on the procedural requirements for packaging IDC 300 waste and the waste description, the only areas of noncompliance are carbon filters, unpunctured rigid liners, headspace gas analysis, and visual characterization.

1,1,1-Trichloroethane was detected by headspace gas analysis in IDC 300, but is not on the TRUPACT Chemical List for Content Code RF 115A.

Personnel performing RTR examination at Rocky Flats would accept up to $10 \%$ of another IDC. The other IDCs could be combustibles, glass, concrete, metal, leaded gloves, and plastics.

a. Many of the limiting parameters were taken from TRU Waste Compliance Program (Rockwell International 1983a, 1987e, and 1989b).

3.6.1.10 Combustible and Organic Content. Table 3.6.1-6 outlines available data from the TRU Waste Sampling Program for IDC 300. SWIMS data indicate that this waste form does not contain $>20 \%$ combustibles or $>20 \%$ organics. 
Table 3.6.1-6. Item Description Code 300 Data Summary for Combustible and Organic Content.

\begin{tabular}{ccccccc}
\hline Container & $\begin{array}{c}\text { Wt. } \\
\text { combustibles } \\
(\mathrm{lb})^{\mathrm{a}}\end{array}$ & $\begin{array}{c}\text { Wt. } \\
\text { organics } \\
(\mathrm{bb})^{\mathrm{b}}\end{array}$ & $\begin{array}{c}\text { Net wt. of } \\
\text { container } \\
(\mathrm{lb})^{\mathrm{c}}\end{array}$ & $\begin{array}{c}\text { Wt\% } \\
\text { combustibles }^{\mathrm{d}}\end{array}$ & $\begin{array}{c}\text { Vol\% } \\
\text { combustibles }^{\mathrm{c}}\end{array}$ & $\begin{array}{c}\text { Wt\% } \\
\text { organics }^{\mathrm{f}}\end{array}$ \\
\hline $12-11023$ & 8.5 & 8.5 & 147.25 & 6 & 5 & 6 \\
$19-01811$ & 2.3 & 2.3 & 78.75 & 3 & 5 & 3 \\
$12-11229$ & 5.5 & 5.5 & 76.25 & 7 & 5 & 7 \\
$41-01531$ & 5.0 & 5.0 & 106.8 & 5 & 10 & 5 \\
$12-09189$ & 8.0 & 8.0 & 161.8 & 5 & 10 & 5 \\
$12-09295$ & 8.0 & 8.0 & 222.0 & 4 & 10 & 4 \\
$12-09161$ & 7.8 & 7.8 & 179.75 & 4 & 10 & 4 \\
$12-09300$ & 7.0 & 7.0 & 196.0 & 4 & 10 & 4 \\
\hline
\end{tabular}

a. Sum of weights of all combustible material and leaded rubber from Table 25 (Clements and Kudera 1985).

b. Sum of weights of all combustible material, leaded rubber, and organic material from Table 25 (Clements and Kudera 1985).

c. Net weight of container from Table 25 (Clements and Kudera 1985).

d. Weight of combustible material/net weight of container $\times 100$.

e. Vol\% of combustible material from visual examination, obtained from Appendix B (Clements and Kudera 1985).

f. Weight of organic material/net weight of container $\times 100$.

3.6.1.10.1 Combustible Content-SWIMS data show that IDC 300 waste is noncombustible (Rockwell International 1985a). In support of the TRU Waste Sampling Program, eight drums of IDC 300 waste were opened. They were found to contain an average wt\% combustible content of $4.8 \%$. Visual inspection showed an average vol\% combustible content of 8.1\% (Clements and Kudera 1985).

3.6.1.10.2 Organic Content-SWIMS data show that IDC 300 waste contains 20\% organics (Rockwell International 1985a). In support of the TRU Waste Sampling Program, eight drums of IDC 300 waste were opened. They were found to contain an average wt\% organic content of $4.8 \%$ (Clements and Kudera 1985).

3.6.1.11 Analytical Information. Analytical data from the TRU Waste Sampling Waste Characterization Program (Clements and Kudera 1985) for IDC 300-Graphite Molds, indicate that eight drums were subject to headspace gas analysis. Gas composition analytical results are presented 
in Table 3.6.1-7. Waste boxes were not sampled. Hydrogen, oxygen, nitrogen, argon, carbon dioxide, saturated hydrocarbons, and 1,1,1-trichloroethane were detected in the drums.

IDC 300, Graphite Molds, contains no hazardous constituents (Rockwell International 1989b) and (D). 
Table 3.6.1-7. Gas Sampling Results-Compositional Analysis (vol\%).

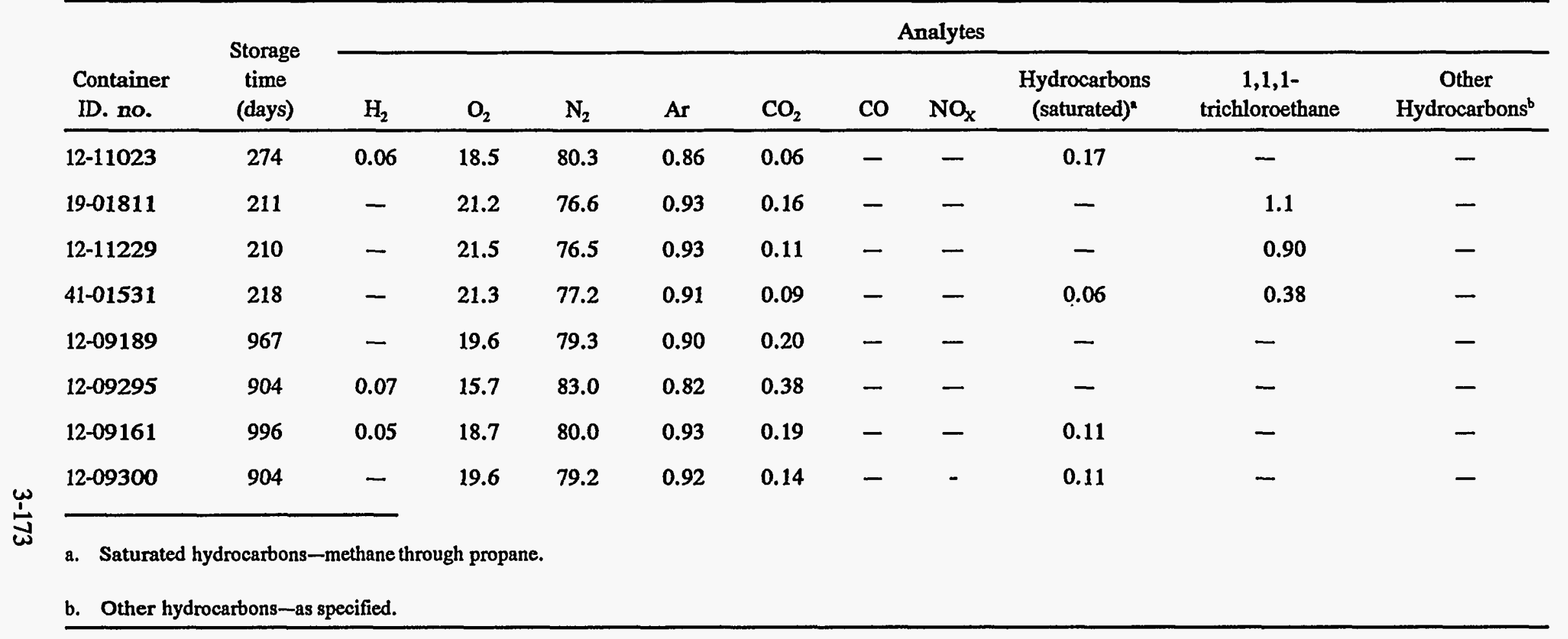




\subsection{Waste Form Number 115-TRU Graphite Waste, Content Code RF 115A}

\subsubsection{Item Description Code 303-Scarfed Graphite Chunks}

3.6.2.1 Certification Assessment. This IDC is certifiable without further waste treatment. Assay and thermal power calculations, including error, need to be updated to meet the current WIPP WAC. Several gas generation criteria need to be addressed. Carbon filters may need to be installed, drums will require inspection to identify unvented or unpunctured rigid liners, and headspace gas analysis and visual waste characterization will need to be performed.

3.6.2.2 Waste Description. After the casting of plutonium in production foundry operations, IDC 300 was mechanically cleaned using a rotary-type sanding tool to grind off contamination, generating IDC 303-Scarfed Graphite Chunks. The mechanical cleaning (scarfing) of the mold surface removes most of the mold coating and plutonium contamination (D).

3.6.2.3 Generation Source. IDC 303 waste was generated Buildings $371,707,771$ and 777 (D).

3.6.2.4 Recovery Method. IDC 303 waste had no recovery method. This waste consists of graphite chunks that have been scarfed. The scarfing removed most of the plutonium, although the graphite chunks may still have contained discernible amounts of plutonium.

3.6.2.5 Waste Packaging and Handling. TRU graphite waste was segregated from all noncomplying materials and placed into a 55-gal waste drum or placed into a 55-gal waste drum that was connected to the glovebox by an 11-mil, PVC, O-ring bag. When the drum was full, the drum liners were sealed and the drum was closed. The drum label, completed with all necessary information, was then taped to the drum lid and a TID was attached to the drum.

If the drum contained classified graphite shapes, it was sent to Size Reduction in Building 776 for shredding to declassify the waste, and then repackaged into the drum.

3.6.2.6 Container Preparation. Only approved containers could be used to package TRU waste for shipment offsite. The containers approved for shipment to INEL during this time were DOT-17C, white, 55-gal drums (Rockwell specification SX-200). These containers met the requirements for certification as DOT-7A Type A packaging (Rockwell International 1989e).

Table 3.6.2-1 shows the current inventory of IDC 303 waste containers from the Rocky Flats Plant that have been shipped to INEL since 1985 . 
Table 3.6.2-1. Item Description Code 303 Container Information.

\begin{tabular}{|c|c|c|c|}
\hline \multicolumn{2}{|l|}{ Information } & \multirow{2}{*}{$\frac{\text { Drums }}{78}$} & \multirow{2}{*}{$\frac{\text { Boxes }}{0}$} \\
\hline Total Containers & & & \\
\hline \multirow[t]{3}{*}{ Net Container Weight (lb) } & Maximum & 214 & N/A \\
\hline & Minimum & 29 & N/A \\
\hline & Average & 175 & N/A \\
\hline
\end{tabular}

3.6.2.6.1 Drum Preparation-Approved liners for drums of TRU waste packaged for offsite shipment were the round-bottom liner (Rockwell specification SX-203) inside a 90-mil rigid polyethylene liner (Rockwell specification SX-202), or an O-ring bag and a polyethylene bag placed inside the rigid liner if the drum was attached to a glovebox (Rockwell International 1989e) Type III rigid liners have been used since September 1983 (Bearly 1989a). The IDC 303 waste packaged for offsite shipment required a fiberboard liner and a round bottom liner inside the rigid liner (Rockwell International 1988c). Figure C-1 shows the appropriate drum liners for this IDC (Rockwell International 1989b). All bags were closed using the twist-and-tape method (Rockwell International 1989e).

Flow-in, ventable gaskets were installed in the drums beginning in December 1982 . They were used until October 1988, when tubular gaskets with carbon filters were required. Drums shipped to INEL between 1985 and 1988 may not meet the current WIPP WAC, owing to their lack of carbon filters (Bearly 1989a).

3.6.2.6.2 Box Preparation-No boxes of IDC 303 waste were shipped to INEL between 1985 and 1989.

3.6.2.7 Assay. The drums may have been assayed on an SGS counter or a PADC. Containers of waste that have not been PADC assayed and had SGS assay values of 1 gram or less should be PADC assayed to verify that they are transuranic waste. Table 3.6.2-2 summarizes the dose rates measured on containers of this IDC. Table 3.6.2-3 provides a summary of the assay information. Seven drums were evaluated for uranium content, no drums were evaluated for americium content.

Table 3.6.2-2. Item Description Code 303 Dose Information.

\begin{tabular}{crcc} 
Information & & Drums & Boxes \\
\hline One Meter Dose Rate (mrem/h) & $0-0.5$ & 47 & N/A \\
& $0.5-10$ & 31 & N/A \\
Surface Dose Rate $(\mathrm{mrem} / \mathrm{h})$ & $<10$ & 76 & N/A \\
& $10-200$ & 2 & N/A
\end{tabular}


Table 3.6.2-3. Item Description Code 303 Assay Information.

\begin{tabular}{|c|c|c|c|}
\hline \multicolumn{2}{|c|}{ Radionuclide inventory } & \multirow{2}{*}{$\frac{\text { Drums }}{95}$} & \multirow{2}{*}{$\frac{\text { Boxes }}{\text { N/A }}$} \\
\hline Plutonium (g) & Maximum & & \\
\hline & Minimum & 0 & N/A \\
\hline & Average & 18.4 & $\mathbf{N} / \mathbf{A}$ \\
\hline \multirow[t]{3}{*}{ Americium (g) } & Maximum & 0 & N/A \\
\hline & Minimum & 0 & N/A \\
\hline & Average & 0 & N/A \\
\hline \multirow[t]{3}{*}{ Uranium-235 (g) } & Maximum & 9 & N/A \\
\hline & Minimum & 1 & N/A \\
\hline & Average & 4.29 & N/A \\
\hline
\end{tabular}

3.6.2.8 Inspection. Waste Certification personnel performed periodic inspections of the generating and packaging process to verify compliance with waste acceptance criteria. In addition, each drum was viewed using RTR to

- Ensure the drum does not contain nonconforming items

- Ensure the drum is properly packaged

- Verify the waste form description

- Evaluate the presence of free liquids.

3.6.2.9 Waste Form Evaluation. Table 3.6.2-4 evaluates the waste form against the WIPP WAC for such items as free liquids, pyrophoric materials, and compressed gases. Table 3.6.2-5 evaluates the waste against TRUPACT criteria. 
Table 3.6.2-4. Waste Form Evaluation.

Criterion or requirement

Limiting parameters ${ }^{\mathbf{2}}$

Immobilization

Particulates were prohibited by procedural control. Based on the description of the waste, fine particulates are not expected in this IDC.

Liquids

This waste form meets the free liquid criteria by procedural control and RTR inspection prior to shipment from Rocky Flats.

Pyrophoric

Materials

Pyrophoric materials were prohibited by procedural control. The absence of the pyrophoric materials was verified by the generating supervisor and periodic inspection by the Waste Certification Organization.

Explosives and

Compressed Gases

Explosives and compressed gases were prohibited by procedural control. The absence of the explosives and compressed gases was verified by the generating supervisor and periodic inspection by the Waste Certification Organization. In addition, unvented, closed containers and pressurized containers were excluded by procedural controls and RTR examination.

TRU-Mixed Wastes The RCRA constituents exist as co-contaminants with the transuranic radionuclides. Compliance with the WIPP RCRA permits and NMD will be required before shipment of the stored waste to WIPP.

Specific Activity of

Waste

A portion of the waste stored at INEL may contain $<100$ nanocuries per gram transuranic radionuclides.

$\mathrm{Pu}^{239}$ Equivalent None of the IDC 303 waste containers recorded as shipped to INEL in the Activity SWIMS exceed 1,000 Ci of plutonium-equivalent activity.

a. Many of the limiting parameters were taken from TRU Waste Compliance Program (Rockwell International 1983a, 1987e, and 1989b). 
Table 3.6.2-5. TRUPACT Evaluation.

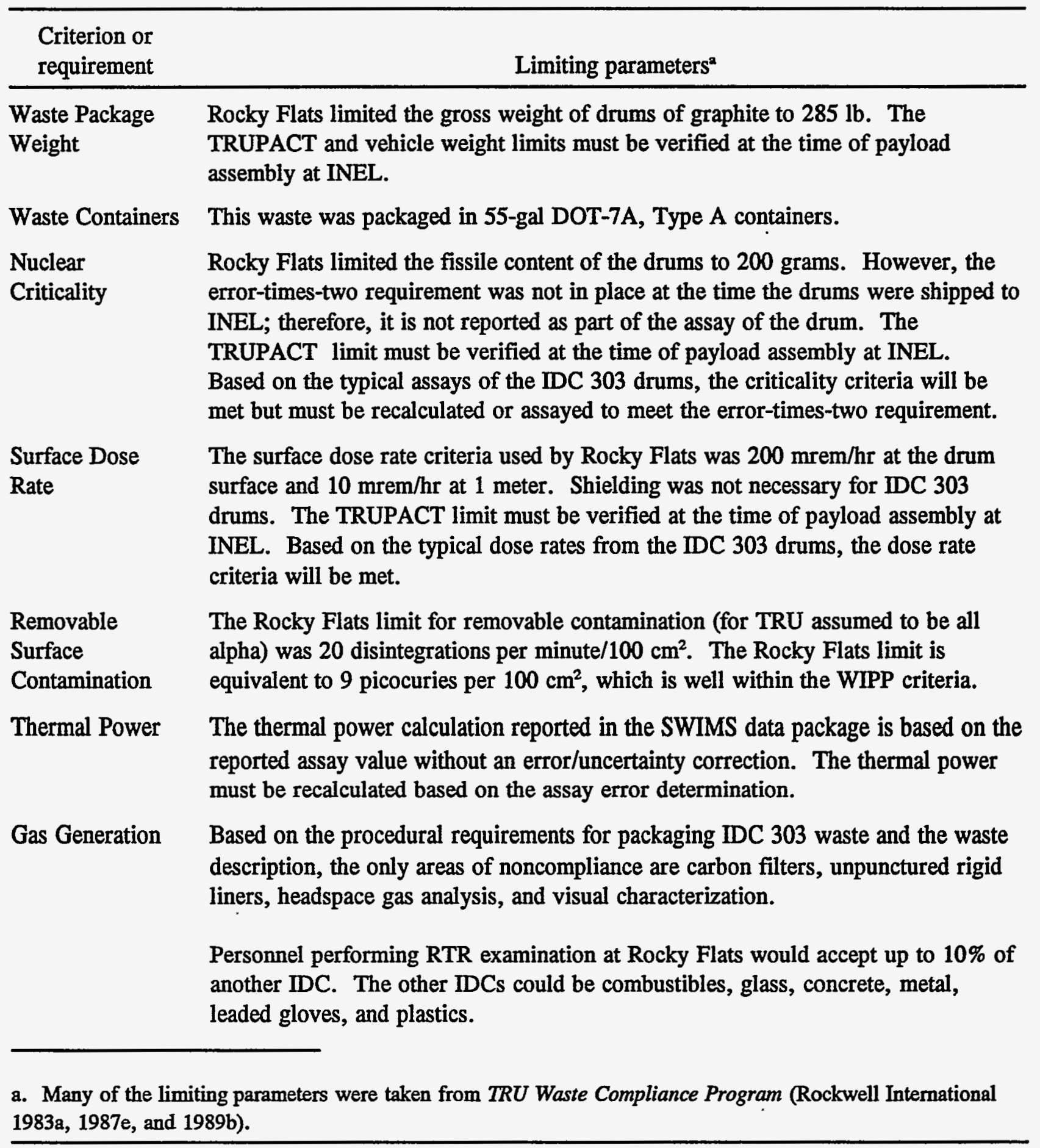

3.6.2.10 Combustible and Organic Content. SWIMS data indicate that this waste form does not contain $>20 \%$ combustibles or $>20 \%$ organics.

3.6.2.10.1 Combustible Content-SWIMS data show that IDC 303 waste is noncombustible (Rockwell International 1985a). 
3.6.2.10.2 Organic Content-SWIMS data show that IDC 303 waste may contain zero\% organics (Rockwell International 1985a).

3.6.2.11 Analytical Information. No analytical information is available for IDC 303 .

IDC 303, Scarfed Graphite Chunks, contains no hazardous constituents (Rockwell International 1989b) and (D). 


\subsection{Waste Form Number 116-TRU Combustible Waste, Content Code RF 116A}

\subsubsection{Item Description Code 330-Combustibles, Dry}

3.7.1.1 Certification Assessment. This IDC is certifiable without further waste treatment. Assay and thermal power calculations, including error, need to be updated to meet the current WIPP WAC. Several gas generation criteria need to be addressed. Carbon filters may need to be installed, drums will require inspection to identify unvented or unpunctured rigid liners, and headspace gas analysis and visual waste characterization will need to be performed.

3.7.1.2 Waste Description. IDC 330 waste consists mainly of dry cloth and paper products from cleanup of gloveboxes and spills involving hazardous solvents. Plutonium-contaminated dry combustibles were identified as IDC 330 until assayed. Beginning in 1988, IDC 330 was changed to IDC 831 if the assay determined the waste was TRU waste (EG\&G RFP 1994a).

3.7.1.3 Generation Source. Combustible wastes were generated plant-wide including, but not limited to, Buildings $371,374,559,707,771,774,776$, and 779.

3.7.1.4 Recovery Method. Combustible waste contaminated with amounts of plutonium above the discard limit was incinerated by Plutonium Recovery Operations and the ash recovered for further processing (Clements 1982).

3.7.1.5 Waste Packaging and Handling. Line-generated dry combustible waste was segregated from all other materials, especially removing all free liquid, particulates, and process residues. The waste was then collected and bagged out of the glovebox line. A small amount of Oil Dri was added to the bags if the waste was wet. All line-generated waste was usually double-bagged and monitored for contamination before being placed into the waste collection drum for line-generated waste. The drums were DOT-17C, white, 55-gal drums (Rockwell International 1989b).

Dry combustible wastes generated within the Pu processing area, but outside of a glovebox line, were termed "nonline-generated wastes." These wastes were collected in 55-gal drums located in all $\mathrm{Pu}$ areas. The drum covers were clearly marked for nonline waste. Normally, nonline waste was not bagged before being placed in the collection drum (Rockwell International 1989e). Nonline waste was rarely TRU and would have been repackaged in a box or drum with a rigid liner prior to shipment.

When the drum was full, the drum liners were sealed and the drum was closed. The drum label, completed with all necessary information, was then taped to the drum lid and a TID was attached to the drum.

Drums were held in Size Reduction in Building 776 until about 20 drums of either linegenerated or nonline-generated combustibles had accumulated. The line-generated or nonlinegenerated wastes were then repackaged separately into boxes equipped with a certified filter-and-vent system (Rockwell International 1989b). In 1987, Nuclear Safeguards, Solid Waste Operations, and 
Waste Compliance and Planning agreed that line and non-line generated IDC 330 waste may be mixed, provided the non-line waste has been counted by the Low Specific Activity Counter (LOSAC) and determined to be TRU waste. Also up to four drums of IDC 336 or IDC 337 waste may be mixed with IDC 330 waste.

3.7.1.6 Container Preparation. Only approved containers could be used to package TRU waste for shipment offsite. Containers approved for shipment to INEL during this time were DOT17C, white, 55-gal drums (Rockwell specification SX-200); white, corrugated steel boxes (Rockwell specification SX-231); and fiberglass-reinforced polyester (FRP) boxes (Rockwell specification SX207). Each of these containers met the requirements for certification as DOT-7A Type A packaging (Rockwell International 1989e).

Table 3.7.1-1 shows the current inventory of IDC 330 waste containers from the Rocky Flats Plant that have been shipped to INEL since 1985.

Table 3.7.1-1. Item Description Code 330 Container Information.

\begin{tabular}{lccc}
\hline \multicolumn{1}{c}{ Information } & & Drums & Boxes \\
\cline { 2 - 4 } Total Containers & & 3 & 424 \\
Net Container Weight (lb) & Maximum & 129 & 2,120 \\
& Minimum & 61 & 320 \\
& Average & 91 & 1,010 \\
\hline
\end{tabular}

3.7.1.6.1 Drum Preparation. Approved liners for drums of TRU waste packaged for offsite shipment were the round-bottom liner (Rockwell specification SX-203) inside a 90-mil rigid polyethylene liner (Rockwell specification SX-202), or an O-ring bag and a polyethylene bag placed inside the rigid liner if the drum was attached to a glovebox (Rockwell International 1989e). Type III rigid liners have been used since September 1983 (Bearly 1989a). The IDC 330 waste packaged for offsite shipment required a fiberboard liner and two polyethylene bags inside the rigid liner (Rockwell International 1988c). Figure C-1 shows the appropriate drum liners for this IDC. All bags were closed using the twist-and-tape method (Rockwell International 1989e).

Flow-in, ventable gaskets were installed in the drums beginning in December 1982. They were used until October 1988, when tubular gaskets with carbon filters were required. Drums shipped to INEL between 1985 and 1988 may not meet the current WIPP WAC, owing to their lack of carbon filters (Bearly 1989a).

3.7. 1.6.2 Box Preparation. FRP boxes were used for waste shipped to INEL from 1972 through 1982 (Riddle and others 1985). In 1982, the use of the corrugated metal waste box was phased in. The last FRP box was shipped to INEL in 1986. In the interim, waste packaged in both types of boxes had been shipped to INEL. SWIMS information did not track the type of box used in individual shipments.

The FRP box was constructed of $3 / 4$-in. exterior plywood with $2 \times 4$-in. framing members and skids. The entire box was coated with a 0.12 -in. coat of fiberglass-reinforced polyester with flame- 
retardant properties. The continuous FRP coating provided a leakproof, tamper-proof package. Inner liners used for contamination control during loading consisted of a PVC liner protected by a 50-mil fiberboard sheet. The box size was $4 \times 4 \times 7 \mathrm{ft}$ or larger. The gross weight was normally restricted to 5,000 lb (Riddle and others 1985).

The corrugated metal waste boxes were made entirely out of 14-gauge (0.0747-in.), low-carbon steel. All seams including the closure were welded to produce a leaktight container (Brugger 1983). These boxes required a 10-mil PVC liner (Rockwell specification SX-209) and a 0.051-in. fiberboard liner (Rockwell specification SX-209) (Riddle and others 1985; Bearly and others 1988). Figure C-5 shows the appropriate box liners required for this IDC. Four sizes of the box had been certified as DOT-7A containers, with a maximum size of $54 \times 54 \times 89$ in. and a maximum gross weight of $7,000 \mathrm{lb}$. These containers were commonly referred to as "Sand Boxes" (Riddle and others 1985).

Where necessary, items that had a weight distribution or configuration which caused them to sit in an unstable condition in the container were blocked, braced, or banded to prevent the items from shifting (Rockwell International 1989e). All items that had the potential to puncture or otherwise compromise the integrity of the waste box were adequately prepackaged to cover sharp corners (Rockwell International 1989e).

3.7.1.7 Assay. Line-generated combustibles were assayed using SGS equipment. Nonline generated waste was assayed with LOSAC equipment, unless the assay value was $>20$ grams. If the LOSAC assay was $>20$ grams, the drums are assayed with SGS equipment. Assay results from the individual drums repackaged into a box were used as the primary assay results. This cumulative assay was checked using a crate counter or passive-action neutron (PAN) equipment. The results of the check must agree with the cumulative assay within the established errors for the assay equipment. Table 3.7.1-2 provides dose rate information. Table 3.7.1-3 provides assay information. One drum and 17 boxes were evaluated for americium content. No drums were evaluated for uranium, but 68 boxes were evaluated.

Table 3.7.1-2. Item Description Code 330 Dose Information.

\begin{tabular}{crcr} 
Information & & Drums & Boxes \\
\hline One Meter Dose Rate (mrem/h) & $0-0.5$ & 2 & 407 \\
& $0.5-10$ & 1 & 17 \\
Surface Dose Rate (mrem/h) & $<10$ & 3 & 418 \\
& $10-200$ & 0 & 6 \\
\hline
\end{tabular}


Table 3.7.1-3. Item Description Code 330 Assay Information.

\begin{tabular}{|c|c|c|c|}
\hline \multicolumn{2}{|c|}{ Radionuclide inventory } & $\frac{\text { Drums }}{130}$ & $\frac{\text { Boxes }}{261}$ \\
\hline Plutonium (g) & $\begin{array}{r}\text { Maximum } \\
\text { Minimum } \\
\text { Average }\end{array}$ & $\begin{array}{r}130 \\
2 \\
47\end{array}$ & $\begin{array}{r}261 \\
0 \\
36\end{array}$ \\
\hline Americium (g) & $\begin{array}{r}\text { Maximum } \\
\text { Minimum } \\
\text { Average }\end{array}$ & $\begin{array}{l}1 \\
0 \\
0.3\end{array}$ & $\begin{array}{r}11 \\
0 \\
2\end{array}$ \\
\hline Uranium-235 (g) & $\begin{array}{r}\text { Maximum } \\
\text { Minimum } \\
\text { Average }\end{array}$ & $\begin{array}{l}- \\
-\end{array}$ & $\begin{array}{r}32 \\
0 \\
6\end{array}$ \\
\hline
\end{tabular}

3.7.1.8 Inspection. Waste Certification personnel performed periodic inspections of the generating and packaging process to verify compliance with waste acceptance criteria. In addition, each drum was viewed using RTR to

- Ensure the drum did not contain nonconforming items

- Ensure the drum was properly packaged

- Verify the waste form description

- Evaluate the presence of free liquids.

3.7.1.9 Waste Form Evaluation. Table 3.7.1-4 evaluates the waste form against the WIPP WAC for such items as free liquids, pyrophoric materials, and compressed gases. Table 3.7.1-5 evaluates the waste against TRUPACT criteria. 
Table 3.7.1-4. Waste Form Evaluation.

Criterion or

requirement

Limiting parameters ${ }^{2}$

Immobilization

Particulates were prohibited by procedural control. Based on the description of the waste, fine particulates are not expected in this IDC.

Liquids

There are normally no liquids associated with this IDC. Personnel performing RTR examination at Rocky Flats would accept up to 2 cups of free liquid, if liquids were present.

Pyrophoric Pyrophoric materials were prohibited by procedural control. The absence of the

Materials pyrophoric materials was verified by the generating supervisor and periodic inspection by the Waste Certification Organization.

Explosives and Compressed Gases

Explosives and compressed gases were prohibited by procedural control. The absence of the explosives and compressed gases was verified by the generating supervisor and periodic inspection by the Waste Certification Organization. In addition, unvented, closed containers and pressurized containers were excluded by procedural controls and RTR examination.

TRU-Mixed Wastes The RCRA constituents exist as co-contaminants with the transuranic radionuclides. Compliance with the WIPP RCRA permits and NMD will be required before shipment of the stored waste to WIPP.

Specific Activity of This waste contains at least 100 nanocuries per gram transuranic radionuclides. Waste

$\mathrm{Pu}^{239}$ Equivalent None of the IDC 330 waste containers recorded as shipped to INEL in the Activity SWIMS exceed 1,000 $\mathrm{Ci}$ of plutonium-equivalent activity.

a. Many of the limiting parameters were taken from TRU Waste Compliance Program (Rockwell International 1983a, 1987e, and 1989b). 
Table 3.7.1-5. TRUPACT Evaluation.

Criterion or

requirement

Limiting parameters ${ }^{2}$

Waste Package

Weight

Rocky Flats limited the gross weight of drums to $800 \mathrm{lb}$. The TRUPACT and vehicle weight limits must be verified at the time of payload assembly at INEL. Based on the typical weights of the IDC 330 drums, the maximum payload weight will not be reached.

Waste Containers Dry combustibles were in 55-gal DOT-7A, Type A drums or $4 \times 4 \times 7$-ft DOT7A, Type A metal boxes. The metal boxes will not meet the TRUPACT waste container requirements.

Nuclear

Criticality

Rocky Flats limited the fissile content of the drums to 200 grams. However, the error-times-two requirement was not in place at the time the drums were shipped to INEL; therefore, it is not reported as part of the assay of the drum. The TRUPACT limit must be verified at the time of payload assembly at INEL. Based on the typical assays of the IDC 330 drums, the criticality criteria will be met but must be recalculated or assayed to meet the error-times-two requirement.

Surface Dose The surface dose rate criteria used by Rocky Flats was $200 \mathrm{mrem} / \mathrm{hr}$ at the Rate container surface and $10 \mathrm{mrem} / \mathrm{hr}$ at 1 meter. Shielding was used for two IDC 330 containers. The TRUPACT limit must be verified at the time of payload assembly at INEL. Based on the typical dose rates from the IDC 330 drums, the dose rate criteria will be met.

Removable

Surface

The Rocky Flats limit for removable contamination (for TRU assumed to be all Contamination alpha) was 20 disintegrations per minute $100 \mathrm{~cm}^{2}$. The Rocky Flats limit is equivalent to 9 picocuries per $100 \mathrm{~cm}^{2}$, which is well within the WIPP criteria.

Thermal Power

The thermal power calculation reported in the SWIMS data package is based on the reported assay value without an error/uncertainty correction. The thermal power must be recalculated based on the assay error determination.

Gas Generation Based on the procedural requirements for packaging IDC 330 waste and the waste description, the only areas of noncompliance are carbon filters, nonpunctured rigid liners, headspace gas analysis, and visual characterization.

Headspace gas analysis of IDC 831 is considered applicable to IDC 330 . IDC 831 was created to describe TRU combustibles, not to denote a process change. Cyclohexane, 1,1-dichloroethene, toluene, ethylbenzene, and xylene may be present in IDC 330, but are not listed in the TRUPACT Chemical list for RF 116A. 1,1,1Trichloro-ethane and dichloromethane were detected by headspace analysis and are on the TRUPACT Chemical List. These chemicals appear to be in total concentrations $<1 \%$. 1,1,2-Trichloro-1,2,2-trifluoroethane and carbon tetrachloride are on the TRUPACT Chemical List for halogenated organics, but were not detected.

Personnel performing RTR examination at Rocky Flats would accept up to $10 \%$ of another IDC. The other IDCs could be glass, concrete, metal, leaded gloves, and plastics.

a: Many of the limiting parameters were taken from TRU Waste Compliance Program (Rockwell International 1983a, 1987e, and 1989b). 
3.7.1.10 Combustible and Organic Content. Table 3.7.1-6 outlines available data from the TRU Waste Sampling Program for IDC 330. SWIMS data indicate that this waste form contains $>20 \%$ combustibles and $>20 \%$ organics.

Table 3.7.1-6. Item Description Code 330 Data Summary for Combustible or Organic Content.

\begin{tabular}{ccccccc}
\hline & $\begin{array}{c}\text { Wt. } \\
\text { combustibles } \\
(\mathrm{lb})^{\mathrm{a}}\end{array}$ & $\begin{array}{c}\text { Wt. } \\
\text { organics } \\
(\mathrm{lb})^{\mathrm{b}}\end{array}$ & $\begin{array}{c}\text { Net wt. of } \\
\text { container } \\
(\mathrm{lb})^{\mathrm{c}}\end{array}$ & $\begin{array}{c}\text { Wt\% } \\
\text { combustibles }^{\mathrm{d}}\end{array}$ & $\begin{array}{c}\text { Vol\% } \\
\text { combustibles }^{\text {c }}\end{array}$ & $\begin{array}{c}\text { Wt\% } \\
\text { organics }^{\mathrm{f}}\end{array}$ \\
\hline $22-01194$ & 59.5 & 59.5 & 63.0 & 94 & 100 & 94 \\
$38-00101$ & 90.3 & 90.3 & 91.0 & 99 & 100 & 99 \\
$76-02898$ & 63.3 & 63.3 & 180.0 & 35 & 95 & 35 \\
$02-39195$ & 83.0 & 83.0 & 87.5 & 95 & 100 & 95 \\
$389-90417$ & $1,038.0$ & $1,038.0$ & $1,054.0$ & 98 & 100 & 98 \\
$389-90609$ & 816.0 & 816.0 & 840.0 & 97 & 100 & 97 \\
$02-35272$ & 88.3 & 88.3 & 92.5 & 95 & 100 & 95 \\
$01-08200$ & 44.2 & 44.2 & 53.4 & 83 & 100 & 83 \\
$01-08796$ & 40.9 & 40.9 & 56.9 & 100 & 100 & 100 \\
$90-00042$ & 165.9 & 165.9 & 244.9 & 67 & 98 & 67 \\
$37-00689$ & 63.7 & 63.7 & 65.2 & 98 & 95 & 98 \\
$89-03607$ & 67.0 & 67.0 & 90.6 & 74 & 100 & 74 \\
$90-00039$ & 191.4 & 191.4 & 196.8 & 97 & 100 & 97 \\
$02-39465$ & 46.0 & 46.0 & 49.0 & 94 & 100 & 94 \\
$02-39084$ & 81.3 & 81.3 & 84.8 & 96 & 100 & 96 \\
$02-40137$ & 47.5 & 47.5 & 52.5 & 90 & 90 & 95 \\
\hline
\end{tabular}


Table 3.7.1-6. (continued).

\begin{tabular}{lcccccc}
\hline Container & $\begin{array}{c}\text { Wt. } \\
\text { combustibles } \\
(\mathrm{lb})^{\mathrm{a}}\end{array}$ & $\begin{array}{c}\text { Wt. } \\
\text { organics } \\
(\mathrm{lb})^{\mathrm{b}}\end{array}$ & $\begin{array}{c}\text { Net wt. of } \\
\text { container }^{(\mathrm{lb})^{\mathrm{c}}}\end{array}$ & $\begin{array}{c}\text { Wt\% } \\
\text { combustibles }^{\mathrm{d}}\end{array}$ & $\begin{array}{c}\text { Vol\% } \\
\text { combustibles }^{\mathrm{e}}\end{array}$ & $\begin{array}{c}\text { Wt\% } \\
\text { organics }^{\mathrm{f}}\end{array}$ \\
\hline $02-10215$ & 59 & 59 & 71.4 & 83 & 100 & 83 \\
$01-08604$ & 62.2 & 62.2 & 64.4 & 97 & 100 & 97
\end{tabular}

a. Sum of weights of all combustible material and leaded rubber from Table 25 (Clements and Kudera 1985).

b. Sum of weights of all combustible material, leaded rubber, and organic material from Table 25 (Clements and Kudera 1985).

c. Net weight of container from Table 25 (Clements and Kudera 1985).

d. Weight of combustible material/net weight of container $\times 100$.

e. Vol\% of combustible material from visual examination, obtained from Appendix B (Clements and Kudera 1985).

f. Weight of organic material/net weight of container $\times 100$.

3.7.1.10.1 Combustible Content-SWIMS data show that IDC 330 waste is combustible (EG\&G RFP 1993c). In support of the TRU Waste Sampling Program, 18 drums of IDC 330 waste were opened. They were found to contain an average wt\% combustible content of 88.4\%. Visual inspection showed an average vol\% combustibles content of $99.3 \%$. (Clements and Kudera 1985).

3.7.1.10.2 Organic Content-SWIMS data show that IDC 330 waste may contain $100 \%$ organics (Rockwell International 1985a). In support of the TRU Waste Sampling Program, 18 drums of IDC 330 waste were opened. They were found to contain an average wt\% organic content of $88.4 \%$ (Clements and Kudera 1985).

3.7.1.11 Analytical Information. Analytical data from the TRU Waste Sampling Waste Characterization Program for IDC 330, Dry Combustibles, indicate that 16 drums were subject to headspace gas analysis (Clements and Kudera 1985).

Gas composition analytical results are presented in Table 3.7.1-7. Waste boxes were not sampled. Hydrogen, oxygen, nitrogen, argon, carbon dioxide, carbon monoxide, saturated hydrocarbons, 1,1,1-trichloroethane, dichloromethane, and a $\mathrm{CF}_{3}{ }^{+}$fragment were detected in the drums.

Combustibles were used for cleanup of gloveboxes and spills involving hazardous solvents. Because IDC 330 contains solvents, it is assigned EPA Codes F001, F002, and F005 (EG\&G RFP 1994a). 
Table 3.7.1-7. Gas Sampling Results-Compositional Analysis (vol\%).

\begin{tabular}{|c|c|c|c|c|c|c|c|c|c|c|c|}
\hline \multirow[b]{2}{*}{$\begin{array}{l}\text { Container } \\
\text { ID. no. } \\
\end{array}$} & \multirow[b]{2}{*}{$\begin{array}{c}\text { Storage } \\
\text { time } \\
\text { (days) }\end{array}$} & \multicolumn{10}{|c|}{ Analytes } \\
\hline & & $\mathrm{H}_{2}$ & $\mathrm{O}_{2}$ & $\mathrm{~N}_{2}$ & $\mathrm{Ar}$ & $\mathrm{CO}_{2}$ & $\mathrm{CO}$ & $\mathrm{NO}_{\mathrm{x}}$ & $\begin{array}{l}\text { Hydrocarbons } \\
\text { (saturated) }^{1}\end{array}$ & $\begin{array}{c}1,1,1- \\
\text { trichloro- } \\
\text { ethane }\end{array}$ & $\begin{array}{c}\text { Other } \\
\text { Hydrocarbons }^{2} \\
\end{array}$ \\
\hline $42-00291$ & 251 & 0.09 & - & 79.3 & 0.91 & 17.3 & - & 2.26 & 0.14 & - & - \\
\hline $22-01194$ & 276 & 0.40 & 18.8 & 79.2 & 0.91 & 0.24 & - & - & 0.27 & 0.16 & - \\
\hline $38-00101$ & 269 & 0.28 & - & 78.0 & 0.93 & 19.5 & - & - & 0.87 & 0.11 & $0.25^{\mathrm{a}}$ \\
\hline $76-02898$ & 326 & 18.2 & - & 64.6 & 0.75 & 15.2 & - & 0.36 & 0.65 & 0.11 & $0.11^{a}$ \\
\hline 02-39195 & 307 & 0.34 & 12.5 & 83.3 & 0.93 & 2.09 & - & - & 0.29 & 0.53 & - \\
\hline 02-39465 & 227 & 0.87 & 17.2 & 79.4 & 0.90 & 1.1 & - & - & 0.25 & 0.32 & - \\
\hline 02-39084 & 328 & 0.15 & 13.6 & 82.8 & 0.94 & 2.23 & - & - & 0.22 & - & - \\
\hline $02-40137$ & 163 & 0.97 & 17.9 & 78.8 & 0.92 & 1.2 & - & - & 0.18 & - & - \\
\hline $02-35272$ & 903 & 0.10 & 19.3 & 79.1 & 0.92 & 0.35 & - & - & 0.24 & - & - \\
\hline $01-08200$ & 4,361 & - & 20.1 & 78.5 & 0.93 & 0.44 & - & - & - & 0.06 & - \\
\hline $01-08796$ & 4,334 & 0.05 & 18.0 & 80.6 & 0.96 & 0.61 & - & - & - & - & - \\
\hline $90-00042$ & 4,215 & 13.6 & 0.10 & 76.4 & 0.94 & 8.45 & - & - & 0.22 & - & $0.32^{b}$ \\
\hline $37-00689$ & 4,340 & 1.9 & 0.13 & 94.7 & $1.1^{\circ}$ & 1.9 & - & 0.37 & - & - & - \\
\hline $89-03607$ & 4,306 & 1.4 & 0.13 & 91.3 & 1.1 & 5.94 & - & - & - & 0.07 & - \\
\hline $02-10215$ & 4,318 & 3.42 & 0.13 & 95.3 & 1.1 & 0.06 & - & - & - & - & - \\
\hline $90-00039$ & 4,227 & 7.33 & 0.29 & 90.4 & 1.0 & 0.74 & - & - & 0.17 & - & - \\
\hline $\begin{array}{l}\text { 1. Saturated } \\
\text { 2. Other hy } \\
\text { a. Di } \\
\text { b. Co }\end{array}$ & $\begin{array}{l}\text { arbons - } \\
\text { ons - as } \\
\text { ethane } \\
\mathrm{CF}_{3}{ }^{+} \mathrm{f}\end{array}$ & $\begin{array}{l}\text { ane th } \\
\text { fied. } \\
\text { ent }\end{array}$ & h props & & & & & & & & \\
\hline
\end{tabular}




\subsection{Waste Form Number 116-TRU Combustible Waste, Content Code RF 116A}

\subsubsection{Item Description Code 336-Combustibles, Wet}

3.7.2.1 Certification Assessment. This IDC is certifiable without further waste treatment. Assay and thermal power calculations, including error, need to be updated to meet the current WIPP WAC. Several gas generation criteria need to be addressed. Carbon filters may need to be installed, drums will require inspection to identify unvented or unpunctured rigid liners, and headspace gas analysis and visual waste characterization will need to be performed. Metal boxes are not authorized for shipment in TRUPACT.

3.7.2.2 Waste Description. IDC 336 waste consists mainly of wet cloth and paper products from cleanup of gloveboxes and spills involving hazardous solvents. These waste materials were drained or wrung out prior to packaging to prevent an accumulation of free liquid. Plutoniumcontaminated wet combustibles were identified as IDC 336 until assayed. Beginning in 1988, IDC 336 was changed to IDC 832 if the assay determined the waste was TRU waste (EG\&G RFP 1994a).

3.7.2.3 Generation Source. Combustible wastes were generated plant wide including, but not limited to, Buildings 371, 374, 559, 707, 771, 774, 776, and 779.

3.7.2.4 Recovery Method. Combustible waste contaminated with amounts of plutonium above the discard limit was incinerated by Plutonium Recovery Operations and the ash recovered for further processing (Clements 1985).

3.7.2.5 Waste Packaging and Handling. Line-generated wet combustible waste was segregated from all other materials, especially removing all free liquid, particulates, and process residues. The waste was then collected and bagged out of the glovebox line. A small amount of Oil Dri was added to the bags if the waste was wet. All line-generated waste was usually double-bagged and monitored for contamination before being placed into the waste collection drum for line-generated waste. The drums were DOT-17C, white, 55-gal drums (Rockwell International 1989b).

Wet combustible wastes generated within the Pu processing area, but outside of a glovebox line, were termed "nonline-generated wastes." These wastes were collected in 55-gal drums located in all $\mathrm{Pu}$ areas. The drum covers were clearly marked for nonline waste. Normally, nonline waste was not bagged before being placed in the collection drum (Rockwell International 1989e). Nonline waste was rarely TRU and would have been repackaged in a box or drum with a rigid liner prior to shipment.

When the drum was full, the drum liners were sealed and the drum was closed. The drum label, completed with all necessary information, was then taped to the drum lid and a TID was attached to the drum.

Drums were held in Size Reduction in Building 776 until about 20 drums of either linegenerated or nonline-generated wet combustibles had accumulated. The line-generated or nonline- 
generated wastes were then repackaged separately into boxes equipped with a certified filter-and-vent system (Rockwell International 1989b).

3.7.2.6 Container Preparation. Only approved containers could be used to package TRU waste for shipment offsite. Containers approved for shipment to INEL during this time were DOT17C, white, 55-gal drums (Rockwell specification SX-200); white, corrugated steel boxes (Rockwell specification SX-231); and FRP boxes (Rockwell specification SX-207). Each of these containers met the requirements for certification as DOT-7A Type A packaging (Rockwell International 1989e).

Table 3.7.2-1 shows the current inventory of IDC 336 waste containers from the Rocky Flats Plant that have been shipped to INEL since 1985.

Table 3.7.2-1. Item Description Code 336 Container Information.

\begin{tabular}{lccc}
\hline \multicolumn{1}{c}{ Information } & & Drums & Boxes \\
\cline { 2 - 4 } Total Containers & & 1 & 413 \\
Net Container Weight (lb) & Maximum & 9 & 2,430 \\
& Minimum & 9 & 380 \\
& Average & 9 & 1,119 \\
\hline
\end{tabular}

3.7.2.6.1 Drum Preparation-Approved liners for drums of TRU waste packaged for offsite shipment were the round-bottom liner (Rockwell specification SX-203) inside a 90-mil rigid polyethylene liner (Rockwell specification SX-202), or an O-ring bag and a polyethylene bag placed inside the rigid liner if the drum was attached to a glovebox (Rockwell International 1989e). Type III rigid liners have been used since September 1983 (Bearly 1989a). The IDC 336 waste packaged for offsite shipment required a fiberboard liner and two polyethylene bags inside the rigid liner (Rockwell International 1988c). Figure C-1 shows the appropriate drum liners for this IDC. All bags were closed using the twist-and-tape method (Rockwell International 1989e).

Flow-in, ventable gaskets were installed in the drums beginning in December 1982. They were used until October 1988, when tubular gaskets with carbon filters were required. Drums shipped to INEL between 1985 and 1988 may not meet the current WIPP WAC, owing to their lack of carbon filters (Bearly 1989a).

3.7.2.6.2 Box Preparation-FRP boxes were used for waste shipped to INEL from 1972 through 1982 (Riddle and others 1985). In 1982, the use of the corrugated metal waste box was phased in. The last FRP box was shipped to INEL in 1986. In the interim, waste packaged in both types of boxes had been shipped to INEL. SWIMS information did not track the type of box used in individual shipments.

The FRP box was constructed of $3 / 4$-in. exterior plywood with $2 \times 4$-in. framing members and skids. The entire box was coated with a 0.12 -in. coat of fiberglass-reinforced polyester with flameretardant properties. The continuous FRP coating provides a leakproof, tamper-proof package. Inner liners used for contamination control during loading consist of a PVC liner protected by a 50-mil 
fiberboard sheet. The box size was $4 \times 4 \times 7 \mathrm{ft}$ or larger. The gross weight was normally restricted to $5,000 \mathrm{lb}$ (Riddle and others 1985).

The corrugated metal waste boxes were made entirely out of 14-gauge (0.0747-in.), low-carbon steel. All seams including the closure were welded to produce a leaktight container (Brugger 1983) These boxes required a 10-mil PVC liner (Rockwell specification SX-209) and a 0.051-in. fiberboard liner (Rockwell specification SX-209) (Riddle and others 1985; Bearly and others 1988). Figure C-5 shows the appropriate box liners required for this IDC. Four sizes of the box have been certified as DOT-7A containers, with a maximum size of $54 \times 54 \times 89$ in. and a maximum gross weight of 7,000 lb. These containers are commonly referred to as "Sand Boxes" (Riddle and others 1985).

Where necessary, items that had a weight distribution or configuration that caused them to sit in an unstable condition in the container were blocked, braced, or banded to prevent the items from shifting (Rockwell International 1989e). All items that had the potential to puncture or otherwise compromise the integrity of the waste box were adequately prepackaged to cover sharp corners (Rockwell International 1989e).

3.7.2.7 Assay. Line-generated combustibles were assayed using SGS equipment. Nonline generated waste was assayed with LOSAC equipment unless the assay value was $>\mathbf{2 0}$ grams. If the LOSAC assay were $>20$ grams, the drums were assayed with SGS equipment. Assay results from the individual drums repackaged into a box were used as the primary assay results. This cumulative assay was checked using a crate counter or PAN equipment. The results of the check had to agree with the cumulative assay within the established errors for the assay equipment. Containers of waste that have not been PADC assayed and had SGS or LOSAC assay values of 1 gram or less should be PADC assayed to verify that they are transuranic waste. Table 3.7.2-2 summarizes the dose rate information for this waste. Table 3.7.2-3 summarizes the assay information. One drum and 11 boxes were evaluated for americium content. Uranium content was evaluated for 81 boxes, but no drums were evaluated.

Table 3.7.2-2. Item Description Code 336 Dose Information.

\begin{tabular}{crcr} 
Information & & Drums & Boxes \\
\hline One Meter Dose Rate (mrem/h) & $0-0.5$ & 1 & 407 \\
& $0.5-10$ & 0 & 6 \\
Surface Dose Rate $(\mathrm{mrem} / \mathrm{h})$ & $<10$ & 1 & 412 \\
& $10-200$ & 0 & 1 \\
\hline
\end{tabular}


Table 3.7.2-3. Item Description Code 336 Assay Information.

\begin{tabular}{|c|c|c|c|}
\hline \multicolumn{2}{|c|}{ Radionuclide inventory } & $\frac{\text { Drums }}{0}$ & $\frac{\text { Boxes }}{269}$ \\
\hline Plutonium (g) & $\begin{array}{r}\text { Maximum } \\
\text { Minimum } \\
\text { Average }\end{array}$ & $\begin{array}{l}0 \\
0 \\
0\end{array}$ & $\begin{array}{r}269 \\
0 \\
24\end{array}$ \\
\hline Americium (g) & $\begin{array}{r}\text { Maximum } \\
\text { Minimum } \\
\text { Average }\end{array}$ & $\begin{array}{l}1 \\
1 \\
1\end{array}$ & $\begin{array}{l}5 \\
0 \\
2\end{array}$ \\
\hline Uranium-235 (g) & $\begin{array}{r}\text { Maximum } \\
\text { Minimum } \\
\text { Average }\end{array}$ & $\begin{array}{l}- \\
- \\
-\end{array}$ & $\begin{array}{r}59 \\
0 \\
8\end{array}$ \\
\hline
\end{tabular}

3.7.2.8 Inspection. Waste Certification personnel performed periodic inspections of the generating and packaging process to verify compliance with waste acceptance criteria. In addition, each container was viewed using RTR to

- Ensure the container did not contain nonconforming items

- Ensure the container was properly packaged

- Verify the waste form description

- Evaluate the presence of free liquids.

3.7.2.9 Waste Form Evaluation. Table 3.7.2-4 evaluates the waste form against the WIPP WAC for such items as free liquids, pyrophoric materials, and compressed gases. Table 3.7.2-5 evaluates the waste against TRUPACT criteria. 
Table 3.7.2-4. Waste Form Evaluation.

Criterion or requirement Limiting parameters ${ }^{\mathrm{a}}$

Immobilization Particulates were prohibited by procedural control. Based on the description of the waste, fine particulates are not expected in this IDC.

Liquids There are normally no free liquids associated with this waste. Personnel performing RTR examination at Rocky Flats would accept up to 2 cups of free liquid, if free liquids were present.

Pyrophoric

Materials Pyrophoric materials were prohibited by procedural control. The absence of the pyrophoric materials was verified by the generating supervisor and periodic inspection by the Waste Certification Organization.

Explosives and Compressed Gases Explosives and compressed gases were prohibited by procedural control. The absence of the explosives and compressed gases was verified by the generating supervisor and periodic inspection by the Waste Certification Organization. In addition, unvented, closed containers and pressurized containers were excluded by procedural controls and RTR examination.

TRU-Mixed Wastes The RCRA constituents exist as co-contaminants with the transuranic radionuclides. Compliance with the WIPP RCRA permits and NMD will be required before shipment of the stored waste to WIPP.

Specific Activity of Waste A portion of the waste shipped to INEL may contain $<100$ nanocuries per gram of transuranic radionuclides.

$\mathrm{Pu}^{299}$ Equivalent None of the IDC 336 waste containers recorded as shipped to INEL in the Activity SWIMS exceed $1,000 \mathrm{Ci}$ of plutonium-equivalent activity.

a. Many of the limiting parameters were taken from TRU Waste Compliance Program (Rockwell International 1983a, 1987e, and 1989b). 
Table 3.7.2-5. TRUPACT Evaluation.

Criterion or

requirement

Limiting parameters ${ }^{2}$

Waste Package

Weight

Rocky Flats limited the gross weight of drums to $800 \mathrm{lb}$. The TRUPACT and vehicle weight limits must be verified at the time of payload assembly at INEL. Based on the typical weights of the IDC 336 drums, the maximum payload weight will not be reached. Metal boxes are not authorized for shipment in TRUPACT.

Waste Containers Wet combustibles were in 55-gal DOT-7A, Type A drums or $4 \times 4 \times 7$-ft DOT-7A, Type A metal boxes. The metal boxes will not meet the TRUPACT. waste container requirements.

Nuclear

Criticality

Rocky Flats limited the fissile content of the drums to 200 grams and boxes to 350

grams. However, the error-times-two requirement was not in place at the time the drums were shipped to INEL; therefore, it is not reported as part of the assay of the drum. The TRUPACT limit must be verified at the time of payload assembly at INEL. Based on the typical assays of the IDC 336 drums, the criticality criteria will be met but must be recalculated or assayed to meet the error-times-two requirement.

Surface Dose The surface dose rate criteria used by Rocky Flats was $200 \mathrm{mrem} / \mathrm{hr}$ at the Rate container surface and $10 \mathrm{mrem} / \mathrm{hr}$ at 1 meter. Shielding was used for one IDC 336 container. The TRUPACT limit must be verified at the time of payload assembly at INEL. Based on the typical dose rates from the IDC 336 containers, the dose rate criteria will be met.

Removable The Rocky Flats limit for removable contamination (for TRU assumed to be all Surface

Contamination alpha) was 20 disintegrations per minute $/ 100 \mathrm{~cm}^{2}$. The Rocky Flats limit is equivalent to 9 picocuries per $100 \mathrm{~cm}^{2}$, which is well within the WIPP criteria.

Thermal Power

The thermal power calculation reported in the SWIMS data package is based on the reported assay value without an error/uncertainty correction. The thermal power must be recalculated based on the assay error determination.

Gas Generation Based on the procedural requirements for packaging IDC 336 waste and the waste description, the only areas of noncompliance are carbon filters, nonpunctured rigid liners, headspace gas analysis, and visual characterization.

Toluene was detected by headspace analysis in IDC 336, but is not listed in the TRUPACT Chemical List for RF 116A. 1,1,1-Trichloroethane, 1,2,2-trichloro1,2,2-trifluoroethane, and carbon tetrachloride were detected by headspace gas analysis and are on the TRUPACT Chemical List. Methylene chloride was not detected but is on the TRUPACT Chemical List.

Personnel performing RTR examination at Rocky Flats would accept up to $10 \%$ of another IDC. The other IDCs could be glass, concrete, metal, leaded gloves, and plastics.

a. Many of the limiting parameters were taken from TRU Waste Compliance Program (Rockwell International 1983a, 1987e, and 1989b). 
3.7.2.10 Combustible and Organic Content. Table 3.7.2-6 outlines available data from the TRU Waste Sampling Program for IDC 336. SWIMS data indicate that this waste form contains $>20 \%$ combustibles and $>20 \%$ organics.

Table 3.7.2-6. Item Description Code 336 Data Summary for Combustible and Organic Content.

\begin{tabular}{lcccccc}
\hline Container & $\begin{array}{c}\text { Wt. } \\
\text { combustibles } \\
(\mathrm{lb})^{\mathrm{a}}\end{array}$ & $\begin{array}{c}\text { Wt. } \\
\text { organics }^{(\mathrm{lb})^{\mathrm{b}}}\end{array}$ & $\begin{array}{c}\text { Net wt. of } \\
\text { container } \\
(\mathrm{lb})^{\mathrm{c}}\end{array}$ & $\begin{array}{c}\text { Wt\% } \\
\text { combustibles }^{\mathrm{d}}\end{array}$ & $\begin{array}{c}\text { Vol\% } \\
\text { combustibles }^{\mathrm{e}}\end{array}$ & $\begin{array}{c}\text { Wt\% } \\
\text { organics }^{\mathrm{f}}\end{array}$ \\
\hline $42-00291$ & 53.3 & 53.3 & 59.5 & 89 & 100 & 89 \\
$23-01599$ & 69.8 & 69.8 & 73.25 & 95 & 100 & 95 \\
$47-00256$ & 69.3 & 69.3 & 74.5 & 93 & 100 & 93 \\
$02-34820$ & 17 & 17 & 26.5 & 64 & 100 & 64 \\
$22-00748$ & 21.8 & 21.8 & 27.8 & 79 & 98 & 79 \\
\hline
\end{tabular}

a. Sum of weights of all combustible material and leaded rubber from Table 25 (Clements and Kudera 1985).

b. Sum of weights of all combustible material, leaded rubber, and organic material from Table 25 (Clements and Kudera 1985).

c. Net weight of container from Table 25 (Clements and Kudera 1985).

d. Weight of combustible material/net weight of container $\times 100$.

e. Vol\% of combustible material from visual examination, obtained from Appendix B (Clements and Kudera 1985).

f. Weight of organic material/net weight of container $\times 100$.

3.7.2.10.1 Combustible Content-SWIMS data show that IDC 336 waste is combustible (EG\&G RFP 1993c). In support of the TRU Waste Sampling Program, five drums of IDC 336 waste were opened. They were found to contain an average wt\% combustible content of $84 \%$. Visual inspection showed an average vol\% combustible content of $99.6 \%$. (Clements and Kudera 1985).

3.7.2.10.2 Organic Content-SWIMS data show that IDC 336 waste may contain $100 \%$ organics (Rockwell International 1985a). In support of the TRU Waste Sampling Program, five drums of IDC 336 were opened. They were found to contain an average wt\% organic content of 84\% (Clements and Kudera 1985).

3.7.2.11 Analytical Information. Analytical data from the WIPP Experimental Waste Characterization Program for IDC 336, Wet Combustibles, indicate that one drum (D77621) was subject to headspace gas analysis (EG\&G 1994t). 
IDC 336 Gas Mass Spectrometry analytical results are presented in Table 3.7.2-7. Drums were subject to the operational lid headspace sampling program. Nitrogen, oxygen, argon, carbon dioxide, and carbon monoxide were detected in the drum.

IDC 336 VOC Gas Chromatography/Mass Spectrometry analytical results indicate 6.2 ppmv trichloro-trifluoroethane, 19.3 ppmv carbon tetrachloride, and 9.5 ppmv toluene. All other analytes were undetected, or detected at or above the MDL but at a level below the PRQL.

Analytical data from the TRU Waste Sampling Waste Characterization Program for IDC 336, Wet Combustibles, indicate that seven drums were subject to headspace gas analysis (Clements and Kudera 1985).

Gas composition analytical results are presented in Table 3.7.2-8. Waste boxes were not sampled. Hydrogen, oxygen, nitrogen, argon, carbon dioxide, carbon monoxide, saturated hydrocarbons, nitrogen oxide(s), 1,1,1-trichloro-ethane, and 1,1,2-trichloro-1,2,2-trifluoroethane were detected in the drums.

Combustibles were used for cleanup of gloveboxes and spills involving hazardous solvents. Because IDC 336 contains solvents, it is assigned EPA codes F001, F002, and F005 (EG\&G RFP 1994a).

Table 3.7.2-7. Gas Mass Spectrometry Results (vol\%).

\begin{tabular}{|c|c|c|c|c|c|c|c|c|c|c|c|c|c|}
\hline \multirow[b]{2}{*}{$\begin{array}{l}\text { Drum } \\
\text { No. }\end{array}$} & \multirow{2}{*}{\multicolumn{2}{|c|}{$\begin{array}{c}\text { Headspace } \\
\text { Sample } \\
\text { Program }\end{array}$}} & \multirow[b]{2}{*}{ Vented } & \multicolumn{10}{|c|}{ Analytes } \\
\hline & & & & $\mathbf{H}_{2}$ & $\mathrm{~N}_{2}$ & $\mathrm{O}_{2}$ & Ar & $\mathrm{CO}_{2}$ & Co & $\mathrm{CH}_{4}$ & $\mathrm{C}_{2} \mathrm{H}_{6}$ & $\mathrm{C}_{3} \mathrm{H}_{8}$ & $\mathrm{NO}_{\mathrm{x}}$ \\
\hline D776211 & A & & $\mathbf{Y}$ & - & 77.5 & 19. & 0.953 & 2.393 & 0.010 & - & - & - & - \\
\hline \multicolumn{14}{|l|}{ Notes: } \\
\hline \multicolumn{14}{|c|}{ Headspace Sample Program } \\
\hline & $1 \mathrm{~A}$ & \multicolumn{12}{|c|}{ Operational Lid, Gas Mass Spectrometry Results (vol\%) } \\
\hline & & \multicolumn{12}{|c|}{ Yes } \\
\hline & \multicolumn{13}{|c|}{$\begin{array}{l}\text { Unreported analyte values indicate that analyte was undetected, or was detected at or above the MDL but at a } \\
\text { level below the PRQL. }\end{array}$} \\
\hline
\end{tabular}


Table 3.7.2-8. Gas Sampling Results-Compositional Analysis (vol\%).

\begin{tabular}{|c|c|c|c|c|c|c|c|c|c|c|c|}
\hline \multirow[b]{2}{*}{$\begin{array}{l}\text { Container } \\
\text { ID. no. }\end{array}$} & \multirow[b]{2}{*}{$\begin{array}{c}\text { Storage } \\
\text { time } \\
\text { (days) } \\
\end{array}$} & \multicolumn{10}{|c|}{ Analytes } \\
\hline & & $\mathrm{H}_{2}$ & $\mathrm{O}_{2}$ & $\mathrm{~N}_{2}$ & $\mathrm{Ar}$ & $\mathrm{CO}_{2}$ & $\mathrm{CO}$ & $\mathrm{NO}_{\mathrm{x}}$ & $\begin{array}{l}\text { Hydrocarbons } \\
\text { (saturated) }^{1}\end{array}$ & $\begin{array}{c}1,1,1- \\
\text { trichloro- } \\
\text { ethane }\end{array}$ & $\begin{array}{c}\text { Other } \\
\text { Hydrocarbons }\end{array}$ \\
\hline 23-01599 & 260 & 1.1 & - & 77.1 & 0.81 & 17.6 & - & - & - & 0.50 & $2.87^{a}$ \\
\hline $47-00256$ & 154 & 1.4 & 12.7 & 79.9 & 0.78 & 4.12 & - & - & 0.77 & 0.21 & - \\
\hline 92-00419 & 190 & - & 16.9 & 78.3 & 0.92 & 2.62 & - & 0.89 & - & 0.34 & - \\
\hline $02-34820$ & 993 & - & 0.54 & 80.2 & 0.95 & 18.2 & - & - & 0.12 & - & - \\
\hline $22-00748$ & 925 & 0.51 & 7.45 & 84.0 & 0.96 & 7.04 & - & - & - & - & - \\
\hline $02-10348$ & 4,262 & 3.30 & 11.1 & 78.8 & 0.94 & 5.85 & - & - & - & - & - \\
\hline $65-00137$ & 4,369 & 0.87 & 0.26 & 76.9 & 0.91 & 21.0 & - & - & - & - & - \\
\hline $\begin{array}{l}\text { 1. Saturate } \\
\text { 2. Other hy } \\
\text { a. } F x\end{array}$ & $\begin{array}{l}\text { ocarbon } \\
\text { rbons- } \\
1,2 \text {-tri }\end{array}$ & $\begin{array}{l}\text { nethan } \\
\text { ecifiec } \\
0-1,2,\end{array}$ & rough $p$ & $\begin{array}{l}\text { pane. } \\
\text { ane). }\end{array}$ & & & & & & & \\
\hline
\end{tabular}




\subsection{Waste Form Number 116-TRU Combustible Waste, Content Code RF 116A}

\subsubsection{Item Description Code 337-Plastic and Nonlead Rubber}

3.7.3.1 Certification Assessment. This IDC is certifiable without further waste treatment. Assay and thermal power calculations, including error, need to be updated to meet the current WIPP WAC. Several gas generation criteria need to be addressed. Carbon filters may need to be installed, and headspace gas analysis and visual waste characterization will need to be performed. Metal boxes are not authorized for shipment in TRUPACT.

3.7.3.2 Waste Description. IDC 337 consisted mainly of plastic waste contaminated with hazardous solvents. Plutonium-contaminated plastic combustibles were identified as IDC 337 until assayed. Beginning in 1988, IDC 337 was changed to IDC 833 if the assay determined the waste was TRU waste (EG\&G RFP 1994a).

3.7.3.3 Generation Source. Combustible wastes were generated plant-wide including, but not limited to, Buildings 371, 374, 559, 707, 771, 774, 776, and 779.

3.7.3.4 Recovery Method. Combustible waste contaminated with amounts of plutonium above the discard limit was incinerated by Plutonium Recovery Operations and the ash recovered for further processing (Clements 1982).

3.7.3.5 Waste Packaging and Handling. Line-generated plastic waste was segregated from all other materials, especially removing all free liquid, particulates, and process residues. The waste was then collected and bagged out of the glovebox line. A small amount of Oil Dri was added to the bags if the waste was wet. All line-generated waste was usually double-bagged and monitored for contamination before being placed into the waste collection drum for line-generated waste. The drums were DOT-17C, white, 55-gal drums (Rockwell International 1989b).

Plastic wastes generated within the Pu processing area, but outside of a glovebox line, were termed "nonline-generated wastes." These wastes were collected in 55-gal drums located in all Pu areas. The drum covers were clearly marked for nonline waste. Normally, nonline waste was not bagged before being placed in the collection drum (Rockwell International 1989e). Nonline waste was rarely TRU and would have been repackaged in a box or drum with a rigid liner prior to shipment.

When the drum was full, the drum liners were sealed and the drum was closed. The drum label, completed with all necessary information, was then taped to the drum lid and a TID was attached to the drum.

Drums were held in Size Reduction in Building 776 until about 20 drums of either linegenerated or nonline-generated plastics had accumulated. The line-generated or nonline-generated wastes were then repackaged separately into boxes equipped with a certified filter-and-vent system (Rockwell International 1989b). 
3.7.3.6 Container Preparation. Only approved containers could be used to package TRU waste for shipment offsite. Containers approved for shipment to INEL during this time were DOT17C, white, 55-gal drums (Rockwell specification SX-200); white, corrugated steel boxes (Rockwell specification SX-231); and FRP boxes (Rockwell specification SX-207). Each of these containers met the requirements for certification as DOT-7A Type A packaging (Rockwell International 1989e).

Table 3.7.3-1 shows the current inventory of IDC 337 waste containers from RFP that have been shipped to INEL since 1985 .

Table 3.7.3-1. Item Description Code 337 Container Information.

\begin{tabular}{lrrr}
\hline \multicolumn{1}{c}{ Information } & & Drums & Boxes \\
\hline Total Containers & & 0 & 6 \\
Net Container Weight $(\mathrm{lb})$ & Maximum & N/A & 1200 \\
& Minimum & N/A & 350 \\
& Average & N/A & 925 \\
\hline
\end{tabular}

3.7.3.6.1 Drum Preparation-No drums of IDC 337 waste were shipped to INEL between 1985 and 1989.

3.7.3.6.2 Box Preparation-FRP boxes were used for waste shipped to INEL from 1972 through 1982 (Riddle and others 1985). In 1982, the use of the corrugated metal waste box was phased in. The last FRP box was shipped to INEL in 1986. In the interim, waste packaged in both types of boxes had been shipped to INEL. SWIMS information did not track the type of box used in individual shipments.

The FRP box was constructed of 34 -in. exterior plywood with $2 \times 4$-in. framing members and skids. The entire box was coated with a 0.12 -in. coat of fiberglass-reinforced polyester with flameretardant properties. The continuous FRP coating provided a leakproof, tamper-proof package. Inner liners used for contamination control during loading consisted of a PVC liner protected by a 50-mil fiberboard sheet. The box size was $4 \times 4 \times 7 \mathrm{ft}$ or larger. The gross weight was normally restricted to 5,000 lb (Riddle and others 1985 ).

The corrugated metal waste boxes were made entirely out of 14-gauge (0.0747-in.), low-carbon steel. All seams including the closure were welded to produce a leaktight container (Brugger 1983). These boxes required a 10-mil PVC liner (Rockwell specification SX-209) and a 0.051-in. fiberboard liner (Rockwell specification SX-209) (Riddle and others 1985; Bearly and others 1988). Figure C-5 shows the appropriate box liners required for this IDC. Four sizes of the box had been certified as DOT-7A containers, with a maximum size of $54 \times 54 \times 89$ in. and a maximum gross weight of 7,000 lb. These containers were commonly referred to as "Sand Boxes" (Riddle and others 1985).

Where necessary, items that had a weight distribution or configuration which caused them to sit in an unstable condition in the container were blocked, braced, or banded to prevent the items from shifting (Rockwell International 1989e). All items that had the potential to puncture or otherwise 
compromise the integrity of the waste box were adequately prepackaged to cover sharp corners (Rockwell International 1989e).

3.7.3.7 Assay. Line-generated combustibles were assayed using SGS equipment. Nonlinegenerated waste was assayed with LOSAC equipment unless the assay value was $>20$ grams. If the LOSAC assay was $>20$ grams, the drums were assayed with SGS equipment. Assay results from the individual drums repackaged into a box were used as the primary assay results. This cumulative assay was checked using a crate counter or PAN equipment. The results of the check must have agreed with the cumulative assay within the established errors for the assay equipment. Containers of waste that have not been PADC assayed and had SGS or LOSAC assay values of 1 gram or less should be PADC assayed to verify that they are transuranic waste. Table 3.7.3-2 summarizes dose rate information for this waste. Table 3.7.3-3 summarizes the assay information.

Table 3.7.3-2. Item Description Code 337 Dose Information.

\begin{tabular}{|c|c|c|c|}
\hline Information & & Drums & Boxes \\
\hline One Meter Dose Rate $(\mathrm{mrem} / \mathrm{h})$ & $\begin{array}{r}0-0.5 \\
0.5-10\end{array}$ & $\begin{array}{l}\text { N/A } \\
\text { N/A }\end{array}$ & $\begin{array}{l}6 \\
0\end{array}$ \\
\hline Surface Dose Rate (mrem/h) & $\begin{array}{r}<10 \\
10-200\end{array}$ & $\begin{array}{l}\text { N/A } \\
\text { N/A }\end{array}$ & $\begin{array}{l}6 \\
0\end{array}$ \\
\hline
\end{tabular}

Table 3.7.3-3. Item Description Code 337 Assay Information.

\begin{tabular}{|c|c|c|c|c|}
\hline & \multicolumn{2}{|c|}{ Radionuclide inventory } & \multirow{2}{*}{$\frac{\text { Drums }}{\text { N/A }}$} & \multirow{2}{*}{$\frac{\text { Boxes }}{17}$} \\
\hline & Plutonium (g) & Maximum & & \\
\hline & & Minimum & N/A & 0 \\
\hline & & Average & N/A & 7 \\
\hline & Americium (g) & Maximum & N/A & - \\
\hline & & Minimum & N/A & - \\
\hline & & Average & N/A & - \\
\hline & Uranium-235 (g) & Maximum & N/A & - \\
\hline & & Minimum & N/A & - \\
\hline & & Average & N/A & - \\
\hline
\end{tabular}

3.7.3.8 Inspection. Waste Certification personnel performed periodic inspections of the generating and packaging process to verify compliance with waste acceptance criteria. In addition, each container was viewed using RTR to

- Ensure the container did not contain nonconforming items

- Ensure the container was properly packaged

- Verify the waste form description 
- Evaluate the presence of free liquids.

3.7.3.9 Waste Form Evaluation. Table 3.7.3-4 evaluates the waste form against the WIPP WAC for such items as free liquids, pyrophoric materials, and compressed gases. Table 3.7.3-5 evaluates the waste against TRUPACT criteria.

Table 3.7.3-4. Waste Form Evaluation.

Criterion or requirement

Limiting parameters ${ }^{\mathrm{a}}$

Immobilization Particulates were prohibited by procedural control. Based on the description of the waste, fine particulates are not expected in this IDC.

Liquids This waste form meets the free liquid criteria by procedural control and RTR inspection prior to shipment from Rocky Flats.

Pyrophoric

Materials

Pyrophoric materials were prohibited by procedural control. The absence of the pyrophoric materials was verified by the generating supervisor and periodic inspection by the Waste Certification Organization.

Explosives and

Compressed Gases

Explosives and compressed gases were prohibited by procedural control. The absence of the explosives and compressed gases was verified by the generating supervisor and periodic inspection by the Waste Certification Organization. In addition, unvented, closed containers and pressurized containers were excluded by procedural controls and RTR examination.

TRU-Mixed Wastes The RCRA constituents exist as co-contaminants with the transuranic radionuclides. Compliance with the WIPP RCRA permits and NMD will be required before shipment of the stored waste to WIPP.

Specific Activity of Waste

A portion of the waste stored at INEL may contain $<100$ nanocuries per gram transuranic radionuclides.

$\mathrm{Pu}^{299}$ Equivalent None of the IDC 337 waste containers recorded as shipped to INEL in the Activity SWIMS exceed $1,000 \mathrm{Ci}$ of plutonium-equivalent activity.

a. Many of the limiting parameters were taken from TRU Waste Compliance Program (Rockwell International 1983a, 1987e, and 1989b). 
Table 3.7.3-5. TRUPACT Evaluation.

Criterion or

requirement

Limiting parameters ${ }^{\mathrm{a}}$

Waste Package

Weight

The boxes that IDC 337 were shipped in are not authorized for shipment in the

Waste Containers TRUPACT.

Nuclear

Criticality

Waste was shipped in $4 \times 4 \times 7$-ft DOT-7A, Type A metal boxes. The metal boxes will not meet the TRUPACT waste container requirements.

Rocky Flats limited the fissile content of the boxes to 350 grams. However, the error-times-two requirement was not in place at the time the boxes were shipped to INEL; therefore, it is not reported as part of the assay of the box. The TRUPACT limit must be verified at the time of payload assembly at INEL. Based on the typical assays of the IDC 831 boxes, the criticality criteria will be met but must be recalculated or assayed to meet the error-times-two requirement.

Surface Dose

Rate

The surface dose rate criteria used by Rocky Flats was $200 \mathrm{mrem} / \mathrm{hr}$ at the container surface and $10 \mathrm{mrem} / \mathrm{hr}$ at 1 meter. Shielding was not necessary for IDC 337. The TRUPACT limit must be verified at the time of payload assembly at INEL. Based on the typical dose rates from the IDC 337 containers, the dose rate criteria will be met.

Removable

Surface

The Rocky Flats limit for removable contamination (for TRU assumed to be all

Contamination alpha) was 20 disintegrations per minute $/ 100 \mathrm{~cm}^{2}$. The Rocky Flats limit is equivalent to 9 picocuries per $100 \mathrm{~cm}^{2}$, which is well within the WIPP criteria.

Thermal Power

The thermal power calculation reported in the SWIMS data package is based on the reported assay value without an error/uncertainty correction. The thermal power must be recalculated based on the assay error determination.

Gas Generation Based on the procedural requirements for packaging IDC 337 waste and the waste description, the only areas of noncompliance are carbon filters, headspace gas analysis, and visual characterization.

Trichloroethylene was detected by headspace analysis in IDC 337, but is not listed in the TRUPACT Chemical List for RF 116A. 1,1,1-Trichloroethane, 1,2,2trichloro-1,2,2-trifluoroethane and methylene chloride were detected by headspace gas analysis and are on the TRUPACT Chemical List. All of the detected chemicals appear to be in total concentrations $<1 \%$. Carbon tetrachloride is on the TRUPACT Chemical List, but was not detected. Headspace gas analysis of drums of IDC 833 is considered applicable to boxes of IDC 337.

Personnel performing RTR examination at Rocky Flats would accept up to $10 \%$ of another IDC. The other IDCs could be glass, concrete, metal, leaded gloves, and plastics.

a. Many of the limiting parameters were taken from TRU Waste Compliance Program (Rockwell International 1983a, 1987e, and 1989b). 
3.7.3.10 Combustible and Organic Content. Table 3.7.3-6 outlines available data from the TRU Waste Sampling Program for IDC 337. SWIMS data indicate that this waste form contains $>20 \%$ combustibles and $>20 \%$ organics.

Table 3.7.3-6. Item Description Code 337 Data Summary for Combustible and Organic Content.

\begin{tabular}{ccccccc}
\hline Container & $\begin{array}{c}\text { Wt. } \\
\text { combustibles } \\
(\mathrm{lb})^{\mathrm{b}}\end{array}$ & $\begin{array}{c}\text { Wt. } \\
\text { organics } \\
(\mathrm{lb})^{\mathrm{b}}\end{array}$ & $\begin{array}{c}\text { Net wt. of } \\
\text { container } \\
(\mathrm{lb})^{\mathrm{c}}\end{array}$ & $\begin{array}{c}\text { Wt\% } \\
\text { combustibles }^{\mathrm{d}}\end{array}$ & $\begin{array}{c}\text { Vol\% } \\
\text { combustibles }^{\mathrm{e}}\end{array}$ & $\begin{array}{c}\text { Wt\% } \\
\text { organics }^{\mathrm{f}}\end{array}$ \\
\hline $744-3792$ & 31.5 & 31.5 & 54.0 & 58 & 100 & 58 \\
$744-3823$ & 28.0 & 28.0 & 44.75 & 63 & 100 & 63 \\
$744-3789$ & 27.3 & 27.3 & 38.75 & 70 & 100 & 70 \\
$55-00435$ & 49.3 & 49.3 & 53.25 & 92 & 100 & 92 \\
$02-10180$ & 61.6 & 61.6 & 68.6 & 90 & 100 & 90 \\
$37-00698$ & 152.8 & 152.8 & 156.2 & 98 & 100 & 98 \\
$37-00711$ & 84.5 & 84.5 & 92.0 & 92 & 100 & 92 \\
$36-00723$ & 94.1 & 94.1 & 106.1 & 89 & 100 & 89 \\
$65-00137$ & 88.3 & 88.3 & 94.8 & 93 & 100 & 93 \\
$389-85743$ & 478.8 & 478.8 & $1,063.1$ & 45 & 95 & 45
\end{tabular}

a. Sum of weights of all combustible material and leaded rubber from Table 25 (Clements and Kudera 1985).

b. Sum of weights of all combustible material, leaded rubber, and organic material from Table 25 (Clements and Kudera 1985).

c. Net weight of container from Table 25 (Clements and Kudera 1985).

d. Weight of combustible material/net weight of container $\times 100$.

e. Vol\% of combustible material from visual examination, obtained from Appendix B (Clements and Kudera 1985).

f. Weight of organic material/net weight of container $\times 100$.

3.7.3.10.1 Combustible Content-SWIMS data show that IDC 337 waste is combustible (EG\&G RFP 1993c). In support of the TRU Waste Sampling Program, 10 drums of IDC 337 waste were opened. They were found to contain an average wt\% combustible content of 79\%. Visual inspection showed an average vol\% combustible content of $99.5 \%$. (Clements and Kudera 1985). 
3.7.3.10.2 Organic Content-SWIMS data show that IDC 337 waste may contain $100 \%$ organics (Rockwell International 1985a). In support of the TRU Waste Sampling Program, 10 drums of IDC 337 waste were opened. They were found to contain an average wt\% organic content of 79\% (Clements and Kudera 1985).

3.7.3.11 Analytical Information. Analytical data from the TRU Waste Sampling Waste Characterization Program (Clements and Kudera 1985) for IDC 337, Plastic and Nonlead Rubber, indicate that 10 drums were subject to headspace gas analysis. Gas composition analytical results are presented in Table 3.7.3-7. Waste boxes were not sampled. Hydrogen, oxygen, nitrogen, argon, carbon dioxide, nitrogen oxide(s), saturated hydrocarbons, 1,1,1-trichloroethane, dichloromethane, 1,1,2-trichloro-1,2,2-trifluoroethane, and trichloroethylene were detected in the drums.

Plastic combustibles were contaminated with hazardous solvents. Because IDC 337 contains solvents, it is assigned EPA codes F001, F002, and F005 (EG\&G RFP 1994a). 
Table 3.7.3-7. Gas Sampling Results-Compositional Analysis (Vol\%).

\begin{tabular}{|c|c|c|c|c|c|c|c|c|c|c|c|}
\hline $\begin{array}{l}\text { Container } \\
\text { ID. no. }\end{array}$ & $\begin{array}{c}\text { Storage } \\
\text { time } \\
\text { (days) }\end{array}$ & $\mathrm{H}_{2}$ & $\mathrm{O}_{2}$ & $\mathrm{~N}_{2}$ & $\mathrm{Ar}$ & $\mathrm{CO}_{2}$ & $\mathrm{CO}$ & $\mathrm{NO}_{\mathbf{x}}$ & $\begin{array}{c}\text { Hydrocarbons } \\
\text { (saturated) }^{1}\end{array}$ & $\begin{array}{c}1,1,1- \\
\text { trichloro- } \\
\text { ethane }\end{array}$ & $\begin{array}{c}\text { Other } \\
\text { Hydrocarbons }^{2}\end{array}$ \\
\hline $744-3792$ & 340 & 0.10 & 21.5 & 77.1 & 1.1 & - & - & - & 0.12 & 0.10 & - \\
\hline $744-3823$ & 256 & 0.10 & 20.8 & 77.6 & 1.1 & 0.16 & - & - & - & 0.24 & $0.05^{a}$ \\
\hline $744-3789$ & 367 & 0.21 & 19.9 & 78.0 & 0.82 & - & - & - & 0.29 & 0.26 & $0.13^{b}$ \\
\hline $55-00435$ & 182 & 1.4 & 8.73 & 78.5 & 2.97 & 7.97 & - & - & 0.16 & 0.30 & - \\
\hline 01-08906 & 4,328 & 0.06 & 7.26 & 82.3 & 0.98 & 9.33 & - & - & - & 0.05 & - \\
\hline $02-10180$ & 4,318 & 0.85 & 0.12 & 81.8 & 0.95 & 16.1 & - & 0.17 & - & - & - \\
\hline $37-00672$ & 4,309 & 0.01 & 8.67 & 90.1 & 1.1 & 0.10 & - & - & - & 0.05 & $0.01^{\circ}$ \\
\hline $37-00698$ & 4,318 & 2.86 & 0.14 & 92.6 & 1.1 & 3.18 & - & 0.15 & - & - & - \\
\hline $37-00711$ & 4,252 & 0.18 & 18.1 & 80.7 & 0.96 & 0.14 & - & - & - & - & - \\
\hline $36-00723$ & 4,257 & 2.55 & 12.1 & .82 .3 & 1.0 & 1.9 & - & - & - & 0.12 & - \\
\hline $\begin{array}{l}\text { 1. Saturated } \\
\text { 2. Other hy } \\
\text { a. Di } \\
\text { b. } 1 \text {, } \\
\text { c. } \mathrm{Tr}\end{array}$ & $\begin{array}{l}\text { lrocarbons- } \\
\text { arbons-as } 8 \\
\text { romethane } \\
\text { richloro- } 1,1 \\
\text { roethylene }\end{array}$ & $\begin{array}{l}\text { Ine thr } \\
\text { ed. } \\
\text { luoroe }\end{array}$ & props & & & & & & & & \\
\hline
\end{tabular}




\subsection{Waste Form Number 116-TRU Combustible Waste, Content Code RF 116A}

\subsubsection{Item Description Code 491-Plenum Prefilters}

3.7.4.1 Certification Assessment. This IDC is certifiable without further waste treatment. The filter mesh used was intended for large particles. Most of the 200-micron and smaller particles would have passed through the filter. Assay and thermal power calculations, including error, need to be updated to meet the current WIPP WAC. Several gas generation criteria need to be addressed. Carbon filters may need to be installed, and headspace gas analysis and visual waste characterization will need to be performed. Metal boxes are not authorized for shipment in the TRUPACT.

3.7.4.2 Waste Description. IDC 491 included a variety of plenum prefilters used in the ventilation systems at the Rocky Flats Plant. Plenum prefilters had been and are used in all of the buildings that contain plutonium processing activities. These prefilters were used in large plenums that filter the room and glovebox air. Used prefilters were removed from their position in the ventilation system and packaged for further processing. IDC 491 plenum prefilters ranged from furnace-type filters to pleated fiberglass filters and could be as large as $24 \times 24 \times 12$ in. The filter medium consisted of fiberglass packing or paper which may have been more or less dense, depending on filtering needs. Wire mesh could have been used to hold the media in place. The frame material for these prefilters was cardboard (EG\&G RFP 1994f).

3.7.4.3 Generation Source. IDC 491 plenum prefilters consisted of filters from Buildings $371,374,559,707,771,776,777$, and 779 (EG\&G RFP 1994f).

3.7.4.4 Recovery Method. Combustible waste contaminated with amounts of plutonium above the discard limit was incinerated by Plutonium Recovery Operations and the ash recovered for further processing.

3.7.4.5 Waste Packaging and Handling. Plenum prefilters waste was bagged out of a plenum. A small amount of Oil Dri was added to the bags if the waste was wet. All TRU waste was usually double-bagged and monitored for contamination before being placed into the waste collection drum for line-generated waste. The drums were DOT-17C, white, 55-gal drums (Rockwell International 1989e).

When the drum was full, the drum liners were sealed and the drum was closed. The drum label, completed with all necessary information, was then taped to the drum lid and a TID was attached to the drum.

Drums were held in Size Reduction in Building 776 until about 20 drums of nonline-generated plenum prefilters had accumulated. The wastes were then repackaged into boxes equipped with a certified filter-and-vent system (Rockwell International 1989e).

3.7.4.6 Container Preparation. Only approved containers could be used to package TRU waste for shipment offsite. Containers approved for shipment to INEL during this time were DOT17C, white, 55-gal drums (Rockwell specification SX-200); white, corrugated steel boxes (Rockwell 
specification SX-231); and FRP boxes (Rockwell specification SX-207). Each of these containers met the requirements for certification as DOT-7A Type A packaging (Rockwell International 1989e).

Table 3.7.4-1 shows the current inventory of IDC 491 waste containers from the Rocky Flats Plant that have been shipped to INEL since 1985.

Table 3.7.4-1. Item Description Code 491 Container Information.

\begin{tabular}{lccc}
\hline \multicolumn{1}{c}{ Information } & & Drums & Boxes \\
\cline { 2 - 4 } Total Containers & & 0 & 30 \\
Net Container Weight (lb) & Maximum & N/A & 1,010 \\
& Minimum & N/A & 670 \\
& Average & N/A & 867 \\
\hline
\end{tabular}

3.7.4.6.1 Drum Preparation-No drums of IDC 491 waste were shipped to INEL between 1985 and 1989 .

3.7.4.6.2 Box Preparation-FRP boxes were used for waste shipped to INEL from 1972 through 1982 (Riddle and others 1985). In 1982, the use of the corrugated metal waste box was phased in. The last FRP box was shipped to INEL in 1986. In the interim, waste packaged in both types of boxes had been shipped to INEL. SWIMS information did not track the type of box used in individual shipments.

The FRP box was constructed of $3 / 4$-in. exterior plywood with $2 \times 4$-in. framing members and skids. The entire box was coated with a 0.12 -in. coat of fiberglass-reinforced polyester with flameretardant properties. The continuous FRP coating provides a leakproof, tamper-proof package. Inner liners used for contamination control during loading consist of a PVC liner protected by a 50-mil fiberboard sheet. The box size was $4 \times 4 \times 7 \mathrm{ft}$ or larger. The gross weight was normally restricted to $5,000 \mathrm{lb}$ (Riddle and others 1985 ).

The corrugated metal waste boxes were made entirely out of 14-gauge (0.0747-in.), low-carbon steel. All seams including the closure were welded to produce a leaktight container (Brugger 1983). These boxes required a 10-mil PVC liner (Rockwell specification SX-209) and a 0.051-in. fiberboard liner (Rockwell specification SX-209) (Riddle and others 1985; Bearly and others 1988). Figure C-5 shows the appropriate box liners required for this IDC. Four sizes of the box had been certified as DOT-7A containers, with a maximum size of $54 \times 54 \times 89$ in. and a maximum gross weight of $7,000 \mathrm{lb}$. These containers were commonly referred to as "Sand Boxes" (Riddle and others 1985).

Where necessary, items that had a weight distribution or configuration which caused them to sit in an unstable condition in the container were blocked, braced, or banded to prevent the items from shifting (Rockwell International 1989e). All items that had the potential to puncture or otherwise compromise the integrity of the waste box were adequately prepackaged to cover sharp corners (Rockwell International 1989e). 
3.7.4.7 Assay. Plenum prefilters were considered combustible material and were handled like the other line-generated combustible IDCs. Drums of filters were assayed using SGS equipment. Drums were then repackaged into boxes. Assay results from the individual drums repackaged into a box were used as the primary assay results. This cumulative assay was checked using a crate counter or PAN equipment. The results of the check had to agree with the cumulative assay within the established errors for the assay equipment. Table 3.7.4-2 summarizes dose rate information for this waste. Table 3.7.4-3 summarizes assay information.

Table 3.7.4-2. Item Description Code 491 Dose Information.

\begin{tabular}{crcc} 
Information & & Drums & Boxes \\
\hline One Meter Dose Rate $(\mathrm{mrem} / \mathrm{h})$ & $0-0.5$ & N/A & 3 \\
& $0.5-10$ & N/A & 0 \\
Surface Dose Rate $(\mathrm{mrem} / \mathrm{h})$ & $<10$ & N/A & 3 \\
& $10-200$ & N/A & 0
\end{tabular}

Table 3.7.4-3. Item Description Code 491 Assay Information.

\begin{tabular}{lrcc}
\multicolumn{2}{c}{ Radionuclide inventory } & Drums & Boxes \\
\hline Plutonium (g) & Maximum & N/A & 8 \\
& Minimum & N/A & 5 \\
& Average & N/A & 6 \\
Americium (g) & Maximum & N/A & - \\
& Minimum & N/A & - \\
Uranium-235 (g) & Average & N/A & - \\
& Maximum & N/A & - \\
& Minimum & N/A & - \\
& Average & N/A & -
\end{tabular}

3.7.4.8 Inspection. Waste Certification personnel performed periodic inspections of the generating and packaging process to verify compliance with waste acceptance criteria. In addition, each container was viewed using RTR to:

- Ensure the container did not contain nonconforming items

- Ensure the container was properly packaged

- Verify the waste form description

- Evaluate the presence of free liquids.

3.7.4.9 Waste Form Evaluation. Table 3.7.4-4 evaluates the waste form against the WIPP WAC for such items as free liquids, pyrophoric materials, and compressed gases. Table 3.7.4-5 evaluates the waste against TRUPACT criteria. 
Table 3.7.4-4. Waste Form Evaluation.

Criterion or requirement

Limiting parameters ${ }^{2}$

Immobilization

The plenum filters were similar to furnace filters. The size of these filters most likely allowed 200-micron and smaller particles to pass through. It is expected that particles in this size range would not be present in quantities greater than allowed by the WIPP WAC.

Liquids

This waste form meets the free liquid criteria by procedural control and RTR inspection prior to shipment from Rocky Flats.

Pyrophoric

Materials

Pyrophoric materials were prohibited by procedural control. The absence of the pyrophoric materials was verified by the generating supervisor and periodic inspection by the Waste Certification Organization.

Explosives and Compressed Gases Explosives and compressed gases were prohibited by procedural control. The absence of the explosives and compressed gases was verified by the generating supervisor and periodic inspection by the Waste Certification Organization. In addition, unvented, closed containers and pressurized containers were excluded by procedural controls and RTR examination.

TRU-Mixed Wastes This waste is not a RCRA hazardous waste. These filters are generated in filter plenums from buildings 371 and 774 only.

Specific Activity of This waste contains at least 100 nanocuries per gram transuranic radionuclides. Waste

$\mathrm{Pu}^{239}$ Equivalent None of the IDC 491 waste containers recorded as shipped to INEL in the Activity SWIMS exceed $1,000 \mathrm{Ci}$ of plutonium-equivalent activity.

a. Many of the limiting parameters were taken from TRU Waste Compliance Program (Rockwell International 1983a, 1987e, and 1989b). 
Table 3.7.4-5. TRUPACT Evaluation.

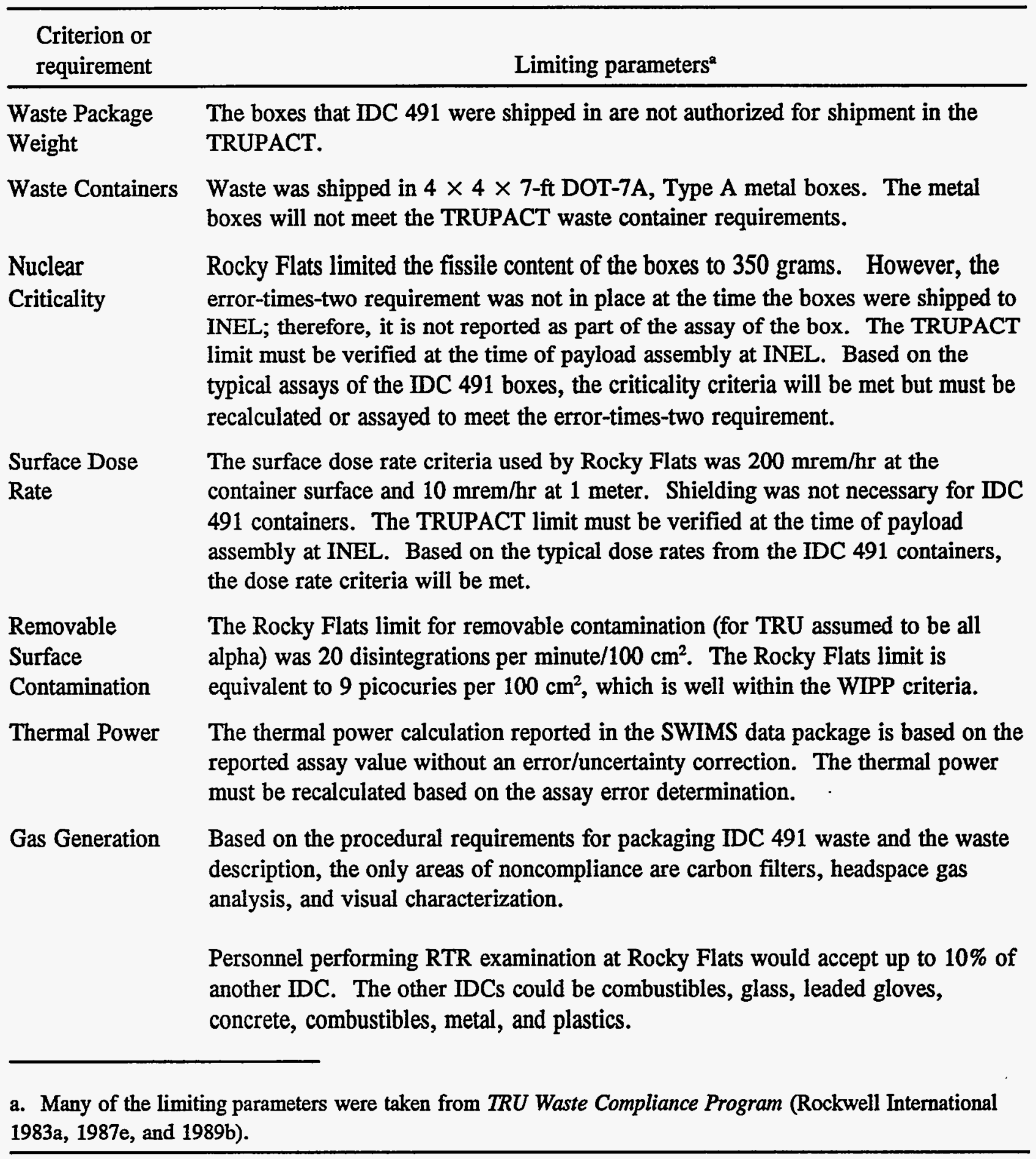

3.7.4.10 Combustible and Organic Content. SWIMS data indicate that this waste form contains $>20 \%$ combustibles or $>20 \%$ organics.

3.7.4.10.1 Combustible Content-SWIMS data show that IDC 491 waste is combustible (EG\&G RFP 1993c). 
3.7.4.10.2 Organic Content-SWIMS data show that IDC 491 waste contains $100 \%$ organics (Rockwell International 1985a).

3.7.4.11 Analytical Information. No analytical information is available for IDC 491 .

These filters were generated from processes for which there would be no "carry-over" of solvent contamination from vapors (Colorado Department of Health 1993). Exclusion of filters from "carryover" contamination is based on Waste Stream Residue Identification and Characterization (WSRIC) information and a Waste Technical Support Memorandum (EG\&G RFP 1993d). These filters are, therefore, nonhazardous (EG\&G RFP 1994f). 


\subsection{Waste Form Number 116-TRU Combustible Waste, Content Code RF 116A}

\subsubsection{Item Description Code 831-Dry Combustibles TRU Mixed}

3.7.5.1 Certification Assessment. This IDC is certifiable without further waste treatment. Assay and thermal power calculations, including error, need to be updated to meet the current WIPP WAC. Several gas generation criteria need to be addressed. Carbon filters may need to be installed, and headspace gas analysis and visual waste characterization will need to be performed. Metal boxes are not authorized for shipment in TRUPACT.

3.7.5.2 Waste Description. IDC 831 waste consists mainly of dry cloth and paper products from cleanup of gloveboxes and spills involving hazardous solvents. Plutonium-contaminated dry combustibles were identified as IDC 330 until assayed. Beginning in 1988, IDC 330 was changed to IDC 831 if the assay determined the waste was TRU waste (EG\&G RFP 1994a).

3.7.5.3 Generation Source. Combustible wastes were generated plant wide including, but not limited to, Buildings 371, 374, 559, 707, 771, 774, 776, and 779.

3.7.5.4 Recovery Method. This IDC was never generated as a residue and therefore had no recovery method.

3.7.5.5 Waste Packaging and Handling. Line-generated dry combustible waste was segregated from all other materials, especially removing all free liquid, particulates, and process residues. The waste was then collected and bagged out of the glovebox line. A small amount of Oil Dri was added to the bags if the waste was wet. All line-generated waste was usually double-bagged and monitored for contamination before being placed into the waste collection drum for line-generated waste. The drums were DOT-17C, white, 55-gal drums (Rockwell International 1989b).

Dry combustible wastes generated within the Pu processing area, but outside of a glovebox line, were termed "nonline-generated wastes." These wastes were collected in 55-gal drums located in all $\mathrm{Pu}$ areas. The drum covers were clearly marked for nonline waste. Normally, nonline waste was not bagged before being placed in the collection drum (Rockwell International 1989e). Nonline waste was rarely TRU and would have been repackaged in a box or drum with a rigid liner prior to shipment.

When the drum was full, the drum liners were sealed and the drum was closed. The drum label, completed with all necessary information, was then taped to the drum lid and a TID was attached to the drum.

Drums were held in Size Reduction in Building 776 until about 20 drums of either linegenerated or nonline-generated combustibles had accumulated. The line-generated or nonlinegenerated wastes were then repackaged separately into boxes equipped with a certified filter-and-vent system (Rockwell International 1989b). 
3.7.5.6 Container Preparation. Only approved containers could be used to package TRU waste for shipment offsite. Containers approved for shipment to INEL during this time were DOT17C, white, 55-gal drums (Rockwell specification SX-200); white, corrugated steel boxes (Rockwell specification SX-231); and FRP boxes (Rockwell specification SX-207). Each of these containers met the requirements for certification as DOT-7A Type A packaging (Rockwell International 1989e).

Table 3.7.5-1 shows the current inventory of IDC 831 waste containers from the Rocky Flats Plant that have been shipped to INEL since 1985.

Table 3.7.5-1. Item Description Code 831 Container Information.

\begin{tabular}{lrrr}
\multicolumn{1}{c}{ Information } & & Drums & Boxes \\
\hline Total Containers & & 0 & 71 \\
Net Container Weight (lb) & Maximum & N/A & 1,960 \\
& Minimum & N/A & 750 \\
& Average & N/A & 1,092
\end{tabular}

3.7.5.6.1 Drum Preparation-No drums of IDC 831 waste were shipped to INEL between 1985 and 1989.

3.7.5.6.2 Box Preparation-FRP boxes were used for waste shipped to INEL from 1972 through 1982 (Riddle and others 1985). In 1982, the use of the corrugated metal waste box was phased in. The last FRP box was shipped to INEL in 1986. In the interim, waste packaged in both types of boxes had been shipped to INEL. SWIMS information did not track the type of box used in individual shipments.

The FRP box was constructed of $3 / 4$-in. exterior plywood with $2 \times 4$-in. framing members and skids. The entire box was coated with a 0.12 -in. coat of fiberglass-reinforced polyester with flameretardant properties. The continuous FRP coating provides a leakproof, tamper-proof package. Inner liners used for contamination control during loading consist of a PVC liner protected by a 50 -mil fiberboard sheet. The box size was $4 \times 4 \times 7 \mathrm{ft}$ or larger. The gross weight was normally restricted to $5,000 \mathrm{lb}$ (Riddle and others 1985 ).

The corrugated metal waste boxes were made entirely out of 14 -gauge (0.0747-in.), low-carbon steel. All seams including the closure were welded to produce a leaktight container (Brugger 1983). These boxes required a 10-mil PVC liner (Rockwell specification SX-209) and a 0.051-in. fiberboard liner (Rockwell specification SX-209) (Riddle and others 1985; Bearly and others 1988). Figure C-5 shows the appropriate box liners required for this IDC. Four sizes of the box have been certified as DOT-7A containers, with a maximum size of $54 \times 54 \times 89$ in. and a maximum gross weight of 7,000 lb. These containers are commonly referred to as "Sand Boxes" (Riddle and others 1985).

Where necessary, items that had a weight distribution or configuration that caused them to sit in an unstable condition in the container were blocked, braced, or banded to prevent the items from shifting (Rockwell International 1989e). All items that had the potential to puncture or otherwise 
compromise the integrity of the waste box were adequately prepackaged to cover sharp corners (Rockwell International 1989e).

3.7.5.7 Assay. Line-generated combustibles were assayed using SGS equipment. Nonlinegenerated waste was assayed with LOSAC equipment unless the assay value was $>\mathbf{2 0}$ grams. If the LOSAC assay was $>20$ grams, the drums were assayed with SGS equipment. Assay results from the individual drums repackaged into a box were used as the primary assay results. This cumulative assay was checked using a crate counter or PAN equipment. The results of the check had to agree with the cumulative assay within the established errors for the assay equipment. Containers of waste that have not been PADC assayed and had SGS or LOSAC assay values of 1 gram or less should be PADC assayed to verify that they are transuranic waste. Table 3.7.5-2 provides dose rate information. Table 3.7.5-3 provides assay information. Two boxes were evaluated for americium content, no boxes were evaluated for uranium.

Table 3.7.5-2. Item Description Code 831 Dose Information.

\begin{tabular}{crrr}
\hline \multicolumn{1}{c}{ Information } & & Drums & Boxes \\
\hline One Meter Dose Rate $(\mathrm{mrem} / \mathrm{h})$ & $0-0.5$ & N/A & 69 \\
& $0.5-10$ & N/A & 2 \\
Surface Dose Rate $(\mathrm{mrem} / \mathrm{h})$ & $<10$ & N/A & 71 \\
& $10-200$ & N/A & 0 \\
\hline
\end{tabular}

Table 3.7.5-3. Item Description Code 831 Assay Information.

\begin{tabular}{|c|c|c|c|}
\hline \multicolumn{2}{|c|}{ Radionuclide inventory } & \multirow{2}{*}{$\frac{\text { Drums }}{\text { N/A }}$} & \multirow{2}{*}{$\frac{\text { Boxes }}{109}$} \\
\hline Plutonium (g) & Maximum & & \\
\hline & Minimum & N/A & 0 \\
\hline & Average & N/A & 18 \\
\hline \multirow[t]{3}{*}{ Americium (g) } & Maximum & $N / A$ & 1 \\
\hline & Minimum & $\mathrm{N} / \mathrm{A}$ & 1 \\
\hline & Average & N/A & 1 \\
\hline \multirow[t]{3}{*}{ Uranium-235 (g) } & Maximum & N/A & - \\
\hline & Minimum & N/A & - \\
\hline & Average & $\mathbf{N} / \mathbf{A}$ & - \\
\hline
\end{tabular}

3.7.5.8 Inspection. Waste Certification personnel performed periodic inspections of the generating and packaging process to verify compliance with waste acceptance criteria. In addition, each box was viewed using RTR to

- Ensure the box did not contain nonconforming items

- Ensure the box was properly packaged

- Verify the waste form description 
- Evaluate the presence of free liquids.

3.7.5.9 Waste Form Evaluation. Table 3.7.5-4 evaluates the waste form against the WIPP WAC for such items as free liquids, pyrophoric materials, and compressed gases. Table 3.7.5-5 evaluates the waste against TRUPACT criteria.

Table 3.7.5-4. Waste Form Evaluation.

Criterion or requirement Limiting parameters ${ }^{2}$

Immobilization Particulates were prohibited by procedural control. Based on the description of the waste, fine particulates are not expected in this IDC.

Liquids There are normally no free liquids associated with this IDC. Personnel performing RTR examination at Rocky Flats would accept up to 2 cups of free liquid, if liquids were present.

Pyrophoric Pyrophoric materials were prohibited by procedural control. The absence of the Materials pyrophoric materials was verified by the generating supervisor and periodic inspection by the Waste Certification Organization.

Explosives and Compressed Gases

Explosives and compressed gases were prohibited by procedural control. The absence of the explosives and compressed gases was verified by the generating supervisor and periodic inspection by the Waste Certification Organization. In addition, unvented, closed containers and pressurized containers were excluded by procedural controls and RTR examination.

TRU-Mixed Wastes The RCRA constituents exist as co-contaminants with the transuranic radionuclides. Compliance with the WIPP RCRA permits and NMD will be required before shipment of the stored waste to WIPP.

Specific Activity of Waste $\mathrm{Pu}^{239}$ Equivalent Activity
A portion of the waste stored at INEL may contain $<100$ nanocuries per -gram transuranic radionuclides.

None of the IDC 831 waste containers recorded as shipped to INEL in the SWIMS exceed $1,000 \mathrm{Ci}$ of plutonium-equivalent activity.

a. Many of the limiting parameters were taken from TRU Waste Compliance Program (Rockwell International 1983a, 1987e, and 1989b). 
Table 3.7.5-5. TRUPACT Evaluation.

Criterion or

requirement

Limiting parameters ${ }^{2}$

Waste Package

Weight

The boxes that IDC 831 were shipped in are not authorized for shipment in the

Waste Containers TRUPACT.

Dry combustibles were packaged in $4 \times 4 \times 7$-ft DOT-7A, Type A containers. These metal boxes will not meet the TRUPACT waste container requirements.

Nuclear

Criticality

Rocky Flats limited the fissile content of the boxes to 350 grams. However, the error-times-two requirement was not in place at the time the boxes were shipped to INEL; therefore, it is not reported as part of the assay of the box. The TRUPACT limit must be verified at the time of payload assembly at INEL. Based on the typical assays of the IDC 831 boxes, the criticality criteria will be met but must be recalculated or assayed to meet the error-times-two requirement.

Surface Dose The surface dose rate criteria used by Rocky Flats was $200 \mathrm{mrem} / \mathrm{hr}$ at the Rate container surface and $10 \mathrm{mrem} / \mathrm{hr}$ at 1 meter. Shielding was not necessary for IDC 831 boxes. The TRUPACT limit must be verified at the time of payload assembly at INEL. Based on the typical dose rates from the IDC 831 containers, the dose rate criteria will be met.

Removable The Rocky Flats limit for removable contamination (for TRU assumed to be all

Surface alpha) was 20 disintegrations per minute $/ 100 \mathrm{~cm}^{2}$. The Rocky Flats limit is

Contamination equivalent to 9 picocuries per $100 \mathrm{~cm}^{2}$, which is well within the WIPP criteria.

Thermal Power The thermal power calculation reported in the SWIMS data package is based on the reported assay value without an error/uncertainty correction. The thermal power must be recalculated based on the assay error determination.

Gas Generation Based on the procedural requirements for packaging IDC 831 waste and the waste description, the only areas of noncompliance are waste container size, carbon filters, headspace gas analysis, and visual characterization.

Cyclohexane, 1,1-dichloroethene, toluene, ethylbenzene, and xylene were detected by headspace analysis in IDC 831 but are not listed in the TRUPACT Chemical List for RF 116A. 1,1,2-Trichloro-1,2,2-trifluoroethane, 1,1,1-trichloroethane, methylene chloride, and carbon tetrachloride were detected by headspace analysis and are on the TRUPACT Chemical List. Headspace gas analysis of IDC 330 is considered applicable to IDC 831. IDC 831 was created to describe TRU combustibles, not to denote a process change.

Personnel performing RTR examination at Rocky Flats would accept up to $10 \%$ of another IDC. The other IDCs could be glass, concrete, metal, leaded gloves, and plastics.

a. Many of the limiting parameters were taken from TRU Waste Compliance Program (Rockwell International 1983a, 1987e, and 1989b). 
3.7.5.10 Combustible and Organic Content. SWIMS data for IDC 330 indicate that this waste form contains $>20 \%$ combustibles and $>20 \%$ organics. IDC 330 data are presumed to be representative of IDC 831 .

3.7.5.10.1 Combustible Content-SWIMS data show that IDC 330 waste is combustible (EG\&G RFP 1993c). IDC 330 data are presumed to be representative of IDC 831 waste.

3.7.5.10.2 Organic Content-SWIMS data show that IDC 330 waste contains $100 \%$ organics (Rockwell International 1985a). IDC 330 data are presumed to be representative of IDC 831 waste.

3.7.5.11 Analytical Information. Analytical data from the WIPP Experimental Waste Characterization Program (EG\&G RFP 1994t) for IDC 831, Dry Combustibles TRU Mixed, indicate that 38 drums were subject to headspace gas analysis for Gas Mass Spectrometry and 41 drums for VOC Gas Chromatography/ Mass Spectrometry.

IDC 831 Gas Mass Spectrometry analytical results are presented in Table 3.7.5-6. Drums were subject to the operational lid headspace sampling program. All analytes, with the exception of methane, were detected. Nitrogen, oxygen, and argon were detected in every drum tested.

IDC 831 VOC Gas Chromatography/Mass Spectrometry analytical results are presented in Tables 3.7.5-7 though 3.7.5-9. Drums were subject to the operational lid headspace sampling program. Unreported analyte values indicate that analytes were undetected, or detected at or above the MDL but at a level below the PRQL in these drums.

Analytical results for nine analytes are presented in Table 3.7.5-7. Analytes were detected in 6 of the 41 drums tested. Three analytes (trichloro-trifluoroethane, 1,1-dichloroethene, and methylene chloride) were detected in the drums.

Analytical results for nine analytes are presented in Table 3.7.5-8. Analytes were detected in 31 of 41 drums tested. Three analytes (1,1,1-trichloroethane, cyclohexane, and carbon tetrachloride) were detected in the drums.

Analytical results for 10 analytes are presented in Table 3.7.5-9. Analytes were detected in 18 of the 41 drums tested. Four analytes (toluene, ethyl-benzene, m,p-xylene and o-xylene) were detected in the drums.

Combustibles were used for cleanup of gloveboxes and spills involving hazardous solvents. Because IDC 831 contains solvents, it is assigned EPA codes F001, F002, and F005 (EG\&G RFP 1994a). 
Table 3.7.5-6. Gas Mass Spectrometry Results (vol\%).

\begin{tabular}{|c|c|c|c|c|c|c|c|c|c|c|c|c|}
\hline \multirow[b]{2}{*}{$\begin{array}{l}\text { Drum } \\
\text { No. }\end{array}$} & \multirow{2}{*}{$\begin{array}{c}\text { Headspace } \\
\text { sample } \\
\text { program }\end{array}$} & \multicolumn{11}{|c|}{ Analytes } \\
\hline & & Vented & $\mathrm{H}_{2}$ & $\mathrm{~N}_{2}$ & $\mathrm{O}_{2}$ & Ar & $\mathrm{CO}_{2}$ & $\mathrm{CO}$ & $\mathrm{CH}_{4}$ & $\mathrm{C}_{2} \mathrm{H}_{6}$ & $\mathrm{C}_{3} \mathrm{H}_{8}$ & $\mathrm{NO}_{\mathrm{x}}$ \\
\hline D15680 & $1 \mathrm{~A}$ & $\mathbf{Y}$ & - & 77.0 & 21.9 & 0.952 & 0.122 & 0.013 & - & 0.016 & 0.002 & - \\
\hline D48200 & $1 \mathrm{~A}$ & - & - & 77.5 & 21.4 & 0.960 & 0.104 & - & - & - & - & - \\
\hline D56595 & $1 \mathrm{~A}$ & - & - & 76.6 & 14.2 & 0.948 & 8.076 & 0.156 & - & - & - & - \\
\hline D58627 & $1 \mathrm{~A}$ & $\mathbf{Y}$ & - & 78.3 & 20.5 & 0.925 & 0.246 & 0.010 & - & - & - & 0.016 \\
\hline D58889 & $1 \mathrm{~A}$ & $\mathbf{Y}$ & - & 77.2 & 11.7 & 0.942 & 10.152 & 0.014 & - & - & - & - \\
\hline D62714 & $1 \mathrm{~A}$ & $\mathbf{Y}$ & - & 78.1 & 20.8 & 0.930 & 0.125 & 0.029 & - & - & - & - \\
\hline D64860 & $1 \mathrm{~A}$ & $\mathbf{Y}$ & - & 77.9 & 21.0 & 0.931 & 0.085 & 0.025 & - & - & - & - \\
\hline $\mathrm{D} 65212$ & $1 \mathrm{~A}$ & $\mathbf{Y}$ & - & 78.3 & 20.7 & 0.931 & - & 0.013 & - & - & - & - \\
\hline D65213 & $1 \mathrm{~A}$ & $\mathbf{Y}$ & 0.013 & 78.1 & 20.7 & 0.932 & 0.174 & 0.041 & - & - & - & - \\
\hline D65754 & $1 \mathrm{~A}$ & $\mathbf{Y}$ & - & 78.7 & 8.2 & 0.950 & 12.175 & - & - & - & - & - \\
\hline D65757 & $1 \mathrm{~A}$ & - & - & 76.9 & 22.1 & 0.958 & - & 0.012 & - & - & - & - \\
\hline D66128 & $1 \mathrm{~A}$ & - & - & 77.2 & 21.7 & 0.950 & 0.162 & 0.012 & - & - & - & - \\
\hline D66213 & $1 \mathrm{~A}$ & $\mathbf{Y}$ & - & 78.0 & 20.8 & 0.949 & 0.244 & 0.029 & - & - & - & - \\
\hline D66356 & $1 \mathrm{~A}$ & - & - & 77.1 & 21.8 & 0.958 & 0.127 & 0.016 & - & - & - & - \\
\hline D66378 & $1 \mathrm{~A}$ & $\mathbf{Y}$ & - & 78.0 & 20.9 & 0.927 & 0.127 & 0.042 & - & - & - & - \\
\hline D66637 & $\mathbf{1 A}$ & $\mathbf{Y}$ & - & 77.9 & 20.9 & 0.932 & 0.142 & 0.046 & - & - & - & - \\
\hline D66948 & $1 \mathrm{~A}$ & - & - & 77.5 & 21.4 & 0.960 & 0.100 & - & - & - & - & - \\
\hline D66949 & $1 \mathrm{~A}$ & - & - & 77.4 & 19.8 & 0.964 & 1.751 & - & - & - & - & - \\
\hline D66958 & $1 \mathrm{~A}$ & - & - & 78.0 & 21.0 & 0.910 & - & - & - & - & - & - \\
\hline D67263 & $1 \mathrm{~A}$ & - & - & 78.8 & 14.6 & 0.927 & 5.575 & 0.097 & - & - & - & - \\
\hline D67535 & $1 \mathrm{~A}$ & $\mathbf{Y}$ & - & 78.2 & 20.7 & 0.961 & - & - & - & - & - & 0.022 \\
\hline D67582 & $1 \mathrm{~A}$ & - & - & 78.0 & 21.0 & 0.913 & - & - & - & - & - & - \\
\hline D67707 & $1 \mathrm{~A}$ & $\mathbf{Y}$ & - & 80.2 & 12.4 & 0.979 & 6.377 & 0.021 & - & - & - & 0.013 \\
\hline D67764 & $1 \mathrm{~A}$ & $\mathbf{Y}$ & - & 76.1 & 8.7 & 0.922 & 14.177 & 0.036 & - & - & - & - \\
\hline D67766 & $1 \mathrm{~A}$ & - & 0.259 & 79.2 & 5.6 & 0.984 & 13.595 & 0.352 & - & - & - & - \\
\hline D67989 & $1 \mathrm{~A}$ & - & - & 77.7 & 21.3 & 0.919 & - & - & - & - & - & - \\
\hline D67994 & $1 \mathrm{~A}$ & - & - & 77.2 & 21.9 & 0.955 & - & - & - & - & - & - \\
\hline D69113 & $1 \mathrm{~A}$ & - & - & 77.3 & 20.1 & 0.961 & 1.583 & 0.030 & - & - & - & - \\
\hline D69418 & $1 \mathrm{~A}$ & - & - & 77.0 & 21.5 & 0.929 & 0.118 & - & - & - & - & - \\
\hline D69431 & $1 \mathrm{~A}$ & - & - & 77.2 & 21.7 & 0.945 & - & 0.012 & - & - & $\cdot-$ & - \\
\hline D70077 & $\mathbf{1 A}$ & - & - & 77.4 & 21.4 & 0.965 & 0.174 & - & - & - & - & - \\
\hline
\end{tabular}


Table 3.7.5-6. (continued).

\begin{tabular}{|c|c|c|c|c|c|c|c|c|c|c|c|c|}
\hline \multirow{2}{*}{$\begin{array}{l}\text { Drum } \\
\text { No. }\end{array}$} & \multirow{2}{*}{$\begin{array}{c}\text { Headspace } \\
\text { sample } \\
\text { program }\end{array}$} & \multicolumn{11}{|c|}{ Analytes } \\
\hline & & Vented & $\mathbf{H}_{2}$ & $\mathbf{N}_{2}$ & $\mathrm{O}_{2}$ & Ar & $\mathrm{CO}_{2}$ & $\mathrm{CO}$ & $\mathrm{CH}_{4}$ & $\mathrm{C}_{2} \mathrm{H}_{6}$ & $\mathrm{C}_{3} \mathrm{H}_{8}$ & NO $_{x}$ \\
\hline D70229 & $1 \mathrm{~A}$ & - & - & 77.6 & 21.1 & 0.918 & 0.288 & - & - & - & - & - \\
\hline D71838 & $1 \mathrm{~A}$ & - & - & 77.5 & 20.5 & 0.934 & 1.053 & 0.031 & - & - & - & - \\
\hline D72822 & $1 \mathrm{~A}$ & $\mathbf{Y}$ & - & 78.0 & 18.4 & 0.934 & 2.659 & 0.016 & - & - & - & 0.012 \\
\hline D73123 & $1 \mathrm{~A}$ & - & - & 77.4 & 21.5 & 0.962 & 0.131 & - & - & - & - & - \\
\hline D73134 & $1 \mathrm{~A}$ & - & - & 77.4 & 21.5 & 0.950 & - & - & - & - & - & - \\
\hline D73274 & $1 \mathrm{~A}$ & - & - & 78.0 & 20.5 & 0.911 & 0.487 & 0.024 & - & - & - & - \\
\hline D76044 & $1 \mathrm{~A}$ & - & - & 77.2 & 18.2 & 0.927 & 3.653 & 0.012 & - & - & - & - \\
\hline $\begin{array}{r}\text { Notes: } \\
\mathrm{H}\end{array}$ & $\begin{array}{ll} & \\
\text { Ispace } & \text { Sampl } \\
1 \mathrm{~A} \text { Ope } \\
\text { Y Yes } \\
\text { Unreported } \\
\text { level belou }\end{array}$ & $\begin{array}{l}\text { Program } \\
\text { tional Lid } \\
\text { analyte va } \\
\text { the PRQL }\end{array}$ & Gas 1 & $\begin{array}{l}\text { is Spect } \\
\text { te that }\end{array}$ & $\begin{array}{l}\text { ometry } \\
\text { nalyte }\end{array}$ & $\begin{array}{l}\text { Results ( } \\
\text { ras undet }\end{array}$ & $\begin{array}{l}\text { ol\%) } \\
\text { cted, }\end{array}$ & was dete & ed at & ove & $\mathrm{ADL}$ & tat a \\
\hline
\end{tabular}


Table 3.7.5-7. Volatile Organic Compound Gas Chromatography/Mass Spéctrometry Results (parts per million by volume).

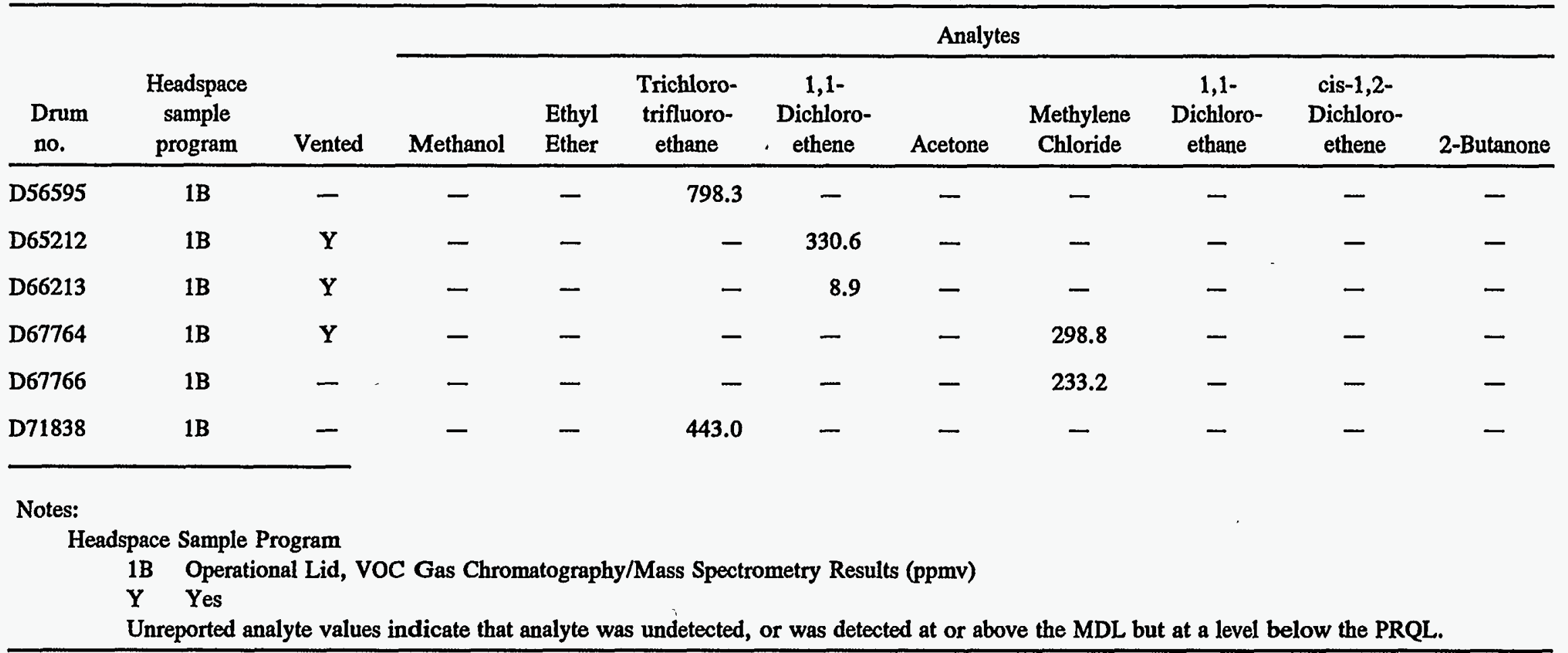


Table 3.7.5-8. Volatile Organic Compound Gas Chromatography/Mass Spectrometry Results (parts per million by volume).

\begin{tabular}{|c|c|c|c|c|c|c|c|c|c|c|c|}
\hline \multirow[b]{2}{*}{ Drum no. } & \multirow[b]{2}{*}{$\begin{array}{c}\text { Headspace } \\
\text { sample } \\
\text { program }\end{array}$} & \multirow[b]{2}{*}{ Vented } & \multicolumn{9}{|c|}{ Analytes } \\
\hline & & & $\begin{array}{l}\text { Chloro- } \\
\text { form }\end{array}$ & $\begin{array}{c}\text { 1,1,1- } \\
\text { Trichloro } \\
\text { ethane }\end{array}$ & $\begin{array}{l}\text { Cyclo- } \\
\text { hexane }\end{array}$ & $\begin{array}{l}\text { Carbon } \\
\text { Tetra- } \\
\text { chloride }\end{array}$ & Benzene & $\begin{array}{c}\text { 1,2- } \\
\text { Dichloro- } \\
\text { ethane }\end{array}$ & 1-Butanol & $\begin{array}{l}\text { Trichloro- } \\
\text { ethene }\end{array}$ & $\begin{array}{l}\text { 4-Methyl-2- } \\
\text { pentanone }\end{array}$ \\
\hline D15680 & 1B & $Y$ & - & $4,587.5$ & - & - & - & - & - & - & - \\
\hline D48200 & $1 B$ & - & - & 349.2 & - & - & - & - & - & - & - \\
\hline D62714 & $1 B$ & $\mathbf{Y}$ & - & 30.1 & - & 15.7 & - & - & - & - & - \\
\hline D64860 & 1B & $\mathbf{Y}$ & - & 681.1 & - & - & - & - & - & - & - \\
\hline D65212 & 1B & $\mathbf{Y}$ & - & 664.7 & - & - & - & - & - & - & - \\
\hline D65213 & 1B & $\mathbf{Y}$ & - & 394.1 & - & - & - & - & - & - & - \\
\hline D65757 & 1B & - & - & 34.3 & - & 134.0 & - & - & - & - & - \\
\hline D66128 & 1B & - & - & - & - & 21.9 & - & - & - & - & - \\
\hline D66213 & 1B & $\mathbf{Y}$ & - & 23.1 & 5.2 & 10.1 & - & - & - & - & - \\
\hline D66356 & 1B & - & - & $10,387.0$ & - & - & - & - & - & - & - \\
\hline D66378 & 1B & $\mathrm{Y}$ & - & $9,184.5$ & - & - & - & - & - & - & - \\
\hline D66637 & 1B & $\mathbf{Y}$ & - & 403.8 & - & - & - & - & - & - & - \\
\hline D66948 & 1B & - & - & 348.7 & - & - & - & - & - & - & - \\
\hline D66949 & $1 B$ & - & - & 36.1 & - & - & - & - & - & - & - \\
\hline D66958 & $1 B$ & - & - & - & - & 4.1 & - & - & - & - & - \\
\hline D67263 & $1 B$ & - & - & 481.6 & - & - & - & - & - & - & - \\
\hline D67582 & $1 B$ & - & - & - & - & 8.8 & - & - & - & - & - \\
\hline D67707 & $1 B$ & $\mathbf{Y}$ & - & - & - & 36.3 & - & - & - & - & - \\
\hline D67989 & $1 \mathrm{~B}$ & - & - & 11.2 & - & 43.4 & - & - & - & - & - \\
\hline D67994 & $1 \mathrm{~B}$ & - & - & 29.5 & - & 165.0 & - & - & - & - & - \\
\hline D69113 & $1 B$ & - & - & $2,954.1$ & - & - & - & - & - & - & - \\
\hline
\end{tabular}


Table 3.7.5-8. (continued).

\begin{tabular}{|c|c|c|c|c|c|c|c|c|c|c|c|}
\hline \multirow[b]{2}{*}{ Drum no. } & \multirow[b]{2}{*}{$\begin{array}{c}\text { Headspace } \\
\text { sample } \\
\text { program }\end{array}$} & \multirow[b]{2}{*}{ Vented } & \multicolumn{9}{|c|}{ Analytes } \\
\hline & & & $\begin{array}{l}\text { Chloro- } \\
\text { form }\end{array}$ & $\begin{array}{c}1,1,1- \\
\text { Trichloro } \\
\text { ethane }\end{array}$ & $\begin{array}{l}\text { Cyclo- } \\
\text { hexane }\end{array}$ & $\begin{array}{c}\text { Carbon } \\
\text { Tetra- } \\
\text { chloride }\end{array}$ & Benzene & $\begin{array}{c}1,2- \\
\text { Dichloro- } \\
\text { ethane }\end{array}$ & 1-Butanol & $\begin{array}{c}\text { Trichloro- } \\
\text { ethene }\end{array}$ & $\begin{array}{c}\text { 4-Methyl-2- } \\
\text { pentanone }\end{array}$ \\
\hline D69418 & $1 B$ & - & - & $4,816.7$ & - & - & - & - & - & - & - \\
\hline D69431 & 1B & - & - & $4,070.6$ & - & - & - & - & - & - & - \\
\hline D70077 & $1 B$ & - & - & $3,533.4$ & - & - & - & - & - & - & - \\
\hline D71838 & $1 B$ & - & - & 364.8 & - & - & - & - & - & - & - \\
\hline D72434 & 1B & - & - & $10,516.8$ & - & - & - & - & - & - & - \\
\hline D72822 & $1 B$ & $\mathbf{Y}$ & - & - & - & 15.1 & - & - & - & - & - \\
\hline D73123 & $1 \mathrm{~B}$ & - & - & $7,343.0$ & - & - & - & - & - & - & - \\
\hline D73134 & 1B & - & - & $3,648.5$ & - & - & - & - & - & - & - \\
\hline D73274 & 1B & - & - & $2,711.8$ & - & - & - & - & - & - & - \\
\hline D76054 & $1 B$ & - & - & - & 5.4 & - & - & - & - & - & - \\
\hline \multicolumn{12}{|l|}{ Notes: } \\
\hline II & $\begin{array}{l}\text { Operational } \\
\text { Yes }\end{array}$ & id, VOC & as Chrom & tography/M & s Spectro & aetry Resu & s (ppmv) & & & & \\
\hline
\end{tabular}


Table 3.7.5-9. Volatile Organic Compound Gas Chromatography/Mass Spectrometry Results (parts per million by volume).

\begin{tabular}{|c|c|c|c|c|c|c|c|c|c|c|c|c|}
\hline \multirow[b]{2}{*}{$\begin{array}{l}\text { Drum } \\
\text { no. }\end{array}$} & \multirow[b]{2}{*}{$\begin{array}{c}\text { Headspace } \\
\text { sample } \\
\text { program }\end{array}$} & \multirow[b]{2}{*}{ Vented } & \multicolumn{10}{|c|}{ Analytes } \\
\hline & & & Toluene & $\begin{array}{l}\text { Tetra- } \\
\text { chloro- } \\
\text { ethene }\end{array}$ & $\begin{array}{l}\text { Chloro- } \\
\text { benzene }\end{array}$ & $\begin{array}{l}\text { Ethyl- } \\
\text { benzene }\end{array}$ & $\begin{array}{c}\mathrm{m}, \mathrm{p}- \\
\text { Xylene } \\
\end{array}$ & $\begin{array}{c}0- \\
\text { Xylene }\end{array}$ & $\begin{array}{c}\text { Bromo- } \\
\text { form }\end{array}$ & $\begin{array}{c}1,1,2,2- \\
\text { Tetrachloro- } \\
\text { ethane }\end{array}$ & $\begin{array}{c}1,3,6- \\
\text { Trimethyl- } \\
\text { benzene }\end{array}$ & $\begin{array}{c}1,2,4- \\
\text { Trimethyl- } \\
\text { benzene }\end{array}$ \\
\hline$\overline{\mathrm{D} 58627}$ & 1B & $Y$ & 11.6 & - & - & 10.0 & 36.0 & 10.3 & - & - & - & - \\
\hline D58889 & $1 \mathrm{~B}$ & $Y$ & 13.0 & - & - & - & - & - & - & - & - & - \\
\hline D62714 & 1B & $Y$ & 29.9 & - & - & - & - & - & - & - & - & - \\
\hline D65754 & 1B & $\mathrm{Y}$ & 68.6 & - & - & - & - & - & - & - & - & - \\
\hline D66128 & $1 \mathrm{~B}$ & - & 39.1 & - & - & - & - & - & - & - & - & - \\
\hline D66213 & 1B & $\mathrm{Y}$ & 13.2 & - & - & - & - & - & - & - & - & - \\
\hline D66631 & 1B & - & 48.2 & - & - & - & - & - & - & - & - & - \\
\hline D66949 & $1 \mathrm{~B}$ & - & 13.6 & - & - & - & - & - & - & - & - & - \\
\hline D66958 & $1 \mathrm{~B}$ & - & 22.2 & - & - & - & - & - & - & - & - & - \\
\hline D67535 & $1 \mathrm{~B}$ & $\mathrm{Y}$ & 19.3 & - & - & - & - & - & - & - & - & - \\
\hline D67582 & 1B & - & 28.0 & - & - & - & - & - & - & - & - & - \\
\hline D67707 & $1 \mathrm{~B}$ & $\mathrm{Y}$ & 7.9 & - & - & - & - & - & - & - & - & - \\
\hline D67764 & $1 \mathrm{~B}$ & $Y$ & 142.1 & - & - & - & - & - & - & - & - & - \\
\hline D67766 & $1 \mathrm{~B}$ & - & 60.8 & - & - & - & - & - & - & - & - & - \\
\hline D70229 & 1B & - & 19.1 & - & - & - & - & - & - & - & - & - \\
\hline D72822 & 1B & $Y$ & 19.9 & - & - & - & - & - & - & - & - & - \\
\hline D76044 & 1B & - & 25.1 & - & - & - & - & - & - & - & - & - \\
\hline D76054 & 1B & - & 20.8 & - & - & - & - & - & - & - & - & - \\
\hline
\end{tabular}

Notes:

Headspace Sample Program

1B Operational Lid, VOC Gas Chromatography/Mass Spectrometry Results (ppmv)

Y Yes

Unreported analyte values indicate that analyte was undetected, or was detected at or above the MDL but at a level below the PRQL. 


\subsection{Waste Form Number 116-TRU Combustible Waste, Content Code RF 116A}

\subsubsection{Item Description Code 832-Wet Combustibles TRU Mixed}

3.7.6.1 Certification Assessment. This IDC is certifiable without further waste treatment. Assay and thermal power calculations, including error, need to be updated to meet the current WIPP WAC. Several gas generation criteria need to be addressed. Carbon filters may need to be installed, and headspace gas analysis and visual waste characterization will need to be performed. Metal boxes are not authorized for shipment in TRUPACT.

3.7.6.2 Waste Description. IDC 832 waste consists mainly of wet cloth and paper products from cleanup of gloveboxes and spills involving hazardous solvents. These wastes materials were drained or wrung out prior to packaging to prevent an accumulation of free liquid. Plutonium contaminated wet combustibles were identified as IDC 336 until assayed. Beginning in 1988, IDC 336 was changed to IDC 832 if the assay determined the waste was TRU waste (EG\&G RFP 1994a).

3.7.6.3 Generation Source. Combustible wastes were generated plant-wide including, but not limited to, Buildings 371, 374, 559, 707, 771, 774, 776, and 779.

3.7.6.4 Recovery Method. This IDC was never generated as a residue and therefore had no recovery method.

3.7.6.5 Waste Packaging and Handling. Line-generated wet combustible waste was segregated from all other materials, especially removing all free liquid, particulates, and process residues. The waste was then collected and bagged out of the glovebox line. A small amount of Oil Dri was added to the bags if the waste was wet. All line-generated waste was usually double-bagged and monitored for contamination before being placed into the waste collection drum for line-generated waste. The drums were DOT-17C, white, 55-gal drums (Rockwell International 1989b).

Wet combustible wastes generated within the $\mathrm{Pu}$ processing area, but outside of a glovebox line, were termed "nonline-generated wastes." These wastes were collected in 55-gal drums located in all $\mathrm{Pu}$ areas. The drum covers were clearly marked for nonline waste. Normally, nonline waste was not bagged before being placed in the collection drum (Rockwell International 1989e). Nonline waste was rarely TRU and would have been repackaged in a box or drum with a rigid liner prior to shipment.

When the drum was full, the drum liners were sealed and the drum was closed. The drum label, completed with all necessary information, was then taped to the drum lid and a TID was attached to the drum.

Drums were held in Size Reduction in Building 776 until about twenty drums of either linegenerated or nonline-generated combustibles had accumulated. The line-generated or nonlinegenerated wastes were then repackaged separately into boxes equipped with a certified filter-and-vent system (Rockwell International 1989b). 
3.7.6.6 Container Preparation. Only approved containers could be used to package TRU waste for shipment offsite. Containers approved for shipment to INEL during this time were DOT17C, white, 55-gal drums (Rockwell specification SX-200); white, corrugated steel boxes (Rockwell specification SX-231); and FRP boxes (Rockwell specification SX-207). Each of these containers met the requirements for certification as DOT-7A Type A packaging (Rockwell International 1989e).

Table 3.7.6-1 shows the current inventory of IDC 832 waste containers from the Rocky Flats Plant that have been shipped to INEL since 1985 .

Table 3.7.6-1. Item Description Code 832 Container Information.

\begin{tabular}{|c|c|c|c|}
\hline \multicolumn{2}{|l|}{ Information } & \multirow{2}{*}{$\frac{\text { Drums }}{0}$} & \multirow{2}{*}{$\frac{\text { Boxes }}{96}$} \\
\hline Total Containers & & & \\
\hline \multirow[t]{3}{*}{ Net Container Weight (lb) } & Maximum & N/A & 1,760 \\
\hline & Minimum & N/A & 800 \\
\hline & Average & N/A & 1,157 \\
\hline
\end{tabular}

3.7.6.6.1 Drum Preparation-No drums of IDC 832 waste were shipped to INEL between 1985 and 1989.

3 7.6.6.2 Box Preparation-FRP boxes were used for waste shipped to INEL from 1972 through 1982 (Riddle and others 1985). In 1982, the use of the corrugated metal waste box was phased in. The last FRP box was shipped to INEL in 1986. In the interim, waste packaged in both types of boxes had been shipped to INEL. SWIMS information did not track the type of box used in individual shipments.

The FRP box was constructed of $3 / 4$-in. exterior plywood with $2 \times 4$-in. framing members and skids. The entire box was covered with a 0.12-in. coat of fiberglass-reinforced polyester with flameretardant properties. The continuous FRP coating provided a leakproof, tamper-proof package. Inner liners used for contamination control during loading consist of a PVC liner protected by a 50-mil fiberboard sheet. The box size was $4 \times 4 \times 7 \mathrm{ft}$ or larger. The gross weight was normally restricted to 5,000 lb (Riddle and others 1985).

The corrugated metal waste boxes were made entirely out of 14-gauge (0.0747-in.), low-carbon steel. All seams including the closure were welded to produce a leaktight container (Brugger 1983). These boxes required a 10-mil PVC liner (Rockwell specification SX-209) and a 0.051-in. fiberboard liner (Rockwell specification SX-209) (Riddle and others 1985; Bearly and others 1988). Figure C-5 shows the appropriate box liners required for this IDC. Four sizes of the box have been certified as DOT-7A containers, with a maximum size of $54 \times 54 \times 89$ in. and a maximum gross weight of 7,000 lb. These containers were commonly referred to as "Sand Boxes" (Riddle and others 1985).

Where necessary, items that had a weight distribution or configuration which caused them to sit in an unstable condition in the container were blocked, braced, or banded to prevent the items from shifting (Rockwell International 1989e). All items that had the potential to puncture or otherwise 
compromise the integrity of the waste box were adequately prepackaged to cover sharp corners (Rockwell International 1989e).

3.7.6.7 Assay. Line-generated combustibles were assayed using SGS equipment. Nonlinegenerated waste was assayed with LOSAC equipment unless the assay value was $>20$ grams. If the LOSAC assay was $>20$ grams, the drums were assayed with SGS equipment. Assay results from the individual drums repackaged into a box were used as the primary assay results. This cumulative assay was checked using a crate counter or PAN equipment. The results of the check had to agree with the cumulative assay within the established errors for the assay equipment. Containers of waste that have not been PADC assayed and had SGS or LOSAC assay values of 1 gram or less should be PADC assayed to verify that they are transuranic waste. Table 3.7.6-2 summarizes the dose rate information for this waste. Table 3.7.6-3 summarizes the assay information. Four boxes were evaluated for americium and four were evaluated for uranium content.

Table 3.7.6-2. Item Description Code 832 Dose Information.

\begin{tabular}{crcc} 
Information & & Drums & Boxes \\
\hline One Meter Dose Rate $(\mathrm{mrem} / \mathrm{h})$ & $0-0.5$ & N/A & 92 \\
& $0.5-10$ & N/A & 4 \\
Surface Dose Rate $(\mathrm{mrem} / \mathrm{h})$ & $<10$ & N/A & 95 \\
& $10-200$ & N/A & 1 \\
\hline
\end{tabular}

Table 3.7.6-3. Item Description Code 832 Assay Information.

\begin{tabular}{lccr}
\hline \multicolumn{2}{c}{ Radionuclide inventory } & Drums & Boxes \\
\hline Plutonium (g) & Maximum & N/A & 191 \\
& Minimum & N/A & 0 \\
& Average & N/A & 28 \\
\multirow{3}{*}{ Americium (g) } & Maximum & N/A & 4 \\
& Minimum & N/A & 1 \\
& Average & N/A & 2 \\
\multirow{2}{*}{ Uranium-235 (g) } & Maximum & N/A & 10 \\
& Minimum & N/A & 4 \\
& Average & N/A & 6 \\
\hline
\end{tabular}

3.7.6.8 Inspection. Waste Certification personnel performed periodic inspections of the generating and packaging process to verify compliance with waste acceptance criteria. In addition, each box was viewed using RTR to

- Ensure the box did not contain nonconforming items

- Ensure the box was properly packaged

- Verify the waste form description 
- $\quad$ Evaluate the presence of free liquids.

3.7.6.9 Waste Form Evaluation. Table 3.7.6-4 evaluates the waste form against the WIPP WAC for such items as free liquids, pyrophoric materials, and compressed gases. Table 3.7.65 evaluates the waste against TRUPACT criteria.

Table 3.7.6-4. Waste Form Evaluation.

Criterion or

requirement

Limiting parameters ${ }^{2}$

Immobilization Particulates were prohibited by procedural control. Based on the description of the waste, fine particulates are not expected in this IDC.

Liquids This waste form meets the free liquid criteria by procedural control and RTR inspection prior to shipment from Rocky Flats.

Pyrophoric Pyrophoric materials were prohibited by procedural control. The absence of the

Materials pyrophoric materials was verified by the generating supervisor and periodic inspection by the Waste Certification Organization.

Explosives and Explosives and compressed gases were prohibited by procedural control. The Compressed Gases absence of the explosives and compressed gases was verified by the generating supervisor and periodic inspection by the Waste Certification Organization. In addition, nonvented, closed containers and pressurized containers were excluded by procedural controls and RTR examination.

TRU-Mixed Wastes The RCRA constituents exist as co-contaminants with the transuranic radionuclides. Compliance with the WIPP RCRA permits and NMD will be required before shipment of the stored waste to WIPP.

Specific Activity of A portion of the waste stored at INEL may contain $<100$ nanocuries per gram Waste transuranic radionuclides.

$\mathrm{Pu}^{239}$ Equivalent None of the IDC 832 waste containers recorded as shipped to INEL in the Activity SWIMS exceed $1,000 \mathrm{Ci}$ of plutonium-equivalent activity.

a. Many of the limiting parameters were taken from TRU Waste Compliance Program (Rockwell International 1983a, 1987e, and 1989b). 
Table 3.7.6-5. TRUPACT Evaluation.

Criterion or

requirement

Limiting parameters ${ }^{2}$

Waste Package

Weight

Waste Containers Wet combustibles were shipped in $4 \times 4 \times 7-\mathrm{ft}$ DOT-7A, Type A metal boxes. The metal boxes will not meet the TRUPACT waste container requirements.

Nuclear

Criticality

Rocky Flats limited the fissile content of the boxes to $\mathbf{3 5 0}$ grams. However, the error-times-two requirement was not in place at the time the containers were shipped to INEL; therefore, it is not reported as part of the assay of the container. The TRUPACT limit must be verified at the time of payload assembly at INEL. Based on the typical assays of the IDC 832 containers, the criticality criteria will be met but must be recalculated or assayed to meet the error-times-two requirement.

Surface Dose The surface dose rate criteria used by Rocky Flats was $200 \mathrm{mrem} / \mathrm{hr}$ at the Rate container surface and $10 \mathrm{mrem} / \mathrm{hr}$ at 1 meter. Shielding was not necessary for IDC 832 drums. The TRUPACT limit must be verified at the time of payload assembly at INEL. Based on the typical dose rates from the IDC 832 containers, the dose rate criteria will be met.

Removable

Surface

The Rocky Flats limit for removable contamination (for TRU assumed to be all

Contamination alpha) was 20 disintegrations per minute $/ 100 \mathrm{~cm}^{2}$. The Rocky Flats limit is equivalent to 9 picocuries per $100 \mathrm{~cm}^{2}$, which is well within the WIPP criteria.

Thermal Power

The thermal power calculation reported in the SWIMS data package is based on the reported assay value without an error/uncertainty correction. The thermal power must be recalculated based on the assay error determination.

Gas Generation Based on the procedural requirements for packaging IDC 832 waste and the waste description, the only areas of noncompliance are carbon filters, headspace gas analysis, and visual characterization.

Toluene, methane, chloroform, cyclohexane, benzene, ethylbenzene, m,p-xylene, o-xylene, 1,1,2,2-tetrachloroethane, 1,3,6-trimethylbenzene, and 1,2,4-trimethylbenzene were detected in IDC 832 but are not listed in the TRUPACT Chemical List for RF 116A. 1,1,1-Trichloroethane, methylene chloride, and carbon tetrachloride were detected by headspace gas analysis and are on the TRUPACT Chemical List. All of the detected chemicals appear to be in total concentrations $<1 \%$. 1,1,2-trichloro-1,2,2-trifluoroethane was not detected but is on the TRUPACT chemical list.

Personnel performing RTR examination at Rocky Flats would accept up to $10 \%$ of another IDC. The other IDCs could be glass, concrete, metal, leaded gloves, and plastics.

a. Many of the limiting parameters were taken from TRU Waste Compliance Program (Rockwell International 1983a, 1987e, and 1989b). 
3.7.6.10 Combustible and Organic Content. SWIMS data show that IDC 336 waste is combustible (EG\&G RFP 1993c). IDC 336 data are presumed to be representative of IDC 832.

3.7.6.10.1 Combustible Content-SWIMS data show that IDC 336 waste contains 100\% organics (Rockwell International 1985a). IDC 336 data are presumed to be representative of IDC 832 waste.

3.7.6.10.2 Organic Content-SWIMS data show that IDC 336 waste contains $100 \%$ organics (Rockwell International 1985a). IDC 336 data are presumed to be representative of IDC 832 waste.

3.7.6.11 Analytical Information. Analytical data from the WIPP Experimental Waste Characterization Program (EG\&G RFP 1994t) for IDC 832, Wet Combustibles TRU Mixed, indicate that 20 drums were subject to headspace gas analysis for Gas Mass Spectrometry and 22 drums for VOC Gas Chromatography/ Mass Spectrometry.

IDC 832 Gas Mass Spectrometry analytical results are presented in Table 3.7.6-6. Drums were subject to the operational lid headspace sampling program. Nitrogen, oxygen, argon, carbon dioxide, carbon monoxide, methane, and nitrogen oxide(s) analytes were detected. Nitrogen, oxygen, and argon were detected in every drum tested.

IDC 832 VOC Gas Chromatography/Mass Spectrometry analytical results are presented in Tables 3.7.6-7 through 3.7.6-9. Drums were subject to the operational lid headspace sampling program. Unreported analyte values indicate analytes were undetected, or detected at or above the MDL but at a level below the PRQL in these drums.

Analytical results for nine analytes are presented in Table 3.7.6-7. Analytes were detected in 2 of the 22 drums tested. One analyte (methylene chloride) was detected in the drums.

Analytical results for nine analytes are presented in Table 3.7.6-8. Analytes were detected in 10 of the 22 drums tested. Five analytes (chloroform, 1,1,1-trichloroethane, cyclohexane, carbon tetrachloride, and benzene) were detected in the drums.

Analytical results for 10 analytes are presented in Table 3.7.6-9. Analytes were detected in 16 of the 22 drums tested. Seven analytes (toluene, ethylbenzene, m,p-xylene, o-xylene, 1,1,2,2tetrachloroethane, 1,3,6-trimethylbenzene, and 1,2,4-trimethylbenzene) were detected in the drums.

Combustibles were used for cleanup of gloveboxes and spills involving hazardous solvents. Because IDC 832 contains solvents, it is assigned EPA codes F001, F002, and F005 (EG\&G RFP 1994a). 
Table 3.7.6-6. Gas Mass Spectrometry Results (vol\%).

\begin{tabular}{|c|c|c|c|c|c|c|c|c|c|c|c|c|}
\hline \multirow[b]{2}{*}{$\begin{array}{l}\text { Drum } \\
\text { No. }\end{array}$} & \multirow{2}{*}{$\begin{array}{c}\text { Headspace } \\
\text { Sample } \\
\text { Program }\end{array}$} & \multicolumn{11}{|c|}{ Analytes } \\
\hline & & Vented & $\mathrm{H}_{2}$ & $\mathrm{~N}_{2}$ & $\mathrm{O}_{2}$ & $\mathrm{Ar}$ & $\mathrm{CO}_{2}$ & Co & $\mathrm{CH}_{4}$ & $\mathrm{C}_{2} \mathrm{H}_{6}$ & $\mathrm{C}_{3} \mathrm{H}_{8}$ & $\mathrm{NO}_{\mathrm{x}}$ \\
\hline D013322 & $1 \mathrm{~A}$ & $\mathbf{Y}$ & - & 77.7 & 20.9 & 0.953 & 0.357 & 0.022 & - & - & - & 0.016 \\
\hline D66875 & $1 \mathrm{~A}$ & - & - & 77.4 & 19.2 & 0.962 & 2.403 & - & - & - & - & - \\
\hline D67524 & $1 \mathrm{~A}$ & - & - & 76.6 & 14.2 & 0.924 & 8.166 & 0.045 & - & - & - & - \\
\hline D67929 & $1 \mathrm{~A}$ & - & - & 72.6 & 12.7 & 0.897 & 11.702 & - & 2.077 & - & - & - \\
\hline D68460 & $1 \mathrm{~A}$ & $\mathbf{Y}$ & - & 77.0 & 14.6 & 0.915 & 7.444 & 0.025 & - & - & - & 0.020 \\
\hline D70780 & $1 \mathrm{~A}$ & - & - & 77.5 & 20.3 & 0.925 & 1.255 & - & - & - & - & - \\
\hline D71804 & $1 \mathrm{~A}$ & $\mathbf{Y}$ & - & 77.8 & 21.1 & 0.951 & 0.119 & - & - & - & - & - \\
\hline D72010 & $1 \mathrm{~A}$ & $\mathbf{Y}$ & - & 77.8 & 21.0 & 0.953 & 0.220 & 0.030 & - & - & - & - \\
\hline D72542 & $1 \mathrm{~A}$ & $\mathbf{Y}$ & - & 78.0 & 21.0 & 0.928 & - & - & - & - & - & 0.037 \\
\hline D72546 & $1 \mathrm{~A}$ & $\mathbf{Y}$ & - & 77.5 & 21.4 & 0.956 & - & 0.013 & - & - & - & - \\
\hline D73745 & $1 \mathrm{~A}$ & $\mathbf{Y}$ & - & 77.3 & 18.4 & 0.945 & 3.358 & 0.016 & - & - & - & - \\
\hline D75267 & $1 \mathrm{~A}$ & - & - & 77.7 & 14.9 & .0 .888 & 6.393 & 0.128 & - & - & - & - \\
\hline D75930 & $1 \mathrm{~A}$ & $\mathrm{Y}$ & - & 77.6 & 18.5 & 0.942 & 2.204 & - & - & - & - & - \\
\hline D75947 & $1 \mathrm{~A}$ & - & - & 77.7 & 21.3 & 0.924 & - & - & - & - & - & - \\
\hline D76050 & $1 \mathrm{~A}$ & - & - & 78.0 & 21.1 & 0.891 & - & - & - & - & - & - \\
\hline D76098 & $1 \mathrm{~A}$ & $\mathbf{Y}$ & - & 77.9 & 19.1 & 0.927 & 2.041 & - & - & - & - & - \\
\hline D76715 & $1 \mathrm{~A}$ & - & - & 77.4 & 20.5 & 0.953 & 1.187 & - & - & - & - & - \\
\hline D76811 & $1 \mathrm{~A}$ & - & - & 78.1 & 20.4 & 0.925 & 0.606 & 0.014 & - & - & - & - \\
\hline D76911 & $1 \mathrm{~A}$ & $\mathbf{Y}$ & - & 77.8 & 15.9 & 0.911 & 5.357 & 0.059 & - & - & - & - \\
\hline D80776 & $1 \mathrm{~A}$ & - & - & 77.6 & 21.0 & 0.961 & 0.334 & 0.035 & - & - & - & - \\
\hline
\end{tabular}

Notes:

Headspace Sample Program

1A Operational Lid, Gas Mass Spectrometry Results (vol\%)

$Y$ Yes

Unreported analyte values indicate that analyte was undetected, or was detected at or above the MDL but at a level below the PRQL. 
Table 3.7.6-7. VOC Gas Chromatography/Mass Spectrometry Results (parts per million by volume).

\begin{tabular}{|c|c|c|c|c|c|c|c|c|c|c|c|}
\hline \multirow[b]{2}{*}{$\begin{array}{l}\text { Drum } \\
\text { no. }\end{array}$} & \multirow[b]{2}{*}{$\begin{array}{c}\text { Headspace } \\
\text { sample } \\
\text { program }\end{array}$} & \multirow[b]{2}{*}{ Vented } & \multicolumn{9}{|c|}{ Analytes } \\
\hline & & & Methanol & $\begin{array}{l}\text { Ethyl } \\
\text { Ether }\end{array}$ & $\begin{array}{l}\text { Trichloro- } \\
\text { trifluoro- } \\
\text { ethane }\end{array}$ & $\begin{array}{c}1,1- \\
\text { Dichloro- } \\
\text { ethene }\end{array}$ & Acetone & $\begin{array}{c}\text { Methylene } \\
\text { Chloride }\end{array}$ & $\begin{array}{c}1,1- \\
\text { Dichloro- } \\
\text { ethane }\end{array}$ & $\begin{array}{l}\text { cis-1,2- } \\
\text { Dichloro- } \\
\text { ethene }\end{array}$ & 2-Butanone \\
\hline D71804 & $1 B$ & $\mathbf{Y}$ & - & - & - & - & - & 1.2 & - & - & - \\
\hline D80776 & $1 B$ & - & - & - & - & - & - & 1.7 & - & - & - \\
\hline
\end{tabular}

Table 3.7.6-8. VOC Gas Chromatography/Mass Spectrometry Results.

\begin{tabular}{|c|c|c|c|c|c|c|c|c|c|c|c|}
\hline \multirow[b]{2}{*}{ Drum no. } & \multirow[b]{2}{*}{$\begin{array}{c}\text { Headspace } \\
\text { sample } \\
\text { program }\end{array}$} & \multirow[b]{2}{*}{ Vented } & \multicolumn{9}{|c|}{ Analytes } \\
\hline & & & $\begin{array}{c}\text { Chloro- } \\
\text { form }\end{array}$ & $\begin{array}{l}\text { 1,1,1- } \\
\text { Trichloro } \\
\text { ethane }\end{array}$ & $\begin{array}{l}\text { Cyclo- } \\
\text { hexane }\end{array}$ & $\begin{array}{l}\text { Carbon } \\
\text { Tetra- } \\
\text { chloride }\end{array}$ & Benzene & $\begin{array}{c}1,2- \\
\text { Dichloro- } \\
\text { ethane }\end{array}$ & 1-Butanol & $\begin{array}{c}\text { Trichloro- } \\
\text { ethene }\end{array}$ & $\begin{array}{c}\text { 4-Methyl-2- } \\
\text { pentanone }\end{array}$ \\
\hline D66875 & $1 B$ & - & - & - & 1.4 & & - & - & - & - & - \\
\hline D67524 & 1B & - & - & - & - & 887.7 & - & - & - & - & - \\
\hline D67908 & 1B & - & - & 2.5 & - & - & - & - & - & - & - \\
\hline D71804 & 1B & $\mathbf{Y}$ & - & - & - & - & 2.1 & - & - & - & - \\
\hline D72542 & $1 \mathrm{~B}$ & $\mathbf{Y}$ & - & - & $1,394.4$ & - & - & - & - & - & - \\
\hline D72546 & $1 \mathrm{~B}$ & $\mathbf{Y}$ & - & - & $1,801.3$ & - & - & - & - & - & - \\
\hline D73745 & $1 B$ & $\mathbf{Y}$ & - & 1.9 & 10.6 & 1.8 & - & - & - & - & - \\
\hline D75267 & $1 B$ & - & - & - & 2.4 & - & - & - & - & - & - \\
\hline D75930 & $1 \mathrm{~B}$ & $\mathbf{Y}$ & - & - & - & $6,912.5$ & - & - & - & - & - \\
\hline D80776 & $1 B$ & - & 2.5 & - & - & - & 1.2 & - & - & - & - \\
\hline $\begin{array}{l}\text { Notes: } \\
\text { Headsp }\end{array}$ & $\begin{array}{l}\text { Sample Pro } \\
\text { Operationa } \\
\text { Yes } \\
\text { ported analy }\end{array}$ & $\begin{array}{l}\text { im, vOC } \\
\text { values in }\end{array}$ & $\begin{array}{l}\text { ias Chrom } \\
\text { cate that a }\end{array}$ & $\begin{array}{l}\text { ography/M } \\
\text { alyte was ur }\end{array}$ & Iass Spectro & $\begin{array}{l}\text { metry Resu } \\
\text { or was detex }\end{array}$ & $\begin{array}{l}s \text { (ppmv) } \\
\text { ed at or ab }\end{array}$ & ve the MDL & ut at a lev & below the $\mathbf{P}$ & \\
\hline
\end{tabular}


Table 3.7.6-9. VOC Gas Chromatography/Mass Spectrometry Results (ppmv).

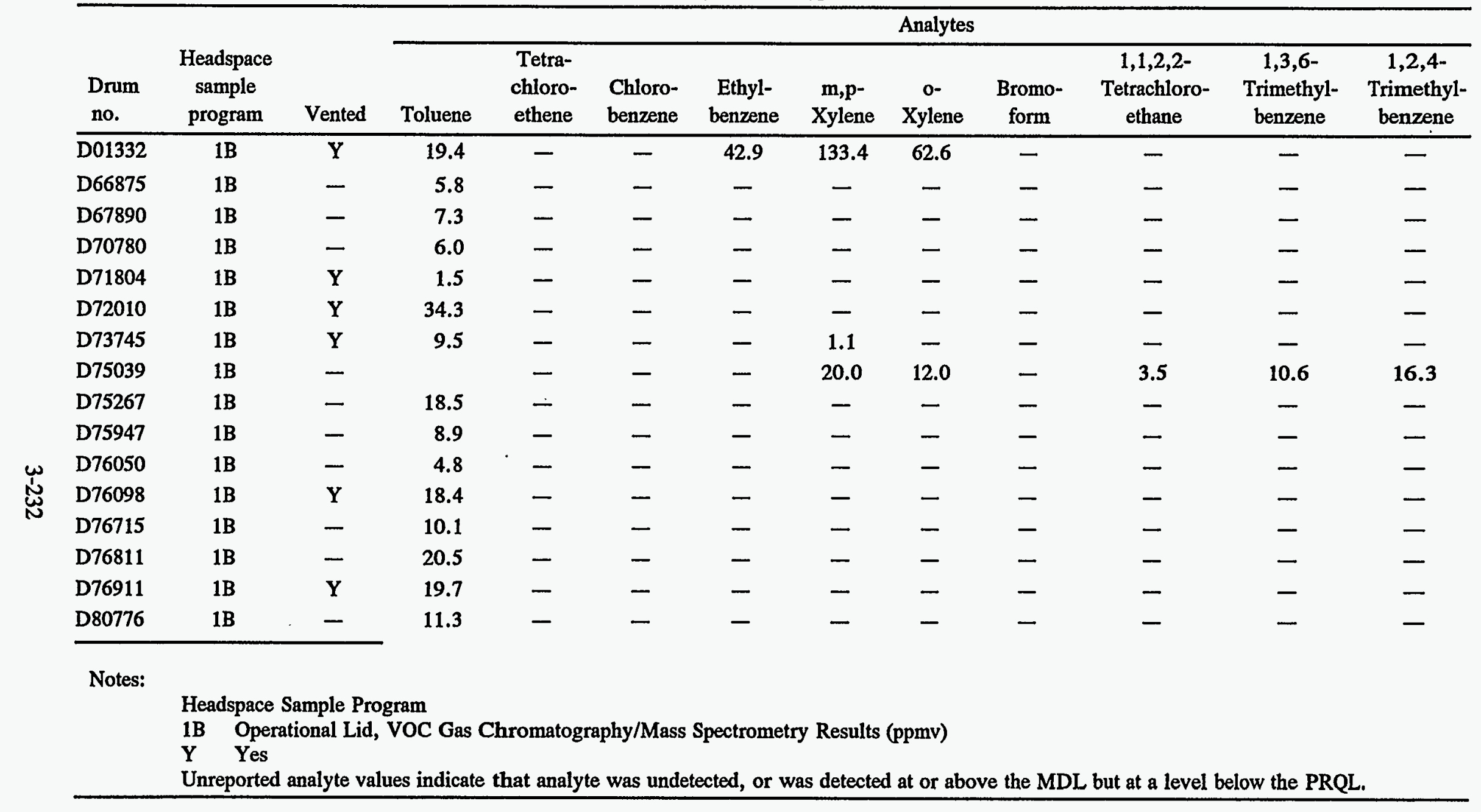




\subsection{Waste Form Number 116-TRU Combustible Waste, Content Code RF 116A}

\subsubsection{Item Description Code 833-Plastics TRU Mixed}

3.7.7.1 Certification Assessment. This IDC is certifiable without further waste treatment. Assay and thermal power calculations, including error, need to be updated to meet the current WIPP WAC. Several gas generation criteria need to be addressed. Carbon filters may need to be installed, and headspace gas analysis and visual waste characterization will need to be performed. Metal boxes are not authorized for shipment in the TRUPACT.

3.7.7.2 Waste Description. IDC 833 consists mainly of plastic waste contaminated with hazardous solvents. Plutonium-contaminated plastic combustibles were identified as IDC 337 until assayed. Beginning in 1988, IDC 337 was changed to IDC 833 if the assay determined the waste was TRU waste (EG\&G RFP 1994a).

3.7.7.3 Generation Source. Combustible wastes were generated plant-wide including, but not limited to, Buildings 371, 374, 559, 707, 771, 774, 776, and 779.

3.7.7.4 Recovery Method. This IDC was never generated as a residue and therefore had no recovery method.

3.7.7.5 Waste Packaging and Handling. Line-generated plastic waste was segregated from all other materials, especially removing all free liquid, particulates, and process residues. The waste was then collected and bagged out of the glovebox line. A small amount of Oil Dri was added to the bags if the waste was wet. All line-generated waste was usually double-bagged and monitored for contamination before being placed into the waste collection drum for line-generated waste. The drums were DOT-17C, white, 55-gal drums (Rockwell International 1989b).

Plastic wastes generated within the Pu processing area, but outside of a glovebox line, were termed "nonline-generated wastes." These wastes were collected in 55-gal drums located in all Pu areas. The drum covers were clearly marked for nonline waste. Normally, nonline waste was not bagged before being placed in the collection drum (Rockwell International 1989e). Nonline waste was rarely TRU and would have been repackaged in a box or drum with a rigid liner prior to shipment.

When the drum was full, the drum liners were sealed and the drum was closed. The drum label, completed with all necessary information, was then taped to the drum lid and a TID was attached to the drum.

Drums were held in Size Reduction in Building 776 until about 20 drums of either linegenerated or nonline-generated plastics had accumulated. The line-generated or nonline-generated wastes were then repackaged separately into boxes equipped with a certified filter-and-vent system (Rockwell International 1989e).

3.7.7.6 Container Preparation. Only approved containers could be used to package TRU waste for shipment offsite. Containers approved for shipment to INEL during this time were DOT17C, white, 55-gal drums (Rockwell specification SX-200); white, corrugated steel boxes (Rockwell specification SX-231); and FRP boxes (Rockwell specification SX-207). Each of these containers met the requirements for certification as DOT-7A Type A packaging (Rockwell International 1989e). 
Table 3.7.7-1 shows the current inventory of IDC 833 waste containers from the Rocky Flats Plant which were shipped to INEL since 1985.

Table 3.7.7-1. Item Description Code 833 Container Information.

\begin{tabular}{lrcr}
\multicolumn{1}{c}{ Information } & & Drums & Boxes \\
\hline Total Containers & & 0 & 10 \\
Net Container Weight (lb) & Maximum & N/A & 1,340 \\
& Minimum & N/A & 460 \\
& Average & N/A & 999
\end{tabular}

3.7.7.6.1 Drum Preparation-No drums of IDC 833 waste were shipped to INEL between 1985 and 1989.

3.7.7.6.2 Box Preparation-FRP boxes were used for waste shipped to INEL from 1972 through 1982 (Riddle and others 1985). In 1982, the use of the corrugated metal waste box was phased in. The last FRP box was shipped to INEL in 1986. In the interim, waste packaged in both types of boxes had been shipped to INEL. SWIMS information did not track the type of box used in individual shipments.

The FRP box was constructed of $3 / 4$-in. exterior plywood with $2 \times 4$-in. framing members and skids. The entire box was coated with a 0.12-in. coat of fiberglass-reinforced polyester with flameretardant properties. The continuous FRP coating provides a leakproof, tamper-proof package. Inner liners used for contamination control during loading consist of a PVC liner protected by a 50-mil fiberboard sheet. The box size was $4 \times 4 \times 7 \mathrm{ft}$ or larger. The gross weight was normally restricted to 5,000 lb (Riddle and others 1985).

The corrugated metal waste boxes were made entirely out of 14-gauge (0.0747-in.), low-carbon steel. All seams including the closure were welded to produce a leaktight container (Brugger 1983). These boxes required a 10-mil PVC liner (Rockwell specification SX-209) and a 0.051-in. fiberboard liner (Rockwell specification SX-209) (Riddle and others 1985; Bearly and others 1988). Figure C-5 shows the appropriate box liners required for this IDC. 'Four sizes of the box had been certified as DOT-7A containers, with a maximum size of $54 \times 54 \times 89$ in. and a maximum gross weight of $7,000 \mathrm{lb}$. These containers were commonly referred to as "Sand Boxes" (Riddle and others 1985).

Where necessary, items that had a weight distribution or configuration that caused them to sit in an unstable condition in the container were blocked, braced, or banded to prevent the items from shifting (Rockwell and others 1989e). All items that had the potential to puncture or otherwise compromise the integrity of the waste box were adequately prepackaged to cover sharp corners (Rockwell and others 1989e).

3.7.7.7 Assay. Line-generated combustibles were assayed using SGS equipment. Nonlinegenerated waste was assayed with LOSAC equipment unless the assay value was $>20$ grams. If the LOSAC assay was $>20$ grams, the drums were assayed with SGS equipment. Assay results from the individual drums repackaged into a box were used as the primary assay results. This cumulative assay was checked using a crate counter or PAN equipment. The results of the check must agree with the cumulative assay within the established errors for the assay equipment. Containers of waste that have not been PADC assayed and had SGS or LOSAC assay values of 1 gram or less should be PADC assayed to verify that they are transuranic waste. Table 3.7.7-2 summarizes dose rate information for this waste. Table 3.7.7-3 summarizes assay information. 
Table 3.7.7-2. Item Description Code 833 Dose Information.

\begin{tabular}{crcc} 
Information & & Drums & Boxes \\
\hline One Meter Dose Rate (mrem/h) & $0-0.5$ & N/A & 10 \\
& $0.5-10$ & N/A & 0 \\
Surface Dose Rate (mrem/h) & $<10$ & N/A & 10 \\
& $10-200$ & N/A & 0 \\
\hline
\end{tabular}

Table 3.7.7-3. Item Description Code 833 Assay Information.

\begin{tabular}{lrlr}
\hline \multicolumn{2}{c}{ Radionuclide inventory } & Drums & Boxes \\
\cline { 2 - 4 } Plutonium (g) & Maximum & N/A & 32 \\
& Minimum & N/A & 0 \\
& Average & N/A & 10 \\
Americium (g) & Maximum & N/A & - \\
& Minimum & N/A & - \\
& Average & N/A & - \\
Uranium-235 (g) & Maximum & N/A & - \\
& Minimum & N/A & - \\
& Average & N/A & - \\
\hline
\end{tabular}

3.7.7.8 Inspection. Waste Certification personnel performed periodic inspections of the generating and packaging process to verify compliance with waste acceptance criteria. In addition, each box was viewed using RTR to

- Ensure the box did not contain nonconforming items

- Ensure the box was properly packaged

- Verify the waste form description

- Evaluate the presence of free liquids.

3.7.7.9 Waste Form Evaluation. Table 3.7.7-4 evaluates the waste form against the WIPP WAC for such items as free liquids, pyrophoric materials, and compressed gases. Table 3.7.7-5 evaluates the waste against TRUPACT criteria. 
Table 3.7.7-4. Waste Form Evaluation.

Criterion or requirement

Limiting parameters ${ }^{2}$

Immobilization

Particulates were prohibited by procedural control. Based on the description of the waste, fine particulates are not expected in this IDC.

Liquids - There are normally no liquids associated with this IDC. Personnel performing RTR examination at Rocky Flats would accept up to 2 cups of free liquid, if liquids were present.

Pyrophoric

Pyrophoric materials were prohibited by procedural control. The absence of the

Materials pyrophoric materials was verified by the generating supervisor and periodic inspection by the Waste Certification Organization.

Explosives and Compressed Gases

Explosives and compressed gases were prohibited by procedural control. The absence of the explosives and compressed gases were verified by the generating supervisor and periodic inspection by the Waste Certification Organization. In addition, nonvented, closed containers and pressurized containers were excluded by procedural controls and RTR examination.

TRU-Mixed Wastes The RCRA constituents exist as co-contaminants with the transuranic radionuclides. Compliance with the WIPP RCRA permits and NMD will be required before shipment of the stored waste to WIPP.

Specific Activity of Waste

$\mathrm{Pu}^{239}$ Equivalent Activity
A portion of the waste stored at INEL may contain $<100$ nanocuries per gram transuranic radionuclides.

None of the IDC 833 waste containers recorded as shipped to INEL in the SWIMS exceed $1,000 \mathrm{Ci}$ of plutonium-equivalent activity.

a. Many of the limiting parameters were taken from TRU Waste Compliance Program (Rockwell International 1983a, 1987e, and 1989b). 
Table 3.7.7-5. TRUPACT Evaluation.

Criterion or

requirement

Limiting parameters ${ }^{\mathbf{x}}$

Waste Package

Weight

The boxes that IDC 833 were shipped in are not authorized for shipment in the TRUPACT.

Waste Containers Waste was shipped in $4 \times 4 \times 7-\mathrm{ft}$ DOT-7A, Type A metal boxes. The metal boxes will not meet the TRUPACT waste container requirements.

Nuclear

Criticality

Rocky Flats limited the fissile content of the boxes to 350 grams. However, the error-times-two requirement was not in place at the time the boxes were shipped to INEL; therefore, it is not reported as part of the assay of the box. The TRUPACT limit must be verified at the time of payload assembly at INEL. Based on the typical assays of the IDC 833 boxes, the criticality criteria will be met but must be recalculated or assayed to meet the error-times-two requirement.

Surface Dose

Rate

The surface dose rate criteria used by Rocky Flats was $200 \mathrm{mrem} / \mathrm{hr}$ at the container surface and $10 \mathrm{mrem} / \mathrm{hr}$ at 1 meter. Shielding was not necessary for IDC 833. The TRUPACT limit must be verified at the time of payload assembly at INEL. Based on the typical dose rates from the IDC 833 containers, the dose rate criteria will be met.

Removable

Surface

The Rocky Flats limit for removable contamination (for TRU assumed to be all Contamination alpha) was 20 disintegrations per minute $/ 100 \mathrm{~cm}^{2}$. The Rocky Flats limit is equivalent to 9 picocuries per $100 \mathrm{~cm}^{2}$, which is well within the WIPP criteria.

Thermal Power

The thermal power calculation reported in the SWIMS data package is based on the reported assay value without an error/uncertainty correction. The thermal power must be recalculated based on the assay error determination.

Gas Generation Based on the procedural requirements for packaging IDC 833 waste and the waste description, the only areas of noncompliance are carbon filters, headspace gas analysis, and visual characterization.

Trichloroethene, chloroform, toluene, cyclohexane, and $\mathrm{m}, \mathrm{p}$-xylene were detected by headspace analysis in IDC 833 but are not listed in the TRUPACT Chemical List for RF 116A. 1,1,1-Trichloroethane, carbon tetrachloride, and 1,2,2trichloro-1,2,2-trifluoroethane were detected by headspace gas analysis and are on the TRUPACT Chemical List. All of the detected chemicals appear to be in total concentrations $<1 \%$. Methylene chloride is on the TRUPACT Chemical List but was not detected. Headspace gas analysis of drums of IDC 337 is considered applicable to boxes of IDC 833 .

Personnel performing RTR examination at Rocky Flats would accept up to $10 \%$ of another IDC. The other IDCs could be glass, concrete, metal, leaded gloves, and plastics.

a. Many of the limiting parameters were taken from TRU Waste Compliance Program (Rockwell International 1983a, 1987e, and 1989b). 
3.7.7.10 Combustible and Organic Content. SWIMS data for IDC 337 indicate that this waste form contains $>20 \%$ combustibles and $>20 \%$ organics. IDC 337 data are presumed to be representative of IDC 833.

3.7.7.10.1 Combustible Content-SWIMS data show that IDC 337 waste is combustible (EG\&G RFP 1993c). IDC 337 data are presumed to be representative of IDC 833.

3.7.7.10.2 Organic Content-SWIMS data show that IDC 337 waste contains $100 \%$ organics (Rockwell International 1985a). IDC 337 data are presumed to be representative of IDC 833 waste.

3.7.7.11 Analytical Information. Analytical data from the WIPP Experimental Waste Characterization Program for IDC 833, Plastics TRU Mixed, indicate that 14 drums were subject to headspace gas analysis for Gas Mass Spectrometry and 20 drums for VOC Gas Chromatography/Mass Spectrometry (EG\&G RFP 1994t).

IDC 833 Gas Mass Spectrometry analytical results are presented in Table 3.7.7-6. Drums were subject to the operational lid headspace sampling program. Nitrogen, oxygen, argon, carbon dioxide, carbon monoxide, and nitrogen oxide(s) analytes were detected. Nitrogen, oxygen, and argon were detected in every drum tested.

IDC 833 VOC Gas Chromatography/Mass Spectrometry analytical results are presented below and in Tables 3.7.7-7 and 3.7.7-8. Drums were subject to the operational lid headspace sampling program. Unreported analyte values indicate analytes were undetected, or detected at or above the MDL but at a level below the PRQL in these drums.

Analytical results for nine analytes indicate $60.7 \mathrm{ppmv}$ trichloro-trifluoroethane in 1 of 20 drums tested (D76217).

Analytical results for nine analytes are presented in Table 3.7.7-7. Analytes were detected in 13 of the 20 drums tested. Five analytes (chloroform, 1,1,1-trichloroethane, cyclohexane, carbon tetrachloride, and trichloroethene) were detected in the drums.

Analytical results for 10 analytes are presented in Table 3.7.7-8. Analytes were detected in 12 of the 20 drums tested. Two analytes (toluene and $\mathrm{m}, \mathrm{p}$-xylene) were detected in the 12 drums.

Plastic combustibles were contaminated with hazardous solvents. Because IDC 833 contains solvents, it is assigned EPA codes F001, F002, and F005 (EG\&G RFP 1994a). 
Table 3.7.7-6. Gas Mass Spectrometry Results (vo1\%).

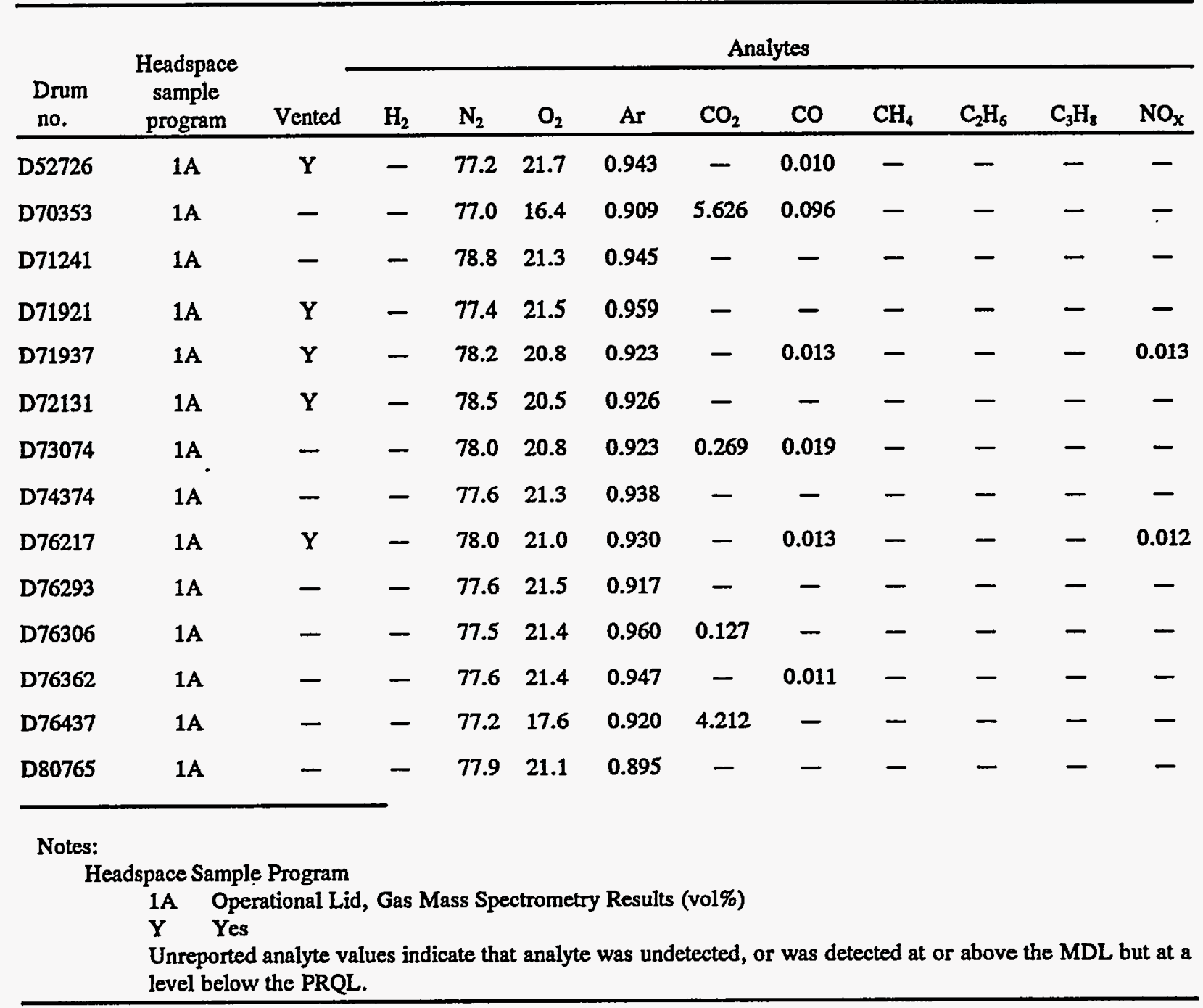


Table 3.7.7-7. Volatile Organic Compound Gas Chromatography/Mass Spectrometry Results (parts per million by volume).

\begin{tabular}{|c|c|c|c|c|c|c|c|c|c|c|c|}
\hline \multirow[b]{2}{*}{ Drum no. } & \multirow[b]{2}{*}{$\begin{array}{c}\text { Headspace } \\
\text { sample } \\
\text { program } \\
\end{array}$} & \multirow[b]{2}{*}{ Vented } & \multicolumn{9}{|c|}{ Analytes } \\
\hline & & & $\begin{array}{l}\text { Chloro- } \\
\text { form }\end{array}$ & $\begin{array}{l}\text { 1,1,1- } \\
\text { Trichloro } \\
\text { ethane }\end{array}$ & $\begin{array}{l}\text { Cyclo- } \\
\text { hexane }\end{array}$ & $\begin{array}{l}\text { Carbon } \\
\text { Tetra- } \\
\text { chloride }\end{array}$ & Benzene & $\begin{array}{c}1,2- \\
\text { Dichloro- } \\
\text { ethane }\end{array}$ & 1-Butanol & $\begin{array}{c}\text { Trichloro- } \\
\text { ethene }\end{array}$ & $\begin{array}{c}\text { 4-Methyl-2- } \\
\text { pentanone }\end{array}$ \\
\hline D52726 & 1B & $\mathbf{Y}$ & - & 62.3 & - & - & - & - & - & 21.1 & - \\
\hline D71937 & 1B & $\mathbf{Y}$ & - & $1,343.5$ & - & $2,458.9$ & - & - & - & - & - \\
\hline D72131 & 1B & $\mathbf{Y}$ & - & 12.3 & - & - & - & - & - & 19.9 & - \\
\hline D74374 & 1B & - & - & - & - & 1.9 & - & - & - & 1.8 & - \\
\hline D75265 & 1B & - & - & - & - & 63.7 & - & - & - & - & - \\
\hline D76293 & 1B & - & - & 5.0 & - & 22.4 & - & - & - & - & - \\
\hline D76306 & 1B & - & - & 17.0 & - & 37.1 & - & - & - & - & - \\
\hline D76362 & 1B & - & 554.2 & - & - & - & - & - & - & - & - \\
\hline D76437 & 1B & - & - & - & 2.2 & - & - & - & - & - & - \\
\hline D76710 & 1B & - & 136.9 & - & - & - & - & - & - & - & - \\
\hline D80765 & 1B & - & - & - & 2.6 & - & - & - & - & - & - \\
\hline D80772 & 1B & - & - & 47.6 & - & - & - & - & - & 13.2 & - \\
\hline D80774 & 1B & - & - & 53.3 & - & 127.7 & - & - & - & - & - \\
\hline $\begin{array}{l}\text { Notes: } \\
\text { Headsp }\end{array}$ & $\begin{array}{l}\text { Sample Pro } \\
\text { Operationa } \\
\text { Yes } \\
\text { eported analy }\end{array}$ & $\begin{array}{l}\text { id, voc } \\
\text { values in }\end{array}$ & $\begin{array}{l}\text { s Chrom } \\
\text { ate that an }\end{array}$ & $\begin{array}{l}\text { ography/M } \\
\text { alyte was u }\end{array}$ & $\begin{array}{l}\text { Spectro } \\
\text { tected, }\end{array}$ & $\begin{array}{l}\text { metry Resu } \\
\text { or was detec }\end{array}$ & (ppmv) & e the MD & ut at a le & elow the & \\
\hline
\end{tabular}


Table 3.7.7-8. Volatile Organic Compound Gas Chromatography/Mass Spectrometry Results (parts per million by volume).

\begin{tabular}{|c|c|c|c|c|c|c|c|c|c|c|c|c|}
\hline \multirow[b]{2}{*}{$\begin{array}{l}\text { Drum } \\
\text { No. }\end{array}$} & \multirow[b]{2}{*}{$\begin{array}{c}\text { Headspace } \\
\text { Sample } \\
\text { Program }\end{array}$} & \multirow[b]{2}{*}{ Vented } & \multicolumn{10}{|c|}{ Analytes } \\
\hline & & & Toluene & $\begin{array}{l}\text { Tetra- } \\
\text { chloro- } \\
\text { ethene }\end{array}$ & $\begin{array}{l}\text { Chloro- } \\
\text { benzene }\end{array}$ & $\begin{array}{c}\text { Ethyl- } \\
\text { benzene }\end{array}$ & $\begin{array}{c}\text { m,p- } \\
\text { Xylene }\end{array}$ & $\begin{array}{c}0- \\
\text { Xylene }\end{array}$ & $\begin{array}{l}\text { Bromo- } \\
\text { form }\end{array}$ & $\begin{array}{c}1,1,2,2- \\
\text { Tetrachloro- } \\
\text { ethane }\end{array}$ & $\begin{array}{c}1,3,6- \\
\text { Trimethyl- } \\
\text { benzene }\end{array}$ & $\begin{array}{c}1,2,4- \\
\text { Trimethyl- } \\
\text { benzene }\end{array}$ \\
\hline D52726 & $1 \mathrm{~B}$ & $\mathrm{Y}$ & 11.7 & - & - & - & - & - & - & - & - & - \\
\hline D70353 & 1B & - & 19.7 & - & - & - & - & - & - & - & - & - \\
\hline D71241 & $1 \mathrm{~B}$ & - & 5.3 & - & - & - & - & - & - & - & - & - \\
\hline D71921 & 1B & $\mathbf{Y}$ & 7.2 & - & - & - & - & - & - & - & - & - \\
\hline D74374 & 1B & - & 14.0 & - & - & - & - & - & - & - & - & - \\
\hline D75265 & 1B & - & 24.7 & - & - & - & - & - & - & - & - & - \\
\hline D75399 & 1B & - & 16.3 & - & - & - & - & - & - & - & - & - \\
\hline D76306 & $1 \mathrm{~B}$ & - & - & - & - & - & 8.7 & - & - & - & - & - \\
\hline D76437 & 1B & - & 24.0 & - & - & - & - & - & - & - & - & - \\
\hline D76712 & 1B & - & 14.0 & - & - & - & - & - & - & - & - & - \\
\hline D80765 & 1B & - & 10.0 & - & - & - & - & - & - & - & - & - \\
\hline D80772 & $1 \mathrm{~B}$ & - & 24.4 & - & - & - & - & - & - & - & - & - \\
\hline \multicolumn{13}{|l|}{ Notes: } \\
\hline \multicolumn{13}{|c|}{$\begin{array}{l}\text { 1B Operational Lid, VOC Gas Chromatography/Mass Spectrometry Results (ppmv) } \\
\text { Y Yes }\end{array}$} \\
\hline
\end{tabular}




\subsection{Waste Form Number 117-TRU Metal Waste, Content Code RF 117A}

\subsubsection{Item Description Code 320-Heavy Non-SS Metal}

3.8.1.1 Certification Assessment. This IDC is certifiable without further waste treatment. Assay and thermal power calculations, including error, need to be updated to meet the current WIPP WAC. Several gas generation criteria need to be addressed. Carbon filters may need to be installed, drums will require inspection to identify unvented or unpunctured rigid liners, and headspace gas analysis and visual waste characterization will need to be performed.

3.8.1.2 Waste Description. IDC 320 includes nonspecial source scrap metals heavier than iron (metal elements above copper on the periodic table of elements) (EG\&G RFP 1994a). Examples of this waste include crucibles, funnels, rods, and process fixtures. These items were made primarily from tantalum, tungsten, and platinum, but some parts could have been manufactured or contaminated with lead if the accumulation start date was prior to 1987 . IDC 320 originally included lead. In 1987, IDC 321 was created to better account for the generation and material control of lead waste (EG\&G RFP 1994h).

3.8.1.3 Generation Source. Heavy nonspecial source metal waste was generated in Buildings 371, 707, 771, 776, 777, and 779 (EG\&G RFP 1994h).

3.8.1.4 Recovery Method. Since 1975, above-discard, plutonium-contaminated tantalum waste was processed by plutonium-hydriding, the tantalum waste was wiped off with a damp cloth prior to being repackaged. Tantalum waste contaminated with amounts of americium from Pyrochemical Operations above the discard limit was retained in storage at Rocky Flats due to lack of adequate recovery capabilities (Clements 1982).

3.8.1.5 Waste Packaging and Handling. Line-generated metal waste was segregated from all other materials, especially removing all free liquid, particulates, and process residues. Items for disposal were inspected before removal from the line. Gearbox oil, hydraulic fluid, and other liquids were removed. All electrical equipment was checked to ensure that electrical potential had been discharged. The waste was then collected and bagged out of the glovebox line. A small amount of Oil Dri was added to the bags if the waste was wet. All line-generated waste was usually doublebagged and monitored for contamination before being placed into the waste collection drum for linegenerated waste. The drums were DOT-17C, white, 55-gal drums.

Metal wastes generated within the Pu processing area, but outside of a glovebox line, were termed "nonline-generated wastes." These wastes were collected in 55-gal drums located in all $\mathrm{Pu}$ areas. The drum covers were clearly marked for nonline waste. Normally, nonline waste was not bagged before being placed in the collection drum (Rockwell International 1989e). Nonline waste was rarely TRU and would have been repackaged in a box or drum with a rigid liner prior to shipment. 
When the drum was full, the drum liners were sealed and the drum was closed. The drum label, completed with all necessary information, was then taped to the drum lid and a TID was attached to the drum.

3.8.1.6 Container Preparation. Only approved containers could be used to package TRU waste for shipment offsite. The containers approved for shipment to INEL during this time were DOT-17C, white, 55-gal drums (Rockwell specification SX-200). These containers met the requirements for certification as DOT-7A Type A packaging (Rockwell International 1989e).

Table 3.8.1-1 shows the current inventory of IDC 320 waste containers from the Rocky Flats Plant that have been shipped to INEL since 1985.

Table 3.8.1-1. Item Description Code 320 Container Information.

\begin{tabular}{|c|c|c|c|}
\hline \multicolumn{2}{|l|}{ Information } & \multirow{2}{*}{$\frac{\text { Drums }}{116}$} & \multirow{2}{*}{$\frac{\text { Boxes }}{0}$} \\
\hline Total Containers & & & \\
\hline \multirow[t]{3}{*}{ Net Container Weight (lb) } & Maximum & 630 & N/A \\
\hline & Minimum & 1 & N/A \\
\hline & Average & 154 & N/A \\
\hline
\end{tabular}

3.8.1.6.1 Drum Preparation-Approved liners for drums of TRU waste packaged for offsite shipment were the round-bottom liner (Rockwell specification SX-203) inside a 90-mil rigid polyethylene liner (Rockwell specification SX-202), or an O-ring bag and a polyethylene bag placed inside the rigid liner if the drum was attached to a glovebox (Rockwell International 1989e). Type III rigid liners have been used since September 1983 (Bearly 1989a). The IDC 320 waste packaged for offsite shipment required a fiberboard liner and a round bottom liner inside the rigid liner (Rockwell International 1988c). Figure $\mathrm{C}-1$ shows the appropriate drum liners for this IDC. If a single piece of heavy metal was packaged in a drum, it was braced to prevent shifting. Sharp edges were taped to prevent puncturing of the liners (Rockwell International 1989b). All bags were closed using the twistand-tape method (Rockwell International 1989e).

Flow-in, ventable gaskets were installed in the drums beginning in December 1982. They were used until October 1988, when tubular gaskets with carbon filters were required. Drums shipped to INEL between 1985 and 1988 may not meet the current WIPP WAC, owing to their lack of carbon filters (Bearly 1989a).

3.8.1.6.2 Box Preparation-No boxes of IDC 320 waste were shipped to INEL between 1985 and 1989.

3.8.1.7 Assay. The drums may have been assayed on a SGS counter or a PADC. Containers of waste that have not been PADC assayed and had SGS assay values of 1 gram or less should be PADC assayed to verify that they are transuranic waste. Table 3.8.1-2 is a summary of dose rate information on the containers of this waste. Table 3.8.1-3 is a summary of assay information. 
Table 3.8.1-2. Item Description Code 320 Dose Information.

\begin{tabular}{|c|c|c|c|}
\hline \multicolumn{2}{|l|}{ Information } & \multirow{2}{*}{$\frac{\text { Drums }}{78}$} & \multirow{2}{*}{$\frac{\text { Boxes }}{N / A}$} \\
\hline One Meter Dose Rate (mrem $/ \mathrm{h}$ ) & $0-0.5$ & & \\
\hline & $0.5-10$ & 38 & N/A \\
\hline \multirow[t]{2}{*}{ Surface Dose Rate (mrem/h) } & $<10$ & 109 & N/A \\
\hline & $10-200$ & 7 & N/A \\
\hline
\end{tabular}

Table 3.8.1-3. Item Description Code 320 Assay Information.

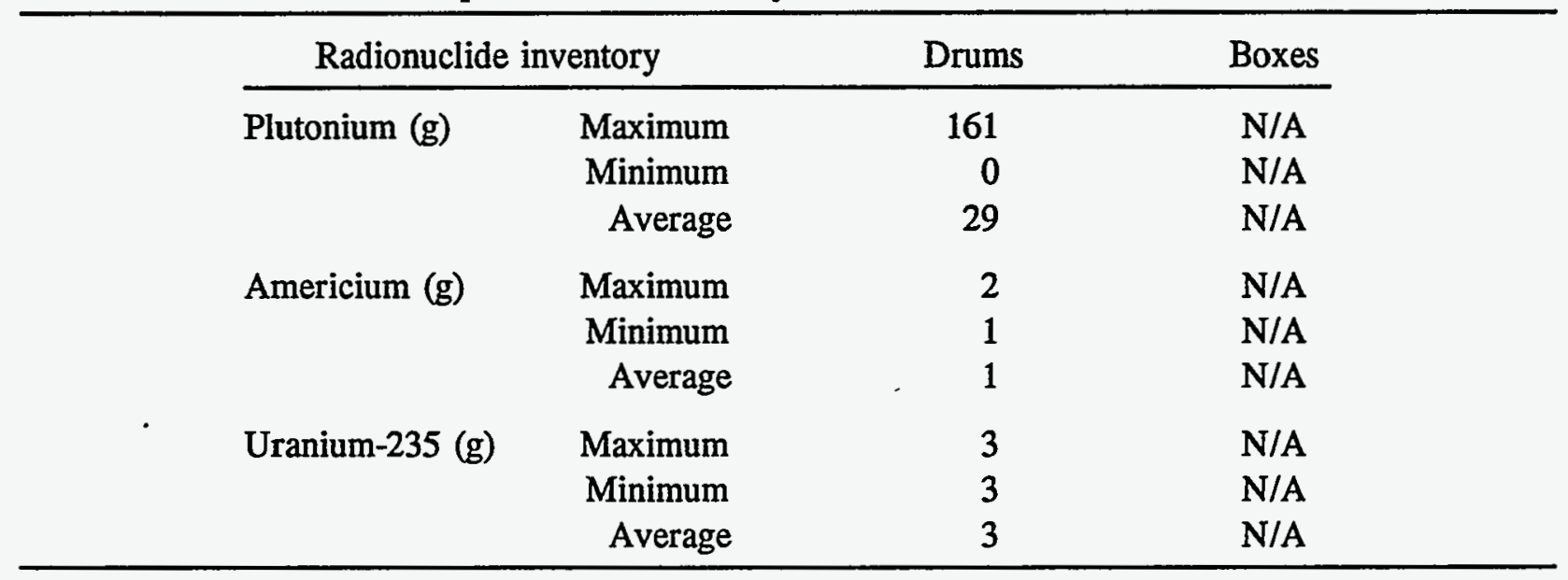

3.8.1.8 Inspection. Waste Certification personnel performed periodic inspections of the generating and packaging process to verify compliance with waste acceptance criteria. In addition, each drum was viewed using RTR to

- Ensure the drum does not contain nonconforming items

- Ensure the drum is properly packaged

- Verify the waste form description

- Evaluate the presence of free liquids.

3.8.1.9 Waste Form Evaluation. Table 3.8.1-4 evaluates the waste form against the WIPP WAC for such items as free liquids, pyrophoric materials, and compressed gases. Table 3.8.1-5 evaluates the waste against TRUPACT criteria. 
Table 3.8.1-4. Waste Form Evaluation.

Criterion or requirement

Limiting parameters ${ }^{\mathbf{a}}$

Immobilization

Metal fines generated by conventional working operations such as sawing, grinding, and filing have been evaluated for particle size. The particle size distribution, based on five random samples of Rocky Flats waste metal fines, has $<1 \%$ of the particles $<200$ microns and $<0.01 \%$ of the particles $<10$ microns (Rockwell International 1989b).

Liquids This waste form meets the free liquid criteria by procedural control and RTR inspection prior to shipment from Rocky Flats.

Pyrophoric

Materials

Pyrophoric materials were prohibited by procedural control. The absence of the pyrophoric materials was verified by the generating supervisor and periodic inspection by the Waste Certification Organization.

Explosives and Compressed Gases

Explosives and compressed gases were prohibited by procedural control. The absence of the explosives and compressed gases was verified by the generating supervisor and periodic inspection by the Waste Certification Organization. In addition, unvented, closed containers and pressurized containers were excluded by procedural controls and RTR examination.

TRU-Mixed Wastes The RCRA constituents exist as co-contaminants with the transuranic radionuclides. Compliance with the WIPP RCRA permits and NMD will be required prior to shipment of the stored waste to WIPP.

Specific Activity of Waste

A portion of the waste stored at INEL may contain $<100$ nanocuries per gram transuranic radionuclides.

$\mathrm{Pu}^{239}$ Equivalent None of the IDC 320 waste containers recorded as shipped to INEL in the Activity SWIMS exceed $1,000 \mathrm{Ci}$ of plutonium-equivalent activity.

a. Many of the limiting parameters were taken from TRU Waste Compliance Program (Rockwell International 1983a, 1987e, and 1989b). 
Table 3.8.1-5. TRUPACT Evaluation.

Criterion or

requirement

Limiting parameters ${ }^{\mathrm{a}}$

Waste Package

Weight

Rocky Flats limited the gross weight of drums to $800 \mathrm{lb}$. The TRUPACT and

Waste Containers

vehicle weight limits must be verified at the time of payload assembly at INEL.

Nuclear

Criticality

This waste form was packaged in 55-gal DOT-7A, Type A containers.

Rocky Flats limited the fissile content of the drums to 200 grams. However, the error-times-two requirement was not in place at the time the drums were shipped to INEL; therefore, it is not reported as part of the assay of the drum. The TRUPACT limit must be verified at the time of payload assembly at INEL. Based on the typical assays of the IDC 320 drums, the criticality criteria will be met but must be recalculated or assayed to meet the error-times-two requirement.

Surface Dose The surface dose rate criteria used by Rocky Flats was $200 \mathrm{mrem} / \mathrm{hr}$ at the drum Rate surface and $10 \mathrm{mrem} / \mathrm{hr}$ at 1 meter. Shielding was not necessary for IDC 320 drums. The TRUPACT limit must be verified at the time of payload assembly at INEL. Based on the typical dose rates from the IDC 320 drums, the dose rate criteria will be met.

Removable The Rocky Flats limit for removable contamination (for TRU assumed to be all

Surface alpha) was 20 disintegrations per minute $/ 100 \mathrm{~cm}^{2}$. The Rocky Flats limit is

Contamination equivalent to 9 picocuries per $100 \mathrm{~cm}^{2}$, which is well within the WIPP criteria.

Thermal Power

The thermal power calculation reported in the SWIMS data package is based on the reported assay value without an error/uncertainty correction. The thermal power must be recalculated based on the assay error determination.

Gas Generation Based on the procedural requirements for packaging IDC 320 waste and the waste description, the only areas of noncompliance are carbon filters, unpunctured rigid liners, headspace gas analysis, and visual characterization.

Headspace gas analysis did not detect the TRUPACT Chemical List halogenated organics for Content Code RF 117A (1,1,1-trichloroethane, 1,1,2-trichloro-1,2,2trifluoroethane, carbon tetrachloride, and methylene chloride).

Personnel performing RTR examination at Rocky Flats would accept up to $10 \%$ of another IDC. The other IDCs could be combustibles, glass, concrete, leaded gloves, and plastics.

a. Many of the limiting parameters were taken from TRU Waste Compliance Program (Rockwell International 1983a, 1987e, and 1989b). 
3.8.1.10 Combustible and Organic Content. Table 3.8.1-6 outlines available data from the TRU Waste Sampling Program for IDC 320. SWIMS data indicate that this waste form does not contain $>20 \%$ combustibles or $>20 \%$ organics.

Table 3.8.1-6. IDC 320 Data Summary for Combustible and Organic Content.

\begin{tabular}{lcccccc}
\hline Container & $\begin{array}{c}\text { Wt. } \\
\text { combustibles } \\
(\mathrm{lb})^{\mathrm{z}}\end{array}$ & $\begin{array}{c}\text { Wt. } \\
\text { organics } \\
(\mathrm{lb})^{\mathrm{b}}\end{array}$ & $\begin{array}{c}\text { Net Wt. of } \\
\text { container } \\
(\mathrm{lb})^{\mathrm{c}}\end{array}$ & $\begin{array}{c}\text { Wt\% } \\
\text { combustibles }^{\text {s }}\end{array}$ & $\begin{array}{c}\text { Vol\% } \\
\text { combustiblese }^{\mathrm{n}}\end{array}$ & $\begin{array}{c}\text { Wt\% } \\
\text { organics }^{\text {s }}\end{array}$ \\
\hline $55-00290$ & 6.8 & 6.8 & 51.12 & 13 & 10 & 13 \\
$02-10613$ & 21.2 & 21.2 & 123 & 17 & 20 & 17 \\
\hline
\end{tabular}

a. Sum of weights of all combustible material and leaded rubber from Table 22 (Clements and Kudera 1985).

b. Sum of weights of all combustible material, leaded rubber, and organic material from Table 22 (Clements and Kudera 1985).

c. Net weight of container from Table 22 (Clements and Kudera 1985).

d. Weight of combustible material/net weight of container $\times 100$.

e. Vol\% of combustible material from visual examination, obtained from Appendix B (Clements and Kudera 1985).

f. Weight of organic material/net weight of container $\times 100$.

3.8.1.10.1 Combustible Content-SWIMS data show that IDC 320 waste is noncombustible (Rockwell International 1985a). In support of the TRU Waste Sampling Program, two drums of IDC 320 waste were opened. They were found to contain an average wt\% combustible content of $15 \%$. Visual inspection showed an average vol\% combustible content of $15 \%$. (Clements and Kudera 1985).

3.8.1.10.2 Organic Content-SWIMS data show that IDC 320 waste may contain $20 \%$ organics (Rockwell International 1985a). In support of the TRU Waste Sampling Program, two drums of IDC 320 waste were opened. They were found to contain an average wt\% organic content of $15 \%$. (Clements and Kudera 1985)

3.8.1.11 Analytical Information. Analytical data from the TRU Waste Sampling Waste Characterization Program (Clements and Kudera 1985) for IDC 320, Heavy Non-SS Metal, indicate that four drums were subject to headspace gas analysis. 
Gas composition analytical results are presented in Table 3.8.1-7. Waste boxes were not sampled. Hydrogen, oxygen, nitrogen, argon, carbon dioxide, and saturated hydrocarbons were detected in the drums.

IDC 321 was created in 1987 for lead waste. Drums of IDC 320 generated prior to 1987 may contain lead waste; therefore, the assigned EPA code, D008 (lead) applies. 
Table 3.8.1-7. Gas Sampling Results-Compositional Analysis (vol\%).

\begin{tabular}{|c|c|c|c|c|c|c|c|c|c|c|c|}
\hline \multirow[b]{2}{*}{$\begin{array}{l}\text { Container } \\
\text { ID. no. }\end{array}$} & \multirow[b]{2}{*}{$\begin{array}{c}\text { Storage } \\
\text { time (days) }\end{array}$} & \multicolumn{10}{|c|}{ Analytes } \\
\hline & & $\mathrm{H}_{2}$ & $\mathrm{O}_{2}$ & $\mathrm{~N}_{2}$ & Ar & $\mathrm{CO}_{2}$ & co & $\mathrm{NO}_{\mathrm{x}}$ & $\begin{array}{l}\text { Hydrocarbons } \\
\text { (saturated) }\end{array}$ & $\begin{array}{l}1,1,1- \\
\text { trichloro-ethane }\end{array}$ & $\begin{array}{c}\text { Other } \\
\text { Hydrocarbons }^{b}\end{array}$ \\
\hline $29-01396^{c}$ & 211 & - & 20.4 & 78.4 & 0.98 & 0.19 & - & - & 0.05 & - & - \\
\hline $55-00290$ & 654 & 0.94 & 12.9 & 79.2 & 4.23 & 2.56 & - & - & 0.15 & - & - \\
\hline $02-10613$ & 4,329 & 0.04 & 18.8 & 79.5 & 0.94 & 0.75 & - & - & - & - & - \\
\hline 02-10128 & 4,442 & - & 3.80 & 95.0 & 1.1 & 0.05 & - & - & 0.02 & - & - \\
\hline \multicolumn{12}{|c|}{ Saturated hydrocarbons-methane through propane. } \\
\hline \multicolumn{12}{|c|}{ b. Other hydrocarbons-as specified. } \\
\hline c. Drum s & vith a semi & meabl & & & & & & & & & \\
\hline
\end{tabular}




\subsection{Waste Form Number 117-TRU Metal Waste, Content Code RF 117A}

\subsubsection{Item Description Code 321 - Lead}

3.8.2.1 Certification Assessment. This IDC is certifiable without further waste treatment. Assay and thermal power calculations, including error, need to be updated to meet the current WIPP WAC. Several gas generation criteria need to be addressed. Carbon filters may need to be installed, drums will require inspection to identify unvented or unpunctured rigid liners, and headspace gas analysis and visual waste characterization will need to be performed.

3.8.2.2 Waste Description. IDC 321 waste consists primarily of lead bricks, lead shielding, and lead tape. Other forms of this waste include components from radiographic film processing and lead scraps from machining processes. The EPA Code assigned to IDC 321 is D008 (EG\&G RFP 1994i). The Item Description Code for Lead (IDC 321) was created in 1987 to allow for separation from Heavy Metals (IDC 320) (EG\&G RFP 1994h).

3.8.2.3 Generation Source. The lead waste was most commonly generated as a result of maintenance activities in Buildings 371, 559, 707, 771, 776, 777, and 779 (EG\&G RFP 1994i).

3.8.2.4 Recovery Method. This IDC was never generated as a residue and therefore has no recovery method (EG\&G RFP 1994i).

3.8.2.5 Waste Packaging and Handling. Line-generated metal waste was segregated from all other materials, especially removing all free liquid, particulates, and process residues. Items for disposal were inspected before removal from the line. Gearbox oil, hydraulic fluid, and other liquids were removed. All electrical equipment was checked to ensure that electrical potential had been discharged. The waste was then collected and bagged out of the glovebox line. A small amount of Oil Dri was added to the bags if the waste was wet. All line-generated waste was usually doublebagged and monitored for contamination before being placed into the waste collection drum for linegenerated waste. The drums were DOT-17C, white, 55-gal drums.

Metal wastes generated within the Pu processing area, but outside of a glovebox line, were termed "nonline-generated wastes." These wastes were collected in 55-gal drums located in all Pu areas. The drum covers were clearly marked for nonline waste. Normally, nonline waste was not bagged before being placed in the collection drum (Rockwell International 1989e). Nonline waste was rarely TRU and would have been repackaged in a box or drum with a rigid liner prior to shipment.

When the drum was full, the drum liners were sealed and the drum was closed. The drum label, completed with all necessary information, was then taped to the drum lid and a TID was attached to the drum.

3.8.2.6 Container Preparation. Only approved containers could be used to package TRU waste for shipment offsite. The containers approved for shipment to INEL during this time were 
DOT-17C, white, 55-gal drums (Rockwell specification SX-200). These containers met the requirements for certification as DOT-7A Type A packaging (Rockwell International 1989e).

Table 3.8.2-1 shows the current inventory of IDC 321 waste containers from the Rocky Flats Plant that have been shipped to INEL since 1985 .

Table 3.8.2-1. Item Description Code 321 Container Information.

\begin{tabular}{lccc}
\hline \multicolumn{1}{c}{ Information } & & Drums & Boxes \\
\hline Total Containers & & 4 & 0 \\
Net Container Weight (lb) & Maximum & 448 & N/A \\
& Minimum & 46 & N/A \\
& Average & 247 & N/A \\
\hline
\end{tabular}

3.8.2.6.1 Drum Preparation-Approved liners for drums of TRU waste packaged for offsite shipment were the round-bottom liner (Rockwell specification SX-203) inside a 90-mil rigid polyethylene liner (Rockwell specification SX-202), or an O-ring bag and a polyethylene bag placed inside the rigid liner if the drum was attached to a glovebox (Rockwell International 1989e). Type III rigid liners have been used since September 1983 (Bearly 1989a). The IDC 321 waste packaged for offsite shipment required a fiberboard liner and a round bottom liner inside the rigid liner (Rockwell International 1988c). Figure C-1 shows the appropriate drum liners for this IDC. If a single piece of heavy metal was packaged in a drum, it was braced to prevent shifting. Sharp edges were taped to prevent puncturing of the liners (Rockwell International 1989b). All bags were closed using the twistand-tape method (Rockwell International 1989e).

Flow-in, ventable gaskets were installed in the drums beginning in December 1982. They were used until October 1988, when tubular gaskets with carbon filters were required. Drums shipped to INEL between 1985 and 1988 may not meet the current WIPP WAC, owing to their lack of carbon filters (Bearly 1989a).

3.8.2.6.2 Box Preparation-No boxes of IDC 321 waste were shipped to INEL between 1985 and 1989.

3.8.2.7 Assay. High-resolution SGS counters began operating in 1984; the lead waste was assayed using a PADC beginning in 1987. The PADC assay was only used as a supplement to the SGS counter for assay of dense wastes, such as lead, that resulted in poor gamma ray transmission. Assay results were used to calculate $\mathrm{Pu}^{239}$ fissile equivalent and decay heat. Drummed waste was generally assayed in the building of generation subject to the operational status of the assay equipment and any special assay needs based on the waste matrix. IDC 321 was typically assayed using the PADC drum counter due to the density of the waste matrix (WASTREN, Inc. 1994c). Containers of waste that have not been PADC assayed and had SGS assay values of 1 gram or less should be PADC assayed to verify that they are transuranic waste. Table 3.8.2-2 summarizes the dose rates measured on containers of this IDC. Table 3.8.2-3 provides a summary of the assay information. 
Table 3.8.2-2. Item Description Code 321 Dose Information.

\begin{tabular}{|c|c|c|c|}
\hline \multicolumn{2}{|l|}{ Information } & \multirow{2}{*}{$\frac{\text { Drums }}{4}$} & \multirow{2}{*}{$\frac{\text { Boxes }}{\text { N/A }}$} \\
\hline One Meter Dose Rate (mrem $/ \mathrm{h})$ & $0-0.5$ & & \\
\hline & $0.5-10$ & 0 & N/A \\
\hline \multirow[t]{2}{*}{ Surface Dose Rate (mrem/h) } & $<10$ & 4 & N/A \\
\hline & $10-200$ & 0 & N/A \\
\hline
\end{tabular}

Table 3.8.2-3. Item Description Code 321 Assay Information.

\begin{tabular}{|c|c|c|c|}
\hline \multicolumn{2}{|c|}{ Radionuclide inventory } & \multirow{2}{*}{$\frac{\text { Drums }}{3}$} & \multirow{2}{*}{$\frac{\text { Boxes }}{\text { N/A }}$} \\
\hline Plutonium (g) & Maximum & & \\
\hline & Minimum & 1 & N/A \\
\hline & Average & 2 & N/A \\
\hline \multirow[t]{3}{*}{ Americium (g) } & Maximum & - & N/A \\
\hline & Minimum & - & N/A \\
\hline & Average & - & N/A \\
\hline \multirow[t]{3}{*}{ Uranium-235 (g) } & Maximum & - & N/A \\
\hline & Minimum & - & N/A \\
\hline & Average & - & N/A \\
\hline
\end{tabular}

3.8.2.8 Inspection. Only conforming waste items were placed in a drum. Waste contents were verified by the generating supervisor and periodic inspection by the Waste Certification Organization. Lead drums were generally not examined with RTR.

3.8.2.9 Waste Form Evaluation. Table 3.8.2-4 evaluates the waste form against the WIPP WAC for such items as free liquids, pyrophoric materials, and compressed gases. Table 3.8.2-5 evaluates the waste against TRUPACT criteria. 
Table 3.8.2-4. Waste Form Evaluation.

Criterion or

requirement

Limiting parameters ${ }^{\mathrm{a}}$

Immobilization

The lead metal meets the immobilization criteria by the typical bulk size of the waste. In addition, five samples of metal fines from grinding, sawing, and filing were evaluated against the particulate criteria and passed.

Liquids

The lead metal meets the free liquid criteria by procedural control and RTR inspection prior to shipment from Rocky Flats.

Pyrophoric

Materials

Pyrophoric materials were prohibited by procedural control. The absence of the pyrophoric materials was verified by the generating supervisor and periodic inspection by the Waste Certification Organization.

Explosives and

Compressed Gases

Explosives and compressed gases were prohibited by procedural control. The absence of the explosives and compressed gases were verified by the generating supervisor and periodic inspection by the Waste Certification Organization. In addition, nonvented, closed containers and pressurized containers were excluded by procedural controls and RTR examination.

TRU-Mixed Wastes The RCRA constituents exist as co-contaminants with the transuranic radionuclides. Compliance with the WIPP RCRA permits and NMD will be required prior to shipment of the stored waste to WIPP.

Specific Activity of Activity of $>100$ nanocuries per gram was verified by the PADC. Any IDC Waste 321 containers assayed prior to the usage of the PADC should be verified to be above 100 nanocuries per gram.

$\mathrm{Pu}^{239}$ Equivalent None of the IDC 321 waste containers recorded as shipped to INEL in the Activity SWIMS exceed 1,000 $\mathrm{Ci}$ of plutonium-equivalent activity.

a. Many of the limiting parameters were taken from TRU Waste Compliance Program (Rockwell International 1983a, 1987e, and 1989b). 
Table 3.8.2-5. TRUPACT Evaluation.

Criterion or requirement

Limiting parameters ${ }^{2}$

Waste Package

Weight

Waste Containers This waste form was packaged in DOT-7A, Type A metal boxes. The metal boxes will not meet the TRUPACT waste container requirements.

Nuclear

Criticality

The TRUPACT limit must be verified at the time of payload assembly at INEL. Based on the typical assays of the IDC 321 drums, the criticality criteria will be met but must be recalculated or assayed to meet the error-times-two requirement.

Surface Dose

The TRUPACT limit must be verified at the time of payload assembly at INEL.

Rate

Based on the typical dose rates from the IDC 321 boxes, the dose rate criteria will be met.

Removable

The Rocky Flats limit for removable contamination (for TRU assumed to be all

Surface

Contamination alpha) was 20 disintegrations per minute $/ 100 \mathrm{~cm}^{2}$. The Rocky Flats limit is equivalent to 9 picocuries per $100 \mathrm{~cm}^{2}$, which is well within the WIPP criteria.

Thermal Power

The thermal power calculation reported in the SWIMS data package is based on the reported assay value without an error/uncertainty correction. The thermal power must be recalculated based on the assay error determination.

Gas Generation Based on the procedural requirements for packaging IDC 321 waste and the waste description, the only areas of noncompliance are carbon filters, nonpunctured rigid liners, headspace gas analysis, and visual characterization.

Headspace gas analysis did not detect the TRUPACT Chemical List halogenated organics for Content Code RF 117A (1,1,1-trichloroethane, 1,1,2-trichloro-1,2,2trifluororethane, carbon tetrachloride, and methylene chloride).

Personnel performing RTR examination at Rocky Flats would accept up to $10 \%$ of another IDC. The other IDCs could be combustibles, glass, concrete, leaded gloves, and plastics.

a. Many of the limiting parameters were taken from TRU Waste Compliance Program (Rockwell International 1983a, 1987e, and 1989b).

3.8.2.10 Combustible and Organic Content. SWIMS data indicate that this waste form does not contain $>20 \%$ combustibles or $>20 \%$ organics.

3.8.2.10.1 Combustible Content-SWIMS data show that IDC 321 waste should be noncombustible (Rockwell International 1985a). 
3.8.2.10.2 Organic Content-SWIMS data show that IDC 321 waste may contain about $20 \%$ organics (Rockwell International 1985a).

3.8.2.11 Analytical Information. Analytical data obtained through the Waste Stream and Residue Identification and Characterization Sampling and Analysis Database (EG\&G RFP 1994s) in 1991 and 1992 show the presence of lead (EPA Code D008) above the regulatory levels stated in 6 CCR 1007-3, Section 261, and in 40 CFR 261.24. The analytical data are summarized in Table 3.8.2-6 (EG\&G RFP 1994i).

Table 3.8.2-6. Item Description Code 321 Analytical Data Summary.

\begin{tabular}{cccc}
\hline Lab report & $\begin{array}{c}\text { TCLP } \\
\text { limit } \\
(\mathrm{mg} / \mathrm{L})\end{array}$ & Constituents & $\begin{array}{c}\text { Concentration } \\
(\mathrm{mg} / \mathrm{L})\end{array}$ \\
\hline G910078 & 5.0 & Lead & 260 \\
G920007 & 5.0 & Lead & 478 \\
9360001 & 5.0 & Lead & 467 \\
\hline
\end{tabular}

a. Concentration of constituent at which a solid waste exhibits the characteristic of toxicity. A concentration greater than or equal to this level characterizes a solid waste as a RCRA hazardous waste.

Additional EPA codes that may apply to IDC 321 are D006 (cadmium), D002 (corrosivity), and D005 (barium) (EG\&G RFP 1994i).

Analytical data from the WIPP Experimental Waste Characterization Program (EG\&G RFP 1994t) for IDC 321- Lead, indicate that one drum (D52318) was subject to headspace gas analysis.

IDC 321 Gas Mass Spectrometry analytical results are presented in Table 3.8.2-7. The drum was subject to the operational lid headspace sampling program. Nitrogen, oxygen, and argon were detected in the drum.

Table 3.8.2-7. Gas Mass Spectrometry Results (vol\%).

\begin{tabular}{|c|c|c|c|c|c|c|c|c|c|c|c|c|}
\hline \multirow[b]{2}{*}{$\begin{array}{l}\text { Drum } \\
\text { No. }\end{array}$} & \multirow{2}{*}{$\begin{array}{c}\text { Headspace } \\
\text { Sample } \\
\text { Program } \\
\end{array}$} & \multirow[b]{2}{*}{ Vented } & \multicolumn{10}{|c|}{ Analytes } \\
\hline & & & $\mathrm{H}_{2}$ & $\mathrm{~N}_{2}$ & $\mathrm{O}_{2}$ & $\mathrm{Ar}$ & $\mathrm{CO}_{2}$ & $\mathrm{CO}$ & $\mathrm{CH}_{4}$ & $\mathrm{C}_{2} \mathrm{H}_{6}$ & $\mathrm{C}_{3} \mathrm{H}_{8}$ & $\mathrm{NO}_{\mathrm{x}}$ \\
\hline D52318 & $1 \mathrm{~A}$ & - & - & 78.2 & 20.8 & 0.945 & - & - & - & - & - & - \\
\hline \multicolumn{13}{|l|}{ Notes: } \\
\hline \multicolumn{13}{|c|}{ Headspace Sample Program } \\
\hline \multicolumn{13}{|c|}{$\begin{array}{l}\text { 1A Operational Lid, Gas Mass Spectrometry Results (vol\%) } \\
\text { Unreported analyte values indicate that analyte was undetected, or was detected at or above the MDL but at a } \\
\text { level below the PRQL. }\end{array}$} \\
\hline
\end{tabular}




\subsection{Waste Form Number 117-TRU Metal Waste, Content Code RF 117A}

\subsubsection{Item Description Code 480 - Light Metal}

3.8.3.1 Certification Assessment. This IDC is certifiable without further waste treatment. Assay and thermal power calculations, including error, need to be updated to meet the current WIPP WAC. Several gas generation criteria need to be addressed. Carbon filters may need to be installed, drums will require inspection to identify unvented or unpunctured rigid liners, and headspace gas analysis and visual waste characterization will need to be performed. Metal boxes are not authorized for shipment in the TRUPACT.

3.8.3.2 Waste Description. IDC 480, Light Metal, includes waste aluminum, copper, iron, brass, bronze, galvanized metal, stainless steel, carbon steel, and other metal alloys contained in waste mechanical and electrical parts, tools, containers, scrap metals, piping, wire, cable, gauges, valves, foil, planchets, and a variety of other metal items (EG\&G RFP 1994k).

3.8.3.3 Generation Source. IDC 480 was generated in Buildings $371,374,559,707,771$, 774, 776, 777, 779 and 991 (EG\&G RFP 1994k).

3.8.3.4 Recovery Method. Small waste items, contaminated with significant quantities of plutonium, were washed in a ball-mill washer or leached. Larger plutonium contaminated waste items were washed by Size Reduction with hot water.

3.8.3.5 Waste Packaging and Handling. Line-generated metal waste was segregated from all other materials. All free liquid, particulates, and process residues were removed. Items for disposal were inspected before removal from the line. Gearbox oil, hydraulic fluid, and other liquids were removed. All electrical equipment was checked to ensure that electrical potential had been discharged. The waste was then collected and bagged out of the glovebox line. A small amount of Oil Dri was added to the bags if the waste was wet. All line-generated waste was usually doublebagged and monitored for contamination before being placed into the waste collection drum for linegenerated waste. The drums were DOT-17C, white, 55-gal drums.

Metal wastes generated within the $\mathrm{Pu}$ processing area, but outside of a glovebox line, were termed "nonline-generated wastes." These wastes were collected in 55-gal drums located in all $\mathrm{Pu}$ areas. The drum covers were clearly marked for nonline waste. Normally, nonline waste was not bagged before being placed in the collection drum (Rockwell International 1989e). Nonline waste was rarely TRU and was repackaged in a box or drum with a rigid liner prior to shipment.

When the drum was full, the drum liners were sealed and the drum was closed. The drum label, completed with all necessary information, was then taped to the drum lid and a TID was attached to the drum.

Drums were held in Size Reduction in Building 776 until enough of either line-generated or nonline-generated metals to fill a waste box had accumulated. The line-generated or nonlinegenerated wastes were then repackaged separately into boxes equipped with a certified filter-and-vent 
system. Each bag of waste was opened and distributed in the waste box to obtain greater packing density (Rockwell International 1989b).

Metal waste that was too large to fit into a 55-gal drum, but did not require size reduction, decontamination, or disassembly to meet the WIPP WAC, was placed directly into an approved waste box (Rockwell International 1989b).

3.8.3.6 Container Preparation. Only approved containers could be used to package TRU waste for shipment offsite. Containers approved for shipment to INEL during this time were DOT17C, white, 55-gal drums (Rockwell specification SX-200); white, corrugated steel boxes (Rockwell specification SX-231); and FRP boxes (Rockwell specification SX-207). Each of these containers met the requirements for certification as DOT-7A Type A packaging (Rockwell International 1989e).

Table 3.8.3-1 shows the current inventory of IDC 480 waste containers from the Rocky Flats Plant that have been shipped to INEL since 1985.

Table 3.8.3-1. Item Description Code 480 Container Information.

\begin{tabular}{lccc}
\hline \multicolumn{1}{c}{ Information } & & Drums & Boxes \\
\hline Total Containers & & 14 & 536 \\
Net Container Weight (lb) & Maximum & 293 & 5,250 \\
& Minimum & 40 & 310 \\
& Average & 121 & 2,304 \\
\hline
\end{tabular}

3.8.3.6. 1. Drum Preparation-Approved liners for drums of TRU waste packaged for offsite shipment were the round-bottom liner (Rockwell specification SX-203) inside a 90-mil rigid polyethylene liner (Rockwell specification SX-202), or an O-ring bag and a polyethylene bag placed inside the rigid liner if the drum was attached to a glovebox (Rockwell International 1989e). Type III rigid liners have been used since September 1983 (Bearly 1989a). The IDC 480 waste packaged for offsite shipment required a round bottom liner inside the rigid liner (Rockwell International 1988c). Figure C-1 shows the appropriate drum liners for this IDC. If a single piece of heavy metal was packaged in a drum, it was braced to prevent shifting. Sharp edges were taped to prevent puncturing of the liners (Rockwell International 1989b). All bags were closed using the twist-and-tape method (Rockwell International 1989e).

Flow-in, ventable gaskets were installed in the drums beginning in December 1982. They were used until October 1988, when tubular gaskets with carbon filters were required. Drums shipped to INEL between 1985 and 1988 may not meet the current WIPP WAC, owing to their lack of carbon filters (Bearly 1989a).

3.8.3.6.2 Box Preparation-FRP boxes were used for waste shipped to INEL from 1972 through 1982 (Riddle and others 1985). In 1982, the use of the corrugated metal waste box was phased in. The last FRP box was shipped to INEL in 1986. In the interim, waste packaged in both types of boxes had been shipped to INEL. SWIMS information did not track the type of box used in individual shipments. 
The FRP box was constructed of $3 / 4$-in. exterior plywood with $2 \times 4$-in. framing members and skids. The entire box was coated with a 0.12 -in. coat of fiberglass-reinforced polyester with flameretardant properties. The continuous FRP coating provides a leakproof, tamper-proof package. Inner liners used for contamination control during loading consist of a PVC liner protected by a 50-mil fiberboard sheet. The box size was $4 \times 4 \times 7 \mathrm{ft}$ or larger. The gross weight was normally restricted to 5,000 lb (Riddle and others 1985).

The corrugated metal waste boxes were made entirely out of 14-gauge (0.0747-in.), low-carbon steel. All seams including the closure were welded to produce a leaktight container (Brugger 1983). These boxes required a 10-mil PVC liner (Rockwell specification SX-209), a 0.75-in. plywood liner, and a 0.051-in. fiberboard liner (Rockwell specification SX-209) (Riddle and others 1985; Bearly and others 1988). Figure C-4 shows the appropriate box liners required for this IDC. Four sizes of the box have been certified as DOT-7A containers, with a maximum size of $54 \times 54 \times 89$ in. and a maximum gross weight of $7,000 \mathrm{lb}$. These containers are commonly referred to as "Sand Boxes" (Riddle and others 1985).

Where necessary, items that had a weight distribution or configuration that caused them to sit in an unstable condition in the container were blocked, braced, or banded to prevent the items from shifting (Rockwell International 1989e). All items that had the potential to puncture or otherwise compromise the integrity of the waste box were adequately prepackaged to cover sharp corners (Rockwell International 1989e).

3.8.3.7 Assay. The drums may have been assayed on a SGS counter or a PADC. Boxes are counted in the crate counter. Containers of waste that have not been PADC assayed and had SGS or crate counter assay values of 1 gram or less should be PADC assayed to verify that they are transuranic waste. Table 3.8.3-2 is a summary of the dose rate information for this waste. Table 3.8.3-3 is a summary of the assay information. One drum was evaluated for uranium, no drums were evaluated for americium. Uranium was evaluated in 48 boxes, and americium was evaluated in 25 boxes. This IDC may contain tritium.

Table 3.8.3-2. Item Description Code 480 Dose Information.

\begin{tabular}{crrr}
\hline Information & & Drums & Boxes \\
\cline { 2 - 5 } One Meter Dose Rate (mrem/h) & $0-0.5$ & 11 & 491 \\
& $0.5-10$ & 3 & 45 \\
Surface Dose Rate (mrem/h) & $<10$ & 14 & 532 \\
& $10-200$ & 0 & 4 \\
\hline
\end{tabular}


Table 3.8.3-3. Item Description Code 480 Assay Information.

\begin{tabular}{|c|c|c|c|}
\hline \multicolumn{2}{|c|}{ Radionuclide inventory } & \multirow{2}{*}{$\frac{\text { Drums }}{91}$} & \multirow{2}{*}{$\frac{\text { Boxes }}{345}$} \\
\hline Plutonium (g) & Maximum & & \\
\hline & Minimum & 0 & 0 \\
\hline & Average & 29 & 79 \\
\hline \multirow[t]{3}{*}{ Americium (g) } & Maximum & - & 9 \\
\hline & Minimum & - & 0 \\
\hline & Average & - & 1 \\
\hline \multirow[t]{3}{*}{ Uranium-235 (g) } & Maximum & 12 & 20 \\
\hline & Minimum & 12 & 0 \\
\hline & Average & 12 & 5 \\
\hline
\end{tabular}

3.8.3.8 Inspection. Waste Certification personnel performed periodic inspections of the generating and packaging process to verify compliance with waste acceptance criteria. In addition, each container was viewed using RTR to

- Ensure the container does not contain nonconforming items

- Ensure the container is properly packaged

- Verify the waste form description

- Evaluate the presence of free liquids.

Waste that was placed directly into a box was controlled by Waste Certification personnel. The box was locked when Waste Certification personnel were not present.

3.8.3.9 Waste Form Evaluation. Table 3.8.3-4 evaluates the waste form against the WIPP WAC for such items as free liquids, pyrophoric materials, and compressed gases. Table 3.8.3-5 evaluates the waste against TRUPACT criteria. 
Table 3.8.3-4. Waste Form Evaluation.

Criterion or requirement

Limiting parameters ${ }^{\mathrm{a}}$

Immobilization

Metal fines generated by conventional working operations such as sawing, grinding, and filing have been evaluated for particle size. The particle size distribution, based on five random samples of Rocky Flats waste metal fines, has $<1 \%$ of the particles $<200$ microns and $<0.01 \%$ of the particles $<10$ microns (Rockwell International 1989b).

Liquids

This waste form meets the free liquid criteria by procedural control and RTR inspection prior to shipment from Rocky Flats.

Pyrophoric

Materials

. Pyrophoric materials were prohibited by procedural control. The absence of the pyrophoric materials was verified by the generating supervisor and periodic inspection by the Waste Certification Organization.

Explosives and Compressed Gases

Explosives and compressed gases were prohibited by procedural control. The absence of the explosives and compressed gases was verified by the generating supervisor and periodic inspection by the Waste Certification Organization. In addition, unvented, closed containers and pressurized containers were excluded by procedural controls and RTR examination.

TRU-Mixed Wastes The RCRA constituents exist as co-contaminants with the transuranic radionuclides. Compliance with the WIPP RCRA permits and NMD will be required prior to shipment of the stored waste to WIPP.

Specific Activity of A portion of the waste stored at INEL may contain $<100$ nanocuries per gram Waste transuranic radionuclides. This IDC may contain tritium.

$\mathrm{Pu}^{239}$ Equivalent Activity None of the IDC 480 waste containers recorded as shipped to INEL in the SWIMS exceed $1,000 \mathrm{Ci}$ of plutonium-equivalent activity.

a. Many of the limiting parameters were taken from TRU Waste Compliance Program (Rockwell International 1983a, 1987e, and 1989b). 
Table 3.8.3-5. TRUPACT Evaluation.

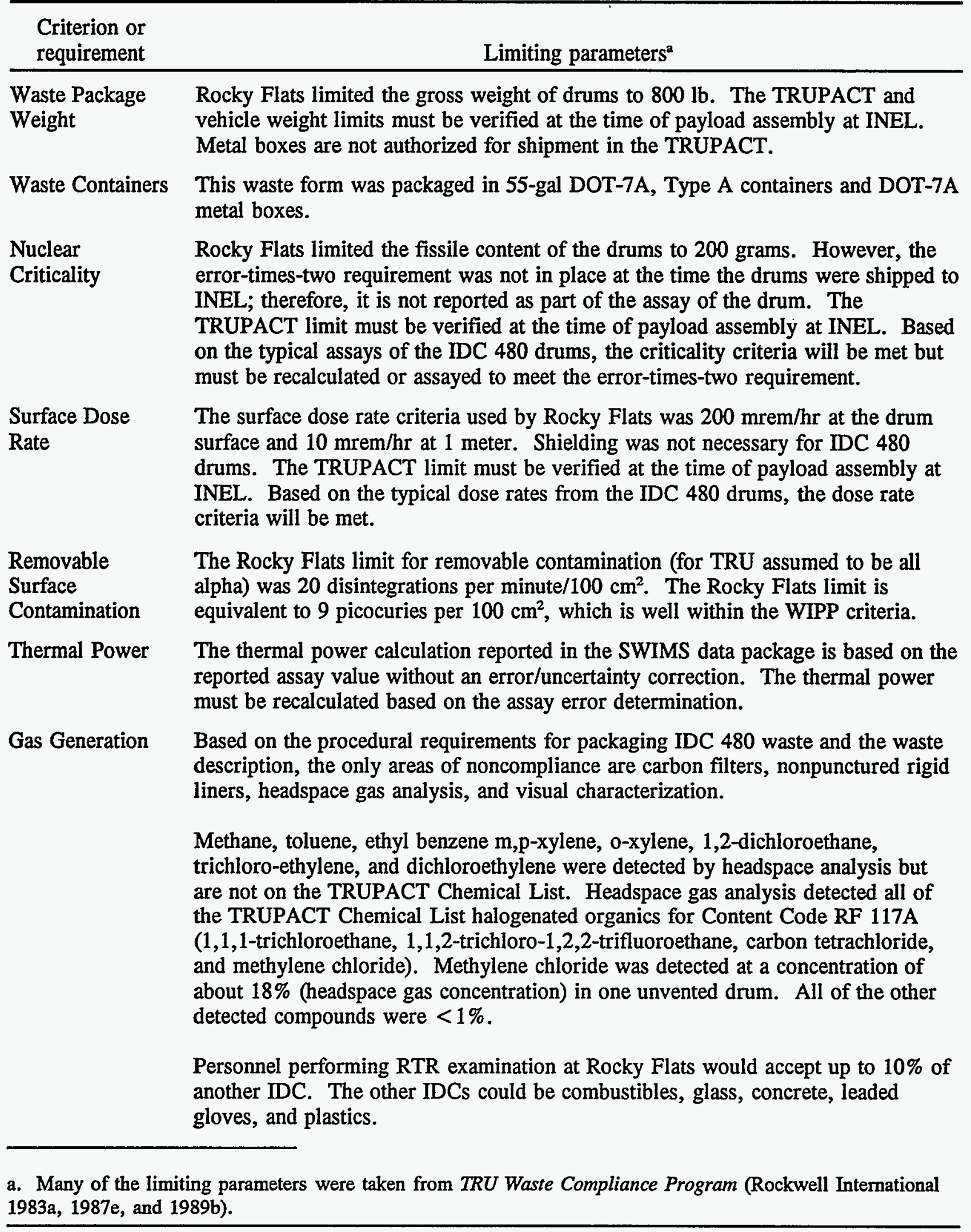


3.8.3.10 Combustible and Organic Content. Table 3.8.3-6 outlines available data from the TRU Waste Sampling Program for IDC 480. SWIMS data indicate that this waste form does not contain $>20 \%$ combustibles or $>20 \%$ organics.

Table 3.8.3-6. Item Description Code 480 Data Summary for Combustible and Organic Content.

\begin{tabular}{|c|c|c|c|c|c|c|}
\hline Container & $\begin{array}{c}\text { Wt. } \\
\text { combustibles } \\
(\mathrm{lb})^{\mathrm{a}}\end{array}$ & $\begin{array}{l}\text { Wt. } \\
\text { organics } \\
\text { (lb) }\end{array}$ & $\begin{array}{l}\text { Net wt. of } \\
\text { container } \\
(\mathrm{lb})^{c}\end{array}$ & $\begin{array}{c}\text { Wt\% } \\
\text { combustibles }^{\mathrm{d}}\end{array}$ & $\begin{array}{c}\text { Vol\% } \\
\text { combustibles }^{\mathrm{e}}\end{array}$ & $\begin{array}{c}\text { Wt\% } \\
\text { organics }\end{array}$ \\
\hline $02-40153$ & 0 & -0 & 197 & 0 & 2 & 0 \\
\hline $29-00513$ & 4.0 & 4.0 & 56 & 7 & 3 & 7 \\
\hline $29-00528$ & 4.5 & 4.5 & 70 & 6 & 2 & 6 \\
\hline $78-00199$ & 8.5 & 8.5 & 211.5 & 4 & 5 & 4 \\
\hline $02-40002$ & 8.5 & 8.5 & 260.5 & 3 & 10 & 3 \\
\hline $31-00939$ & 8.8 & 8.8 & 66.25 & 13 & 5 & 13 \\
\hline 02-39738 & 9.5 & 9.5 & 27.5 & 35 & 30 & 35 \\
\hline $45-00528$ & 18.3 & 18.3 & 146.5 & 12 & 10 & 12 \\
\hline $389-90895$ & 86 & 86 & $2,427.0$ & 4 & 2 & 4 \\
\hline $389-90828$ & 73 & 73 & 2000 & 4 & 2 & 4 \\
\hline $29-01396$ & 14.2 & 14.2 & 177.4 & 8 & 20 & 8 \\
\hline $12-12505$ & 17.2 & 17.2 & 84.1 & 20 & 10 & 20 \\
\hline $02-34855$ & 2 & 2 & 178.25 & 1 & 5 & 1 \\
\hline $02-35083$ & 23.8 & 23.8 & 131.12 & 18 & 20 & 18 \\
\hline $31-01321$ & 13.5 & 13.5 & 67.75 & 20 & 15 & 20 \\
\hline $42-00209$ & 19.3 & 19.3 & 169.87 & 11 & 35 & 11 \\
\hline $02-10128$ & 20.3 & 20.3 & 142.6 & 14 & 5 & 14 \\
\hline $01-08226$ & 15.6 & 15.6 & 344.5 & 5 & 20 & 5 \\
\hline $01-08232$ & 7.2 & 7.2 & 245.2 & 3 & 20 & 3 \\
\hline $02-12224$ & 14.4 & 14.4 & 145.9 & 10 & 15 & 10 \\
\hline $18-00025$ & 13.9 & 13.9 & 92.9 & 15 & 20 & 15 \\
\hline $32-00544$ & 35.0 & 35.0 & 115.1 & 30 & 20 & 30 \\
\hline $42-00043$ & 21.8 & 21.8 & 170.6 & 13 & 20 & 13 \\
\hline $389-85769$ & 66.4 & 66.4 & $2,558.0$ & 3 & 3 & 3 \\
\hline
\end{tabular}


Table 3.8.3-6. (continued).

\begin{tabular}{lcccccc}
\hline & $\begin{array}{c}\text { Wt. } \\
\text { combustibles } \\
(\mathrm{lb})^{\mathrm{a}}\end{array}$ & $\begin{array}{c}\text { Wt. } \\
\text { organics }^{(\mathrm{lb})^{\mathrm{b}}}\end{array}$ & $\begin{array}{c}\text { Net wt. of } \\
\text { container } \\
(\mathrm{lb})^{\mathrm{c}}\end{array}$ & $\begin{array}{c}\text { Wt\% } \\
\text { combustibles }^{\mathrm{d}}\end{array}$ & $\begin{array}{c}\text { Vol\% } \\
\text { combustibles }^{\text {e }}\end{array}$ & $\begin{array}{c}\text { Wt\% } \\
\text { organics }^{f}\end{array}$ \\
\hline $389-85811$ & 108 & 108 & $2,787.3$ & 4 & 5 & 4 \\
$25-00036$ & 17.6 & 17.6 & 63.1 & 28 & 10 & 28 \\
\hline
\end{tabular}

a. Sum of weights of all combustible material and leaded rubber from Table 22 (Clements and Kudera 1985).

b. Sum of weights of all combustible material, leaded rubber, and organic material from Table 22 (Clements and Kudera 1985).

c. Net weight of container from Table 22 (Clements and Kudera 1985).

d. Weight of combustible material/net weight of container $\times 100$.

e. Vol\% of combustible material from visual examination, obtained from Appendix B (Clements and Kudera 1985).

f. Weight of organic material/net weight of container $\times 100$.

3.8.3.10.1 Combustible Content-SWIMS data show that IDC 480 waste is noncombustibles (Rockwell International 1985a). In support of the TRU Waste Sampling Program, 26 drums of IDC 480 waste were opened. They were found to contain an average wt\% combustible content of $11.2 \%$. Visual inspection showed an average vol\% combustible content of $12.1 \%$ (Clements and Kudera 1985).

3.8.3.10.2 Organic Content-SWIMS data show that IDC 480 waste may contain $20 \%$ organics (Rockwell International 1985a). In support of the TRU Waste Sampling Program, 26 drums of IDC 480 waste were opened. They were found to contain an average wt\% organic content of 11.2\% (Clements and Kudera 1985).

3.8.3.11 Analytical Information. Analytical data from the WIPP Experimental Waste Characterization Program (EG\&G RFP 1994t) for IDC 480, Light Metal, indicate that 21 drums were subject to headspace gas analysis.

IDC 480 Gas Mass Spectrometry analytical results are presented in Table 3.8.3-7. Drums were subject to the operational lid headspace sampling program. Hydrogen, nitrogen, oxygen, argon, carbon dioxide, carbon monoxide, and methane analytes were detected. Nitrogen, oxygen, and argon were detected in every drum tested.

IDC 480 VOC Gas Chromatography/Mass Spectrometry analytical results are presented in Tables 3.8.3-8 through 3.8.3-10. Drums were subject to the operational lid headspace sampling 
program. Unreported analyte values indicate analytes were undetected, or detected at or above the MDL but at a level below the PRQL in these drums.

Analytical results for nine analytes are presented in Table 3.8.3-9. Analytes were detected in 11 of the 21 drums tested. Two analytes (1,1,1-trichloroethane, and carbon tetrachloride) were detected in the drums.

Analytical results for 10 analytes are presented in Table 3.8.3-10. Analytes were detected in 16 of the 21 drums tested. Four analytes (toluene, ethylbenzene, m,p-xylene, and o-xylene) were detected in the drums. Toluene was present in every drum tested.

Analytical data from the TRU Waste Sampling Waste Characterization Program (Clements and Kudera 1985) for IDC 480, Light Metal, indicate that 20 drums were subject to headspace gas analysis.

Gas composition analytical results are presented in Table 3.8.3-11. Waste boxes were not sampled. Hydrogen, oxygen, nitrogen, argon, carbon dioxide, saturated hydrocarbons, 1,1,1-trichloroethane, dichloromethane, carbon tetrachloride, 1,2-dichloroethane, trichloroethylene, and possible dichloroethylene were detected in the drums.

EPA codes that have been assigned to this waste include D001, D004-D011, D019, F001, F002, F005, F006, F007, F009 and F039 (EG\&G RFP 1994k). 
Table 3.8.3-7. Gas Mass Spectrometry Results (vol\%).

\begin{tabular}{|c|c|c|c|c|c|c|c|c|c|c|c|c|}
\hline \multirow{2}{*}{$\begin{array}{l}\text { Drum } \\
\text { no. }\end{array}$} & \multirow{2}{*}{$\begin{array}{c}\text { Headspace } \\
\text { sample } \\
\text { program }\end{array}$} & \multicolumn{11}{|c|}{ Analytes } \\
\hline & & Vented & $\mathrm{H}_{2}$ & $\mathbf{N}_{2}$ & $\mathrm{O}_{2}$ & $\mathrm{Ar}$ & $\mathrm{CO}_{2}$ & $\mathrm{CO}$ & $\mathrm{CH}_{4}$ & $\mathrm{C}_{2} \mathrm{H}_{6}$ & $\mathrm{C}_{3} \mathrm{H}_{8}$ & $\mathrm{NO}_{\mathrm{x}}$ \\
\hline D36606 & $1 \mathrm{~A}$ & $\mathrm{Y}$ & - & 77.9 & 21.1 & 0.951 & - & - & - & - & - & - \\
\hline D57847 & $1 \mathrm{~A}$ & $\mathbf{Y}$ & - & 77.7 & 21.1 & 0.948 & 0.229 & - & - & - & - & - \\
\hline D64752 & $1 \mathrm{~A}$ & $\mathrm{Y}$ & - & 78.4 & 20.6 & 0.951 & - & - & - & - & - & - \\
\hline D66157 & $1 \mathrm{~A}$ & $\mathbf{N}$ & 0.249 & 80.4 & 17.9 & 0.963 & 0.256 & 0.146 & 0.029 & - & - & - \\
\hline D66953 & $1 \mathrm{~A}$ & $\mathbf{Y}$ & - & 78.4 & 20.6 & 0.930 & - & - & - & - & - & - \\
\hline D67251 & $1 \mathrm{~A}$ & $\mathbf{N}$ & - & 71.7 & 7.8 & 0.876 & 0.796 & 0.172 & - & - & - & - \\
\hline D67317 & $1 \mathrm{~A}$ & $\mathbf{N}$ & 0.470 & 82.9 & 14.0 & 0.898 & 1.524 & 0.200 & - & - & - & - \\
\hline D67603 & $1 \mathrm{~A}$ & - & - & 78.3 & 20.4 & 0.944 & 0.272 & 0.059 & - & - & - & - \\
\hline D67735 & $1 \mathrm{~A}$ & - & - & 77.7 & 21.3 & 0.928 & 0.129 & 0.023 & - & - & - & - \\
\hline D68277 & $1 \mathrm{~A}$ & - & - & 77.4 & 21.6 & 0.934 & - & - & - & - & - & - \\
\hline D68377 & $1 \mathrm{~A}$ & $\mathrm{~N}$ & - & 78.2 & 20.8 & 0.923 & - & - & - & - & - & - \\
\hline D70446 & $1 \mathrm{~A}$ & $\mathrm{Y}$ & - & 78.7 & 20.1 & 0.924 & 0.273 & 0.019 & - & - & - & - \\
\hline D70669 & $1 \mathrm{~A}$ & - & - & 77.4 & 21.5 & 0.960 & - & - & - & - & - & - \\
\hline D71351 & $1 \mathrm{~A}$ & $\mathrm{Y}$ & - & 78.6 & 20.2 & 0.926 & 0.271 & 0.024 & - & - & - & - \\
\hline D71354 & $1 \mathrm{~A}$ & $\mathrm{Y}$ & - & 78.3 & 20.7 & 0.925 & - & - & - & - & - & - \\
\hline D71638 & $1 \mathrm{~A}$ & $Y$ & - & 77.7 & 21.3 & 0.941 & - & - & - & - & - & - \\
\hline D72079 & $1 \mathrm{~A}$ & - & - & 77.2 & 21.7 & 0.938 & 0.113 & 0.015 & - & - & - & - \\
\hline D72436 & $1 \mathrm{~A}$ & $\mathrm{Y}$ & - & 77.4 & 21.5 & 0.958 & - & 0.025 & - & - & - & - \\
\hline D72831 & $1 \mathrm{~A}$ & $\mathbf{Y}$ & - & 77.6 & 21.3 & 0.952 & - & - & - & - & - & - \\
\hline D73117 & $1 \mathrm{~A}$ & $Y$ & - & 78.2 & 20.8 & 0.922 & - & - & - & - & - & - \\
\hline D74007 & $1 \mathrm{~A}$ & $Y$ & - & 78.3 & 20.5 & 0.930 & 0.251 & - & - & - & - & - \\
\hline
\end{tabular}

Notes:

Headspace Sample Program

1A Operational Lid, Gas Mass Spectrometry Results (vol\%)

Y Yes

N No

Unreported analyte values indicate that analyte was undetected, or was detected at or above the MDL but at a level below the PRQL. 
Table 3.8.3-8. Volatile Organic Compound Gas Chromatography/Mass Spectrometry Results (parts per million by volume).

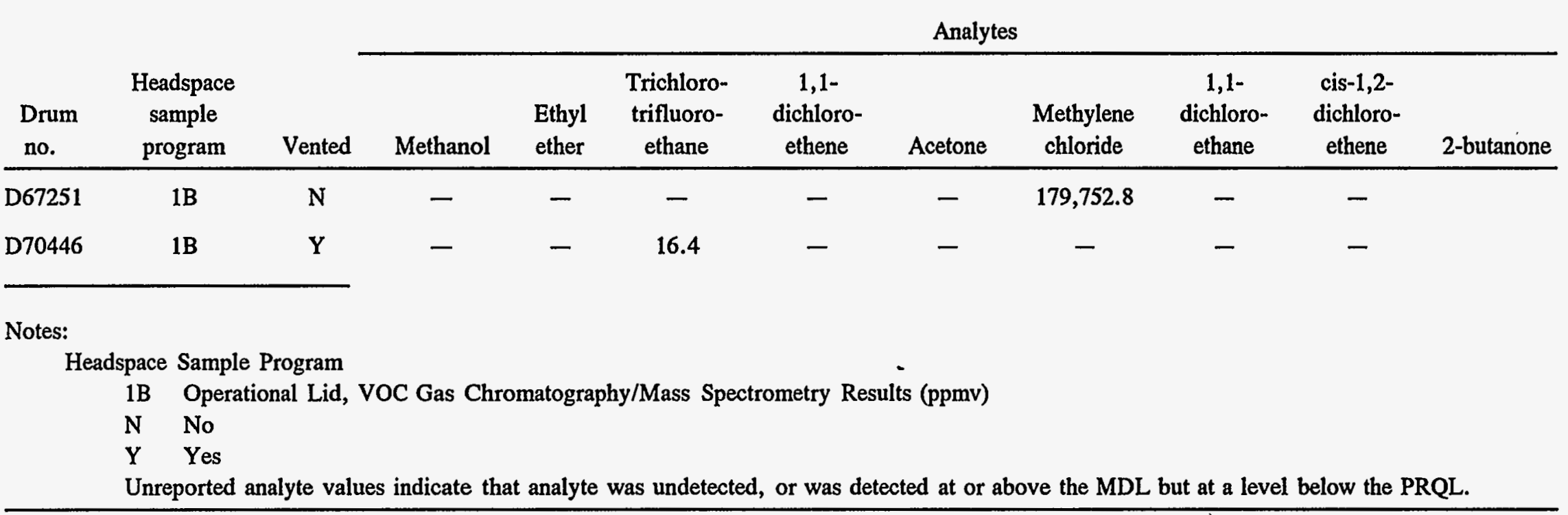


Table 3.8.3-9. Volatile Organic Compound Gas Chromatography/Mass Spectrometry Results (parts per million by volume).

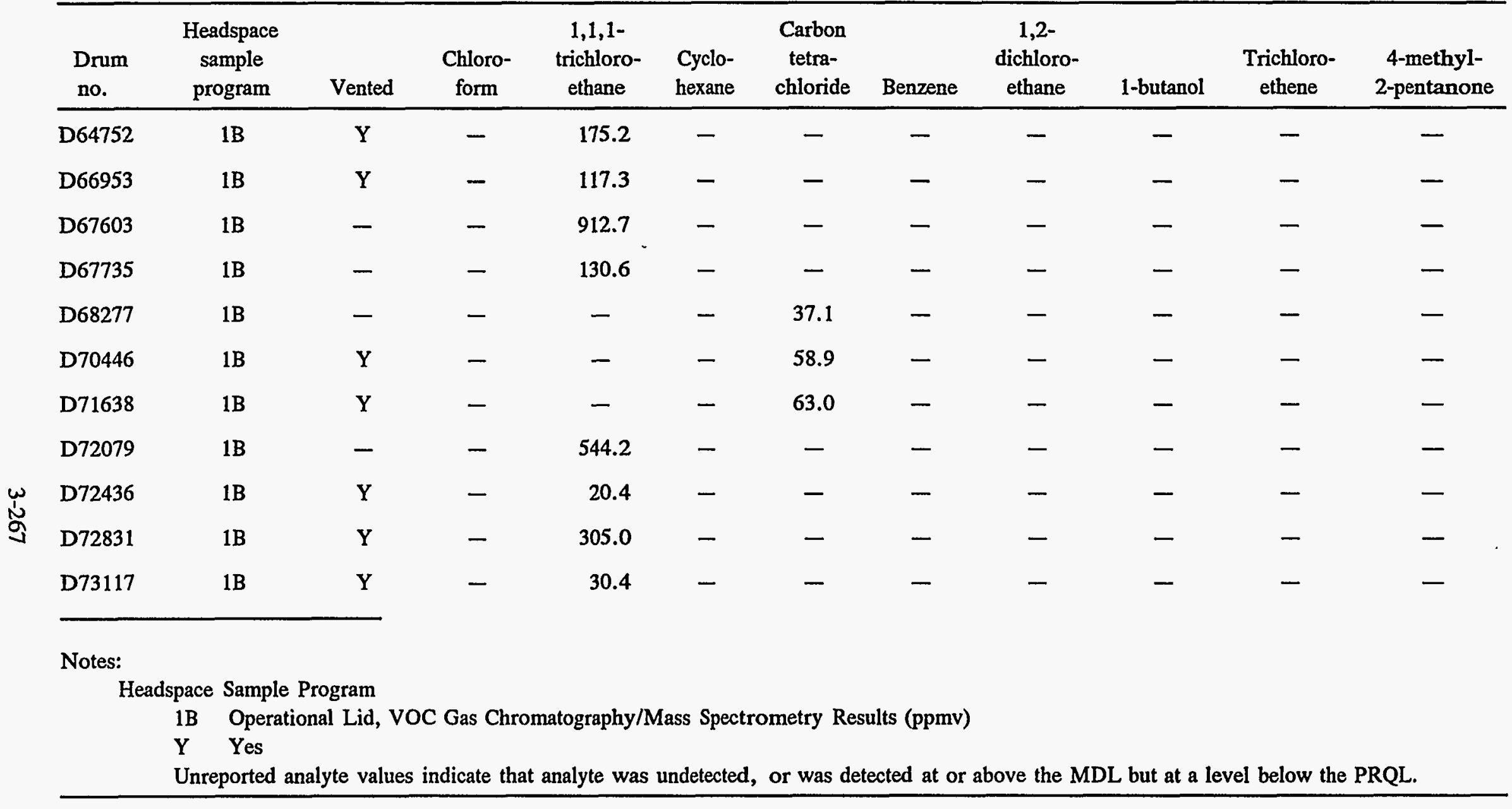


Table 3.8.3-10. Volatile Organic Compound Gas Chromatography/Mass Spectrometry Results (parts per million by volume).

\begin{tabular}{|c|c|c|c|c|c|c|c|c|c|c|c|c|c|}
\hline $\begin{array}{l}\text { Drum } \\
\text { no. }\end{array}$ & $\begin{array}{r}\text { Heads } 1 \\
\text { samp } \\
\text { progr }\end{array}$ & & Vented & Toluene & $\begin{array}{l}\text { Tetra- } \\
\text { chloro- } \\
\text { ethene }\end{array}$ & $\begin{array}{l}\text { Chloro- } \\
\text { benzene }\end{array}$ & $\begin{array}{l}\text { Ethyl- . } \\
\text { benzene }\end{array}$ & $\mathrm{m}, \mathrm{p}$-xylene & o-xylene & $\begin{array}{c}\text { Bromo- } \\
\text { form }\end{array}$ & $\begin{array}{c}1,1,2,2- \\
\text { tetra- } \\
\text { chloro- } \\
\text { ethane }\end{array}$ & $\begin{array}{c}1,3,6- \\
\text { trimethyl- } \\
\text { benzene }\end{array}$ & $\begin{array}{c}1,2,4- \\
\text { trimethyl- } \\
\text { benzene }\end{array}$ \\
\hline D36606 & $1 \mathrm{~B}$ & & $Y$ & 40.5 & - & - & - & - & - & - & - & - & - \\
\hline D57847 & 1B & & $\mathrm{Y}$ & 41.2 & - & - & - & - & - & - & - & - & - \\
\hline D64752 & $1 \mathrm{~B}$ & & $\mathrm{Y}$ & 28.4 & - & - & - & - & - & - & - & - & - \\
\hline D66157 & 1B & & $\mathbf{N}$ & 106.8 & - & - & 132.2 & 407.1 & 59.6 & - & - & - & - \\
\hline D67317 & $1 \mathrm{~B}$ & & $\mathrm{~N}$ & 20.0 & - & - & - & - & - & - & - & - & - \\
\hline D67735 & $1 \mathrm{~B}$ & & - & 18.2 & - & - & - & - & - & - & - & - & - \\
\hline D68277 & 1B & & - & 27.4 & - & - & - & - & - & - & - & - & - \\
\hline D68377 & $1 \mathrm{~B}$ & & N & 2.5 & - & - & - & - & - & - & - & - & - \\
\hline D70446 & 1B & & $\mathrm{Y}$ & 37.4 & - & - & - & - & - & - & - & - & - \\
\hline D70669 & 1B & & - & 11.8 & - & - & - & - & - & - & - & - & - \\
\hline D71351 & 1B & & $\mathrm{Y}$ & 1.2 & - & - & - & - & - & - & - & - & - \\
\hline D71354 & 1B & & $\mathrm{Y}$ & 1.6 & - & - & - & - & - & - & - & - & - \\
\hline D71638 & 1B & & $Y$ & 10.8 & - & - & - & - & - & - & - & - & - \\
\hline D72436 & $1 \mathrm{~B}$ & & $\mathbf{Y}$ & 17.2 & - & - & - & - & - & - & - & - & - \\
\hline D73117 & $1 \mathrm{~B}$ & & $\mathbf{Y}$ & 15.1 & - & - & - & - & - & - & - & - & - \\
\hline D74007 & $1 \mathrm{~B}$ & & $\mathbf{Y}$ & 19.5 & - & - & - & - & - & - & - & - & - \\
\hline \multicolumn{14}{|l|}{ Notes: } \\
\hline \multicolumn{14}{|c|}{ Headspace Sample Program } \\
\hline & 1B & \multicolumn{12}{|c|}{ Operational Lid, VOC Gas Chromatography/Mass Spectrometry Results (ppmv) } \\
\hline & $\mathbf{N}$ & \multicolumn{12}{|l|}{ No } \\
\hline & Y & \multicolumn{12}{|c|}{ an } \\
\hline
\end{tabular}


Table 3.8.3-11. Gas Sampling Results-Compositional Analysis (vol\%).

\begin{tabular}{|c|c|c|c|c|c|c|c|c|c|c|c|}
\hline \multirow[b]{2}{*}{$\begin{array}{l}\text { Container } \\
\text { ID. no. }\end{array}$} & \multirow{2}{*}{$\begin{array}{c}\text { Storage } \\
\text { time } \\
\text { (days) }\end{array}$} & \multicolumn{10}{|c|}{ Analytes } \\
\hline & & $\mathrm{H}_{2}$ & $\mathrm{O}_{2}$ & $\mathrm{~N}_{2}$ & $\mathrm{Ar}$ & $\mathrm{CO}_{2}$ & $\mathrm{CO}$ & $\mathrm{NO}_{\mathrm{x}}$ & $\begin{array}{l}\text { Hydrocarbons } \\
\text { (saturated) }^{1}\end{array}$ & $\begin{array}{c}1,1,1- \\
\text { trichloroethane }\end{array}$ & $\begin{array}{c}\text { Other } \\
\text { hydrocarbons }\end{array}$ \\
\hline $02-40002$ & 175 & 0.15 & 16.3 & 78.6 & 1.1 & 3.35 & - & - & 0.20 & 0.38 & - \\
\hline $31-00939$ & 188 & 0.05 & 20.9 & 76.0 & 0.92 & 0.06 & - & - & - & 2.06 & - \\
\hline $02-39738$ & 188 & - & 21.4 & 77.1 & 1.1 & 0.13 & - & - & 0.07 & - & - \\
\hline $45-00528$ & 157 & 0.12 & 20.5 & 77.5 & 1.1 & 0.48 & - & - & - & 0.25 & - \\
\hline $02-40153$ & 386 & 0.07 & 21.5 & 77.0 & 0.94 & 0.06 & - & - & 0.06 & 0.26 & $0.10^{2}$ \\
\hline & & & & & & & & & & & $0.02^{b}$ \\
\hline $12-12505^{3}$ & 216 & 0.06 & 19.4 & 79.1 & 0.94 & 0.42 & - & - & 0.06 & 0.08 & - \\
\hline $29-00513$ & 385 & 0.10 & 21.4 & 76.8 & 0.89 & 0.12 & - & - & 0.03 & 0.17 & $0.06^{\mathrm{a}}$ \\
\hline & & & & & & & & & & & $0.40^{\circ}$ \\
\hline $29-00528$ & 385 & 0.02 & 21.6 & 76.9 & 0.96 & 0.10 & - & - & 0.16 & 0.11 & $0.20^{c}$ \\
\hline 78-00199 & 181 & 0.05 & 20.9 & 77.8 & 0.92 & 0.006 & - & - & 0.13 & 0.12 & $0.01^{b}$ \\
\hline $02-34855$ & 990 & 0.20 & 13.6 & 84.4 & 1.0 & - & - & - & 0.32 & 0.43 & - \\
\hline $02-35083$ & 935 & 0.38 & 8.37 & 89.6 & 1.0 & 0.13 & - & - & 0.50 & - & - \\
\hline $31-01321$ & 903 & 0.96 & 18.8 & 78.2 & 0.94 & 0.97 & - & - & 0.15 & - & - \\
\hline $42-00209$ & 960 & 0.32 & 18.0 & 79.7 & 0.96 & 0.93 & - & - & 0.10 & - & - \\
\hline $01-08226$ & 4,366 & 0.03 & 18.1 & 79.8 & 0.94 & 0.83 & - & - & 0.08 & - & $0.30^{d}$ \\
\hline $01-08232$ & 4,365 & - & 20.5 & 78.3 & 0.92 & 0.27 & - & - & - & - & - \\
\hline $02-12224$ & 4,220 & 0.05 & 17.9 & 80.9 & 0.96 & 0.22 & - & - & - & 0.03 & $0.02^{\circ}$ \\
\hline $18-00025$ & 4,310 & 1.55 & 0.13 & 96.9 & 1.1 & 0.07 & - & - & 0.17 & - & - \\
\hline $32-00544$ & 4,294 & 0.23 & 13.1 & 84.9 & 1.0 & 0.16 & - & - & 0.21 & - & $0.42^{2}$ \\
\hline $42-00043$ & 4,246 & 1.8 & 4.48 & 90.3 & 1.1 & 2.38 & - & - & - & - & - \\
\hline $25-00036$ & 4,483 & 0.90 & 10.2 & 85.4 & 1.0 & 2.1 & - & - & 0.16 & 0.09 & $0.09^{\circ}$ \\
\hline $\begin{array}{r}\text { Notes: } \\
1 . \\
2 .\end{array}$ & $\begin{array}{l}\text { Saturated hydr } \\
\text { Other hydroca } \\
\text { a. Dichloro } \\
\text { b. Carbon } \\
\text { c. 1,2-dich } \\
\text { d. Possible } \\
\text { e. Trichlor } \\
\text { Drums sealed }\end{array}$ & $\begin{array}{l}\text { arbons- } \\
\text { ons-as s } \\
\text { thane } \\
\text { rachlorid } \\
\text { oethane } \\
\text { chloroetl } \\
\text { hylene } \\
\text { th a sem } \\
\end{array}$ & $\begin{array}{l}\text { ethane } \\
\text { ecified. } \\
\text { lene } \\
\text { germeat }\end{array}$ & $\begin{array}{l}\text { ugh pr } \\
\text { asket. }\end{array}$ & & & & & & & \\
\hline
\end{tabular}




\subsection{Waste Form Number 117-TRU Metal Waste, Content Code RF 117A}

\subsubsection{Item Description Code 481 - Leached Non-SS Metals}

3.8.4.1 Certification Assessment. This IDC is certifiable without further waste treatment. Assay and thermal power calculations, including error, need to be updated to meet the current WIPP WAC. Several gas generation criteria need to be addressed. Carbon filters may need to be installed, and headspace gas analysis and visual waste characterization will need to be performed. Metal boxes are not authorized for shipment in the TRUPACT.

3.8.4.2 Waste Description. IDC 481 was assigned to light, nonspecial source metals. This material consisted primarily of stainless-steel and aluminum equipment used throughout the plant; this equipment was rinsed to remove plutonium contamination. This IDC is no longer active and has been replaced by IDC 480 (EG\&G RFP 1994k).

3.8.4.3 Generation Source. It is presumed that the generation source for IDC 480 also applies to IDC 481. IDC 480, light metal, was generated in Buildings 371, 374, 559, 707, 771, 774, 776, 777, 779 and 991 (EG\&G RFP 1994k).

3.8.4.4 Recovery Method. Small waste items, contaminated with significant quantities of plutonium, were washed in a ball-mill washer or leached. Larger plutonium contaminated waste items were washed by Size Reduction with hot water.

3.8.4.5 Waste Packaging and Handling. Line-generated metal waste was segregated from all other materials. All free liquid, particulates, and process residues were removed. Items for disposal were inspected before removal from the line. Gearbox oil, hydraulic fluid, and other liquids were removed. All electrical equipment was checked to ensure that electrical potential had been discharged. The waste was then collected and bagged out of the glovebox line. A small amount of Oil Dri was added to the bags if the waste was wet. All line-generated waste was usually doublebagged and monitored for contamination before being placed into the waste collection drum for linegenerated waste.

Metal wastes generated within the Pu processing area, but outside of a glovebox line, were termed "nonline-generated wastes." These wastes were collected in 55-gal drums located in all Pu areas. The drum covers were clearly marked for nonline waste. Normally, nonline waste was not bagged before being placed in the collection drum (Rockwell International 1989e). Nonline waste was rarely TRU and would have been repackaged in a box or drum with a rigid liner prior to shipment.

When the drum was full, the drum liners were sealed and the drum was closed. The drum label, completed with all necessary information, was then taped to the drum lid and a TID was attached to the drum.

Drums were held in Size Reduction in Building 776 until enough of either line-generated or nonline-generated metals to fill a waste box had accumulated. The line-generated or nonline- 
generated wastes were then repackaged separately into boxes equipped with a certified filter-and-vent system. Each bag of waste is opened and distributed in the waste box to obtain greater packing density (Rockwell International 1989b).

Metal waste which was too large to fit into a 55-gal drum, but did not require size reduction, decontamination, or disassembly to meet the WIPP WAC, was placed directly into an approved waste box (Rockwell International 1989b).

3.8.4.6 Container Preparation. Only approved containers could be used to package TRU waste for shipment offsite. Containers approved for shipment to INEL during this time were DOT17C, white, 55-gal drums (Rockwell specification SX-200); white, corrugated steel boxes (Rockwell specification SX-231); and FRP boxes (Rockwell specification SX-207). Each of these containers met the requirements for certification as DOT-7A Type A packaging (Rockwell International 1989e).

Table 3.8.4-1 shows the current inventory of IDC 481 waste containers from the Rocky Flats Plant that have been shipped to INEL since 1985.

Table 3.8.4-1. Item Description Code 481 Container Information.

\begin{tabular}{lccr}
\hline \multicolumn{1}{c}{ Information } & & Drums & Boxes \\
\hline Total Containers & & 0 & 3 \\
Net Container Weight (lb) & Maximum & N/A & $1, \dot{410}$ \\
& Minimum & N/A & 1,160 \\
& Average & N/A & 1,283 \\
\hline
\end{tabular}

3.8.4.6.1 Drum Preparation-No drums of IDC 481 waste were shipped to INEL between 1985 and 1989.

3.8.4.6.2 Box Preparation-FRP boxes were used for waste shipped to INEL from 1972 through 1982 (Riddle and others 1985). In 1982, the use of the corrugated metal waste box was phased in. The last FRP box was shipped to INEL in 1986. In the interim, waste packaged in both types of boxes had been shipped to INEL. SWIMS information did not track the type of box used in individual shipments.

The FRP box was constructed of $3 / 4$-in. exterior plywood with $2 \times 4$-in. framing members and skids. The entire box was coated with a 0.12 -in. coat of fiberglass-reinforced polyester with flameretardant properties. The continuous FRP coating provides a leakproof, tamper-proof package. Inner liners used for contamination control during loading consist of a PVC liner protected by a 50-mil fiberboard sheet. The box size was $4 \times 4 \times 7 \mathrm{ft}$ or larger. The gross weight was normally restricted to $5,000 \mathrm{lb}$ (Riddle and others 1985).

The corrugated metal waste boxes were made entirely out of 14-gauge (0.0747-in.), low-carbon steel. All seams including the closure were welded to produce a leaktight container (Brugger 1983). These boxes required a 10-mil PVC liner (Rockwell specification SX-209) and a 0.051-in. fiberboard liner (Rockwell specification SX-209) (Riddle and others 1985; Bearly and others 1988). Figure C-5 
shows the appropriate box liners required for this IDC. Four sizes of the box have been certified as DOT-7A containers, with a maximum size of $54 \times 54 \times 89$ in. and a maximum gross weight of $7,000 \mathrm{lb}$. These containers are commonly referred to as "Sand Boxes" (Riddle and others).

Where necessary, items that had a weight distribution or configuration which caused them to sit in an unstable condition in the container were blocked, braced, or banded to prevent the items from shifting (Rockwell International 1989e). All items which had the potential to puncture or otherwise compromise the integrity of the waste box were adequately prepackaged to cover sharp corners (Rockwell International 1989e).

3.8.4.7 Assay. This waste is either repackaged waste from drums or metal waste packaged directly into a metal box. The drums may have been assayed on a SGS counter or a PADC. The individual assays of the drums were then summed to provide an assay value for the box. Box assay values are checked in the Building 569 crate counter. The assay values must agree within the error of the counting equipment. Containers of waste that have not been PADC assayed and had SGS assay values of 1 gram or less should be PADC assayed to verify that they are transuranic waste. Table 3.8.4-2 is a summary of the dose rate information for this waste. Table 3.8.4-3 is a summary of the assay information.

Table 3.8.4-2. Item Description Code 481 Dose Information.

\begin{tabular}{crcc} 
Information & & Drums & Boxes \\
\hline One Meter Dose Rate (mrem/h) & $0-0.5$ & N/A & 2 \\
& $0.5-10$ & N/A & 1 \\
Surface Dose Rate (mrem/h) & $<10$ & N/A & 3 \\
& $10-200$ & N/A & 0 \\
\hline
\end{tabular}

Table 3.8.4-3. Item Description Code 481 Assay Information.

\begin{tabular}{|c|c|c|c|}
\hline \multicolumn{2}{|c|}{ Radionuclide inventory } & \multirow{2}{*}{$\frac{\text { Drums }}{\text { N/A }}$} & \multirow{2}{*}{$\frac{\text { Boxes }}{2}$} \\
\hline Plutonium (g) & Maximum & & \\
\hline & Minimum & N/A & 0 \\
\hline & Average & N/A & 0.66 \\
\hline \multirow[t]{3}{*}{ Americium (g) } & Maximum & N/A & - \\
\hline & Minimum & N/A & - \\
\hline & Average & N/A & - \\
\hline \multirow[t]{3}{*}{ Uranium-235 (g) } & Maximum & N/A & - \\
\hline & Minimum & N/A & - \\
\hline & Average & N/A & - \\
\hline
\end{tabular}

3.8.4.8 Inspection. Drums repackaged into boxes were verified to be in compliance by the immediate supervisor and by periodic inspections by Waste Certification personnel. All waste 
packaged directly into boxes was inspected by Waste Certification personnel. In addition, each container was viewed using RTR to

- Ensure the container does not contain nonconforming items

- Ensure the container is properly packaged

- Verify the waste form description

- Evaluate the presence of free liquids.

3.8.4.9 Waste Form Evaluation. Table 3.8.4-4 evaluates the waste form against the WIPP WAC for such items as free liquids, pyrophoric materials, and compressed gases. Table 3.8.4-5 evaluates the waste against TRUPACT criteria.

Table 3.8.4-4. Waste Form Evaluation.

Criterion or requirement

Immobilization

Liquids

Pyrophoric Materials

Explosives and Compressed Gases

TRU-Mixed Wastes

Specific Activity of Waste $\mathrm{Pu}^{239}$ Equivalent Activity
Limiting parameters ${ }^{2}$

Metal fines generated by conventional working operations such as sawing, grinding, and filing have been evaluated for particle size. The particle size distribution, based on five random samples of Rocky Flats waste metal fines, has $<1 \%$ of the particles $<200$ microns and $<0.01 \%$ of the particles $<10$ microns (Rockwell International 1989e).

This waste form meets the free liquid criteria by procedural control and RTR inspection prior to shipment from Rocky Flats.

Pyrophoric materials were prohibited by procedural control. The absence of the pyrophoric materials was verified by the generating supervisor and periodic inspection by the Waste Certification Organization.

Explosives and compressed gases were prohibited by procedural control. The absence of the explosives and compressed gases was verified by the generating supervisor and periodic inspection by the Waste Certification Organization. In addition, unvented, closed containers and pressurized containers were excluded by procedural controls and RTR examination.

The RCRA constituents exist as co-contaminants with the transuranic radionuclides. Compliance with the WIPP RCRA permits and NMD will be required prior to shipment of the stored waste to WIPP.

A portion of the waste stored at INEL may contain $<100$ nanocuries per gram transuranic radionuclides.

None of the IDC 481 waste containers recorded as shipped to INEL in the SWIMS exceed $1,000 \mathrm{Ci}$ of plutonium-equivalent activity.

a. Many of the limiting parameters were taken from TRU Waste Compliance Program (Rockwell International 1983a, 1987e, and 1989b). 
Table 3.8.4-5. TRUPACT Evaluation.

Criterion or

requirement

Limiting parameters ${ }^{\mathrm{a}}$

Waste Packag

Weight

Waste Containers This waste form was packaged in DOT-7A metal boxes.

Nuclear

Criticality

Rocky Flats limited the fissile content of the boxes to 350 grams. However, the error-times-two requirement was not in place at the time the boxes were shipped to INEL; therefore, it is not reported as part of the assay of the drum. Metal boxes are not authorized for shipment in the TRUPACT.

Surface Dose

The surface dose rate criteria used by Rocky Flats was $200 \mathrm{mrem} / \mathrm{hr}$ at the

Rate container surface and $10 \mathrm{mrem} / \mathrm{hr}$ at 1 meter. Shielding was not necessary for IDC 481 containers. The TRUPACT limit must be verified at the time of payload assembly at INEL. Based on the typical dose rates from the IDC 481 containers, the dose rate criteria will be met.

Removable The Rocky Flats limit for removable contamination (for TRU assumed to be all

Surface alpha) was 20 disintegrations per minute $/ 100 \mathrm{~cm}^{2}$. The Rocky Flats limit is

Contamination equivalent to 9 picocuries per $100 \mathrm{~cm}^{2}$, which is well within the WIPP criteria.

Thermal Power

The thermal power calculation reported in the SWIMS data package is based on the reported assay value without an error/uncertainty correction. The thermal power must be recalculated based on the assay error determination.

Gas Generation Based on the procedural requirements for packaging IDC 481 waste and the waste description, the only areas of noncompliance are carbon filters, headspace gas analysis, and visual characterization.

Headspace gas analysis detected all of the TRUPACT Chemical List halogenated organics for RF 117A (1,1,1-trichloroethane, methylene chloride, carbon tetrachloride, and 1,1,2-trichloro-1,2,2-trifluoroethane). These chemicals appear to be in total concentrations $<1 \%$.

Personnel performing RTR examination at Rocky Flats would accept up to $10 \%$ of another IDC. The other IDCs could be combustibles, glass, concrete, leaded gloves, and plastics.

a. Many of the limiting parameters were taken from TRU Waste Compliance Program (Rockwell International 1983a, 1987e, and 1989b).

3.8.4.10 Combustible and Organic Content. Table 3.8.4-6 outlines available data from the TRU Waste Sampling Program for IDC 481. SWIMS data indicate that this waste form does not contain $>20 \%$ combustibles or $>20 \%$ organics. 
Table 3.8.4-6. Item Description Code 481 Data Summary for Combustible and Organic Content.

\begin{tabular}{ccccccc}
\hline Container & $\begin{array}{c}\text { Wt. } \\
\text { combustibles } \\
(\mathrm{lb})^{\mathrm{a}}\end{array}$ & $\begin{array}{c}\text { Wt. } \\
\text { organics } \\
(\mathrm{lb})^{\mathrm{b}}\end{array}$ & $\begin{array}{c}\text { Net wt. of } \\
\text { container } \\
(\mathrm{lb})^{\mathrm{c}}\end{array}$ & $\begin{array}{c}\text { Wt\% } \\
\text { combustibles }^{\mathrm{d}}\end{array}$ & $\begin{array}{c}\text { Vol\% } \\
\text { combustibles }^{\mathrm{e}}\end{array}$ & $\begin{array}{c}\text { Wt\% } \\
\text { organics }^{\mathrm{f}}\end{array}$ \\
\hline $15-00049$ & 11.0 & 11.0 & 71.0 & 15 & 3 & 15 \\
$19-01827$ & 18.0 & 18.0 & 147.5 & 12 & 10 & 12 \\
$19-01901$ & 2 & 2 & 255.5 & 1 & 2 & 1 \\
$19-01919$ & 3 & 3 & 124.0 & 2 & 2 & 2 \\
$76-00416$ & 3.6 & 3.6 & 182.8 & 2 & 3 & 2 \\
\hline
\end{tabular}

a. Sum of weights of all combustible material and leaded rubber from Table 22 (Clements and Kudera 1985).

b. Sum of weights of all combustible material, leaded rubber, and organic material from Table 22 (Clements and Kudera 1985).

c. Net weight of container from Table 22 (Clements and Kudera 1985).

d. Weight of combustible material/net weight of container $\times 100$.

e. Vol\% of combustible material from visual examination, obtained from Appendix B (Clements and Kudera 1985).

f. Weight of organic material/net weight of container $\times 100$.

3.8.4.10.1 Combustible Content-SWIMS data show that IDC 481 waste is noncombustible (Rockwell International 1985a). In support of the TRU Waste Sampling Program, five drums of IDC 481 waste were opened. They were found to contain an average wt\% combustibles content of $6.4 \%$. Visual inspection showed an average vol\% combustible content of 4\%. (Clements and Kudera 1985).

3.8.4.10.2 Organic Content-SWIMS data show that IDC 481 waste may contain $20 \%$ organics (Rockwell International 1985a). In support of the TRU Waste Sampling Program, five drums of IDC 481 waste were opened. They were found to contain an average wt\% organic content of $6.4 \%$ (Clements and Kudera 1985).

3.8.4.11 Analytical Information. Analytical data from the TRU Waste Sampling Waste Characterization Program (Clements and Kudera 1985) for IDC 481, Leached Non-SS Metals, indicates that five drums were subject to headspace gas analysis. Gas composition analytical results are presented in Table 3.8.4-7. Waste boxes were not-sampled. Hydrogen, oxygen, nitrogen, argon, carbon dioxide, nitrogen oxide(s), saturated hydrocarbons, 1,1,1-trichloroethane, dichloromethane, carbon tetrachloride, and Freon TF were detected in the drums.

This material has no hazardous waste characteristics, therefore no EPA Codes apply (EG\&G RFP 1994k). 
Table 3.8.4-7. Gas Sampling Results-Compositional Analysis (vol\%).

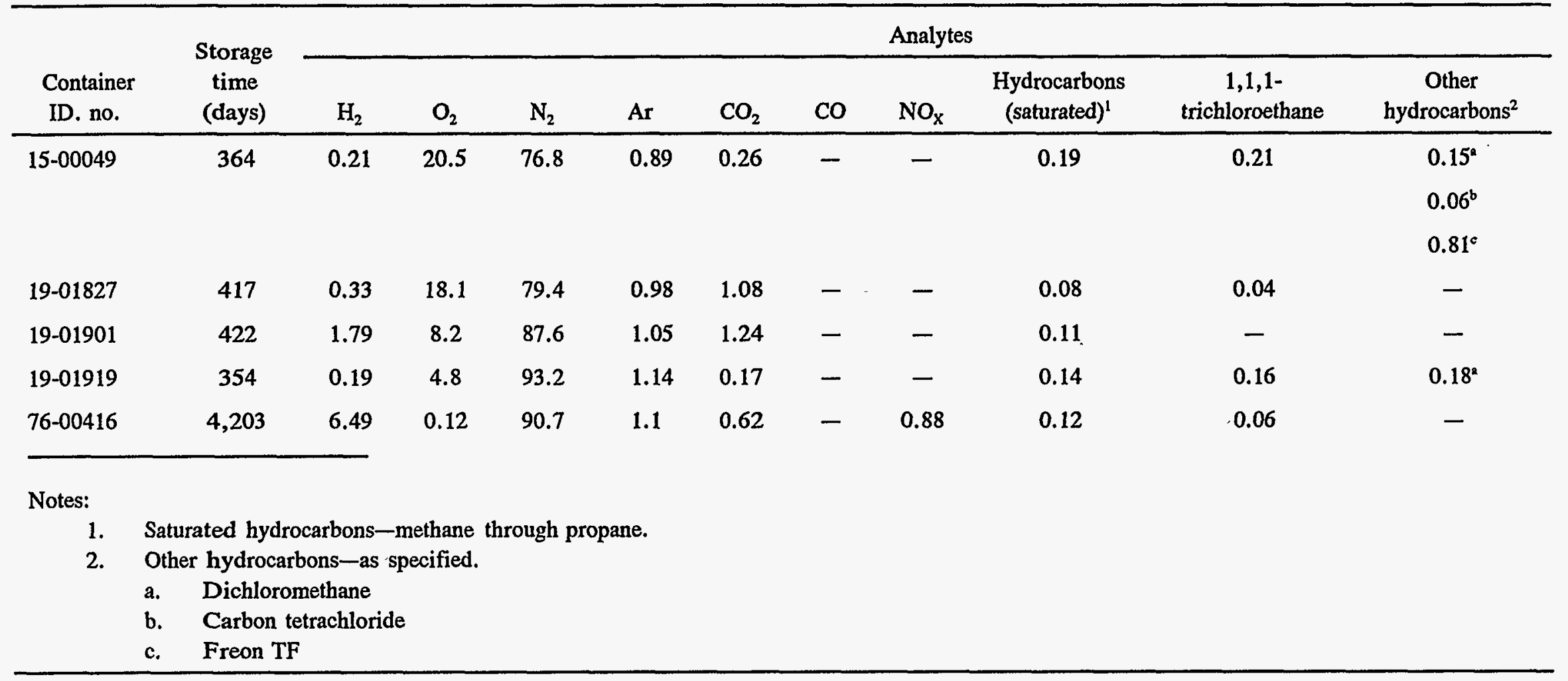




\subsection{Waste Form Number 117-TRU Metal Waste, Content Code RF 117A}

\subsubsection{Item Description Code 488-Glovebox Parts with Lead}

3.8.5.1 Certification Assessment. This IDC is certifiable without further waste treatment. Assay and thermal power calculations, including error, need to be updated to meet the current WIPP WAC. Several gas generation criteria need to be addressed. Carbon filters may need to be installed, and headspace gas analysis and visual waste characterization will need to be performed. Metal boxes are not authorized for shipment in the TRUPACT.

3.8.5.2 Waste Description. IDC 488 waste (glovebox parts with lead) consists of glovebox components covered with lead and may include glove port covers and access doors and covered surfaces which essentially include the entire glovebox, excluding only those areas needed for visual or physical access. The lead-covered components may become waste due to replacement, modification, or decommissioning activities (EG\&G RFP 1994i).

3.8.5.3 Generation Source. IDC 488 was generated in Building 771 and 707 (EG\&G RFP 1994i).

3.8.5.4 Recovery Method. This IDC was never generated as a residue and therefore has no recovery method (EG\&G RFP 1994i).

3.8.5.5 Waste Packaging and Handling. Line-generated metal waste was segregated from all other materials. All free liquid, particulates, and process residues were removed. Items for disposal were inspected before removal from the line. Gearbox oil, hydraulic fluid, and other liquids were removed. All electrical equipment was checked to ensure that electrical potential had been discharged. The waste was then collected and bagged out of the glovebox line. A small amount of Oil Dri was added to the bags if the waste was wet. All line-generated waste was usually doublebagged and monitored for contamination before being placed into the waste collection container for line-generated waste.

Metal wastes generated within the Pu processing area, but outside of a glovebox line, were termed "nonline-generated wastes." These wastes were collected in 55-gal drums located in all $\mathrm{Pu}$ areas. The drum covers were clearly marked for nonline waste. Normally, nonline waste was not bagged before being placed in the collection drum (Rockwell International 1989e). Nonline waste was rarely TRU and would have been repackaged in a box or drum with a rigid liner prior to shipment.

When the drum was full, the drum liners were sealed and the drum was closed. The drum label, completed with all necessary information, was then taped to the drum lid and a TID was attached to the drum.

Drums were held in Size Reduction in Building 776 until enough of either line-generated or nonline-generated metals to fill a waste box had accumulated. The line-generated or nonlinegenerated wastes were then repackaged separately into boxes equipped with a certified filter-and-vent 
system. Each bag of waste was opened and distributed in the waste box to obtain greater packing density (Rockwell International 1989b).

Metal waste that was too large to fit into a 55-gal drum, but did not require size reduction, decontamination, or disassembly to meet the WIPP WAC, was placed directly into an approved waste box (Rockwell International 1989b).

3.8.5.6 Container Preparation. Only approved containers could be used to package TRU waste for shipment offsite. Containers approved for shipment to INEL during this time were white, corrugated steel boxes (Rockwell specification SX-231) and FRP boxes (Rockwell specification SX207). Each of these containers met the requirements for certification as DOT-7A Type A packaging (Rockwell International 1989e).

Table 3.8.5-1 shows the current inventory of IDC 488 waste containers from the Rocky Flats Plant that have been shipped to INEL since 1985 .

Table 3.8.5-1. Item Description Code 488 Container Information.

\begin{tabular}{lccc}
\hline \multicolumn{1}{c}{ Information } & & Drums & Boxes \\
\hline Total Containers & & 0 & 3 \\
Net Container Weight (lb) & Maximum & N/A & 3,160 \\
& Minimum & N/A & 2,460 \\
& Average & N/A & 2,760 \\
\hline
\end{tabular}

3.8.5.6.1 Drum Preparation-No drums of IDC 488 waste were shipped to INEL between 1985 and 1989.

3.8.5.6.2 Box Preparation-The corrugated metal waste boxes were made entirely out of 14-gauge (0.0747-in.), low-carbon steel. All seams including the closure were welded to produce a leaktight container (Brugger 1983). These boxes required a 10-mil PVC liner (Rockwell specification SX-209) and a 0.051-in. fiberboard liner (Rockwell specification SX-209) (Riddle and others 1985; Bearly and others 1988). Figure C-5 shows the appropriate box liners required for this IDC. Four sizes of the box have been certified as DOT-7A containers, with a maximum size of $54 \times$ $54 \times 89$ in. and a maximum gross weight of $7,000 \mathrm{lb}$. These containers are commonly referred to as "Sand Boxes" (Riddle and others 1985).

Where necessary, items that had a weight distribution or configuration that caused them to sit in an unstable condition in the container were blocked, braced, or banded to prevent the items from shifting (Rockwell International 1989e). All items that had the potential to puncture or otherwise compromise the integrity of the waste box were adequately prepackaged to cover sharp corners (Rockwell International 1989e).

3.8.5.7 Assay. Boxes were counted in the crate counter. Containers of waste that have not been PADC assayed and had crate counter assay values of 1 gram or less should be PADC assayed to 
verify that they are transuranic waste. Table 3.8.5-2 is a summary of the dose rate information for this waste. Table 3.8.5-3 is a summary of the assay information.

Table 3.8.5-2. Item Description Code 488 Dose Information.

\begin{tabular}{crcc} 
Information & & Drums & Boxes \\
\hline One Meter Dose Rate (mrem/h) & $0-0.5$ & N/A & 3 \\
& $0.5-10$ & N/A & 0 \\
Surface Dose Rate (mrem/h) & $<10$ & N/A & 3 \\
& $10-200$ & N/A & 0 \\
\hline
\end{tabular}

Table 3.8.5-3. Item Description Code 488 Assay Information.

\begin{tabular}{|c|c|c|c|}
\hline \multicolumn{2}{|c|}{ Radionuclide inventory } & \multirow{2}{*}{$\frac{\text { Drums }}{\text { N/A }}$} & \multirow{2}{*}{$\begin{array}{r}\text { Boxes } \\
253\end{array}$} \\
\hline Plutonium (g) & Maximum & & \\
\hline & Minimum & N/A & 0 \\
\hline & Average & N/A & 84 \\
\hline \multirow[t]{3}{*}{ Americium (g) } & Maximum & N/A & - \\
\hline & Minimum & N/A & - \\
\hline & Average & N/A & - \\
\hline \multirow[t]{3}{*}{ Uranium-235 (g) } & Maximum & N/A & - \\
\hline & Minimum & N/A & - \\
\hline & Average & N/A & - \\
\hline
\end{tabular}

3.8.5.8 Inspection. Compliance is verified by the immediate supervisor. Waste Certification personnel inspect $100 \%$ of the material at the time it is placed in the box. Boxes with lead were not examined by RTR.

3.8.5.9 Waste Form Evaluation. Table 3.8.5-4 evaluates the waste form against the WIPP WAC for such items as free liquids, pyrophoric materials, and compressed gases. Table 3.8.5-5 evaluates the waste against TRUPACT criteria. 
Table 3.8.5-4. Waste Form Evaluation.

Criterion or

requirement

Limiting parameters ${ }^{\mathrm{a}}$

Immobilization

Metal fines generated by conventional working operations such as sawing, grinding, and filing have been evaluated for particle size. The particle size distribution, based on five random samples of Rocky Flats waste metal fines, has $<1 \%$ of the particles $<200$ microns and $<0.01 \%$ of the particles $<10$ microns (Rockwell International 1989b).

Liquids

This waste form meets the free liquid criteria by procedural control.

Pyrophoric

Materials

Pyrophoric materials were prohibited by procedural control. The absence of the pyrophoric materials was verified by the generating supervisor and inspection by the Waste Certification Organization.

Explosives and

Compressed Gases

Explosives and compressed gases was prohibited by procedural control. The absence of the explosives and compressed gases were verified by the generating supervisor and inspection by the Waste Certification Organization. In addition, unvented, closed containers and pressurized containers were excluded by procedural controls.

TRU-Mixed Wastes The RCRA constituents exist as co-contaminants with the transuranic radionuclides. Compliance with the WIPP RCRA permits and NMD will be required prior to shipment of the stored waste to WIPP.

Specific Activity of Waste

A portion of the waste stored at INEL may contain $<100$ nanocuries per gram transuranic radionuclides.

$\mathrm{Pu}^{239}$ Equivalent None of the IDC 488 waste containers recorded as shipped to INEL in the Activity SWIMS exceed $1,000 \mathrm{Ci}$ of plutonium-equivalent activity.

a. Many of the limiting parameters were taken from TRU Waste Compliance Program (Rockwell International 1983a, 1987e, and 1989b). 
Table 3.8.5-5. TRUPACT Evaluation.

\begin{tabular}{|c|c|}
\hline $\begin{array}{l}\text { Criterion or } \\
\text { requirement }\end{array}$ & Limiting parameters $^{2}$ \\
\hline $\begin{array}{l}\text { Waste Package } \\
\text { Weight }\end{array}$ & Metal boxes are not authorized for shipment in the TRUPACT. \\
\hline Waste Containers & This waste form was packaged in DOT-7A metal boxes. \\
\hline $\begin{array}{l}\text { Nuclear } \\
\text { Criticality }\end{array}$ & $\begin{array}{l}\text { Rocky Flats limited the fissile content of the boxes to } 350 \text { grams. However, the } \\
\text { error-times-two requirement was not in place at the time the boxes were shipped to } \\
\text { INEL; therefore, it is not reported as part of the assay of the box. Metal boxes are } \\
\text { not authorized for shipment in the TRUPACT. }\end{array}$ \\
\hline $\begin{array}{l}\text { Surface Dose } \\
\text { Rate }\end{array}$ & $\begin{array}{l}\text { The surface dose rate criteria used by Rocky Flats was } 200 \mathrm{mrem} / \mathrm{hr} \text { at the } \\
\text { container surface and } 10 \mathrm{mrem} / \mathrm{hr} \text { at } 1 \text { meter. Shielding was not necessary for IDC } \\
488 \text {, this IDC contains lead. The TRUPACT limit must be verified at the time of } \\
\text { payload assembly at INEL. Based on the typical dose rates from the IDC } 488 \\
\text { containers, the dose rate criteria will be met. }\end{array}$ \\
\hline $\begin{array}{l}\text { Removable } \\
\text { Surface } \\
\text { Contamination }\end{array}$ & $\begin{array}{l}\text { The Rocky Flats limit for removable contamination (for TRU assumed to be all } \\
\text { alpha) was } 20 \text { disintegrations per minute } 100 \mathrm{~cm}^{2} \text {. The Rocky Flats limit is } \\
\text { equivalent to } 9 \text { picocuries per } 100 \mathrm{~cm}^{2} \text {, which is well within the WIPP criteria. }\end{array}$ \\
\hline Thermal Power & $\begin{array}{l}\text { The thermal power calculation reported in the SWIMS data package is based on the } \\
\text { reported assay value without an error/uncertainty correction. The thermal power } \\
\text { must be recalculated based on the assay error determination. }\end{array}$ \\
\hline Gas Generation & $\begin{array}{l}\text { Based on the procedural requirements for packaging IDC } 488 \text { waste and the waste } \\
\text { description, the only areas of noncompliance are carbon filters, headspace gas } \\
\text { analysis, and visual characterization. }\end{array}$ \\
\hline & $\begin{array}{l}\text { Personnel performing RTR examination at Rocky Flats would accept up to } 10 \% \text { of } \\
\text { another IDC. The other IDCs could be combustibles, glass, concrete, leaded } \\
\text { gloves, and plastics. }\end{array}$ \\
\hline
\end{tabular}

3.8.5.10 Combustible and Organic Content. SWIMS data indicate that this waste form does not contain $>20 \%$ combustibles or $>20 \%$ organics.

3.8.5.10.1 Combustible Content-SWIMS data show that IDC 488 waste is noncombustible (Rockwell International 1985a).

3.8.5.10.2 Organic Content-SWIMS data show that IDC 488 waste contains $20 \%$ organics (Rockwell International 1985a).

3.8.5.11 Analytical Information. No analytical data are available for IDC 488.

The EPA Code for lead (D008) has been assigned this waste (EG\&G RFP 1994i). 


\subsection{Waste Form Number 118-TRU Glass Waste, Content Code RF 118A}

\subsubsection{Item Description Code 368-Magnesium Oxide Crucibles}

3.9.1.1 Certification Assessment. This IDC is certifiable without further waste treatment. Assay and thermal power calculations, including error, need to be updated to meet the current WIPP WAC. Several gas generation criteria need to be addressed. Carbon filters may need to be installed, drums will require inspection to identify unvented or unpunctured rigid liners, and headspace gas analysis and visual waste characterization will need to be performed.

3.9.1.2 Waste Description. IDC 368 consists of magnesium oxide ceramic crucibles and fragments with reactive salts of calcium, magnesium, sodium, potassium, or a combination of these adhering to the surface and containing plutonium residue (EG\&G RFP 1994a). The crucibles were used to heat plutonium with salts or accelerators allowing for purification or recovery of actinide metals. Upon cooling to room temperature, the crucible or crucible insert used in the process would be broken and its contents removed (EG\&G RFP 1994e).

3.9.1.3 Generation Source. During normal process operations, the Electorefining, Reduction, and Button Breakout; Direct Oxide Reduction; and Salt Scrub Processes in Buildings 559, 771, 776, and 779 generated broken magnesium oxide crucible pieces (EG\&G RFP 1994e).

3.9. 1.4 Recovery Method. This IDC was never generated as a residue and therefore has no recovery method (EG\&G RFP 1994e).

3.9. 1.5 Waste Packaging and Handling. Line-generated crucibles were segregated from all other materials, especially removing all free liquid, particulates, and process residues. The waste was collected and bagged out of the glovebox line. A small amount of Oil Dri was added to the bags if the waste was wet. All line-generated waste was usually double-bagged and monitored for contamination before being placed into the waste collection drum for line-generated waste. The drums were DOT-17C, white, 55-gal drums (Rockwell International 1989b).

When the drum was full, the drum liners were sealed and the drum was closed. The drum label, completed with all necessary information, was then taped to the drum lid and a TID was attached to the drum (Rockwell International 1989b).

3.9.1.6 Container Preparation. Only approved containers could be used to package TRU waste for shipment offsite. Containers approved for shipment to INEL during this time were DOT17C, white, 55-gal drums (Rockwell specification SX-200). These containers met the requirements for certification as DOT-7A Type A packaging (Rockwell International 1989e).

Table 3.9.1-1 shows the current inventory of IDC 368 waste containers from the Rocky Flats Plant that have been shipped to INEL since 1985. 
Table 3.9.1-1. Item Description Code 368 Container Information.

\begin{tabular}{lrcc}
\hline \multicolumn{1}{c}{ Information } & & Drums & Boxes \\
\hline Total Containers & & 1 & 0 \\
Net Container Weight (lb) & Maximum & 369 & N/A \\
& Minimum & 369 & N/A \\
& Average & 369 & N/A \\
\hline
\end{tabular}

3.9.1.6.1 Drum Preparation-Approved liners for drums of TRU waste packaged for offsite shipment were the round-bottom liner (Rockwell specification SX-203) inside a 90-mil rigid polyethylene liner (Rockwell specification SX-202), or an O-ring bag and a polyethylene bag placed inside the rigid liner if the drum was attached to a glovebox (Rockwell International 1989e). Type III rigid liners have been used since September 1983 (Bearly 1989a). The IDC 368 waste packaged for offsite shipment required a round bottom liner inside the rigid liner. (Rockwell International 1988c). Figure C-2 shows the appropriate drum liners for this IDC. Sharp edges were taped to prevent puncturing of the liners (Rockwell International 1989b). All bags were closed using the twist-andtape method (Rockwell International 1989e).

Flow-in, ventable gaskets were installed in the drums beginning in December 1982. They were used until October 1988, when tubular gaskets with carbon filters were required. Drums shipped to INEL between 1985 and 1988 may not meet the current WIPP WAC, owing to their lack of carbon filters (Bearly 1989a).

3.9.1.6.2 Box Preparation-No boxes of IDC 368 waste were shipped to INEL between 1985 and 1989.

3.9.1.7 Assay. This IDC may have assayed using a SGS counter or a PAN counter. Table 3.9.1-2 summarizes the dose rates measured on containers of this IDC. Table 3.9.1-3 provides a summary of the assay information.

Table 3.9.1-2. Item Description Code 368 Dose Information.

\begin{tabular}{crcc}
\hline Information & & Drums & Boxes \\
\hline One Meter Dose Rate (mrem/h) & $0-0.5$ & 1 & N/A \\
& $0.5-10$ & 0 & N/A \\
Surface Dose Rate (mrem/h) & $<10$ & 1 & N/A \\
& $10-200$ & 0 & N/A \\
\hline
\end{tabular}


Table 3.9.1-3. Item Description Code 368 Assay Information.

\begin{tabular}{|c|c|c|c|c|}
\hline & \multicolumn{2}{|c|}{ Radionuclide inventory } & \multirow{2}{*}{$\frac{\text { Drums }}{129}$} & \multirow{2}{*}{$\frac{\text { Boxes }}{\text { N/A }}$} \\
\hline & Plutonium (g) & Maximum & & \\
\hline & & Minimum & 129 & N/A \\
\hline & & Average & 129 & N/A \\
\hline & Americium (g) & Maximum & - & N/A \\
\hline & & Minimum & 一 & N/A \\
\hline & & Average & - & N/A \\
\hline & Uranium-235 (g) & Maximum & - & N/A \\
\hline & & Minimum & 一 & N/A \\
\hline & & Average & - & N/A \\
\hline
\end{tabular}

3.9.1.8 Inspection. Waste Certification personnel performed periodic inspections of the generating and packaging process to verify compliance with waste acceptance criteria. In addition, drums not lead lined were viewed using RTR to

- Ensure the drum does not contain nonconforming items

- Ensure the drum is properly packaged

- Verify the waste form description

- Evaluate the presence of free liquids.

3.9. 1.9 Waste Form Evaluation. Table 3.9.1-4 evaluates the waste form against the WIPP WAC for such items as free liquids, pyrophoric materials, and compressed gases. Table 3.9.1-5 evaluates the waste against TRUPACT criteria. 
Table 3.9.1-4. Waste Form Evaluation.

Criterion or

requirement

Limiting parameters ${ }^{2}$

Immobilization

It is likely that this waste form will contain significant amounts of particulate in excess of the WIPP WAC.

Liquids

This waste form meets the free liquid criteria by procedural control and RTR inspection prior to shipment from Rocky Flats.

Pyrophoric

Materials

Pyrophoric materials were prohibited by procedural control. The absence of the pyrophoric materials was verified by the generating supervisor and periodic inspection by the Waste Certification Organization.

Explosives and

Compressed Gases

Explosives and compressed gases were prohibited by procedural control. The absence of the explosives and compressed gases was verified by the generating supervisor and periodic inspection by the Waste Certification Organization. In addition, unvented, closed containers and pressurized containers were excluded by procedural controls and RTR examination.

TRU-Mixed Wastes The RCRA constituents exist as co-contaminants with the transuranic radionuclides. Compliance with the WIPP RCRA permits and NMD will be required prior to shipment of the stored waste to WIPP.

Specific Activity of This waste contains $>100$ nanocuries per gram of plutonium.

Waste

$\mathrm{Pu}^{239}$ Equivalent

The IDC 368 waste container recorded as shipped to INEL in the SWIMS does Activity not exceed $1,000 \mathrm{Ci}$ of plutonium-equivalent activity.

a. Many of the limiting parameters were taken from TRU.Waste Compliance Program (Rockwell International 1983a, 1987e, and 1989b). 
Table 3.9.1-5. TRUPACT Evaluation.

Criterion or

requirement

Limiting parameters ${ }^{\mathrm{a}}$

Waste Package

Weight

Waste Containers

Nuclear

Criticality

Surface Dose

Rate

Removable

Surface

Contamination

Thermal Power

Gas Generation
Rocky Flats limited the gross weight of drums to $800 \mathrm{lb}$. The TRUPACT and vehicle weight limits must be verified at the time of payload assembly at INEL.

This waste form was packaged in 55-gal DOT-7A, Type A containers.

Rocky Flats limited the fissile content of the drums to 200 grams. However, the error-times-two requirement was not in place at the time the drums were shipped to INEL; therefore, it is not reported as part of the assay of the drum. The TRUPACT limit must be verified at the time of payload assembly at INEL. Based on the typical assays of the IDC 368 drums, the criticality criteria will be met but must be recalculated or assayed to meet the error-times-two requirement.

The surface dose rate criteria used by Rocky Flats was $200 \mathrm{mrem} / \mathrm{hr}$ at the drum surface and $10 \mathrm{mrem} / \mathrm{hr}$ at 1 meter. Shielding was not necessary for IDC 368 drums. The TRUPACT limit must be verified at the time of payload assembly at INEL. Based on the typical dose rates from the IDC 368 drums, the dose rate criteria will be met.

The Rocky Flats limit for removable contamination (for TRU assumed to be all alpha) was 20 disintegrations per minute $/ 100 \mathrm{~cm}^{2}$. The Rocky Flats limit is equivalent to 9 picocuries per $100 \mathrm{~cm}^{2}$, which is well within the WIPP criteria.

The thermal power calculation reported in the SWIMS data package is based on the reported assay value without an error/uncertainty correction. The thermal power must be recalculated based on the assay error determination.

Based on the procedural requirements for packaging IDC 368 waste and the waste description, the only areas of noncompliance are carbon filters, unpunctured rigid liners, headspace gas analysis, and visual characterization.

Personnel performing RTR examination at Rocky Flats would accept up to $10 \%$ of another IDC. The other IDCs could be combustibles, concrete, metal, leaded gloves, and plastics.

a. Many of the limiting parameters were taken from TRU Waste Compliance Program (Rockwell International 1983a, 1987e, and 1989b).

3.9.1.10 Combustible and Organic Content. SWIMS data indicate that this waste form does not contain $>20 \%$ combustibles or $>20 \%$ organics.

3.9.1.10.1 Combustible Content-SWIMS data show that IDC 368 waste is noncombustible (Rockwell International 1985a).

3.9.1.10.2 Organic Content-SWIMS data show that IDC 368 waste contains 10\% organics (Rockwell International 1985a). 
3.9.1.11 Analytical Information. No analytical information is available for IDC 368 .

Waste characterization is based on specific process knowledge. IDC 368 crucibles were purged of all reactive metals upon breaking and removal of material, so no EPA hazardous waste codes apply. IDC 368 crucibles exhibit no RCRA-hazardous characteristics and contains no RCRA-listed wastes (EG\&G RFP 1994e). 


\subsection{Waste Form Number 118-TRU Glass Waste, Content Code RF 118A}

\subsubsection{Item Description Code 440-Glass}

3.9.2.1 Certification Assessment. This IDC is not certifiable without further waste treatment. Some of the drums will contain crushed glass in excess of the WIPP WAC for particulates (immobilization). Assay and thermal power calculations, including error, need to be updated to meet the current WIPP WAC. Several gas generation criteria need to be addressed. Carbon filters may need to be installed, drums will require inspection to identify unvented or unpunctured rigid liners, and headspace gas analysis and visual waste characterization will need to be performed. Boxes shipped to INEL are not authorized for shipment in the TRUPACT.

3.9.2.2 Waste Description. IDC 440 includes glass waste from analytical laboratories and recovery processes, standard and fluorescent light bulbs generated inside the Protected Area, and ceramic materials (EG\&G RFP 1994g). Fluorescent bulbs constitute a small portion of the waste. IDC 444 (ground glass) was created in 1989, and was separated from glass (IDCs 440 and 442) in the March 1993 version of the Annual Land Disposal Restrictions Progress Report because the two waste forms exhibit different chemical characteristics, hazardous constituents, and are assigned different EPA codes (EG\&G RFP 1994g and EG\&G RFP 1993a).

3.9.2.3 Generation Source. Glass waste assigned IDC 440 was generated in Buildings 371, 559, 707, 771, 776 and 777 (EG\&G RFP 1994g).

3.9.2.4 Recovery Method. Glass contaminated with amounts of plutonium above the discard limit was leached with hot nitric acid by Plutonium Recovery Operations (Building 771). After leaching, the glass was rinsed with water and air-dried before repackaging (Clements 1982).

3.9.2.5 Waste Packaging and Handling. Line-generated glass was segregated from all other materials. All free liquid, particulates, and process residues were removed. The waste was collected and bagged out of the glovebox line. A small amount of Oil Dri was added to the bags if the waste was wet. The glass was prepackaged to prevent cutting the O-ring bag as it was removed from the line. The glass waste was then double-bagged and monitored for contamination before being placed into the waste collection drum for line-generated waste. The drums were DOT-17C, white, 55-gal drums.

When the drum was full, the drum liners were sealed and the drum was closed. The drum label, completed with all necessary information, was then taped to the drum lid and a TID was attached to the drum.

Drums were held in Size Reduction in Building 776 until enough waste had accumulated to fill a waste box. The wastes were then repackaged into boxes equipped with a certified filter-and-vent system. 
3.9.2.6 Container Preparation. Only approved containers could be used to package TRU waste for shipment offsite. Containers approved for shipment to INEL during this time were DOT-17C, white, 55-gal drums (Rockwell specification SX-200); white, corrugated steel boxes (Rockwell specification SX-231); and FRP boxes (Rockwell specification SX-207). Each of these containers met the requirements for certification as DOT-7A Type A packaging (Rockwell International 1989e).

Table 3.9.2-1 shows the current inventory of IDC 440 waste containers from the Rocky Flats Plant that have been shipped to INEL since 1985.

Table 3.9.2-1. Item Description Code 440 Container Information.

\begin{tabular}{lccc}
\hline \multicolumn{1}{c}{ Information } & & Drums & Boxes \\
\cline { 3 - 4 } Total Containers & & 21 & 29 \\
Net Container Weight $(\mathrm{lb})$ & Maximum & 328 & 2,350 \\
& Minimum & 100 & 900 \\
& Average & 226 & 1,600 \\
\hline
\end{tabular}

3.9.2.6.1 Drum Preparation-Approved liners for drums of TRU waste packaged for offsite shipment were the round-bottom liner (Rockwell specification SX-203) inside a 90-mil rigid polyethylene liner (Rockwell specification SX-202), or an O-ring bag and a polyethylene bag placed inside the rigid liner if the drum was attached to a glovebox (Rockwell International 1989e). Type III rigid liners have been used since September 1983 (Bearly 1989a). The IDC 440 waste packaged for offsite shipment required a fiberboard liner and two polyethylene bags inside the rigid liner (Rockwell International 1988c). Figure C-1 shows the appropriate drum liners for this IDC. All bags were closed using the twist-and-tape method (Rockwell International 1989e).

Flow-in, ventable gaskets were installed in the drums beginning in December 1982. They were used until October 1988, when tubular gaskets with carbon filters were required. Drums shipped to INEL between 1985 and 1988 may not meet the current WIPP WAC, owing to their lack of carbon filters (Bearly 1989a).

3.9.2.6.2 Box Preparation-FRP boxes were used for waste shipped to INEL from 1972 through 1982 (Riddle and others 1985). In 1982, the use of the corrugated metal waste box was phased in. The last FRP box was shipped to INEL in 1986. In the interim, waste packaged in both types of boxes had been shipped to INEL. SWIMS information did not track the type of box used in individual shipments.

The FRP box was constructed of $3 / 4$-in. exterior plywood with $2 \times 4$-in. framing members and skids. The entire box was coated with a 0.12 -in. coat of fiberglass-reinforced polyester with flameretardant properties. The continuous FRP coating provides a leakproof, tamper-proof package. Inner liners used for contamination control during loading consist of a PVC liner protected by a 50-mil fiberboard sheet. The box size was $4 \times 4 \times 7 \mathrm{ft}$ or larger. The gross weight was normally restricted to $5,000 \mathrm{lb}$ (Riddle and others 1985). 
The corrugated metal waste boxes were made entirely out of 14-gauge (0.0747-in.) low-carbon steel. All seams including the closure were welded to produce a leaktight container (Brugger 1983). These boxes required a 10-mil PVC liner (Rockwell specification SX-209) and a 0.051-in. fiberboard liner (Rockwell specification SX-209) (Riddle and others 1985; Bearly and others 1988). Figure C-5 shows the appropriate box liners required for this IDC. Four sizes of the box have been certified as DOT-7A containers, with a maximum size of $54 \times 54 \times 89$ in. and a maximum gross weight of $7,000 \mathrm{lb}$. These containers are commonly referred to as "Sand Boxes" (Riddle and others 1985).

Where necessary, items that had a weight distribution or configuration that caused them to sit in an unstable condition in the container were blocked, braced, or banded to prevent the items from shifting (Rockwell International 1989e). All items which had the potential to puncture or otherwise compromise the integrity of the waste box were adequately prepackaged to cover sharp corners (Rockwell International 1989e).

3.9.2.7 Assay. The drums may have been assayed on an SGS counter or PADC. Boxes would have been assayed at the crate counter. Containers of waste that have not been PADC assayed and had SGS or crate counter assay values of 1 gram or less should be PADC assayed to verify that they are transuranic waste. Table 3.9.2-2 summarizes the dose rates measured on containers of this IDC. Table 3.9.2-3 provides a summary of the assay information. Four drums and two boxes were evaluated for americium content, and four boxes were evaluated for uranium content.

Table 3.9.2-2. Item Description Code 440 Dose Information.

\begin{tabular}{lrrr}
\multicolumn{1}{c}{ Information } & & Drums & Boxes \\
\hline One Meter Dose Rate (mrem/h) & $0-0.5$ & 15 & 25 \\
& $0.5-10$ & 6 & 4 \\
Surface Dose Rate (mrem/h) & $<10$ & 19 & 28 \\
& $10-200$ & 2 & 1 \\
\hline
\end{tabular}

Table 3.9.2-3. Item Description Code 440 Assay Information.

\begin{tabular}{|c|c|c|c|}
\hline \multicolumn{2}{|c|}{ Radionuclide inventory } & $\frac{\text { Drums }}{175}$ & \multirow{2}{*}{$\begin{array}{c}\text { Boxes } \\
\begin{array}{c}309 \\
0 \\
93.21\end{array}\end{array}$} \\
\hline Plutonium (g) & $\begin{array}{r}\text { Maximum } \\
\text { Minimum } \\
\text { Average }\end{array}$ & $\begin{array}{c}175 \\
0 \\
72.24\end{array}$ & \\
\hline Americium (g) & $\begin{array}{r}\text { Maximum } \\
\text { Minimum } \\
\text { Average }\end{array}$ & $\begin{array}{l}1 \\
0 \\
0.25\end{array}$ & $\begin{array}{l}2 \\
2 \\
2\end{array}$ \\
\hline Uranium-235 (g) & $\begin{array}{r}\text { Maximum } \\
\text { Minimum } \\
\text { Average }\end{array}$ & $\begin{array}{l}- \\
-\end{array}$ & $\begin{array}{r}12 \\
0 \\
5\end{array}$ \\
\hline
\end{tabular}


3.9.2.8 Inspection. Waste Certification personnel performed periodic inspections of the generating and packaging process to verify compliance with waste acceptance criteria. In addition, drums not lead-lined were viewed using RTR to

- Ensure the drum does not contain nonconforming items

- Ensure the drum is properly packaged

- Verify the waste form description

- Evaluate the presence of free liquids.

3.9.2.9 Waste Form Evaluation. Table 3.9.2-4 evaluates the waste form against the WIPP WAC for such items as free liquids, pyrophoric materials, and compressed gases. Table 3.9.2-5 evaluates the waste against TRUPACT criteria.

Table 3.9.2-4. Waste Form Evaluation.

Criterion or requirement Limiting parameters ${ }^{2}$

Immobilization This IDC contains crushed glass in excess of the WIPP WAC for particulate.

Liquids This waste form meets the free liquid criteria by procedural control and RTR inspection prior to shipment from Rocky Flats.

Pyrophoric

Materials

Pyrophoric materials were prohibited by procedural control. The absence of the pyrophoric materials was verified by the generating supervisor and periodic inspection by the Waste Certification Organization.

Explosives and Compressed Gases

Explosives and compressed gases were prohibited by procedural control. The absence of the explosives and compressed gases was verified by the generating supervisor and periodic inspection by the Waste Certification Organization. In addition, unvented, closed containers and pressurized containers were excluded by procedural controls and RTR examination.

TRU-Mixed Wastes The RCRA constituents exist as co-contaminants with the transuranic radionuclides. Compliance with the WIPP RCRA permits and NMD will be required prior to shipment of the stored waste to WIPP.

Specific Activity of A portion of the waste stored at INEL may contain $<100$ nanocuries per gram Waste transuranic radionuclides.

$\mathrm{Pu}^{239}$ Equivalent None of the IDC 440 waste containers recorded as shipped to INEL in the Activity SWIMS exceed 1,000 Ci of plutonium-equivalent activity.

a. Many of the limiting parameters were taken from TRU Waste Compliance Program (Rockwell International 1983a, 1987e, and 1989b). 
Table 3.9.2-5. TRUPACT Evaluation.

Criterion or

requirement

Limiting parameters ${ }^{2}$

Waste Package

Weight

Rocky Flats limited the gross weight of drums to $800 \mathrm{lb}$. The TRUPACT and vehicle weight limits must be verified at the time of payload assembly at INEL. Boxes shipped to INEL are not authorized for shipment in the TRUPACT.

Waste Containers This waste form was packaged in 55-gal DOT-7A, Type A containers and DOT-7A metal boxes.

Nuclear

Criticality

Rocky Flats limited the fissile content of the drums to 200 grams and the boxes to 350 grams. However, the error-times-two requirement was not in place at the time the drums were shipped to INEL; therefore, it is not reported as part of the assay of the drum. The TRUPACT limit must be verified at the time of payload assembly at INEL. Based on the typical assays of the IDC 440 drums, the criticality criteria will be met but must be recalculated or assayed to meet the errortimes-two requirement.

Surface Dose The surface dose rate criteria used by Rocky Flats was $200 \mathrm{mrem} / \mathrm{hr}$ at the Rate container surface and $10 \mathrm{mrem} / \mathrm{hr}$ at 1 meter. Shielding was not necessary for IDC 440 containers. The TRUPACT limit must be verified at the time of payload assembly at INEL. Based on the typical dose rates from the IDC 440 containers, the dose rate criteria will be met.

Removable The Rocky Flats limit for removable contamination (for TRU assumed to be all

Surface alpha) was 20 disintegrations per minute $/ 100 \mathrm{~cm}^{2}$. The Rocky Flats limit is

Contamination

Thermal Power equivalent to 9 picocuries per $100 \mathrm{~cm}^{2}$, which is well within the WIPP criteria.

The thermal power calculation reported in the SWIMS data package is based on the reported assay value without an error/uncertainty correction. The thermal power must be recalculated based on the assay error determination.

Gas Generation Based on the procedural requirements for packaging IDC 440 waste and the waste description, the only areas of noncompliance are carbon filters, nonpunctured rigid liners, headspace gas analysis, and visual characterization.

Cyclohexane, dichloromethane, and toluene were detected by headspace analysis in IDC 440 but are not listed in the TRUPACT Chemical List for RF 118A. 1,1,1trichoroethane was detected by headspace analysis and is on the TRUPACT Chemical List. These chemicals appear to be in total concentrations $<1 \%$.

Personnel performing RTR examination at Rocky Flats would accept up to $10 \%$ of another IDC. The other IDCs could be combustibles, concrete, metal, leaded gloves, and plastics.

a. Many of the limiting parameters were taken from TRU Waste Compliance Program (Rockwell International 1983a, 1987e, and 1989b). 
3.9.2.10 Combustible and Organic Content. Table 3.9.2-6 outlines available data from the TRU Waste Sampling Program for IDC 440. SWIMS data indicate that this waste form does not contain $>20 \%$ combustibles or $>20 \%$ organics.

Table 3.9.2-6. Item Description Code 440 Data Summary for Combustible and Organic Content.

\begin{tabular}{lcccccc}
\hline Container & $\begin{array}{c}\text { Wt. } \\
\text { combustibles } \\
(\mathrm{lb})^{\mathrm{a}}\end{array}$ & $\begin{array}{c}\text { Wt. } \\
\text { organics }_{(\mathrm{lb})^{\mathrm{b}}}\end{array}$ & $\begin{array}{c}\text { Net wt. of } \\
\text { container } \\
\left(\mathrm{lb}^{\mathrm{c}}\right.\end{array}$ & $\begin{array}{c}\text { Wt\% } \\
\text { combustibles }^{\mathrm{d}}\end{array}$ & $\begin{array}{c}\text { Vol\% } \\
\text { combustibles }^{\mathrm{e}}\end{array}$ & $\begin{array}{c}\text { Wt\% } \\
\text { organics }^{\mathrm{f}}\end{array}$ \\
\hline $36-00805$ & 24.5 & 24.5 & 173 & 14 & 20 & 14 \\
$37-02339$ & 18 & 18 & 72.75 & 25 & 30 & 25 \\
$28-00755$ & 8.5 & 8.5 & 94.5 & 9 & 10 & 9 \\
$37-02018$ & 2.0 & 2.0 & 116.75 & 2 & 15 & 2 \\
$12-11241$ & 12.8 & 12.8 & 46.75 & 27 & 15 & 27 \\
$76-01366$ & 5 & 5 & 394.0 & 1 & 1 & 1 \\
$37-02336$ & 28.5 & 28.5 & 52.0 & 55 & 20 & 55 \\
$02-10576$ & 8.6 & 8.6 & 303.4 & 3 & 2 & 3 \\
$29-0030$ & 16.0 & 16.0 & 133.25 & 12 & 15 & 12 \\
$36-00628$ & 1.0 & 1.0 & 356.8 & 1 & 2 & 1 \\
$28-00781$ & 10.5 & 100 & 176 & 11 & 20 & 11
\end{tabular}

a. Sum of weights of all combustible material and leaded rubber from Table 22 (Clements and Kudera 1985).

b. Sum of weights of all combustible material, leaded rubber, and organic material from Table 22 (Clements and Kudera 1985).

c. Net weight of container from Table 22 (Clements and Kudera 1985).

d. Weight of combustible material/net weight of container $\times 100$.

e. Vol\% of combustible material from visual examination, obtained from Appendix B (Clements and Kudera 1985).

f. Weight of organic material/net weight of container $\times 100$.

3.9.2.10.1 Combustible Content-SWIMS data show that IDC 440 waste is noncombustible (Rockwell International 1985a). In support of the TRU Waste Sampling Program, 11 drums of IDC 440 waste were opened. They were found to contain an average wt\% combustible content of $14.5 \%$. Visual inspection showed an average vol\% combustible content of $13.6 \%$. (Clements and Kudera 1985). 
3.9.2.10.2 Organic Content-SWIMS data show that IDC 440 waste may contain $15 \%$ organics (Rockwell International 1985a). In support of the TRU Waste Sampling Program, 11 drums of IDC 440 waste were opened. They were found to contain an average wt\% organic content of 14.5\% (Clements and Kudera 1985).

3.9.2.11 Analytical Information. Analytical data from the WIPP Experimental Waste Characterization Program (EG\&G RFP 1994t) for IDC 440- Glass, indicate that one drum was subject to headspace gas analysis.

IDC 440 Gas Mass Spectrometry analytical results are presented in Table 3.9.2-7. The drum was subject to the operational lid headspace sampling program. Nitrogen, oxygen, argon, carbon dioxide, and carbon monoxide analytes were detected.

IDC 440 VOC Gas Chromatography/Mass Spectrometry analytical results indicate 1.9 ppmv toluene in the single drum tested (D60463).

Analytical data from the TRU Waste Sampling Waste Characterization Program (Clements and Kudera 1985) for IDC 440, Glass, indicate that 12 drums were subject to headspace gas analysis. Gas composition analytical results are presented in Table 3.9.2-8. Waste boxes were not sampled. Hydrogen, oxygen, nitrogen, argon, carbon dioxide, nitrogen oxide(s), saturated hydrocarbons, 1,1,1trichloroethane, dichloromethane, and cyclohexane were detected in the drums.

EPA has compiled data for spent and unused fluorescent bulbs and has found that in many cases, the materials fail the TCLP for mercury (EG\&G RFP 1994g). Therefore, the EPA Code for mercury (D009) applies to IDC 440 waste.

Table 3.9.2-7. Gas Mass Spectrometry Results (vol\%).

\begin{tabular}{|c|c|c|c|c|c|c|c|c|c|c|c|c|}
\hline \multirow{2}{*}{$\begin{array}{l}\text { Drum } \\
\text { no. }\end{array}$} & \multirow{2}{*}{$\begin{array}{l}\text { Headspace } \\
\text { sample } \\
\text { program }\end{array}$} & \multicolumn{11}{|c|}{ Analytes } \\
\hline & & Vented & $\mathrm{H}_{2}$ & $\mathrm{~N}_{2}$ & $\mathrm{O}_{2}$ & $\mathrm{Ar}$ & $\mathrm{CO}_{2}$ & $\mathrm{CO}$ & $\mathrm{CH}_{4}$ & $\mathrm{C}_{2} \mathrm{H}_{6}$ & $\mathrm{C}_{3} \mathrm{H}_{8}$ & $\mathrm{NO}_{\mathrm{x}}$ \\
\hline D60463 & $1 \mathrm{~A}$ & - & - & 78.2 & 20.7 & 0.922 & 0.14 & 0.019 & - & - & - & - \\
\hline \multicolumn{13}{|c|}{ Notes: } \\
\hline \multicolumn{13}{|c|}{ Headspace Sample Program } \\
\hline & Operat & nal Lid, C & $\mathrm{Ma}$ & Spectro & letry $R$ & iults (vo & & & & & & \\
\hline & \multicolumn{12}{|c|}{$\begin{array}{l}\text { Unreported analyte values indicate that analyte was undetected, or was detected at or above the MDL but at a } \\
\text { level below the PRQL. }\end{array}$} \\
\hline
\end{tabular}


Table 3.9.2-8. Gas Sampling Results-Compositional Analysis (vol\%).

\begin{tabular}{|c|c|c|c|c|c|c|c|c|c|c|c|}
\hline \multirow[b]{2}{*}{$\begin{array}{l}\text { Container } \\
\text { ID. no. }\end{array}$} & \multirow{2}{*}{$\begin{array}{l}\text { Storage } \\
\text { time } \\
\text { (days) }\end{array}$} & \multicolumn{10}{|c|}{ Analytes } \\
\hline & & $\mathrm{H}_{2}$ & $\mathrm{O}_{2}$ & $\mathrm{~N}_{2}$ & Ar & $\mathrm{CO}_{2}$ & $\mathrm{CO}$ & $\mathrm{NO}_{\mathrm{x}}$ & $\begin{array}{l}\text { Hydrocarbons } \\
\text { (saturated) }^{1}\end{array}$ & $\begin{array}{c}1,1,1- \\
\text { trichloroethane }\end{array}$ & $\begin{array}{c}\text { Other } \\
\text { hydrocarbons }\end{array}$ \\
\hline \multirow[t]{2}{*}{$37-02339$} & 225 & 0.06 & 19.7 & 75.5 & 0.81 & 0.99 & - & 0.89 & 0.88 & 0.91 & $0.10^{2}$ \\
\hline & & & & & & & & & & & $0.17^{b}$ \\
\hline $28-00781$ & 240 & 0.16 & 21.1 & 74.5 & 0.73 & 0.61 & - & 0.18 & 1.7 & 0.87 & $0.15^{2}$ \\
\hline $28-00755$ & 258 & 0.13 & 19.6 & 76.8 & 0.91 & 1.0 & - & 0.08 & 0.35 & 0.93 & $0.12^{\mathrm{a}}$ \\
\hline $12-11241$ & 218 & 0.07 & 21.0 & 76.4 & 0.90 & 0.14 & - & - & - & 1.27 & $0.17^{2}$ \\
\hline $37-02336$ & 245 & 0.07 & 20.5 & 75.8 & 0.89 & 1.1 & - & 0.11 & 0.14 & 0.48 & $0.07^{2}$ \\
\hline 02-34934 & 972 & - & 20.0 & 77.4 & 1.0 & 0.07 & - & - & 0.21 & 0.39 & - \\
\hline $29-00030$ & 966 & 0.47 & 10.0 & 80.0 & 0.97 & 8.10 & - & 0.31 & 0.07 & - & - \\
\hline $37-02018$ & 932 & 0.12 & 15.5 & 77.5 & 0.87 & 3.70 & - & 1.9 & 0.37 & - & - \\
\hline $76-01366$ & 914 & - & 21.3 & 77.5 & 0.93 & 0.09 & - & - & 0.20 & - & - \\
\hline $02-10576$ & 4,291 & - & 20.6 & 78.3 & 0.93 & 0.14 & - & - & - & - & - \\
\hline $36-00628$ & 4,389 & 0.01 & 20.6 & 78.4 & 0.92 & 0.08 & - & - & - & - & - \\
\hline $36-00805$ & 4,206 & 0.95 & 11.3 & 83.8 & 0.99 & 2.96 & - & - & - & - & - \\
\hline \multicolumn{12}{|l|}{ Notes: } \\
\hline $\begin{array}{l}1 . \\
2 .\end{array}$ & \multicolumn{11}{|c|}{$\begin{array}{l}\text { Saturated hydrocarbons-methane through propane. } \\
\text { Other hydrocarbons-as specified. } \\
\text { a. Dichloromethane } \\
\text { b. Cyclohexane }\end{array}$} \\
\hline
\end{tabular}




\subsection{Waste Form Number 118-TRU Glass Waste, Content Code RF 118A}

\subsubsection{Item Description Code 441-Unleached Raschig Rings}

3.9.3.1 Certification Assessment. This IDC is certifiable without further waste treatment. Assay and thermal power calculations, including error, need to be updated to meet the current WIPP WAC. Several gas generation criteria need to be addressed. Carbon filters may need to be installed, and headspace gas analysis and visual waste characterization will need to be performed. Boxes shipped to INEL are not authorized for shipment in the TRUPACT.

3.9.3.2 Waste Description. IDC 441 includes unleached Raschig rings to be discarded. Raschig rings are borosilicate glass rings used to maintain subcritical conditions in fissile solution storage tanks that are not safe by dimension. The boron in the rings is a neutron poison, an element that absorbs neutrons. The volume of the ring displaces a proportionate volume of solution and, in combination with the boron, creates a critically safe configuration. Over time, the rings can be become broken or otherwise damaged, especially in air-sparged tanks. In those cases, the rings were removed and replaced. The rings were also replaced if the assay of the tank exceeded acceptable limits. The old rings were assayed, and if the material count was above the economic discard limit (EDL), the rings were leached and stored for plutonium recovery. If the material count was below EDL, the rings were packaged for discard without leaching (EG\&G RFP 1994g).

3.9.3.3 Generation Source. IDC 441 was generated in Buildings 371 and 771 . Rings generated in Building 371 were generated by the Process Vent Scrubber System in Rooms 1105 and 2319. The system removed nitric- and sulfuric-acid vapors and entrained liquids from the process vent header streams connected to the Building 371 tanks. The acids were neutralized with potassium hydroxide and water. Vent scrubbers D229 A and B were filled with Raschig rings. Rings generated in Building 771 were generated in production processes in tanks used to temporarily store radioactive solutions. The solutions could have contained nitric or sulfuric acids, or potassium hydroxide. (EG\&G RFP 1994g).

3.9.3.4 Recovery Method. Raschig rings contaminated with amounts of plutonium above the discard limit were leached with hot nitric acid by Plutonium Recovery Operations (Building 771). After leaching, the Rashig rings were rinsed with water and air-dried before repackaging (Clements 1982).

3.9.3.5 Waste Packaging and Handling. Raschig rings were segregated from other noncomplying materials as they were removed from tanks. The rings were placed in plastic bags and all other material was collected in 2-liter poly bottles. The Raschig rings were then double-bagged and placed in waste collection drums that had been prepared specifically for that ring change job. The drums were DOT-17C, white, 55-gal drums.

When the drum was full, the drum liners were sealed and the drum was closed. The drum label, completed with all necessary information, was then taped to the drum lid and a TID was attached to the drum. 
Drums were held in Size Reduction in Building 776 until enough waste had accumulated to fill a waste box. The wastes were then repackaged into boxes equipped with a certified filter-and-vent system.

3.9.3.6 Container Preparation. Only approved containers could be used to package TRU waste for shipment offsite. Containers approved for shipment to INEL during this time were DOT17C, white, 55-gal drums (Rockwell specification SX-200); white, corrugated steel boxes (Rockwell specification SX-231); and FRP boxes (Rockwell specification SX-207). Each of these containers met the requirements for certification as DOT-7A Type A packaging (Rockwell International 1989e).

Table 3.9.3-1 shows the current inventory of IDC 441 waste containers from the Rocky Flats Plant that have been shipped to INEL since 1985.

Table 3.9.3-1. Item Description Code 441 Container Information.

\begin{tabular}{lccr}
\hline \multicolumn{1}{c}{ Information } & & Drums & Boxes \\
\hline Total Containers & & N/A & 1 \\
Net Container Weight $(\mathrm{lb})$ & Maximum & N/A & 2,750 \\
& Minimum & N/A & 2,750 \\
& Average & N/A & 2,750 \\
\hline
\end{tabular}

3.9.3.6.1 Drum Preparation-No drums of IDC 441 waste were shipped to INEL between 1985 and 1989.

3.9.3.6.2 Box Preparation-FRP boxes were used for waste shipped to INEL from 1972 through 1982 (Riddle and others 1985). In 1982, the use of the corrugated metal waste box was phased in. The last FRP box was shipped to INEL in 1986. In the interim, waste packaged in both types of boxes had been shipped to INEL. SWIMS information did not track the type of box used in individual shipments.

The FRP box was constructed of $3 / 4$-in. exterior plywood with $2 \times 4$-in. framing members and skids. The entire box was coated with a 0.12 -in. coat of fiberglass-reinforced polyester with flameretardant properties. The continuous FRP coating provides a leakproof, tamper-proof package. Inner liners used for contamination control during loading consist of a PVC liner protected by a 50-mil fiberboard sheet. The box size was $4 \times 4 \times 7 \mathrm{ft}$ or larger. The gross weight was normally restricted to 5,000 lb (Riddle and others 1985).

The corrugated metal waste boxes were made entirely out of 14-gauge (0.0747-in.), low-carbon steel. All seams including the closure were welded to produce a leaktight container (Brugger 1983). These boxes required a 10-mil PVC liner (Rockwell specification SX-209) and a 0.051-in. fiberboard liner (Rockwell specification SX-209) (Riddle and others 1985; Bearly and others 1988). Figure C-5 shows the appropriate box liners required for this IDC. Four sizes of the box have been certified as DOT-7A containers, with a maximum size of $54 \times 54 \times 89$ in. and a maximum gross weight of 7,000 lb. These containers are commonly referred to as "Sand Boxes" (Riddle and others 1985). 
All items that had the potential to puncture or otherwise compromise the integrity of the waste box were adequately prepackaged to cover sharp corners (Rockwell International 1989e).

3.9.3.7 Assay. The drums may have been assayed on an SGS counter or PADC. Assay results from the individual drums repackaged into a box are used as the primary assay results. This cumulative assay was checked using the Building 569 crate counter. The results of the check must agree with the cumulative assay within the established errors for the assay equipment. Table 3.9.3-2 summarizes the dose rates measured on containers of this IDC. Table 3.9.3-3 provides a summary of the assay information.

Table 3.9.3-2. Item Description Code 441 Dose Information.

\begin{tabular}{crcc} 
Information & & Drums & Boxes \\
\hline One Meter Dose Rate (mrem/h) & $0-0.5$ & N/A & 1 \\
& $0.5-10$ & N/A & 0 \\
Surface Dose Rate (mrem/h) & $<10$ & N/A & 1 \\
& $10-200$ & N/A & 0 \\
\hline
\end{tabular}

Table 3.9.3-3. Item Description Code 441 Assay Information.

\begin{tabular}{|c|c|c|c|}
\hline \multicolumn{2}{|c|}{ Radionuclide inventory } & \multirow{2}{*}{$\frac{\text { Drums }}{\text { N/A }}$} & \multirow{2}{*}{$\frac{\text { Boxes }}{43}$} \\
\hline Plutonium (g) & Maximum & & \\
\hline & Minimum & N/A & 43 \\
\hline & Average & N/A & 43 \\
\hline \multirow[t]{3}{*}{ Americium (g) } & Maximum & N/A & - \\
\hline & Minimum & N/A & - \\
\hline & Average & N/A & - \\
\hline \multirow[t]{3}{*}{ Uranium-235 (g) } & Maximum & N/A & - \\
\hline & Minimum & N/A & - \\
\hline & Average & N/A & - \\
\hline
\end{tabular}

3.9.3.8 Inspection. Bags of waste were opened and distributed inside the box during repackaging. Compliance was ensured by the immediate supervisor performed and by periodic inspections by Waste Certification personnel. In addition, each container without lead lining was viewed using RTR to

- Ensure the container does not contain nonconforming items

- Ensure the container is properly packaged

- Verify the waste form description

- Evaluate the presence of free liquids. 
3.9.3.9 Waste Form Evaluation. Table 3.9.3-4 evaluates the waste form against the WIPP WAC for such items as free liquids, pyrophoric materials, and compressed gases. Table 3.9.3-5 evaluates the waste against TRUPACT criteria.

Table 3.9.3-4. Waste Form Evaluation.

Criterion or

requirement

Limiting parameters ${ }^{\mathrm{a}}$

Immobilization Particulates were prohibited by procedural control. Based on the description of the waste, fine particulates are not expected in this IDC.

Liquids There are normally no liquids associated with this IDC. Personnel performing RTR examination at Rocky Flats would accept up to 2 cups of free liquid, if liquids were present.

Pyrophoric

Pyrophoric materials were prohibited by procedural control. The absence of the Materials pyrophoric materials was verified by the generating supervisor and periodic inspection by the Waste Certification Organization.

Explosives and Explosives and compressed gases were prohibited by procedural control. The Compressed Gases absence of the explosives and compressed gases was verified by the generating supervisor and periodic inspection by the Waste Certification Organization. In addition, unvented, closed containers and pressurized containers were excluded by procedural controls and RTR examination.

TRU-Mixed Wastes The RCRA constituents exist as co-contaminants with the transuranic radionuclides. Compliance with the WIPP RCRA permits and NMD will be required prior to shipment of the stored waste to WIPP.

Specific Activity of A portion of the waste stored at INEL may contain $<100$ nanocuries per gram Waste transuranic radionuclides.

$\mathrm{Pu}^{239}$ Equivalent None of the IDC 441 waste containers recorded as shipped to INEL in the Activity SWIMS exceed 1,000 $\mathrm{Ci}$ of plutonium-equivalent activity.

a. Many of the limiting parameters were taken from TRU Waste Compliance Program (Rockwell International 1983a, 1987e, and 1989b). 
Table 3.9.3-5. TRUPACT Evaluation.

Criterion or

requirement

Limiting parameters ${ }^{\mathrm{a}}$

Waste Package Boxes shipped to INEL are not authorized for shipment in the TRUPACT.

Weight

Waste Containers Waste was shipped in $4 \times 4 \times 7$-ft DOT-7A, Type A metal boxes. The boxes will not meet the TRUPACT waste container requirements.

Nuclear

Criticality

Rocky Flats limited the fissile content of the boxes to 350 grams. However, the error-times-two requirement was not in place at the time the drums were shipped to INEL; therefore, it is not reported as part of the assay of the drum.

Surface Dose Rate

The surface dose rate criteria used by Rocky Flats was $200 \mathrm{mrem} / \mathrm{hr}$ at the container surface and $10 \mathrm{mrem} / \mathrm{hr}$ at 1 meter. Shielding was not necessary for IDC 441 containers. The TRUPACT limit must be verified at the time of payload assembly at INEL. Based on the typical dose rates from the IDC 441 containers, the dose rate criteria will be met.

Removable The Rocky Flats limit for removable contamination (for TRU assumed to be all

Surface alpha) was 20 disintegrations per minute/100 $\mathrm{cm}^{2}$. The Rocky Flats limit is Contamination equivalent to 9 picocuries per $100 \mathrm{~cm}^{2}$, which is well within the WIPP criteria.

Thermal Power

The thermal power calculation reported in the SWIMS data package is based on the reported assay value without an error/uncertainty correction. The thermal power must be recalculated based on the assay error determination.

Gas Generation Based on the procedural requirements for packaging IDC 441 waste and the waste description, the only areas of noncompliance are carbon filters, headspace gas analysis, and visual characterization.

Trichloroethylene was detected by headspace analysis but is not on the TRUPACT Chemical List for RF 118A. Carbon tetrachloride and 1,1,1-trichloroethane were detected by headspace analysis and are on the TRUPACT Chemical List. All of the detected chemicals appear to be in total concentrations $<1 \%$. 1,1,2-trichloro1,2,2-trifluoroethane is on the TRUPACT Chemical List, but was not detected.

Personnel performing RTR examination at Rocky Flats would accept up to $10 \%$ of another IDC. The other IDCs could be combustibles, concrete, metal, leaded gloves, and plastics.

a. Many of the limiting parameters were taken from TRU Waste Compliance Program (Rockwell International 1983a, 1987e, and 1989b).

3.9.3.10 Combustible and Organic Content. Table 3.9.3-6 outlines available data from the TRU Waste Sampling Program for IDC 441. SWIMS data indicate that this waste form does not contain $>20 \%$ combustibles or $>20 \%$ organics. 
Table 3.9.3-6. Item Description Code 441 Data Summary for Combustible and Organic Content.

\begin{tabular}{ccccccc}
\hline Container & $\begin{array}{c}\text { Wt. } \\
\text { combustibles } \\
(\mathrm{lb})^{\mathrm{a}}\end{array}$ & $\begin{array}{c}\text { Wt. } \\
\text { organics } \\
(\mathrm{lb})^{\mathrm{b}}\end{array}$ & $\begin{array}{c}\text { Net wt. of } \\
\text { container } \\
(\mathrm{lb})^{\mathrm{c}}\end{array}$ & $\begin{array}{c}\text { Wt\% } \\
\text { combustibles }^{\mathrm{d}}\end{array}$ & $\begin{array}{c}\text { Vol\% } \\
\text { combustibles }^{\mathrm{c}}\end{array}$ & $\begin{array}{c}\text { Wt\% } \\
\text { organics }^{\mathrm{f}}\end{array}$ \\
\hline $89-04043$ & 8.2 & 8.2 & 201.5 & 4 & 10 & 4 \\
$89-04071$ & 16.4 & 16.4 & 114.4 & 14 & 10 & 14 \\
$89-04114$ & 18.8 & 18.8 & 172.1 & 11 & 10 & 11 \\
$89-04072$ & 8.5 & 8.5 & 211.3 & 4 & 5 & 4 \\
\hline
\end{tabular}

a. Sum of weights of all combustible material and leaded rubber from Table 23 (Clements and Kudera 1985).

b. Sum of weights of all combustible material, leaded rubber, and organic material from Table 23 (Clements and Kudera 1985).

c. Net weight of container from Table 23 (Clements and Kudera 1985).

d. Weight of combustible material/net weight of container $\times 100$.

e. Vol\% of combustible material from visual examination, obtained from Appendix B (Clements and Kudera 1985).

f. Weight of organic material/net weight of container $\times 100$.

3.9.3.10.1 Combustible Content-SWIMS data show that IDC 441 waste is noncombustible (Rockwell International 1985a). In support of the TRU Waste Sampling Program, four drums of IDC 441 waste were opened. They were found to contain an average wt\% combustible content of $8.3 \%$. Visual inspection showed an average vol\% combustible content of $8.8 \%$ (Clements and Kudera 1985).

3.9.3.10.2 Organic Content-SWIMS data show that IDC 441 waste may contain $20 \%$ organics (Rockwell International 1985a). In support of the TRU Waste Sampling Program, four drums of IDC 441 waste were opened. They were found to contain an average wt\% organic content of $8.3 \%$ (Clements and Kudera 1985).

3.9.3.11 Analytical Information. Analytical data from the TRU Waste Sampling Waste Characterization Program (Clements and Kudera 1985) for IDC 441-Unleached Raschig rings, indicate that four drums were subject to headspace gas analysis. Gas composition analytical results are presented in Table 3.9.3-7. Waste boxes were not sampled. Hydrogen, oxygen, nitrogen, argon, carbon dioxide, saturated hydrocarbons, 1,1,1-trichloroethane, trichloroethylene and carbon tetrachloride were detected in the drums.

Analytical data compiled by EG\&G Rocky Flats (EG\&G RFP 1994q) indicate that IDC 441 does not exhibit the characteristic of toxicity for RCRA metals and is characterized as nonhazardous waste (EG\&G RFP 1994g). 
Table 3.9.3-7. Gas Sampling Results-Compositional Analysis (vol\%).

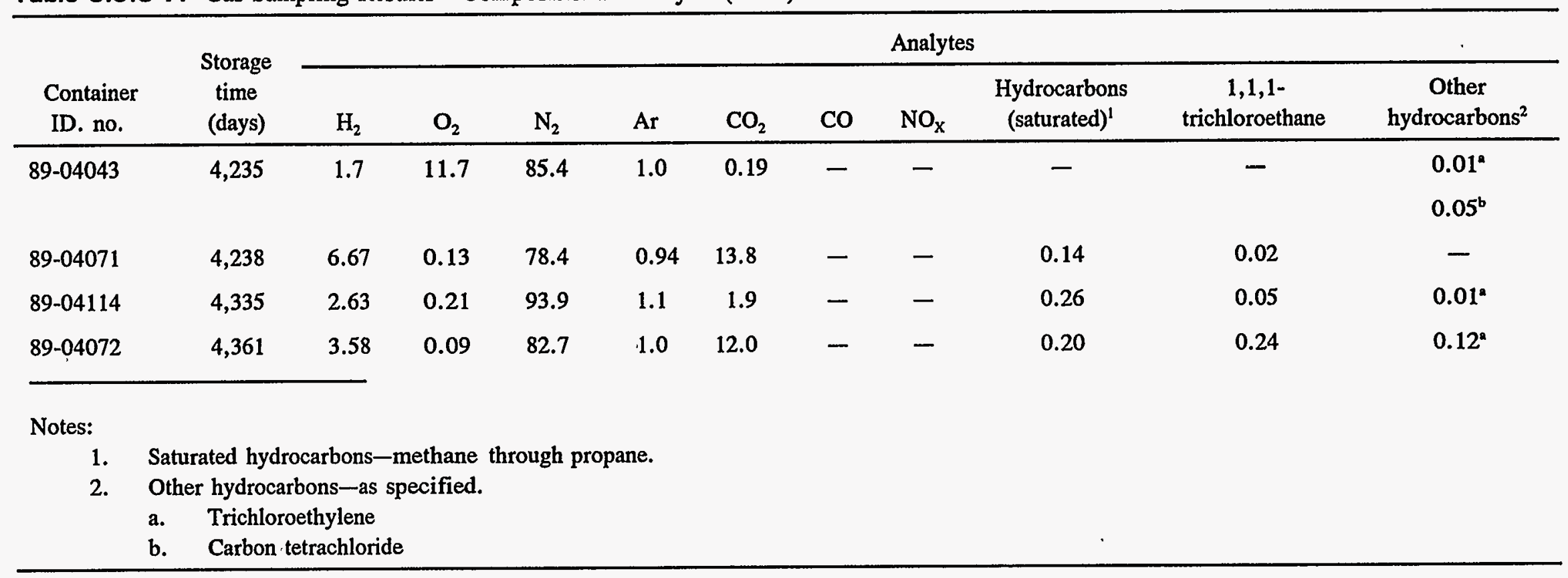




\subsection{Waste Form Number 118-TRU Glass Waste, Content Code RF 118A}

\subsubsection{Item Description Code 442-Leached Raschig Rings}

3.9.4.1 Certification Assessment. This IDC is certifiable without further waste treatment. Assay and thermal power calculations, including error, need to be updated to meet the current WIPP WAC. Several gas generation criteria need to be addressed. Carbon filters may need to be installed, drums will require inspection to identify unvented or unpunctured rigid liners, and headspace gas analysis and visual waste characterization will need to be performed. Boxes shipped to INEL are not authorized for shipment in the TRUPACT.

3.9.4.2 Waste Description. IDC 442 includes all leached, nonsolvent-contaminated Raschig Rings to be discarded. Raschig Rings are borosilicate glass rings used to maintain subcritical conditions in fissile solution storage tanks that are not safe by dimension. The boron in the rings is a neutron poison, an element that absorbs neutrons. The volume of the ring displaces a proportionate volume of solution and, in combination with the boron, creates a critically safe configuration. Over time, the rings can be become broken or otherwise damaged, especially in air-sparged tanks. In those cases, the rings were removed and replaced. The rings were also replaced if the assay of the tank exceeded acceptable limits. The old rings were assayed, and if the material count was below the economic discard limit (EDL), the rings were packaged for discard without leaching. If the material count was above the EDL, the rings were leached and stored for plutonium recovery. The leached, nonsolvent-contaminated Raschig Rings were assigned IDC 442 (EG\&G RFP 1994g).

3.9.4.3 Generation Source. Raschig rings assigned IDC 442 were generated in Buildings 771, 776, and 777 (EG\&G RFP 1994g).

3.9.4.4 Recovery Method. Raschig rings contaminated with amounts of plutonium above the discard limit are leached with hot nitric acid by Plutonium Recovery Operations (Building 771). After leaching, the Rashig rings are rinsed with water and air-dried before repackaging (Clements 1982).

3.9.4.5 Waste Packaging and Handling. Raschig rings were segregated from other noncomplying materials as they were removed from tanks. The rings were placed in plastic bags and all other material was collected in 2-liter poly bottles. The Raschig rings were then double-bagged and placed in waste collection drums which have been prepared specifically for that ring change job. The drums were DOT-17C, white, 55-gal drums. When the drum was full, the drum liners were sealed and the drum was closed. The drum label, completed with all necessary information, was then taped to the drum lid and a TID was attached to the drum.

Drums were held in Size Reduction in Building 776 until enough waste had accumulated to fill a waste box. The wastes were then repackaged into boxes equipped with a certified filter-and-vent system.

3.9.4.6 Container Preparation. Only approved containers could be used to package TRU waste for shipment offsite. Containers approved for shipment to INEL during this time were DOT- 
17C, white, 55-gal drums (Rockwell specification SX-200); white, corrugated steel boxes (Rockwell specification SX-231); and FRP boxes (Rockwell specification SX-207). Each of these containers met the requirements for certification as DOT-7A Type A packaging (Rockwell International 1989e).

Table 3.9.4-1 shows the current inventory of IDC 442 waste containers from the Rocky Flats Plant that have been shipped to INEL since 1985.

Table 3.9.4-1. Item Description Code 442 Container Information.

\begin{tabular}{lrrr}
\hline \multicolumn{1}{c}{ Information } & & Drums & Boxes \\
\hline Total Containers & & 28 & 34 \\
Net Container Weight $(\mathrm{lb})$ & Maximum & 229 & 3,500 \\
& Minimum & 22 & 1,760 \\
& Average & 176 & 2,580 \\
\hline
\end{tabular}

3.9.4.6.1 Drum Preparation-Approved liners for drums of TRU waste packaged for offsite shipment were the round-bottom liner (Rockwell specification SX-203) inside a 90-mil rigid polyethylene liner (Rockwell specification SX-202), or an O-ring bag and a polyethylene bag placed inside the rigid liner if the drum was attached to a glovebox (Rockwell International 1989e). Type III rigid liners have been used since September 1983 (Bearly 1989a). The IDC 442 waste packaged for offsite shipment required a fiberboard liner, a round bottom liner, and two polyethylene bags inside the rigid liner (Rockwell International 1988c). Figure C-1 shows the appropriate drum liners for this IDC. If a single piece of heavy metal was packaged in a drum, it was braced to prevent shifting. Sharp edges were taped to prevent puncturing of the liners (Rockwell International 1989b). All bags were closed using the twist-and-tape method (Rockwell International 1989e).

Flow-in, ventable gaskets were installed in the drums beginning in December 1982 . They were used until October 1988, when tubular gaskets with carbon filters were required. Drums shipped to INEL between 1985 and 1988 may not meet the current WIPP WAC, owing to their lack of carbon filters (Bearly 1989a).

3.9.4.6.2 Box Preparation-FRP boxes were used for waste shipped to INEL from 1972 through 1982 (Riddle and others 1985). In 1982, the use of the corrugated metal waste box was phased in. The last FRP box was shipped to INEL in 1986. In the interim, waste packaged in both types of boxes had been shipped to INEL. SWIMS information did not track the type of box used in individual shipments.

The FRP box was constructed of 34 -in. exterior plywood with $2 \times 4$-in. framing members and skids. The entire box was coated with a 0.12 -in. coat of fiberglass-reinforced polyester with flameretardant properties. The continuous FRP coating provides a leakproof, tamper-proof package. Inner liners used for contamination control during loading consist of a PVC liner protected by a 50-mil fiberboard sheet. The box size was $4 \times 4 \times 7 \mathrm{ft}$ or larger. The gross weight was normally restricted to 5,000 lb (Riddle and others 1985 ). 
The corrugated metal waste boxes were made entirely out of 14 -gauge $(0.0747$-in.), low-carbon steel. All seams including the closure were welded to produce a leaktight container (Brugger 1983). These boxes required a 10-mil PVC liner (Rockwell specification SX-209) and a 0.051-in. fiberboard liner (Rockwell specification SX-209) (Riddle and others 1985; Bearly and others 1988). Figure C-5 shows the appropriate box liners required for this IDC. Four sizes of the box have been certified as DOT-7A containers, with a maximum size of $54 \times 54 \times 89$ in. and a maximum gross weight of 7,000 lb. These containers are commonly referred to as "Sand Boxes" (Riddle and others 1985).

All items that had the potential to puncture or otherwise compromise the integrity of the waste box were adequately prepackaged to cover sharp corners (Rockwell International 1989e).

3.9.4.7 Assay. The drums may have been assayed on a SGS counter or a PADC. Assays for individual drums repackaged into a box were used summed to provide an assay value for the box. Box assay values would have been checked at the Building 569 crate counter. The assay and the crate counter assay must agree within the error of the counting equipment. Containers of waste that have not been PADC assayed and had SGS or crate counter assay values of 1 gram or less should be PADC assayed to verify that they are transuranic waste. Table 3.9.4-2 summarizes the dose rates measured on containers of this IDC. Table 3.9.4-3 provides a summary of the assay information. Four boxes were evaluated for americium and five were evaluated for uranium. Drums were not evaluated for americium or uranium.

Table 3.9.4-2. Item Description Code 442 Dose Information.

\begin{tabular}{crcc} 
Information & & Drums & Boxes \\
\hline One Meter Dose Rate $(\mathrm{mrem} / \mathrm{h})$ & $0-0.5$ & 28 & 33 \\
& $0.5-10$ & 0 & 1 \\
Surface Dose Rate $(\mathrm{mrem} / \mathrm{h})$ & $<10$ & 28 & 34 \\
& $10-200$ & 0 & 0 \\
\hline
\end{tabular}

Table 3.9.4-3. Item Description Code 442 Assay Information.

\begin{tabular}{lccc}
\multicolumn{2}{c}{ Radionuclide inventory } & Drums & Boxes \\
\hline Plutonium (g) & Maximum & 5 & 298 \\
& Minimum & 0 & 0 \\
& Average & 0.71 & 96.06 \\
Americium (g) & Maximum & - & 3 \\
& Minimum & - & 1 \\
& Average & - & 2 \\
Uranium-235 (g) & Maximum & - & 16 \\
& Minimum & - & 0 \\
& Average & - & 7.8
\end{tabular}


3.9.4.8 Inspection. Waste Certification personnel performed periodic inspections of the generating and packaging process to verify compliance with waste acceptance criteria. Drums of waste may have been repackaged into boxes. Bags of waste were opened and distributed inside the box during repackaging. Compliance was ensured by the immediate supervisor performed and by periodic inspections by Waste Certification personnel. In addition, each container not lead-lined was viewed using RTR to

- Ensure the container does not contain nonconforming items

- Ensure the container is properly packaged

- Verify the waste form description

- Evaluate the presence of free liquids.

3.9.4.9 Waste Form Evaluation. Table 3.9.4-4 evaluates the waste form against the WIPP WAC for such items as free liquids, pyrophoric materials, and compressed gases. Table 3.9.4-5 evaluates the waste against TRUPACT criteria. 
Table 3.9.4-4. Waste Form Evaluation.

Criterion or

requirement

Limiting parameters ${ }^{\mathrm{a}}$

Immobilization

Raschig Rings were rinsed prior to packaging. Generation of fines due to shipping and handling is not expected. This waste form will meet the WIPP WAC for particulates.

Liquids

This waste form meets the free liquid criteria by procedural control and RTR inspection prior to shipment from Rocky Flats.

Pyrophoric

Materials

Pyrophoric materials were prohibited by procedural control. The absence of the pyrophoric materials was verified by the generating supervisor and periodic inspection by the Waste Certification Organization.

Explosives and Compressed Gases

Explosives and compressed gases were prohibited by procedural control. The absence of the explosives and compressed gases was verified by the generating supervisor and periodic inspection by the Waste Certification Organization. In addition, unvented, closed containers and pressurized containers were excluded by procedural controls and RTR examination.

TRU-Mixed Wastes The RCRA constituents exist as co-contaminants with the transuranic radionuclides. Compliance with the WIPP RCRA permits and NMD will be required prior to shipment of the stored waste to WIPP.

Specific Activity of Waste A portion of the waste stored at INEL may contain $<100$ nanocuries per gram transuranic radionuclides.

$\mathrm{Pu}^{239}$ Equivalent None of the IDC 442 waste containers recorded as shipped to INEL in the Activity SWIMS exceed 1,000 Ci of plutonium-equivalent activity.

a. Many of the limiting parameters were taken from TRU Waste Compliance Program (Rockwell International 1983a, 1987e, and 1989b). 
Table 3.9.4-5. TRUPACT Evaluation.

Criterion or requirement

Waste Package

Weight

Waste Containers

Nuclear Criticality

Surface Dose Rate

Removable Surface Contamination

Thermal Power

Gas Generation
Limiting parameters ${ }^{2}$

Rocky Flats limited the gross weight of drums to $800 \mathrm{lb}$. The TRUPACT and vehicle weight limits must be verified at the time of payload assembly at INEL. The boxes shipped to INEL do not meet TRUPACT criteria.

This waste form was packaged in 55-gal DOT-7A, Type A containers and DOT-7A boxes. .

Rocky Flats limited the fissile content of the drums to 200 grams and boxes to 350 grams. However, the error-times-two requirement was not in place at the time the drums were shipped to INEL; therefore, it is not reported as part of the assay of the drum. The TRUPACT limit must be verified at the time of payload assembly at INEL. Based on the typical assays of the IDC 442 containers, the criticality criteria will be met but must be recalculated or assayed to meet the error-times-two requirement.

The surface dose rate criteria used by Rocky Flats was $200 \mathrm{mrem} / \mathrm{hr}$ at the container surface and $10 \mathrm{mrem} / \mathrm{hr}$ at 1 meter. Shielding was not necessary for IDC 442 containers. The TRUPACT limit must be verified at the time of payload assembly at INEL. Based on the typical dose rates from the IDC 442 containers, the dose rate criteria will be met.

The Rocky Flats limit for removable contamination (for TRU assumed to be all alpha) was 20 disintegrations per minute $/ 100 \mathrm{~cm}^{2}$. The Rocky Flats limit is equivalent to 9 picocuries per $100 \mathrm{~cm}^{2}$, which is well within the WIPP criteria.

The thermal power calculation reported in the SWIMS data package is based on the reported assay value without an error/uncertainty correction. The thermal power must be recalculated based on the assay error determination.

Based on the procedural requirements for packaging IDC 442 waste and the waste description, the only areas of noncompliance are carbon filters, nonpunctured rigid liners, headspace gas analysis, and visual characterization.

Dichloromethane was detected by headspace analysis in IDC 442 but is not listed in the TRUPACT Chemical List for RF 118A. 1,1,1-Trichloroethane was detected by headspace analysis and is on the TRUPACT Chemical List. The chemicals appear to be in total concentrations $<1 \%$, except for one drum which indicated about 3\% 1,1,1-trichloroethane. 1,1,2-Trichloro-1,2,2-trifluoroethane is on the TRUPACT Chemical List for halogenated organics and aromatic hydrocarbons, but was not detected.

Personnel performing RTR examination at Rocky Flats would accept up to $10 \%$ of another IDC. The other IDCs could be combustibles, concrete, metal, leaded gloves, and plastics.

a. Many of the limiting parameters were taken from TRU Waste Compliance Program (Rockwell International 1983a, 1987e, and 1989b). 
3.9.4.10 Combustible and Organic Content. Table 3.9.4-6 outlines available data from the TRU Waste Sampling Program for IDC 442. SWIMS data indicate that this waste form does not contain $>20 \%$ combustibles or $>20 \%$ organics.

Table 3.9.4-6. Item Description Code 442 Data Summary for Combustible and Organic Content.

\begin{tabular}{ccccccc}
\hline Container & $\begin{array}{c}\text { Wt. } \\
\text { combustibles } \\
(\mathrm{lb})^{\mathrm{a}}\end{array}$ & $\begin{array}{c}\text { Wt. } \\
\text { organics }_{(\mathrm{lb})^{\mathrm{b}}}\end{array}$ & $\begin{array}{c}\text { Net wt. of } \\
\text { container } \\
(\mathrm{lb})^{\mathrm{c}}\end{array}$ & $\begin{array}{c}\text { Wt\% } \\
\text { combustibles }^{\mathrm{d}}\end{array}$ & $\begin{array}{c}\text { Vol\% } \\
\text { combustibles }^{\mathrm{e}}\end{array}$ & $\begin{array}{c}\text { Wt\% } \\
\text { organics }^{\mathrm{f}}\end{array}$ \\
\hline $02-39564$ & 16.0 & 16.0 & 54.5 & 29 & 20 & 29 \\
$02-39533$ & 214.0 & 14.0 & 81.75 & 17 & 20 & 17 \\
$02-39803$ & 14.0 & 14.0 & 117.5 & 12 & 20 & 12 \\
$02-39805$ & 14.5 & 14.5 & 108.0 & 13 & 20 & 13 \\
$19-02730$ & 11.3 & 11.3 & 171.3 & 7 & 20 & 7 \\
$05-01596$ & 15 & 15 & 103.5 & 14 & 10 & 14 \\
$05-01772$ & 16.5 & 16.5 & 103.75 & 16 & 15 & 16 \\
$17-04562$ & 16.0 & 16.0 & 110.0 & 15 & 10 & 15 \\
$22-00722$ & 21.3 & 21.3 & 114.25 & 19 & 10 & 19 \\
$42-00226$ & 16.5 & 16.5 & 77.5 & 21 & 10 & 21
\end{tabular}

a. Sum of weights of all combustible material and leaded rubber from Table 23 (Clements and Kudera 1985).

b. Sum of weights of all combustible material, leaded rubber, and organic material from Table 23 (Clements and Kudera 1985).

c. Net weight of container from Table 23 (Clements and Kudera 1985).

d. Weight of combustible material/net weight of container $\times 100$.

e. Vol\% of combustible material from visual examination, obtained from Appendix B (Clements and Kudera 1985).

f. Weight of organic material/net weight of container $\times 100$.

3.9.4.10.1 Combustible Content-SWIMS data show that IDC 442 waste is noncombustible (Rockwell International 1985a). In support of the TRU Waste Sampling Program, 10 drums of IDC 442 waste were opened. They were found to contain an average wt\% combustible content of $16.3 \%$. Visual inspection showed an average vol\% combustible content of $15.5 \%$. (Clements and Kudera 1985).

3.9.4.10.2 Organic Content-SWIMS data show that IDC 442 waste may contain 20\% organics (Rockwell International 1985a). In support of the TRU Waste Sampling Program, 10 drums 
of IDC 442 were opened. They were found to contain an average wt\% organic content of $16.3 \%$ (Clements and Kudera 1985).

3.9.4.11 Analytical Information. Analytical data from the TRU Waste Sampling Waste Characterization Program (Clements and Kudera 1985) for IDC 442-Leached Raschig Rings, indicate that 10 drums were subject to headspace gas analysis. Gas composition analytical results are presented in Table 3.9.4-7. Waste boxes were not sampled. Hydrogen, oxygen, nitrogen, argon, carbon dioxide, nitrogen oxide(s), saturated hydrocarbons, 1,1,1-trichloroethane, and dichloromethane were detected in the drums.

Analytical data compiled by EG\&G Rocky Flats (EG\&G RFP 1994q) indicate that IDC 442 does not exhibit the characteristic of toxicity for RCRA metals and is characterized as nonhazardous waste (EG\&G RFP 1994g). 
Table 3.9.4-7. Gas Sampling Results-Compositional Analysis (vol\%).

\begin{tabular}{|c|c|c|c|c|c|c|c|c|c|c|c|}
\hline \multirow[b]{2}{*}{$\begin{array}{l}\text { Container } \\
\text { ID. no. }\end{array}$} & \multirow{2}{*}{$\begin{array}{l}\text { Storage } \\
\text { time } \\
\text { (days) }\end{array}$} & \multicolumn{10}{|c|}{ Analytes } \\
\hline & & $\mathrm{H}_{2}$ & $\mathrm{O}_{2}$ & $\mathrm{~N}_{2}$ & $\mathrm{Ar}$ & $\mathrm{CO}_{2}$ & $\mathrm{CO}$ & $\mathrm{NO}_{\mathrm{x}}$ & $\begin{array}{l}\text { Hydrocarbons } \\
\text { (saturated) }^{1}\end{array}$ & $\begin{array}{l}1,1,1- \\
\text { trichloroethane }\end{array}$ & $\begin{array}{c}\text { Other } \\
\text { hydrocarbons }\end{array}$ \\
\hline 02-39564 & 252 & - & 17.3 & 80.4 & 1.1 & 0.54 & - & 0.13 & - & 0.49 & - \\
\hline $02-39533$ & 258 & - & 16.6 & 81.3 & 1.1 & 0.52 & - & 0.14 & 0.12 & 0.32 & - \\
\hline $02-39803$ & 218 & - & 21.0 & 76.9 & 1.1 & 0.14 & - & - & - & 0.83 & $0.05^{a}$ \\
\hline 02-39805 & 211 & - & 21.6 & 77.1 & 1.1 & 0.13 & - & - & 0.11 & - & - \\
\hline $19-02730^{3}$ & 195 & - & 21.1 & 77.9 & 0.92 & 0.06 & - & - & 0.02 & - & - \\
\hline 05-01596 & 1,073 & 0.38 & 16.0 & 77.6 & 1.0 & 2.0 & - & - & 0.15 & 2.84 & - \\
\hline $05-01772$ & 913 & 0.21 & 14.5 & 82.9 & 0.97 & 0.68 & - & 0.58 & 0.20 & - & - \\
\hline $17-04562$ & 994 & 9.88 & 1.5 & 86.1 & 1.0 & 0.36 & - & - & 1.1 & - & - \\
\hline $22-00722$ & 932 & 0.43 & 18.3 & 79.5 & 0.98 & 0.45 & - & - & 0.32 & - & - \\
\hline $42-00226$ & 876 & - & 20.6 & 77.2 & 0.93 & 0.09 & - & - & 0.36 & 0.81 & - \\
\hline \multicolumn{12}{|l|}{ Notes: } \\
\hline $\begin{array}{l}1 . \\
2 .\end{array}$ & \multicolumn{11}{|c|}{$\begin{array}{l}\text { Saturated hydrocarbons-methane through propane. } \\
\text { Other hydrocarbons-as specified. } \\
\text { a. Dichloromethane } \\
\text { Drum sealed with a semi-nermeable-gasket. }\end{array}$} \\
\hline
\end{tabular}




\subsection{Waste Form Number 119-TRU Filter Waste, Content Code RF 119A}

\subsubsection{Item Description Code 335-Absolute Drybox Filters}

3.10.1.1 Certification Assessment. This IDC is certifiable without further waste treatment. Assay and thermal power calculations, including error, need to be updated to meet the current WIPP WAC. Several gas generation criteria need to be addressed. Carbon filters may need to be installed, drums will require inspection to identify unvented or unpunctured rigid liners, and headspace gas analysis and visual waste characterization will need to be performed.

3.10.1.2 Waste Description. HEPA filters were used on gloveboxes and in large filter plenums that filter the room air.

Used filters were removed from their position in the ventilation system and packaged for further processing. The filters used on gloveboxes (nominal $8 \times 8 \times 5$ in.) were identified as IDC 335 if they were not acid contaminated. These filters consist of filter media contained within a wooden or metal frame.

The filter medium is composed of glass fiber with a small percentage of asbestos. An organic binder, elastomeric adhesive, or polyurethane sealant were used during construction. The medium also contains corrugated aluminum foil. The newer HEPA media consist of glass and aromatic polyamide fibers (Nomex) and aluminum alloy metal coated with a thermoset vinyl or epoxy. Various sealants could be present. The material is not homogenous because of the different materials used in the various sizes and by the different manufacturers of the filters. The material in IDC 335 has not been contaminated with mineral acid. However, the material may be moist or dry.

The frame material will be either $3 / 4$-in. fire-retardant, exterior-grade plywood or wood-particle board and 14-gauge cadmium-plated or chromized carbon steel. Neoprene, closed-cell expanded rubber gaskets, precoated with a rubber-based adhesive will be present on each filter (EG\&G RFP 1994f).

3.10.1.3 Generation Source. The IDC 335 HEPA filters were used to filter particulates from glovebox systems in Buildings 371, 374, 559, 707, 771, 774, 776, 777 and 779. (EG\&G RFP $1994 f$ ).

3.10.1.4 Recovery Method. Filters contaminated with amounts of plutonium above the discard limit were processed by Plutonium Recovery Operations (Building 771). The filter frame and filter media were separated. The filter frame was usually below the discard limit and was disposed of as combustible waste (IDC 330). The filter media, which were assigned IDC 338, were then packaged and reassayed. Filter media contaminated with above-discard amounts of plutonium above the discard limit were placed in storage (Clements 1982 and EG\&G RFP 1994f).

3.10.1.5 Waste Packaging and Handling. Each absolute dry-box filter removed from a glovebox was double contained in plastic bags, sealed with tape, and placed in a 55-gal drum. Generally, absolute filters were dry when packaged. Absorbent was added to any bags containing 
damp filters. When the drum was full, the drum liners were sealed and the drum was closed. The drum label, completed with all necessary information, was then taped to the drum lid and a TID was attached to the drum. The waste was initially packaged into drums by each waste-generating area and then assayed for plutonium content in Building 771. Waste contaminated with discardable amounts of plutonium were then transported to Size Reduction (Building 776) for processing. The filter wastes were relabeled as IDC 376 following processing. Alternatively, in some cases, absolute dry box filters from nonacid lines were packaged into boxes with first stage HEPA filters (IDC 490) (Rockwell International 1989b).

3.10.1.6 Container Preparation. Only approved containers could be used to package TRU waste for shipment offsite. Containers approved for shipment to INEL during this time were DOT-17C, white, 55-gal drums (Rockwell specification SX-200). These containers met the requirements for certification as DOT-7A Type A packaging (Rockwell International 1989e).

Table 3.10.1-1 shows the current inventory of IDC 335 waste containers from the Rocky Flats Plant that have been shipped to INEL since 1985.

Table 3.10.1-1. Item Description Code 335 Container Information.

\begin{tabular}{|c|c|c|c|}
\hline \multicolumn{2}{|c|}{ Information } & \multirow{2}{*}{$\frac{\text { Drums }}{13}$} & \multirow{2}{*}{$\frac{\text { Boxes }}{0}$} \\
\hline Total Containers & & & \\
\hline \multirow[t]{3}{*}{ Net Container Weight (lb) } & Maximum & 136 & N/A \\
\hline & Minimum & 2 & N/A \\
\hline & Average & 37 & $\mathrm{~N} / \mathrm{A}$ \\
\hline
\end{tabular}

3.10.1.6.1 Drum Preparation-Approved liners for drums of TRU waste packaged for offsite shipment were the round-bottom liner (Rockwell specification SX-203) inside a 90-mil rigid polyethylene liner (Rockwell specification SX-202), or an O-ring bag and a polyethylene bag placed inside the rigid liner if the drum was attached to a glovebox (Rockwell International 1989e). Type III rigid liners have been used since September 1983 (Bearly 1989a). The IDC 335 waste packaged for offsite shipment required a fiberboard liner and a two polyethylene bags inside the rigid liner (Rockwell International 1988c). Figure C-1 shows the appropriate drum liners for this IDC. All bags were closed using the twist-and-tape method (Rockwell International 1989e).

Flow-in, ventable gaskets were installed in the drums beginning in December 1982. They were used until October 1988, when tubular gaskets with carbon filters were required. Drums shipped to INEL between 1985 and 1988 may not meet the current WIPP WAC, owing to their lack of carbon filters (Bearly 1989a).

3.10.1.6.2 Box Preparation-No boxes of IDC 335 waste were shipped to INEL between 1985 and 1989 .

3.10.1.7 Assay. The drums may have been assayed on a SGS counter or a PADC. Filters of this IDC that were used in non-acid lines may have been packaged in boxes with IDC 490 (First Stage HEPA Filters). These boxes would have been assayed in the crate counter in Building 569. 
Containers of waste that have not been PADC assayed and had SGS assay values of 1 gram or less should be PADC assayed to verify that they are transuranic waste. Table 3.10.1-2 summarizes the dose rates measured on containers of this IDC. Table 3.10.1-3 provides a summary of the assay information. One drum was evaluated for uranium content, and no drums were evaluated for americium content.

Table 3.10.1-2. Item Description Code 335 Dose Information.

\begin{tabular}{crrc} 
Information & & Drums & Boxes \\
\hline One Meter Dose Rate (mrem/h) & $0-0.5$ & 10 & N/A \\
& $0.5-10$ & 3 & N/A \\
Surface Dose Rate (mrem/h) & $<10$ & 11 & N/A \\
& $10-200$ & 2 & N/A \\
\hline
\end{tabular}

Table 3.10.1-3. Item Description Code 335 Assay Information.

\begin{tabular}{|c|c|c|c|}
\hline \multicolumn{2}{|c|}{ Radionuclide inventory } & \multirow{2}{*}{$\frac{\text { Drums }}{20}$} & \multirow{2}{*}{$\frac{\text { Boxes }}{\text { N/A }}$} \\
\hline Plutonium (g) & Maximum & & \\
\hline & Minimum & 0 & N/A \\
\hline & Average & 6 & N/A \\
\hline \multirow[t]{3}{*}{ Americium (g) } & Maximum & 0 & N/A \\
\hline & Minimum & 0 & N/A \\
\hline & Average & 0 & N/A \\
\hline \multirow[t]{3}{*}{ Uranium-235 (g) } & Maximum & 9 & N/A \\
\hline & Minimum & 9 & N/A \\
\hline & Average & 9 & N/A \\
\hline
\end{tabular}

3.10.1.8 Inspection. Waste Certification personnel performed periodic inspections of the generating and packaging process to verify compliance with waste acceptance criteria. In addition, each drum was viewed using RTR to

- Ensure the drum does not contain nonconforming items

- Ensure the drum is properly packaged

- Verify the waste form description

- Evaluate the presence of free liquids.

3.10.1.9 Waste Form Evaluation. Table 3.10.1-4 evaluates the waste form against the WIPP WAC for such items as free liquids, pyrophoric materials, and compressed gases.

Table 3.10.1-5 evaluates the waste against TRUPACT criteria. 
Table 3.10.1-4. Waste Form Evaluation.

Criterion or

requirement

Limiting parameters ${ }^{2}$

Immobilization

HEPA filters were evaluated to determine if the trapped particulate could become free particulate. This evaluation demonstrated that HEPA filters meet the immobilization criteria (Arnold 1986).

Liquids This waste form meets the free liquid criteria by procedural control and RTR inspection prior to shipment from Rocky Flats. Filters are drained, dried, and packaged with Oil-Dri to ensure there is no liquid in the waste package.

Pyrophoric

Pyrophoric materials were prohibited by procedural control. The absence of the

Materials pyrophoric materials was verified by the generating supervisor and periodic inspection by the Waste Certification Organization.

Explosives and Compressed Gases

Explosives and compressed gases were prohibited by procedural control. The absence of the explosives and compressed gases was verified by the generating supervisor and periodic inspection by the Waste Certification Organization. In addition, unvented, closed containers and pressurized containers were excluded by procedural controls and RTR examination.

TRU-Mixed Wastes The RCRA constituents exist as co-contaminants with the transuranic radionuclides. Compliance with the WIPP RCRA permits and NMD will be required prior to shipment of the stored waste to WIPP.

Specific Activity of A portion of the waste stored at INEL may contain $<100$ nanocuries per gram Waste transuranic radionuclides.

$\mathrm{Pu}^{239}$ Equivalent None of the IDC 335 waste containers recorded as shipped to INEL in the Activity SWIMS exceed $1,000 \mathrm{Ci}$ of plutonium-equivalent activity.

a. Many of the limiting parameters were taken from TRU Waste Compliance Program (Rockwell International 1983a, 1987e, and 1989b). 
Table 3.10.1-5. TRUPACT Evaluation.

Criterion or

requirement

Limiting parameters ${ }^{\mathrm{a}}$

Waste Package

Weight

Waste Containers

Rocky Flats limited the gross weight of drums to $800 \mathrm{lb}$. The TRUPACT and vehicle weight limits must be verified at the time of payload assembly at INEL.

This IDC was packaged in 55-gal DOT-7A, Type A containers and with IDC 490 in metal DOT-7A metal boxes.

Nuclear

Criticality

Rocky Flats limited the fissile content of the drums to 200 grams. However, the error-times-two requirement was not in place at the time the drums were shipped to INEL; therefore, it is not reported as part of the assay of the drum. The TRUPACT limit must be verified at the time of payload assembly at INEL. Based on the typical assays of the IDC 335 drums, the criticality criteria will be met but must be recalculated or assayed to meet the error-times-two requirement.

Surface Dose Rate

The surface dose rate criteria used by Rocky Flats was $200 \mathrm{mrem} / \mathrm{hr}$ at the drum surface and $10 \mathrm{mrem} / \mathrm{hr}$ at 1 meter. Shielding was used for one IDC 335 . The TRUPACT limit must be verified at the time of payload assembly at INEL. Based on the typical dose rates from the IDC 335 drums, the dose rate criteria will be met.

Removable

Surface

The Rocky Flats limit for removable contamination (for TRU assumed to be all

Contamination alpha) was 20 disintegrations per minute $/ 100 \mathrm{~cm}^{2}$. The Rocky Flats limit is equivalent to 9 picocuries per $100 \mathrm{~cm}^{2}$, which is well within the WIPP criteria.

Thermal Power

The thermal power calculation reported in the SWIMS data package is based on the reported assay value without an error/uncertainty correction. The thermal power must be recalculated based on the assay error determination.

Gas Generation Based on the procedural requirements for packaging IDC 335 waste and the waste description, the only areas of noncompliance are carbon filters, nonpunctured rigid liners, headspace gas analysis, and visual characterization.

Halogenated organics on the TRUPACT Chemical List for Content Code RF 119A were not detected during headspace analysis.

Personnel performing RTR examination at Rocky Flats would accept up to $10 \%$ of another IDC. The other IDCs could be combustibles, glass, concrete, metal, leaded gloves, and plastics.

a. Many of the limiting parameters were taken from TRU Waste Compliance Program (Rockwell International 1983a, 1987e, and 1989b).

3.10.1.10 Combustible and Organic Content. SWIMS data indicate that this waste form contains $>20 \%$ combustibles and $>20 \%$ organics. 
3.10.1.10.1 Combustible Content-SWIMS data show that IDC 335 waste is combustible (EG\&G RFP 1993c).

3.10.1.10.2 Organic Content-SWIMS data show that IDC 335 waste contains $80 \%$ organics (Rockwell International 1985a).

3.10.1.11 Analytical Information. Analytical data from the TRU Waste Sampling Waste Characterization Program (Clements and Kudera 1985) for IDC 335, Absolute Drybox Filters, indicates that one drum was subject to headspace gas analysis. Gas composition analytical results are presented in Table 3.10.1-6. Waste boxes were not sampled. Oxygen, nitrogen, argon, carbon dioxide and nitrogen oxides(s) were detected in the drum.

The Absolute drybox filters used in conjunction with the Saltcrete process in Building 374 are contaminated with RCRA metals and F-listed solvents and sludges. Any filters generated from Building 774 may have been contaminated by carbon tetrachloride and other solvents from the OASIS process. Other IDC 335 glovebox HEPA filters could have been used to filter glovebox exhaust with Freon, carbon tetrachloride, trichloroethane, and other solvent vapors. Therefore, EPA codes that may pertain to this waste include D001, D004, D005, D006, D007, D008, D009, D010, D011, D019, F001, F002, F005, F006, F007 and F009 (EG\&G RFP 1994f). 
Table 3.10.1-6. Gas Sampling Results-Compositional Analysis (vol\%).

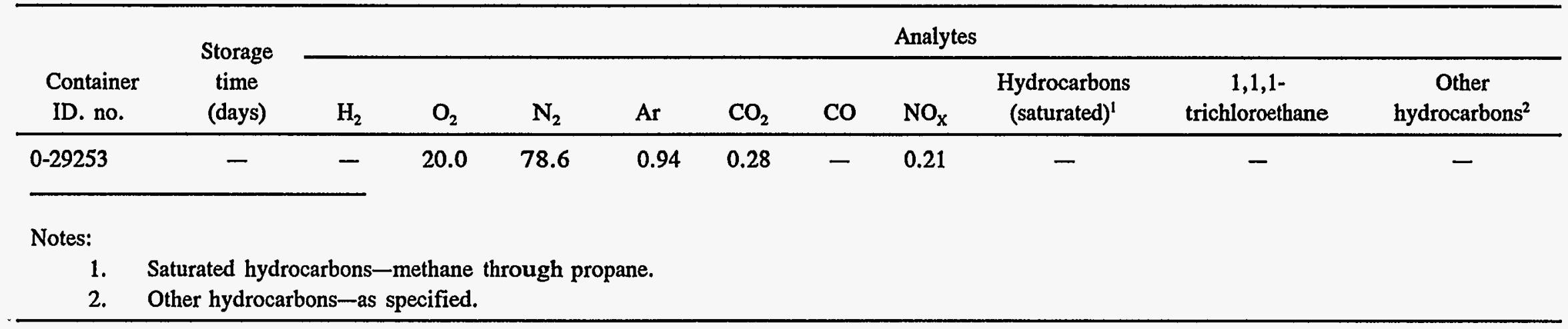




\subsection{Waste Form Number 119-TRU Filter Waste, Content Code RF 119A}

\subsubsection{Item Description Code 376-Processed Filter Media}

3.10.2.1 Certification Assessment. This IDC is certifiable without further waste treatment. Assay and thermal power calculations, including error, need to be updated to meet the current WIPP WAC. Several gas generation criteria need to be addressed. Carbon filters may need to be installed, drums will require inspection to identify unvented or unpunctured rigid liners, and headspace gas analysis and visual waste characterization will need to be performed.

3 10.2.2 Waste Description. IDC 376 is the filter media portion of HEPA filters, and includes the processed filter media portion of the used HEPA filters. This material consists of pieces ranging in size from $20 \times 20$-in. to $2 \times 2$-in. square pieces. These pieces are composed of glass fibers with a small percentage of asbestos. An organic binder, elastomeric adhesive, or polyurethane sealant was used during construction. The pieces also contain corrugated aluminum foil. The newer media consist of glass and aromatic polyamide fibers (Nomex) and aluminum alloy metal coated with a thermoset vinyl or epoxy. Various sealants could be present. The material is not homogeneous because of the different materials used and the different manufacturers of the filters. The filter media material can be free of acid contamination or can be heavily contaminated with acid residue. It can also be either moist or dry (EG\&G RFP 1994f).

3.10.2.3 Generation Source. IDC 376 filter media was derived from the processing of HEPA filters from Buildings 371, 771, 776, and 779 (EG\&G RFP 1994f).

3.10.2.4 Recovery Method. This $\mathrm{DC}$ was never generated as a residue and therefore has no recovery method.

3.10.2.5 Waste Packaging and Handling. Ful-flo filters were bagged out of the glovebox and placed in prepared 55-gal waste drums. Filter media was packaged by placing the media into a 1-gal polyethylene bottle or in a polyethylene bag and bagging it out of the glovebox. Each bottle or bag is placed in a prepared 55-gal drum. The absolute dry box filters, Ful-flo filters, and filter media are mixed with Portland cement, which neutralizes acid and adsorbs any residual liquid to meet the WIPP WAC. IDCs 335, 328, and 338 are identified as processed filter media (IDC 376) following mixing with Portland cement (Rockwell International 1989b).

3.10.2.6 Container Preparation. Only approved containers could be used to package TRU waste for shipment offsite. Containers approved for shipment to INEL during this time were DOT17C, white, 55-gal drums (Rockwell specification SX-200). These containers met the requirements for certification as DOT-7A Type A packaging (Rockwell International 1989e).

Table 3.10.2-1 shows the current inventory of IDC 376 waste containers from the Rocky Flats Plant that have been shipped to INEL since 1985 . 
Table 3.10.2-1. Item Description Code 376 Container Information.

\begin{tabular}{lrrc}
\hline \multicolumn{1}{c}{ Information } & & Drums & Boxes \\
\hline Total Containers & & 1,095 & 0 \\
Net Container Weight (lb) & Maximum & 292 & N/A \\
& Minimum & 7 & N/A \\
& Average & 77 & N/A \\
\hline
\end{tabular}

3 10.2.6.1 Drum Preparation-Approved liners for drums of TRU waste packaged for offsite shipment were the round-bottom liner (Rockwell specification SX-203) inside a 90-mil rigid polyethylene liner (Rockwell specification SX-202), or an O-ring bag and a polyethylene bag placed inside the rigid liner if the drum was attached to a glovebox (Rockwell International 1989e). Type III rigid liners have been used since September 1983 (Bearly 1989a). The IDC 376 waste packaged for offsite shipment required a fiberboard liner and a two polyethylene bags inside the rigid liner (Rockwell International 1988c). Figure C-1 shows the appropriate drum liners for this IDC. If a single piece of heavy metal was packaged in a drum, it was braced to prevent shifting. Sharp edges were taped to prevent puncturing of the liners (Rockwell International 1989b). All bags were closed using the twist-and-tape method (Rockwell International 1989e).

Flow-in, ventable gaskets were installed in the drums beginning in December 1982. They were used until October 1988, when tubular gaskets with carbon filters were required. Drums shipped to INEL between 1985 and 1988 may not meet the current WIPP WAC, owing to their lack of carbon filters (Bearly 1989a).

3.10.2.6.2 Box Preparation-No boxes of IDC 376 waste were shipped to INEL between 1985 and 1989.

3.10.2.7 Assay. The drums may have been assayed on a SGS counter or a PADC. Containers of waste that have not been PADC assayed and had SGS assay values of 1 gram or less should be PADC assayed to verify that they are transuranic waste. Table 3.10.2-2 summarizes the dose rates measured on containers of this IDC. Table $3.10 .2-3$ provides a summary of the assay information. Seven drums were evaluated for americium content and 15 drums were evaluated for uranium content.

Table 3.10.2-2. Item Description Code 376 Dose Information.

\begin{tabular}{crrr}
\hline Information & & Drums & Boxes \\
\hline One Meter Dose Rate (mrem/h) & $0-0.5$ & 827 & N/A \\
& $0.5-10$ & 268 & N/A \\
Surface Dose Rate (mrem/h) & $<10$ & 1,078 & N/A \\
& $10-200$ & 17 & N/A \\
\hline
\end{tabular}


Table 3.10.2-3. Item Description Code 376 Assay Information.

\begin{tabular}{|c|c|c|c|}
\hline \multicolumn{2}{|c|}{ Radionuclide inventory } & \multirow{2}{*}{$\frac{\text { Drums }}{198}$} & \multirow{2}{*}{$\frac{\text { Boxes }}{\text { N/A }}$} \\
\hline Plutonium (g) & Maximum & & \\
\hline & Minimum & 0 & N/A \\
\hline & Average & 34 & N/A \\
\hline Americium (g) & Maximum & 1 & N/A \\
\hline & Minimum & 0 & N/A \\
\hline & Average & 0.6 & N/A \\
\hline Uranium-235 (g) & Maximum & 23 & N/A \\
\hline & Minimum & 1 & N/A \\
\hline & Average & 14 & N/A \\
\hline
\end{tabular}

3.10.2.8 Inspection. Waste Certification personnel performed periodic inspections of the generating and packaging process to verify compliance with waste acceptance criteria. In addition, each drum was viewed using RTR to

- Ensure the drum does not contain nonconforming items

- Ensure the drum is properly packaged

- Verify the waste form description

- Evaluate the presence of free liquids.

3.10.2.9 Waste Form Evaluation. Table 3.10.2-4 evaluates the waste form against the WIPP WAC for such items as free liquids, pyrophoric materials, and compressed gases.

Table 3.10.2-5 evaluates the waste against TRUPACT criteria. 
Table 3.10.2-4. Waste Form Evaluation.

Criterion or

requirement

Limiting parameters ${ }^{a}$

Immobilization

HEPA filters were evaluated to determine if the trapped particulate could become free particulate. This evaluation demonstrated that processed HEPA filters meet the immobilization criteria (Arnold 1986).

Liquids

This waste form meets the free liquid criteria by procedural control and RTR inspection prior to shipment from Rocky Flats.

Pyrophoric

Materials

Pyrophoric materials were prohibited by procedural control. The absence of the pyrophoric materials was verified by the generating supervisor and periodic inspection by the Waste Certification Organization.

Explosives and Compressed Gases

Explosives and compressed gases were prohibited by procedural control. The absence of the explosives and compressed gases was verified by the generating supervisor and periodic inspection by the Waste Certification Organization. In addition, unvented, closed containers and pressurized containers were excluded by procedural controls and RTR examination.

TRU-Mixed Wastes The RCRA constituents exist as co-contaminants with the transuranic radionuclides. Compliance with the WIPP RCRA permits and NMD will be required prior to shipment of the stored waste to WIPP. Filters from Building 771 FU2B Incinerator Plenum are contaminated with barium and lead.

Specific Activity of Waste

A portion of the waste stored at INEL may contain $<100$ nanocuries per gram transuranic radionuclides.

$\mathrm{Pu}^{239}$ Equivalent None of the IDC 376 waste containers recorded as shipped to INEL in the Activity SWIMS exceed $1,000 \mathrm{Ci}$ of plutonium-equivalent activity.

a. Many of the limiting parameters were taken from TRU Waste Compliance Program (Rockwell International 1983a, 1987e, and 1989b). 
Table 3.10.2-5. TRUPACT Evaluation.

Criterion or

requirement

Limiting parameters ${ }^{2}$

Waste Package

Weight

Waste Containers

Rocky Flats limited the gross weight of drums to $800 \mathrm{lb}$. The TRUPACT and

Nuclear

Criticality

vehicle weight limits must be verified at the time of payload assembly at INEL.

\author{
Criticality
}

Surface Dose The surface dose rate criteria used by Rocky Flats was $200 \mathrm{mrem} / \mathrm{hr}$ at the drum

Rate

This IDC was packaged in 55-gal DOT-7A, Type A containers.

Rocky Flats limited the fissile content of the drums to 200 grams. However, the error-times-two requirement was not in place at the time the drums were shipped to INEL; therefore, it is not reported as part of the assay of the drum. The TRUPACT limit must be verified at the time of payload assembly at INEL.

Based on the typical assays of the IDC 376 drums, the criticality criteria will be met but must be recalculated or assayed to meet the error-times-two requirement. The TRUPACT limit must be verified at the time of payload assembly at INEL. Based on the typical dose rates from the IDC 376 drums, the dose rate criteria will be met.

Removable The Rocky Flats limit for removable contamination (for TRU assumed to be all Surface alpha) was 20 disintegrations per minute $/ 100 \mathrm{~cm}^{2}$. The Rocky Flats limit is

Contamination equivalent to 9 picocuries per $100 \mathrm{~cm}^{2}$, which is well within the WIPP criteria.

Thermal Power The thermal power calculation reported in the SWIMS data package is based on the reported assay value without an error/uncertainty correction. The thermal power must be recalculated based on the assay error determination.

Gas Generation Based on the procedural requirements for packaging IDC 376 waste and the waste description, the only areas of noncompliance are carbon filters, nonpunctured rigid liners, headspace gas analysis, and visual characterization.

Halogenated organics on the TRUPACT Chemical List for Content Code RF 119A were not detected during headspace analysis.

Personnel performing RTR examination at Rocky Flats would accept up to $10 \%$ of another IDC. The other IDCs could be combustibles, glass, concrete, metal, leaded gloves, and plastics.

a. Many of the limiting parameters were taken from TRU Waste Compliance Program (Rockwell International 1983a, 1987e, and 1989b).

3.10.2.10 Combustible and Organic Content. SWIMS data indicate that this waste form does not contain $>20 \%$ combustibles or $>20 \%$ organics.

3.10.2.10.1 Combustible Content-SWIMS data show that IDC 376 waste is noncombustible (Rockwell International 1985a). 
3.10.2.10.2 Organic Content-SWIMS data show that IDC 376 waste contains $20 \%$ organics (Rockwell International 1985a).

3.10.2.11 Analytical Information. Analytical data from the TRU Waste Sampling Waste Characterization Program (Clements and Kudera 1985) for IDC 376, Processed Filter Media, indicates that three drums were subject to headspace gas analysis. Gas composition analytical results are presented in Table 3.10.2-6. Waste boxes were not sampled. Hydrogen, oxygen, nitrogen, argon and carbon dioxide were detected in the drums.

Processed filter media could have been used to filter nitric-acid vapors and could exhibit the characteristic of ignitability due to the presence of nitric acid. These containers are therefore assigned EPA Code D001 (EG\&G RFP 1994f). 


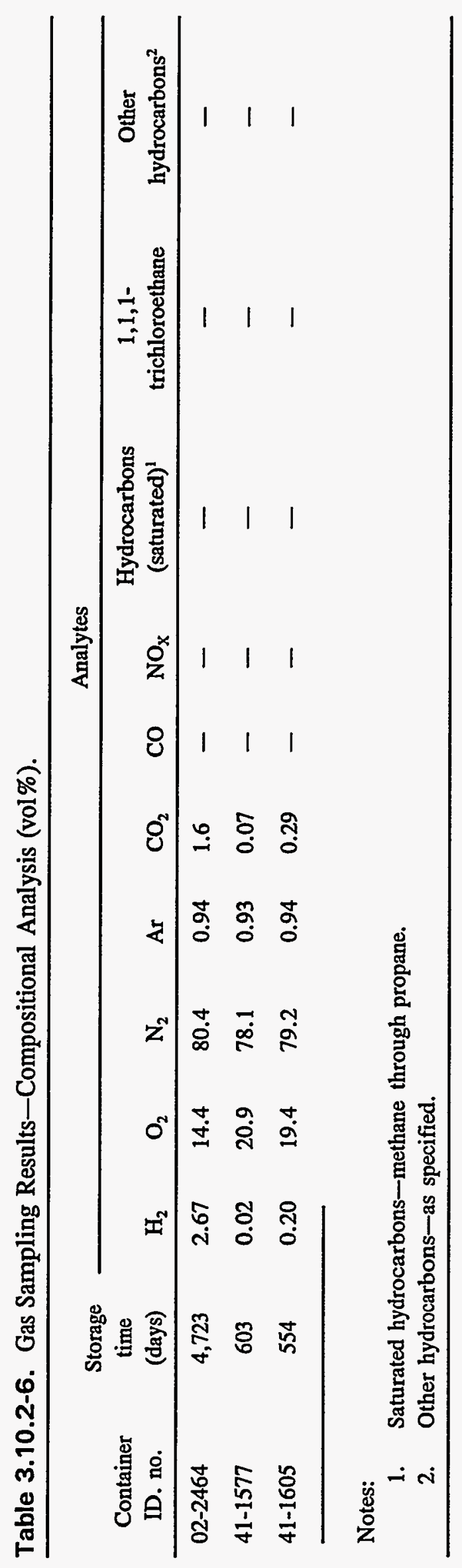




\subsection{Waste Form Number 119-TRU Filter Waste, Content Code RF 119A}

\subsubsection{Item Description Code 490-HEPA Filters}

3.10.3.1 Certification Assessment. This IDC is certifiable without further waste treatment. Assay and thermal power calculations, including error, need to be updated to meet the current WIPP WAC. Several gas generation criteria need to be addressed. Carbon filters may need to be installed, drums will require inspection to identify unvented or unpunctured rigid liners, and headspace gas analysis and visual waste characterization will need to be performed. Metal boxes are not authorized for shipment in the TRUPACT II.

3. 10.3.2 Waste Description. IDC 490 HEPA Filters $(24 \times 24$-in.), not acid contaminated, are large HEPA filters (nominal $24 \times 24 \times 5$-in.) that were used in filter plenum racks. These filters consist of filter media contained within a wooden or metal frame.

The filter medium is composed of glass fibers, with a small percentage of asbestos. An organic binder, elastomeric adhesive, or polyurethane sealant was used during construction. The medium also contains corrugated aluminum foil: The newer HEPA media will consist of glass and aromatic polyamide fibers (Nomex) and aluminum alloy metal coated with a thermoset vinyl or epoxy. Various sealants could be present. The material will not be homogeneous because of the different materials used in the different sizes and by the different manufacturers of the filters. The material in IDC 490 has not been contaminated with mineral acid. However, the material may be moist or dry.

The frame material will be either $3 / 4$-in., fire-retardant, exterior-grade plywood or wood-particle board and 14-gauge cadmium-plated or chromized carbon steel. Neoprene, closed-cell, expanded rubber, precoated with a rubber-based adhesive is present on each filter. (EG\&G RFP 1994f).

3.10.3.3 Generation Source. IDC 490 HEPA filters consist of filters from Buildings 374, 664, 690K, 771, 774, 776, and 777 (EG\&G RFP 1994f).

3.10.3.4 Recovery Method. Filters contaminated with amounts of plutonium above the discard limit were processed by Plutonium Recovery Operations (Building 771). The filter frame and filter media were separated. The filter frame was usually below the discard limit and was disposed of as combustible waste (IDC 330). The filter media, which were assigned IDC 338, were then packaged and reassayed. Filter media contaminated with amounts of plutonium above the discard limit were placed in storage. Contaminated media below the discard limit were processed by Size Reduction as IDC 376 waste (Clements 1982 and EG\&G RFP 1994f).

3. 10.3.5 Waste Packaging and Handling. Waste HEPA filters were sent to the Size Reduction Facility in Building 776. Processing and repackaging are performed under controlled conditions in the vault. The HEPA filters were crushed in a press after being removed from their cardboard carton. The crushed filter was then placed into a prepared waste box. The cardboard boxes used for transporting the filters were cut flat and placed on top of the filters before the box was closed and sealed. 
3.10.3.6 Container Preparation. Only approved containers could be used to package TRU waste for shipment offsite. Containers approved for shipment to INEL during this time were DOT17C, white, 55-gal drums (Rockwell specification SX-200); white, corrugated steel boxes (Rockwell specification SX-231); and FRP boxes (Rockwell specification SX-207). Each of these containers met the requirements for certification as DOT-7A Type A packaging (Rockwell International 1989e).

Table 3.10.3-1 shows the current inventory of IDC 490 waste containers from the Rocky Flats Plant that have been shipped to INEL since 1985.

Table 3.10.3-1. Item Description Code 490 Container Information.

\begin{tabular}{lrrr}
\hline \multicolumn{1}{c}{ Information } & & Drums & Boxes \\
\hline Total Containers & & 47 & 147 \\
Net Container Weight (lb) & Maximum & 105 & 2,070 \\
& Minimum & 3 & 410 \\
& Average & 53 & 1,220 \\
\hline
\end{tabular}

3.10.3.6.1 Drum Preparation-Approved liners for drums of TRU waste packaged for offsite shipment were the round-bottom liner (Rockwell specification SX-203) inside a 90-mil rigid polyethylene liner (Rockwell specification SX-202), or an O-ring bag and a polyethylene bag placed inside the rigid liner if the drum was attached to a glovebox (Rockwell International 1989e). Type III rigid liners have been used since September 1983 (Bearly 1989a). The IDC 490 waste packaged for offsite shipment required a fiberboard liner and a two polyethylene bags inside the rigid liner (Rockwell International 1988c). Figure C-1 shows the appropriate drum liners for this IDC. All bags were closed using the twist-and-tape method (Rockwell International 1989e).

Flow-in, ventable gaskets were installed in the drums beginning in December 1982. They were used until October 1988, when tubular gaskets with carbon filters were required. Drums shipped to INEL between 1985 and 1988 may not meet the current WIPP WAC, owing to their lack of carbon filters (Bearly 1989a).

3.10.3.6.2 Box Preparation-FRP boxes were used for waste shipped to INEL from 1972 through 1982 (Riddle and others 1985). In 1982, the use of the corrugated metal waste box was phased in. The last FRP box was shipped to INEL in 1986. In the interim, waste packaged in both types of boxes had been shipped to INEL. SWIMS information did not track the type of box used in individual shipments.

The FRP box was constructed of $3 / 4$-in. exterior plywood with $2 \times 4$-in. framing members and skids. The entire box was coated with a 0.12 -in. coat of fiberglass-reinforced polyester with flameretardant properties. The continuous FRP coating provides a leakproof, tamper-proof package. Inner liners used for contamination control during loading consist of a PVC liner protected by a 50-mil fiberboard sheet. The box size was $4 \times 4 \times 7 \mathrm{ft}$ or larger. The gross weight was normally restricted to 5,000 lb (Riddle and others 1985). 
The corrugated metal waste boxes were made entirely out of 14-gauge (0.0747-in.), low-carbon steel. All seams including the closure were welded to produce a leaktight container (Brugger 1983). These boxes required a 10-mil PVC liner (Rockwell specification SX-209) and a 0.051-in. fiberboard liner (Rockwell specification SX-209) (Riddle and others 1985; Bearly and others 1988). Figure C-5 shows the appropriate box liners required for this IDC. Four sizes of the box have been certified as DOT-7A containers, with a maximum size of $54 \times 54 \times 89$ in. and a maximum gross weight of $7,000 \mathrm{lb}$. These containers are commonly referred to as "Sand Boxes" (Riddle and others 1985).

Where necessary, items that had a weight distribution or configuration which caused them to sit in an unstable condition in the container were blocked, braced, or banded to prevent the items from shifting (Rockwell International 1989e). All items that had the potential to puncture or otherwise compromise the integrity of the waste box were adequately prepackaged to cover sharp corners (Rockwell International 1989e).

3.10.3.7 Assay. The drums may have been assayed on a SGS counter or a PADC. A HEPA LOSAC counter was installed in Building 771 in 1988. This counter used nontransmissioncorrected, low-resolution sodium iodide technology. This counter has the capability to perform TRU/LLW sorting of individual plenum HEPA filters or drums of low-density wastes such as combustibles. Boxes of this IDC may contain IDC 335 filters that were used in non-acid lines. Boxes were assayed in the crate counter in Building 569. Containers of waste that have not been PADC assayed and had crate counter assay values of 1 gram or less should be PADC assayed to verify that they are transuranic waste. Table 3.10.3-2 summarizes the dose rates measured on containers of this IDC. Table 3.10.3-3 provides a summary of the assay information. Five drums were evaluated for americium content, and no drums were evaluated for uranium content. Five boxes were evaluated for uranium content, and no boxes were evaluated for americium content.

Table 3.10.3-2. Item Description Code 490 Dose Information.

\begin{tabular}{|c|c|c|c|}
\hline Information & & Drums & Boxes \\
\hline One Meter Dose Rate (mrem/h) & $\begin{array}{r}0-0.5 \\
0.5-10\end{array}$ & $\begin{array}{r}14 \\
\cdot \quad 33\end{array}$ & $\begin{array}{r}143 \\
4\end{array}$ \\
\hline Surface Dose Rate $(\mathrm{mrem} / \mathrm{h})$ & $\begin{array}{r}<10 \\
10-200\end{array}$ & $\begin{array}{l}32 \\
15\end{array}$ & $\begin{array}{r}147 \\
0\end{array}$ \\
\hline
\end{tabular}


Table 3.10.3-3. Item Description Code 490 Assay Information.

\begin{tabular}{|c|c|c|c|}
\hline \multicolumn{2}{|c|}{ Radionuclide inventory } & \multirow{2}{*}{$\frac{\text { Drums }}{127}$} & \multirow{2}{*}{$\frac{\text { Boxes }}{175}$} \\
\hline Plutonium (g) & Maximum & & \\
\hline & Minimum & 12 & 0 \\
\hline & Average & 37 & 27 \\
\hline Americium (g) & Maximum & 1 & 0 \\
\hline & Minimum & 0 & 0 \\
\hline & Average & 0.8 & 0 \\
\hline Uranium-235 (g) & Maximum & - & 5 \\
\hline & Minimum & - & 5 \\
\hline & Average & - & 5 \\
\hline
\end{tabular}

3.10.3.8 Inspection. Waste Certification personnel performed periodic inspections of the generating and packaging process to verify compliance with waste acceptance criteria. In addition, each container was viewed using RTR to

- Ensure the container does not contain nonconforming items

- Ensure the container is properly packaged

- Verify the waste form description

- Evaluate the presence of free liquids.

3.10.3.9 Waste Form Evaluation. Table 3.10.3-4 evaluates the waste form against the WIPP WAC for such items as free liquids, pyrophoric materials, and compressed gases.

Table 3.10.3-5 evaluates the waste against TRUPACT criteria. 
Table 3.10.3-4 Waste Form Evaluation.

Criterion or

requirement

Limiting parameters ${ }^{2}$

Immobilization

HEPA filters were evaluated to determine if the trapped particulates could become free particulates. This evaluation demonstrated that HEPA filters meet the immobilization criteria (Arnold 1986).

Liquids

This waste form meets the free liquid criteria by procedural control and RTR inspection prior to shipment from Rocky Flats. Filters are drained, dried, and packaged with Oil-Dri to ensure there is no liquid in the waste package.

Pyrophoric

Materials

Pyrophoric materials were prohibited by procedural control. The absence of the pyrophoric materials was verified by the generating supervisor and periodic inspection by the Waste Certification Organization.

Explosives and Compressed Gases

Explosives and compressed gases were prohibited by procedural control. The absence of the explosives and compressed gases was verified by the generating supervisor and periodic inspection by the Waste Certification Organization. In addition, unvented, closed containers and pressurized containers were excluded by procedural controls and RTR examination.

TRU-Mixed Wastes This is a nonhazardous waste. Compliance with the WIPP RCRA permits and NMD will be required prior to shipment of the stored waste to WIPP. Filters from the Building 771 FU2B Incinerator Plenum are contaminated with barium and lead.

Specific Activity of Waste

A portion of the waste stored at INEL may contain $<100$ nanocuries per gram transuranic radionuclides.

$\mathrm{Pu}^{239}$ Equivalent None of the IDC 490 waste containers recorded as shipped to INEL in the Activity SWIMS exceed $1,000 \mathrm{Ci}$ of plutonium-equivalent activity.

a. Many of the limiting parameters were taken from TRU Waste Compliance Program (Rockwell International 1983a, 1987e, and 1989b). 
Table 3.10.3-5. TRUPACT Evaluation.

Criterion or

requirement

Limiting parameters ${ }^{2}$

Waste Package

Weight

Waste Containers

Rocky Flats limited the gross weight of drums to $800 \mathrm{lb}$. The TRUPACT and vehicle weight limits must be verified at the time of payload assembly at INEL. Metal boxes are not authorized for shipment in the TRUPACT II.

Nuclear Criticality

This IDC was packaged in 55-gal DOT-7A, Type A containers and in metal DOT7A metal boxes.

Rocky Flats limited the fissile content of the drums to 200 grams and boxes to 350 grams. However, the error-times-two requirement was not in place at the time the containers were shipped to INEL; therefore, it is not reported as part of the assay of the container. The TRUPACT limit must be verified at the time of payload assembly at INEL. Based on the typical assays of the IDC 490 containers, the criticality criteria will be met but must be recalculated or assayed to meet the errortimes-two requirement.

Surface Dose The surface dose rate criteria used by Rocky Flats was $200 \mathrm{mrem} / \mathrm{hr}$ at the Rate container surface and $10 \mathrm{mrem} / \mathrm{hr}$ at 1 meter. Shielding was not necessary for IDC 490 containers. The TRUPACT limit must be verified at the time of payload assembly at INEL. Based on the typical dose rates from the IDC 490 containers, the dose rate criteria will be met.

Removable The Rocky Flats limit for removable contamination (for TRU assumed to be all Surface

Contamination alpha) was 20 disintegrations per minute $/ 100 \mathrm{~cm}^{2}$. The Rocky Flats limit is

Thermal Power equivalent to 9 picocuries per $100 \mathrm{~cm}^{2}$, which is well within the WIPP criteria.

The thermal power calculation reported in the SWIMS data package is based on the reported assay value without an error/uncertainty correction. The thermal power must be recalculated based on the assay error determination.

Gas Generation Based on the procedural requirements for packaging IDC 490 waste and the waste description, the only areas of noncompliance are carbon filters, nonpunctured rigid liners, headspace gas analysis, and visual characterization.

Halogenated organics on the TRUPACT Chemical List for Content Code RF 119A were not detected during headspace analysis.

Personnel performing RTR examination at Rocky Flats would accept up to $10 \%$ of another IDC. The other IDCs could be combustibles, glass, concrete, metal, leaded gloves, and plastics.

a. Many of the limiting parameters were taken from TRU Waste Compliance Program (Rockwell International 1983a, 1987e, and 1989b).

3.10.3.10 Combustible and Organic Content. SWIMS data indicate that this waste form contains $>20 \%$ combustibles and $>20 \%$ organics. 
3.10.3.10.1 Combustible Content-SWIMS data show that IDC 490 waste is combustible (EG\&G RFP 1993c).

3.10.3.10.2 Organic Content-SWIMS data show that IDC 490 waste contains $80 \%$ organics (Rockwell International 1985a).

3.10.3.11 Analytical Information. No analytical information is available for IDC 490 .

These filters were generated from processes for which there would be no "carry-over" of solvent contamination from vapors (Colorado Department of Health 1993). Exclusion of filters from "carryover" contamination is based on WSRIC information and a Waste Technical Support Memorandum (EG\&G RFP 1993d). These filters are, therefore, nonhazardous (EG\&G RFP 1994f).

One container of IDC 490 waste (M00821) may contain filters generated in the 804A and 804B plenums of the Building 374 evaporation operation. Based on information obtained from Liquid Waste Treatment Operations by Waste Technical Support, there is a visible buildup of salt on the first and second stage filters. The F-codes and D-codes applicable to the salt would be retained by these filters since the filters are "carrying over" the waste. Box M00821 is assigned EPA Codes D001, D004, D005, D006, D007, D008, D009, D010, D011, F001, F002, F005, F006, F007, F009 (WASTREN, Inc. 1994a). 


\subsection{Waste Form Number 121-TRU Organic Solid Waste, Content Code RF 121A}

\subsubsection{Item Description Code 302-Benelex \& Plexiglas}

3.11.1.1 Certification Assessment. This IDC is certifiable without further waste treatment. Assay and thermal power calculations, including error, need to be updated to meet the current WIPP WAC. Several gas generation criteria need to be addressed. Carbon filters may need to be installed, drums will require inspection to identify unvented or unpunctured rigid liners, and headspace gas analysis and visual waste characterization will need to be performed.

3.11.1.2 Waste Description. IDC 302 included Benelex and Plexiglas. Benelex was a very dense organic material used for radiation shielding around gloveboxes and tanks. In some cases, Benelex was laminated with lead. However, none of the containers identified here had lead lamination. The Benelex used by RFP was usually 2 -in. thick, although occasionally two 2-in. thick pieces were bolted together to increase shield thickness. Plexiglas was a trade name used to describe a family of polycarbonate materials used for radiation shielding in glovebox windows and equipment enclosures. Plexiglas glovebox windows were generally 2- to 4-in. thick and could be in various sizes and shapes (EG\&G RFP 1994g).

3.11.1.3 Generation Source. Benelex and Plexiglas were generated in Buildings 371, 707, 771 , and 776. The IDC was generated as waste during replacement of shielding or installation of new gloveboxes or tanks

(EG\&G RFP 1994g).

3.11.1.4 Recovery Method. This IDC was never generated as a residue and therefore had no recovery method (EG\&G RFP 1994g).

3.11.1.5 Waste Packaging and Handling. Benelex and Plexiglas waste was generated during strip-out operations. This waste was considered TRU waste only if the Radiation Monitoring survey results indicated high enough contamination levels. The drums were DOT-17C, white, 55-gal drums (Rockwell International 1989b). When the drum was full, the drum liners were sealed and the drum was closed. The drum label, completed with all necessary information, was then taped to the drum lid and a TID was attached to the drum. Benelex and Plexiglas were generally massive sheets or slabs of material and were generally placed directly into boxes (Rockwell International 1989b).

3.11.1.6 Container Preparation. Only approved containers could be used to package TRU waste for shipment offsite. Containers approved for shipment to INEL during this time were DOT17C, white, 55-gal drums (Rockwell specification SX-200). These containers met the requirements for certification as DOT-7A Type A packaging (Rockwell International 1989e).

Table 3.11.1-1 shows the current inventory of IDC 302 waste containers from the Rocky Flats Plant that had been shipped to INEL since 1985. 
Table 3.11.1-1. Item Description Code 302 Container Information.

\begin{tabular}{lrcc}
\hline \multicolumn{1}{c}{ Information } & & Drums & Boxes \\
\hline Total Containers & & 2 & 0 \\
Net Container Weight $(\mathrm{lb})$ & Maximum & 90 & N/A \\
& Minimum & 17 & N/A \\
& Average & 54 & N/A \\
\hline
\end{tabular}

3.11 1.6.1 Drum Preparation-Approved liners for drums of TRU waste packaged for offsite shipment were the round-bottom liner (Rockwell specification SX-203) inside a 90-mil rigid polyethylene liner (Rockwell specification SX-202), or an O-ring bag and a polyethylene bag placed inside the rigid liner if the drum was attached to a glovebox (Rockwell International 1989e). Type III rigid liners had been used since September 1983 (Bearly 1989a). The IDC 302 waste packaged for offsite shipment required a fiberboard liner and two polyethylene bags inside the rigid liner (Rockwell International 1988c). Figure C-1 shows the appropriate drum liners for this IDC. All bags were closed using the twist-and-tape method (Rockwell International 1989e).

Flow-in, ventable gaskets were installed in the drums beginning in December 1982. They were used until October 1988, when tubular gaskets with carbon filters were required. Drums shipped to INEL between 1985 and 1988 may not have met the current WIPP WAC, owing to their lack of carbon filters (Bearly 1989a).

3.11. 1.6.2 Box Preparation-No boxes of IDC 302 waste were shipped to INEL between 1985 and 1989.

3.11.1.7 Assay. The drums may have been assayed on an SGS counter or a PADC. Containers of waste that have not been PADC assayed and had SGS assay values of 1 gram or less should be PADC assayed to verify that they are transuranic waste. Table 3.11.1-2 summarizes the dose rates measured on containers of this IDC. Table $3.11 .1-3$ provides a summary of the assay information.

Table 3.11.1-2. Item Description Code 302 Dose Information.

\begin{tabular}{crcc} 
Information & & Drums & Boxes \\
\hline One Meter Dose Rate (mrem/h) & $0-0.5$ & 2 & N/A \\
& $0.5-10$ & 0 & N/A \\
Surface Dose Rate (mrem/h) & $<10$ & 2 & N/A \\
& $10-200$ & 0 & N/A \\
\hline
\end{tabular}


Table 3.11.1-3. Item Description Code 302 Assay Information.

\begin{tabular}{|c|c|c|c|}
\hline \multicolumn{2}{|c|}{ Radionuclide inventory } & \multirow{2}{*}{$\frac{\text { Drums }}{12}$} & \multirow{2}{*}{$\frac{\text { Boxes }}{\text { N/A }}$} \\
\hline Plutonium (g) & Maximum & & \\
\hline & Minimum & 0 & N/A \\
\hline & Average & 6 & N/A. \\
\hline \multirow[t]{3}{*}{ Americium (g) } & Maximum & 0 & N/A \\
\hline & Minimum & 0 & N/A \\
\hline & Average & 0 & N/A \\
\hline \multirow[t]{3}{*}{ Uranium-235 (g) } & Maximum & 0 & N/A \\
\hline & Minimum & 0 & N/A \\
\hline & Average & 0 & N/A \\
\hline
\end{tabular}

3.11.1.8 Inspection. Waste Certification personnel performed periodic inspections of the generating and packaging process to verify compliance with waste acceptance criteria. In addition, each drum was viewed using RTR to

- Ensure the drum did not contain nonconforming items

- Ensure the drum was properly packaged

- Verify the waste form description

- Evaluate the presence of free liquids.

Other IDCs were not allowed to be packaged with this IDC; however, if such material was not rejected by Waste Certification inspections, RTR examination would accept up to $10 \%$ of another IDC.

3.11.1.9 Waste Form Evaluation. Table 3.11.1-4 evaluates the waste form against the WIPP WAC for such items as free liquids, pyrophoric materials, and compressed gases.

Table 3.11.1-5 evaluates the waste against TRUPACT criteria. 
Table 3.11.1-4. Waste Form Evaluation.

Criterion or requirement

Limiting parameters ${ }^{2}$

Immobilization

Particulates were prohibited by procedural control. Based on the description of the waste, fine particulates are not expected in this IDC.

Liquids

There are normally no liquids associated with this IDC. Personnel performing RTR examination at Rocky Flats would accept up to 2 cups of liquid, if liquids were present.

Pyrophoric

Pyrophoric materials were prohibited by procedural control. The absence of the

Materials pyrophoric materials was verified by the generating supervisor and periodic inspection by the Waste Certification Organization.

Explosives and

Compressed Gases

Explosives and compressed gases were prohibited by procedural control. The absence of the explosives and compressed gases was verified by the generating supervisor and periodic inspection by the Waste Certification Organization. In addition, unvented, closed containers and pressurized containers were excluded by procedural controls and RTR examination.

TRU-Mixed Wastes Any RCRA constituents exist as co-contaminants with the transuranic radionuclides. EG\&G RFP has characterized IDC 302 as nonmixed waste. Compliance with the WIPP RCRA permits and NMD will be required prior to shipment of the stored waste to WIPP.

Specific Activity of Drums with plutonium assays of 1 gram or less may contain $<100$ nanocuries Waste per gram of transuranic radionuclides.

$\mathrm{Pu}^{239}$ Equivalent None of the IDC 302 waste containers recorded as shipped to INEL in the Activity SWIMS exceed $1,000 \mathrm{Ci}$ of plutonium-equivalent activity.

a. Many of the limiting parameters were taken from TRU Waste Compliance Program (Rockwell International 1983a, 1987e, and 1989b). 
Table 3.11.1-5. TRUPACT Evaluation.

\section{Criterion or requirement}

Waste Package Weight

Waste Containers

Nuclear Criticality

Surface Dose Rate

Removable Surface Contamination Thermal Power

Gas Generation
The maximum gross drum weight of any IDC 302 drum shipped to INEL was $<200 \mathrm{lb}$, which complies with the waste package and TRUPACT payload weight limits.
Limiting parameters ${ }^{\mathbf{a}}$

Rocky Flats limited the fissile content of the drums to 200 grams. However, the error-times-two requirement was not in place at the time the drums were shipped to INEL; therefore, it is not reported as part of the assay of the drum. The TRUPACT limit must be verified at the time of payload assembly at INEL. Based on the typical assays of the IDC 302 drums, the criticality criteria will be met but must be recalculated or assayed to meet the error-times-two requirement.

The surface dose rate criteria used by Rocky Flats was $200 \mathrm{mrem} / \mathrm{hr}$ at the drum surface and $10 \mathrm{mrem} / \mathrm{hr}$ at 1 meter. Shielding was not necessary for IDC 302 drums. The TRUPACT limit must be verified at the time of payload assembly at INEL. Based on the typical dose rates from the IDC 302 drums, the dose rate criteria will be met.

The Rocky Flats limit for removable contamination (for TRU assumed to be all alpha) was 20 disintegrations per minute $/ 100 \mathrm{~cm}^{2}$. The Rocky Flats limit is equivalent to 9 picocuries per $100 \mathrm{~cm}^{2}$, which is well within the WIPP criteria.

The thermal power calculation reported in the SWIMS data package is based on the reported assay value without an error/uncertainty correction. The thermal power must be recalculated based on the assay error determination.

Based on the procedural requirements for packaging IDC 302 waste and the waste description, the only areas of noncompliance are carbon filters, nonpunctured rigid liners, headspace gas analysis, and visual characterization.

Trichloroethylene, isopropanol, and carbon tetrachloride were detected by headspace analysis in IDC 302 but are not listed in the-TRUPACT Chemical List for RF 116A. 1,1,1-Trichloroethane was detected by headspace analysis and is listed in the TRUPACT Chemical List. All of the chemicals appear to be in concentrations of $<1 \%$. While trichloroethylene was detected in the headspace of IDC 302 waste generated in the early 1970's, trichloroethylene will most likely not be present in wastes generated after the 1970's. 1,1,1-trichloroethane became a replacement for trichloroethylene at Rocky Flats in 1973.

Personnel performing RTR examination at Rocky Flats would accept up to $10 \%$ of another IDC. The other IDCs could be glass, concrete, metal, leaded gloves, and plastics.

a. Many of the limiting parameters were taken from TRU Waste Compliance Program (Rockwell International 1983a, 1987e, and 1989b). 
3.11.1.10 Combustible and Organic Content. Table 3.11.1-6 outlines available data from the TRU Waste Sampling Program for IDC 302. SWIMS data indicates this waste form contains $>20 \%$ combustibles and $<20 \%$ organics.

Table 3.11.1-6. Item Description Code 302 Data Summary for Combustible and Organic Content.

\begin{tabular}{lcccccc}
\hline Container & $\begin{array}{c}\text { Wt. } \\
\text { combustibles } \\
(\mathrm{lb})^{\mathrm{a}}\end{array}$ & $\begin{array}{c}\text { Wt. } \\
\text { organics }_{(\mathrm{b})^{\mathrm{b}}}\end{array}$ & $\begin{array}{c}\text { Net wt. of } \\
\text { container } \\
(\mathrm{lb})^{\mathrm{c}}\end{array}$ & $\begin{array}{c}\text { Wt\% } \\
\text { combustibles }^{\mathrm{d}}\end{array}$ & $\begin{array}{c}\text { Vol\% } \\
\text { combustibles }^{\mathrm{e}}\end{array}$ & $\begin{array}{c}\text { Wt\% } \\
\text { organics }^{\mathrm{f}}\end{array}$ \\
\hline $02-10126$ & 11.0 & 11.0 & 389.5 & 32 & 10 & 3 \\
$02-10283$ & 14.5 & 14.5 & 189.0 & 8 & 15 & 8 \\
$02-10436$ & 9.8 & 9.8 & 88.6 & 11 & 10 & 11 \\
$02-10502$ & 13.0 & 13.0 & 134.1 & 10 & 10 & 10 \\
$01-08991$ & 18.0 & 18.0 & 205.1 & 9 & 10 & 9 \\
$02-10316$ & 10.9 & 10.9 & 157.9 & 7 & 15 & 7 \\
\hline
\end{tabular}

a. Sum of weights of all combustible material and leaded rubber from Table 30 (Clements and Kudera 1985).

b. Sum of weights of all combustible material, leaded rubber, and organic material from Table 30 (Clements and Kudera 1985).

c. Net weight of container from Table 30 (Clements and Kudera 1985).

d. Weight of combustible material/net weight of container $\times 100$.

e. Vol\% of combustible material from visual examination, obtained from Appendix B (Clements and Kudera 1985).

f. Weight of organic material/net weight of container $\times 100$.

3.11.1.10.1 Combustible Content-SWIMS data show that IDC 302 waste is combustible (EG\&G RFP 1993c). In support of the TRU Waste Sampling Program, six drums of IDC 302 waste were opened. They were found to contain an average wt $\%$ combustible content of 12.8\%. Visual inspection showed an average vol\% combustible content of $11 \%$ (Clements and Kudera 1985).

3.11.1.10.2 Organic Content-SWIMS data show that IDC 302 waste may contain 15\% organics (Rockwell International 1985a). In support of the TRU Waste Sampling Program, six drums of IDC 302 waste were opened. they were found to contain an average wt\% organic content of $8 \%$ (Clements and Kudera 1985).

3.11.1.11 Analytical Information. Analytical data from the TRU Waste Sampling Waste Characterization Program (Clements and Kudera 1985) for IDC 302, Benelex \& Plexiglas, indicate that six drums were subject to headspace gas analysis. Gas composition analytical results are 
presented in Table 3.11.1-7. Waste boxes were not sampled. Hydrogen, oxygen, nitrogen, argon, carbon dioxide, saturated hydrocarbons, 1,1,1-trichloroethane, trichloroethylene, isopropanol, and carbon tetrachloride were detected in the drums.

IDC 302-Benelex \& Plexiglas, has been characterized as nonhazardous waste (EG\&G RFP 1994g). 
Table 3.11.1-7. Gas Sampling Results-Compositional Analysis (vol\%).

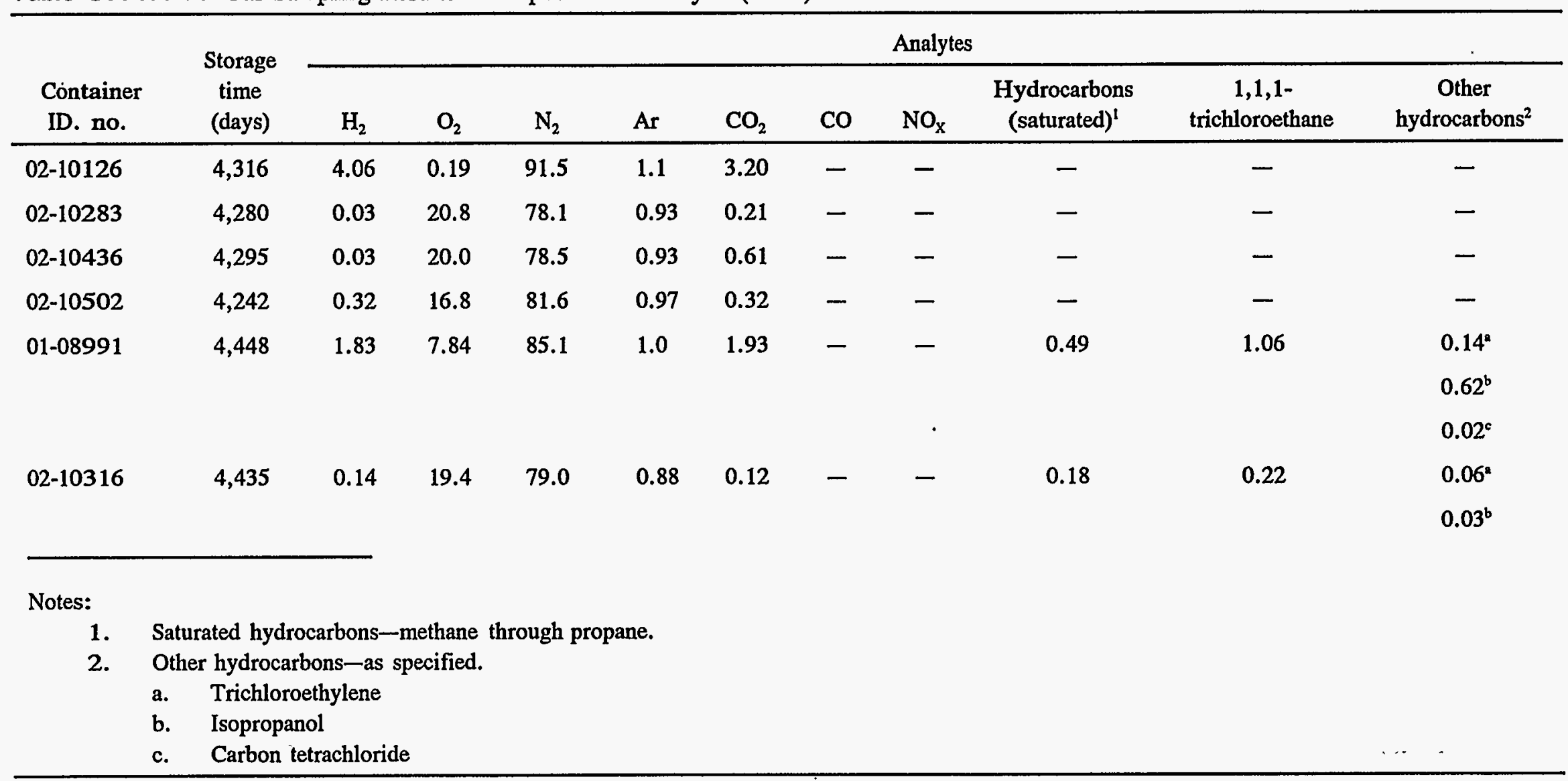




\subsection{Waste Form Number 122-TRU Inorganic Solid Waste, Content Code RF 122A}

\subsubsection{Item Description Code 371-Firebrick}

3.12.1.1 Certification Assessment. This IDC is certifiable without further waste treatment. Assay and thermal power calculations, including error, need to be updated to meet the current WIPP WAC. Several gas generation criteria need to be addressed. Carbon filters may need to be installed, drums will require inspection to identify unvented or unpunctured rigid liners, and headspace gas analysis and visual waste characterization will need to be performed.

3.12.1.2 Waste Description. Firebrick consists of brick and chunks of high-density alumina ceramic material used to line the firebox of the incinerator. Firebrick was generated during incinerator maintenance and stripout operations (A).

3.12.1.3 Generation Source. Firebrick was generated during maintenance operations in the incineration systems in Buildings 771 and 776. This material was also generated during incinerator stripout operations in Building 371 (A).

3.12.1.4 Recovery Method. Plutonium Recovery incinerator firebrick contaminated with amounts of plutonium above the discard limit is "scarfed" to remove surface contamination. The scarfings are then processed by leaching with nitric acid. The remaining firebrick is repackaged (Clements 1982).

3.12.1.5 Waste Packaging and Handling. TRU inorganic solid waste was segregated from all noncomplying materials and was bagged out of the glovebox. The waste was then placed in a DOT-17C, 55-gal drum. When the drum was full, the drum liners were sealed and the drum was closed. The drum label, completed with all necessary information, was then taped to the drum lid and a TID was attached to the drum.

3.12.1.6 Container Preparation. Only approved containers could be used to package TRU waste for shipment offsite. Containers approved for shipment to INEL during this time were DOT17C, white, 55-gal drums (Rockwell specification SX-200). These containers met the requirements for certification as DOT-7A Type A packaging (Rockwell International 1989e).

Table 3.12.1-1 shows the current inventory of IDC 371 waste containers from the Rocky Flats Plant that have been shipped to INEL since 1985.

Table 3.12.1-1. Item Description Code 371 Container Information.

\begin{tabular}{lccc}
\multicolumn{1}{c}{ Information } & & Drums & Boxes \\
\cline { 3 - 5 } Total Containers & & 11 & 0 \\
Net Container Weight (lb) & Maximum & 140 & N/A \\
& Minimum & 52 & N/A \\
& Average & 114 & N/A \\
\hline
\end{tabular}


3.12.1.6.1 Drum Preparation-Approved liners for drums of TRU waste packaged for offsite shipment were the round-bottom liner (Rockwell specification SX-203) inside a 90-mil rigid polyethylene liner (Rockwell specification SX-202), or an O-ring bag and a polyethylene bag placed inside the rigid liner if the drum was attached to a glovebox (Rockwell International 1989e). Type III rigid liners have been used since September 1983 (Bearly 1989a). The IDC 371 waste packaged for offsite shipment required a fiberboard liner and a round bottom liner inside the rigid liner (Rockwell International 1988c). Figure C-1 shows the appropriate drum liners for this IDC. All bags were closed using the twist-and-tape method (Rockwell International 1989e).

Flow-in, ventable gaskets were installed in the drums beginning in December 1982. They were used until October 1988, when tubular gaskets with carbon filters were required. Drums shipped to INEL between 1985 and 1988 may not meet the current WIPP WAC, owing to their lack of carbon filters (Bearly 1989a).

3.12. 1.6.2 Box Preparation-No boxes of IDC 371 waste were shipped to INEL between 1985 and 1989.

3.12.1.7 Assay. The drums may have been assayed on a SGS counter or a PADC. Table 3.12.1-2 summarizes the dose rates measured on containers of this IDC. Table 3.12.1-3 provides a summary of the assay information.

Table 3.12.1-2. Item Description Code 371 Dose Information.

\begin{tabular}{crcc} 
Information & & Drums & Boxes \\
\hline One Meter Dose Rate (mrem/h) & $0-0.5$ & 1 & N/A \\
& $0.5-10$ & 10 & N/A \\
Surface Dose Rate (mrem/h) & $<10$ & 7 & N/A \\
& $10-200$ & 4 & N/A \\
\hline
\end{tabular}

Table 3.12.1-3. Item Description Code 371 Assay Information.

\begin{tabular}{|c|c|c|c|}
\hline \multicolumn{2}{|c|}{ Radionuclide inventory } & \multirow{2}{*}{$\frac{\text { Drums }}{168}$} & \multirow{2}{*}{$\frac{\text { Boxes }}{\text { N/A }}$} \\
\hline Plutonium (g) & Maximum & & \\
\hline & Minimum & 18 & N/A \\
\hline & Average & 97 & $\mathrm{~N} / \mathrm{A}$ \\
\hline \multirow[t]{3}{*}{ Americium (g) } & Maximum & - & N/A \\
\hline & Minimum & - & N/A \\
\hline & Average & - & N/A \\
\hline \multirow[t]{3}{*}{ Uranium-235 (g) } & Maximum & - & N/A \\
\hline & Minimum & - & N/A \\
\hline & Average & - & N/A \\
\hline
\end{tabular}


3.12.1.8 Inspection. Waste Certification personnel performed periodic inspections of the generating and packaging process to verify compliance with waste acceptance criteria. In addition, each drum was viewed using RTR to

- Ensure the drum does not contain nonconforming items

- Ensure the drum is properly packaged

- Verify the waste form description

- Evaluate the presence of free liquids.

3.12.1.9 Waste Form Evaluation. Table 3.12.1-4 evaluates the waste form against the WIPP WAC for such items as free liquids, pyrophoric materials, and compressed gases.

Table 3.12.1-5 evaluates the waste against TRUPACT criteria.

Table 3.12.1-4. Waste Form Evaluation.

Criterion or

requirement

Limiting parameters ${ }^{2}$

Immobilization

Particulates were prohibited by procedural control. Based on the description of the waste, fine particulates are not expected in this IDC.

Liquids

There are normally no liquids associated with this IDC. Personnel performing RTR examination at Rocky Flats would accept up to 2 cups of free liquid, if liquids were present.

Pyrophoric

Materials

Pyrophoric materials were prohibited by procedural control. The absence of the pyrophoric materials was verified by the generating supervisor and periodic inspection by the Waste Certification Organization.

Explosives and Compressed Gases

Explosives and compressed gases were prohibited by procedural control. The absence of the explosives and compressed gases was verified by the generating supervisor and periodic inspection by the Waste Certification Organization. In addition, unvented, closed containers and pressurized containers were excluded by procedural controls and RTR examination.

TRU-Mixed Wastes The RCRA constituents exist as co-contaminants with the transuranic radionuclides. Compliance with the WIPP RCRA permits and NMD will be required prior to shipment of the stored waste to WIPP.

Specific Activity of This waste contains at least 100 nanocuries per gram transuranic radionuclides. Waste

$\mathrm{Pu}^{239}$ Equivalent Activity

None of the IDC 371 waste containers recorded as shipped to INEL in the SWIMS exceed 1,000 $\mathrm{Ci}$ of plutonium-equivalent activity.

a. Many of the limiting parameters were taken from TRU Waste Compliance Program (Rockwell International 1983a, 1987e, and 1989b). 
Table 3.12.1-5. TRUPACT Evaluation.

Criterion or requirement

Limiting parameters ${ }^{\mathrm{a}}$

Waste Package

Weight

Waste Containers

Nuclear

Criticality

Surface Dose

Rate

Removable

Surface

Contamination

Thermal Power

Gas Generation
Rocky Flats limited the gross weight of drums to $800 \mathrm{lb}$. The TRUPACT and vehicle weight limits must be verified at the time of payload assembly at INEL.

Waste was shipped in 55-gal DOT-7A, Type A drums.

Rocky Flats limited the fissile content of the drums to 200 grams. However, the error-times-two requirement was not in place at the time the drums were shipped to INEL; therefore, it is not reported as part of the assay of the drum. The TRUPACT limit must be verified at the time of payload assembly at INEL. Based on the typical assays of the IDC 371 drums, the criticality criteria should be met but must be recalculated or assayed to meet the error-times-two requirement.

The surface dose rate criteria used by Rocky Flats was $200 \mathrm{mrem} / \mathrm{hr}$ at the drum surface and $10 \mathrm{mrem} / \mathrm{hr}$ at 1 meter. Shielding was not necessary for IDC 371 drums. The TRUPACT limit must be verified at the time of payload assembly at INEL. Based on the typical dose rates from the IDC 371 drums, the dose rate criteria will be met.

The Rocky Flats limit for removable contamination (for TRU assumed to be all alpha) was 20 disintegrations per minute $/ 100 \mathrm{~cm}^{2}$. The Rocky Flats limit is equivalent to 9 picocuries per $100 \mathrm{~cm}^{2}$, which is well within the WIPP criteria.

The thermal power calculation reported in the SWIMS data package is based on the reported assay value without an error/uncertainty correction. The thermal power must be recalculated based on the assay error determination.

Based on the procedural requirements for packaging IDC 371 waste and the waste description, the only areas of noncompliance are carbon filters, unpunctured rigid liners, headspace gas analysis, and visual characterization.

Trichloroethylene was detected by headspace analysis but is not listed in the TRUPACT Chemical List for RF 122A. 1,1,1-Trichloroethane and methylene chloride were detected by headspace analysis and are listed on the TRUPACT Chemical List. These chemicals appear to be in total concentrations $<1 \%$. Carbon tetrachloride and methylene chloride are on the TRUPACT Chemical List but were not detected.

Personnel performing RTR examination at Rocky Flats would accept up to $10 \%$ of another IDC. The other IDCs could be combustibles, glass, concrete, metal, leaded gloves, and plastics.

a. Many of the limiting parameters were taken from TRU Waste Compliance Program (Rockwell International 1983a, 1987e, and 1989b). 
3.12.1.10 Combustible and Organic Content. Table 3.12.1-6 outlines available data from the TRU Waste Sampling Program for IDC 371. SWIMS data indicate that this waste form does not contain $>20 \%$ combustibles or $>20 \%$ organics.

Table 3.12.1-6. Item Description Code 371 Data Summary for Combustible and Organic Content.

\begin{tabular}{ccccccc}
\hline & $\begin{array}{c}\text { Wt. } \\
\text { combustibles } \\
(\mathrm{lb})^{2}\end{array}$ & $\begin{array}{c}\text { Wt. } \\
\text { organics }^{\mathrm{(lb})^{\mathrm{b}}}\end{array}$ & $\begin{array}{c}\text { Net wt. of } \\
\text { container } \\
(\mathrm{lb})^{\mathrm{c}}\end{array}$ & $\begin{array}{c}\text { Wt\% } \\
\text { combustibles }^{\mathrm{d}}\end{array}$ & $\begin{array}{c}\text { Vol\% } \\
\text { combustibles }^{\mathrm{e}}\end{array}$ & $\begin{array}{c}\text { Wt\% } \\
\text { organics }^{\mathrm{f}}\end{array}$ \\
\hline $02-21470$ & 30.0 & 30.0 & 139.05 & 22 & 20 & 22 \\
$02-45508$ & 14.2 & 14.2 & 45.0 & 32 & 15 & 32 \\
$01-08836$ & 20.0 & 20.0 & 179.3 & 11 & 20 & 11 \\
$02-10586$ & 17.2 & 17.2 & 135.0 & 13 & 20 & 13 \\
$02-11061$ & 17.0 & 17.0 & 353.7 & 5 & 10 & 5 \\
$02-11379$ & 11.0 & 11.0 & 299.2 & 4 & 20 & 4
\end{tabular}

a. Sum of weights of all combustible material and leaded rubber from Table 27 (Clements and Kudera 1985).

b. Sum of weights of all combustible material, leaded rubber, and organic material from Table 27 (Clements and Kudera 1985).

c. Net weight of container from Table 257(Clements and Kudera 1985).

d. Weight of combustible material/net weight of container $\times 100$.

e. Vol\% of combustible material from visual examination, obtained from Appendix B (Clements and Kudera 1985).

f. Weight of organic material/net weight of container $\times 100$.

3.12.1.10.1 Combustible Content-SWIMS data show that IDC 371 waste is noncombustible (Rockwell International 1985a). In support of the TRU Waste Sampling Program, six drums of IDC 371 waste were opened. They were found to contain an average wt\% combustible content of $14.5 \%$. Visual inspection showed an average vol\% combustible content of $17.5 \%$. (Clements and Kudera 1985).

3.12.1 10.2 Organic Content-SWIMS data show that IDC 371 waste may contain $20 \%$ organics (Rockwell International 1985a). In support of the TRU Waste Sampling Program, six drums of IDC 371 waste were opened. They were found to contain an average wt\% organic content of $14.5 \%$ (Clements and Kudera 1985).

3.12.1.11 Analytical Information. Analytical data from the TRU Waste Sampling Waste Characterization Program (Clements and Kudera 1985) for IDC 371, Firebrick, indicate that eight drums were subject to headspace gas analysis. Gas composition analytical results are presented in 
Table 3.12.1-7. Waste boxes were not sampled. Hydrogen, oxygen, nitrogen, argon, carbon dioxide, nitrogen oxide(s), saturated hydrocarbons, 1,1,1-trichloroethane, dichloromethane and trichloroethylene were detected in the drums.

Because the specific sources of the incinerator feed cannot be determined at this time, it has been assumed that the process could have accepted any of the combustible, plastic, or filter waste that was generated during the time the incinerator was operational. Alcohols, glycols, halogenated solvents, and metals may have been introduced into the incinerator. The EPA Codes assigned to this waste include D004-D011, F001, F002, F003, and F005 (A). 
Table 3.12.1-7. Gas Sampling Results-Compositional Analysis (vol\%).

\begin{tabular}{|c|c|c|c|c|c|c|c|c|c|c|c|}
\hline \multirow[b]{2}{*}{$\begin{array}{l}\text { Container } \\
\text { ID. no. }\end{array}$} & \multirow{2}{*}{$\begin{array}{c}\text { Storage } \\
\text { time } \\
\text { (days) }\end{array}$} & \multicolumn{10}{|c|}{ Analytes } \\
\hline & & $\mathrm{H}_{2}$ & $\mathrm{O}_{2}$ & $\mathrm{~N}_{2}$ & $\mathrm{Ar}$ & $\mathrm{CO}_{2}$ & $\mathrm{CO}$ & $\mathrm{NO}_{\mathrm{x}}$ & $\begin{array}{l}\text { Hydrocarbons } \\
\text { (saturated)' }\end{array}$ & $\begin{array}{c}1,1,1- \\
\text { trichloroethane }\end{array}$ & $\begin{array}{c}\text { Other } \\
\text { hydrocarbons }\end{array}$ \\
\hline $02-45508^{3}$ & 98 & - & 20.9 & 78.0 & 0.96 & 0.09 & - & - & 0.01 & - & - \\
\hline $02-44115^{3}$ & 222 & 0.02 & 21.1 & 77.8 & 0.96 & 0.04 & - & - & 0.04 & - & - \\
\hline $02-21470$ & 565 & 0.12 & 20.4 & 78.0 & 0.97 & 0.03 & - & - & 0.06 & 0.28 & $0.12^{\mathrm{a}}$ \\
\hline $01-00201$ & 4,343 & 17.1 & 11.4 & 69.9 & 0.80 & 0.10 & - & 0.30 & 0.37 & - & - \\
\hline $01-08836$ & 4,454 & 0.07 & 19.8 & 78.8 & 0.93 & 0.08 & - & - & 0.15 & 0.18 & - \\
\hline $02-10586$ & 4,290 & 0.13 & 18.8 & 80.0 & 0.94 & 0.09 & - & - & - & 0.10 & - \\
\hline $02-11061$ & 4,255 & 3.88 & 3.78 & 90.9 & 1.1 & 0.12 & - & - & 0.19 & 0.06 & $0.01^{b}$ \\
\hline $02-11379$ & 4,378 & 0.08 & 20.3 & 77.7 & 0.92 & 0.07 & - & - & 0.29 & 0.46 & $0.17^{b}$ \\
\hline $\begin{array}{c}\text { Notes: } \\
1 . \\
2 .\end{array}$ & $\begin{array}{l}\text { Saturated hyc } \\
\text { Other hydroc } \\
\text { a. Dichlor } \\
\text { b. Trichlo } \\
\text { Drum sealed }\end{array}$ & $\begin{array}{l}\text { carbons- } \\
\text { bons-as } \\
\text { nethane } \\
\text { ethylene } \\
\text { ith a sem }\end{array}$ & $\begin{array}{l}\text { methan } \\
\text { pecifie }\end{array}$ & hrough & pane. & & & & & . & \\
\hline
\end{tabular}




\subsection{Waste Form Number 122-TRU Inorganic Solid Waste, Content Code RF 122A}

\subsubsection{Item Description Code 374-Blacktop/Concrete/Dirt}

3.12.2.1 Certification Assessment. This IDC is not certifiable without further waste treatment for immobilization. Assay and thermal power calculations, including error, need to be updated to meet the current WIPP WAC. Several gas generation criteria need to be addressed. Carbon filters may need to be installed, drums will require inspection to identify unvented or unpunctured rigid liners, and headspace gas analysis and visual waste characterization will need to be performed.

3.12.2.2 Waste Description. The soil and cleanup debris waste form consists of blacktop, concrete, dirt, sand, and rock. Soil and debris were generated by a variety of cleanup and construction activities around RFP (EG\&G RFP 1994m).

3.12.2.3 Generation Source. Soil and cleanup debris (IDC 374) was generated during cleanup and construction activities around the Rocky Flats Plant. In most cases, construction or demolition activities generated rubble. IDC 374 was generated in Buildings $371,374,559,707,771$, 774, 776 and 779. Soil and cleanup debris are still being generated (EG\&G RFP 1994m).

3.12.2.4 Recovery Method. This IDC was never generated as a residue and therefore has no recovery method (EG\&G RFP 1994m).

3.12.2.5 Waste Packaging and Handling. TRU inorganic solid waste was segregated from all noncomplying materials and was bagged out of the glovebox. The waste was then placed in a DOT-17C, 55-gal drum. When the drum was full, the drum liner was sealed and the drum was closed. The drum label, completed with all necessary information, was then taped to the drum lid and a TID was attached to the drum.

3.12.2.6 Container Preparation. Only approved containers could be used to package TRU waste for shipment offsite. Containers approved for shipment to INEL during this time were DOT17C, white, 55-gal drums (Rockwell specification SX-200). These containers met the requirements for certification as DOT-7A Type A packaging (Rockwell International 1989e).

Table 3.12.2-1 shows the current inventory of IDC 374 waste containers from the Rocky Flats Plant that have been shipped to INEL since 1985.

Table 3.12.2-1. Item Description Code 374 Container Information.

\begin{tabular}{lrcc}
\multicolumn{1}{c}{ Information } & & Drums & Boxes \\
\hline Total Containers & & 109 & 0 \\
Net Container Weight (lb) & Maximum & 719 & N/A \\
& Minimum & 32 & N/A \\
& Average & 288 & N/A \\
\hline
\end{tabular}


3.12.2.6.1 Drum Preparation-Approved liners for drums of TRU waste packaged for offsite shipment were the round-bottom liner (Rockwell specification SX-203) inside a 90-mil rigid polyethylene liner (Rockwell specification SX-202), or an O-ring bag and a polyethylene bag placed inside the rigid liner if the drum was attached to a glovebox (Rockwell International 1989e). Type III rigid liners have been used since September 1983 (Bearly 1989a). The IDC 374 waste packaged for offsite shipment required a fiberboard liner and a round bottom liner inside the rigid liner (Rockwell International 1988c). Figure C-1 shows the appropriate drum liners for this IDC. All bags were closed using the twist-and-tape method (Rockwell International 1989e).

Flow-in, ventable gaskets were installed in the drums beginning in December 1982. They were used until October 1988, when tubular gaskets with carbon filters were required. Drums shipped to INEL between 1985 and 1988 may not meet the current WIPP WAC, owing to their lack of carbon filters (Bearly 1989a).

3.12.2.6.2 Box Preparation-No boxes of IDC 374 waste were shipped to INEL between 1985 and 1989 .

3.12.2.7 Assay. The drums may have been assayed on an SGS counter or PADC. Containers of waste that have not been PADC assayed and had SGS assay values of 1 gram or less should be PADC assayed to verify that they are transuranic waste. Table 3.12.2-2 summarizes the dose rates measured on containers of this IDC. Table 3.12.2-3 provides a summary of the assay information.

Table 3.12.2-2. Item Description Code 374 Dose Information.

\begin{tabular}{lrrr}
\multicolumn{1}{c}{ Information } & & Drums & Boxes \\
\hline One Meter Dose Rate (mrem/h) & $0-0.5$ & 106 & N/A \\
& $0.5-10$ & 3 & N/A \\
Surface Dose Rate (mrem/h) & $<10$ & 109 & N/A \\
& $10-200$ & 0 & N/A \\
\hline
\end{tabular}

Table 3.12.2-3. Item Description Code 374 Assay Information.

\begin{tabular}{|c|c|c|c|}
\hline \multicolumn{2}{|c|}{ Radionuclide inventory } & \multirow{2}{*}{$\frac{\text { Drums }}{12}$} & \multirow{2}{*}{$\frac{\text { Boxes }}{\text { N/A }}$} \\
\hline Plutonium (g) & Maximum & & \\
\hline & Minimum & 0 & N/A \\
\hline & Average & 1 & N/A \\
\hline \multirow[t]{3}{*}{ Americium (g) } & Maximum & 0 & N/A \\
\hline & Minimum & 0 & N/A \\
\hline & Average & 0 & N/A \\
\hline \multirow[t]{3}{*}{ Uranium-235 (g) } & Maximum & - & N/A \\
\hline & Minimum & - & N/A \\
\hline & Average & - & N/A \\
\hline
\end{tabular}


3.12.2.8 Inspection. Waste Certification personnel performed periodic inspections of the generating and packaging process to verify compliance with waste acceptance criteria. In addition, each drum was viewed using RTR to

- Ensure the drum does not contain nonconforming items

- Ensure the drum is properly packaged

- Verify the waste form description

- Evaluate the presence of free liquids.

3.12.2.9 Waste Form Evaluation. Table 3.12.2-4 evaluates the waste form against the WIPP WAC for such items as free liquids, pyrophoric materials, and compressed gases.

Table 3.12.2-5 evaluates the waste against TRUPACT criteria.

Table 3.12.2-4. Waste Form Evaluation.

Criterion or

requirement

Limiting parameters ${ }^{\mathrm{a}}$

Immobilization

This IDC will contain large amounts of particulate material. This waste is not expected to meet the WIPP WAC for particulate material.

Liquids

There are normally no liquids associated with this IDC. Personnel performing RTR examination at Rocky Flats would accept up to 2 cups of free liquid, if liquids were present.

Pyrophoric

Materials

Pyrophoric materials were prohibited by procedural control. The absence of the pyrophoric materials was verified by the generating supervisor and periodic inspection by the Waste Certification Organization.

Explosives and

Compressed Gases

Explosives and compressed gases were prohibited by procedural control. The absence of the explosives and compressed gases was verified by the generating supervisor and periodic inspection by the Waste Certification Organization. In addition, unvented, closed containers and pressurized containers were excluded by procedural controls and RTR examination.

TRU-Mixed Wastes The RCRA constituents exist as co-contaminants with the transuranic radionuclides. Compliance with the WIPP RCRA permits and NMD will be required prior to shipment of the stored waste to WIPP.

Specific Activity of Waste

A portion of the waste stored at INEL may contain $<100$ nanocuries per gram transuranic radionuclides.

$\mathrm{Pu}^{239}$ Equivalent None of the IDC 374 waste containers recorded as shipped to INEL in the Activity SWIMS exceed 1,000 Ci of plutonium-equivalent activity.

a. Many of the limiting parameters were taken from TRU Waste Compliance Program (Rockwell International 1983a, 1987e, and 1989b). 
Table 3.12.2-5. TRUPACT Evaluation.

\begin{tabular}{|c|c|}
\hline $\begin{array}{l}\text { Criterion or } \\
\text { requirement }\end{array}$ & Limiting parameters ${ }^{\mathbf{a}}$ \\
\hline $\begin{array}{l}\text { Waste Package } \\
\text { Weight }\end{array}$ & $\begin{array}{l}\text { Rocky Flats limited the gross weight of drums to } 800 \mathrm{lb} \text {. The TRUPACT and } \\
\text { vehicle weight limits must be verified at the time of payload assembly at INEL. }\end{array}$ \\
\hline Waste Containers & Waste was shipped in 55-gal DOT-7A, Type A drums. \\
\hline $\begin{array}{l}\text { Nuclear } \\
\text { Criticality }\end{array}$ & $\begin{array}{l}\text { Rocky Flats limited the fissile content of the drums to } 200 \text { grams. However, the } \\
\text { error-times-two requirement was not in place at the time the drums were shipped to } \\
\text { INEL; therefore, it is not reported as part of the assay of the drum. The } \\
\text { TRUPACT limit must be verified at the time of payload assembly at INEL. } \\
\text { Based on the typical assays of the IDC } 374 \text { drums, the criticality criteria will be } \\
\text { met but must be recalculated or assayed to meet the error-times-two requirement. }\end{array}$ \\
\hline $\begin{array}{l}\text { Surface Dose } \\
\text { Rate }\end{array}$ & $\begin{array}{l}\text { The surface dose rate criteria used by Rocky Flats was } 200 \mathrm{mrem} / \mathrm{hr} \text { at the drum } \\
\text { surface and } 10 \mathrm{mrem} / \mathrm{hr} \text { at } 1 \text { meter. Shielding was not necessary for IDC } 374 \\
\text { drums. The TRUPACT limit must be verified at the time of payload assembly at } \\
\text { INEL. Based on the typical dose rates from the IDC } 374 \text { drums, the dose rate } \\
\text { criteria will be met. }\end{array}$ \\
\hline $\begin{array}{l}\text { Removable } \\
\text { Surface } \\
\text { Contamination }\end{array}$ & $\begin{array}{l}\text { The Rocky Flats limit for removable contamination (for TRU assumed to be all } \\
\text { alpha) was } 20 \text { disintegrations per minute } / 100 \mathrm{~cm}^{2} \text {. The Rocky Flats limit is } \\
\text { equivalent to } 9 \text { picocuries per } 100 \mathrm{~cm}^{2} \text {, which is well within the WIPP criteria. }\end{array}$ \\
\hline Thermal Power & $\begin{array}{l}\text { The thermal power calculation reported in the SWIMS data package is based on the } \\
\text { reported assay value without an error/uncertainty correction. The thermal power } \\
\text { must be recalculated based on the assay error determination. }\end{array}$ \\
\hline \multirow[t]{2}{*}{ Gas Generation } & $\begin{array}{l}\text { Based on the procedural requirements for packaging IDC } 374 \text { waste and the waste } \\
\text { description, the only areas of noncompliance are carbon filters, unpunctured rigid } \\
\text { liners, headspace gas analysis, and visual characterization. } \\
\text { Carbon tetrachloride, 1,1,1-trichloroethane, and methylene chloride are on the } \\
\text { TRUPACT Chemical List, but were not detected. }\end{array}$ \\
\hline & $\begin{array}{l}\text { Personnel performing RTR examination at Rocky Flats would accept up to } 10 \% \text { of } \\
\text { another IDC. The other IDCs could be combustibles, glass, metal, leaded gloves, } \\
\text { and plastics. }\end{array}$ \\
\hline , & $\begin{array}{l}\text { parameters were taken from TRU Waste Compliance Program (Rockwell International } \\
\text { b). }\end{array}$ \\
\hline
\end{tabular}

3.12.2.10 Combustible and Organic Content. SWIMS data indicate that this waste form does not contain $>20 \%$ combustibles or $>20 \%$ organics.

3.12.2.10.1 Combustible Content-SWIMS data show that IDC 374 waste is noncombustible (Rockwell International 1985a). 
3.12.2.10.2 Organic Content-SWIMS data show that IDC 374 waste contains zero percent organics (Rockwell International 1985a).

3.12.2.11 Analytical Information. Analytical data from the TRU Waste Sampling Waste Characterization Program (Clements and Kudera 1985) for IDC 374-Blacktop/Concrete/Dirt, indicate that one drum was subject to headspace gas analysis. Gas composition analytical results are presented in Table 3.12.2-6. Waste boxes were not sampled. Hydrogen, oxygen, nitrogen, argon, and carbon dioxide were detected in the drum.

Applicable EPA Codes include D004-D011, F001-F007, F009 and F039 (EG\&G RFP 1994m). 


\subsection{Waste Form Number 122-TRU Inorganic Solid Waste, Content Code RF 122A}

\subsubsection{Item Description Code 377-Firebrick, Coarse}

3.12.3.1 Certification Assessment. This IDC is certifiable without further waste treatment. Assay and thermal power calculations, including error, need to be updated to meet the current WIPP WAC. Several gas generation criteria need to be addressed. Carbon filters may need to be installed, drums will require inspection to identify unvented or unpunctured rigid liners, and headspace gas analysis and visual waste characterization will need to be performed.

3 12.3.2 Waste Description. Coarse chunks of scarred firebrick were generated during incinerator maintenance and stripout operations. Spent firebrick was subjected to a mechanical scarfing process to remove plutonium-bearing surface layers. Coarse firebrick consists of chunks of unpulverized, plutonium-bearing surface layers of the high-density alumina ceramic firebrick material (A).

3.12.3.3 Generation Source. During maintenance operations, coarse chunks of scarred firebrick were generated in Building 771. This material was also generated during incinerator stripout operations in Building 371 (A).

3.12.3.4 Recovery Method. Firebrick was scarfed, and the scarfings were leached with acid to remove plutonium.

3.12.3.5 Waste Packaging and Handling. TRU inorganic solid waste was segregated from all noncomplying materials and was bagged out of the glovebox. The waste was then placed in a DOT-17C, 55-gal drum. When the drum was full, the drum liner was sealed and the drum was closed. The drum label, completed with all necessary information, was then taped to the drum lid and a TID was attached to the drum.

3.12.3.6 Container Preparation. Only approved containers could be used to package TRU waste for shipment offsite. Containers approved for shipment to INEL during this time were DOT17C, white, 55-gal drums (Rockwell specification SX-200). These containers met the requirements for certification as DOT-7A Type A packaging (Rockwell International 1989e).

Table 3.12.3-1 shows the current inventory of IDC 377 waste containers from the Rocky Flats Plant that have been shipped to INEL since 1985 .

Table 3.12.3-1. Item Description Code 377 Container Information.

\begin{tabular}{|c|c|c|c|}
\hline \multicolumn{2}{|l|}{ Information } & \multirow{2}{*}{$\frac{\text { Drums }}{29}$} & \multirow{2}{*}{$\frac{\text { Boxes }}{0}$} \\
\hline Total Containers & & & \\
\hline \multirow[t]{3}{*}{ Net Container Weight (lb) } & Maximum & 147 & N/A \\
\hline & Minimum & 100 & N/A \\
\hline & Average & 124 & N/A \\
\hline
\end{tabular}


3.12.3.6.1 Drum Preparation-Approved liners for drums of TRU waste packaged for offsite shipment were the round-bottom liner (Rockwell specification SX-203) inside a 90-mil rigid polyethylene liner (Rockwell specification SX-202), or an O-ring bag and a polyethylene bag placed inside the rigid liner if the drum was attached to a glovebox (Rockwell International 1989e). Type III rigid liners have been used since September 1983 (Bearly 1989a). The IDC 377 waste packaged for offsite shipment required a fiberboard liner and a round bottom liner inside the rigid liner (Rockwell International 1988c) Figure C-1 shows the appropriate drum liners for this IDC. All bags were closed using the twist-and-tape method (Rockwell International 1989e).

Flow-in, ventable gaskets were installed in the drums beginning in December 1982. They were used until October 1988, when tubular gaskets with carbon filters were required. Drums shipped to INEL between 1985 and 1988 may not meet the current WIPP WAC, owing to their lack of carbon filters (Bearly 1989a).

3.12.3.6.2 Box Preparation-No boxes of IDC 377 waste were shipped to INEL between 1985 and 1989.

3.12.3.7 Assay. The drums may have been assayed on an SGS or PADC. Table 3.12.3-2 summarizes the dose rates measured on containers of this IDC. Table 3.12.3-3 provides a summary of the assay information. Uranium was evaluated in 16 drums, and americium was not evaluated.

Table 3.12.3-2. Item Description Code 377 Dose Information.

\begin{tabular}{crccc}
\hline \multicolumn{2}{c}{ Information } & & Drums & Boxes \\
\cline { 2 - 5 } One Meter Dose Rate (mrem/h) & $0-0.5$ & 18 & N/A \\
& $0.5-10$ & 11 & N/A \\
Surface Dose Rate $(\mathrm{mrem} / \mathrm{h})$ & $<10$ & 29 & N/A \\
& $10-200$ & 0 & N/A \\
\hline
\end{tabular}

Table 3.12.3-3. Item Description Code 377 Assay Information.

\begin{tabular}{|c|c|c|c|c|}
\hline & \multicolumn{2}{|c|}{ Radionuclide inventory } & \multirow{2}{*}{$\frac{\text { Drums }}{169}$} & \multirow{2}{*}{$\frac{\text { Boxes }}{\text { N/A }}$} \\
\hline \multirow[t]{9}{*}{. } & Plutonium (g) & Maximum & & \\
\hline & & Minimum & 7 & N/A \\
\hline & & Average & 51 & N/A \\
\hline & Americium (g) & Maximum & - & N/A \\
\hline & & Minimum & - & N/A \\
\hline & & Average & 一 & $\mathrm{N} / \mathrm{A}$ \\
\hline & Uranium-235 (g) & Maximum & 7 & N/A \\
\hline & & Minimum & 1 & N/A \\
\hline & & Average & 4 & N/A \\
\hline
\end{tabular}


3.12.3.8 Inspection. Waste Certification personnel performed periodic inspections of the generating and packaging process to verify compliance with waste acceptance criteria. In addition, each drum was viewed using RTR to

- Ensure the drum does not contain nonconforming items

- Ensure the drum is properly packaged

- Verify the waste form description

- Evaluate the presence of free liquids.

3.12.3.9 Waste Form Evaluation. Table 3.12.3-4 evaluates the waste form against the WIPP WAC for such items as free liquids, pyrophoric materials, and compressed gases.

Table 3.12.3-5 evaluates the waste against TRUPACT criteria. 
Table 3.12.3-4. Waste Form Evaluation.

Criterion or

requirement

Limiting parameters ${ }^{2}$

Immobilization

Firebrick, coarse, consists of particle sizes $<1$ in. in diameter but larger than $1 / 4$-in. in diameter. Particulates were prohibited by procedural control. Based on the description of the waste, fine particulates are not expected in this IDC.

Liquids

There are normally no liquids associated with this IDC. Personnel performing RTR examination at Rocky Flats would accept up to 2 cups of free liquid, if liquids were present.

Pyrophoric

Pyrophoric materials were prohibited by procedural control. The absence of the Materials pyrophoric materials was verified by the generating supervisor and periodic inspection by the Waste Certification Organization.

Explosives and Compressed Gases

Explosives and compressed gases were prohibited by procedural control. The absence of the explosives and compressed gases was verified by the generating supervisor and periodic inspection by the Waste Certification Organization. In addition, unvented, closed containers and pressurized containers were excluded by procedural controls and RTR examination.

TRU-Mixed Wastes The RCRA constituents exist as co-contaminants with the transuranic radionuclides. Compliance with the WIPP RCRA permits and NMD will be required prior to shipment of the stored waste to WIPP.

Specific Activity of This waste contains at least 100 nanocuries per gram transuranic radionuclides. Waste

$\mathrm{Pu}^{239}$ Equivalent

Activity
None of the IDC 377 waste containers recorded as shipped to INEL in the SWIMS exceed $1,000 \mathrm{Ci}$ of plutonium-equivalent activity.

a. Many of the limiting parameters were taken from TRU Waste Compliance Program (Rockwell International 1983a, 1987e, and 1989b). 
Table 3.12.3-5. TRUPACT Evaluation.

Criterion or

requirement

Limiting parameters ${ }^{\mathrm{a}}$

Waste Package

Weight

Rocky Flats limited the gross weight of drums to $800 \mathrm{lb}$. The TRUPACT and

Waste Containers

vehicle weight limits must be verified at the time of payload assembly at INEL.

Nuclear .

Criticality

Waste was shipped in 55-gal DOT-7A, Type A drums.

Rocky Flats limited the fissile content of the drums to 200 grams. However, the error-times-two requirement was not in place at the time the drums were shipped to INEL; therefore, it is not reported as part of the assay of the drum. The TRUPACT limit must be verified at the time of payload assembly at INEL. Based on the typical assays of the IDC 377 drums, the criticality criteria should be met but must be recalculated or assayed to meet the error-times-two requirement.

Surface Dose

Rate

The surface dose rate criteria used by Rocky Flats was $200 \mathrm{mrem} / \mathrm{hr}$ at the drum surface and $10 \mathrm{mrem} / \mathrm{hr}$ at 1 meter. Shielding was not necessary for IDC 377 drums. The TRUPACT limit must be verified at the time of payload assembly at INEL. Based on the typical dose rates from the IDC 377 drums, the dose rate criteria will be met.

Removable

Surface

The Rocky Flats limit for removable contamination (for TRU assumed to be all

Contamination alpha) was 20 disintegrations per minute $/ 100 \mathrm{~cm}^{2}$. The Rocky Flats limit is equivalent to 9 picocuries per $100 \mathrm{~cm}^{2}$, which is well within the WIPP criteria.

Thermal Power

The thermal power calculation reported in the SWIMS data package is based on the reported assay value without an error/uncertainty correction. The thermal power must be recalculated based on the assay error determination.

Gas Generation Based on the procedural requirements for packaging IDC 377 waste and the waste description, the only areas of noncompliance are carbon filters, unpunctured rigid liners, headspace gas analysis, and visual characterization.

Toluene was detected by headspace analysis, but is not listed in the TRUPACT Chemical List for RF 122A. Carbon tetrachloride, 1,1,1-trichloroethane, and methylene chloride are on the TRUPACT Chemical List, but were not detected.

Personnel performing RTR examination at Rocky Flats would accept up to $10 \%$ of another IDC. The other IDCs could be combustibles, glass, concrete, metal, leaded gloves, and plastics.

a. Many of the limiting parameters were taken from TRU Waste Compliance Program (Rockwell Intemational 1983a, 1987e, and 1989b). 
3.12.3.10 Combustible and Organic Content. Table 3.12.3-6 outlines available data from the TRU Waste Sampling Program for IDC 377. SWIMS data indicate that this waste form does not contain $>20 \%$ combustibles or $>20 \%$ organics.

Table 3.12.3-6. Item Description Code 377 Data Summary for Combustible and Organic Content.

\begin{tabular}{ccccccc}
\hline Container & $\begin{array}{c}\text { Wt. } \\
\text { combustibles } \\
(\mathrm{lb})^{\mathrm{a}}\end{array}$ & $\begin{array}{c}\text { Wt. } \\
\text { organics } \\
(\mathrm{lb})^{\mathrm{b}}\end{array}$ & $\begin{array}{c}\text { Net wt. of } \\
\text { container } \\
(\mathrm{lb})^{\mathrm{c}}\end{array}$ & $\begin{array}{c}\text { Wt\% } \\
\text { combustibles }^{\mathrm{d}}\end{array}$ & $\begin{array}{c}\text { Vol\% } \\
\text { combustibles }^{\mathrm{e}}\end{array}$ & $\begin{array}{c}\text { Wt\% } \\
\text { organics }^{\mathrm{f}}\end{array}$ \\
\hline $\mathbf{0 2 - 4 4 1 1 5}$ & 16.4 & 16.4 & 42.8 & 38 & 20 & 38
\end{tabular}

a. Sum of weights of all combustible material and leaded rubber from Table 27 (Clements and Kudera 1985).

b. Sum of weights of all combustible material, leaded rubber, and organic material from Table 27 (Clements and Kudera 1985).

c. Net weight of container from Table 27 (Clements and Kudera 1985).

d. Weight of combustible material/net weight of container $\times 100$.

e. Vol\% of combustible material from visual examination, obtained from Appendix B (Clements and Kudera 1985).

f. Weight of organic material/net weight of container $\times 100$.

3.12.3.10.1 Combustible Content-SWIMS data show that IDC 377 waste is noncombustible (Rockwell International 1985a). In support of the TRU Waste Sampling Program, one drum of IDC 377 waste was opened. It was found to contain a wt\% combustible.content of $16.4 \%$. Visual inspection showed an average vol\% combustible content of $20 \%$. (Clements and Kudera 1985).

3.12.3.10.2 Organic Content-SWIMS data show that IDC 377 waste may contain zero percent organics (Rockwell International 1985a). In support of the TRU Waste Sampling Program, one drum of IDC 377 waste was opened. It was found to contain a wt\% organic content of 38\% (Clements and Kudera 1985).

3.12.3.11 Analytical Information. Analytical data from the WIPP Experimental Waste Characterization Program (EG\&G RFP 1994t) for IDC 377-Firebrick, Coarse, indicate that one drum was subject to headspace gas analysis.

IDC 377 Gas Mass Spectrometry analytical results are presented in Table 3.12.3-7. The drum was subject to the operational lid headspace sampling program. Nitrogen, oxygen, argon, carbon dioxide, and carbon monoxide analytes were detected.

IDC 377 VOC Gas Chromatography/Mass Spectrometry analytical results indicate $26.1 \mathrm{ppmv}$ toluene in the single drum tested (D61473). 
Because the specific sources of the incinerator feed cannot be determined at this time, it has been assumed that the process could have accepted any of the combustible, plastic, or filter waste that was generated during the time the incinerator was operational. Alcohols, glycols, halogenated solvents, and metals may have been introduced into the incinerator. The EPA Codes assigned to this waste include D004-D011, F001, F002, F003, and F005 (A).

Table 3.12.3-7. Gas Mass Spectrometry Results (vol\%).

\begin{tabular}{|c|c|c|c|c|c|c|c|c|c|c|c|c|}
\hline \multirow[b]{2}{*}{$\begin{array}{l}\text { Drum } \\
\text { no. }\end{array}$} & \multirow{2}{*}{$\begin{array}{l}\text { Headspace } \\
\text { sample } \\
\text { program }\end{array}$} & & & & & & Analyte & & & & & \\
\hline & & Vented & $\mathrm{H}_{2}$ & $\mathrm{~N}_{2}$ & $\mathrm{O}_{2}$ & Ar & $\mathrm{CO}_{2}$ & $\mathrm{CO}$ & $\mathrm{CH}_{4}$ & $\mathrm{C}_{2} \mathrm{H}_{6}$ & $\mathrm{C}_{3} \mathrm{H}_{8}$ & $\mathrm{NO}_{\mathrm{x}}$ \\
\hline D61473 & $1 A$ & - & - & 79.4 & 19.4 & 0.952 & 0.138 & 0.085 & - & - & - & - \\
\hline \multicolumn{13}{|c|}{$\begin{array}{l}\text { Notes: } \\
\text { Headspace Sample Program }\end{array}$} \\
\hline \multicolumn{13}{|c|}{$\begin{array}{l}\text { 1A Operational Lid, Gas Mass Spectrometry Results (vol\%) } \\
\text { Unreported analyte values indicate that analyte was undetected, or was detected at or above the MDL but at a } \\
\text { level below the PRQL. . }\end{array}$} \\
\hline
\end{tabular}




\subsection{Waste Form Number 123-TRU Leaded Rubber, Content Code RF 123A}

\subsubsection{Item Description Code 339-Leaded Gloves}

3.13.1.1 Certification Assessment. This IDC is not certifiable because it carries the reactive EPA hazardous waste code. Assay and thermal power calculations, including error, need to be updated to meet the current WIPP WAC. Several gas generation criteria need to be addressed. Carbon filters may need to be installed, drums will require inspection to identify unvented or unpunctured rigid liners, and headspace gas analysis and visual waste characterization will need to be performed.

3.13.1.2 Waste Description. This waste consists of leaded glovebox gloves used for operator protection from process materials and shielding against penetrating radiation. Two types of leaded gloves were used at Rocky Flats: S6 and S2P2. Both glove types were made with an $84 \%$ $\mathrm{Pb304-loaded} \mathrm{Neoprene} \mathrm{rubber} \mathrm{core} \mathrm{between} \mathrm{two} \mathrm{Hypalon} \mathrm{rubber} \mathrm{layers.} \mathrm{The} \mathrm{S6} \mathrm{glove} \mathrm{was} \mathrm{used} \mathrm{in}$ Building 707, had a mass of 785 grams, an internal Hypalon thickness of 11 millimeters and an external Hypalon thickness of 11 millimeters. The S2P2 glove was used in Buildings 371 and 771, had a mass of 1,030 grams, an internal Hypalon thickness of 8 millimeters, and an external Hypalon thickness of 28 millimeters. Lead constitutes $40-50 \%$ of the gloves' weight (WASTREN, Inc. 1994b). Prior to January 22, 1986, all leaded glovebox gloves, acid contaminated and nonacid contaminated, were accumulated together as IDC 339. After this date, IDC 341 was created for leaded glovebox gloves, acid contaminated (EG\&G RFP 1994j).

3.13.1.3 Generation Source. IDC 339 waste was generated primarily in Buildings 371, $374,559,707,771,774,776,777$, and 779 by processes requiring controlled atmospheres (EG\&G RFP 1994j).

3.13.1.4 Recovery Method. All backlog leaded glovebox gloves (IDC 339 and 341) were washed in Building 776 until about September 1989, at which time the process was curtailed. The primary purpose of the washing process was to remove the accountable material; however, the acid from the acid-contaminated gloves (IDC 341) was removed as well. After the acid-contaminated gloves were washed, the IDC was changed from 341 to 339 . The glove-washing process was curtailed upon completion of the inventory of backlog gloves (EG\&G RFP 1994j).

3.13.1.5 Waste Packaging and Handling. Leaded glovebox gloves and aprons were double-contained in plastic and placed in prepared, DOT-17C, white, 55-gal drums. Absorbent material was added to the drum. When the drum was full, the drum liners were sealed and the drum was closed. The drum label, completed with all necessary information, was then taped to the drum lid and a TID was attached to the drum (Rockwell International 1989b).

3.13.1.6 Container Preparation. Only approved containers can be used to package TRU waste for shipment offsite. Containers approved for shipment to INEL or WIPP are the DOT-17C, white, 55-gal drums (SX-200). These containers meet the requirements for certification as DOT-7A Type A packaging (Rockwell International 1989e). 
Table 3.13.1-1 shows the current inventory of IDC 339 waste containers from the Rocky Flats Plant that have been shipped to INEL since 1985.

Table 3.13.1-1. Item Description Code 339 Container Information.

\begin{tabular}{|c|c|c|c|}
\hline \multicolumn{2}{|l|}{ Information } & \multirow{2}{*}{$\frac{\text { Drums }}{320}$} & \multirow{2}{*}{$\frac{\text { Boxes }}{0}$} \\
\hline Total Containers & & & \\
\hline \multirow[t]{3}{*}{ Net Container Weight (lb) } & Maximum & 402 & N/A \\
\hline & Minimum & 14 & N/A \\
\hline & Average & 187.2 & N/A \\
\hline
\end{tabular}

3.13. 1.6.1 Drum Preparation-Approved liners for drums of TRU waste packaged for offsite shipment were the round-bottom liner (Rockwell specification SX-203) inside a 90-mil rigid polyethylene liner (Rockwell specification SX-202), or an O-ring bag and a polyethylene bag placed inside the rigid liner if the drum was attached to a glovebox (EG\&G RFP 1989e). Type III rigid liners have been used since September 1983 (Bearly 1989a). The IDC 339 waste packaged for offsite shipment required a round bottom liner inside the rigid liner (EG\&G RFP 1988c). Figure C-2 shows the appropriate drum liners for this IDC. If a single piece of heavy metal was packaged in a drum, it was braced to prevent shifting. Sharp edges were taped to prevent puncturing of the liners (Rockwell International 1989b). All bags were closed using the twist-and-tape method (Rockwell International 1989e).

Flow-in, ventable gaskets were installed in the drums beginning in December 1982. They were used until October 1988, when tubular gaskets with carbon filters were required. Drums shipped to INEL between 1985 and 1988 may not meet the current WIPP WAC, owing to their lack of carbon filters (Bearly 1989b).

3.13.1.6.2 Box Preparation-No boxes of IDC 339 waste were shipped to INEL between 1985 and 1989.

3.13.1.7 Assay. The drums may have been assayed on an SGS or PADC. Containers of waste that have not been PADC assayed and had SGS assay values of 1 gram or less should be PADC assayed to verify that they are transuranic waste. Table 3.13.1-2 summarizes the dose rates measured on containers of this IDC. Table 3.13.1-3 provides a summary of the assay information.

Table 3.13.1-2. Item Description Code 339 Dose Information.

\begin{tabular}{crrc}
\hline Information & & Drums & Boxes \\
\hline One Meter Dose Rate (mrem/h) & $0-0.5$ & 306 & N/A \\
& $0.5-10$ & 14 & N/A \\
Surface Dose Rate (mrem/h) & $<10$ & 320 & N/A \\
& $10-200$ & 0 & N/A \\
\hline
\end{tabular}


Table 3.13.1-3. Item Description Code 339 Assay Information.

\begin{tabular}{|c|c|c|c|}
\hline \multicolumn{2}{|c|}{ Radionuclide inventory } & \multirow{2}{*}{$\frac{\text { Drums }}{170}$} & \multirow{2}{*}{$\frac{\text { Boxes }}{\text { N/A }}$} \\
\hline Plutonium (g) & Maximum & & \\
\hline & Minimum & 0 & N/A \\
\hline & Average & 23.8 & N/A \\
\hline \multirow[t]{3}{*}{ Americium (g) } & Maximum & 0 & N/A \\
\hline & Minimum & 0 & N/A \\
\hline & Average & 0 & N/A \\
\hline \multirow[t]{3}{*}{ Uranium-235 (g) } & Maximum & - & N/A \\
\hline & Minimum & - & N/A \\
\hline & Average & - & N/A \\
\hline
\end{tabular}

3.13.1.8 Inspection. Waste Certification personnel performed periodic inspections of the generating and packaging process to verify compliance with waste acceptance criteria. In addition, each drum was viewed using RTR to

- Ensure the drum does not contain nonconforming items

- Ensure the drum is properly packaged

- Verify the waste form description

- Evaluate the presence of free liquids.

3.13.1.9 Waste Form Evaluation. Table 3.13.1-4 evaluates the waste form against the WIPP WAC for such items as free liquids, pyrophoric materials, and compressed gases.

Table 3.13.1-5 evaluates the waste against TRUPACT criteria. 
Table 3.13.1-4. Waste Form Evaluation.

Criterion or

requirement

Limiting parameters ${ }^{2}$

Immobilization Particulates were prohibited by procedural control. Based on the description of the waste, fine particulates are not expected in this IDC.

Liquids

There are normally no liquids associated with this IDC. Personnel performing RTR examination at Rocky Flats would accept up to 2 cups of free liquid, if liquids were present.

Pyrophoric

Materials

Pyrophoric materials were prohibited by procedural control. The absence of the pyrophoric materials was verified by the generating supervisor and periodic inspection by the Waste Certification Organization.

Explosives and Compressed Gases

Explosives and compressed gases were prohibited by procedural control. The absence of the explosives and compressed gases was verified by the generating supervisor and periodic inspection by the Waste Certification Organization. In addition, unvented, closed containers and pressurized containers were excluded by procedural controls and RTR examination. This waste carries the reactive EPA hazardous waste code.

TRU-Mixed Wastes The RCRA constituents exist as co-contaminants with the transuranic radionuclides. Compliance with the WIPP RCRA permits and NMD will be required prior to shipment of the stored waste to WIPP.

Specific Activity of A portion of the waste stored at INEL may contain < 100 nanocuries per gram Waste transuranic radionuclides.

$\mathrm{Pu}^{239}$ Equivalent Activity

None of the IDC 339 waste containers recorded as shipped to INEL in the SWIMS exceed $1,000 \mathrm{Ci}$ of plutonium-equivalent activity.

a. Many of the limiting parameters were taken from TRU Waste Compliance Program (Rockwell International 1983a, 1987e, and 1989b). 
Table 3.13.1-5. TRUPACT Evaluation.

Criterion or

requirement

Limiting parameters ${ }^{\mathrm{a}}$

Waste Package

Weight

Rocky Flats limited the gross weight of drums to $800 \mathrm{lb}$. The TRUPACT and

Waste Containers

vehicle weight limits must be verified at the time of payload assembly at INEL.

Nuclear

Criticality

Waste was shipped in 55-gal DOT-7A, Type A drums.

Rocky Flats limited the fissile content of the drums to 200 grams. However, the error-times-two requirement was not in place at the time the drums were shipped to INEL; therefore, it is not reported as part of the assay of the drum. The TRUPACT limit must be verified at the time of payload assembly at INEL. Based on the typical assays of the IDC 339 drums, the criticality criteria will be met but must be recalculated or assayed to meet the error-times-two requirement.

Surface Dose

Rate

The surface dose rate criteria used by Rocky Flats was $200 \mathrm{mrem} / \mathrm{hr}$ at the drum surface and $10 \mathrm{mrem} / \mathrm{hr}$ at 1 meter. Shielding was not used for one for IDC 339 drum. The TRUPACT limit must be verified at the time of payload assembly at INEL. Based on the typical dose rates from the IDC 339 drums, the dose rate criteria will be met.

Removable The Rocky Flats limit for removable contamination (for TRU assumed to be all

Surface alpha) was 20 disintegrations per minute $/ 100 \mathrm{~cm}^{2}$. The Rocky Flats limit is

Contamination equivalent to 9 picocuries per $100 \mathrm{~cm}^{2}$, which is well within the WIPP criteria.

Thermal Power

The thermal power calculation reported in the SWIMS data package is based on the reported assay value without an error/uncertainty correction. The thermal power must be recalculated based on the assay error determination.

Gas Generation Based on the procedural requirements for packaging IDC 339 waste and the waste description, the only areas of noncompliance are carbon filters, nonpunctured rigid liners, headspace gas analysis, and visual characterization.

Carbon tetrachloride, 1,1,1-trichloroethane, 1,1,2-trichloro-1,2,2-trifluoroethane, dichloromethane, toluene, and trichloroethylene were detected by headspace analysis in IDC 339. These chemicals appear to be in total concentrations $<1 \%$. There are no organics on the TRUPACT Chemical list for RF 123A.

Personnel performing RTR examination at Rocky Flats would accept up to $10 \%$ of another IDC. The other IDCs could be combustibles, glass, concrete, metal, and plastics.

a. Many of the limiting parameters were taken from TRU Waste Compliance Program (Rockwell International 1983a, 1987e, and 1989b). 
3.13.1.10 Combustible and Organic Content. Table 3.13.1-6 outline available data from the TRU Waste Sampling Program for IDC 339. SWIMS data indicate that this waste form contains $>20 \%$ combustibles and $>20 \%$ organics.

Table 3.13.1-6. Item Description Code 339 Data Summary for Combustible and Organic Content.

\begin{tabular}{ccccccc}
\hline Container & $\begin{array}{c}\text { Wt. } \\
\text { combustibles } \\
(\mathrm{lb})^{\mathrm{a}}\end{array}$ & $\begin{array}{c}\text { Wt. } \\
\text { organics } \\
(\mathrm{lb})^{\mathrm{b}}\end{array}$ & $\begin{array}{c}\text { Net wt. of } \\
\text { container } \\
(\mathrm{lb})^{\mathrm{c}}\end{array}$ & $\begin{array}{c}\text { Wt\% } \\
\text { combustibles }^{\mathrm{d}}\end{array}$ & $\begin{array}{c}\text { Vol\% } \\
\text { combustibles }^{\mathrm{c}}\end{array}$ & $\begin{array}{c}\text { Wt\% } \\
\text { organics }^{f}\end{array}$ \\
\hline $19-01831$ & 185.0 & 185.0 & 192.0 & 96 & 100 & 96 \\
$19-01840$ & 260.5 & 260.5 & 269.5 & 97 & 100 & 97 \\
$19-01845$ & 165.5 & 165.5 & 178.0 & 93 & 100 & 93 \\
$19-01884$ & 296.0 & 296.0 & 300.5 & 99 & 100 & 99 \\
$19-01472$ & 126.1 & 126.1 & 130.5 & 97 & 100 & 97 \\
$22-00224$ & 295.3 & 295.3 & 324.8 & 91 & 100 & 91 \\
$23-00435$ & 235.5 & 235.5 & 237.9 & 99 & 100 & 99 \\
\hline
\end{tabular}

a. Sum of weights of all combustible material and leaded rubber from Table 29 (Clements and Kudera 1985).

b. Sum of weights of all combustible material, leaded rubber, and organic material from Table 29 (Clements and Kudera 1985).

c. Net weight of container from Table 29 (Clements and Kudera 1985).

d. Weight of combustible material/net weight of container $\times 100$.

e. Vol\% of combustible material from visual examination, obtained from Appendix B (Clements and Kudera 1985).

f. Weight of organic material/net weight of container $\times 100$.

3.13.1.10.1 Combustible Content-SWIMS data show that IDC 339 waste is combustible (EG\&G RFP 1993c). In support of the TRU Waste Sampling Program, seven drums of IDC 339 waste were opened. They were found to contain an average wt\% combustible content of $96 \%$. Visual inspection showed an average vol\% combustible content of $100 \%$. (Clements and Kudera 1985).

3.13.1.10.2 Organic Content-SWIMS data show that IDC 339 waste may contain 20\% organics (Rockwell International 1985a). In support of the TRU Waste Sampling Program, seven drums of IDC 339 waste were opened. They were found to contain an average wt\% organic content of $96 \%$ (Clements and Kudera 1985). 
3.13.1.11 Analytical Information. Analytical data compiled by the Rocky Flats Plant show the presence of lead (EPA Code D008) above the regulatory levels stated in 6 CCR 1007-3, Section 261.24, in one sample, borderline in another, and well below the de minimis level in another (EG\&G RFP 1994j). The available analytical data were obtained from unused, 30-millimeter-thick gloves. A summary of analytical data results is shown in Table 3.13.1-7.

Table 3.13.1-7. Analytical Data Summary.

\begin{tabular}{lcccc}
\hline IDC & Lab report & Sample date & Constituents & Concentration \\
\hline 339 & E901808 & $9-27-90$ & Lead & $1,610 \mu \mathrm{g} / \mathrm{liter}$ \\
339 & G910049 & $8-27-91$ & Lead & $5,940 \mu \mathrm{g} / \mathrm{liter}$ \\
339 & G930444 & $6-29-93$ & Lead & $4,050 \mu \mathrm{g} /$ liter
\end{tabular}

a. Estimated

One drum (D35306) of IDC 339 leaded gloves were exposed to acids but not washed. The acid of greatest concern is nitric acid as it reacts with the lead oxide layer of the glove to form reactive compounds. This drum is therefore assigned D003 for reactivity in addition to D008 for lead (EG\&G RFP 1994j).

Analytical data from the WIPP Experimental Waste Characterization Program (EG\&G RFP 1994t) for IDC 339, Leaded Gloves, indicate that four drums were subject to headspace gas analysis.

IDC 339 Gas Mass Spectrometry analytical results are presented in Table 3.13.1-8. Drums were subject to the operational lid headspace sampling program. Nitrogen, oxygen, argon, and carbon dioxide were detected in the drums.

IDC 339 VOC Gas Chromatography/Mass Spectrometry analytical results are presented below and in Tables 3.13.1-9 and 3.13.1-10. Drums were subject to the operational lid headspace sampling program. Unreported analyte values indicate that analytes were undetected, or detected at or above the MDL but at a level below the PRQL in these drums.

Analytical results for nine analytes indicate $20.7 \mathrm{ppmv}$ trichloro-trifluoroethane in one of four drums tested (D73987).

Analytical results for nine analytes are presented in Table 3.13.1-9. Analytes were detected in two of four drums tested. Two analytes (1,1,1-trichloroethane and carbon tetrachloride) were detected in the drums.

Analytical results for 10 analytes are presented in Table 3.13.1-10. Analytes were detected in three of the four drums tested. One analyte (toluene) was detected in the drums.

Analytical data from the TRU Waste Sampling Waste Characterization Program (Clements and Kudera 1985) for IDC 339, Leaded Gloves, indicate that seven drums were subject to headspace gas 
analysis. Gas composition analytical results are presented in Table 3.13.1-11. Waste boxes were not sampled. Hydrogen, oxygen, nitrogen, argon, carbon dioxide, nitrogen oxide(s), saturated hydrocarbons, 1,1,1-trichloroethane, dichloromethane, carbon tetrachloride, and trichloroethylene were detected in the drums.

Table 3.13.1-8. Gas Mass Spectrometry Results (vol\%).

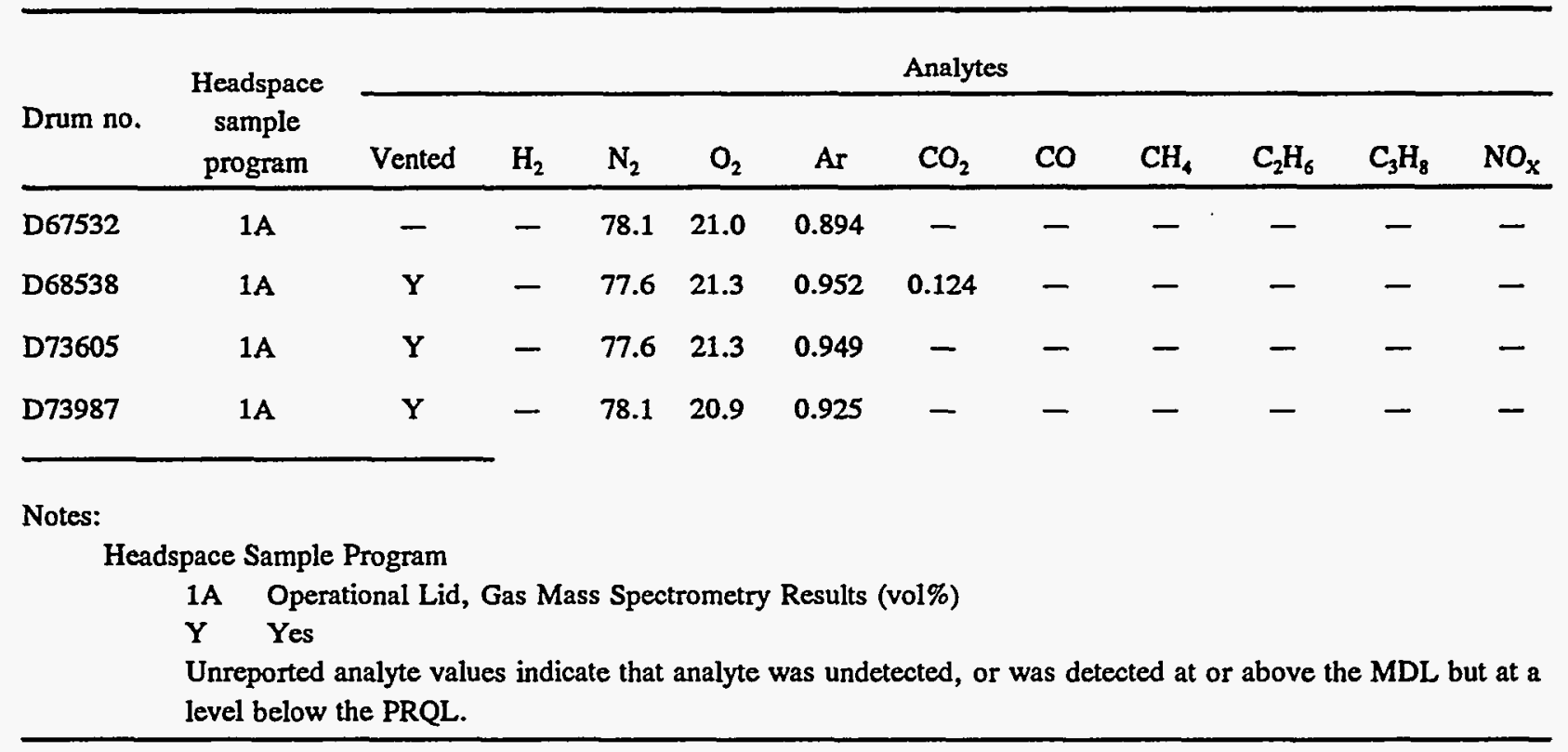


Table 3.13.1-9. Volatile Organic Compound Gas Chromatography/Mass Spectrometry Results (parts per million by volume).

\begin{tabular}{|c|c|c|c|c|c|c|c|c|c|c|c|}
\hline \multirow[b]{2}{*}{$\begin{array}{l}\text { Drum } \\
\text { no. }\end{array}$} & \multirow[b]{2}{*}{$\begin{array}{c}\text { Headspace } \\
\text { sample } \\
\text { program }\end{array}$} & \multirow[b]{2}{*}{ Vented } & \multicolumn{9}{|c|}{ Analytes } \\
\hline & & & $\begin{array}{l}\text { Chloro- } \\
\text { form }\end{array}$ & $\begin{array}{c}1,1,1- \\
\text { trichloro- } \\
\text { ethane }\end{array}$ & $\begin{array}{l}\text { Cyclo- } \\
\text { hexane }\end{array}$ & $\begin{array}{c}\text { Carbon } \\
\text { tetra- } \\
\text { chloride }\end{array}$ & Benzene & $\begin{array}{c}1,2- \\
\text { dichloro- } \\
\text { ethane }\end{array}$ & 1-butanol & $\begin{array}{l}\text { Trichloro- } \\
\text { ethene }\end{array}$ & $\begin{array}{l}\text { 4-methyl-2- } \\
\text { pentanone }\end{array}$ \\
\hline D67532 & $1 B$ & - & - & 456.3 & - & - & - & - & - & 一 & - \\
\hline D73605 & $1 B$ & $\mathbf{Y}$ & - & 3.0 & - & 3.9 & - & - & - & - & - \\
\hline
\end{tabular}

Table 3.13.1-10. Volatile Organic Compound Gas Chromatography/Mass Spectrometry Results (parts per million by volume).

\begin{tabular}{|c|c|c|c|c|c|c|c|c|c|c|c|c|}
\hline $\begin{array}{l}\text { Drum } \\
\text { no. }\end{array}$ & $\begin{array}{c}\text { Headspace } \\
\text { sample } \\
\text { program }\end{array}$ & Vented & Toluene & $\begin{array}{l}\text { Tetra- } \\
\text { chloro- } \\
\text { ethene }\end{array}$ & $\begin{array}{l}\text { Chloro- } \\
\text { benzene }\end{array}$ & $\begin{array}{l}\text { Ethyl- } \\
\text { benzene }\end{array}$ & $\begin{array}{c}\mathrm{m}, \mathrm{p}- \\
\text { xylene }\end{array}$ & o-xylene & $\begin{array}{l}\text { Bromo- } \\
\text { form }\end{array}$ & $\begin{array}{c}1,1,2,2- \\
\text { tetra- } \\
\text { chloro- } \\
\text { ethane }\end{array}$ & $\begin{array}{c}1,3,6- \\
\text { trimethyl- } \\
\text { benzene }\end{array}$ & $\begin{array}{c}1,2,4- \\
\text { trimethyl- } \\
\text { benzene }\end{array}$ \\
\hline D68538 & 1B & $\mathrm{Y}$ & 2.1 & - & - & - & - & - & - & - & - & - \\
\hline D73605 & 1B & $\mathrm{Y}$ & 3.9 & - & - & - & - & - & - & - & - & - \\
\hline D73987 & $1 \mathrm{~B}$ & $\mathrm{Y}$ & 3.1 & - & - & - & - & - & - & - & - & - \\
\hline \multicolumn{13}{|l|}{ Notes: } \\
\hline \multicolumn{13}{|c|}{ Headspace Sample Program } \\
\hline & 1B Opera & ional Lid, & VOC Gas & hromatog & aphy/Mass & Spectromet & Results ( & nv) & & & & \\
\hline & Y Yes & 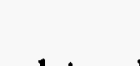 & & \multicolumn{9}{|c|}{ Unreported analyte values indicate that analyte was undetected, or was detected at or above the MDL but at a level below the PRQL. } \\
\hline
\end{tabular}


Table 3.13.1-11. Gas Sampling Results-Compositional Analysis (vol\%).

\begin{tabular}{|c|c|c|c|c|c|c|c|c|c|c|c|}
\hline \multirow[b]{2}{*}{$\begin{array}{l}\text { Container } \\
\text { ID. no. }\end{array}$} & \multirow{2}{*}{$\begin{array}{c}\text { Storage } \\
\text { time } \\
\text { (days) }\end{array}$} & \multicolumn{10}{|c|}{ Analytes } \\
\hline & & $\mathrm{H}_{2}$ & $\mathrm{O}_{2}$ & $\mathrm{~N}_{2}$ & $\mathrm{Ar}$ & $\mathrm{CO}_{2}$ & $\mathrm{CO}$ & $\mathrm{NO}_{\mathrm{x}}$ & $\begin{array}{l}\text { Hydrocarbons } \\
\text { (saturated) }^{1}\end{array}$ & $\begin{array}{c}1,1,1- \\
\text { trichloroethane }\end{array}$ & $\begin{array}{c}\text { Other } \\
\text { hydrocarbons }{ }^{2}\end{array}$ \\
\hline \multirow[t]{2}{*}{$19-01831$} & 420 & 2.38 & 10.5 & 83.6 & 1.0 & 1.4 & - & - & 0.35 & 0.60 & $0.14^{a}$ \\
\hline & & & & & & & & & & & $0.08^{\mathrm{b}}$ \\
\hline \multirow[t]{2}{*}{$19-01840$} & 389 & 0.38 & 18.5 & 79.4 & 0.95 & 0.06 & - & - & 0.22 & 0.14 & $0.06^{a}$ \\
\hline & & & & & & & & & & & $0.29^{b}$ \\
\hline $19-01845$ & 390 & 2.84 & 7.3 & 85.3 & 1.0 & 2.4 & - & 0.97 & 0.13 & - & - \\
\hline $19-01884$ & 369 & 1.09 & 13.9 & 83.3 & 1.0 & 0.35 & - & - & 0.28 & - & - \\
\hline $19-01472$ & 965 & 2.90 & 4.46 & 90.3 & 1.2 & 1.1 & - & - & - & - & - \\
\hline $22-00224$ & 4,268 & 0.74 & 16.0 & 80.7 & 0.96 & 1.6 & - & - & - & - & - \\
\hline \multirow[t]{2}{*}{$23-00435$} & 4,340 & 4.12 & 0.54 & 93.1 & 1.1 & 1.0 & - & - & 0.09 & 0.04 & $0.03^{c}$ \\
\hline & & & & & & & & & & & $0.02^{b}$ \\
\hline \multicolumn{12}{|l|}{ Notes: } \\
\hline 1. & \multicolumn{11}{|c|}{$\begin{array}{l}\text { Saturated hydrocarbons-methane through propane. } \\
\text { Other hydrocarbons-as specified. }\end{array}$} \\
\hline & \multirow{2}{*}{\multicolumn{11}{|c|}{$\begin{array}{l}\text { Dichloromethane } \\
\text { Carbon tetrachloride }\end{array}$}} \\
\hline & \multirow{2}{*}{\multicolumn{10}{|c|}{$\begin{array}{l}\text { Carbon tetrachloride } \\
\text { Trichloroethylene }\end{array}$}} & \\
\hline & & & & & & & & & & & \\
\hline
\end{tabular}




\subsection{Waste Form Number 124-TRU Pyrochemical Salt Waste, Content Code RF 124A}

\subsubsection{Item Description Code 411-Electrorefining Salt}

3.14.1.1 Certification Assessment. This IDC is certifiable without further waste treatment. Assay and thermal power calculations, including error, need to be updated to meet the current WIPP WAC. Several gas generation criteria need to be addressed. Carbon filters may need to be installed, drums will require inspection to identify unvented or unpunctured rigid liners, and headspace gas analysis and visual waste characterization will need to be performed.

3.14.1.2 Waste Description. This waste was produced during the electrorefining of nonspecification plutonium metal. Nonspecification plutonium metal, cast as an anode, was combined with an equimolar mixture of sodium chloride and potassium chloride in a magnesium oxide crucible. Magnesium chloride was then added to initiate the plutonium oxidation. The metal and salts were placed in a furnace and heated until molten. The molten mixture was stirred, and a current applied to the anode which flowed through the molten mixture to the cathode. Plutonium ions migrated from the molten anode through the molten salt to the cathode and were reduced to purified metal. After cooling, the crucible was broken and the salt, anode heel, and purified plutonium metal were separated. IDC 411 waste is composed primarily of sodium chloride, potassium chloride, residual magnesium chloride, entrained magnesium metal, and various plutonium compounds. These salts may contain sodium and potassium metal that was produced during the electrolysis of the molten salt mixture (EG\&G RFP 19941).

3.14.1.3 Generation Source. The primary buildings of generation of IDC 411 waste were Buildings 371, 771, 776, and 779 (EG\&G RFP 19941).

3.14.1.4 Recovery Method. This IDC was never generated as a residue and therefore has no recovery method (EG\&G RFP 19941).

3.14.1.5 Waste Packaging and Handling. Waste salt was packaged in \#303 product cans with the lids rolled-seam sealed to the can. Each can was contained in double plastic bags and placed in an 8802 Vollrath stainless-steel can. The can was placed in a prepared 55-gal drum. An estimated 50 cans of waste would fit into a drum (Clements 1982).

3.14.1.6 Container Preparation. Only approved containers could be used to package TRU waste for shipment offsite. Containers approved for shipment to INEL during this time were DOT17C, white, 55-gal drums (Rockwell specification SX-200). These containers met the requirements for certification as DOT-7A Type A packaging (EG\&G RFP 1989e).

Table 3.14.1-1 shows the current inventory of IDC 411 waste containers from the Rocky Flats Plant that have been shipped to INEL since 1985. 
Table 3.14.1-1. Item Description Code 411 Container Information.

\begin{tabular}{|c|c|c|c|}
\hline \multicolumn{2}{|l|}{ Information } & \multirow{2}{*}{$\frac{\text { Drums }}{17}$} & \multirow{2}{*}{$\frac{\text { Boxes }}{0}$} \\
\hline Total Containers & & & \\
\hline \multirow[t]{3}{*}{ Net Container Weight (lb) } & Maximum & 274 & N/A \\
\hline & Minimum & 23 & N/A \\
\hline & Average & 74 & N/A \\
\hline
\end{tabular}

3.14. 1.6.1 Drum Preparation-Approved liners for drums of TRU waste packaged for offsite shipment were the round-bottom liner (Rockwell specification SX-203) inside a 90-mil rigid polyethylene liner (Rockwell specification SX-202), or an O-ring bag and a polyethylene bag placed inside the rigid liner if the drum was attached to a glovebox (Rockwell International 1989e). Type III rigid liners have been used since September 1983 (Bearly 1989a). The IDC 411 waste packaged for offsite shipment required a fiberboard liner, a round bottom liner and two polyethylene bags inside the rigid liner (EG\&G RFP 1988c). Figure C-1 shows the appropriate drum liners for this IDC. If a single piece of heavy metal was packaged in a drum, it was braced to prevent shifting. Sharp edges were taped to prevent puncturing of the liners (Rockwell International 1989b). All bags were closed using the twist-and-tape method (Rockwell International 1989e).

Flow-in, ventable gaskets were installed in the drums beginning in December 1982 . They were used until October 1988, when tubular gaskets with carbon filters were required. Drums shipped to INEL between 1985 and 1988 may not meet the current WIPP WAC, owing to their lack of carbon filters (Bearly 1989a).

3.14. 1.6.2 Box Preparation-No boxes of IDC 411 waste were shipped to INEL between 1985 and 1989 .

3.14.1.7 Assay. Small containers of spent salt may have been assayed in the "in-line can counter." These cans would then have been checked using SGS assay equipment. Otherwise, the drums would have been assayed on an SGS counter or a PADC. Table 3.14.1-2 summarizes the dose rates measured on containers of this IDC. Table $3.14 .1-3$ provides a summary of the assay information.

Table 3.14.1-2. Item Description Code 411 Dose Information.

\begin{tabular}{crrcc}
\hline \multicolumn{2}{c}{ Information } & & Drums & Boxes \\
\cline { 2 - 4 } One Meter Dose Rate (mrem/h) & $0-0.5$ & 5 & N/A \\
& $0.5-10$ & 12 & N/A \\
Surface Dose Rate (mrem/h) & $<10$ & 8 & N/A \\
& $10-200$ & 9 & N/A \\
\hline
\end{tabular}


Table 3.14.1-3. Item Description Code 411 Assay Information.

\begin{tabular}{|c|c|c|c|}
\hline \multicolumn{2}{|c|}{ Radionuclide inventory } & \multirow{2}{*}{$\frac{\text { Drums }}{200}$} & \multirow{2}{*}{$\frac{\text { Boxes }}{\text { N/A }}$} \\
\hline Plutonium (g) & Maximum & & \\
\hline & Minimum & 43 & N/A \\
\hline & Average & 147 & N/A \\
\hline \multirow[t]{3}{*}{ Americium (g) } & Maximum & - & N/A \\
\hline & Minimum & - & N/A \\
\hline & Average & - & N/A \\
\hline \multirow[t]{3}{*}{ Uranium-235 (g) } & Maximum & - & N/A \\
\hline & Minimum & - & N/A \\
\hline & Average & - & N/A \\
\hline
\end{tabular}

3.14.1.8 Inspection. Waste Certification personnel performed periodic inspections of the generating and packaging process to verify compliance with waste acceptance criteria. In addition, drums which are not lead-lined were viewed using RTR to

- Ensure the drum does not contain nonconforming items

- Ensure the drum is properly packaged

- Verify the waste form description

- Evaluate the presence of free liquids.

3.14.1.9 Waste Form Evaluation. Table 3.14.1-4 evaluates the waste form against the WIPP WAC for such items as free liquids, pyrophoric materials, and compressed gases.

Table 3.14.1-5 evaluates the waste against TRUPACT criteria. 
Table 3.14.1-4. Waste Form Evaluation.

Criterion or

requirement

Limiting parameters ${ }^{a}$

Immobilization

This waste consists of fused salts. Based on the description of the waste, fine particulates are not expected in this IDC.

Liquids

There are normally no liquids associated with this IDC. Personnel performing RTR examination at Rocky Flats would accept up to 2 cups of free liquid, if liquids were present.

Pyrophoric

Pyrophoric materials were prohibited by procedural control. The absence of the Materials pyrophoric materials was verified by the generating supervisor and periodic inspection by the Waste Certification Organization.

Explosives and Compressed Gases

Explosives and compressed gases were prohibited by procedural control. The absence of the explosives and compressed gases was verified by the generating supervisor and periodic inspection by the Waste Certification Organization. In addition, unvented, closed containers and pressurized containers were excluded by procedural controls and RTR examination.

TRU-Mixed Wastes The RCRA constituents exist as co-contaminants with the transuranic radionuclides. Compliance with the WIPP RCRA permits and NMD will be required prior to shipment of the stored waste to WIPP.

Specific Activity of This waste contains at least 100 nanocuries per gram transuranic radionuclides. Waste $\mathrm{Pu}^{239}$ Equivalent None of the IDC 411 waste containers recorded as shipped to INEL in the Activity SWIMS exceed $1,000 \mathrm{Ci}$ of plutonium-equivalent activity.

a. Many of the limiting parameters were taken from TRU Waste Compliance Program (Rockwell International 1983a, 1987e, and 1989b). 
Table 3.14.1-5. TRUPACT Evaluation.

\begin{tabular}{|c|c|}
\hline $\begin{array}{l}\text { Criterion or } \\
\text { requirement }\end{array}$ & Limiting parameters ${ }^{\mathbf{a}}$ \\
\hline $\begin{array}{l}\text { Waste Package } \\
\text { Weight }\end{array}$ & $\begin{array}{l}\text { Rocky Flats limited the gross weight of drums to } 800 \mathrm{lb} \text {. The TRUPACT and } \\
\text { vehicle weight limits must be verified at the time of payload assembly at INEL. }\end{array}$ \\
\hline Waste Containers & Waste was shipped in 55-gal DOT-7A, Type A drums. \\
\hline $\begin{array}{l}\text { Nuclear } \\
\text { Criticality }\end{array}$ & $\begin{array}{l}\text { Rocky Flats limited the fissile content of the drums to } 200 \text { grams. However, the } \\
\text { error-times-two requirement was not in place at the time the drums were shipped to } \\
\text { INEL; therefore, it is not reported as part of the assay of the drum. The } \\
\text { TRUPACT limit must be verified at the time of payload assembly at INEL. } \\
\text { Based on the typical assays of the IDC } 411 \text { drums, the criticality criteria will } \\
\text { require re-assay to meet the error-times-two requirement. }\end{array}$ \\
\hline $\begin{array}{l}\text { Surface Dose } \\
\text { Rate }\end{array}$ & $\begin{array}{l}\text { The surface dose rate criteria used by Rocky Flats was } 200 \mathrm{mrem} / \mathrm{hr} \text { at the drum } \\
\text { surface and } 10 \text { mrem/hr at } 1 \text { meter. Shielding was not necessary for IDC } 411 \\
\text { drums. The TRUPACT limit must be verified at the time of payload assembly at } \\
\text { INEL. Based on the typical dose rates from the IDC } 411 \text { drums, the dose rate } \\
\text { criteria will be met. }\end{array}$ \\
\hline $\begin{array}{l}\text { Removable } \\
\text { Surface } \\
\text { Contamination }\end{array}$ & $\begin{array}{l}\text { The Rocky Flats limit for removable contamination (for TRU assumed to be all } \\
\text { alpha) was } 20 \text { disintegrations per minute } / 100 \mathrm{~cm}^{2} \text {. The Rocky Flats limit is } \\
\text { equivalent to } 9 \text { picocuries per } 100 \mathrm{~cm}^{2} \text {, which is well within the WIPP criteria. }\end{array}$ \\
\hline Thermal Power & $\begin{array}{l}\text { The thermal power calculation reported in the SWIMS data package is based on the } \\
\text { reported assay value without an error/uncertainty correction. The thermal power } \\
\text { must be recalculated based on the assay error determination. }\end{array}$ \\
\hline Gas Generation & $\begin{array}{l}\text { Based on the procedural requirements for packaging IDC } 411 \text { waste and the waste } \\
\text { description, the only areas of noncompliance are carbon filters, nonpunctured rigid } \\
\text { liners, headspace gas analysis, and visual characterization. }\end{array}$ \\
\hline & $\begin{array}{l}\text { Personnel performing RTR examination at Rocky Flats would accept up to } 10 \% \text { of } \\
\text { another IDC. The other IDCs could be combustibles, glass, concrete, metal, } \\
\text { leaded gloves, and plastics. }\end{array}$ \\
\hline
\end{tabular}

a. Many of the limiting parameters were taken from TRU Waste Compliance Program (Rockwell International 1983a, 1987e, and 1989b).

3.14.1.10 Combustible and Organic Content. SWIMS data indicate that this waste form does not contain $>20 \%$ combustibles or $>20 \%$ organics.

3.14.1.10.1 Combustible Content-SWIMS data show that IDC 411 waste is noncombustible (Rockwell International 1985a).

3.14.1.10.2 Organic Content-SWIMS data show that IDC 411 waste contains $20 \%$ organics (Rockwell International 1985a). 
3.14.1.11 Analytical Information. No headspace gas analysis is available for IDC 411 .

IDC 411 is not a RCRA-hazardous waste and has been assigned no EPA codes; however, one drum (D36093) assigned IDC 411 contains a inner package of IDC 420 , incinerator ash, and many inner packages of IDC 411. Because incinerator ash is a hazardous waste, this entire drum is a hazardous waste. The EPA Codes assigned to this waste are D004-D011, F001, F002, F003, and F005 (EG\&G RFP 19941). 


\subsection{Waste Form Number 126-Solidified Process Solids, Content Code RF 126A}

\subsubsection{Item Description Code 822-Cemented Resin}

3.15.1.1 Certification Assessment. This IDC is certifiable without further waste treatment. Assay and thermal power calculations, including error, need to be updated to meet the current WIPP WAC. Several gas generation criteria need to be addressed. Carbon filters may need to be installed, drums will require inspection to identify unvented or unpunctured rigid liners, and headspace gas analysis and visual waste characterization will need to be performed.

3.15.1.2 Waste Description. IDC 822-cemented resin, consists of anion exchange resins used in the purification and recovery of plutonium. The resins were leached prior to cementation (Rockwell International 1987e). A formula was used to precondition the waste (that is, neutralize, thicken), and the amount of Portland cement, mixing method, and cure time were recorded. Cemented wastes were cast into 1-gal molds and allowed to cure. The cured "pucks" were removed from the molds in the form of a solid monolith. IDC 822 is included in IDC 806 (Rockwell International 1989b).

3.15.1.3 Generation Source. The major generator of this waste was Plutonium Recovery Operations in Building 771 (Rockwell International 1987e).

3.15.1.4 Recovery Method. This IDC was never generated as a residue and therefore has no recovery method.

3.15.1.5 Waste Packaging and Handling. Process solids were the particulate and sludgetype wastes that had been processed to recover as much plutonium as economically feasible. After processing, the wastes were removed from the glovebox in 4-liter (or smaller) polyethylene container and assayed for plutonium. The waste packages were collected in a 55-gal drum for transfer to the solidification area (Rockwell International 1989b).

Each drum of process solids was processed as a batch. One drum of unsolidified waste produced three drums of solidified process solids. After solidification, the "pucks" were removed from the glovebox, double-bagged, and placed into a DOT-17C, 55-gal, steel drum with a 90-mil rigid liner.

3.15.1.6 Container Preparation. Only approved containers could be used to package TRU waste for shipment offsite. The containers approved for shipment to INEL during this time were DOT-17C, white, 55-gal drums (Rockwell specification SX-200). These containers met the requirements for certification as DOT-7A Type A packaging (Rockwell International 1989e).

Table 3.15.1-1 shows the current inventory of IDC 822 waste containers from the Rocky Flats Plant that have been shipped to INEL since 1985 . 
Table 3.15.1-1. Item Description Code 822 Container Information.

\begin{tabular}{|c|c|c|c|}
\hline \multicolumn{2}{|l|}{ Information } & \multirow{2}{*}{$\frac{\text { Drums }}{31}$} & \multirow{2}{*}{$\frac{\text { Boxes }}{0}$} \\
\hline Total Containers & & & \\
\hline \multirow[t]{3}{*}{ Net Container Weight (lb) } & Maximum & 342 & N/A \\
\hline & Minimum & 92 & N/A \\
\hline & Average & 235 & N/A \\
\hline
\end{tabular}

3.15. 1.6.1 Drum Preparation-Approved liners for drums of TRU waste packaged for offsite shipment were the round-bottom liner (Rockwell specification SX-203) inside a 90-mil rigid polyethylene liner (Rockwell specification SX-202), or an O-ring bag and a polyethylene bag placed inside the rigid liner if the drum was attached to a glovebox (Rockwell International 1989e). Type III rigid liners have been used since September 1983 (Bearly 1989a). No information regarding packaging requirements for this waste form could be located.

Flow-in, ventable gaskets were installed in the drums beginning in December 1982. They were used until October 1988, when tubular gaskets with carbon filters were required. Drums shipped to INEL between 1985 and 1988 may not meet the current WIPP WAC, owing to their lack of carbon filters (Bearly 1989a).

3.15. 1.6.2 Box Preparation-No boxes of IDC 822 waste were shipped to INEL between 1985 and 1989.

3. 15. 1.7 Assay. Individual containers of processed material were assayed in the "in-line can counter." The individual assay values for containers solidified in a batch and placed into a drum were totaled to provide an assigned assay value for the drum. The drums may have been assayed on an SGS counter or PADC to verify the assigned value. Containers of waste that have not been PADC assayed and had SGS or in-line can counter assay values of 1 gram or less should be PADC assayed to verify that they are transuranic waste. Table 3.15.5-2 summarizes the dose rates measured on containers of this IDC. Table $3.15 .5-3$ provides a summary of the assay information.

Table 3.15.1-2. Item Description Code 822 Dose Information.

\begin{tabular}{crrr}
\hline Information & & Drums & Boxes \\
\hline One Meter Dose Rate (mrem/h) & $0-0.5$ & 31 & N/A \\
& $0.5-10$ & 0 & N/A \\
Surface Dose Rate $(\mathrm{mrem} / \mathrm{h})$ & $<10$ & 31 & N/A \\
& $10-200$ & 0 & N/A \\
\hline
\end{tabular}


Table 3.15.1-3. Item Description Code 822 Assay Information.

\begin{tabular}{|c|c|c|c|}
\hline \multicolumn{2}{|c|}{ Radionuclide inventory } & \multirow{2}{*}{$\frac{\text { Drums }}{76}$} & \multirow{2}{*}{$\frac{\text { Boxes }}{\text { N/A }}$} \\
\hline Plutonium (g) & Maximum & & \\
\hline & Minimum & 0 & N/A \\
\hline & Average & 11 & N/A \\
\hline \multirow[t]{3}{*}{ Americium (g) } & Maximum & - & N/A \\
\hline & Minimum & - & N/A \\
\hline & Average & - & N/A \\
\hline \multirow[t]{3}{*}{ Uranium-235 (g) } & Maximum & 一 & N/A \\
\hline & Minimum & - & N/A \\
\hline & Average & - & N/A \\
\hline
\end{tabular}

3.15.1.8 Inspection. Waste Certification personnel periodically reviewed the process documentation to verify the process was operated properly. Waste Certification personnel performed periodic inspections of the generating and packaging process to verify compliance with waste acceptance criteria. In addition, each drum was viewed using RTR to

- Ensure the drum does not contain nonconforming items

- Ensure the drum is properly packaged

- Verify the waste form description

- Evaluate the presence of free liquids.

3.15.1.9 Waste Form Evaluation. Table 3.15.1-4 evaluates the waste form against the WIPP WAC for such items as free liquids, pyrophoric materials, and compressed gases.

Table 3.15.5-5 evaluates the waste against TRUPACT criteria. 
Table 3.15.1-4. Waste Form Evaluation.

Criterion or

requirement

Limiting parameters ${ }^{2}$

Immobilization

This waste form is the final product of a treatment system designed to immobilize particulates. Based on the description of the waste, fine particulates are not expected in this IDC.

Liquids

There are normally no liquids associated with this IDC. Personnel performing RTR examination at Rocky Flats would accept up to 2 cups of free liquid, if liquids were present.

Pyrophoric

Materials

Pyrophoric materials were prohibited by procedural control. The absence of the pyrophoric materials was verified by the generating supervisor and periodic inspection by the Waste Certification Organization.

Explosives and Compressed Gases

Explosives and compressed gases were prohibited by procedural control. The absence of the explosives and compressed gases was verified by the generating supervisor and periodic inspection by the Waste Certification Organization. In addition, unvented, closed containers and pressurized containers were excluded by procedural controls and RTR examination.

TRU-Mixed Wastes The RCRA constituents exist as co-contaminants with the transuranic radionuclides. Compliance with the WIPP RCRA permits and NMD will be required prior to shipment of the stored waste to WIPP.

Specific Activity of A portion of the waste stored at INEL may contain < 100 nanocuries per gram Waste transuranic radionuclides.

$\mathrm{Pu}^{239}$ Equivalent

None of the IDC 822 waste containers recorded as shipped to INEL in the Activity SWIMS exceed $1,000 \mathrm{Ci}$ of plutonium-equivalent activity.

a. Many of the limiting parameters were taken from TRU Waste Compliance Program (Rockwell International 1983a, 1987e, and 1989b). 
Table 3.15.1-5. TRUPACT Evaluation.

Criterion or

requirement

Limiting parameters ${ }^{\mathbf{a}}$

Waste Package Rocky Flats limited the gross weight of drums to $800 \mathrm{lb}$. The TRUPACT and

Weight vehicle weight limits must be verified at the time of payload assembly at INEL.

Waste Containers This waste was packaged in 55-gal DOT-7A, Type A containers.

Nuclear

Criticality

Rocky Flats limited the fissile content of the drums to 200 grams. However, the error-times-two requirement was not in place at the time the drums were shipped to INEL; therefore, it is not reported as part of the assay of the drum. The TRUPACT limit must be verified at the time of payload assembly at INEL. Based on the typical assays of the IDC 822 drums, the criticality criteria will be met but must be recalculated or assayed to meet the error-times-two requirement.

Surface Dose The surface dose rate criteria used by Rocky Flats was $200 \mathrm{mrem} / \mathrm{hr}$ at the drum Rate surface and $10 \mathrm{mrem} / \mathrm{hr}$ at 1 meter. Shielding was not necessary for IDC 822 drums. The TRUPACT limit must be verified at the time of payload assembly at INEL. Based on the typical dose rates from the IDC 822 drums, the dose rate criteria will be met.

Removable The Rocky Flats limit for removable contamination (for TRU assumed to be all Surface alpha) was 20 disintegrations per minute $/ 100 \mathrm{~cm}^{2}$. The Rocky Flats limit is Contamination equivalent to 9 picocuries per $100 \mathrm{~cm}^{2}$, which is well within the WIPP criteria.

Thermal Power The thermal power calculation reported in the SWIMS data package is based on the reported assay value without an error/uncertainty correction. The thermal power must be recalculated based on the assay error determination.

Gas Generation Based on the procedural requirements for packaging IDC 822 waste and the waste description, the only areas of noncompliance are carbon filters, unpunctured rigid liners, headspace gas analysis, and visual characterization.

Personnel performing RTR examination at Rocky Flats would accept up to $10 \%$ of another IDC. The other IDCs could be combustibles, glass, concrete, metal, leaded gloves, and plastics.

a. Many of the limiting parameters were taken from TRU Waste Compliance Program (Rockwell International 1983a, 1987e, and 1989b).

3.15.1.10 Combustible and Organic Content. SWIMS data indicate that this waste form does not contain $>20 \%$ combustibles or $>20 \%$ organics.

3.15.1.10.1 Combustible Content-SWIMS data show that IDC 822 waste is noncombustible (Rockwell International 1985a). 
3.15.1.10.2 Organic Content-SWIMS data show that IDC 822 waste contains $20 \%$ organics (Rockwell International 1985a).

3.15.1.11 Analytical Information. No analytical information is available for IDC 822 .

IDC 822 is not a RCRA-hazardous waste and has been assigned no EPA codes. 


\section{Appendix A}

\section{Selected References}




$+2-1-1-1-1-2$

A-2

A-2 


\section{Appendix A}

\section{Selected References}

Arnold, P. M. 1986a. Characterization of Spent HEPA Filters from Rocky Flats Plant. . 1986b. EG\&G Drum Sampling Program Results FY 1986.

Bearly, L. A. 1989a. Interview: time periods different types of drums and liners were used.

Bearly, L. A., and J. K. Paynter. 1989. Drop Test of DOT Specification 7A Type A Metal Corrugated Box (Sandbox) With a 3/4" Plywood Liner. WPS 89-001.

Bearly, L. A., J. K. Paynter, and E. F. Lombardi. 1988. Full-Scale Drop-Impact Tests with DOT Specification 7A Waste Containers.

Brugger, Ronald P. 1983. Safety Analysis Report for Packaging - Corrugated Steel Container (Sand Box) for DOT Specification 7A Packaging. Prepared for Rockwell International.

CDH. 1993. Letter from Fred Dowsett of CDH to Michael Karol of DOE-RFO concerning characterization philosophy for HEPA filters. August 11.

Clements, T. L., Jr. 1982. Content Code Assessments for INEL Contact-Handled Stored Transuranic Wastes.

Clements, T. L., Jr. and D. E. Kudera. 1985. TRU Waste Sampling Program: Volume IWaste Characterization.

Conner, W. V. 1993. Evaluation of Residue Drum Storage Safety Risks.

DOE. 1991. Waste Acceptance Criteria for the Waste Isolation Pilot Plant.

. 1989a. TRU Waste Acceptance Criteria for the Waste Isolation Pilot Plant.

WIPP/DOE-069. Rev. 3.

- 1989b. TRU Waste Certification Compliance Requirements For Acceptance of Newly Generated Contact-Handled Wastes to be Shipped to the Waste Isolation Pilot Plant. WIPP/DOE-114. Rev. 2.

- 1981a. TRU Waste Acceptance Criteria for the Waste Isolation Pilot Plant. Rev. 1.

. 1981b. Waste Isolation Pilot Plant (WIPP); Record of Decision. Federal Register. 46, no. 18, January 28.

DOE/WIPP. 1992. TRUPACT-II Content Codes (TRUCON). Rev. 6. 
1989. TRU Waste Certification Compliance Requirements For Acceptance of Newly

Generated Contact-Handled Wastes to be Shipped to the Waste Isolation Pilot Plant.

WIPP/DOE-114. Rev. 2.

EG\&G Idaho, Inc. 1993. Results of the SWEPP Certified Waste Sampling Program for FY 1992 and FY 1993. Engineering Design File RWMC-675, Rev. 0.

1992. Results of the SWEPP Certified Waste Sampling Program for FY-1991. Engineering

Design File RWMC-563, Rev. 0.

EG\&G Rocky Flats, Inc. 1994a. Annual Land Disposal Restriction Progress Report. Rev. 0.

- 1994b. Backlog Baseline Book, Building 374 Solidified Sludge. Rev. 2.

. 1994c. Backlog Baseline Book Draft: Building 774 Solidified Sludge. Rev. 0.

. 1994d. Backlog Baseline Book Draft: Calcium Metal and Sand, Slag and Crucible. Rev. 1.

. 1994e. Backlog Baseline Book Draft: Crucibles. Rev 0.

. 1994f. Backlog Baseline Book Draft: Filters and Filter Waste. Rev. 0.

- 1994g. Backlog Baseline Book Draft: Glass, Ground Glass and Plexiglass. Rev. 0.

1994. Backlog Baseline Book Draft: Graphite. Rev. 1.

- 1994h. Backlog Baseline Book Draft: Heavy Metal. Rev. 0.

A 1994. Backlog Baseline Book Draft: Incinerator Ash, Heel, Soot, Sludge, and Firebrick. Rev. 0.

. 1994i. Backlog Baseline Book Draft: Lead and Glovebox Parts with Lead. Rev. 0.

- 1994j. Backlog Baseline Book Draft: Leaded Glovebox Gloves. Rev. 3.

- 1994k. Backlog Baseline Book Draft: Metal. Rev. 0.

. 19941. Backlog Baseline Book Draft: Pyrochemical Salts. Rev. 1.

. 1994m. Backlog Baseline Book: Soil and Cleanup Debris. Rev. 1.

C 1994. Backlog Baseline Book Draft: Solidified Lab Waste. Rev. 1.

. 1994n. Backlog Baseline Book Draft: Solidified Organics. Rev. 0.

19940. Idaho National Engineering Laboratory Code Assessment of the Rocky Flats Transuranic Waste. 
- 1994p. IDC Crosswalk: Post-1982 Changes to Rocky Flats Transuranic Waste IDCs Stored at INEL.

- 1994q. Interoffice correspondence from R.D. Thiel to A.M. Faucette. "Analytical Data for Samples of Raschig Rings. February 24.

. 1994r. Reactivity of Pyrochemical Salts at Rocky Flats Plant.

- 1994s. Waste Stream and Residue Identification and Characterization Sampling and Analysis

Database. Maintained by EG\&G.

. 1994t. WIPP Experimental Waste Characterization Program Database. Query date June 3, 1994.

- 1993a. Annual Land Disposal Restriction Progress Report.

. 1993b. Letter from D. M. Splett of Statistical Applications to P. Edrich of WIC. November 16.

- 1993c. Preliminary Assessment of Real-Time Radiography and Visual Characterization for Selected Waste Categories.

- 1993d. Recharacterization of Building 707 Glovebox Filters. Documentation of Guidance prepared by Waste Technical Support.

. 1993e. Waste Stream and Residue Identification and Characterization, Building 444.

. 1993f. Waste Stream and Residue Identification and Characterization, Building 559.

- 1993g. Waste Stream and Residue Identification and Characterization, Building 771.

. 1993h. Waste Stream and Residue Identification and Characterization, Building 774.

. 1993i. Waste Stream and Residue Identification and Characterization, Building 776.

. 1993j. Waste Stream and Residue Identification and Characterization, Building 777.

. 1993k. Waste Stream and Residue Identification and Characterization, Building 779.

- 1992a. Backlog Residue Hazardous Waste Determination Status Report.

. 1992b. IDC 393 Sand, Slag and Crucible Heels Residue Analysis Study.

1992c. Incinerator Sludge. Rev. 0. (Extract from the Residue Analysis Study-Document CE-010-001.)

. 1992d. Soot. Rev. 0. (Extract from the Residue Analysis Study-Document CE-010-001.) 
1992e. Waste Stream and Residue Identification and Characterization, Building Valve Vaults.

1992f. Unpulverized Incinerator Ash. Rev. 0. (Extract from the Residue Analysis StudyDocument CE-010-001.)

- 1991. Waste Stream and Residue Identification and Characterization Lab Analysis Report G910078.

. 1990a. (Draft) Rocky Flats Plant TRU Mixed Waste Plan. Prepared by WASTREN, Inc.

- 1990b. Federal Facilities Compliance Agreement Compliance Order Storage Report.

. 1990c. Letter from M. T. Saba of Waste Guidance to S. A. Anderson of Waste Programs. October 3.

EPA. 1990. Test Methods for Evaluating Solid Waste, SW-846. 3rd ed.

Hailey, S.M. 1993. Results of SWEPP Certified Waste Sampling Programs for FY 1992 and FY 1993.

- 1992. Results of the SWEPP Certified Waste Sampling Program for FY 1991.

Hardner, R. V., and A. J. Johnson. 1988. OASIS Solidification and Off Gas Analysis.

Jensen, R. T., and F. J. Wilkinson III. 1983. Characteristic of Transuranic Waste at Department of Energy Sites.

Kazanjian, A. R., P. M. Arnold, W. C. Simmons, and E. L. D'Amico. 1985. Gas Generation Results and Venting Study for Transuranic Waste Drums.

Kirby, W. A. 1986. Rocky Flats Plant Quality Report, August 1986.

Luckett, L. L., and P. T. Faccini. Characterization and Categorization Study of Tru Waste for $E G \& G$.

McKamy, Jerry N. 1988. Use of the Passive-Active Drum Counter. Presentation given by Dr. McKamy of the Safeguards Measurements Group, Rockwell International - Rocky Flats Plant.

Nenni, J. A. 1988. HEPA Filter Optimization/Implementation.

Patton, P. A., and J. W. Lindsay. 1972. Improvements to a 55-Gallon DOT 17C Shipping Container for Alpha-Emitting Transuranium Waste.

Peterson, R.D. 1987. Organic and Sludge Immobilization System. 
Phillips, J.A., G.B. Semones, T. R. Hergert, D. M. Saiki, and T. J. Satkowski. 1994. Toxicity Characteristic Leaching Procedure Test Results of Cemented Surrogate Analytical Laboratory Waste - Part 2.

Riddle, R. R., J. A. Irvin-Zamora, J. K. Paynter, D. M. Krieg, C. A. Meininger. 1985. ATMX-600 Rail Car Safety Analysis Report. Prepared for Rockwell International.

Rockwell International. 1989a. Solid Waste Inspection.

1989b. TRU Waste Compliance Program for WIPP-WAC (U). WO-4500-H.

. 1989c. Waste Certification Program at the Stored Waste Examination Pilot Plant (SWEPP).

. 1989d. Waste Operations Internal Document Control for Documents Pertaining to the WIPP-WAC. WO-4000-A.

. 1989e. Waste Packaging Requirements. WO-4034 (Draft).

. 1988a. Analytical Report for IDC 800 and 807 Samples. AL588.295.

B 1988. Letter from Jeff Paynter of Rockwell International to J. N. Davis of INEL concerning Data Package Information Change for Drum D40197-0743-18283. September 9.

. 1988b. Nuclear Materials Control. "Item Description Codes."

. 1988c. Packaging and Handling Line- and Nonline-Generated Materials (U). I-1002-C/O.

1988d. Procedure for Labeling and Marking Unclassified TRU Waste Containers for

Shipment to INEL. TRAFFIC 300-1.

. 1988e. Quality Assurance Program for TRU Waste Certification. WC-4500-D.

. 1987a. EG\&G Sampling Program Results, FY1987. PSD87-059.

. 1987b. FY-1987 Waste Operations Operating Plan.

. 1987c. Memorandum from W. D. Reinhart to F. G. Trevino. Subject: "Waste Shipment Summary for April Cost Month 1987." April 27.

. 1987d. Rocky Flats Plant Waste Management Site Plan.

. 1987e. TRU Waste Compliance Program for WIPP-WAC (U). (WO-4500-F).

- 1986a. Analytical Report. "Compositional Analysis - Filter Plenum Samples." AL586.0679. 
. 1986b. Interoffice Correspondence. "Addition of Content Code 303." T. L. Clements to Cook. January 23.

- 1986c. Interoffice Correspondence. "Addition of Content Codes 312 and 377."

T. L. Clements to Bower. May 19.

- 1986d. Interoffice Correspondence. "Combustibility of Graphite." Kurdera to

T. L. Clements. December 2.

. 1986e. Standard for Corrugated Metal Waste Container (Steel Box). Rocky Flats Plant Std. No. SX-231.

. 1985a. Solid Waste Information Management System (SWMS) User Guide.

. 1985b. Transuranic Solid Waste Inspection (U). WC-4003-A.

. 1983a. TRU Waste Certification Program for WIPP-WAC (U). CO-4500-A.

. 1983b. Interoffice Correspondence. "Content Code 7 Waste." T. L. Clements to

Distribution. January 17.

Roggenthen, D. K. 1988. Waste Drum Gas Generation Sampling Program at Rocky Flats During FY 1988.

Roggenthen, D. K., T. L. McFeeters, and R. G. Nieweg. 1989. Waste Drum Gas Generation Sampling Program at Rocky Flats.

WASTREN, Inc. 1990. (Draft) Rocky Flats Plant TRU Mixed Waste Plan.

WASTREN, Inc. 1994a. Event 10, IDC 490 (HEPA Filter) Reassessment, Rev. 4.

WASTREN, Inc. 1994b. Telephone interview by Jeff Paynter, WASTREN, of Dick Saiki, EG\&G Rocky flats. July 19.

WASTREN, Inc. 1994c. Telephone interview by Jeff Paynter, WASTREN, of Jerry McKamy and Jim Behanna, EG\&G Rocky flats. June 15.

Watson, L. E. 1989. EG\&G Sampling Program Results FY 1989. . 1987. EG\&G Sampling Program Results FY 1987. 
Appendix B

\section{List of EG\&G Rocky Flats Contacts}




\section{Appendix B}

\section{List of EG\&G Rocky Flats Contacts}

Behanna, Jim. 966-4706.

Conner, Bill. 966-4820.

Damico, Eric. 966-5362.

Dingman, Gary. 966-5873.

Glenn, Gayle. 966-2642.

McKamy, Jerry. 966-4017.

Saiki, Dick. 966-4726.

Wagner, Rick. 966-3190.

Wagner, Rick. 966-3190 


\section{Appendix C}

Waste Container Drawings 
C-2 

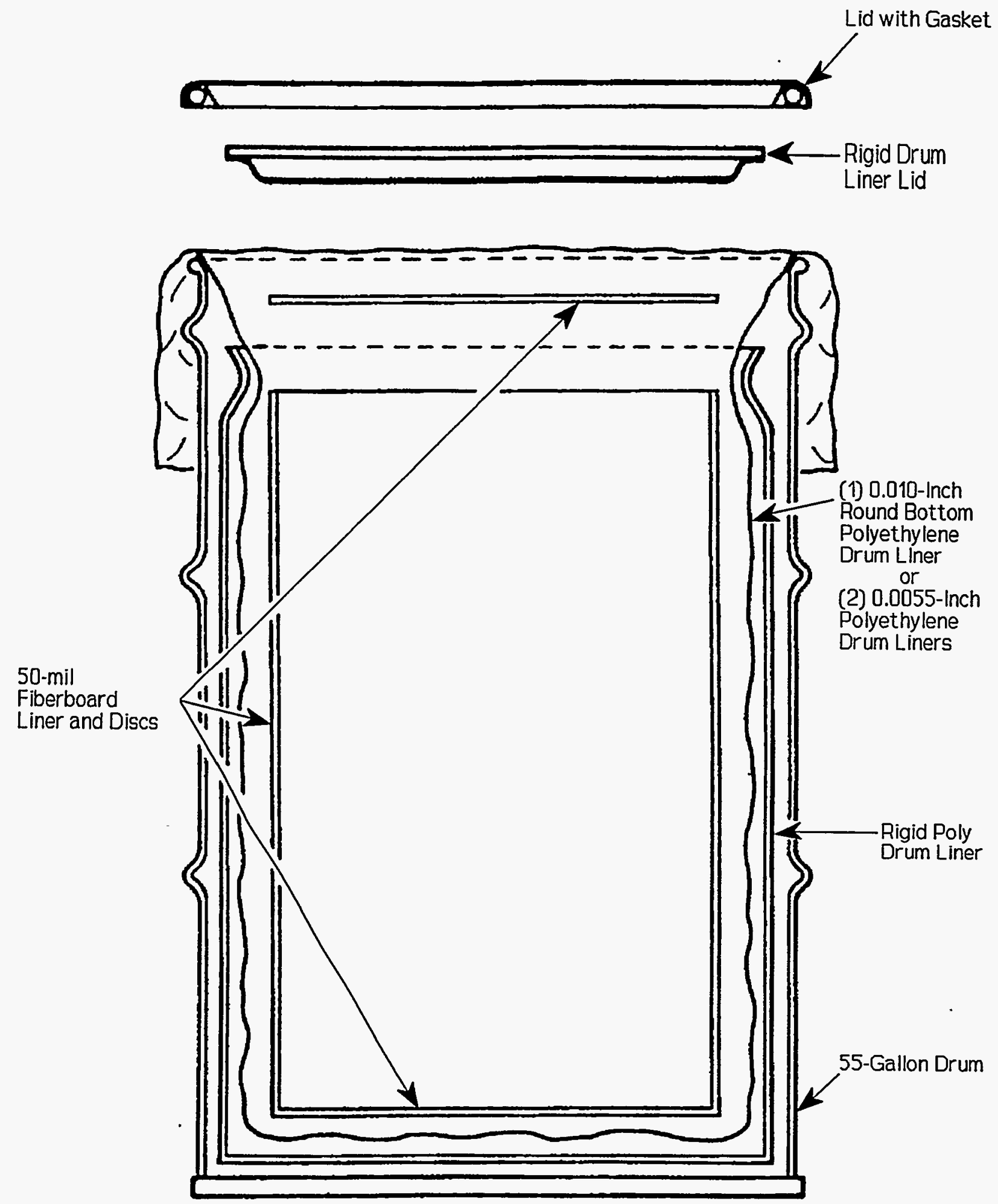

NOTE: Drums containing Americium are

packed as illustrated and include a lead liner.

Figure C-1. Packaging for IDCs that Require a Fiberboard Liner. 
Lid with Gasket
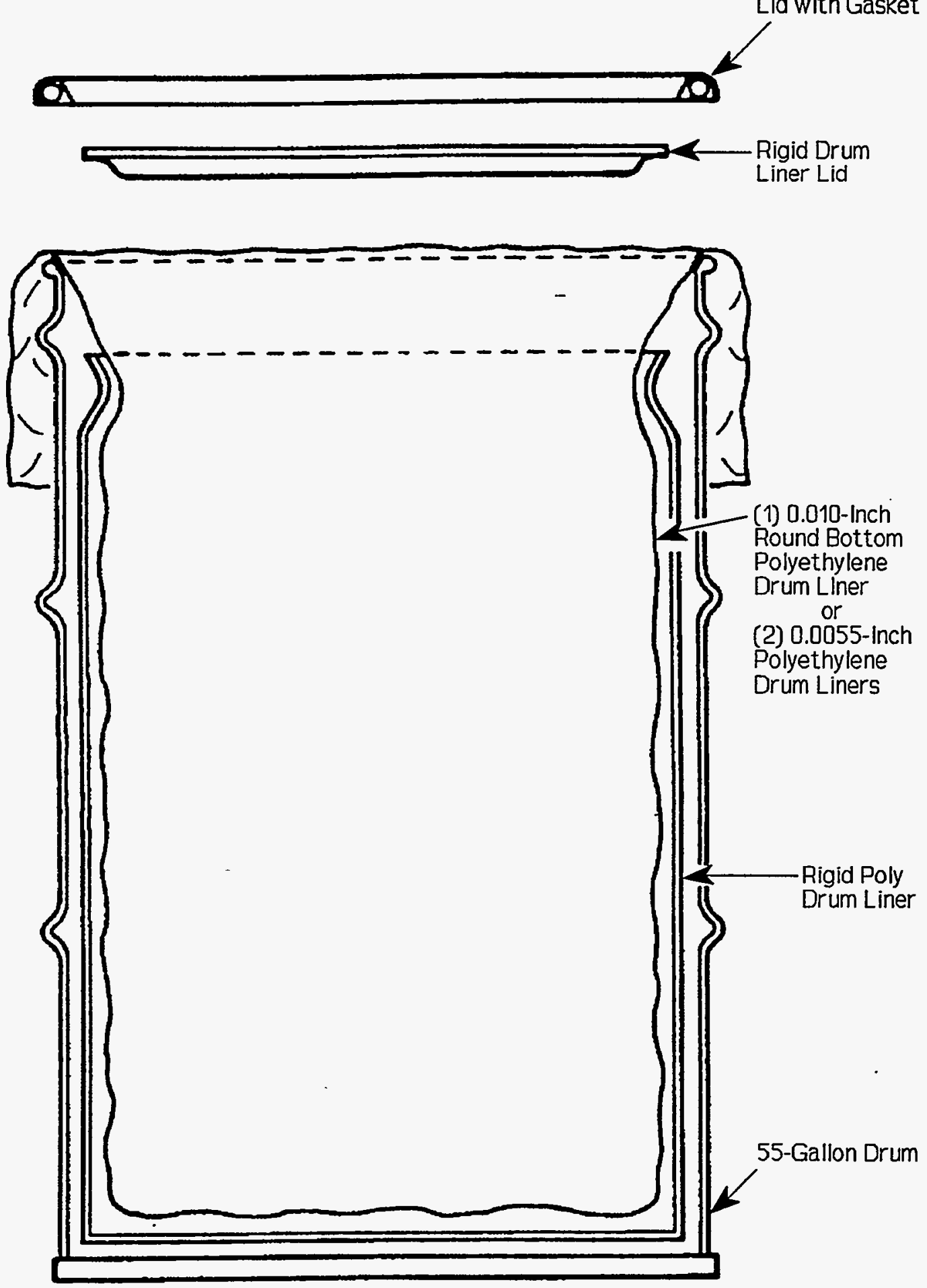

NOTE: Drums containing Americium are

packed as illustrated and include a lead liner.

Figure C-2. Packaging for IDCs that do not require a Fiberboard Liner. 

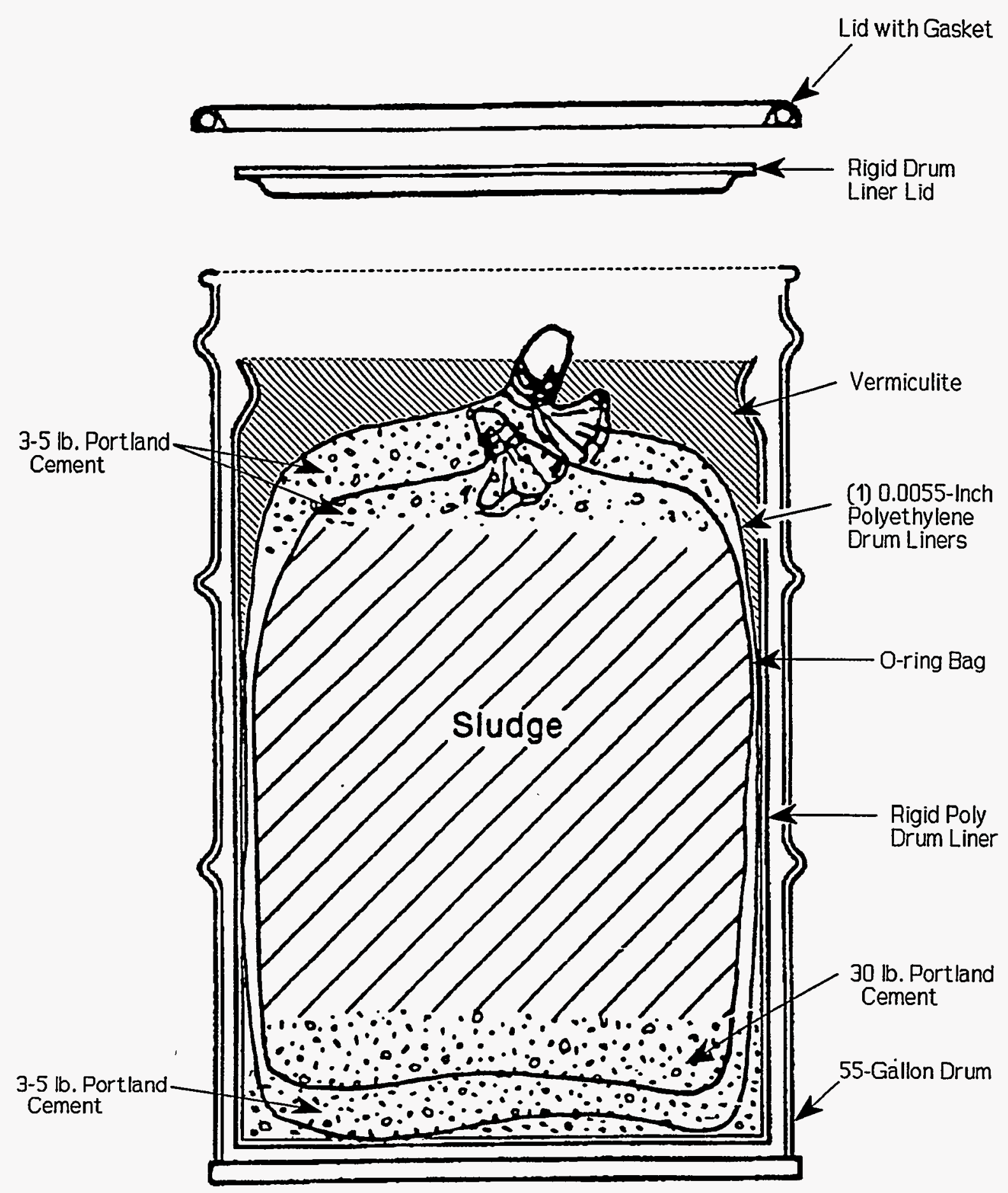

NOTE: Drums containing Americium are packed as illustrated and include a lead liner.

Figure C-3. Packaging for IDC 001. 


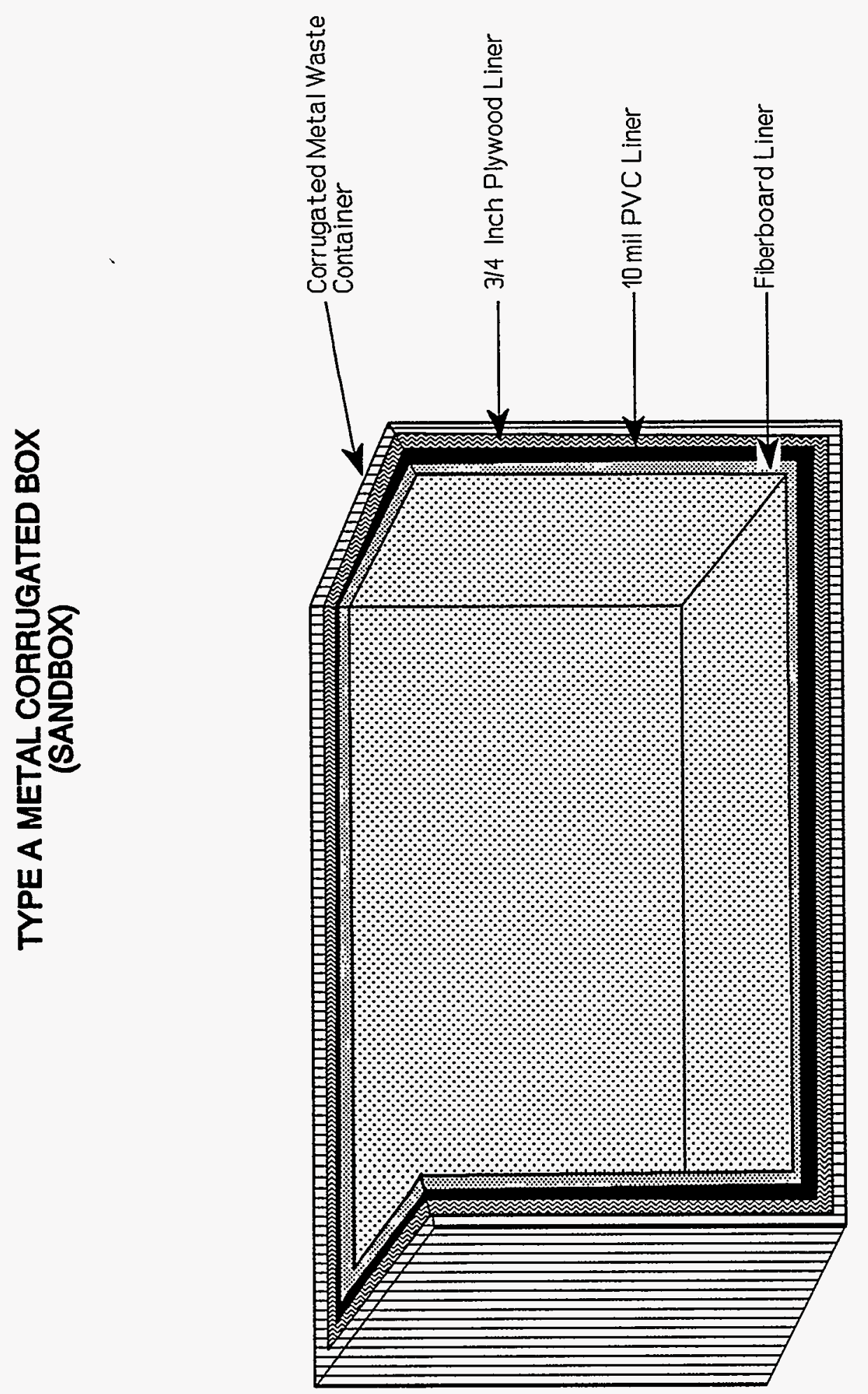

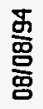

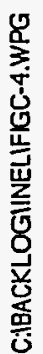




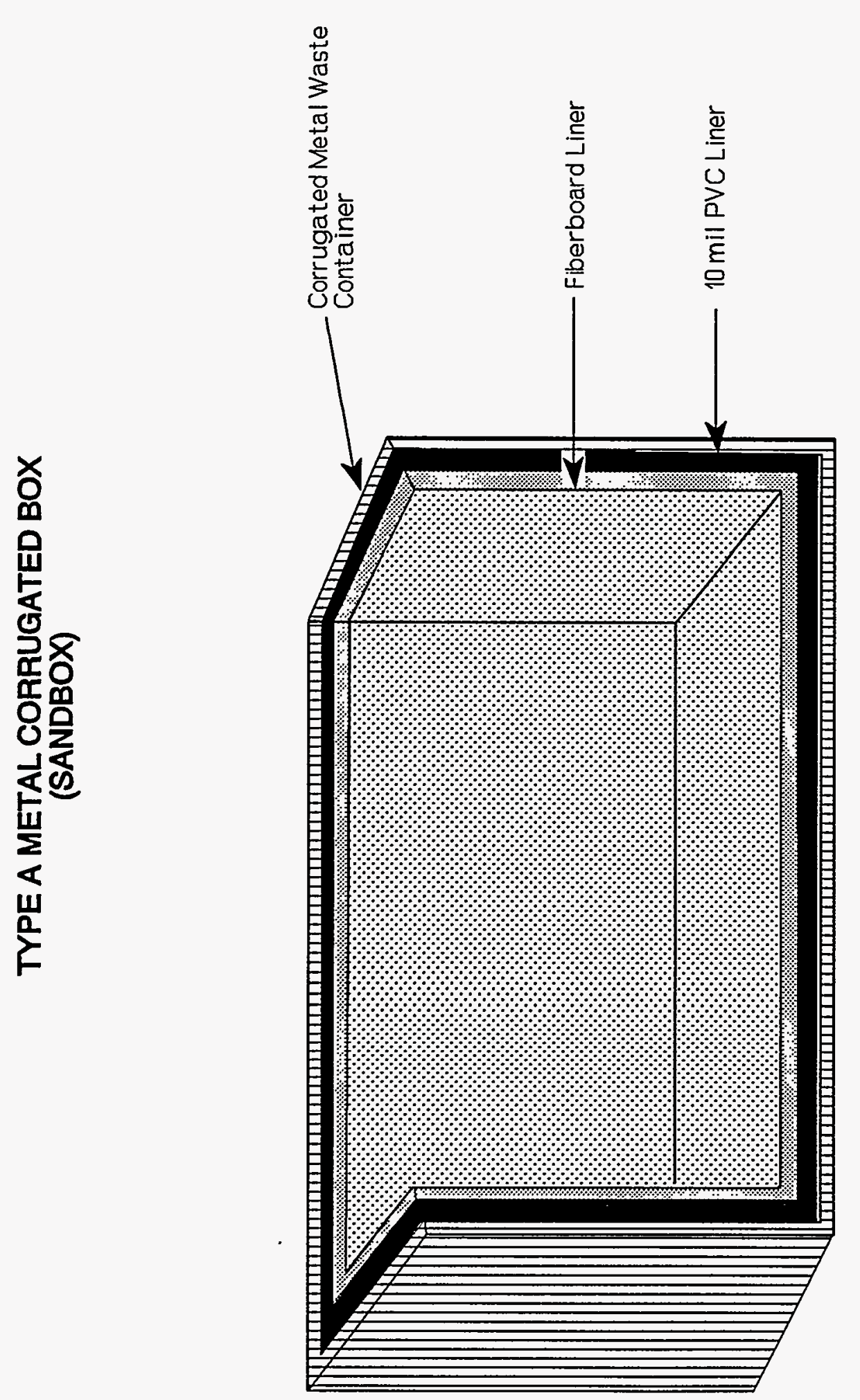

Figure C-5. Type A Metal Corrugated Box (Sandbox) without Plywood Liner. 
Appendix D

Source Documentation

D-1 
D-2$$
\text { -2 }
$$

$$
\cdot
$$

$\cdot$

(1)




\section{TELECON FORM}

June 15, 1994

Project: INEL

To/From: Jerry McKamy and Jim Behanna

Firm: EG\&G, RFP

Telephone No.: Dr. Mckamy: 966-4017, Mr. Behanna: 966-4706

WASTREN Contact: Jeff Paynter

Subject: Assay

Assay interview on 06/15/94 with Dr. Jerry McKamy and Jim Behanna

The information provided concerns assay of RFP TRU waste up to August 1989, the date of the last shipment to INEL.

Crate Counters-The "old" crate counter was used from the mid-1970s on. This counter was a passive gamma counter. In 1986, a Passive/Active Neutron Crate Counter (PACC) was added to Building 664. Transuranic waste crates were counted utilizing both counters until 1988. The procedure used to select assay value obtained from the two methods is not available. Beginning in 1988, the PACC results were selected generally for assays of less than 10 grams of plutonium.

Package Counters-High-resolution, transmission-corrected gamma, "can" counters were used beginning in 1984. Transmission-corrected segmented counters and calorimeters were available for use in 1985. Eight package counters were installed: two in Building 776, two in Building 371, and four in Building 771.

Drum Counters-The first drum counter to be used on a production basis was a nontransmissioncorrected, nonsegmented, sodium iodide unit in Building 771. This counter was first used in 1973. In 1981, a low-resolution segmented sodium iodide counter replaced the nonsegmented counter in Building 771. High-resolution Segmented Gamma Scan (SGS) counters were constructed in Buildings 707 and 371 to replace the low-resolution counter, and they began operations in 1984. The Passive/Active Drum Counter (PADC) began operations in 1987 to perform TRU/LLW sorting and supplement the SGS counters for assay of dense matrices. Drums with dense wastes that resulted in poor gamma ray transmission were routed to the PADC after SGS assay. The IDCs typically counted at the PADC for this reason were 321, 339, 341, 368, 370, 374, and 442. The PADC was also used to "safeguards check" drums of sludge. The safeguards check was to verify that SNM was not being diverted in the container, not to redetermine the radiochemical assay.

Two other counters were developed for TRU/LLW sorting. The HEPA Low-Specific Activity (LOSAC) counter was installed in Building 771 in 1988. This counter utilized nontransmissioncorrected low-resolution sodium iodide technology. This counter has the capability to perform TRU/LLW sorting of individual plenum HEPA filters or drums of low-density wastes such as combustibles. The LOSAC counter in Building 776 used nontransmission-corrected sodium iodide detection on a helical scan of the drum. This counter was dedicated to combustibles with less than $\mathbf{5 0}$ 
kilograms net weight of waste. The LOSAC counter in Building 776 was used after the drum had been initially assayed by an SGS counter in another building. Drummed waste was generally assayed in the building of generation subject to the operational status of the assay equipment and any special assay needs based on the waste matrix. 
Project: INEL

To/From: Rick Wagner

Firm: EG\&G Rocky Flats

Telephone No.: x3190

WASTREN Contact: Jeff P./Susan S.

Subject: Assay of Building 374 and 774 Sludges

Rick provided the following information on assay of sludges and liquids processed in Buildings 374 and 774.

IDC 001/002/800-The assay was based on the amount of plutonium and americium received in the aqueous waste treatment system for a period of operations, usually 1 month. The total amount received was divided evenly between the drums of sludge produced. Uranium was not included on the majority of the assays.

IDC 801-The assay was based on a batch process. The plutonium/americium value for the liquid in the batch tank was divided evenly between the drums produced in the batch. Uranium assay was not routinely performed.

IDC 004/802-The summation of the assays of individual bottles and tank waste placed in one drum was used for the drum assay.

IDC 807-A grab sample for radiochemical assay from each drum was used to calculate the drum assay. 
July 11, 1994

Project: INEL

To/From: Don Pound

Firm: EG\&G IDAHO

Telephone No.: (208) 526-8023

WASTREN Contact: Jeff Paynter

Subject: Division of IDCs for Existing and New Content Code Assessment

Don and Tom Clements concurred that September 1, 1985, would be the beginning date for the new content code assessment document. The comments for the 1982 content code assessment would include wastes shipped to INEL through August 1985. The choice of dates is based on the beginning date for the Rocky Flats SWIMS database.

Don said the organic and combustible calculation includes all liners other than the rigid liner. He said it was okay to express the organic and combustible content as a range of weights.

cc. INEl staff

INEL file 
Project: INEL/BWR

To/From: Dick Saiki

Firm: EG\&G RFP

Telephone No.: $966-4726$

WASTREN Contact: Jeff Paynter

\section{Subject: Composition of Rocky Flats Leaded Gloves}

Rocky Flats uses two types of leaded gloves, S6 and S2P2. Both gloves are made with an 84 percent $\mathrm{Pb}_{3} \mathrm{O}_{4}$-loaded neoprene rubber core sandwiched between two Hypalon rubber layers. The neoprene layer is approximately 15 mils thick.

\begin{tabular}{llccc}
\hline Glove type & \multicolumn{1}{c}{ Usage } & $\begin{array}{c}\text { Mass, } \\
\text { grams }\end{array}$ & $\begin{array}{c}\text { Internal } \\
\text { Hypalon } \\
\text { thickness, mils }\end{array}$ & $\begin{array}{c}\text { External } \\
\text { Hypalon } \\
\text { thickness, mils }\end{array}$ \\
\hline S6 & Building 707 & 785 & 11 & 11 \\
S2P2 & Bldgs 371 and 771 & 1030 & 8 & 28 \\
\hline
\end{tabular}

The thicknesses and weights were taken from acceptance inspections performed by Rocky Flats personnel. The lead loading information was supplied by a manufacturer. Dick recalls calculating the lead (not lead oxide) percentage of the glove weight as $40-50$ percent. 


\section{TELECON FORM}

July 19,1994

Project: BWR/INEL

To/From: Gary Dingman

Firm: EG\&G RFP

Telephone No.: $966-5873$

WASTREN Contact: Jeff Paynter

Subject: RTR Acceptance of Liquids in 1989

I called Gary about a drum of combustibles from Room 463 of Building 777 . One-and-one-half cups of liquid were detected in the drum by RTR in 1989. However, the drum passed RTR inspection. Gary explained that up to 2 cups of liquid in a container was accepted by Waste Certification in the 1980s. In the 1990s, this drum would be rejected. 
Project: INEL

To/From: Gary Dingman

Firm: EG\&G RFP

Telephone No.: (303) 966-5873

WASTREN Contact: Jeff Paynter

Subject: RTR Acceptance of Mixed IDCs

Gary did not have a copy of the RTR procedure prior to 1990 , but he recalled that up to 10 percent of another IDC was acceptable in the 1980s. 
Project: INEL

To/From: Gayle Glenn

Firm: EG\&G, RFP

Telephone No.: 966-2642 D3239

WASTREN Contact: Susan Shrader

\section{Subject: Drum Packaging}

I asked Gayle to review a rough draft of the Waste Packaging section for combustibles and for sludges on July 22. I spoke with her again today. She said I had some misconceptions about packaging, and talked about some of her packaging experience in Building 707.

1)She said that she never packaged line-generated TRU combustibles in drums with rigid liners for offsite shipment. Rigid liners were used for metal types of waste only, not combustibles.

2)They did not store 20-30 drums in Building 707 and then repack in boxes. Once something was packaged, it stayed packaged. Only stuff that didn't fit in drums was packaged in crates.

3)Oil Dri was not used in drums unless the material was wet (wet combustibles). Line-generated waste was taken out of the gloveboxes in small packages, and maybe a handful of Oil Dri went into these small packages before they were sealed.

Jeff Paynter qualified Gayle's statements by saying that she packaged waste in Building 707, and she never saw it again after it was shipped to Size Reduction. She never saw how it was repackaged. Jeff went on to say that prior to going to Size Reduction, the drums probably didn't have rigid liners. At Size Reduction, the drums were emptied into drums with rigid liners or crates. Additional Oil Dri may have been added at this point. 


\section{TELECON FORM}

July 29,1994

Project: INEL

To/From: Bill Conner

Firm: EG\&G, RFP

Telephone No.: $966-4820$

WASTREN Contact: Susan Shrader

Subject: Recovery method for IDCs $292,422,303,377$, and 312

IDC 292 waste was never processed unless it was above-discard. Plutonium was recovered by acid dissolution followed by running the filter solution through anionic exchange and precipitating the plutonium. Bill did not recall ever processing this waste.

IDC 422 was recovered by acid dissolution followed by running the filter solution through anionic exchange and precipitating the plutonium. Bill said this waste was seldom processed.

IDC 303 waste has no recovery method. It consists of graphite chunks which have been scarfed. The scarfing removed most of the plutonium, although the graphite chunks may still contain discernible amounts of plutonium. If this waste were to be processed, it would be processed by acid leaching.

IDC 377 is scarfed and then the scarfings are leached with acid to remove plutonium.

IDC 312 is scarfed and then the scarfings are leached with acid to remove plutonium. 
Project: INEL

To/From: Eric Damico

Firm: EG\&G, RFP

Telephone No.: 966-5362

WASTREN Contact: Kathy Rosow

Subject: WIPP Experimental Waste Characterization Program Data

1)"Operation" headspace sampling method is always done first. If lid was not vented prior to operational sampling, it is put in after.

2)"Detailed" headspace sampling method always follows operational; therefore, all detailed sampling was vented.

3)There is such a thing as an "operational bag" sampling method. 
Project: INEL

To/From: Rick Wagner

Firm: EG\&G, Rocky Flats Plant

Telephone No.: $966-3102$

WASTREN Contact: Kathy Rosow

Subject: OASIS waste drum packaging

Rick clarified how TRU OASIS waste was packaged. The waste container consisted of a rigid liner and two O-ring bags made of PVC material. This description corresponds with that given by R. Peterson (1987) in the "OASIS and Sludge Immobilization System " booklet. 
Project: INEL

To/From: Rick Wagner

Firm: EG\&G, Rocky Flats Plant

Telephone No.: 966-3102

WASTREN Contact: Kathy Rosow

Subject: IDC 800 waste packaging

Mr. Wagner clarified how IDC 800 waste was packaged. It does not have top and bottom caps of portland cement. The waste is co-fed into the drum with portland cement and diatomite. 


\section{Appendix E}

Acronyms and Abbreviations 
E-2 


\section{Appendix E}

Acronyms and Abbreviations

Am

BDAT

$\mathbf{C i}$

CFR

DOE

DOT

EDL

EP

EPA

FBI

FRP

g

HEPA

HOC

IDC

INEL

kg

LDR

LLW

LOSAC

MDL

$\mathrm{mg} / \mathrm{kg}$
Americium

Best Demonstrated Available Technology

Curie

Code of Federal Regulations

U.S. Department of Energy

U.S. Department of Transportation

Economic Discard Limit

Extraction Procedure

U.S. Environmental Protection Agency

Fluidized Bed Incinerator

Fiberglass-Reinforced Polyester

gram

High Efficiency Particulate Air

Halogenated Organic Compounds

Item Description Code

Idaho National Engineering Laboratory

kilogram

Land Disposal Restrictions

low-level waste

Low Specific Activity Counter

Method Detection Limit

milligram per kilogram (equal to ppm) 


\begin{tabular}{ll} 
mg/L & milligrams per liter \\
mL & milliliter \\
mrem/h & millirems per hour \\
nCi/g & nanocurie per gram \\
N/A & not applicable \\
NMD & No Migration Determination \\
OASIS & Organic and Sludge Immobilization System \\
PA & Protected Area \\
PADC & Passive-Active Drum Counter \\
PAN & passive-action neutron (counter) \\
pCi/g & picocurie per gram \\
Pci/mL & picocurie per milliliter \\
ppb & parts per billion \\
ppm & parts per million \\
ppmv & parts per million by volume \\
PRQL & Program Required Quantitation Limit \\
Pu & plutonium \\
PVC & polyvinyl chloride \\
R\&D & Research and Development \\
RCRA & Resource Conservation and Recovery Act \\
RFP & DOE Rocky Flats Plant \\
RTR & Real-Time Radiography \\
SWPP & Segmented Gamma Scan \\
\hline
\end{tabular}




\begin{tabular}{ll} 
SWIMS & Solid Waste Information Management System \\
TCLP & Toxicity Characteristic Leaching Procedure \\
TID & Tamper Indicating Device \\
TRU & Transuranic \\
TRUPACT-II & Transuranic Package Transporter \\
TSCA & Toxic Substances Control Act \\
U & Uranium \\
VOA & Volatile Organics Analysis \\
VOC & volatile organic compounds \\
WAC & Waste Acceptance Criteria \\
WEMS & Waste Environmental Management System \\
WFN & Waste Form Number \\
WIPP & Waste Isolation Pilot Plant \\
WSIC & Waste Stream Identification and Characterization \\
WSRIC & Waste Stream Residue Identification and Characterization \\
$\mu \mathrm{g}$ & microgram \\
$\mu \mathrm{g} / \mathrm{g}$ & microgram per gram (equal to ppm) \\
$\mu \mathrm{g} / \mathrm{kg}$ & microgram per kilogram (equal to ppb) \\
\hline
\end{tabular}

